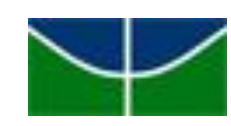

UNIVERSIDADE DE BRASÍLIA

INSTITUTO DE ARTES

DEPARTAMENTO DE ARTES VISUAIS

PROGRAMA DE PÓS-GRADUAÇÃO EM ARTE

MARIA DEL ROSARIO TATIANA FERNÁNDEZ MÉNDEZ

O EVENTO ARTÍSTICO COMO PEDAGOGIA

Brasília

2015 
MARIA DEL ROSARIO TATIANA FERNÁNDEZ MÉNDEZ

\section{O evento artístico como pedagogia}

Tese apresentada ao Programa de Pós-Graduação em Arte da Universidade de Brasília como parte dos requisitos para obtenção do grau de Doutor em Artes na linha de Pesquisa em Educação em Artes Visuais.

Orientador: Professor Dr. Belidson Dias

\section{Brasília}


PROF. DR. BELIDSON DIAS BEZERRA (UNIVERSIDADE DE BRASÍLIA- DF) Presidente e Orientador

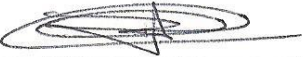

\section{Examinadores:}

PROFA. DRA. MIRIAM CELESTE MARTINS (UNIVERSIDADE PRESBITERIANA MACKENZIE- SP)

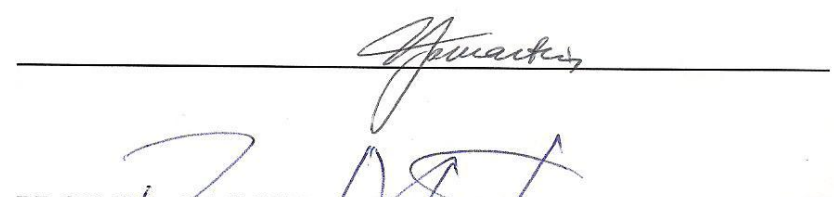

PROF. DR, RAIMUNDO MARTINS (UNIVERSIDADE FEIDERAL DE GOIÁS - GO)

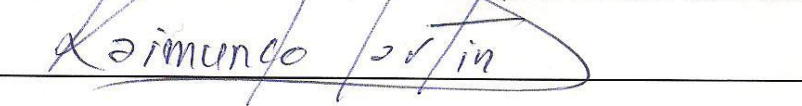

PROFA. DRA. THÉRÈSE HOFMANN GATTI (UNIVERSIDADE DE BRASÍLIA -

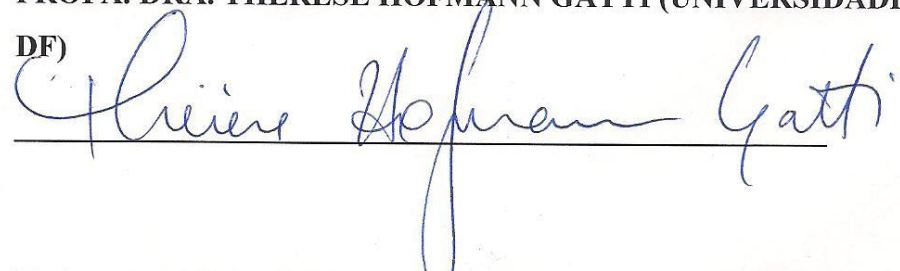

PROF. DR. EMERSON DIONISIO GOMES DE OLIVEIRA (UNIVERSIDADE DE BRASÍLIA- DF)

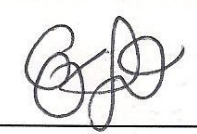

Brasília, 04 de dezembro de 2015 


\section{RESUMO}

Esta investigação trata dos eventos artísticos como pedagogias culturais na Educação em Visualidade. Situa-se no encontro entre a virada da visualidade na educação e a virada pedagógica na arte. No marco das pedagogias culturais procura-se compreender como e em que condições o evento artístico pode ser ao mesmo tempo um evento pedagógico e de que maneira se instituem os espaços que promovem eventos educacionais como experiências estéticas em base à ideia de experiência estética de John Dewey e de evento pedagógico de Dennis Atkinson. As discussões que se desdobram destas reflexões se relacionam principalmente à área curricular e metodológica da Educação em Visualidade, mas se relacionam também com a filosofia da educação, os Estudos da Cultura Visual e as tendências contemporâneas na arte. Dessa maneira apontam-se as bases conceituais que permitem distinguir o espaço de interseção entre a arte e a educação contemporâneas e suas implicações políticas e culturais sob o conceito de arte participante de Claire Bishop e a proposta de pedagogia cultural de Henry Giroux que confluem no principio político de emancipação no ponto de partida, de Jacques Rancière. $\mathrm{O}$ objeto de estudo são artistas e educadores em visualidade que concebem a arte como um evento pedagógico e a pedagogia como um evento artístico. Nesse sentido analisa-se e problematiza-se o cruzamento de fronteiras tanto na arte como na educação e criam-se possibilidades de uma pedagogia de dissenso por meio de uma metodologia de Investigação Baseada nas Artes, IBA, em base a duas perspectivas, a perspectiva $\mathrm{A} / \mathrm{r} /$ tográfica que integra teoria, práxis e poética e reflete sobre as identidades em trânsito de artista, pesquisador(a) e professor(a) e a perspectiva da prática transcognitiva de Graeme Sullivan que considera as múltiplas formas de investigar dos artistas. Nessas bases conceituais e metodológicas aproprio-me do conceito de Objetos de Aprendizagem, OA, que responde a políticas de homogeneização da educação para convertê-lo em Objetos de Aprendizagem Poéticos, OAP, que respondem a políticas emancipadoras de educação em geral e da Educação em Visualidade em particular, onde os estudantes, de maneira similar ao que acontece com os espectadores contemporâneos da arte, se tornam participantes. Para este efeito observo e analiso a criação de OAP para o ensino das artes visuais realizados por participantes de um curso de extensão sobre Objetos de Aprendizagem Poéticos, promovido pelo VIS/IdA, através do DEX-UnB, dirigido a professores de arte e estudantes das licenciaturas. Os resultados das análises das experiências dos participantes que aplicaram os OAP produzidos em contextos de educação evidenciam que as coincidências entre as viradas se dão no plano político por meio da emancipação do espectador, no plano metodológico por meio do foco sobre o papel da visualidade na construção do conhecimento e no plano existencial pela forma como construímos os territórios de subjetivação.

Palavras Chave:

Pedagogias culturais, Educação em visualidade, Virada da visualidade, Virada pedagógica da arte, Arte participante. 


\section{RESUMEN}

Esta investigación trata de los eventos artísticos como pedagogías culturales en la Educación en Visualidad. Se sitúa en el encuentro entre el giro de la visualidad en la educación y el giro pedagógico en el arte. En el marco de las pedagogías culturales se busca comprender como y en qué condiciones el evento artístico puede ser al mismo tiempo un evento pedagógico y de qué manera se instituyen los espacios que promueven eventos educacionales como experiencias estéticas en base a las ideas de experiencia estética de John Dewey y de evento pedagógico de Dennis Atkinson. Las discusiones que se desdoblan de estas reflexiones se relacionan principalmente al área curricular y metodológica de la Educación en Visualidad, pero se relacionan también con la filosofía de la educación, de los Estudios de la Cultura Visual y de las tendencias contemporáneas en el arte. De esa manera se apuntan las bases conceptuales que permiten distinguir el espacio de intersección entre el arte y la educación contemporáneas y sus implicaciones políticas y culturales sobre el concepto de arte participativo de Claire Bishop y la propuesta de pedagogía cultural de Henry Giroux que confluyen en el principio político de emancipación en el punto de partida, de Jacques Rancière. El objeto de estudio son artistas y educadores en visualidad que conciben el arte como un evento pedagógico e la pedagogía como un evento artístico. En ese sentido se analiza y problematiza el cruzamiento de fronteras tanto en el arte como en la educación y se crían posibilidades de una pedagogía de disenso por medio de una metodología de Investigación Basada en las Artes, IBA, en base a dos perspectivas, la perspectiva $\mathrm{A} / \mathrm{r} /$ tográfica que integra teoría, praxis y poética y reflexiona sobre las identidades en tránsito de artista, investigador(a) y profesor(a) y la perspectiva de la práctica transcognitiva de Graeme Sullivan que considera las múltiples formas de investigar de los artistas. En esas bases conceptuales y metodológicas me apropio del concepto de Objetos de Aprendizaje, OA, que responde a políticas de homogenización de la educación para convertirlo en Objetos de Aprendizaje Poéticos, OAP, que responden a políticas emancipadoras de educación en general y de la Educación en Visualidad en particular, donde los estudiantes, de manera similar a lo que sucede con los espectadores contemporáneos del arte, se vuelven participantes. Para este efecto observo y analizo la creación de OAP para la enseñanza de las artes visuales realizados por participantes de un curso de extensión sobre Objetos de Aprendizaje Poéticos, promovido por el VIS/IdA, a través del DEX-UnB, dirigido a profesores de arte y estudiantes de las licenciaturas. Los resultados de los análisis de las experiencias de los participantes que aplicaron los OAP producidos en contextos de educación evidencian que las coincidencias entre los giros se dan en el plano político por medio de la emancipación del espectador, en el plano metodológico por medio del foco sobre el papel de la visualidad en la construcción del conocimiento y en el plano existencial por la forma como construimos los territorios de subjetivación.

Palabras Llave:

Pedagogías culturales, Educación en visualidad, Giro de la visualidad, Giro pedagógico en el arte, Arte participativo. 


\begin{abstract}
This research is about artistic events as cultural pedagogies on Visual Education. It is situated within the encounter of the pictorial turn in education and the pedagogical turn in art. Given the cultural pedagogies framework we seek o understand how and in what conditions the artistic event can be, at the same time, a pedagogical event in its own terms and how the spaces to promote educational events as aesthetic experiences are established, based on John Dewey's idea of aesthetic experience and Dennis Atkinson's pedagogical event. The unfolded discussions from these reflections are also related to educational philosophy, Visual Culture Studies and contemporary tendencies in art. In that manner we point out the conceptual foundations that allow us to distinguish the intersection space between contemporary art and education and its political and cultural implications under Claire Bishop's participatory art concept and Henry Giroux's cultural pedagogy proposal that converge on Jacques Rancière political principle of emancipation from the starting point. The objects of the study are artists and visual educators that conceive art as a pedagogical event and pedagogy as an artistic event. In that regard, we analyze and problematise the border crossings in art and education and create the possibilities for a dissent pedagogy trough an Arts Based Research, ABR, methodology, within two perspectives, the A/r/tographic perspective that integrates theory, praxis and poietics and reflects over transit identities of artist, researcher and teacher and Graeme Sullivan's transcognitive practice perspective which considers the multiple ways in which artists research. On that conceptual and methodological framework I take possession of the Learning Objects, LO, concept, which responds to educational hegemonic policies to turn them into Poietic Learning Objects, PLO, which responds to educational emancipatory policies and to Visual Education policies specifically, where students, in a manner similar to the contemporary art spectator, turn into participants. For that purpose I observe and analyze the creation of PLO for visual education, produced by the participants of an extension course about Poietic Learning Objects, promoted by the VIS/IdA, trough DEX/UnB, aimed at art teachers and graduation art education students. The results, drawn from the analysis of the participant's experiences that applied PLO produced in educational contexts, show that the coincidences between the turnings are given in the political level trough the emancipation of the spectator, in the methodological level trough the attention over the visual role in knowledge construction and in the existential level trough the ways in which we construct territories of subjectivation.
\end{abstract}

Key words:

Cultural pedagogies, Visual Education, Pictorial turn, Pedagogical turn in art, Participatory art. 


\section{SUMÁRIO}

INTRODUÇÃO

1. AS PAISAGENS HÍBRIDAS 26

1.1. As fronteiras 31

1.2. As viradas 33

1.3. Os corpos 40

1.4. Os saberes 44

2. OS TERRITÓRIOS DE EXISTÊNCIA 48

2.1. A arte 52

2.2. O ensino $\quad 57$

2.3. A investigação 61

3. OS MAPAS DE INTERSEÇÃO 66

3.1. O cruzamento das fronteiras: as pedagogias culturais 67

3.2. O currere e a paisagem existencial 82

3.3. A experiência estética e o evento 90

4. OS MAPAS DO ENCONTRO 102

4.1. A virada da visualidade na educação 103

4.1.1. Visualidades e cultura 110

4.1.2. Visualidades e educação 112

4.2. A virada pedagógica da arte 116

4.2.1. O ensino como meio artístico 122

4.2.2. O evento artístico como pedagogia 143

5. OS MAPAS DE INVESTIGAÇÃO 152

5.1. Investigação Baseada nas Artes e Investigação Educacional Baseada nas 154 Artes

5.1.1. Imaginação na investigação 158

5.1.2. Imaginação na Educação 160

$\begin{array}{ll}\text { 5.2. A prática transcognitiva } & 163\end{array}$

5.3. Competências artísticas em situações não artísticas 172

6. AS MÁQUINAS PARA CONSTRUIR TERRITÓRIOS 178

6.1. Máquinas para construir territórios de subjetivação 181

6.1.1. Os Objetos de Aprendizagem 186

6.1.2. Os Objetos de Aprendizagem Poéticos 195

6.2. Apropriação: ocupação dos territórios pedagógicos 205 
7.1. A conversação como forma de construção coletiva 230

7.2. Singularização da produção maquínica 238

7.3. O encontro das águas 241

7.3.1. O que um OAP pode fazer? 245

7.3.2. O que se produz com os OAP? 279

$\begin{array}{ll}\text { 7.3.2.1. Ideias } & 281\end{array}$

7.3.2.2. Situações 284

7.3.2.3. Formas 288

7.3.3. Que afetos formam os OAP? Que afetos os OAP provocam? 290

$\begin{array}{ll}\text { MAPAS DA POTÊNCIA } & 302\end{array}$

$\begin{array}{ll}\text { Referências } & 309\end{array}$

ANEXOS

Anexo I Documentação do curso

Anexo II Avaliações do curso

Anexo III Entrevista cm Narda Fabiola Alvarado

Anexo IV Marcos

Anexo V Quadro de Conversações

Anexo VI Mapa dos OA e OAP

Anexo VII Marco de Investigação dos OA e OAP 


\section{LISTA DE IMAGENS}

Fig. 1 Entre os Andes e Amazonas. Tatiana Fernández, Imagem satelital Google Earth manipulada, 2013

Fig. 2 Paisagens Híbridas: Brasília com montanha nevada Illimani.

Tatiana Fernández. Montagem fotográfica, 2013

Fig. 3 Escola Primaria Rebelde Autônoma Zapatista de Los Altos de

Chiapas Sistema Educativo Rebelde Autônomo Zapatista de

Liberação Nacional - Chiapas, México. Fonte: enredando.org.

Fig. 4 Escola Primaria Rebelde Autônoma Zapatista Comandanta

Ramona. Sistema Educativo Rebelde Autônomo Zapatista de

Liberação Nacional - Chiapas, México. Fonte:

caminatuspensamientos.blogspot.com

Fig. 5 Legofesto. Fantasmas de Abu Ghraib. Museu da Psiquiatria, Ghent, Bélgica, 2013-2014. Fonte: legofesto.blogspot.com,br

Fig. 6 Olhos. Tatiana Fernández. fotografia digita manipulada.

Fig. 7 Heidi Specogna e Rainier Hoffmann. Tupamaros. (Still Image) 38 Produções Del Cerro. Filme 1:34:51. 1996. Fonte: Uruguay Para Siempre, youtube.com.

Fig. 8 Tucumán Arde. Ação. Tucumán, Argentina, 1968. Fonte: rosariarte.com.ar.

Fig. 9 Pawel Althamer, Congresso dos Desenhistas, exposição Os Vizinhos, New Museum, New York, 2012. Fonte: huffingtonpost.com.

Fig.10 Flash Mob Corpos que olham. Curso de extensão Objetos de Aprendizagem Poéticos, IdA/VIS/UnB 1-2014.

Fig. 11 Joseph Beuys. Apagador de quadro sem barulho, 1974. Fotografia de Denise Munhoz

Fig. 12 Territórios de existência. Andes, Bolívia. Tatiana Fernández, fotografia satelital Google Earth manipulada, 2013.

Fig. 13 Domitila Huanca, "Danos Colaterais", figuras de tinta acrílica em contextos cotidianos, 2012.

Fig. 14 Os videntes. Performance (vídeo still), $2^{\circ}$ ano Secundária (equivalente ao $1^{\circ}$ ano do ensino médio). Colégio Saint Andrews, La Paz, Bolívia, 2004. Fotografia Tatiana Fernández.

Fig. 15 Avelino Siñani. Detalhe. Fotografia de Carlos Salazar

Mostajo, Warisata, Bolívia, 1931. Fonte: portal.aprendiz.uol.com.br

Fig. 16 Painel de madeira de construção de 25 m. x 2,50 m. pintada pelos estudantes diversas turmas. (Vídeo still) Colégio Saint Andrews, La Paz, Bolívia, 2006. Fotografia de Tatiana Fernández.

Fig. 17 Mapas da Interseção. Brasília e La Paz superpostas. Tatiana 
Fernández, fotografia satelital. Google Earth manipulada, 2013.

Fig. 18 Joaquin Torres Garcia. Capa para publicação Escuela del Sur, 70

Mapa de América do Sul, 1958. Fonte: ceciliadetorres.com

Fig. 19 Narda Fabiola Alvarado. Un minuto de silencio para ver el 72

cielo, Escuela Primaria Max Paredes, La Paz, Bolívia, 2002.

Fotografia da artista.

Fig. 20 Narda Fabiola Alvarado. Desenhos dos estudantes de 7 a 8

anos da Escuela Primaria Max Paredes depois de verem por um minuto o céu com um olho. Sequencia da obra Un minuto de silencio para ver el cielo, Fotografias da artista.

Fig. 21 Portafolio La Escuela Zapatista. Fonte: w-x.com.mx

Fig. 22 Mural Bienvenido a territorio zapatista. Fonte:

mujeresylasextaorg. wordpress.com.

Fig. 23 Experiência de alfabetização com o método Paulo Freire, 1964. Autor desconhecido, Acervo Paulo Freire. Fonte: acervo. paulofreire.org.

Fig. 24 Crianças modelando na Escola Laboratório da Universidade de Chicago. Fonte: milwaukeeidscohort.wikispaces.com.

Fig. 25 Button \& Provenzo, Sala de têxteis na Escola Laboratório, 1896. Fonte: igs.net

Fig. 26 Escola Ayllu de Warisata, exterior e interior, trabalho na terra e construção da escola, 1936. Warisata, La Paz, Bolívia. Fonte: sala.clacso.edu.ar

Fig. 26 Mapas do encontro. Encontro do Rio Mamoré e Rio Guaporé. Fronteira Brasil- Bolívia. Tatiana Fernández, fotografia satelital Google Earth manipulada, 2013.

Fig. 27 Tatiana Fernández. Carta 5, frente e verso. Jogo Enigma. Objeto de Aprendizagem Poético. Curso de extensão OAP. VIS/IdA/UnB, 2013-14.

Fig. 28 Tatiana Fernández. Carta 2, frente e verso. Jogo Enigma. Objeto de Aprendizagem Poético. Curso de extensão OAP. VIS/IdA/UnB, 2013-14.

Fig. 29 Narda Fabiola Alvarado. Se penteando. Atividade de penteado com os estudantes numa aula de arte no Colégio Internacional del Sur, La Paz, Bolívia, 2003. Fotografia Narda Fabiola Alvarado.

Fg, 30 Luis Camnitzer, A Aula, 2005. Fonte: masdearte.com

Fig. 31 Anton Vidokle, Tirdad ZolghadrJan Verwoert.

Unitednationsplaza. O Julgamento de Madrid: Um Crime Contra a Arte. Madrid, 2007. Captions do filme de Hila Peleg, 1:40:52. Fonte: unitednationsplaza.org 
Fig. 32 Simón Rodríguez, Sociedades Americanas, 1828. Transcrição 123 página 92 da edição de 1990.

Fig. 33 Robert Filliou. Criação Permanente, selo do Princípio de

Equivalência: Bem feito, mal feito, não feito. 1869. Fonte:

mediation.centrepompidou.fr

Fig. 34 Robert Filliou, Teaching and Learning as Performing Arts,

New York: Kasper Köning, página 227, 1970.

Fig. 35 George Maciunas, Flux Year Box 2, 1960.Fotografia

Photograph Service President and Fellows of Harvard College.

Fonte: stretcher.org

Fig. 36 Reprodução presentes de Friedrich Froebel Fonte:

Picasaweb.

Fig. 37 Benjamin Patterson. Carta de jogo Fluxus, Fluxus Year Box 2, 1965.

Fig. 38 Joseph Beuys, Escritório para uma Democracia Direta, Tate

Londres, 1972. Fonte: Documenta 13 - d13.documenta.

Fig. 39 Joseph Beuys, Quatro quadros pretos, Tate Londres, 1972.

Fonte: tate.org.uk

Fig. 40 Pablo Helguera. Escola Panamericana da

Intranqualidade.Texto para curso, Suíça, 2003. Fonte:

pablohelguera.net

Fig. 41 Pablo Helguera. Escola Panamericana da Intranquilidade, 2003. Fonte: pablohelguera.net

Fig. 42 Escola Noturna de Anton Vidokle. Seminário Público 3.

Liam Gillick, Três Textos Curtos sobre a Necessidade de Criar uma

Economia da Equivalência. 27-30 março, 2008. Foto Hatuey Ramos

Fermin. Fonte: museumashub.org

Fig. 43 M7 red, Teatro del chat, instalação - Obra em processo.

Material Educativo, 6a . Bienal do Mercosur, 2007

Fig. 44 Tim Rollins + KOS (Kids of Survival) workshop 2007.

Fonte: gsa.gov

Fig. 45 Tim Rollins + KOS (Kids of Survival) Pinoquio, 1992-93.

Fonte: e-flux.com

Fig. 46 Patrick Rowe. Mobile Print Power Collective, 2015. Estúdio móvel para workshops.

Fig. 47 John Baldessari, Class Assignments, (Optional), 1970. Fonte: 137 wattis.org

Fig. 48 Wide Open School, Hayward Gallery, Londres, $1^{\circ}$ de junho a 138 
$1^{\circ}$ julho de 2012. Fonte: wideopenschool.com

Fig. 49 Tania Bruguera, Cátedra Arte de Conduta, Escola de Arte,

Cuba, 2002-2009. Fonte: taniabruguera.com

Fig. 50 Augusto Boal. Teatro do Oprimido.Paris, 1975. Fonte:

141

Cedoc-Funarte.

Fig. 51 Pawel Althamer, Congresso dos Desenhistas, exposição Os

Vizinhos, New Museum, New York, 2012. Fonte:

huffingtonpost.com.

Fig. 52 Mapas da investigação. Tatiana Fernández, fotografia

satelital Google Earth manipulada, 2013

Fig. 53 Estudantes em aula prática de desenho, possivelmente na

Escola de Arte e Design de Massachusetts, em Boston. 1908. Fonte: papergreat.com

Fig. 54 Tim Rollins + K.O.S. Fonte: barbarayontzatstac.com

Fig. 55 Tim Rollins + K.O.S. "As crianças de Lyman Place” Design

162 de Stephan Neuman e fotografia de Michael McKenzie, Cartaz para exposição no Bronx 1986. Fonte: gallery.98bowery.com

Fig. 56 Tim Rollins + K.O.S. "Workshop para Amerika IX," 1987. Mint Museum of Art, Charlotte, North Carolina. Fonte:

fryemuseum.org

Fig. 57 Imagem do livro Creative and Mental Growth de Viktor 163 Lowenfeld, 1947.

Fig. 58 Marco das práticas de investigação em artes visuais em Anexo relação aos domínios de pesquisa tradicionais segundo modelo de Sullivan (2010, p. 102)

Fig. 59 Anton Vidokle, Escola Noturna, 'Night School', New 166 Museum, New York. 2008 a 2009. Fonte: e-flux.com.

Figura 60 Marco do saber visual na prática transcognitiva segundo Anexo modelo de Sullivan (2010, p. 134).

IV

Figura 61 Marco dos contextos em que se dá a investigação visual Anexo em relação aos domínios de pesquisa tradicionais em base ao modelo IV de Sullivan (2010, p. 159).

Fig. 62 Thomas Hirschhorn. Cavermanman. Instalação, 'pensamentos bomba'. $5^{\circ}$ Carnegie International, Carnegie Museum of Art, Pittsburgh, 2002. Fontes: artnet.com; spainmolly.wordpress.com; flickr.com

Fig. 63 Máquinas para construir territórios, Tatiana Fernández, 177 fotografia satelital Mundo Novo, Minas Gerais, Brasil, Google Earth manipulada, 2015. 
Fig. 64 Página seguinte. Hélio Oiticica, Parangolé. Captura e edição de imagens que aparecem na no buscador de Google com a chamada de "Parangolé Hélio Oiticica", 2015.

Fig. 65 Lygia Clark Captura e edição de imagens que aparecem no buscador de Google com a chamada de "Lygia Clark objetos relacionais", 2015.

Fig. 66 Projeto Condigital MEC - MCT; Grupo de Trabalho de Produção de Conteúdos Digitais Educacionais da Secretaria de Educação do Estado da Bahia, A física e o cotidiano - Fique sabendo ! - A vida das estrelas ( Formação das estrelas).

Animação/simulação.

Fig. 67 Aline; Luma; Arlei; Cibele; Flávia, Água e óleo se misturam? Animação/simulação.

Fig. 68 Objetos de Aprendizagem e Banco Rived do Ministério de Educação. Fonte: rived.mec.gov.br

Fig. 69 Adolfo Gomes. O Nascimento de Vênus de Sandro Botticelli. 190 Animação. Frame da imagem de análise formal e simbólica da peça. CD interativo apresentado com o livro História da Arte de M. Alvaro, Madrid: Anaya, 2003. Fonte:www.ub.edu/histodidactica.

Fig. 70 Oliveira, Juliana Alves dos Santos; Saturnino, Joice; Moresi, 190 Claudina Maria Dutra; Sousa, Onice Maria de. Pigmento in Natura. Apresentação visual de um pigmento. 2011. Galeria Portal Pontociência. MEC. URL:

bjetoseducacionais2.mec.gov.br/handle/mec/24526. Banco Internacional de Objetos Educaionais, SEED, Brasil.

Fig. 71 Christiane Ávila, Gabi Moraes. Os Tr es Porquinhos. Escola 190 Games. Livro infantil com narração, texto e imagens que estimula a leitura. URL: escolagames.com.br/livros/osTresPorquinhos/

Fig. 72 Estúdio Casthalia, A Mansão de Quelícera, jogo interativo. Fonte: casthalia.com.br

Fig. 73. Estúdio Casthalia, A Mansão de Quelícera, jogo interativo. quebra-cabeça em base ao Retrato de Nicolas Kratzer de Hans Holbein. Fonte: casthalia.com.br

Fig. 74 Estúdio Casthalia, A Mansão de Quelícera, jogo interativo. Ícones dos desafios. Fonte: casthalia.com.br

Fig. 75 Estúdio Casthalia, A Mansão de Quelícera, jogo interativo. quebra-cabeça em base a Natureza Morta com Maçãs e Laranjas de Paul Cézanne onde o jogador deve organizar os elementos da mesa que correspondem aos elementos da obra na ordem do quadro original. Fonte: casthalia.com.br

Fig. 76 Tatiana Fernández. Art History Intervention: Gombrich "A História da Arte". Página inserida em livro da biblioteca entre páginas 610 e $611, \mathrm{~N}^{\circ}$ de chamada 7(09) G632s 16ed.=690L. UnB, Brasília, 2012. 
Fig. 77 Tatiana Fernández. Art History Intervention: Gombrich "A

História da Arte”. Página 610. UnB, Brasília, 2012.

Fig. 78 Tatiana Fernández. Art History Intervention: Gombrich “A

História da Arte". Página 611. UnB, Brasília, 2012.

Fig. 79 Ron van der Meer, The Kids' Art Pack, páginas pop-up.

Livro com atividades, e objetos Fonte: vjjoson.com/

Fig. 80 Cartaz para curso de extensão Objetos de Aprendizagem

Poéticos para sua segunda versão de 22 de março a 22 de maio.

Criação com apropriação de fragmento de fotografia da 'Caixa de dedo’ de Ay-O. 2014.

Fig. 81 Cartaz para curso de extensão Objetos de Aprendizagem

Poéticos para sua terceira versão de 30 de agosto a 30 de outubro.

Criação com apropriação de fragmento de fotografia da 'Kit do nome' do Fluxkit de 1965 de George Brecht, 2014.

Fig. 82 Tatiana Fernández. Carta 7, frente e verso. Jogo Enigma.

Objeto de Aprendizagem Poético. Curso de extensão OAP.

VIS/IdA/UnB, 2013-14.

Fig. 83 Curso de extensão Objetos de Aprendizagem Poéticos. aula

Pic-nic, UnB. 2013-2014. Fotografia Denise Munhoz e Tatiana Fernández

Fig. 84 Curso de extensão Objetos de Aprendizagem Poéticos, terceira versão, aula Pic-nic, UnB, 2014. Fotografia Tatiana Fernández.

Fig. 85 Página web Objetos de Aprendizagem Poéticos. Início e Capítulo 2. Tatiana Fernández, 2012.

Fig. 86 Participante ' $B$ ', OAP 'Imagens cegas' produzido no âmbito da primeira versão do curso de extensão Objetos de Aprendizagem Poéticos, VIS/IdA/UnB $2^{\circ}$ semestre de 2013. Still de vídeo.

Fig. 87 Tatiana Fernández e Participantes. História em Quadrinhos Controle de Danos' páginas 9 e 10. Objeto de Aprendizagem Poético. Curso de extensão de Objetos de Aprendizagem Poéticos, VIS/IDA/UnB, 1\%semestre 2014. Intervenção sobre conferências de Henry Giroux, William Pinar, Anton Vidokle e Gayatri Spivak com tradução livre, edição e adpatação de Tatiana Fernández com a participação dos cursistas estabelecendo um diálogo fictício e real ao mesmo tempo.

Fig. 88 Participante ' $Q$ '. Intervenção em carta 7. Jogo Enigma. Objeto de Aprendizagem Poético. Curso de extensão OAP. VIS/IdA/UnB, $1^{\circ}$ semestre 2014.

Fig. 89 Participante ' $F$ ' e participante ' $I$ 'Intervenção em carta 5 com imagem e texto. Jogo Enigma. Objeto de Aprendizagem Poético. Curso de extensão OAP. VIS/IdA/UnB, $1^{\circ}$ semestre 2014.

Fig. 90 Quadro de participantes no curso de extensão Objetos de 
Aprendizagem Poéticos nas três versões.

Fig. 91 Mundo Novo, Os Territórios Ocupados, Tatiana Fernández, 229 fotografia satelital Google Earth manipulada, 2014.

fig. 92 Diagrama de formatos de conversação a partir de Pablo 235 Helguera, 2011a, p. 45

Fig. 93 Quadro de Conversações do Fórum do Capítulo 1. Perguntas Anexo que surgem. $\mathrm{V}$

Fig. 94 Quadro de Conversações do Fórum do Capítulo 2. Explorando OAP.

Anexo

Fig. 95 Quadro de Conversações do Fórum do Capítulo 3. Desenvolvendo OAP. $\mathrm{V}$ Anexo $\mathrm{V}$

Fig. 96 Quadro de Conversações do Fórum do Capítulo 4. Anexo Desenvolvendo OAP. $\mathrm{V}$

Fig. 97 Mapa dos OA e OAP produzidos pelos participantes no Anexo âmbito do curso de extensão Objetos de Aprendizagem Poéticos nas VI três versões.

Fig. 98 Aula Pic Nic de apresentação de artefatos do curso de extensão 'Objetos de Aprendizagem Poéticos' no $1^{\circ}$ semestre de 2014, VIS/IdA/UnB.

Fig. 99 Mãos. Detalhes dos filmes produzidos nas três versões do curso de extensão Objetos de Aprendizagem Poéticos. Tatiana Fernández e Denise Munhoz. 2013-2014.

Fig. 100 Participante ' $N$ ' "Queres-quanto" jogo para aprender sobre

Cultura Popular para crianças do $4^{\circ}$ ano do Ensino Fundamental produzido no âmbito do curso de extensão 'Objetos de Aprendizagem Poéticos' no $1^{\circ}$ semestre de 2014, VIS/IdA/UnB. Fotografia do participante ' $N$ '.

Fig. 101 Detalhe dos desafios e O Arco Iris, poema de estudante/participante do OAP Queres Quanto?, 1-2014. Fotografia do participante ' $N$ '.

Fig. 102 Participante ' $T$ '. Identidades. Artefato para refletir sobre conceitos que se relacionam às identidades dirigido ao ensino médio, produzido no âmbito do curso de extensão 'Objetos de Aprendizagem Poéticos' no $2^{\circ}$ semestre de 2014, VIS/IdA/UnB.

Fig. 103. Livreto de perguntas e conceito fragmentado em transparências para discussão. 'Identidades', curso de extensão 'Objetos de Aprendizagem Poéticos' no $2^{\circ}$ semestre de 2014, VIS/IdA/UnB.

Fig. 104 Participante 'P'. Arte Popular Brasileira. Jogo Interativo para EJA a distância. Escolha e contagem dos acertos e erros. 
Produzido no âmbito do curso de extensão 'Objetos de Aprendizagem Poéticos' no $1^{\circ}$ semestre de 2014, VIS/IdA/UnB. 2014. Fonte: jogadenovo.com.

Fig. 105 Participante 'P'. Arte Popular Brasileira. Jogo Interativo para EJA a distância. Região Nordeste. Produzido no âmbito do curso de extensão 'Objetos de Aprendizagem Poéticos' no $1^{\circ}$ semestre de 2014, VIS/IdA/UnB. 2014. Fonte: jogadenovo.com. Fig. 106 Participante ' $P$ '. Arte Popular Brasileira. Jogo Interativo para EJA a distância. Região Centro- Oeste. produzido no âmbito do curso de extensão 'Objetos de Aprendizagem Poéticos' no $1^{\circ}$ semestre de 2014, VIS/IdA/UnB. 2014. Fonte: jogadenovo.com. Fig. 107 Participante ' $H$ '. Museu Interativo. Entrada e corredor. Jogo Interativo Power Point para ensino médio, produzido no âmbito do curso de extensão 'Objetos de Aprendizagem Poéticos' no $1^{\circ}$ semestre de 2014, VIS/IdA/UnB.

Fig. 108 Participante ' $H$ '. Museu Interativo. Jogo Interativo para ensino médio, produzido no âmbito do curso de extensão 'Objetos de Aprendizagem Poéticos' no $1^{\circ}$ semestre de 2014, VIS/IdA/UnB. Página de entrada à primeira tarefa.

Fig. 109 Participante ' $H$ '. Museu Interativo. Jogo Interativo para 263 ensino médio, produzido no âmbito do curso de extensão 'Objetos de Aprendizagem Poéticos' no $1^{\circ}$ semestre de 2014, VIS/IdA/UnB. Páginas das galerias.

Fig. 110 Participante ' $H$ '. Museu Interativo. Jogo Interativo para 264 ensino médio, produzido no âmbito do curso de extensão 'Objetos de Aprendizagem Poéticos' no $1^{\circ}$ semestre de 2014, VIS/IdA/UnB. Detalhe da galeria de arte egípcia.

Fig. 111 Participante 'I'. Estruturas. Jogo de peças geométricas em 268 papelão, produzido no âmbito do curso de extensão 'Objetos de Aprendizagem Poéticos' no $1^{\circ}$ semestre de 2014, VIS/IdA/UnB. Fig. 112 Participante ' $I$ '. Estruturas. Jogo de peças geométricas em papelão, produzido no âmbito do curso de extensão 'Objetos de Aprendizagem Poéticos' no $1^{\circ}$ semestre de 2014, VIS/IdA/UnB. Fig. 113 Participante ' $I$ '. Estruturas. Jogo de peças geométricas em papelão, produzido no âmbito do curso de extensão 'Objetos de Aprendizagem Poéticos' no $1^{\circ}$ semestre de 2014, VIS/IdA/UnB.

Fig. 114 Participante ' $G$ '. O Crítico de Arte. Jogo de cartas, produzido no âmbito do curso de extensão 'Objetos de Aprendizagem Poéticos' no $1^{\circ}$ semestre de 2014, VIS/IdA/UnB. Fotografia do participante autor.

Fig. 115 Participante ' $G$ ' O Crítico de Arte. Jogo de cartas, 
produzido no âmbito do curso de extensão 'Objetos de Aprendizagem Poéticos' no $1^{\circ}$ semestre de 2014, VIS/IdA/UnB. Fotografia do participante autor.

Fig. 116 Participante ' $F$ ' Missão Egito. Jogo de enigmas, produzido

no âmbito do curso de extensão 'Objetos de Aprendizagem Poéticos' no $1^{\circ}$ semestre de 2014, VIS/IdA/UnB.

Fig. 117 Página anterior. Participante 'F' Relação estabelecida pelo autor entre o alfabeto e os hieróglifos para descifrar os enigmas, curso de extensão 'Objetos de Aprendizagem Poéticos' no $1^{\circ}$ semestre de 2014, VIS/IdA/UnB.

Fig. 118 Marco de Investigação dos OAP, em base aos marcos de Anexo pesquisa de Sullivan. Curso de extensão Objetos de Aprendizagem VII Poéticos.

Fig. 119 Detalhe de Flash Mob Corpos que olham. Curso de 286 extensão Objetos de Aprendizagem Poéticos, IdA/VIS/UnB 1-2014. Fig. 120 Illimani recortado. Tatiana Fernández. Imagem de Google 300 Earth.

Fig. 121 Illimani de cabeça para abaixo. Tatiana Fernández. Imagem 301 de Google Earth. 2015. 


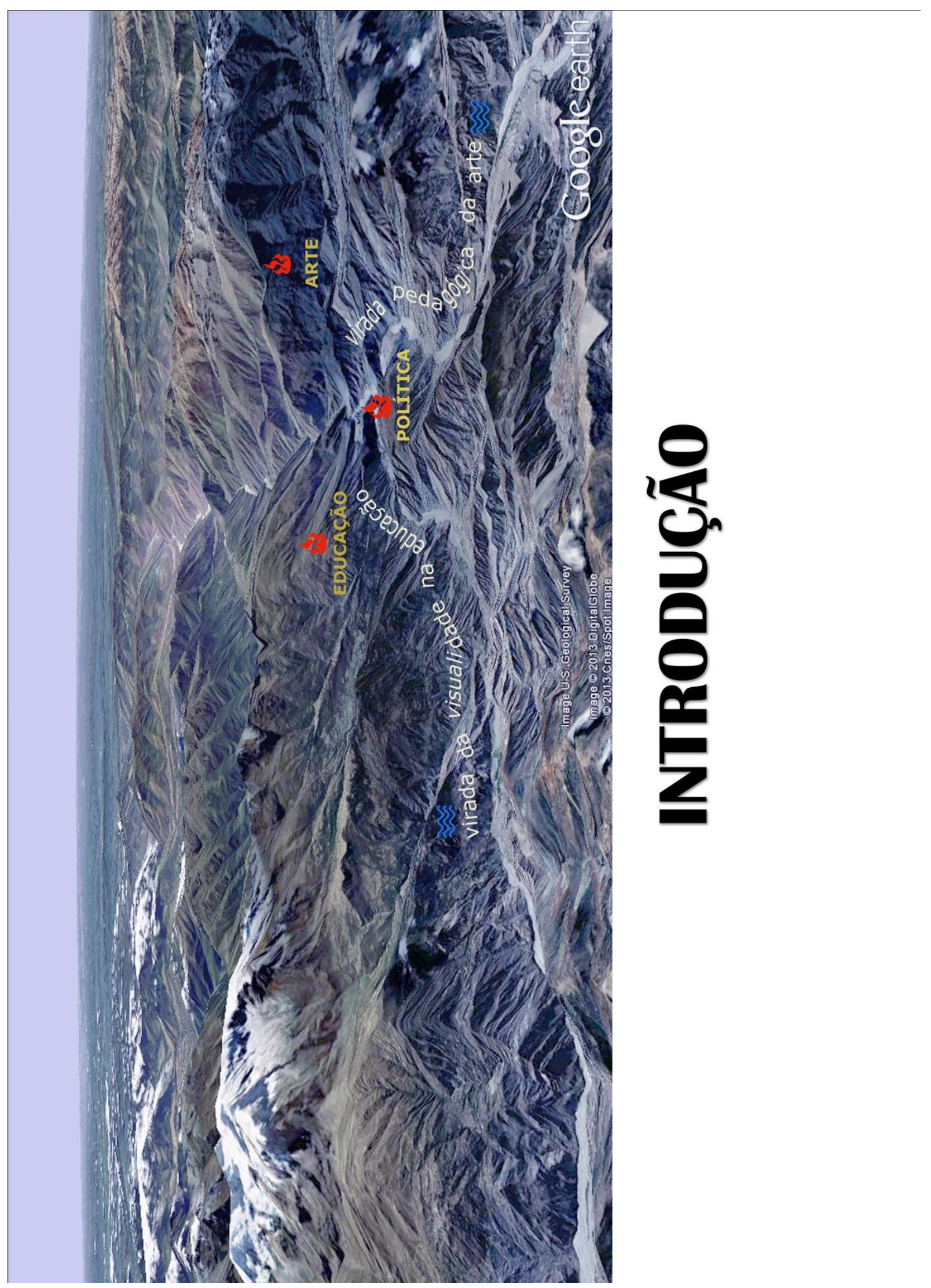

Fig. 1 Entre os Andes e Amazonas. Tatiana Fernández, Imagem satelital Google Earth manipulada, 2013 


\section{INTRODUÇÃO}

O espaço desta investigação situa-se nas justaposições que ocorrem nas últimas décadas entre a virada pedagógica da arte e a virada da visualidade na educação e cujas reverberações começam a ser estudadas por historiadores da arte, artistas e pesquisadores em educação. A virada pedagógica da arte está relacionada a uma compreensão cada vez maior da arte como investigação e seu papel na transformação social. A virada da visualidade na educação está relacionada ao crescente domínio do visual na construção do conhecimento e às relações entre poder e dominação/emancipação que têm implicações diretas sobre como concebemos e fazemos educação. Neste panorama o objeto de estudo são artefatos produzidos por artistas e educadores que concebem a arte como uma forma de pedagogia e a pedagogia como uma forma de arte.

Estas duas viradas ou mudanças paradigmáticas são parte das transformações culturais que vivemos na contemporaneidade. A virada da visualidade não é somente um fenômeno de proliferação de imagens e signos, esta transição é importante porque vai "de uma visão moderna do ver visual a uma visão pós-moderna do saber visual que reconduz a noção do olho inocente ao olho interpretativo, o olho que sabe" (SULLIVAN, 2010, p. 17, itálicas do autor). Na perspectiva desta investigação, esse foco sobre o "ver" não se restringe ao mecanismo óptico, o olho é antes uma metáfora para um corpo que vê por meio de múltiplos sentidos que atuam ao mesmo tempo e que constituem o que sabemos.

Todas estas mudanças conduzem à reflexão sobre como construímos o sentido das imagens e os eventos visuais. Até a modernidade se entendia que o significado estava contido na imagem ou no artefato de arte. A pós-modernidade se abre a outras variáveis contextuais que operam na construção do significado: o espectador se torna coautor, e o contexto o elemento fluido em que o significado transmuta. Na nossa era percebemos que as visualidades se tornam cruciais nas relações que estabelecemos com os conhecimentos e as verdades. $\mathrm{O}$ problema da verdade ou das verdades nesta investigação encontra suas bases nas ideias de Alain Badiou (2005): a verdade como uma relação com a realidade e não mais como uma mimese da realidade, veraz ou fatual.

Nestas bases analiso e problematizo a relação entre arte e educação no cruzamento das suas fronteiras para entender em que medida o evento pedagógico pode ser ao mesmo tempo um 
evento artístico ou de maneira reversa, em que medida o evento artístico pode ser ao mesmo tempo um evento pedagógico. Nesta linha se investiga como surgem as contaminações, interseções, hibridações, perversões, tramas e transmutações quando estes eventos coincidem e de que maneira a Educação em Visualidade indica e institui espaços que promovem eventos educacionais como experiências estéticas designadas aqui de pedagogias culturais.

As discussões que se desdobram destas reflexões se relacionam principalmente à área curricular e metodológica da Educação em Visualidade, mas se relacionam também com a filosofia da educação, os Estudos da Cultura Visual e as tendências contemporâneas na arte. Hoje não se pode discutir sobre as mudanças do papel da arte na educação sem afetar e ser afetado pela filosofia da educação, sem considerar as suas implicações nas transformações culturais e sociais em processo, nem o seu peso perturbador sobre o curso da arte, da estética e da sua historicidade. Portanto é uma investigação dirigida principalmente a educadores visuais $^{1}$ no Brasil em diálogo com artistas, educadores, filósofos, sociólogos, cientistas, agenciadores culturais, teóricos da arte, designers, ativistas e todos aqueles que se interessam pelas visualidades como forma de emancipação do pensamento dominado/colonizado ${ }^{2}$.

Nessa direção apontam-se bases conceituais e metodológicas que permitem distinguir o espaço de interseção entre as visualidades e as pedagogias contemporâneas e suas implicações políticas e culturais. Por uma parte a noção de arte participante no campo da arte e por outro das pedagogias culturais no campo da educação conduzem a uma coincidência nas relações entre política, estética e pedagogia. Esse ponto de coincidência é, como se argumenta, uma estratégia que responde ao contexto distinto e complexo da América Latina para Educação em Visualidade.

Os fundamentos metodológicos se encontram em duas bases. A primeira é a metodologia a/r/tografica ou metodologia de investigação do artista/investigador/professor. A a/r/tografia, que é uma forma de Investigação Baseada nas Artes (em diante IBA) ${ }^{3}$ e de Investigação Educacional Baseada nas Artes (em diante IEBA) integra a teoria, a práxis e a poética, reflete sobre as identidades em trânsito, indaga sobre a imaginação nos processos de construção de

\footnotetext{
${ }^{1}$ Neste estudo será usado o nome de educador em visualidade ao invés de arte educador para coincidir com as mudanças que uma Educação em Visualidade aborda. A denominação de professor/professora de arte será usado no caso de se tratar de uma narrativa no passado ou que se afirma em contexto tradicional.

${ }^{2} \mathrm{O}$ conceito de emancipação do pensamento dominado/colonizado procede das ideias de Simón Rodríguez e Jacques Ranciére, que se descrevem no capítulo IV e atravessa o sentido que se constrói nesta tese.

${ }^{3}$ Esta metodologia é conhecida como Pesquisa Baseada nas Artes (PBA) no Brasil mas neste estudo prefere-se usar 'investigação' ao invés de 'pesquisa' porque evidencia uma maior tendência a questões qualitativas do que quantitativas; uma maior ênfase sobre processos do que sobre produtos;um maior envolvimento com questionamentos do que com soluções e um maior interesse por questões diretamente relacionadas à vida e orientadas para a prática. (DIAS e IRWIN, 2013).
} 
conhecimento e favorece o que os a/r/tógrafos chamam de 'pesquisa viva' ou investigação relacionada à vida presente.

A segunda se refere à 'prática transcognitiva', cunhada por Graeme Sullivan (2010), que caracteriza as múltiplas formas em que os artistas investigam sobre o 'saber visual'. Essas formas de operar do artista se constroem de maneira situada, complexa e em diversos marcos, camadas e domínios. As práticas transcognitivas nos ampliam com maior precisão os alcances de uma IBA e uma IEBA e nos proporcionam ao mesmo tempo um marco teórico para analisar as relações entre evento artístico e evento pedagógico.

O primeiro capítulo aponta o espaço epistemológico para situar as fronteiras em que a arte e a pedagogia se encontram no contexto contemporâneo e sua relação com as viradas, os corpos e os saberes que permeiam esta busca. O que se procura é compreender os espaços de interseção entre o evento pedagógico e o evento artístico para uma Educação em Visualidade que, rompendo fronteiras artísticas e pedagógicas, promovam pedagogias culturais numa paisagem híbrida.

O segundo capítulo recorta o espaço da realidade relacionada com estes conhecimentos e com a minha trajetória como artista e professora de arte cujas dimensões proporcionam sentido a esta investigação. No contexto da América Latina e neste momento de transformações globais a emancipação do pensamento dominado/colonizado se torna um objetivo político, social e cultural de grande significação nas relações de poder que se debatem no mundo. Nesse contexto minha identidade de artista/investigadora/professora se apresenta como uma identidade em trânsito nos territórios de existência e resistência.

O terceiro capítulo é dedicado a análise e reflexão das dimensões de uma Educação em Visualidade que se institui como uma pedagogia cultural. Com este objetivo apontam-se as fronteiras que se cruzam na arte e na educação nas bases da pedagogia crítica e dos Estudos da Cultura Visual; desenha-se a paisagem curricular em fluxo que conduz á ideia de currere de William Pinar (2008) conceituada como a tensão entre um currículo in vivo e um currículo in vitro e discorre-se sobre os conceitos de experiência estética de John Dewey (2005) e de evento pedagógico de Dennis Atkinson (2011). Estes cruzamentos de fronteiras desenham e designam os espaços de interseção entre a arte, a educação e a política.

O quarto capítulo explora os movimentos da virada da visualidade na educação e da virada pedagógica na arte. Neste ponto contrastam-se estas duas viradas com as mudanças culturais, 
tecnológicas e políticas contemporâneas e relacionam-se nos seus aspectos éticos e estéticos. Os estudos da virada da visualidade de J.W.Thomas Mitchell (1995, 2005, 2009) e Nicholas Mirzoeff (2009) por uma parte e as noções de 'arte participante' de Claire Bishop (2006, 2012) por outra permitem situar a ideia de evento artístico como pedagogia. Identifica-se na virada da visualidade o curso das mudanças que levam à ideia de Educação em Visualidade e na virada pedagógica da arte o curso das mudanças que conduzem aos projetos pedagógicos que se multiplicaram nos últimos anos no âmbito artístico. Esses se estabelecem como artefatos que são ao mesmo tempo eventos artísticos e eventos pedagógicos na sua intencionalidade operacional e conceitual. Essas viradas constituem os mapas do encontro para pedagogias culturais.

No quinto capítulo se expõe o mapa da investigação começando pela metodologia de IBA e IEBA que privilegiam a imaginação como espaço da possibilidade do que ainda não é. Este estudo conduz, por outra parte, a uma indagação sobre a identidade de artista, investigador e professor e por este motivo requer também de uma abordagem que reflita sobre as contiguidades, hibridações e conflitos destas identidades que oferece a metodologia a/r/tográfica. Apresentam-se, neste capítulo, os fundamentos metodológicos para pensar o evento artístico como pedagogia e a investigação como artefato. Neste mapa de investigação também se apresentam as bases para a arte como forma de investigação em três das camadas que Sullivan identifica nas formas de operar dos artistas e que sobre os quais se analisam os produtos da investigação.

No sexto capítulo apresentam-se os Objetos de Aprendizagem Poéticos como máquinas para construir territórios de subjetivação, em base às ideias de Gilles Deleuze e Felix Guattari (2002, 2010) e como forma de apropriação da ideia de Objetos de Aprendizagem para conflitar seu sentido e significado na educação contemporânea. Apresentam-se assim, o curso de extensão Objetos de Aprendizagem Poéticos e seus participantes.

No sétimo capítulo analisam-se os territórios ocupados pelos participantes em base às conversações que aconteceram no curso de extensão e aos processos de singularização na investigação com os artefatos criados no curso de extensão. Nesse processo se identificam as contaminações, interseções, hibridações, perversões, tramas e transmutações que ocorrem no encontro das águas, entre a virada da visualidade na educação e a virada pedagógica na arte. Finalmente, sobre estes dados, identifica-se o que um Objeto de Aprendizagem Poético pode fazer, o que se produz com eles, que afetos formam esse tipo de artefatos e que afetos eles 
provocam. As análises dos dados coletados apontam às aperturas a processos estéticos com fins poéticos e pedagógicos como aperturas que permitem ampliar as relações entre arte, cultura, política e educação; aponta uma maior disposição para a pedagogia como uma forma de produção cultural e uma mudança nos professores de arte e artistas na forma de ser ver a si mesmo como criador, provocador e produtor de cultura e de pedagogias.

Os mapas da potência são as considerações finais que refletem sobre as possibilidades que se abrem no encontro das águas entre a duas viradas e as implicações no plano político, metodológico e existencial, a tempo de apontar os desafios que devemos navegar. 


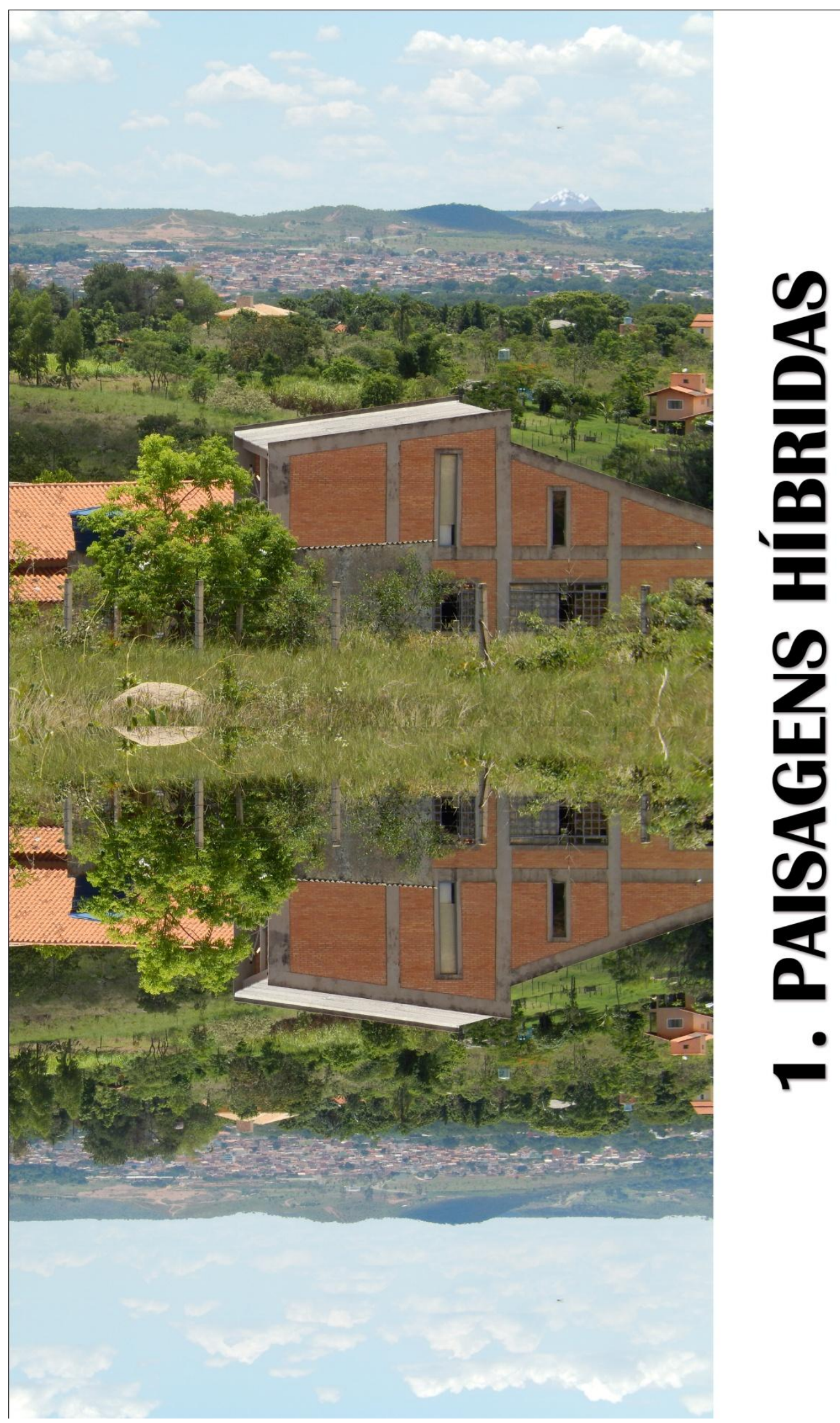

Fig. 2 Paisagens Híbridas: Brasília com montanha nevada Illimani. Tatiana Fernández. Montagem fotográfica, 2013 


\section{PAISAGENS HÍBRIDAS}

"Pensar não é nem um fio estendido entre um sujeito e um objeto, nem uma revolução de um em torno do outro. Pensar se faz antes na relação entre o território e a terra." (DELEUZE e GUATTARI, 2010, p. 110).

Eu sou de muitos lugares. Mas não esqueço quem estou sendo no movimento da paisagem. Meu corpo se fratura e se reconstrói em cada movimento, no entanto não deixo de ser quem eu sou. Eu sou com os outros. E a montanha me acompanha na paisagem mutante para eu lembrar da minha própria ausência. Minha geografia é feita de rugas, quebras, tensões e fluxos. Investigo para criar cartografias possíveis, para inventar novas formas de ser na paisagem híbrida. Meu território se situa nas tensões entre arte, educação e política, mas também entre outras fronteiras. Nas escuelitas de la libertad zapatistas (Chiapas, México) dizem, 'Bem vindo a território em rebeldia'. No mesmo espírito esta investigação recebe o leitor para ocupar um território híbrido, tenso, inquieto, em estado de rebeldia.

Da perspectiva que ocupa esta investigação, as tensões que ocorrem no encontro entre as práticas artísticas e pedagógicas contemporâneas não são fortuitas nem inertes. Provocam choques que na última década lançam atenção redobrada sobre a relação entre arte e educação por parte de artistas, educadores e teóricos da arte. Os sintomas mais visíveis são um maior número de publicações, estudos, experiências, seminários, e eventos artísticos que indagam sobre esta relação em espaços institucionais ou comunitários. A Educação em Visualidade se apresenta neste cenário como um espaço de interseção entre duas grandes mudanças paradigmáticas que se configuram nas transformações sociais do século XXI: a virada da visualidade na educação e a virada pedagógica da arte. Trata-se de um choque porque não é um encontro de conciliação, mas também não é um (des) encontro de práticas dicotômicas. É um encontro de águas onde a arte e a educação sofrem mutações ${ }^{4}$. Essas mutações requerem uma aproximação mais cuidadosa sobre o que ocorre nos espaços de interseção, contaminação e hibridação. Neste capítulo apresento as bases epistemológicas com as quais é possível abordar os espaços de conflito que se dão nas fronteiras, nas visualidades, nos corpos e nos saberes.

\footnotetext{
${ }^{4}$ Nesta investigação se entende a mutação como uma mudança irreversível das variáveis, portanto mais profunda do que uma 'mudança ou transformação' em base ao pensamento de Fritjof Capra (2001).
} 
Mas, antes disso é importante apresentar a noção de pedagogia do evento ${ }^{5}$, proposta por Atkinson (2012) que atravessa estas epistemologias. Ela está na raiz do que chamaremos neste estudo de evento pedagógico e se estende por igual à ideia de evento artístico. Atkinson entende o evento, na linha de Badiou (2002, 2005), como um distúrbio ou uma ruptura na forma de entender e atuar que provoca o que Badiou denomina um "procedimento da verdade" (ATKINSON, 2012, p. 9):

As situações são nada mais [...] do que multiplicidades puramente indiferentes [...] O relativismo cultural não pode ir além do argumento trivial de que existem situações diferentes. Não nos diz nada sobre o que, entre as diferenças, legitimamente interessa aos sujeitos. A estrutura das situações não entrega, em si mesma, nenhuma verdade. [...] Uma verdade é somente constituída pelo rompimento com a ordem que a suporta, nunca como seu efeito. Este tipo de ruptura que abre verdades eu tenho denominado de 'o evento'. (BADIOU, 2005, p. xii)

Atkinson afirma que os eventos precipitam a aprendizagem porque requerem novas relações, ou como pensava Dewey, novos "estados de existência" (ATKINSON, 2012, p. 9). Ele adverte que "é crucial entender que o evento não é a aprendizagem, mas o que acontece para precipitar a aprendizagem. Aquilo que é precipitado pode ser concebido em termos de um 'procedimento da verdade' que permanece fiel ao evento de aprendizagem" (Ibidem). A verdade, então, como uma relação com a realidade ou um procedimento que muda padrões de entendimento; não como uma veracidade fatual. Nesta perspectiva o evento pedagógico e o evento artístico não são verdades nem tratam de verdades, mas provocam procedimentos da verdade. Importante destacar que esta ideia de evento é oposta à ideia de evento como uma comemoração ou reunião organizada. Ao contrário, se refere a um acontecimento inesperado que nos atravessa e do qual aprendemos no processo por trazer uma ruptura com a rotina.

Se tratando de uma ruptura, um evento está, por uma parte, relacionado ao novo ${ }^{6}$, mas também ao inesperado, àquilo que não pode ser calculado ou ao indesejável. Um evento, por outra parte, acontece em uma dada situação, mas não pertence a ela já que um evento só se manifesta como uma perturbação que ainda não se compreende. Um evento não pode se recortar porque está encadeado a outros eventos. Nessa perspectiva uma pedagogia do evento tem o poder de ativar uma aprendizagem real porque sendo algo que perturba uma situação

\footnotetext{
${ }^{5}$ Atkinson também chama-a de pedagogia contra o estado ou anti-pedagogia porque irrompe a normatização na educação com uma pedagogia que procura o assombro do novo, uma pedagogia do desconhecido.

${ }^{6}$ Em concordância com o pensamento de Badiou (2005), 'novo' se entende aqui como uma forma de ver o mundo como se fosse pela primeira vez.
} 
corrente ou interrompe uma repetição pode conduzir a uma nova situação existencial. $\mathrm{O}$ sujeito, pensa Badiou, passa a ter existência através do evento (2005). É isto que Atkinson chama de "um movimento em direção a um novo estado ontológico" (2005, p. 9) ou um novo estado do ser. O evento pedagógico e o evento artístico são perturbações e rupturas que conduzem ao desconhecido, ao inesperado, àquilo que nos faz ver as coisas como se fosse pela primeira vez.

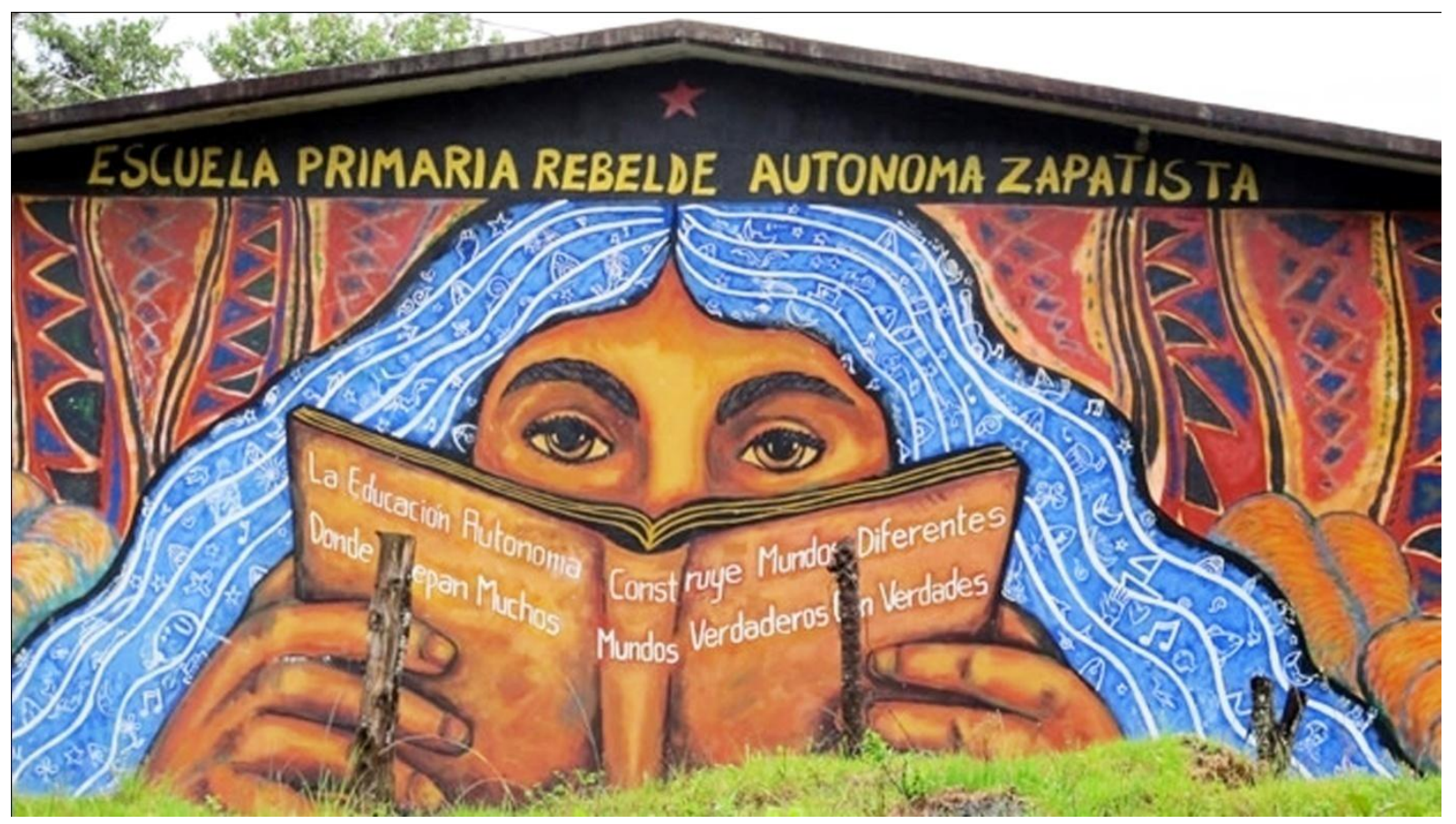

Fig. 3 Escola Primaria Rebelde Autônoma Zapatista de Los Altos de Chiapas Sistema Educativo Rebelde Autônomo Zapatista de Liberação Nacional - Chiapas, México. Fonte: enredando.org.

Assim, o argumento central se apoia na ideia de que o evento pedagógico e o evento artístico são eventos culturais e políticos porque participam da dinâmica do poder social de representação e produção de visualidades (Figuras 3 e 4). Nesses processos surgem questionamentos sobre as metáforas de dominação e colonização modernas que, através da educação, se centram na transmissão, assimilação de valores e adaptação social ao sistema, e que, através da arte, perpetuaram concepções dicotômicas, hegemônicas e monolíticas de cultura. $\mathrm{O}$ encontro entre o evento pedagógico e o evento artístico se move na metáfora da construção que envolve fazer e produzir. Fazer estabelece uma relação com a matéria e com o ambiente e determina uma relação social que está sujeita a uma vontade, portanto é criativa. A produção, diferentemente, deixa espaço ao emergente, ao que ainda não é e que foge de uma vontade ou da previsão (portanto não é criativa). Esta dupla condição é para jan jagodzinski e 
Jason Wallin (2013) práxis e poiesis: na concepção grega "práxis (prattein) se refere ao ato de fazer ou ao poder expressivo da vontade." (p. 85). Já a poiesis se refere à 'pro-dução' (poiein) que é "debelar a verdade sem alguma conexão com considerações práticas ou intento voluntário" (Ibidem). Eles nos lembram que produzir é provocar uma transformação de algo que vai do que é ao campo virtual do que pode ser.

Os procedimentos da verdade "se constroem sobre eventos que acontecem em situações particulares" pensa Atkinson (2012, p. 9). A pedagogia do evento procura dar espaço a procedimentos da verdade na aprendizagem, isto é, dar espaço ao imprevisível. Este tipo de pedagogia nas artes visuais não pode se situar no discurso de reprodução social e cultural que procura ensinar valores e formas estabelecidas, nem pode se situar no discurso crítico que procura ensinar ferramentas para questionar estes valores e formas, pois enquanto estes partem da ideia de que o estudante "não pode pensar por si mesmo" (Idem, p. 41) não haverá espaço para a produção, ou poiese. Para uma pedagogia do evento é importante que exista espaço para personalizar o conhecimento construindo novas formas,

[...] novas orientações ontológicas frente à aprendizagem. Aqui a verdade da aprendizagem não se consegue por meio de formas de conhecimento e prática existentes (reprodutivas ou críticas), mas por meio da sua fratura e da formação e reconfiguração do conhecimento e prática em contextos locais. (Ibidem)

Podemos pensar da mesma maneira em quanto ao evento artístico. A verdade da arte não mais nas formas e práticas existentes, mas na sua fratura e sua reconfiguração em contextos locais.

Para articular este argumento é necessário questionar as concepções que instrumentalizam a arte e a educação na lógica do dominador/colonizador. Por este motivo não pode ser uma investigação politicamente neutra. Isto porque investigar os espaços de contiguidade, proximidade e hibridação entre arte e educação revela muito mais do que transformações no ensino da arte: conduzem a uma ressignificação da arte e da educação na vida das pessoas e das comunidades. É uma mudança cultural e política de grandes dimensões que muitos teóricos da educação, da arte e da cultura observam há mais de três décadas. E em todos os campos de conhecimento há um maior interesse pela arte e pela educação quanto mais intensa é a luta pelo poder social. Sendo estes espaços de vital importância nas relações de poder e dominação/emancipação o lugar deste estudo se assenta em duas tríades: arte/educação/política (poética, práxis e teoria) como espaço de prática transcognitiva e de experiência estética e artista/investigador/professor como subjetivações em fluxo capazes de 
produzir o que Gayatri Spivak (2012) identifica como performances epistemológicas alternativas. Isto significa uma mudança na forma como construímos os objetos de conhecimento e como nos relacionamos com eles, e isto inclui como construímos o 'outro'. Trata-se, como aponta ela, de um reordenamento dos desejos que mudam padrões de entendimento. Dessa maneira indagar sobre as identidades em fluxo e hibridação é vital para compreender os fundamentos epistemológicos.

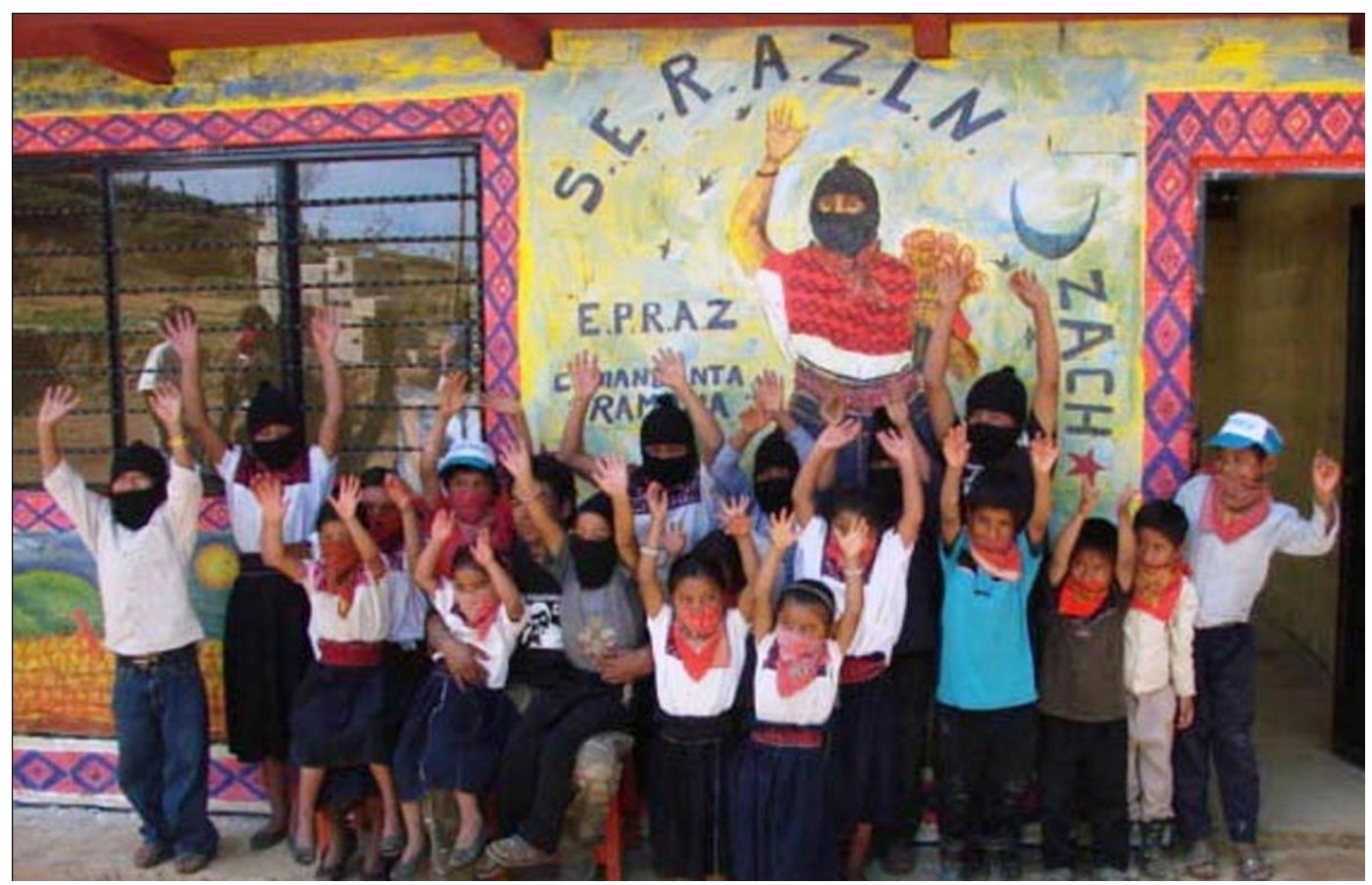

Fig. 4 Escola Primaria Rebelde Autônoma Zapatista Comandanta Ramona. Sistema Educativo Rebelde Autônomo Zapatista de Liberação Nacional - Chiapas, México. Fonte: caminatuspensamientos.blogspot.com

Minha situação como 'eu com os outros' na paisagem híbrida, que configura o contexto deste estudo, exige relações antes que definições. As definições não bastam, o que importa é o que posso ver, fazer ou ser com isso. É necessário estabelecer relações antes que apontar definições porque não se trata exclusivamente, ou principalmente, de produzir conhecimento, mas como destaca Sullivan a respeito da visão dos povos indígenas "o importante é se relacionar com o conhecimento" (2010, p. 172). Esta visão é análoga à ideia do "procedimento da verdade" de Badiou porque situa o conhecimento em relação a uma situação particular.

Seguindo a linha de Badiou (2005) encontramos que sendo a verdade uma relação com a realidade e, portanto, em constante fluxo, não podemos considerar o conhecimento como uma entidade pré-existente, mas como uma relação em que saber para quem, para que e em relação 
ao quê é crucial. Ele observa que o conhecimento é o que repetimos e isto não traz nenhuma verdade porque se limita ao que já se sabe, o evento sendo o novo, o imprevisto ou o surpreendente cria rachaduras por onde emergem as verdades. A verdade está desta maneira ligada aos eventos que mudam nossa vida. Mas o problema da verdade é sua aparência, ela está sempre em fluxo, não se fixa, por este motivo a verdade deve ser compreendida como um processo na realidade que é também um processo de subjetivação. Assim nesta investigação a relação entre o evento pedagógico e o evento artístico é uma relação de potência transformadora porque procura o sentido "para alguém, para algo em relação ao outro".

Nessas bases, as fronteiras, visualidades, corpos e saberes formam uma paisagem híbrida atravessada pelos eventos.

\subsection{As fronteiras}

Uma pedagogia que procura saber "para quem, para que e em relação ao que", que não se funda em dicotomias, mas na complexidade de relações que se estabelecem no fluxo da realidade, requer de uma filosofia de associações e relações antes que de distinções (DEWEY, 1929, 2005). Essa forma de filosofia se inscreve naquilo que Walter Mignolo chama de 'pensamento de fronteira' porque se situa na tensão das fronteiras/limites/bordas onde se pensa em conceitos dicotômicos antes que no ordenamento do mundo em dicotomias (MIGNOLO, 2012). Mignolo localiza este pensamento de fronteira nos limites do sistema moderno/colonial que para ele são dois lados da mesma moeda. A colonização é constitutiva da modernidade, argumenta ele, e o percurso desta história é um percurso que deve ser pensado nas suas dicotomias. Um pensamento de fronteira é capaz então de se articular e relacionar nos espaços em que as coisas são uma $e$ outra, não uma $o u$ outra.

A pedagogia cultural articulada por Henry Giroux, que ele também chama de pedagogia de fronteira (TREND, 1992; WEINER, 2001; GIROUX, 2005; 2011; 2012), vê a prática educativa como uma forma de produção política e cultural que responde às preocupações contemporâneas implicadas na visão ampliada do papel da arte na educação, que vive na tensão com as manifestações, produtos e fenômenos da cultura visual. No âmbito acadêmico nasce de duas linhas de estudo independentes, dos estudos culturais e da pedagoga crítica. Ambas convergiram nas últimas duas décadas no interesse pela práxis transformadora, que indaga sobre as relações entre poder e conhecimento e pelo esforço em relacionar as teorias e 
práticas pedagógicas à produção cultural. A pedagogia crítica por uma parte, se forma nos Estados Unidos e no Canadá na década de 1970 sob influência de "Pedagogia do Oprimido" de Paulo Freire (ver KINCHELOE, 2008).

Os estudos culturais, por outra parte, surgem na Inglaterra com o Centre for Contemporary Cultural Studies da Universidade de Birmingham em 1964 com Richard Hoggart e Stuart Hall onde a cultura se compreende não só como um conjunto de práticas e tradições sociais, mas principalmente como o lugar em que as relações de poder e emancipação se debatem porque incluem questões de identidade e diferença, justiça social, colonialismo, ecologia e paz, tecnologia e mídia. Giroux reúne as ideias da pedagoga crítica e dos estudos culturais na pedagogia cultural (WEINER, 2001) no interesse político pela relação entre cultura e educação. A esses interesses se somam os recentes Estudos da Cultura Visual, os estudos feministas, pós-coloniais, de mídia, o pós-estruturalismo, a teoria queer e a pedagogia póscritica. Essas propostas provocam perturbações que remapeiam as relações entre arte, educação e política. As pedagogias culturais se inserem nesta perspectiva, como aquelas que se dão na tensão das fronteiras e que mantém uma dinâmica fluida entre pedagogia e cultura. Ao final, se trata de compreender a pedagogia como uma forma de produção cultural e a produção cultural como uma forma de pedagogia.

Na Educação em Visualidade, as pedagogias culturais pós-críticas reivindicam epistemologias que abordem outros artefatos, processos, eventos e fenômenos da visualidade, além dos estritamente artísticos. Na minha perspectiva há dois motivos importantes. Por uma parte os processos artísticos contemporâneos constroem relações estreitas com os artefatos, eventos e fenômenos cotidianos e extraordinários em diversas camadas e dimensões: se os artistas trabalham sobre a visualidade o ensino da arte na escola não poderia excluí-lo. Mas, não basta só incluir artefatos da cultura visual, da cultura de massas ou da cultura popular na mesma estrutura curricular e metodológica dos sistemas educativos. É antes uma ruptura com estas estruturas para instituir práticas curriculares e metodológicas que se atrevam a traspassar fronteiras inscritas na cultura, na sociedade, na história, na psique, no corpo e no espaço (GIROUX, 2005; 2011; 2012) como se propõem as pedagogias de fronteira. É importante então traspassar as fronteiras da arte para traspassar as fronteiras culturais.

Esta investigação procura o lugar de cruzamento entre as visualidades a pedagogia e a política onde é possível criar aquilo que Guattari chama de "uma revolução molecular" (1995, p. 133) porque propõe-se, como veremos, rachaduras na ordem das coisas que levam a 
transformações. Num contexto em que a arte é só uma parte das visualidades culturais esta investigação se adere assim à nomenclatura de Educação em Visualidade para se referir ao que Belidson Dias $(2011,2012)$ chama de campo ampliado da Educação em Artes Visuais.

É nesse campo ampliado que os encontros acontecem e onde as pedagogias culturais encontram solo fértil. Dessa maneira, as bases epistemológicas do estudo se encontram nas pedagogias culturais com foco sobre a Educação em Visualidade, em movimento nas fronteiras.

\subsection{As viradas}

Com o surgimento da fotografia e mais tarde o cinematógrafo os artistas foram perdendo o poderoso monopólio das imagens que tiveram durante muitos séculos. Hoje todos podem fazer imagens. Mas hoje não basta o poder de produzir imagens. No amanhecer do século XXI um evento em particular marcou a era do domínio das visualidades sobre a arte. A queda das Torres Gêmeas em setembro de 2001 condensa não só o poder de fazer imagens, mas o poder de maximizar seu impacto sobre nossas vidas (Fig. 5). Naquele evento cruzamos alguma fronteira. Embora a proliferação de imagens, a estetização do mundo, a guerra de signos contra signos, o simulacro e o espetáculo já eram uma realidade de décadas ${ }^{7}$ (DEBORD, 1997; BAUDRILLARD, 1991a, 1991b) esse evento é sua epítome e sua criatura. W.J.T. Mitchel (1995) aponta a virada da visualidade vários anos antes, relacionada aos questionamentos sobre o olhar, aos fenômenos de vigilância óptica, à visualização do conflito e seu papel nas relações entre poder e emancipação (MITCHELL, 1995, 2005; FOUCAULT, 2008). Depois de setembro de 2001 estes questionamentos se tornam cruciais.

A construção das visualidades passa também por ferramentas que permitem construir territórios de subjetivação, o poder de configurar e reconfigurar imagens está diretamente relacionado a estes processos de subjetivação como evidenciam as redes sociais. A manipulação imagética é cada vez mais acessível a todos e toda relação social e laboral começa se estabelecer com interfaces que se articulam na visualidade, que a tecnologia da imagem permite, proporcionando um poder de agencia sem precedentes na história (SANTAELLA e NOTH, 2001). Este é um tempo em que podemos 'imprimir' uma figura tridimensional. A esta facilidade crescente para criar, editar e divulgar imagens e artefatos,

\footnotetext{
${ }^{7} \mathrm{O}$ ataque ao WTC não poderia ter sido concebido sem e o cinema espetacular de Hollywood.
} 
ver e ser visto, se soma uma maior demanda no mercado profissional de conhecimentos culturais, estéticos, artísticos e visuais e um maior trânsito entre diversos conhecimentos que se articulam ao redor dos fenômenos das imagens e das visualidades. Por outra parte o inerente caráter político das visualidades (RANCIÈRE, 2005, 2007; MITCHELL, 2005, 2009) apontam a necessidade de reinventar práticas sociais e institucionais como a educação, capazes de responder ao paradigma ético-estético que se configura na complexidade do nosso tempo (GUATTARI, 1995).

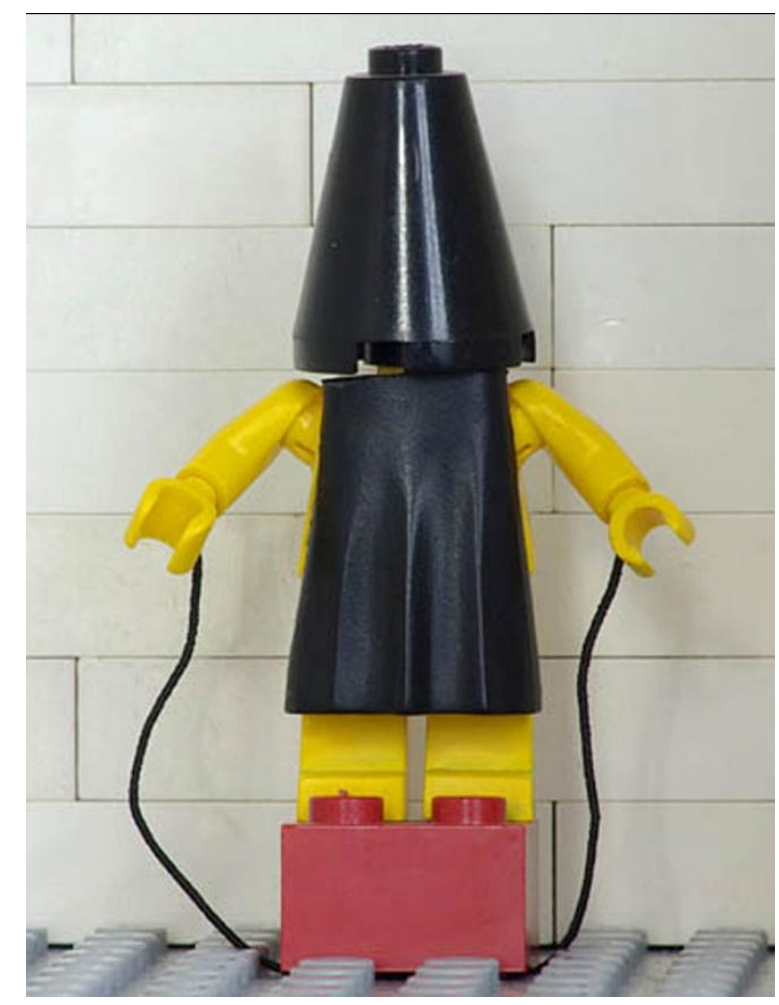

Fig. 5 Legofesto. Fantasmas de Abu Ghraib. Museu da Psiquiatria, Ghent, Bélgica, 2013-2014. Fonte: legofesto.blogspot.com,br

Como a recente historiografia tem nos ensinado, a visualidade se torna um espaço de significação que confere maior poder de agência e transformação. A condição viral da fotografia e do vídeo nas redes sociais, por exemplo, não encontra o limite imposto pela língua. A facilidade para capturar imagens e manipulá-las com interfaces visuais ${ }^{8}$ populariza a criação imagética e oferece com isto um espaço de ruptura e emancipação que é o espaço da subjetivação. O espaço da visualidade é, no entanto, e pelos mesmos motivos, o espaço da

\footnotetext{
${ }^{8}$ Interfaces visuais são os elementos gráficos e estéticos cuja finalidade é facilitar a comunicação entre ser humano e máquina, portanto se refere tanto á aparência gráfica como a sua estrutura interativa.
} 
dominação e da colonização do pensamento. Não é suficiente, então, a facilidade de produzir e publicar imagens, é necessário dialogar com elas. A experiência estética da arte pode ter esse poder de diálogo, mas existem muitas outras forças visuais que entraram em jogo na contemporaneidade.

Esse domínio da visualidade, que Mitchell (1995) cunhou como pictorial turn, aqui se traduz como virada da visualidade (ou virada imagética). Para ele, essa virada é a "redescoberta do visual como uma interação complexa entre aparatos da visualidade, instituições, corpos discursivos e figuração" (MITCHELL, 1995, p. 16). A visualidade emerge como um paradigma nas discussões centrais e críticas das ciências humanas, mas para Mitchell a preocupação cada vez maior para defender a centralidade do discurso frente à visualidade é um dos sinais mais claros de que existe uma virada da visualidade. Hoje o pós-estruturalismo, os movimentos feministas, os estudos pós-coloniais e os Estudos da Cultura Visual aprofundam as reflexões em torno da virada da visualidade como uma mudança nas relações de poder. Esta mudança por sua vez afeta a maneira como construímos o conhecimento e isto significa que deve haver uma mudança nas formas de aprender e ensinar. O que está em jogo é a ressignificação e reapropriação da subjetividade para uma emancipação do pensamento dominado na educação (RODRÍGUEZ, 1990, 2008; RANCIÈRE, 2002, 2010a), onde o estudante se emancipa do seu papel imitativo e passa a ser um produtor (poiese). Mas também nas relações que se estabelecem entre artista e espectador, onde este último se emancipa do seu papel contemplativo e passa a ser um participante (RANCIÈRE, 2011).

Na procura por coincidências entre o evento artístico e o evento pedagógico a noção de virada da visualidade oferece uma maior incidência crítica sobre os fenômenos culturais e artísticos na sociedade porque reflete sobre a imagem e a mídia e não separa o evento do espectador nem do contexto. Podemos identificar a origem destas transformações na aparição da fotografia no espaço moderno/colonial em que o regime representacional da arte se vê desafiado com a reprodutibilidade técnica da imagem (ver RANCIÉRE, 2005, 2009a, 2009b). A perda da aura da obra de arte $^{9}$, que é um processo de dessacralização do objeto da arte, como observou Walter Benjamin (1987, p. 172) conduz os artistas a incursionarem na práxis política. Para Rancière este é o regime estético da arte que se debate na tensão entre a autonomia e a heteronímia dos seus propósitos, entre a sua independência e sua função social. Nesse sentido Rancière aponta a estreita relação entre política e estética já no espaço

\footnotetext{
${ }^{9}$ A aura da obra de arte de Walter Benjamin se refere ao valor sagrado e ritualístico dos artefatos artísticos do regime representacional da arte.
} 
moderno/colonial. No nosso tempo já não estamos mais desafiando um regime representacional, mas a própria ideia da fronteira entre imagem e realidade. No atual domínio das visualidades estas fronteiras se pervertem, se contaminam e se permeiam. Agora se trata de como nos relacionamos com estas imagens em um mundo em que nós nos tornamos a imagem.

No cenário contemporâneo a crescente transculturalização ${ }^{10}$ (ORTIZ, 1983) que acontece no mundo se converte em um desafio para as velhas noções monolíticas e hegemônicas de arte que destilaram no impasse entre a modernidade e a colonização e que se alastram até hoje nas salas de aula, mas também entre artistas e instituições de arte. De outro lado cresce também o entendimento da arte como uma prática autopoiética ou de reconstrução do ser individual e social. Estas transformações não são homogêneas nem instantâneas e afetam de modos diversos as diferentes sociedades e suas práticas estéticas. A arte é um território extremamente complexo que envolve práticas culturais, valores e visões do mundo. A instabilidade conceitual é inerente à arte por muito que possamos incluir nela todas as formas em que é abordada. Não só a sua prática é diversa, mas seu sentido também é amplo, arte é a qualidade do fazer e daquilo que é feito. Quando é visto externamente é substantivo e quando se refere à maneira e ao conteúdo do fazer é um adjetivo (DEWEY, [1934] 2005), portanto pode ter o valor de sujeito, predicado ou complemento. Se nos atrevemos a procurar algo que seja comum às diversas práticas artísticas poderíamos dizer que a arte é uma forma que as culturas têm de se reconstruir, de estabelecer o que Guattari (1995) chama de 'territórios existenciais'. Aprender, criar e produzir são neste caso junções transversais de um mesmo ato. A arte é, devido à sua intenção estética, uma forma de apreender o mundo, mas também de reconstruílo.

Humberto Maturana e Fernando Varela (1995) reconhecem, na teoria da autopoiese ${ }^{11}$ esta mesma dinâmica na estrutura dos organismos vivos: vivemos porque aprendemos e nesse processo nos reconstruímos. O que nos caracteriza como humanos, no entanto, é a capacidade de estender o processo autopoiético à linguagem no esforço por ressignificar o ato de viver. Nessa perspectiva, a arte é uma forma de aprendizagem, ou como prefere Dewey, uma forma de crescimento. Sendo assim podemos falar também de uma virada pedagógica da arte.

\footnotetext{
${ }^{10}$ Termo usado por Fernando Ortiz para compreender o fenômeno dos atravessamentos culturais na América Latina.

11 Autopoiese é o termo usado por Maturara e Varela para definir o sistema dos seres vivos como um sistema de autoprodução biológica.
} 


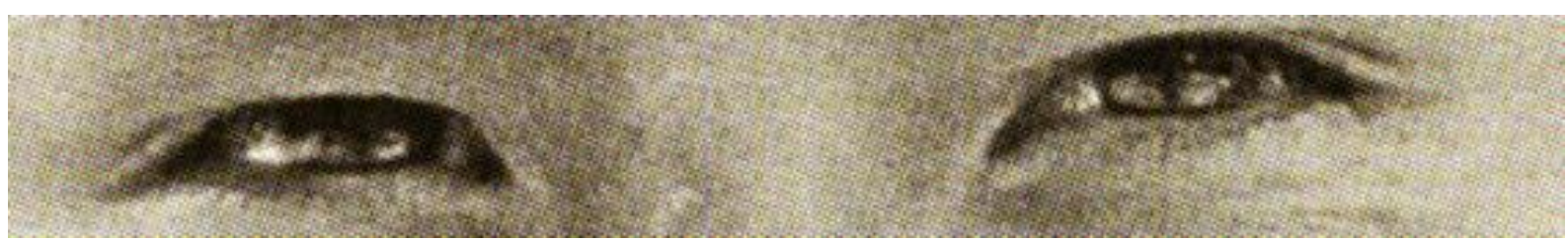

Fig. 6 Olhos. Tatiana Fernández. fotografia digita manipulada.

Pensar a pedagogia como uma forma de arte não é novo e essa relação se estabelece em múltiplas dimensões porque sendo a prática da arte tão diversa e seu sentido tão amplo podemos encontrar muitas relações. Nesta investigação, o interesse se centra nas experiências que estabelecem relações entre arte, educação e política.

$\mathrm{Na}$ transição entre a modernidade e a pós-modernidade, artistas como Joseph Beuys (Figuras 11, 38 e 39), John Cage e Robert Filliou (Figuras 33 e 34) do grupo Fluxus estabeleceram práticas artísticas que eram ao mesmo tempo práticas pedagógicas e políticas. Da mesma maneira o artista conceitualista uruguaio Luis Camnitzer (2009a) (Fig. 30) vê relações transversais entre arte, educação e política na arte conceitualista da América Latina, inclusive estabelecendo aproximações entre as estratégias estéticas dos guerrilheiros uruguaios Tupamaros (Fig. 7) e as estratégias políticas que usaram os artistas de Tucumán Arde (1968) (LONGONI, 2014) (Fig. 8). A obra de Cildo Meirelles, Lygia Clark (Fig. 65), Hélio Oiticica (Fig. 64), León Ferrari e Marta Minujin, entre outros artistas latino americanos, destaca Camnitzer, questionaram as instituições e o sistema da arte, da mesma maneira que, na pedagogia, Freire promovera uma forma de ensino "desinstitucionalizado" e "desmaterializado" (CAMNITZER, 2009a, p. 147). Nessa linha pedagógica Rodríguez e Francisco Julião ${ }^{12}$ são referência para Camnitzer.

Na última década diversos artistas desenvolvem de maneira coletiva e engajada trabalhos que diluem as fronteiras entre arte e educação com artefatos que ocupam instituições educativas ou que se envolvem de maneira relacional com seu público, como por exemplo Pawel Althamer (Fig. 9), Liam Gillick ou Rainer Ganahal, ou que envolvem a comunidade educativa em eventos artísticos, como o trabalho de Tim Rollins, ou a Bienal do Mercosul no Brasil, ou que formam escolas de arte concebidas como artefato de arte como a escola Cátedra de Arte de Conduta realizada em Cuba por Tania Bruguera (Fig. 49). Destacam-se também iniciativas educativas que são consideradas eventos de arte como os projetos Academy de Irit Rogoff e Summit nos Paises Baixos, as universidades livres que surgiram em 2001 como a Copenhagen

\footnotetext{
${ }^{12}$ Líder das Ligas Camponesas da década de 1950 no Brasil, anterior ao Movimento dos Sem Terra, MST.
} 
Free University -CFU que procuravam o debate e produção de processos comunitários de conhecimento enfatizando sobre áreas negligenciadas pelas instituições acadêmicas cada vez mais dirigidas ao serviço da indústria corporativista. Estes artistas reconhecem a natureza ideológica do conhecimento e promovem uma pesquisa politizada e socializada que não encontra espaço nas instituições acadêmicas tradicionais. O privilégio do artista de ser o único que atribui sentido à obra e às práticas interpretativas modernas que viam o significado contido dentro da obra perdem sentido no contexto de uma cultura cada vez mais líquida (BAUMAN, 2006), complexa, espetacular e tecnológica.

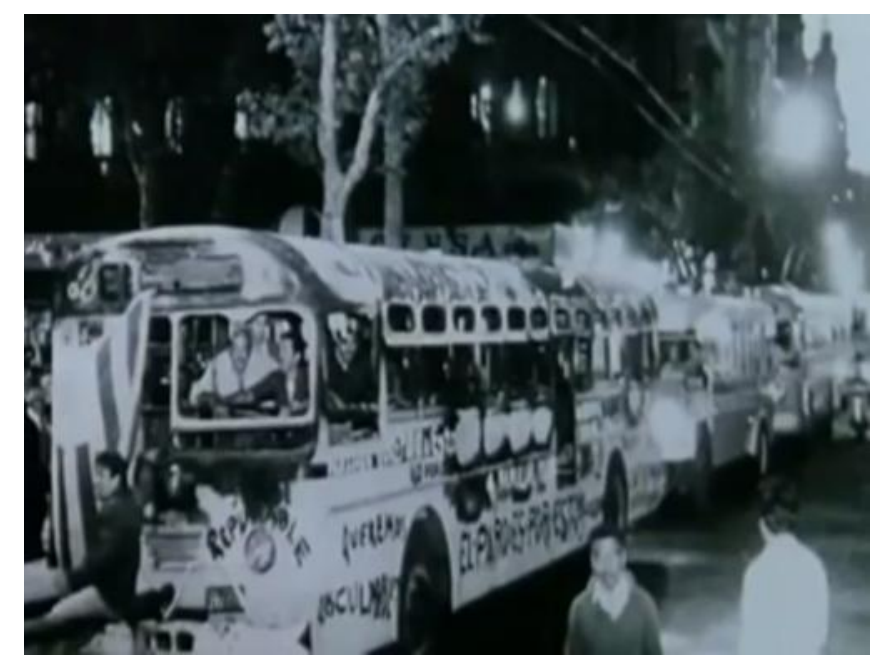

Fig. 7 Heidi Specogna e Rainier Hoffmann. Tupamaros. (Still Image) Produções Del Cerro. Filme 1:34:51. 1996. Fonte: Uruguay Para Siempre, youtube.com.

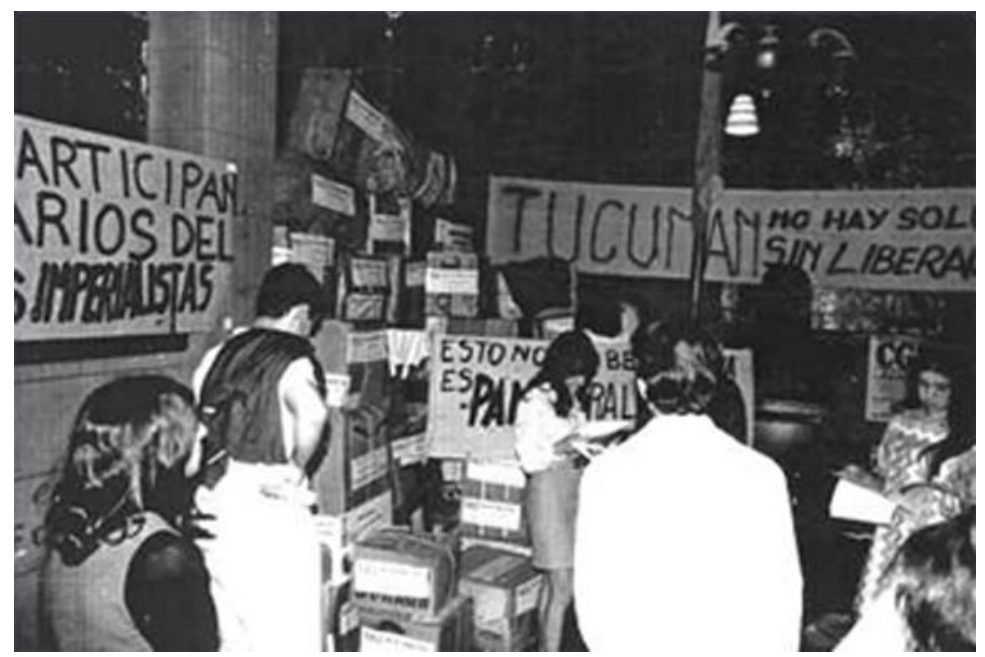

Fig. 8 Tucumán Arde. Ação. Tucumán, Argentina, 1968. Fonte: rosariarte.com.ar.

Nicolas Bourriaud (2009) considera o trabalho de alguns destes artistas como uma estética das interações humanas e seu contexto social que ele chama de 'Estética Relacional'. Nessa visão 
a arte acontece no processo de uma interação onde o sentido é dado nas relações que se estabelecem entre os sujeitos e os objetos, e principalmente no diálogo entre os artistas e os espectadores, que neste caso se transformam em participantes, coautores ou mesmo autores. É uma construção que adquire sentido porque é coletiva antes que privada. Mas é importante observar que na velocidade das mudanças culturais as relações humanas se tornam mais complexas, diversas e fluídas o que aponta uma maior complexidade nos processos de subjetivação.

Já Claire Bishop (2012) prefere ver estes artefatos como propostas criativas de participação politizadas que chama de arte participante ${ }^{13}$ onde as pessoas constituem o meio artístico e material principal. Nesta perspectiva o artista, aponta Bishop, se concebe como um colaborador e produtor de situações, concebe os artefatos de arte como projetos em processo sem um começo ou final delimitado e pensa o público como um coprodutor ou participante. Nessa tendência Bishop identifica um "retorno ao social da arte" e adverte que, para não cair na ambiguidade com que o discurso da arte socialmente engajada pode servir ao programa neoliberal para fortalecer as relações de poder e dominação, é necessário acentuar o caráter estético da experiência e sua singularidade. Esta investigação se inscreve na visão de Bishop, de arte participante, porque não se trata, como é para Bourriaud, de criar espaços de relacionamento (porque retorna à posição de dominação, de quem dá a quem não é capaz de tomar por si), mas de se relacionar com os participantes como singularidades em construção.

Este estudo aponta a hibridação do evento artístico e o evento pedagógico nas bases de uma arte participante onde a escola, sendo um dos espaços mais importantes em que se configuram as relações sociais e culturais, constitui um campo de diálogo coletivo que está em constante negociação, um espaço/tempo social em que é possível explorar uma arte que se proponha ser dos outros ou com os outros. O sentido é uma intervenção radical nos processos sociais em direção à emancipação do pensamento colonizado ou dominado por meio do reconhecimento da diferença. Isto tem consequências importantes sobre como entendemos o conhecimento e, portanto a educação, mas também sobre a noção de arte e a função do artista nas sociedades contemporâneas. Por este motivo pensar a Educação em Visualidade requer uma filosofia estética. Como foi para Dewey, nesta investigação, a estética e a pedagogia, coincidem como

\footnotetext{
${ }^{13}$ Bishop (2012) identifica o surgimento na década de 1990 de um grande interesse dos artistas e dos curadores, em diferentes lugares do mundo, por uma arte socialmente engajada que recebe os nomes de "arte baseada na comunidade", "experimentação comunitária", "arte dialógica", "arte litorânea", "arte intervencionista", "arte colaborativa", "arte contextual" e "arte participante". Argumenta que "arte participante" ou Participatory Art envolve muitas pessoas à diferença de uma arte interativa que implica uma relação de um a um e por outra parte evita as ambiguidades do engajamento social que é inerente ao artista.
} 
uma forma de filosofia e como uma forma de política centrada no corpo e na sua experiência do mundo.

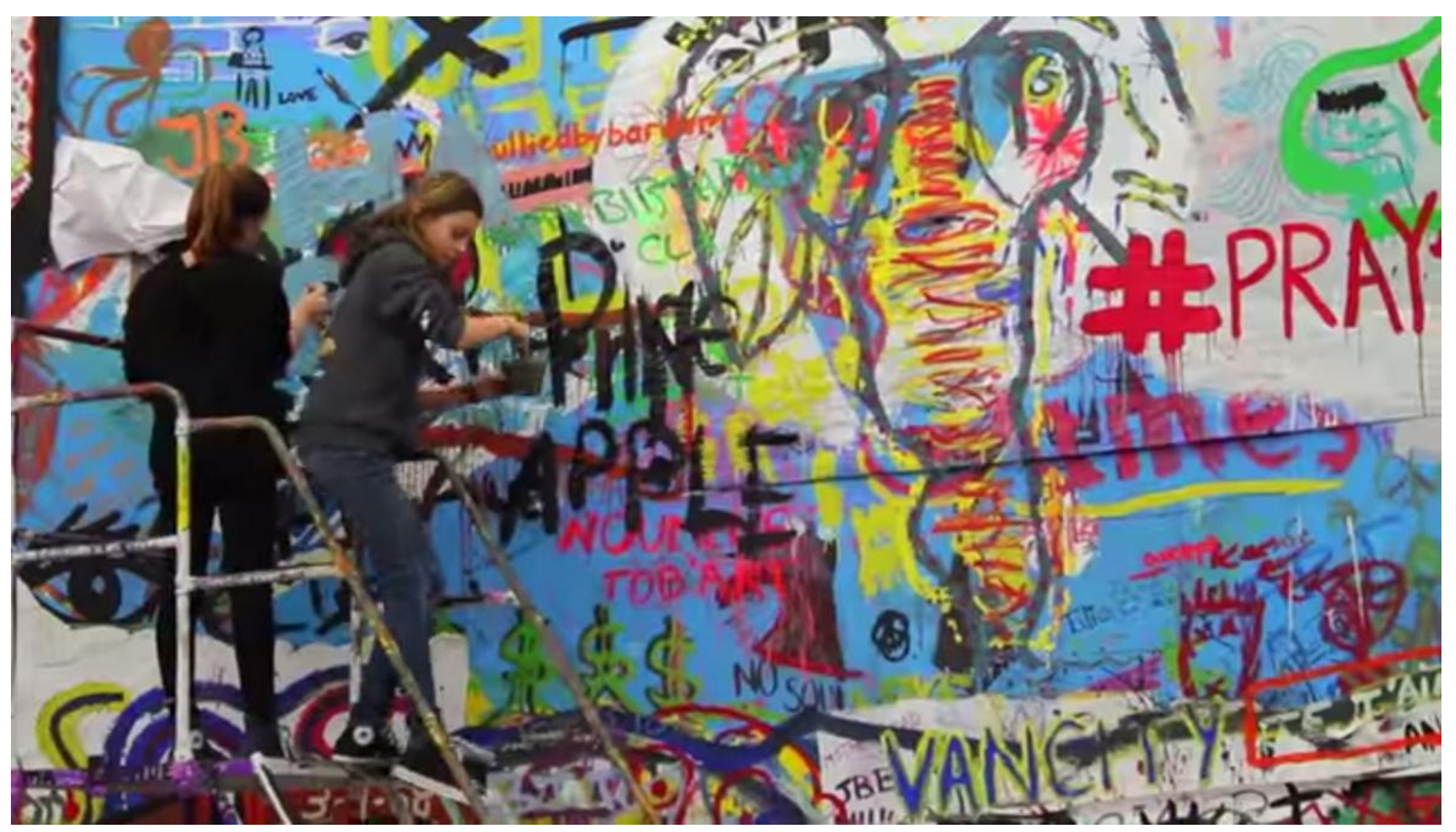

Fig. 9 Pawel Althamer, Congresso dos Desenhistas, exposição Os Vizinhos, New Museum, New York, 2012. Fonte: huffingtonpost.com.

\subsection{Os corpos}

Os filósofos que abordam a fenomenologia se interessaram pela experiência do corpo no mundo (DELEUZE, 1974; MERLEAU - PONTY, 1996; BADIOU, 2005; DERRIDA, 2005; NANCY, 2008, 2013 e outros), mas poucos abordam esta experiência do corpo na interseção entre arte e educação. Dewey é o único filósofo pragmatista que escreveu uma obra extensa e profunda sobre estética e educação que pensa a fenomenologia da experiência estética. Sua filosofia educacional se encontra muitas vezes tecida em todas suas dissertações filosóficas da mesma maneira que a estética. Em Experiência e Natureza (1929) ele concebe uma continuidade entre natureza e experiência que a filosofia tradicional mantinha separada e aponta a arte como o "evento culminante e o clímax da experiência" (DEWEY, 1929, p. ix). Mas é no livro Arte como Experiência (2005) que aborda a filosofia estética com uma visão pragmática e rica em reflexões sobre a forma de operar da arte e seus aspectos tanto formais como reflexivos e críticos. Argumenta nesta linha que não há separação entre arte e ciência, o 
que existe é uma relação de continuidade. A pesquisa científica pensa Dewey, "[...] é uma arte. Em parte instrumental para o controle e com a finalidade de ser o mais puro prazer da mente" (1929, p. ix). Mas este prazer mental não está separado do prazer sensível ou do sentido como argumenta extensamente em Arte como Experiência onde discorre sobre a relação entre arte e vida. O prazer do ser vivo que é ao mesmo tempo corpo e mente é central na sua filosofia estética.

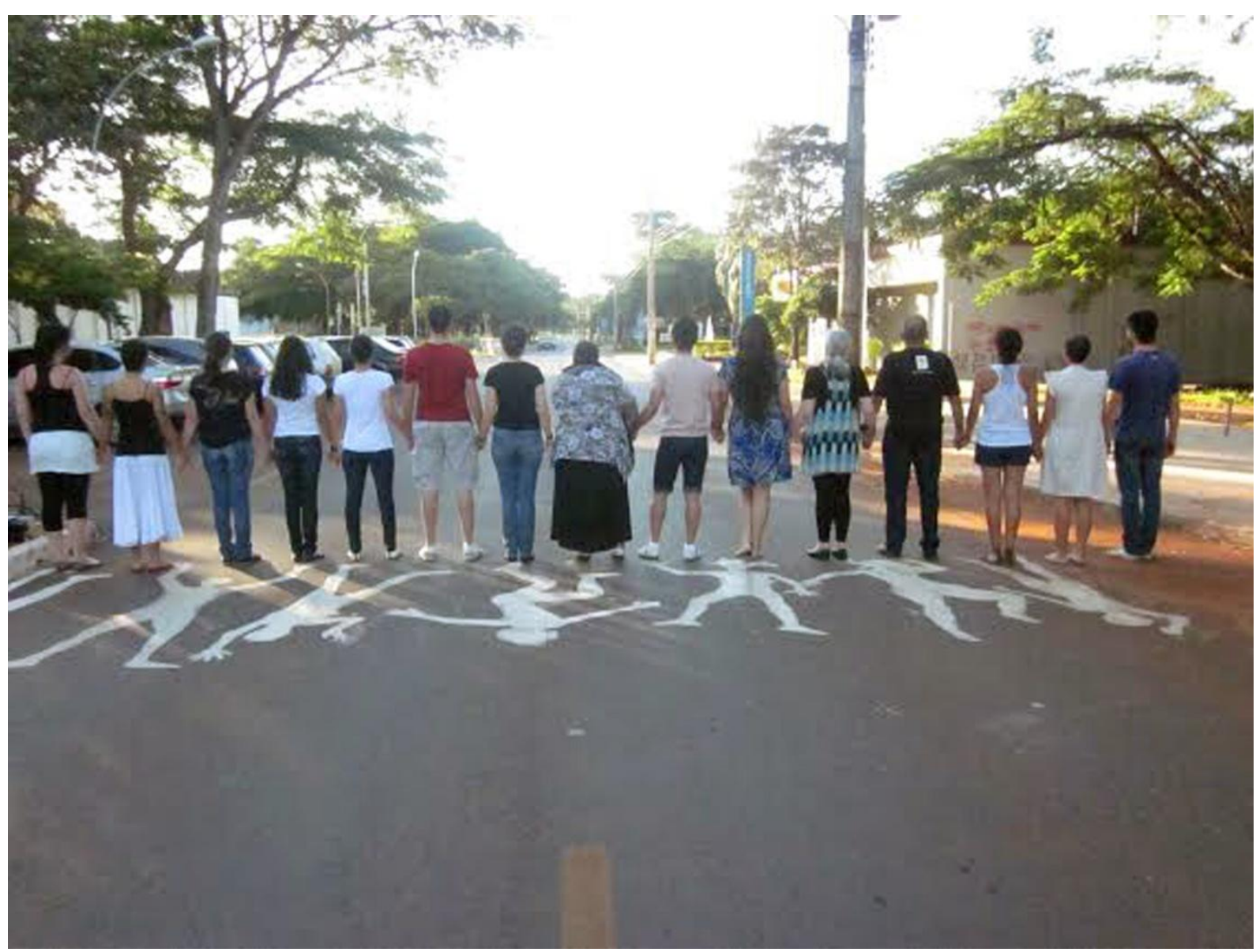

Fig.10 Flash Mob Corpos que olham. Curso de extensão Objetos de Aprendizagem Poéticos, IdA/VIS/UnB 1-2014.

A sua filosofia não se limita à rígida especulação teórica e não concorda com a concepção essencialista e metafísica que reduz a experiência a um sentimento estritamente subjetivo como era para a filosofia continental de Edmund Husserl. É justamente uma experiência porque é compartilhada, ela é sempre a interação de um organismo com seu ambiente ecológico e etológico.

[...] o único caráter distintivo da experiência estética é exatamente o fato de que não existe nela uma distinção entre sujeito e objeto, já que é estética no grau em que o organismo e o ambiente cooperam para instituir uma 
experiência em que ambos estão tão integrados que cada um desaparece. (DEWEY, [1934], 2005, p. 259)

A integração à qual Dewey se refere não é um estado de complacência, mas o ajuste consciente entre o novo e o velho onde o 'eu' se cria na criação dos artefatos. É, pois uma ação em processo, é um 'se tornar'. Nesse ponto é importante lembrar que a experiência é compreendida aqui, não como uma série de conhecimentos acumulados sobre algo ou um trajeto percorrido e finalizado. A experiência aqui é entendida como um 'estar sendo' em que o passado se torna presente. Este ser em gerúndio é central na noção de experiência estética deweyana. A experiência estética de Dewey não se refere somente à memória ou ao trabalho meramente intelectual, se refere ao corpo que entra em ação, um corpo que muda junto com o objeto.

Richard Shusterman reconhece a ênfase de Dewey numa estética ligada ao corpo (estética somática) como uma das diferenças de Dewey com a estética kantiana que separa o prazer estético dos "apetites e energias corporais" (SHUSTERMAN, 1998, p. 45) onde o prazer corporal é mero divertimento. Para Dewey a experiência estética envolve a ideia do organismo vivo, a ideia de uma arte de viver. Dewey advoga pela compreensão da arte como uma experiência significativa onde a emoção, o pensamento e a ação fazem parte da mesma dinâmica. Numa experiência vital não é possível dividir o prático do intelectual nem do emocional. As emoções unem as partes da experiência em um todo, o intelectual dá nome ao significado e o prático indica que o organismo interatua com os eventos e artefatos do seu contexto. A relação entre o corpo e o mundo na estética somática deweyana se acerca à preocupação fenomenológica pela experiência do mundo, uma experiência que para Maurice Merleau-Ponty (1996) é corporificada, intersubjetiva e situada. A fenomenologia "aponta as bases existenciais e experienciais da prática artística" (ATKINSON, 2002, p. 166) com uma narrativa que favorece a diferença em oposição ao que são sujeitos normatizados e onde quem vê se torna um com o que é visto.

A ideia de experiência estética é fundamental nesta investigação por duas razões. A primeira se encontra na necessidade de situar a discussão da estética no domínio do corpo antes que no puro discurso teórico (Fig. 10). No ensino básico a estética deve começar pelo engajamento do corpo na construção do mundo. Os corpos são o meio principal da experiência estética, é, 
portanto, neles que acontece a filosofia. Essa centralidade no corpo permite uma construção situada da filosofia estética que pode se relacionar com os diversos discursos teóricos. Alguns dos artistas que trabalharam com uma arte participante, como o grupo Fluxus, estiveram interessados na ideia de experiência estética justamente pela centralidade do corpo na obra a partir do qual se constrói a estética. A experiência estética é assim, um processo de subjetivação.

A segunda razão se refere à necessidade de advogar por um campo ampliado da educação em artes visuais: a Educação em Visualidade. E aqui o conceito de arte como experiência estética aponta não mais sobre os objetos da arte, mas sobre a relação que estabelecemos com as visualidades e que incluem a arte entre outras formas de visualidade. Esta mudança de foco é uma mudança epistemológica porque não encontra mais seu objeto de estudo na obra de arte, mas na experiência estética e poética das visualidades. O objeto de arte passa de ser objeto de conhecimento a processo de conhecimento. A experiência estética é assim um processo de emancipação.

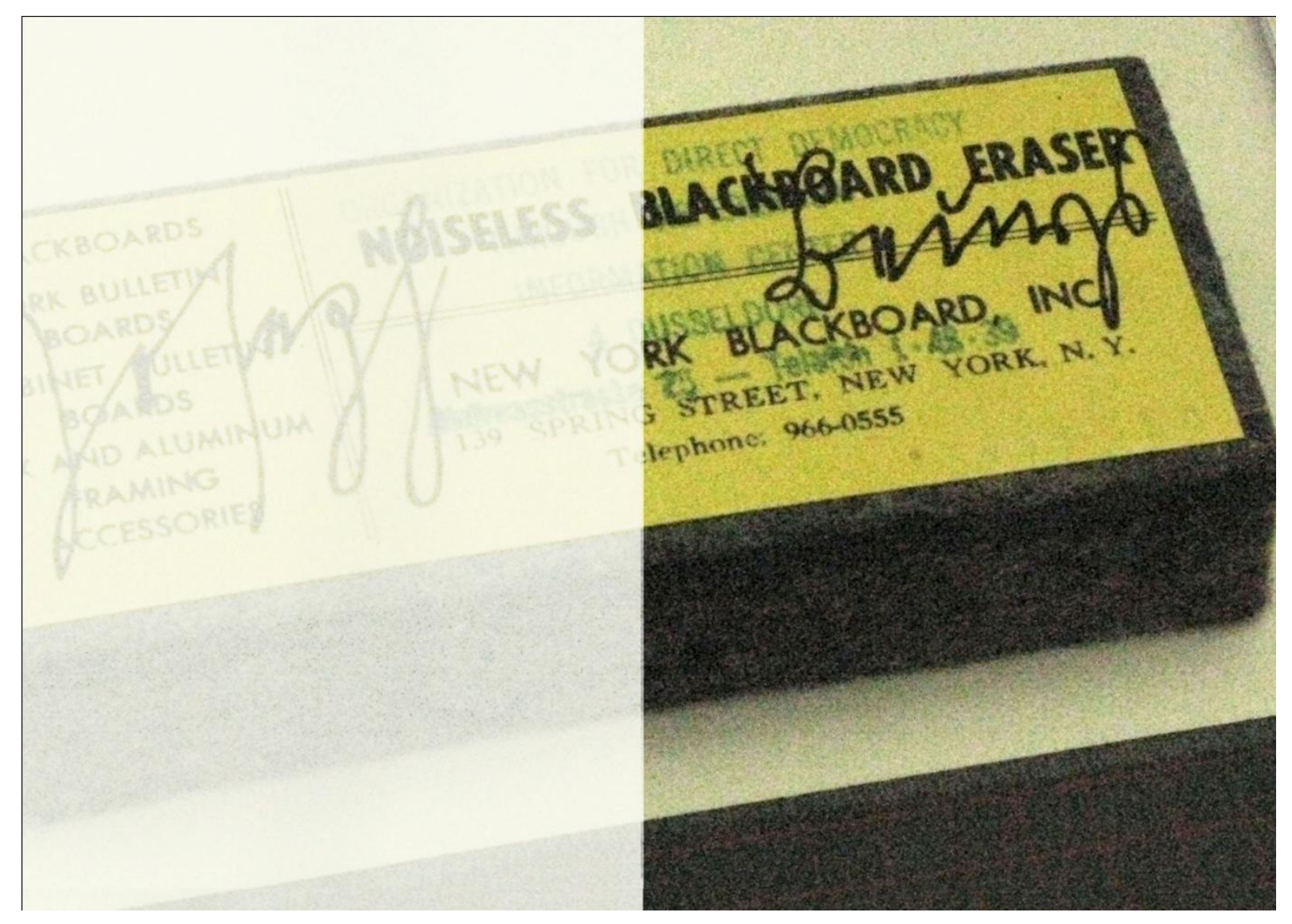

Fig.11 Joseph Beuys. Apagador de quadro sem barulho, 1974. Fotografia de Denise Munhoz. 


\subsection{Os saberes}

Os estudos sobre o saber visual de Sullivan (2010) abordam as relações entre os processos artísticos e a construção de conhecimento/significado e as relações entre o corpo e o mundo da perspectiva dos estudos cognitivos com a ideia de um 'saber corporificado'. Esta abordagem não se limita ao sentido da visão, mas se estende a todos os sentidos que atuam de maneira integral na percepção do mundo. Ele aponta as pesquisas neurobiológicas que revelam que, embora as experiências corporificadas sejam construções culturais, surgem também da interação entre a consciência e o meio que cria novas conexões sinápticas para responder aos desafios do ambiente com uma corporificação interativa. As extensões do nosso corpo (máquinas, instrumentos, aparelhos, etc.) e a forma de habitar espaços virtuais corporificando avatares e cyborgs são exemplos da nossa complexa capacidade adaptativa (HALES, 2004, apud SULLIVAN, 2010). Nosso corpo está feito para aprender, se transformar, crescer e se estender. Em um "mundo dinâmico, interconectado e relacional", ressalta Sullivan, a "corporificação do eu" (2010, p. 132), que foi negada pelas ciências cognitivas, cobra protagonismo.

Sullivan $(2002,2010)$ observa as práticas cognitivas de artistas no seu processo criativo e estabelece um marco que descreve as bases do saber visual nas artes visuais. Para Sullivan o saber visual se forma de maneira complexa e dinâmica, entre o conhecido e o desconhecido, estabelecendo um trançado de relações com outros conhecimentos e experiências. Este marco é importante para esta investigação em três aspectos, em primeiro lugar destaca o envolvimento do pensamento e o pensamento imaginativo nas artes visuais porque se enfrenta tanto ao que se sabe como ao que não se sabe ou se apresenta como uma possibilidade. Em segundo lugar apresenta um marco conceitual importante para uma metodologia de IBA $^{14}$ ou como prefere Sullivan, uma Investigação Centrada nas $\operatorname{Artes}^{15}$ (ICA) em base à ideia de que o artista é um investigador que procura o entendimento através de um processo de aprendizagem em diálogo com a situação, o espectador e o artefato. Nessa visão a investigação artística é um espaço criativo e educativo onde o sentido se tece no processo e onde há uma continuidade e contiguidade entre teoria, prática e poética:

Meu argumento é que para apreciar como as artes visuais contribuem à compreensão humana, é necessário localizar a investigação artística dentro das teorias e práticas do fazer artístico. É deste lugar central de prática criativa que

\footnotetext{
${ }^{14}$ Arts Based Research [ABR]

${ }^{15}$ Arts Centered Research [ACR]
} 
outras formas de investigação emergem, como a análise crítica e filosófica, comentário histórico e cultural e experiência educacional. (SULLIVAN, 2010, p. 97)

No caso do território híbrido em que nos encontramos, o argumento de Sullivan é valioso porque destaca o processo de investigação artístico nas fronteiras que a arte atravessa.

Em terceiro lugar Sullivan pesquisa as condições que influenciam a maneira de operar dos artistas e as estruturas e estratégias que usam. Encontra que o processo do saber visual nas artes visuais se alimenta intelectualmente da interação entre formas, ideias e situações. Estas estratégias de interação levam tempo, envolvem uma negociação com o meio e são flexíveis e abertas a novas conexões. Este estudo pretende nestas bases sugerir este processo característico da produção artística que ele chama de 'prática transcognitiva', como uma forma de operar na construção de uma pedagogia cultural.

Dessa maneira, a 'prática transcognitiva' é, no contexto deste estudo, uma metodologia de investigação e criação que procura rupturas nas noções de arte, cultura, educação e política porque promove aprendizagens transacionais de negociação de significados entre a vida subjetiva e o mundo objetivo que não podem estar separados (SULLIVAN, 2010).

Essa relação entre investigação, arte, educação e vida é uma das características mais destacadas da A/r/tografia ${ }^{16}$ (IRWIN e COSSON, 2004; SPRINGGAY, IRWIN e KIND, 2005), uma proposta metodológica de IEBA que surgiu na universidade de British Columbia no Canadá. Para os a/r/tógrafos a experiência da vida, a subjetividade e a comunidade são "elementos significantes na construção de conhecimento e mudança sociocultural quando se apresenta através no marco da investigação artística" (SULLIVAN, 2010, p. 58). Esta metodologia se baseia nas subjetivações em fluxo entre a identidade de artista, investigador e professor que constituem o marco de referencia através do qual estudam a prática artística como espaço de investigação. A metodologia a/r/tográfica se propõe desconstrutora, rizomática, colaborativa, transcultural, transdisciplinar, transacional e dialógica. É uma forma de investigação que privilegia da mesma maneira a imagem e o texto, a criação, a imaginação e a emoção. Mas o que mais distingue esta metodologia das metodologias aplicadas tradicionalmente na investigação educacional em artes visuais que procedem das ciências

\footnotetext{
${ }^{16}$ A denominação surge da contiguidade entre artista, pesquisador e professor no contexto da IEBA ou Arts Based Educational Research (ABER). Na língua inglesa a conjunção entre artist, researcher e teacher leva à palavra a/r/tography, onde graphy constitui a grafia, a marca, o texto ou a imagem.
} 
sociais é a noção de 'pesquisa viva': a a/r/tografia é uma metodologia que parte da vida e se dirige a ela, portanto deve se situar nas necessidades, interesses, ações, valores e imaginação das comunidades.

Esta metodologia abre uma possibilidade importante neste estudo porque entrelaça a criação, o ensino e a investigação; fundamenta-se na prática artística e destaca a complementaridade entre imagem e texto. Nesta perspectiva a teoria e a prática não são vistas como dicotômicas; mas como dialéticas e de preferência antes práticas que teóricas. Por uma parte, permite abordar o objeto de estudo desde diversos ângulos e desde diversos territórios existenciais e relacioná-los. Por outra, permite empreender uma investigação corporificada porque está engajada no mundo, permite valorizar as narrativas particulares para relacionar a arte, a educação e a investigação à vida e proporciona instrumentos para construir um diálogo intertextual. Esta metodologia permite ainda, situar o estudo na articulação das diversas relações entre visualidades, educação e política; artista, investigador e educador; evento, experiência estética e 'prática transcognitiva'.

$\mathrm{Na}$ a/r/tografia todo o processo de investigação, da identificação do problema, coleta de dados, realização do artefato até a apresentação da dissertação, é compreendido como um processo criativo que, além do mais, permanece aberto e se ramifica. Nessas bases a proposta a/r/tográfica oferece uma visão que abraça a complexidade das relações que estabelecemos com os conhecimentos, que situa a investigação no fazer artístico e que proporciona conceitos norteadores de avaliação metodológica.

\begin{tabular}{|c|}
\hline $\begin{array}{l}\text { "Bom, tínhamos que nos } \text { manter sozinhos. Eu tentei outros trabalhos e } \\
\text { eram muito aborrecidos. Queria alguma coisa relacionada à arte. Comecei } \\
\text { como um professor de escola pública, e aos poucos, enquanto ia, pensei 'Se eu } \\
\text { não quiser cometer suicido vou ter que fazer o ensino como arte'. Ou alguma } \\
\text { forma de arte. E se podia pensar dessa maneira }- \text { e a arte é uma forma de } \\
\text { invenção - } \quad \text { então, como podia fazer arte que fosse interessante para mim e } \\
\text { não ter que sair da minha pele? } \\
\text { com meus estudantes". } \\
\text { John Baldessari, In MADOFF, 2009. }\end{array}$ \\
\hline
\end{tabular}




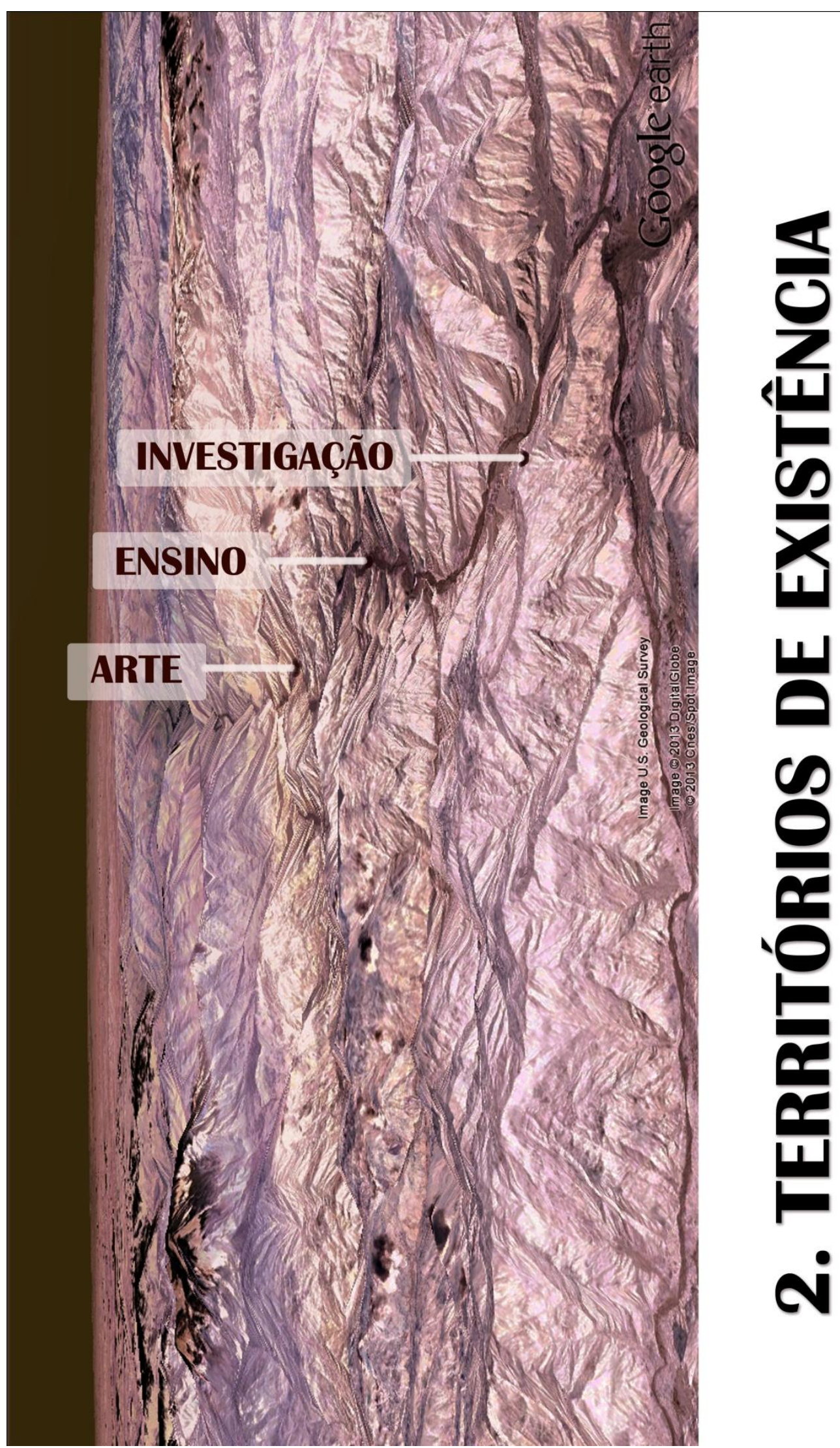

Fig. 12 Territórios de existência. Andes, Bolívia. Tatiana Fernández, fotografia satelital Google Earth manipulada, 2013. 


\section{TERRITÓRIOS DE EXISTÊNCIA}

Investigar sobre as coincidências, contaminações, transmutações e hibridações entre o evento pedagógico e o evento artístico é indagar sobre as minhas próprias hibridações, meus percursos e os eventos que me atravessam. Neste sentido investigar é procurar entender aquilo que não pode ainda sequer se tornar uma pergunta porque está continuamente em processo de ser. Investigar, poderíamos dizer, é descobrir as perguntas. Assim como o evento, só pode se entender quando há uma distância, uma diferença e uma deferência. O novo requer de um processo de relações: sentimos as mudanças e especulamos sobre as possibilidades, e nesse processo, que é um processo de indagação, imaginamos novas formas de ser e fazer.

Dessa maneira, as perguntas revelam mais da natureza de quem pergunta do que as respostas revelam a natureza de quem responde. As experiências de mais de dois séculos sobre arte na educação se desenvolveram em base a diversas formas de colocar os questionamentos que guiaram as ações. No século XIX, dependendo da intenção social da escola se perguntavam o que era necessário saber da arte para aplicá-lo à indústria ou o que era necessário saber da arte para educar o espírito. No século XX se perguntavam se era melhor não saber nada para promover a livre expressão e alcançar o subconsciente, ou se era melhor saber tudo sobre a capacidade comunicativa da imagem artística para contribuir no desenvolvimento das mídias e da indústria. No final daquele século começamos a nos perguntar o que é necessário saber da arte para participar dos processos multiculturais e tecnológicos num mundo globalizado. Hoje nos perguntamos o que é possível aprender da arte para uma transformação social. Meu percurso de investigação se configura dentro deste último território de questionamentos, no entanto requer de uma desconstrução para destacar o lugar da fala nesta investigação em face às pedagogias culturais.

A pergunta assume a ideia de um mundo em conflito, de uma realidade aterradora, de um presente inerte e/ou de um futuro ameaçador. E não estamos muito longe da visão apocalíptica que se filtra pelo mundo. Estamos frente a transformações sociais e ambientais de enormes proporções, mas não são todas iguais. No choque de conflitos formam-se muitos cenários. E neste panorama existem muitas reformas educativas que levam o selo da transformação social. A ideia de transformação social é, então, ambígua e corre seu curso em todo momento. 
Esta pergunta carrega por outra parte a ideia de que a arte e o artista, de alguma maneira, tem um determinado poder para gerar uma transformação social. No contexto atual esta possibilidade parece extremamente lunática. Mas qual é esse poder? Para Dewey (2005) da mesma maneira que para Badiou (2002) o poder não está nem no gênio do sujeito, nem no artefato artístico. Dewey destaca na noção de obra de arte a qualidade ativa da palavra "obra" (em inglês work) que denota um processo ativo. Este processo não se refere ao trabalho da criação, mas ao poder que este processo pode ter para provocar uma experiência estética em que sujeito e objeto se completam e que desencadeia outras experiências. Os eventos artísticos não estão nos artefatos nem nos sujeitos, mas passam através deles, pensa Badiou, a "verdade da arte $^{17 "}$, portanto, deve ser procurada "nos procedimentos artísticos" (ZANE SHAW, 2007, p. 189) que se dão na contingência de uma ruptura com a ordem das coisas, depois dos eventos. Aquilo que a arte faz é se abrir à possibilidade daquilo- que- ainda- não- é (BADIOU, 1995), à imaginação do que pode chegar a ser e como pode se fazer. Maxine Greene concebe a imaginação como o lugar "que se resiste às fixações, procurando as aberturas [...] onde sentimos a incompletude, porque isso significa que algo ainda há na frente" (GREENE, 2003 apud SULLIVAN, 2010, p. 21). Um dos procedimentos artísticos é se aventurar nestes espaços do desconhecido entre a procura e a surpresa. Muitas vezes se trata mais da aventura do que dos produtos que resultam dela,

Os fins emergem como uma função dentro da ação. Não são, como as teorias correntes deduzem, coisas que esperam fora da atividade em direção à qual esta se dirige. Estes não são o fim ou os terminais da ação, são terminais de deliberação, portanto pontos de mudança nas atividades [...]. Inclusive a mais importante entre todas as consequências de um ato não são necessariamente seus objetivos. (DEWEY, [1922], 2001 apud ATKINSON, 2012, p. 10)

O poder da arte na educação está, dessa maneira, na experiência estética que foca sobre os processos relacionais, as conexões que podem se estabelecer com o mundo e a energia para desencadear outros processos. Os produtos da arte são importantes como 'terminais de deliberação' no percurso do processo, mas não são um fim em si mesmo. Isto significa, como bem identifica jagodzinski,

[...] ir além do que a arte significa em direção a aquilo que a arte faz, se a arte ou a pedagogia podem ser um evento é porque acontecem no tempo, no

\footnotetext{
${ }^{17}$ Aqui a verdade da arte deve ser entendida em base à ideia de verdade de Badiou, como apontado anteriormente, a verdade se entende nesta perspectiva como relação com a realidade e não como imitação da realidade. Quando a verdade é uma relação ela está em constante fluxo, portanto em formação atravessando os eventos. Esta posição é diferente daquela que entende a verdade como um valor fixo e definitivo sob critérios parciais do que é um fato ou uma veracidade.
} 
processo emergente, portanto o evento não pode ser uma metodologia de ensino, o que a pedagogia pode aprender é como os artistas [...] estão em sintonia com os traços do seu encontro com o Real do evento que é singular e imanente a eles, e só a eles. (JAGODZINSKI, 2010, p. 191)

Aprender a entrar em sintonia com a realidade é uma tarefa estética. Esta inclui metodologias de dissenso e diferença que possam criar rachaduras na ordem das coisas por onde as verdades possam irromper. Estas metodologias são o que Badiou chamaria de 'procedimentos da verdade', isto é, procedimentos estéticos que possam nos ajudar a compreender o que ainda não é, a possibilidade de ser, a relação. Para Badiou (1995) a arte é pedagógica pela simples razão de que produz verdades (relação, sentido) e a única educação é uma educação pelas verdades. O que a arte faz então, e ai sua diferença, não é proporcionar ferramentas para transformar a sociedade, mas dar sentido (significado e direção) ao ato de mudar.

No entanto essa pergunta também implica que todos compreendem a arte e o artista de maneira homogênea. Atualmente se superpõem nas sociedades distintas maneiras de compreender a arte e o artista. Além das diferenças culturais existem diferenças entre o que é arte para os especialistas e o que é arte na perspectiva da doxa ${ }^{18}$ (CAUQUELIN, 2005), entre o que é ser artista do mainstream ou centro e o que é ser artista da periferia e dentro destes ainda existem outras diferenças.

Esta pergunta sugere também a ideia de que o conhecimento artístico se limita à arte e aos artistas. Mas os conhecimentos da arte não só afetam as ciências como são afetados por elas e assim é com todos os eventos históricos, sociais e culturais. Os conhecimentos artísticos são transdisciplinares e pós-disciplinares (além de um conhecimento disciplinar), isto quer dizer que não há de fato limites intransponíveis entre arte e ciência, não são territórios fixos, há fluxos. Indagar sobre as visualidades é, por este motivo, uma tarefa estética que demanda flexibilidade para transitar não só na arte, mas nas diversas áreas, tópicos, abordagens e metodologias de investigação visual. Os artefatos, fenômenos e convenções sociais que fazem parte das visualidades cotidianas são o coração desse processo.

Nesse panorama, questionar o quê aprender da arte para uma transformação social requer uma reflexão profunda dos critérios sobre os quais construímos a ideia de arte, educação e transformação social. Como educadora em visualidade argumento, então, por uma pedagogia

${ }^{18}$ Segundo Anne Cauquelin "[...] doxa é o nome de um conhecimento de primeiro grau, o mais baixo: o que põe em cena o 'ouvi dizer'. [...] Poder-se-ia mesmo dizer que não se trata em absoluto de conhecimento" (2005, p. 160). 
existencial que procura a transformação do 'ser em sociedade', que começa pelo reconhecimento da diferença, do dissenso e da transgressão como espaços de aprendizagem e criação. Portanto o interesse desta investigação não é metodológica ou conceitual, mas filosófica. Como vimos, os questionamentos que mudam as possibilidades metodológicas e conceituais estão relacionados à filosofia da educação e da arte. Podemos dizer que a filosofia muda tudo.

As bases filosóficas que permeiam os questionamentos, nesta investigação, se estruturam nas ideias de Simón Rodríguez e Jospeh Jacotot. Rodríguez (1990, 2008), mestre de Simón Bolívar no século XIX, aponta a ideia de 'emancipação do pensamento dominado'. Para Rodríguez a colonização deixou implantada uma maneira de pensar colonizada da qual é necessário se emancipar, mas esta emancipação não pode ser uma concessão do colonizador, a equidade é uma exigência, um princípio. Esta equidade só é possível quando a existência do outro, do diferente e do dissidente é possível.

Nesse sentido, as ideias formuladas no mesmo século por Jacotot, professor de francês, que Rancière evoca como o Mestre Ignorante (2002, 2010a), reverberam as de Rodríguez. De maneira análoga ele aponta a ideia de 'emancipação intelectual'. Partindo dessa ideia, Rancière propõe o princípio político da equidade como ponto de partida e não de chegada, como base para uma compreensão do que é a emancipação. Para entender isto basta lembrar que a educação tradicional parte do princípio de que a emancipação é um processo em direção ao conhecimento, dessa maneira a emancipação é o ponto de chegada. O professor, neste caso, é um emancipador que concede ao subalterno a emancipação através da explicação. Já a ideia de Jacotot é a de que o professor pode ensinar algo do qual é ignorante ele mesmo, pois parte do princípio de que todos podem aprender por si mesmos. Ele começa pela ideia de que todos são emancipados no ponto de partida. Essa ideia, revolucionária para o século XIX, sugere que o papel do professor não é o do explicador, mas do investigador e produtor junto com seus estudantes. Essa é uma relação de emancipação tanto para o professor como para o estudante, pois coloca os dois frente ao conhecimento, não para acumulá-lo, mas para fazer algo com ele na construção da sociedade.

Para Rodríguez e Jacotot a equidade é um princípio filosófico da educação que é ao mesmo tempo um princípio estético. Pensando em Jacotot, Rancière se pronuncia assim a sobre a equidade: 
A equidade se manifesta na máquina social através do dissenso. $\mathrm{E}$ o dissenso não é primeiramente uma querela, mas uma fenda na mesma configuração de conceitos sensíveis, uma dissociação introduzida na correspondência entre maneiras de ser e maneiras de fazer, ver e falar. (RANCIÈRE, 2010a, p. 15)

O que é estético na equidade é o espaço destas dissociações porque é o espaço em que é possível ver o outro, é o espaço do dissenso. Ranciére (2010b) estabelece esta relação entre dissenso e estética na base da ideia de emancipação. As políticas da diferença apontam de forma similar esta relação: a visibilidade é uma forma de emancipação porque o 'outro' se faz visível nas fendas que se abrem.

Entretanto, pensar a emancipação na educação não é, como argumenta Gert Biesta (2010), fazer visível aquilo que está oculto aos estudantes (aqueles que vão ser emancipados) como geralmente se propõe a escola progressista e conservadora por igual. A emancipação não se outorga porque esta ideia supõe uma relação de dominação, concorda Biesta com Rancière, ao invés disso eles vêm a emancipação como uma ruptura na ordem das coisas, uma ruptura que é a "aparência da subjetividade" (BIESTA, 2010, p. 46).

É nesse marco filosófico da emancipação como um processo de subjetivação que se baseia esta investigação, tanto no campo da arte como do ensino e da pesquisa. Por este motivo a investigação pretende ser um ato de emancipação antes que uma tentativa de emancipar o outro (por meio da explicação).

Partindo então desse princípio o meu questionamento inicial (o que aprender da arte para a transformação social?) requer um ajuste porque deve tomar em conta a posição de onde se indaga: o que se transforma?, para que se transforma?, em relação ao que se transforma? e em favor de quem se transforma? são perguntas que devem acompanhar os processos de investigação. Nesse sentido, é uma investigação que se situa em territórios de fronteira, que são parte da minha experiência na arte, na educação e na investigação e da minha experiência de vida.

\subsection{Arte}

$\mathrm{Na}$ contemporaneidade, uma das tendências no mundo da arte aponta em direção a uma 'virada ética' também chamada de 'virada social' da arte (BISHOP, 2012) que se manifesta não 
só no trabalho dos artistas, mas também nos discursos curatoriais, na preocupação com os programas educativos e sociais das exposições em museus e galerias e nos incentivos governamentais e não governamentais para a arte e a cultura nas capitais dos grandes centros cosmopolitas do mundo. Esta 'virada ética' é perceptível no meio artístico ${ }^{19}$ e cria tensões renovadas entre a autonomia e a heteronímia da arte. Por uma parte seus críticos encontram esta arte socialmente engajada como uma forma de ativismo social que não pertence ao campo da discussão estética porque aponta um maior privilégio dos critérios éticos sobre os estéticos. De outro lado, seus defensores promovem a ideia de que a estética é no melhor dos casos um assunto meramente visual e no pior dos casos uma noção elitista, uma vestimenta do gosto. Parece ser necessário fazer uma escolha entre o engajamento social na arte para entoar com a 'virada ética', ou a valorização da sua autonomia e purismo estético de condicionamentos utilitários ou éticos, considerados valores externos à arte.

Esta contradição é abordada por Rancière (2005, 2009a, 2009b) da mesma maneira que fez Dewey no seu tempo, reabilitando a ideia de estética na sua conexão com a política. Para Rancière o "regime estético" ${ }^{20}$ se caracteriza pela tensão entre a autonomia (singular) e a heteronímia (coletiva) da arte. $\mathrm{O}$ anti - estético ou a rejeição à estética é também uma forma de estética porque é pensada em relação à sua contradição, portanto continua sendo parte da discussão que se dá dentro do 'regime estético'. Mas antes que considerar a autonomia do artefato de arte Rancière considera a "autonomia da experiência em relação à arte" (BISHOP, 2012). Isto me leva a pensar, como já tinha intuído na minha prática artística/pedagógica, que sem a fenda do sensível não há possibilidade de singularização e sem possibilidade de singularização não há possibilidade de dissenso, ruptura ou resistência. Assim a estética é a dimensão que permite pensar a tensão entre arte socialmente engajada e arte autônoma; onde não se nega a singularidade da experiência nem a situação social ou cultural em que acontece. Esta capacidade que a experiência estética tem de abrir as fendas entre o individual e o social, entre o dissenso e o consenso, entre o transitório e o eterno, se torna uma condição para a emancipação do pensamento dominado/colonizado.

\footnotetext{
${ }^{19}$ Esta afirmação se refere ao diálogo entre artistas visuais que ocorre no meio artístico e decorre da minha longa convivência nos meios artísticos na Bolívia, mas está também documentada em inúmeras entrevistas com artistas e artigos que se publicam em revistas de arte pelo mundo todo na última década.

${ }^{20}$ A forma contemporânea de entender a arte corresponde ao "regime estético", argumenta Rancière, à diferença dos regimes que o precedem: o "regime ético das imagens" de raiz platônica se concentra nos efeitos e funções da arte e o "regime representativo das artes", de caráter aristotélico corresponde à classificação da sua ocupação na hierarquia social e política. No "regime estético", que se inicia com o Iluminismo, a arte é uma forma autônoma de vida. Este regime corresponde á visão moderna da "arte pela arte" que a filosofia estética contemporânea critica. Por este motivo a estética se entende hoje como uma mera preocupação formal ou uma inclinação elitista. No entanto Rancière considera que estas atitudes antiestéticas também funcionam dentro do mesmo "regime estético" porque ainda existe a tensão entre a autonomia e a heteronímia (RANCIÈRE, 2009b).
} 
Desta forma aclaro que minha investigação se tece nas fronteiras do contingente entre o individual e o social. E como muitos artistas da periferia global meu trânsito com outros saberes e práticas são estratégias de ação antes que opções. Isto não significa que não haja escolhas, mas que estas escolhas estão condicionadas a uma relação. A autonomia da experiência estética, portanto não é uma questão de liberdade de escolha, mas de relações, à diferença do discurso sociológico da superestrutura no sistema ocidental que oferece uma série de escolhas ou alternativas (formais) como metáforas da democracia, da criatividade, da interação ou da ética. Mais do que escolhas o regime estético, pensa Rancière (2009a), define a necessidade de uma relação. Esta relação na arte se traduz entre forma e conteúdo. jagodzinski (2009, In MARTINS e TOURINHO, 2009) pensa que além do mais é uma relação entre forma e não forma, entre o que é e o que ainda não é.

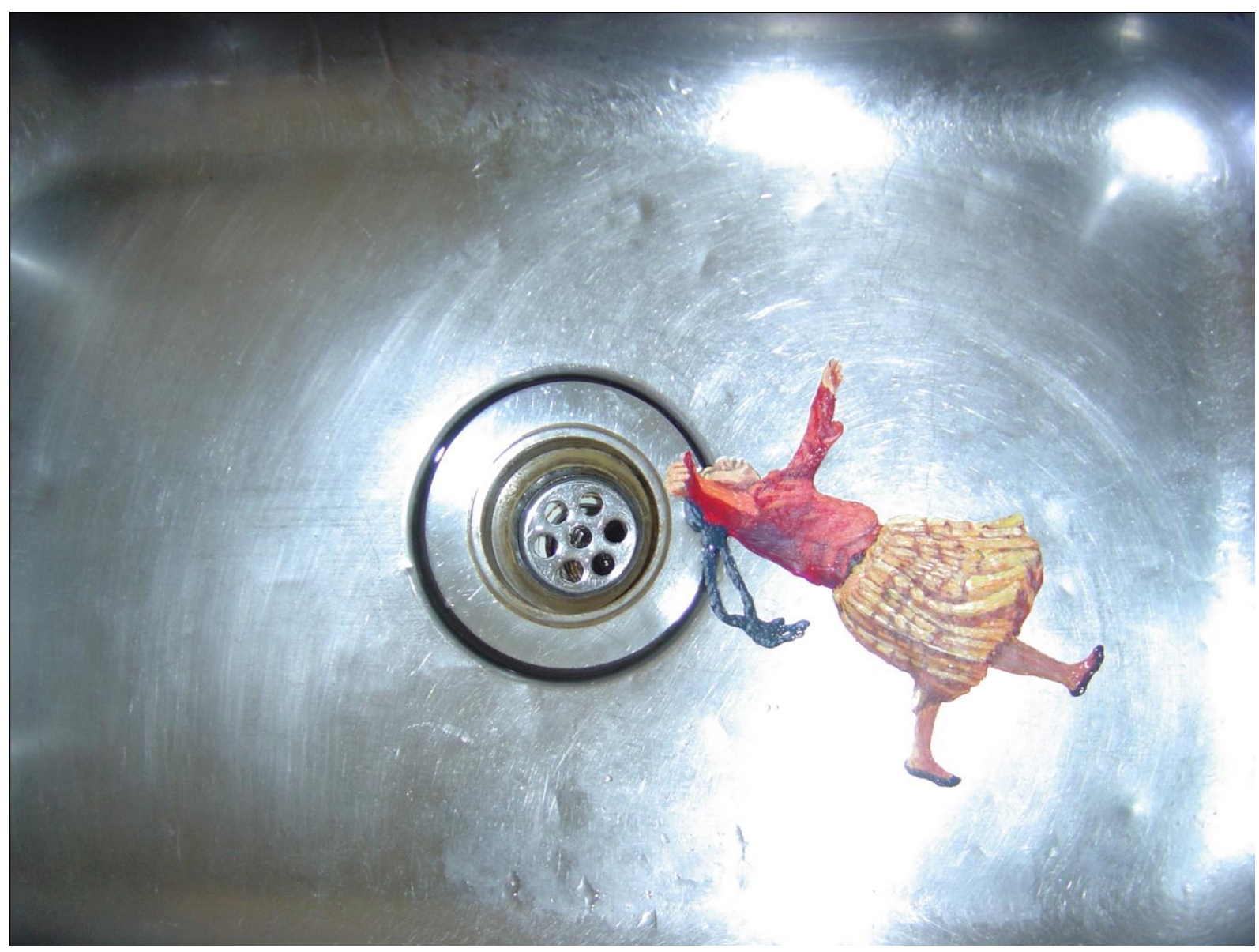

Fig. 13 Domitila Huanca , "Danos Colaterais”, figuras de tinta acrílica em contextos cotidianos, 2012. 
Esta relação entre conteúdo e forma, entre forma e não forma é uma necessidade no contexto da America Latina. Como aponta Camnitzer (2009b), os artistas de periferia ${ }^{21}$ raramente podem especular sobre escolhas formais para que sua marca se destaque no mercado da arte $^{22}$ porque em contextos periféricos não há um mercado neste modelo e porque as escolhas formais nestes contextos muitas vezes obedecem a tradições que não valorizam necessariamente uma marca, um estilo individual, por este motivo são mais interessantes as relações que se estabelecem com a coletividade. O artesanato é uma destas atividades. No interior do Brasil, como é no interior de tantas cidades latino americanas, o artista da comunidade não faz parte do mercado de arte dos centros, mas dos empreendimentos culturais comunitários.

É importante também lembrar que esta relação é territorializada. Um artista da periferia inglesa pode ficar no seu território geográfico e não necessita aprender outra língua e outra cultura para ser integrado ao circuito da arte do centro inglês. Geralmente o artista profissional deve viver nos grandes centros ou se relacionar a eles onde há um mercado e uma demanda. Na periferia de outros continentes como o da América Latina o artista necessita alcançar os centros maiores para sua consagração e isto se dá geralmente fora do seu território e da sua língua. Em muitos casos é necessário um reconhecimento dos grandes centros para uma validação das obras de arte produzidas no âmbito das periferias globais. A arte conceitual surge na América Latina, como bem aponta Camnitzer (2009a, 2009b), de maneira independente (Brasil, Argentina e outros) e em base a outra filosofia, mas é geralmente aceita como uma derivação da arte conceitual dos grandes centros.

Neste ponto é importante lembrar que em países como Bolívia ou Guatemala o mercado de arte no modelo ocidental é muito pequeno, não só porque não há uma economia que sustente políticas para a arte, mas principalmente porque a maioria da população é indígena e o conceito de arte e artista ocidental moderno é distante da visão dos povos indígenas onde a individualidade, por exemplo, não se acomoda nos princípios comunitários (o que não significa que não se reconheça a singularidade na pluralidade). Pedro Pablo Gómez e Walter Mignolo lembram que,

\footnotetext{
${ }^{21}$ Evidentemente todo espaço geográfico é cruzado por diversas dimensões temporais e espaciais na contemporaneidade de tal maneira que há sempre uma periferia respeito a um centro que é, por sua vez, periferia respeito a centros maiores. Nesse caso se trata do sistema de valores da arte que se centraliza nos países ocidentais europeus e norte americanos e o sistema de valores da arte que circula nas periferias destes centros. Esta investigação se situa na fronteira entre a extrema periferia, aquela que não participa do sistema de valores da arte e aquela que participa do mesmo sistema de valores da arte que os centros maiores.

${ }^{22} \mathrm{O}$ mercado de arte se insere na lógica do mercado de capital, isto significa que a obra de arte, como um bem material, se constrói entre a individualidade do artista e do proprietário.
} 
As culturas artísticas (e com isso nos referimos a todo o complexo que suscita e convoca a criação de uma obra) foram parte da matriz colonial de poder nos processos de manejar e manipular subjetividades. Por outro lado, as culturas artísticas foram também os espaços da subversão, não somente da novidade. [...] foram ambos conceitos chaves para marcar a singularidade da arte. Isso, claro, na concepção Européia da arte, e da história da arte, que também se expandiu às colônias e ex-colônias ocupando lugares destacados no âmbito das elites governantes, cujos planos consistiam em civilizar a nação. (GÓMEZ e MIGNOLO, 2012, p. 8)

Nas periferias da América Latina, a arte não é o que chamaríamos uma 'profissão', mas uma maneira de fazer as coisas que obedece a uma lógica diferente. Essa ideia perpassa todas as classes sociais, na maioria dos países latino americanos. Ser artista não é uma opção de profissão para documentos de identificação.

Gómez e Mignolo (2012) encontram que, nesse contexto, os artistas latino-americanos teriam três opções: um, deixar as coisas como estão; dois, pedir licença para entrar e encontrar uma forma de integração ou, três, 'se desenganchar'. Para os autores, o último é o caminho das 'estéticas decoloniais'. São estéticas que desobedecen e que os autores chamam de desobediencia epistêmica, ou "desobediência das regras do fazer artístico e das regras da busca de sentido no mesmo universo em que tanto as obras como a filosofia respondem aos mesmos principios" (p. 9).

A integração é uma posição colonialista no seu fundamento também. No âmbito cultural muitas vezes assume-se que para integrar os espaços periféricos é importante que se leve a arte a estes lugares. Mas não se trata só disso. A multiplicação das bienais ou museus em cidades pequenas não pode ser lida somente como uma integração das periferias ao centro, mas também como uma adesão e afirmação dos valores dos centros. As tensões que existem entre centros e periferias tornam visível o conflito entre identidade (o coletivo) e originalidade (o individual). Na condição de artista boliviana, vivo estas tensões e não as entendo como uma oposição. Em muitos casos esta é, como argumenta Camnitzer, uma oposição criada porque são, na realidade, condições indissociáveis. Esse conflito é análogo ao conflito que Rancière $(2005,2009 b)$ aponta entre a heteronímia e a autonomia da arte no regime estético que é constitutivamente contraditório.

Para esta investigação, o conceito de experiência estética não está desassociada da arte ou da cultura ocidental, mas também não se reduz só a elas. Esse conceito permite a contradição 
entre a epistemologia da estética e da arte moderna ocidental (em uso e debate hoje, e que constituem o que Ranciére chama de regime estético) e as epistemologias de fronteira que vêm o objeto de conhecimento em relação a um impasse entre a modernidade e a colonização. Como boliviana e cidadã de outras culturas, minha investigação navega na tensão entre estas epistemologias. Trata-se de uma epistemologia de fronteira, onde as coisas são uma $e$ outra.

A arte, como se concebe hoje nos países latino americanos, é um fenômeno novo depois de tudo, e ele descende diretamente de uma tradição européia. É difícil ignorar esse fato e defender uma arte nacional como proclamam os mais nacionalistas, geralmente nas periferias $^{23}$. Mas também não é possível ignorar que a arte exige posições respeito a um contexto onde este seja (ou passe a ser) significativo. Portanto não se trata de uma escolha entre arte de centro ou de periferia, mas da expansão consciente do campo de contaminação possível nas fronteiras. Esta estratégia não é resultado de escolhas, é, como aponta Spivak (2012), um impasse (double bind) em que se está existencialmente. Na lógica do colonizador ou se está dentro do centro ou se está fora. Na minha posição estar dentro $e$ fora se torna uma estratégia de resistência à lógica do colonizador.

\subsection{Ensino}

É neste conflito que o ensino da arte me colocou já no meu primeiro ano como educadora visual com crianças, adolescentes e jovens em escolas privadas na Bolívia. Oito anos de intensa convivência, observação, sistematização, construção e registro é uma pele que fica no corpo. Não é minha intenção dedicar o estudo a meu trabalho artístico, mas alimentar meu trabalho no percurso da investigação, como é no percurso da minha prática pedagógica. $\mathrm{O}$ caminho desta investigação se configura em cada um dos estudantes, dos projetos, das invenções, das ausências e dos desafios que vivi na escola. A tensão entre a vida e a arte na sala de aula era mais intensa do que no meu estúdio, não só porque a velocidade era um fator vertiginoso e a quantidade de estudantes por turma era sempre muito grande, mas porque a sala de arte parecia sempre em estado de festa. Os corpos sempre em movimento, os materiais e processos mais diversos correndo ao mesmo tempo. A aula literalmente desbordava dos seus limites físicos. Por esse motivo, minhas aulas sempre significaram um problema para as autoridades da disciplina nas escolas e para mim significavam um esforço físico e psicológico

\footnotetext{
${ }^{23}$ No âmbito artístico em Bolívia, ou Peru, por exemplo, a discussão central entre os artistas se dá ao redor do que seria uma arte eminentemente nacional ou uma arte universal.
} 
extraordinário. A intensidade daqueles anos marcou minha visão da arte e da educação. Podemos dizer que meus estudantes participaram do fluxo da minha prática artística e poética, porque eles sempre vivem nas camadas dos territórios em que existo. São parte da minha experiência estética do mundo. Naquele contexto aprendi o que a arte podia aprender da educação.

Uma parte importante da minha metodologia eram os debates. Depois das aulas expositivas, leituras e práticas o dia do debate chegava com perguntas perturbadoras até para mim, ou tal vez secretamente para mim, pois eu queria saber o que eles pensavam e como ia mudando esse pensamento. Os estudantes deitavam nas mesas e sentavam no chão deixando um círculo no centro para uma eventual performance. Muitos gostavam mais dos debates do que de todas as outras práticas. Era comum serem discussões que visibilizavam o conflito, pensar sobre a arte em termos das suas tensões nos expunha aos nossos próprios pontos cegos. Este diálogo era ao mesmo tempo uma forma de valoração do processo de aprendizagem como uma forma de despertar à complexidade do pensamento estético. Estes debates foram cruciais na direção que tomou a minha investigação artística. Naquele contexto aprendi também o que a educação podia aprender da arte.

No final de 2003 empreendi meus estudos de mestrado em novas tecnologias aplicadas à educação em que desenvolvi um sistema híbrido de trabalho para ganhar espaço e uma dinâmica de aprendizagem mais ampla por meio de um espaço virtual que compreendia também um espaço de exposição de trabalhos. O espaço cresceu apesar das dificuldades apresentadas pela direção da escola ao seu funcionamento. Mas em outubro daquele ano as coisas começaram a mudar. As forças populares lideradas por Evo Morales enfrentaram o governo do então presidente Gonzalo Sánchez de Lozada numa batalha de cinco dias conhecida como a 'guerra do gás' que terminou na fuga de Lozada do país e dois anos mais tarde na eleição de Morales como presidente do país. Minha prática pedagógica (Fig. 14 e 16) começou a se tornar uma prática artística quando percebi que eu ensinava em um contexto cultural em processo de transformação com jovens em processo de transformação em um momento em que eu passava por uma transformação.

Estes eventos, que como aponta Badiou (2005), atravessam nossa vida, são difíceis de entender numa perspectiva muito vívida. As visões simplistas e dicotômicas que dividem tudo em certo ou errado, verdadeiro ou falso, legal ou ilegal não só não respondem à realidade das pessoas, mas não dão conta da complexidade dos eventos. Os conflitos sociais, que as 
políticas neoliberais cultivam, se tornam muito complexos para entender e solucionar. Nessas circunstâncias, a vida não se reduz a uma separação entre o mal e o bem. E, mesmo não sendo situações compreensíveis, são parte de uma experiência do mundo que é estética porque perturba a ordem das coisas de uma maneira tão radical que exige uma posição sempre diferente.

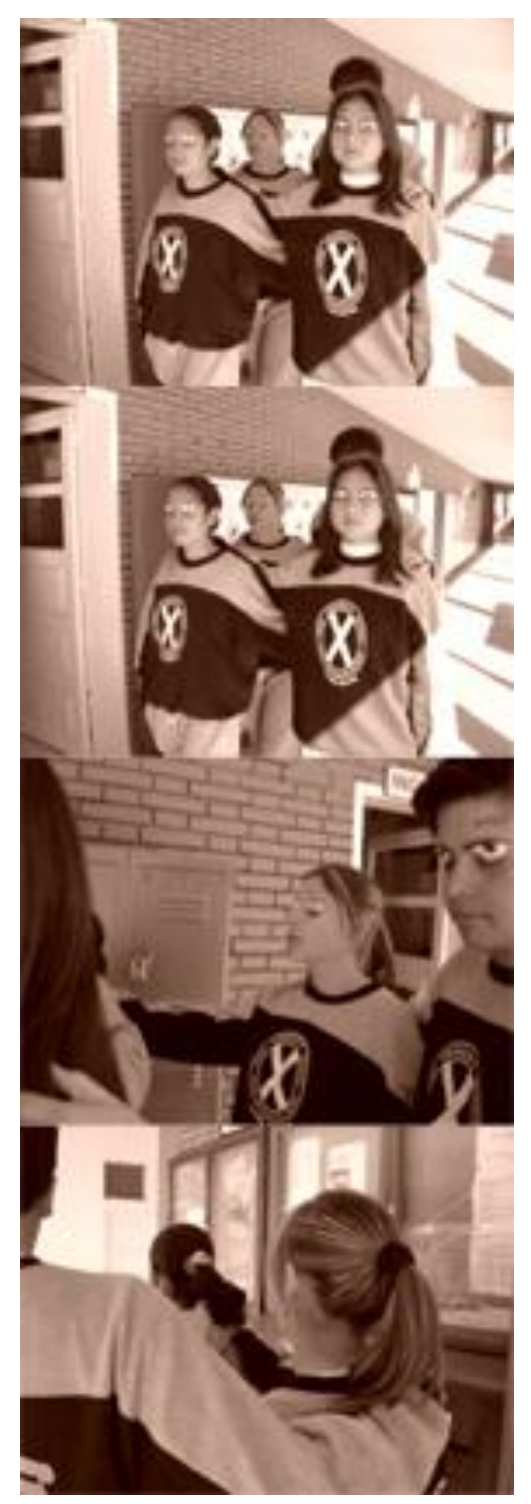

Fig. 14 Os videntes. Performance (vídeo still), $2^{\circ}$ ano Secundária (equivalente ao $1^{\circ}$ ano do ensino médio). Colégio Saint Andrews, La Paz, Bolívia, 2004. Fotografia Tatiana Fernández.

Nesse contexto, os questionamentos na sala de aula se tornaram mais complexos e as contradições culturais começaram a aparecer. Em 2005 com a vitória de Morales foi apresentado o Projeto de Lei para a Reforma Educativa Avelino Siñani - Elizardo Pérez, do então Ministro de Educação Félix Patzi (Fig. 15). A proposta assumia uma direção 
descolonizadora, anti-imperialista, antiglobalizadora, comunitária e laica e um currículo unificado com o objetivo de educar para a produção, de alguma maneira resgatando os princípios da lendária Escuela de Warisata levantada em 1931 por Siñani e Pérez ${ }^{24}$ que marcou uma página importante na história da educação boliviana e latino-americana. Hoje o Plan Educativo Avelino Siñani está implementado em todas as escolas da Bolívia.

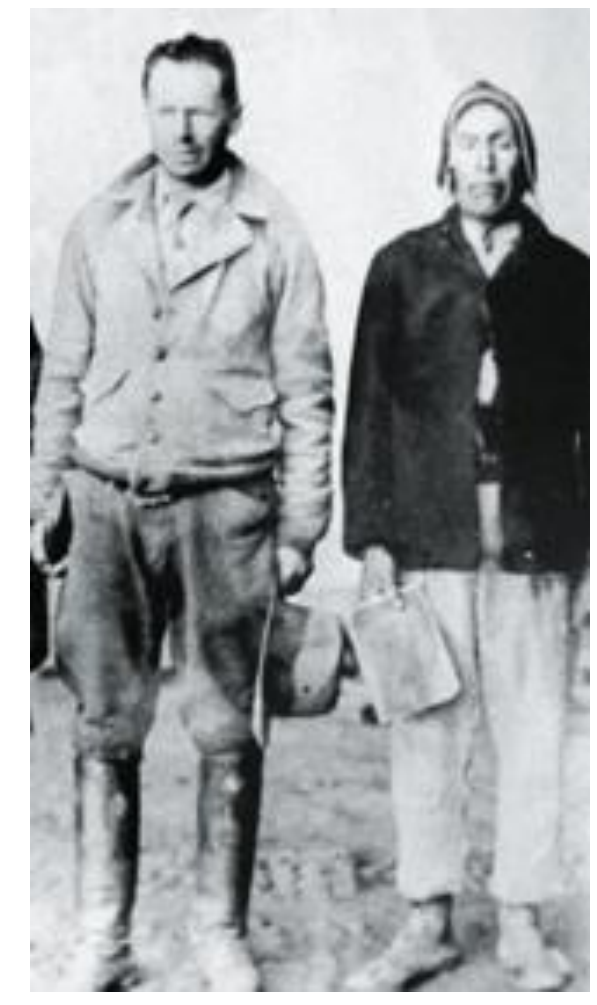

Fig. 15 Avelino Siñani (direita) e Elizardo Pérez (esquerda) Detalhe. Fotografia de Carlos Salazar Mostajo, Warisata, Bolívia, 1931. Fonte: portal.aprendiz.uol.com.br

O plano apresentado na reforma educativa foi para mim um terminal de deliberação, um evento que colocou à prova minha vontade de aprender. Meu trabalho pedagógico no contexto desta reforma educativa se configurava como uma pedagogia colonizadora. Eu compreendo a

\footnotetext{
${ }^{24}$ Em 1931 os professores Elizardo Pérez de origem mestiça, interessado na educação rural e Avelino Siñani, professor indígena aymara, levantaram a primeira escola indígena feita por indígenas e para indígenas em Warisata, na Cordilheira dos Andes. Conhecida como Escola Ayllu de Warista foi construída sob o princípio pedagógico de ayllu, ou comunidade, ligada à produção e aos vínculos da terra. Nesse modelo, a comunidade constrói a escola e se encarrega de administrá-la e de desenhar seus planos de estudos e em forma recíproca a escola fortalece o tecido comunitário (CLAURE, K. 1989, apud ZIBECHI, 2005). Os conceitos que giram em torno do ayllu são os de reciprocidade, ajuda mútua ou solidariedade com o objetivo de produzir, construir, guiar, complementar, enriquecer, imaginar e compartilhar. Os alunos de Warisata se converteram em professores rurais e replicaram as experiências até se tornarem um perigo para a estabilidade das oligarquías, que na década de 1940 adquiriu cores de extrema intolerância. A Escola Ayllu de Warisata ganhou relevância por contraste. Intelectuais socialistas da Bolívia e de outros países latino americanos como o México se interessaram e apoiaram a experiência de Warisata. Isto chamou a atenção da oligarquia, dos governantes e da Igreja Católica que encontraram formas de terminar com as escolas ayllu e obscurecer seus alcances. Hoje retornam estes debates com as políticas educativas de Evo Morales.
} 
arte na educação como uma forma de irromper com a ordem do pensamento e nesta operação não excluo nem a arte ocidental nem a arte ocidentalizada, nem a arte não ocidental ou não ocidentalizada. Mas também não era uma questão de escolhas. O problema não era naquele momento, nem é hoje, de conteúdo (ocidental ou não), para mim o problema se apresenta no sentido da arte na educação (e da mesma maneira o sentido da arte na cultura dos povos originários da América).

Desta tensão e das tensões políticas que surgiam nas discussões sobre a reforma educativa uma pergunta se acomodou na minha paisagem: qual é o propósito da arte na educação num território que é eminentemente indígena onde o conceito de arte é do colonizador? os propósitos delimitados na reforma de Patzi parecem coerentes com a cosmovisão andina e se alinham com os objetivos gerais da reforma. Da mesma maneira o sentido produtivo e comunitário da educação que é sua maior característica, aponta a estreita relação entre educação e vida. Mas a arte continua tendo um caráter vocacional, reprodutivo e contemplativo na educação com a diferença de ressaltar as produções locais e comunitárias (BOLIVIA, 2011).

Entre 2006 e 2007 senti a urgência de repensar tanto a minha prática pedagógica como a minha prática artística com a intenção de entender esta nova situação. Havia no horizonte algo novo que não conseguia compreender: um evento. Naquela paisagem, a arte não se acomodava mais da maneira segura e triunfante que se acomodava uma década antes. $\mathrm{O}$ ensino se converteu para mim numa estratégia de resistência que colocava à prova o meu conjunto de suposições sobre arte.

\subsection{Investigação}

A investigação é um processo que não se limita ao âmbito acadêmico. A vida é cheia de indagações com diversos graus de profundidade e de importância individual e social. É necessário pensar como estas camadas se cruzam. Muitas destas mudanças que me proponho investigar estão relacionadas às mudanças globais que como ondas de uma explosão nos atingem, especialmente nas periferias. Para compreender todas estas mudanças poderia ter empreendido minha investigação no domínio da arte, seja da sua poética ou da sua teoria. Mas sentia que devia procurar fora e ao mesmo tempo dentro dela. Esta é uma tendência muito forte na última década: 
Cada ano mais e mais artistas deixam o circuito do mundo da arte - ou procuram ou experimentam com estratégias viáveis de saída- antes que continuar ampliando ele por meio de expedições predatórias no mundo vivo. $\mathrm{E}$ estes são alguns dos acontecimentos mais excitantes da arte hoje porque deixar o circuito significa sacrificar o próprio coeficiente de visibilidade artística mas potencialmente em troca de uma maior capacidade corrosiva frente à ordem semiótica dominante. (WRIGTH, 2008, apud ATKINSON, 2012, p. 67)

O mesmo pode se dizer dos educadores em geral e dos educadores em visualidade em particular. Cada ano mais e mais professores procuram estratégias de saída que significam a renúncia à figura do professor como autoridade inquestionável do conhecimento provocando também uma maior corrosão da ordem social dominante. A relação entre arte e educação que fui investigando e experimentando na primeira década deste século colocava a prova minha vontade de aprender com muitos mais desafios e renúncias, mas com uma maior possibilidade de sentido.

Nesse processo descobri, sobre a reflexão da minha experiência, que minha prática pedagógica tinha se tornado minha prática artística. Esse pensamento se torna mais claro quando vejo os registros fotográficos e videográficos do trabalho que realizávamos em sala de aula (ou fora dela) com os estudantes (Fig. 16). Não posso me desprender do sentimento de ter feito parte deles sem nunca haver colocado a mão sobre seus trabalhos. O que é esmagador destes rastros de evento pedagógico coincidindo com o evento artístico é que são, por sua vez, estratégias de resistência e sabotagem à ordem das coisas: muitas vezes à educação homogeneizante e muitas outras à arte homogeneizante. Frente a esta vontade de resignificação da minha prática artístico/pedagógica decidi retornar ao Brasil em 2008 para empreender uma investigação de longo prazo.

Minha posição nesta investigação é assim uma posição dada pelas condições de uma identidade em trânsito que flui entre as camadas que se tecem entre arte, educação e política, mas também entre as culturas que formam minha paisagem. Oswaldo Guayasamin (19191999) ${ }^{25}$ disse certa vez que era um artista que vinha pintando há mais de três mil anos. Da mesma maneira sinto que esta investigação é uma indagação que venho perseguindo há mais de quinhentos anos quando um evento maior perturbou a ordem das coisas e transformou as

\footnotetext{
${ }^{25}$ Artista equatoriano expressionista cujo trabalho sobre o tema indigenista se caracterizou pelos rostos e mãos expressivos e trágicos.
} 
sociedades. Esta luta não é só minha, ela me atravessa com os eventos e encontra seu caminho na arte e sua forma na educação.
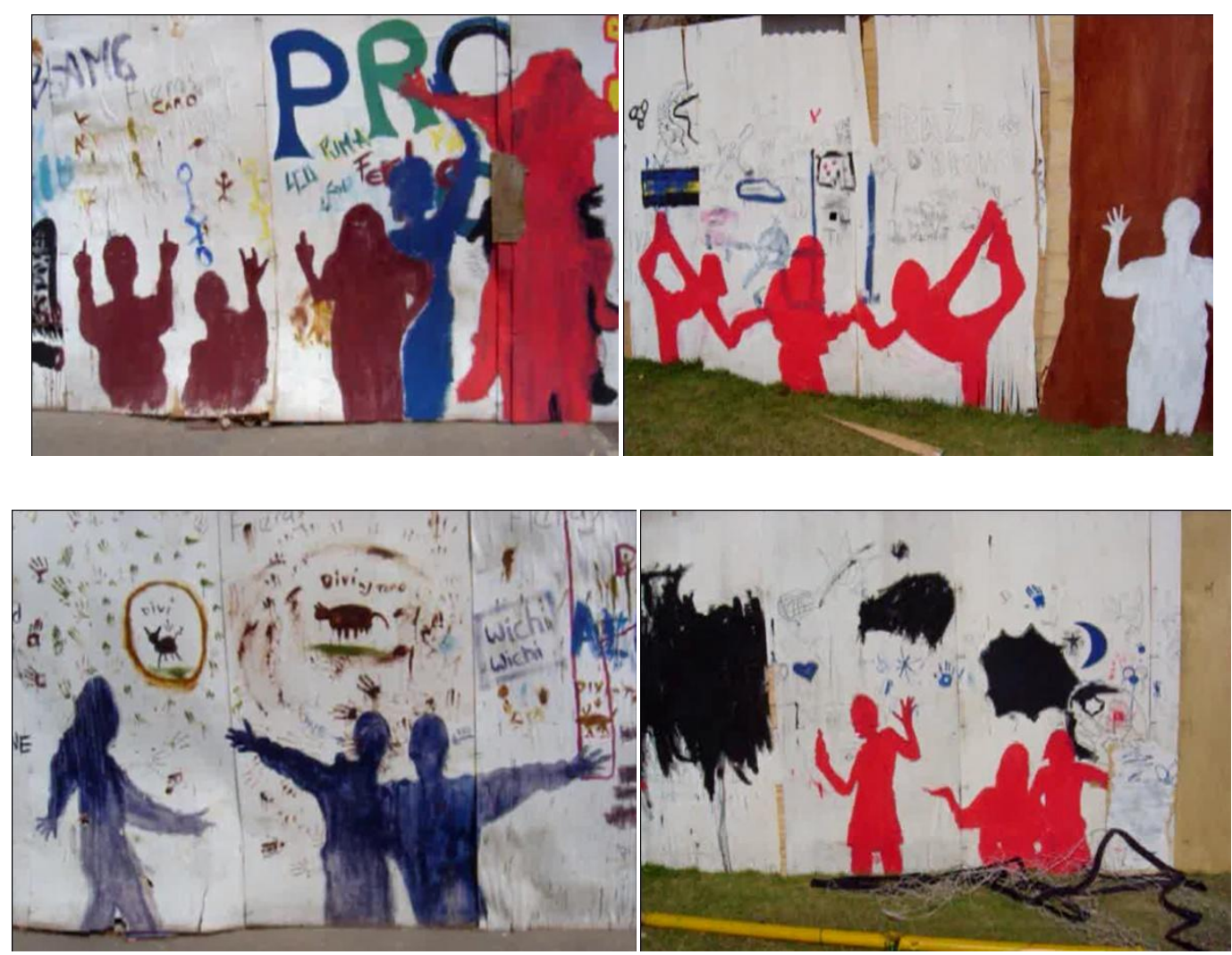

Fig. 16- Painel de madeira de construção de $25 \mathrm{~m}$. x 2,50 m. pintada pelos estudantes diversas turmas. (Vídeo still) Colégio Saint Andrews, La Paz, Bolívia, 2006. Fotografia de Tatiana Fernández. 
"É possível produzir um objeto de arte crítico, mas parece que não há mais público que possa completar sua função transformadora ... Então, se estamos atrás de uma função transformadora, a exposição pode não ser o lugar para começar Tal vez a escola como um modelo possa apontar o caminho para recuperar a capacidade agenciadora da arte na ausência de um público efetivo". Anton Vidolke, In MADOFF, 2009. 


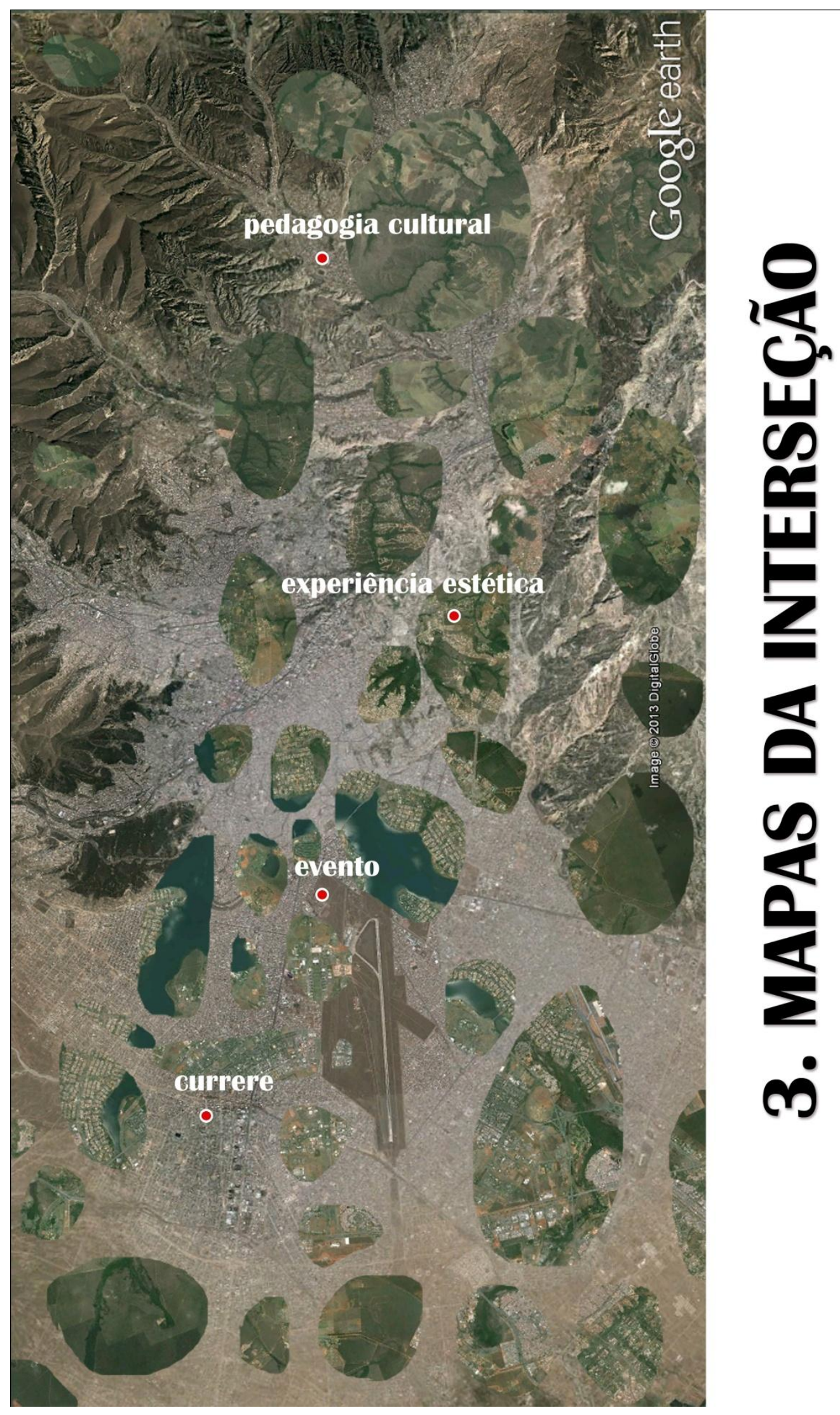

Fig. 17 Mapas da Interseção. Brasília e LaPaz superpostas. Tatiana Fernández, fotografia satelital Google Earth manipulada, 2013. 


\section{MAPAS DA INTERSEÇÃO}

A arte é uma busca de sentido. Mas esses sentidos não se encontram simplesmente: na arte se constroem (SULLIVAN, 2010). De maneira similar na educação é fundamental a construção do sentido para quem estuda, no espaço e no tempo onde aprende e em relação à vida, à circunstância de quem aprende com outros. Os parâmetros curriculares podem nos proporcionar apenas possíveis percursos importantes. O sentido se constrói no diálogo entre o educador em visualidade, os estudantes e suas paisagens. Ele não se encontra fora desta relação nem fora de um dado processo. $\mathrm{O}$ evento artístico como pedagogia requer, portanto, pensar na construção do sentido na paisagem existencial que é complexa e fluida. Nesse contexto é importante se perguntar para quem, para que e em que condições o estudo das visualidades se sustenta na educação. Essas perguntas conduzem ao cruzamento das fronteiras modernas e coloniais onde as todas as formas de construção de visualidades cobram protagonismo na Educação em Visualidade.

Ser professora de arte na primeira década do novo milênio na Bolívia me colocou no olho do furação onde estes questionamentos são urgentes e inapeláveis. Meu trabalho na formação de professores de arte no Brasil nos últimos anos ampliou ainda mais minhas indagações. Nessa situação foi possível perceber as interseções, coincidências, contaminações e hibridações que acontecem no 'espaço entre' a virada da visualidade na educação e a virada pedagógica da arte e as mudanças que estas interseções provocaram na arte e na educação. No processo da investigação, o que se propõe compreender é a complexidade desse encontro no cruzamento das fronteiras. Na revisão de literatura encontrei três conceitos que permeiam esse espaço ou 'entre-lugar'. Esses conceitos atravessam a ideia de uma relação (dentre outras possíveis) entre arte e educação que aqui se investiga.

O primeiro conceito constitui a pedagogia cultural que corresponde ao espaço de cruzamento das fronteiras onde a pedagogia crítica (TREND, 1992; GIROUX, 2005; 2011; 2012; APPLE, 2008; KINCHELOE, 2008) se encontra com os estudos culturais, os Estudos da Cultura Visual, os estudos feministas, os estudos pós-coloniais, as pedagogias pós-críticas e a filosofia pós-estruturalista e fenomenológica. O segundo conceito é o currere de Pinar $(1998 ; 2008)$ 
que oferece uma forma de pensar o currículo na tensão entre um currículo vivo e um currículo planejado. O terceiro conceito se refere à experiência estética de Dewey (2005) e a noção de evento de Badiou $(2002,2005)$ que, por uma parte abrem a possibilidade de situar a arte além das dicotomias modernas, e por outra relacionam a ideia de evento artístico ao evento pedagógico.

\subsection{O cruzamento de fronteiras: as pedagogias culturais}

A relação entre educação e cultura não é uma relação fácil. Até a metade do século XX são discussões separadas que evidenciam a fragmentação e hierarquização nas relações de poder. A educação é discutida por professores e técnicos em instrução centrados na instrumentalidade de mecanismos para aprendizagem em massa e em seguir as tendências culturais; a cultura é discutida por artistas, historiadores, críticos, agentes culturais e expertos em mídia e estas discussões dificilmente se encontram com os interesses puramente instrumentais à qual tende a educação tradicional, conservadora. Nesta perspectiva a escola não faz cultura, mas tende a segui-la.

Este pensamento começou a mudar na década de 1970 sob a influência do marxismo, o feminismo, os estudos culturais, o pós-estruturalismo e o pós-colonialismo. São linhas de estudo que de várias maneiras se cruzam. A crítica cultural marxista da Escola de Frankfurt reflete a partir da crise econômica, política e humana da década de 1930 quando ficou evidente que as revoluções dos trabalhadores não tinham mudado a sociedade da maneira que o marxismo previa. Esses teóricos denunciaram a manipulação da 'indústria cultural' que submerge as massas na adição ao consumo irreflexivo dos seus produtos. Apesar de ser uma importante crítica à comodificação da arte e da cultura, teóricos como Max Horkheimer e Theodor Adorno só veem um consumidor passivo, adormecido e desamparado. Essa visão da teoria cultural marxista, que corresponde à do emancipador, que supõe a incapacidade do outro, é reformulada pelos marxistas pós-estruturalistas Frederic Jameson e Roland Barthes que admitem que existe uma "negociação de possibilidades de significação" (TREND, 1992, p. 12). A ideia de um leitor como um coautor do texto ${ }^{26}$ e a interpretação como um percurso aberto conduz à evolução de um discurso complexo no campo da arte e da cultura. Isto

\footnotetext{
${ }^{26}$ A noção de texto é compreendida aqui não como discurso linguístico, mas como 'marca' em concordância com a desconstrução de Jacques Derrida (1973). Para ele a noção de texto ou traço ou marca é pré-linguística, é a potência da linguagem onde há uma necessidade de ralação com outra coisa ou com o outro. Para estas relações, pensa Derrida, a marca não requer de linguagem. Desta maneira o texto envolve tudo: o texto é o contexto.
} 
significou uma mudança epistemológica no pensamento marxista que vai das preocupações com a luta de classes, revolução do proletariado, formação da história e da sociedade e economia de produção a uma preocupação com as questões de representação, identidade, desejo, tecnologia, poder e linguagem (Ibidem).

Este cenário reclama uma maior preocupação com as relações que o texto estabelece com o público. Na pedagogia as implicações desta mudança são críticas:

A mesma maneira de ver o mundo se torna uma questão de estratégia. Por este motivo assunto de "leitura" e "escritura" cultural são preocupações pedagógicas explícitas. Os textos não precisam ser necessariamente interpretados da maneira que queriam os autores ou os realizadores. Podem ser revisados, combinados, ou questionados dentro do marco das capacidades do leitor. O uso é um fator de conhecimento. (TREND, 1992, p. 12)

É importante notar que as visualidades são estratégias de leitura e escritura do mundo porque são maneiras de ver e neste ato já há uma reconstrução do mundo. A fragmentação das metanarrativas modernas faz parte da permeabilidade cada vez maior entre culturas em que se multiplicam estas estratégias.

O pensamento moderno concebia a história como uma linha evolutiva de eventos que conduzia a um progresso humano centrado em valores universalistas, utópicos e duais que obedeciam a grandes narrativas. O filósofo pós-estruturalista Jean François Lyotard (2011) caracterizou a pós-modernidade como um tempo em que estas visões totalizantes, ou metanarrativas, perdem credibilidade e se fragmentam em narrativas particulares onde os valores são legitimados localmente. Nesse contexto, os valores da arte moderna, que se pretendiam universais, perdem sua referência paradigmática e seu valor hegemônico sobre outras formas de experiência estética. Da mesma maneira esta 'condição pós-moderna' problematiza o discurso absolutista da ciência moderna e da sua metodologia desmontando os pressupostos de uma razão universal como fundamento do conhecimento que subjazem nos princípios da educação moderna de raiz positivista e liberalista ${ }^{27}$. O que está em jogo nas narrativas particulares é a capacidade de agência, de flexibilidade, de negociação, de apertura e de crítica que permitem quando as histórias particulares contam, quando o poder de fazer se corporifica.

\footnotetext{
${ }^{27}$ Dado que a doutrina político-econômica do liberalismo tem uma história muito antiga que se remonta à democracia Grega, aqui se entende na sua concepção moderna baseada nos valores da liberdade e a individualidade e se refere sobretudo aos valores do livre mercado da doutrina capitalista.
} 
Esta abordagem das narrativas particulares é por si mesma conflitante, seja no ensino da arte ou de outra área de conhecimento, porque promove uma visão crítica das noções fixas e conservadoras de identidade cultural, conduz os estudantes e os professores a enfrentar assuntos sensíveis sobre religião, raça, gênero, sexualidade e excepcionalidade e, portanto a uma revisão das próprias estruturas mentais. Estas mudanças implicam em abordagens complexas em que os educadores em visualidade podem tratar com métodos democráticos que favoreçam uma ação comunicativa na forma como foi exposta por Dewey ${ }^{28}$ (BIESTA, 2010). A democracia é por sua vez o que Michel Apple (2008) chama de "significado variável" ${ }^{29}$, isto é, que pode ter múltiplas interpretações e aplicações nos discursos que fazemos sobre transformação ou reforma educativa. As palavras que usamos, como reforma ou democracia, são em si mesmos "como copos que podem conter qualquer tipo de liquido" (APPLE, 2008, p. 244) conceitos sem um significado essencial e que são de fato usados também pelas tendências ultra conservadoras na educação das últimas décadas. Por isso, ele adverte que, o questionamento "os conhecimentos de quem são valiosos?" é mais adequado para hoje do que "que conhecimentos são valiosos?" que fora mais adequado no passado (APPLE, 1995, p. 2).

Estas perguntas evidenciam uma mudança epistemológica e, portanto política, que reverbera em diversos campos acadêmicos, políticos e culturais (Fig. 18). As chamadas epistemologias do sul (SANTOS e MENESES, 2010) propõem o pluralismo epistemológico através de uma abertura a novos desafios epistêmicos. $\mathrm{O} \mathrm{Sul}^{30}$, que o Norte saqueia, nega, cala e destrói por meio de distinções e dicotomias entre bem e mal, verdadeiro e falso, legal e ilegal, se apresenta hoje como uma perspectiva transformadora na sua pluralidade epistêmica porque responde a realidades próprias, diversas e complexas. Como a recente bibliografia nos mostra, os pensadores do Sul colocam em evidência as mudanças paradigmáticas do nosso tempo: Bhabha, Spivak, Hall, Edward Said, Mignolo, entre outros, observam os dilemas que surgem da mentalidade colonialista, mas também da mentalidade colonizada. É justamente esta mentalidade colonizada que Rodríguez propõe mudar, para mudar a mentalidade colonialista. A emancipação do pensamento dominado é para Rodríguez não só uma emancipação do colonizador, mas, sobretudo uma emancipação dos próprios pensamentos colonizados. $\mathrm{Na}$

\footnotetext{
${ }^{28}$ A comunicação está no centro da filosofia da educação de Dewey. A sua visão de comunicação não é compreendida como o transporte de um significado de um lugar a outro. Comunicação para ele é "algo literalmente feito em comum em pelo menos dois centros de comportamento" (1929, p. 178). Para Dewey a ação da comunicação se dá na construção de algo juntos.

${ }_{29}^{29}$ N.T. sliding signifier

${ }^{30}$ Para os teóricos das epistemologias do Sul, a noção de Sul e Norte serve como metáfora da divisão entre ricos e pobres, colonizadores e colonizados, dominadores e dominados, silenciadores e silenciados.
} 
América Latina é comum, como em muitos outros lugares do mundo, que pessoas marginalizadas do poder se tornem os mais fieis serventes dos poderosos e os inimigos mais ferrenhos da sua própria comunidade. A mentalidade colonizada é uma mentalidade submetida aos desejos dos poderosos por meio da altitude servil, para conquistar o poder e se tornar colonizador. No Brasil são conhecidos como 'capitães do mato', escravos que perseguem escravos em nome do seu dono e senhor. As políticas latino americanas das décadas de ditaduras incentivaram no século XX uma subserviência incondicional aos interesses coorporativos do Norte a custo da sua própria negação.

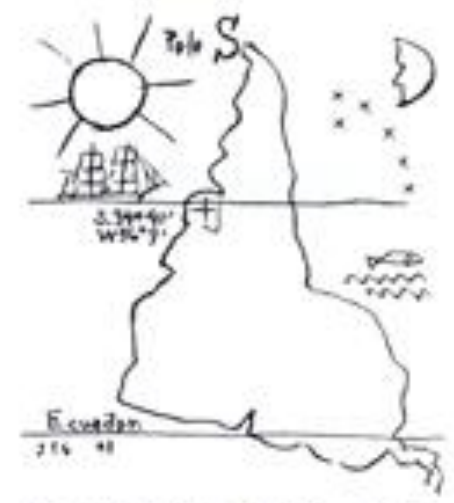

\section{ESCUELA DEL SUR}

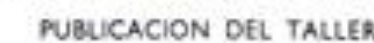

TORRES - GARCIA

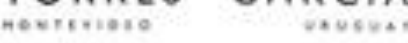

Fig. 18 Joaquin Torres Garcia. Capa para publicação Escuela del Sur, Mapa de América do Sul, 1958. Fonte: ceciliadetorres.com

Mas, quando o conhecimento se tece entre a singularidade de cada existência e a pluralidade do mundo as relações de poder tendem a ser dialógicas. Prestar atenção às narrativas particulares, em qualquer dimensão do saber, favorece um tecido democrático onde a participação é crucial. O poder é, portanto central nos questionamentos contemporâneos da arte e é um elemento crítico para a pedagogia que compreende a educação como um espaço de produção cultural antes que um espaço de reprodução da cultura dominante ou de uma ideia abstrata e totalitária de cultura.

As narrativas particulares valorizam o cotidiano porque visualizam a maneira em que fomos construídos e em que continuamos a construir em sociedade. A ressignificação do cotidiano na arte se manifesta não só em artefatos que operam com a imagem da intimidade ou com os artefatos e seus contextos, mas principalmente naquelas que operam com os espaços de 
relacionamento e participação humana (ver BOURRIAUD, 2009; BISHOP, 2012). As vanguardas modernas já demonstraram uma preocupação com a forma como vemos os artefatos da vida cotidiana, a arte pop e conceitual também estabeleceram relações estreitas com o mundo dos artefatos e das condições de relacionamento humanos. Mas é na arte pósmoderna que a cotidianidade adquire uma atenção relevante.

Dias $(2008,2012)$ faz uma distinção entre o cotidiano que é povoado de artefatos, imagens e fenômenos diversos e o cotidiano das imagens que denomina cotidiano espetacular em relação às ideias de Guy Debord do espetáculo como uma relação social, histórica e política mediada pela visualidade e às ideias de Charles Garoian e Yvonne Gaudelius de uma Pedagogia Espetacular ${ }^{31}$ (DIAS, 2012; GAROIAN e GAUDELIUS, 2008). Mas não se trata somente, como destaca Dias, de associar arte à vida, nem de fixar o estudo das visualidades num único espaço/tempo: "O cotidiano é em si um espaço/tempo que informa o espetáculo de categorias sociais identitárias na nossa cultura" (Idem, p. 68). No contexto pedagógico se trata do imaginário visual e da imagética do cotidiano dos indivíduos, não das imagens. Por isso é importante compreender o cotidiano dos estudantes e sua vida como o centro das questões pedagógicas. Esses deslocamentos são práticas críticas e imaginativas que visualizam o conflito.

Aldo Victorio Filho nota que as escolas ainda se mantém afastadas da realidade e das realizações dos seus atores, que para ele são "criadores de currículos e criadores de acontecimentos estéticos, se não no campo da arte, sempre na cotidianidade de suas vidas" (2008, p. 3). Para ele o maior desafio que temos os educadores em visualidade é explorar o potencial estético da cotidianidade das culturas infanto-juvenis de maneira a favorecer uma pedagogia voltada para "justiça social e coletivização das belezas" (Ibidem.). A cotidianidade é fonte vital de conhecimento aponta Victorio Filho (2007a, 2007b) e defende a pesquisa do/no/com o cotidiano como uma narrativa que não separa a imagem imaterial da material, nem a imaginação da materialidade, mas trabalha com as oportunidades do inesperado no fluxo dos acontecimentos e com o estudo do cotidiano na sua produção imagética.

\footnotetext{
${ }^{31}$ Garoian e Gaudelius caracterizam a "pedagogia do espetáculo da cultura visual em duas direções opostas: primeiro como uma forma ubíqua de representação, que constituem os objetivos pedagógicos da cultura mediática e do capitalismo corporativo para manufaturar nossos desejos e determinar as nossas opções; e segundo, como uma prática democrática que permite examinar críticamente os códigos da cultura visual e das ideologias para resistir à injustiça social." (2008, p. 24)
} 


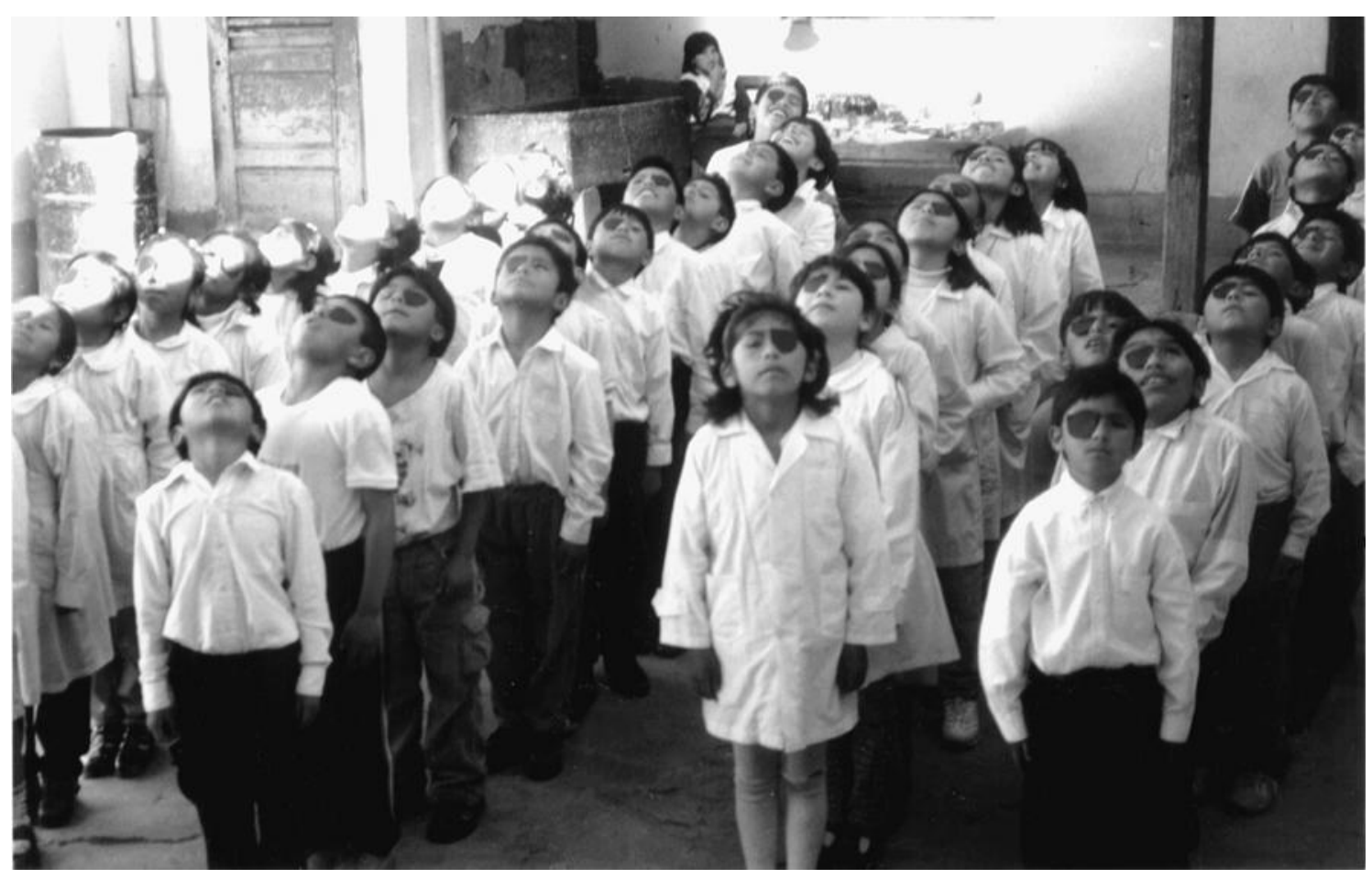

Fig. 19 Narda Fabiola Alvarado. Un minuto de silencio para ver el cielo, Escuela Primaria Max Paredes, La Paz, Bolívia, 2002. Fotografia da artista.
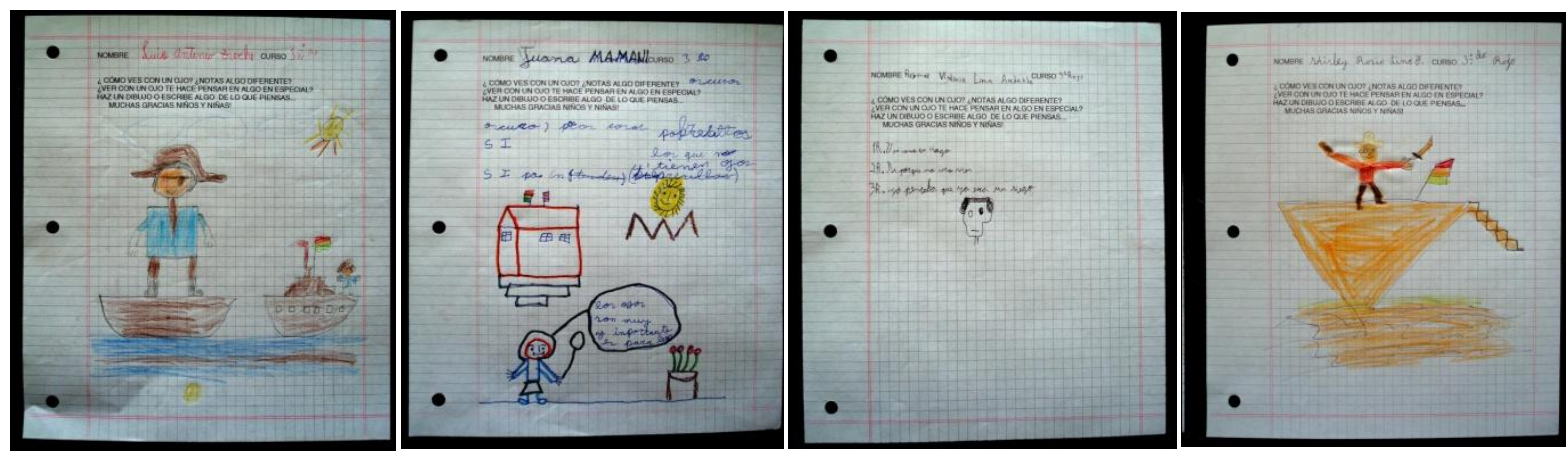

Fig. 20 Narda Fabiola Alvarado. Desenhos dos estudantes de 7 a 8 anos da Escuela Primaria Max Paredes depois de verem por um minuto o céu com um olho. Sequencia da obra Un minuto de silencio para ver el cielo, Fotografias da artista.

Tatiana: Como foi trabalhar com estudantes que não eram teus alunos? o que te
interessava dessa ação em que eles participavam da tua obra? de que maneiras eles se
relacionaram com ela, te fizeram perguntas? queriam entender o que você fazia? o que as
autoridades da escola disseram?
Narda: Um minuto de silêncio...para ver o céu nasceu como uma imagem de crianças com
parches nos olhos, em pé, fazendo fila no pátio da escola. Me interessava reproduzir uma
imagem do meu passado e fazer algo com a experiência da execução [...] Devo dizer que
sempre suspeitei da arte participativa ou colaborativa. Não convido o público nem os


executores das minhas obras para serem parte do processo criativo. Eu gosto de trabalhar sozinha. Meu método é convencer o outro de me ajudar a executar uma obra, usando como argumentos minhas intenções reais e as possíveis leituras

Foi assim que a diretora me deu um período de uma hora e meia com estudantes de duas turmas do terceiro ano do fundamental. Os professores se encarregaram de levar no pátio e fazer filas, eu reparti os parches, pedi para olharem o céu por um minuto e tirei algumas fotos [...] depois retornamos à sala de aula e eles responderam ao questionário com texto e desenhos: como você vê com um olho? Você nota algo diferente? Ver com um olho te faz pensar em algo especial? Faz um desenho ou escreve algo do que você pensa... muito obrigada crianças

Entrevista de Tatiana Fernández com Narda Fabiola Alvarado, junho de 2013 (Anexo III)

A ênfase sobre o cotidiano desafia a categorização das artes em 'altas' ou 'belas' e de outro lado 'populares' ou 'menores' ou inclusive 'kitsch' ${ }^{32}$. Estas categorizações são hierárquicas. Evidentemente podemos diferenciar modos, contextos e propósitos em que os artefatos são ou não são arte para dados contextos culturais, sociais e históricos, mas estabelecer relações hierárquicas verticais entre estes modos, contextos e propósitos só busca fortalecer as relações entre poder e dominação. Por outra parte as diferenças entre os modos, contextos e propósitos em que os artefatos da visualidade são concebidos é mutante, fluída e permeável de maneira que o próprio artefato pode ser arte, artesanato, arte popular, design ou objeto de consumo de massas ao mesmo tempo ou em tempos e lugares diferentes. Precisamente porque há uma multiplicidade de estratégias de leitura e escritura do mundo é que estas diferenças são relacionais.

O encontro entre o evento artístico e o evento pedagógico conduz a uma maior ênfase sobre a experiência estética do cotidiano na educação. Esta é uma abordagem que se distância substancialmente da ideia do artefato artístico como centro das questões pedagógicas na educação em artes visuais porque não procura categorizações hierárquicas. Não entanto, isto não significa se distanciar da arte e seus processos, ao contrário, conduz a uma maior compreensão do seu caráter fluído e mutante.

\footnotetext{
${ }^{32}$ Kitsch é uma palavra alemã que se refere a objetos ordinários copiados dos objetos da cultura erudita em material e qualidade inferior ao original. Termo usado por Clement Greenberg (Avant Garde and Kitsch, 1939) para designar a arte comercial, popular e folclórica e argumentar a sua inferioridade frente a superioridade da arte de vanguarda moderna.
} 
O cotidiano é por outra parte uma forma de participação nas políticas do poder. Inspirado nas ideias de Hall (2006), Giroux destaca a força educacional que a cultura tem para "redefinir as políticas de poder, a natureza política da representação e a centralidade da pedagogia como um principio de mudança social" (2000, In ALLEN, 2011, p. 48). Ele observa que a pedagogia como prática performática "habita" (Ibidem) em todos os espaços públicos onde se formam as identidades, funciona como uma ponte entre conhecimento, prazer e valores e mantém uma estrutura em que a autoridade é tanto crucial como problemática. Assim, as pedagogias culturais se entendem nesta investigação e de acordo com esta linha, como práticas que operam tanto dentro como fora dos espaços educacionais e, portanto práticas que se contaminam nos múltiplos espaços da vida. Se entendemos que o cotidiano tem um valor político e o político um valor pedagógico como Hall e Giroux, reafirmamos "a natureza política do trabalho cultural" (Idem, p. 49) em que os saberes e o cotidiano que os estudantes trazem consigo tem significado e se encontram em diálogo com o mundo.

Por esse motivo esta investigação se alinha na revisão crítica das relações de poder e conhecimento que são construídas e mantidas através do discurso social, mas que também estão estreitamente relacionadas com as formas do olhar, as formas de representação e de vigilância visual. Como argumenta Mirzoeff (2009) "a visualidade é aquilo que faz visível o processo da História para o poder" (Idem, p.5), é, portanto um espaço de tensões em que "a visualidade visualiza o conflito" (Idem, p.6). A Educação em Visualidade como um campo ampliado da educação em Artes Visuais (DIAS, 2011, 2012) se alinha no pensamento foucaultiano do poder de visibilidade como principio de poder. Trata-se de uma abordagem pós- crítica do olhar e da imagem em relação às formas de exercício do poder e o discurso que se instituem na arte e em outras formas de visualidade.

Desde distintas áreas é possível encontrar discussões que destacam a relações entre poder e visualidade. $\mathrm{O}$ dualismo entre conhecimento e sentimento que se cultivou na modernidade é parte destas relações de poder. As pesquisas da psicologia associada ao ensino da arte nos estudos da percepção de Rudolph Arnheim (2000) e Herbert Read (2001), das inteligências múltiplas de Howard Gardner (2011), da biologia da cognição de Maturana (2005) e o papel dos sentimentos na formação dos conceitos de Antonio Damasio (1996) contribuem na discussão sobre poder e conhecimento porque levam à compreensão, por uma parte, de que a emoção é central no pensamento racional e, portanto na aprendizagem. E por outra, que nossos conceitos são construções culturais ligadas às nossas emoções e à nossa experiência 
metafórica do mundo (LAKKOF e JOHNSON, 1980). Estas teorias sugerem que todo conhecimento envolve a construção de significado dentro de um contexto cultural, por esse motivo dependem das nossas crenças que são formas de ver o mundo. Isto nos leva a pensar que o conhecimento não tem um significado inerente, é a experiência das pessoas dentro de uma cultura que torna o conhecimento significativo, da mesma maneira que acontece com a arte (FREEDMAN, 2003).

Assim, é possível pensar que a forma como abordamos a arte e a cultura e seus diversos valores têm implicações importantes em tempos em que múltiplas crenças culturais convivem (em conflito ou em paz) e constroem novos significados. Uma das mais importantes linhas teóricas que contribuíram de maneira vital nas discussões sobre poder e diferença são os estudos feministas. É compreensível que Jana Sawicki (1991) sugira, em base ao pensamento foucaultiano, que o poder não é algo que se possui, ele se exerce; é produtivo, não repressivo; se distribui, não se comprime desde cima. Nesta perspectiva o pluralismo, a convivência democrática, o respeito pelas múltiplas perspectivas enfrentando o conflito e integrando conhecimentos e saberes diferentes é um exercício de poder. Os questionamentos sobre quem define a identidade, quais as relações de poder que influenciam sobre ela, a normalização e o biopoder (ver BUTLER, 2004; SAWICKI, 1991) são semelhantes aos que emergiram dos movimentos raciais e os estudos pós-coloniais.

Para os teóricos pós-colonialistas (SAID, 2003) o olhar de Ocidente representa o 'outro' de uma forma estereotipada. Este jogo da representação do outro é uma ferramenta de colonialismo que cria uma imagem fora da história, uma identidade de subalternidade, pensam eles. Nessa linha, Homi Bhabha (1997), Hall (2006) e outros coincidem no valor da diferença que visualiza e ouve o outro ao invés de somente ver e falar por ele. Isto significa ver e falar com o outro. Assim toda política é uma forma de estética porque "[...] faz visível o que foi excluído do campo perceptivo e faz audível o que era inaudível" (RANCIÉRE, 1999, apud BIESTA, 2010, p. 49). Nesta investigação a diferença se torna, então, um espaço político destacado.

Mas são diversas as formas de abordar este espaço político. Do ponto de vista mais crítico, os teóricos atuais que argumentam por políticas da diferença têm posições múltiplas, e às vezes até contrárias, sobre multiculturalismo. Na primeira metade do século XX estas diferenças de posição existiam entre os chamados assimilacionistas e os pluralistas: os assimilacionistas queriam integrar 'o outro' na própria cultura e os pluralistas defendiam a necessidade de 
manter a integralidade das diferenças. Hoje esta é também uma diferença entre o conceito de tolerância e o de convivência cultural. A tolerância é sempre transitória e condicional, implica alguém que tolera e outro que é tolerado. Os assimilacionistas toleram por meio de uma abordagem étnica que representa 'o outro' como distante, "mantendo as questões sobre relações de poder na sociedade à distância" (CAHAN e KOCUR, 1996, p. xxi). Esta é também a distinção entre diversidade e diferença. A diversidade, como explica Richard Miskolci (2012, p. 47), é "cada um no seu quadrado", todos convivem e se toleram, mas a cultura continua sendo o que ela é. As políticas da diferença põem acento na especificidade e na pluralidade, no "inesperado, o criativo, o novo, o que realmente pode mudar a ordem do poder" (MISKOLCI, 2012, p. 49). A proposta de queerização ou transviar ${ }^{33}$ (DIAS, 2008, 2011) da educação, neste aspecto, aponta à valorização da diferença que compreende não só as diferenças de gênero, mas também às questões de sexualidade, raça, religião, excepcionalidade e colonização.

É dentro desta perspectiva que os artistas contemporâneos aderem às "políticas da diferença" ao buscar desafiar noções monolíticas e hegemônicas da história da arte por meio de uma prática do múltiplo e do heterogêneo que rejeita um discurso universal, genérico e abstrato e valorizam realidades particulares, específicas e concretas (WEST, 1990, apud CAHAN e KOCUR, 1996). Na arte, as questões sobre o como e o que é diferente adquirem centralidade. As referencias ao sincretismo religioso, as narrativas autobiográficas, a complexidade da identidade e o poder da autorrepresentação são materiais para uma "educação interdisciplinar em que a arte se entende tanto como produto da história como agente de mudança social" (CAHAN e KOCUR, 1996, p. xxiii).

É importante notar, como faz Pinar (2009), que as políticas da diferença não são políticas separatistas que promovem uma ideia nostálgica e totalizante de cultura. É comum pensar na cultura negra ou na cultura indígena como culturas homogêneas, da mesma maneira que se pensa na identidade fixa do gênero ou na univocidade da religião. O problema é que a noção de multiculturalismo, sendo um 'significado variável' pode justificar ações que enfatizam sobre a visão totalizante da cultura em que a singularidade desaparece sob uma redução abstrata. O multiculturalismo é hoje uma noção que estabelece uma relação importante entre educação e cultura, mas tem sido usado para privilegiar grupos ou comunidades repetindo o mesmo papel colonialista que se pretende abolir e para conservar estereótipos

\footnotetext{
${ }^{33}$ Aqui relativo à Teoria Queer.
} 
homogeneizantes que tornam invisíveis as diferenças como acontece com as comunidades indígenas e negras. É importante, pois, singularizar a identidade coletiva, argumenta Pinar. A narrativa autobiográfica é neste caso "mais responsável e convincente" (PINAR, 2009, p. 151) que as políticas da identidade, e tem maior potencial educativo porque se centra na experiência vivida da singularidade na pluralidade. Esta singularização só é possível onde existe espaço para a diferença e o dissenso.

De maneira análoga acontece no âmbito da arte. Camnitzer (2009b) observa que apesar da intenção anti- hegemônica da noção de multiculturalismo, provoca uma deterioração considerável na prática artística. O multiculturalismo se torna uma ferramenta de apropriação das manifestações periféricas consideradas úteis e assim as políticas governamentais e coorporativas (de maneira global) neutralizam as expressões de dissenso das subculturas categorizando-as como exóticas e tornando-as grife para explorar no mercado,

Como uma ferramenta para culturas hegemônicas, o multiculturalismo tenta impor alguma ordem em um conjunto potencialmente caótico de subculturas com o propósito de conservar uma identidade nacional e provavelmente também uma imperial (CAMNITZER, 2009b, p. 88).

Por este motivo, nas últimas décadas, muitos artistas da 'periferia' não querem mais ser reconhecidos pelo exotismo da sua "outridade", mas pela especificidade da sua prática artística para evitar a "antropologização" do seu trabalho ou a submissão às regras do mercado internacional. Tudo isto nos leva a pensar que se torna cada vez mais crucial uma pedagogia do dissenso que permita a visibilidade da singularidade na pluralidade para que as estratégias que neutralizam a cultura e a arte sofram sempre um processo de visualização.

Por outra parte devemos considerar que a multiculturalidade é uma noção que surge no mundo anglo-saxão e se refere aos esforços para uma convivência pacífica entre diversas culturas constituídas pelos imigrantes que conservam seus modos de vida. Na América Central e do Sul os colonizadores, os colonizados, os escravizados e os imigrantes formaram uma intrincada rede de relações culturais híbridas porque se misturaram. Isto não significa que a hibridação é isenta de conflito, mas criou uma subjetividade 'camaleão' que é capaz de mudar segundo o contexto. É muito comum nas nossas sociedades latino americanas, as pessoas fluírem entre diversas culturas, estratos sociais, raças, comunidades, linguagens ou gêneros sem maiores dificuldades. Nesse contexto as culturas não se conservam. A mudança 
é, além do mais, recíproca: todos mudam. No nosso casso todos tem algo de colonizador e colonizado ao mesmo tempo. Em base a esses exemplos podemos pensar que é necessário ir além do multiculturalismo e pensar num transculturalismo.

O transculturalismo, como aponta Gerardo Mosquera (CONFERÊNCIA GERARDO MOSQUERA, 2009) faz ênfase sobre a vocação antropofágica, apontada pelo evento modernista no Brasil, de devorar a cultura dominante como forma de resistência. O termo, proposto por Fernando Ortiz (1983) para tratar do intercâmbio e apropriação cultural pela cultura subalterna, propõe uma estratégia cultural consciente da sua capacidade de afetar e ser afetado pelo "outro". A apropriação não é um processo novo na formação das culturas, mas é crítico em condições de dominação cultural como no caso latino americano, pois é necessário reavaliar constantemente até que ponto a apropriação da cultura dominante torna os antropófagos seus consumidores facilitando os propósitos de dominação.

Torna-se evidente por este motivo ocupar os 'entre-lugares' também chamados por Bhabha (1997) de 'Terceiro Espaço' onde as culturas se encontram de diversas maneiras. Estes são espaços de dissenso, portanto espaços de produção que não são necessariamente parte dos espaços culturais instituídos nem parte da hibridação cultural do contexto. Em outras palavras a transculturalidade considera elementos que não se dissolvem, que se querem diferentes, que resistem mesmo à hibridação, que produzem novas subjetivações fora das culturas em criação. Néstor García Canclini pensa que a hibridação "não é sinônimo de fusão sem contradição" (2001, p. II). O "Terceiro Espaço" é o espaço da contradição e, portanto o espaço da "conversação complicada". Daniel Trend (1992) observa que os mecanismos sociais nunca estão completos, como mostram as pesquisas dos Estudos Culturais na década de 1990, sempre se formam resistências, rejeições, ou reconfigurações em subculturas como as dos adolescentes.

Esta visão política da relação entre educação e cultura é a base da pedagogia freiriana. Quando Freire ensinou na Universidade de Harvard em 1969 seu pensamento provocou um encontro do qual surgiu a pedagogia crítica nos Estados Unidos e no Canadá com Giroux, Joe Kincheloe, Peter McLaren, Michael Apple e Greene. Na América do Sul as ditaduras impediram que o pensamento freiriano se disseminasse até o final dos anos 80. Embora a influência de Freire em outros continentes não tenha sido tão grande quanto nas Américas, o pensamento freiriano está hoje nas bases de toda reforma educativa que procura uma 
educação democrática. $\mathrm{O}$ que veio se chamar de pedagogia cultural é esta relação entre a prática pedagógica e o trabalho cultural através das lentes do feminismo, do pós-colonialismo, do pós-estruturalismo e dos estudos culturais. A proposta é a relação entre pedagogia critica e produção cultural como um projeto político e ético (GIROUX, In TREND, 1992). Desta maneira ela é inseparável de democracia cultural ou "democracia radical" como a chama Giroux: "A pedagogia cultural oferece uma nova visão para reescrever não só as relações entre cultura e poder, entre arte e pedagogia, mas também entre o trabalho cultural e o projeto de renovação democrática" (Idem, p. viii).

Na América Latina a noção de 'trabalhador cultural', usada pelos artistas que queriam afetar seu contexto cultural, social e político na década de 1960, encontra uma raiz no papel que o artista teve nas condições da periferia e de ditadura. Era muito comum, lembra Camnitzer (2009a, 2009b), os artistas se considerarem 'trabalhadores culturais' para resistir aos sistemas políticos totalitários aos quais o sistema da arte foi historicamente ligado na colônia e no qual a identidade de artista era uma identidade ligada às elites. A identidade de 'trabalhador cultural' reduz a importância individual do artista, mas não a elimina e enfatiza sobre um trabalho coletivo. Como aponta Giroux, a educação pode e deve participar na "construção e organização do conhecimento, dos desejos, dos valores e das práticas sociais. Isto também serve para contestar as formas dominantes de produção simbólica" (GIROUX, In TREND, 1992, p. ix). Assim, a noção do pedagógico deve estar sujeito a uma constante autoavaliação e reformulação crítica para evitar que o sistema tente despolitizar ou neutralizar a produção cultural.

Esta linha remete á filosofia reconstrucionista de Dewey (1920), que deu nome ao movimento reconstrucionista social na educação (Sec. XX), na ideia da ação reconstrutiva como um espírito filosófico transformador:

Os planos que são formados, os princípios que o homem projeta como guias de uma ação reconstrutiva não são dogmas. São hipóteses para serem trabalhadas na prática e para serem rejeitadas, corrigidas e expandidas quando falham ou acertam em dar a guia que requerem nossas experiências presentes. Podemos chamá-las de programas de ação, mas já que vão ser usadas para fazer menos cegos e mais dirigidos nossos atos futuros, são flexíveis. Inteligência não é algo que se possui de uma vez. É um processo constante que vai se formando e sua retenção requer uma alerta constante na observação das consequências, vontade de mentalidade aberta para aprender e coragem para se reajustar. (DEWEY, 1920, p. 96-97) 
O reconstrucionismo social é uma filosofia da educação baseada na ideia da transformação e reajuste da vida em sociedade. Esta ideia é adequada à contemporaneidade em que as mudanças são velozes. Mas a transformação e o reajuste podem ser interpretados de muitas formas, como vimos antes, conduzem ao questionamento fundamental de quem determina o que, como e para que deve se transformar ou se reajustar uma sociedade.

Esta é outra razão pela qual a escola deve ser compreendida como geradora de cultura, como defende Fernando Hernández. Ele considera a sala de aula como um cenário que tem uma cultura própria, mas não única, que vai se definindo "mediante as diferentes formas do discurso que se desenvolvem e se encenam nas situações de aula". (HERNÁNDEZ, 1998, p. 32). Nesse contexto os processos de ensino-aprendizagem não giram em torno a normas, regularizações ou disciplinarização, mas sobre as complexas relações entre subjetividades, interesses, situações e contextos sociais e culturais e experiências de vida.

Sobre a incerteza que envolve a ação pedagógica e a necessidade de correr o risco de trabalhar na dimensão da complexidade das relações e das incertezas, Atkinson argumenta:

Creio que podemos desenvolver esta linha de indagação pensando sobre o surgimento de uma aprendizagem real através de um evento que envolve um movimento a um novo estado ontológico. Aprender pode se conceber como um problema de existência já que envolve esta evolução ontológica (ATKINSON, 2008b, p. 10).

Em última análise, como Atkinson, Hernández (1998) defende a necessidade de reconhecer a complexidade das situações e a sua singularidade. Isto significa para ele uma escola que privilegie a perspectiva relacional do saber que supõe ensinar a questionar toda forma de pensamento único. Supõe reconhecer as concepções que o regem e incorporar uma visão crítica que pergunte quem se beneficia e quem se marginaliza nisto. Supõe introduzir visões diferenciadas que evidenciem que o saber se constrói desde pontos diferentes e observar as tensões de poder que existem entre estas diferenças de maneira a legitimar sua visão de mundo. Supõe também observar que toda realidade responde a uma interpretação e que esta interpretação tem geralmente um interesse ligado à hegemonia de determinados grupos.

De toda forma, uma pedagogia cultural é uma pedagogia crítica que valoriza o cotidiano e a imagética dos estudantes, que reconhece a transculturalidade, que corre riscos, que se envolve em eventos, que se aventura pelo desconhecido, que se atreve a percorrer a complexidade das 
relações e situações contemporâneas, que se move entre o passado e a memória, o aqui e agora e a imaginação do que ainda não é. Mas, sobretudo, é uma pedagogia geradora antes que reprodutora, criadora antes que imitadora, emancipadora antes que dominadora.

Para Giroux (2005; 2000 In ALLEN, 2011) esses são os termos de uma "pedagogia de fronteira" e Atkinson $(2008 \mathrm{~b}, 2011)$ pensa isso como uma "pedagogia contra o estado" ou "uma pedagogia do evento". Ambos se referem a uma pedagogia que além de crítica é agenciadora de transformações, geradora de um "novo estado das coisas". As pedagogias culturais são, pois, todas estas pedagogias que cruzam fronteiras, que proporcionam condições para que os estudantes sejam "cruzadores de fronteiras", que se engajam em conversações complicadas e experiências estéticas, que criam territórios de existência e de dissidência. $O$ Sistema Educativo Rebelde Autónomo Zapatista de Liberación Nacional estabelecido nos territórios rebeldes autônomos zapatistas em Chiapas, no México (Figura 21 e 22), é evidência de que é possível o cruzamento das fronteiras.

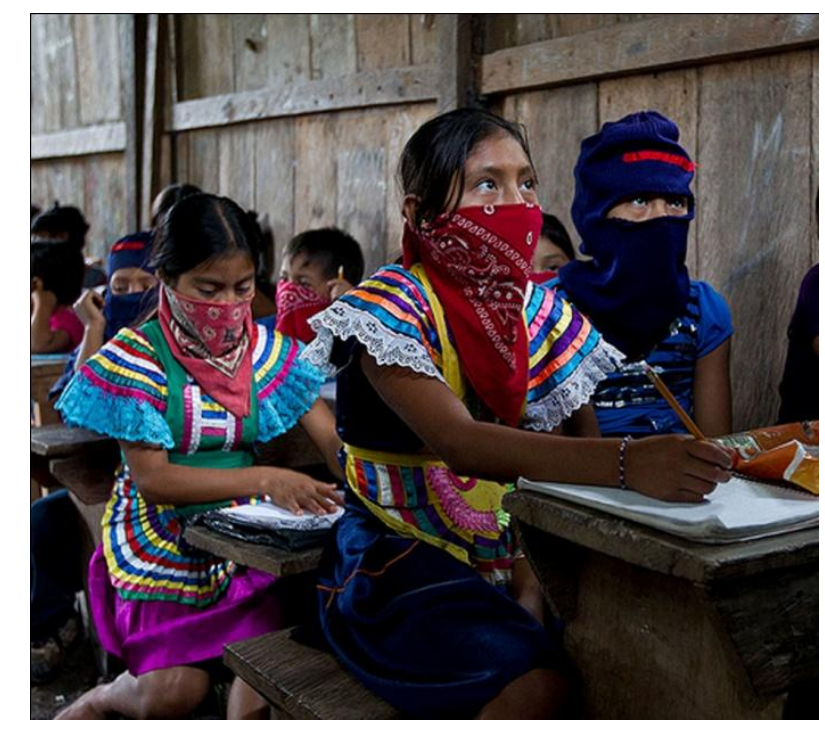

Fig. 21 Portafolio La Escuela Zapatista. Fonte: w-x.com.mx.

O desafio das pedagogias culturais é o de manter espaços de dissidência e diferença que permitam a visualização do conflito e assegurem uma constante reavaliação das relações de poder e conhecimento. As pedagogias culturais necessitam, portanto, não só um novo currículo na educação em artes visuais, mas outras formas de compreender o currículo. Neste sentido a paisagem existencial pode ser uma metáfora importante. 


\subsection{O currere e a paisagem existencial}

Sobre as paisagens de aprendizagem Greene escreveu: "estar em contato com as nossas paisagens é estar consciente da evolução das nossas experiências, ser conscientes das maneiras como nos encontramos com o mundo" (1978, p. 2). Greene se refere às paisagens internas e externas em que as pessoas vivem e que se tecem entre o passado e o futuro, entre o singular e o plural, entre o real e o virtual, entre o sujeito e o objeto. A fidelidade ao que seria "minha paisagem" não exige, no entanto, uma pertença única, unívoca ou patriótica porque as paisagens se fazem, se descobrem e se inventam, mas também se impõem sobre nossa vida, o que exige é uma consciência da sua multiplicidade e da vitalidade que proporcionam suas diferenças. A aprendizagem só ocorre quando algo entra a fazer parte da nossa paisagem. A metáfora da paisagem se aproxima ao que Lev Vygotzky (1984) chamou de "Zona de Desenvolvimento Proximal", ZDP: aprendemos em relação ao que já sabemos, pois não haveria lugar na nossa paisagem para algo que se mostra incompreensível ou insignificante. Aprender só tem sentido na superposição de paisagens que nos constituem, que constituem a nossa existência. Podemos aprender coisas inteiramente novas, mas nossas experiências prévias vão sempre influenciar nossa forma de compreender os fenômenos novos.

Essa visão do corpo imerso num mundo (espaço/tempo) mutante, líquido, que se transforma junto com as transformações da percepção é o centro da filosofia fenomenológica em Maurice Merleau- Ponty (1996). Para ele a experiência do espaço e do tempo é singular porque nossa percepção é situada. Não se trata da posição (coordenada) em que nos encontramos no mundo, mas da situação (relações) que vivemos, isto é, se trata da existência. O espaço/tempo, dessa maneira, é existencial e a existência é espaço/temporal. O espaço/tempo de existência constitui nossa paisagem. Quando olhamos velhas fotos, quando sentimos os cheiros da infância, quando escutamos músicas do passado algo mágico acontece porque subitamente a paisagem se recompõe aos nossos sentidos e percebemos o quanto mudou nosso espaço/tempo. Num mundo globalizado e tecnológico (onde o espaço/tempo pode ser transformar num instante) com grandes massas migratórias a situação da existência é ainda mais mutante e complexa. Um imigrante, por exemplo, desenvolve habilidades para hibridizar sua identidade e assim conservar sua integridade existencial. Um cyborg pode reconfigurar suas paisagens o quanto quiser. A paisagem é, pois, a percepção da nossa existência, que embora possa ser virtual, sempre é real porque existimos nela. 


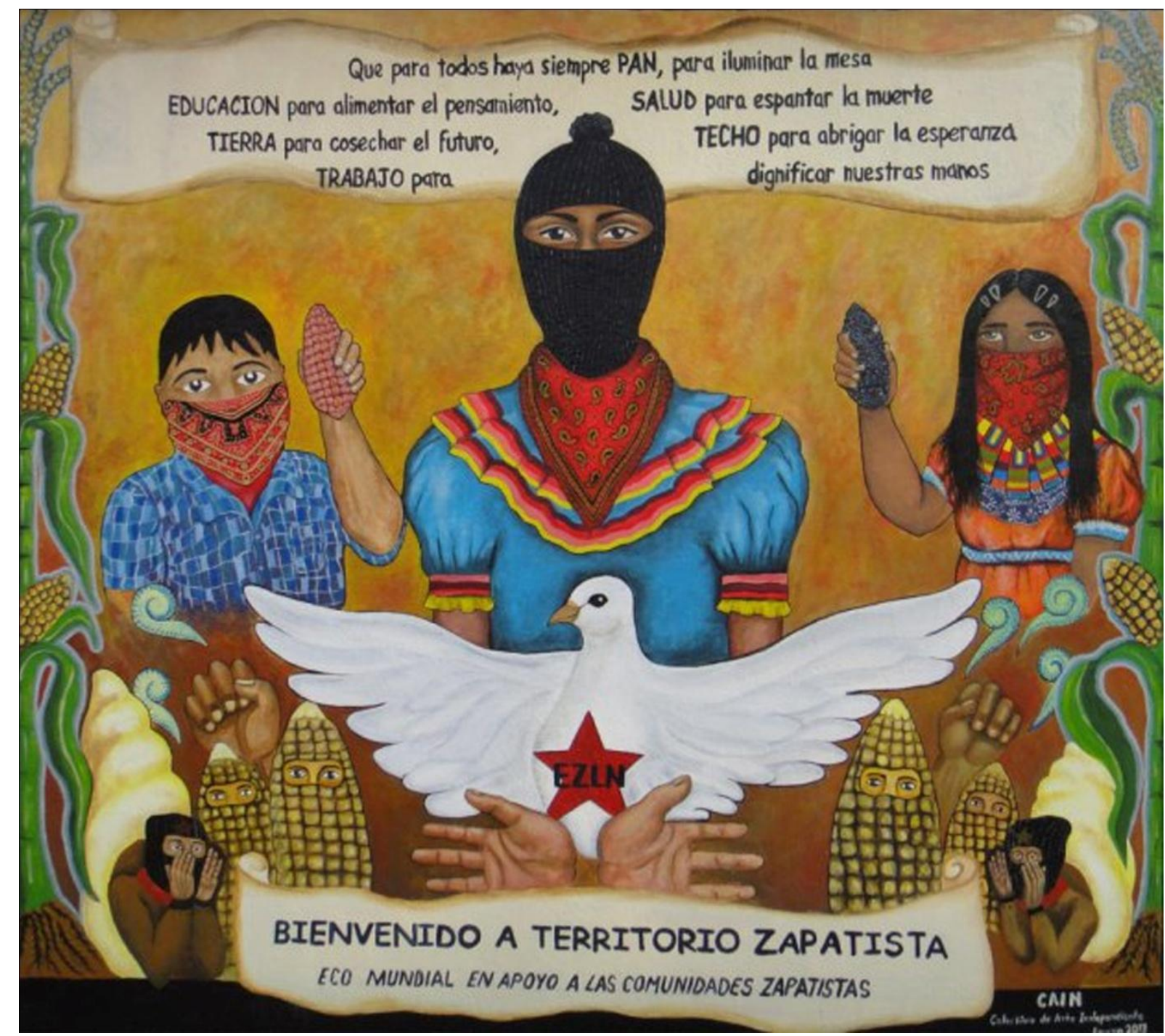

Fig. 22 Mural Bienvenido a territorio zapatista. Fonte: mujeresylasextaorg. wordpress.com.

Esta ênfase sobre a experiência da paisagem é uma ênfase que une a singularidade do ser à pluralidade do mundo como pensou Dewey em Experiência e Natureza (1929). Entre a natureza e a arte há uma continuidade porque a potência humana da significação procede da relação do seu organismo com o meio natural e social. De maneira análoga Guattari (1995), considera territórios de existência que ele chama de cartografias ou sistemas de modelização da subjetividade, que, embora não são dadas pela natureza (mas estão relacionadas a ela), são paisagens nas quais existimos. As cartografias artísticas foram, desde as pinturas préhistóricas, nos lembra Guattari, uma forma de cristalização das subjetividades individuais e coletivas. Sabemos, como seres sociais e culturais, que as cartografias são elementos fundamentais para reterritorializar e resingularizar a existência. Pensando nas instituições sociais e como elas podem criar espaços de construção de cartografias ele se pergunta então 
"como fazer viver uma aula como uma obra de arte?" (GUATTARI, 1995, p. 133). Guattari quer saber como poderia uma instituição como a escola reinventar sistemas de modelização da subjetividade. Podemos pensar, desta maneira, no currículo como uma paisagem existencial que pode ser resingularizada.

Na complexidade da paisagem existencial a reconstrução da realidade, como argumenta Pinar (WILLIAM PINAR SEMINAR, 2011), é intelectual e por este motivo se dá de maneiras que não poderíamos prever. E um currículo é justamente uma previsão dos processos de ensino e aprendizagem. Pinar (2008) oferece então a ideia de currere que, à diferença da ideia do currículo (e do qual é o infinitivo) não é um percurso linear e previsível de objetivos, é uma "conversação complicada consigo mesmo" porque enfatiza sobre um processo autobiográfico na aprendizagem. Nessa perspectiva o sentido da educação é questionado, se perguntando qual o seu significado e a sua relevância para a "autocompreensão e a reconstrução social" (2008, p. 35). Pinar desloca assim nossa atenção de um currículo de padronização a um currículo de diferenciação.

Pinar destaca o Brasil entre os países que permitem um currículo de diferenciação com parâmetros flexíveis e descentralizados capazes de se situar na especificidade do contexto e que valorizam a noção do cotidiano como um elemento curricular relevante (WILLIAM PINAR SEMINAR, 2011). Os sistemas educativos nos Estados Unidos e na Europa, ao contrário, caminham em direção a uma maior padronização curricular com critérios de avaliação cada vez mais desarticulados da realidade diferenciada. Este movimento da padronização curricular na educação não é novo, nos Estados Unidos nas primeiras décadas do século XX se chamou 'movimento da eficiência' e retornou como o movimento do accountability nos anos 50 e como o 'movimento da padronização' nos anos 70 (EFLAND, 1990). Em 1983 o então presidente Ronald Regan reativou a política das padronizações com o histórico informe A Nation at Risk: The Imperative for Educational Reform, que carrega sobre a escola e os professores todos os erros e fracassos do sistema capitalista. Foi o inicio de uma política de privatização da educação que se estendeu com os "interesses" norte americanos pela América Latina na década de 1980. Pinar reconhece nesta acusação não só um conflito político, mas também um conflito de gênero: as escolas, que estão na base da educação empregam mulheres em sua grande maioria. Não podemos então esquecer que o controle da professora na escola é um controle de gênero. (WILLIAM PINAR SEMINAR, 2011) 
Em janeiro de 2002 George W. Bush assinou o Ato do Congresso dos Estados Unidos, chamado No Child Left Behind, que manda uma reforma educativa baseada em altos padrões mensuráveis e previsíveis e condena as escolas públicas que não passarem de níveis aceitáveis a serem fechadas, podendo ser absorvidas pela iniciativa privada. Mas a desproporção da política da padronização levou o Governo do Presidente Barak Obama a suspender a lei em 2011: 82\% das escolas públicas nos Estados Unidos deviam fechar porque não atingiram durante cinco anos sucessivos os níveis cada vez mais altos de padrões exigidos (BLANKINSHIP, 2011).

Em março de 2013 escolas públicas de 27 distritos da Califórnia e 60 escolas públicas de Chicago, entre muitas outras nos Estados Unidos, foram fechadas. A comissão que avalia estas escolas não é uma entidade pública, mas privada, financiada entre outros por Bill Gates (BACON, 2013). E ainda estão em curso muitos outros fechamentos. Três décadas depois da sua aceleração, as políticas das padronizações evidenciam a ineficiência ${ }^{34}$ dos seus propósitos. O problema do desemprego não é cognitivo como querem apontar as forças conservadoras, é um problema político, adverte Pinar (WILLIAM PINAR SEMINAR, 2011). Estas políticas começam destruindo a moral dos professores e continuam com a destruição da infraestrutura dos sistemas para excluir estudantes das classes empobrecidas e marginadas.

O currere pode ser uma forma de reconstruir a paisagem existencial no "pesadelo que é o presente" 35 (PINAR, 2008) em muitas partes do mundo. A ênfase sobre uma subjetividade situada nas bases da diferença e do dissenso apontam a uma "localização no tempo histórico e espaço cultural" que Pinar chama de "situação biográfica" em que o conhecimento se constrói ao redor das narrativas de vida (PINAR, 2008, p. 36). O currere é desta maneira, político, porque sugere um passado e antecipa um futuro na situação do presente. Um currere exige por este motivo estar "amplamente acordado" (Ibidem).

Pinar encontra o exemplo de um currere na crítica da arte onde o artista, o crítico e o público entram numa 'conversação complicada' em que a diferença e o dissenso são valores dinâmicos que mudam o artista, o crítico o público e o artefato. Elliot Eisner (2002) analisa esta possibilidade implícita no julgamento estético que a crítica faz como uma forma de avaliar a aprendizagem das artes e lembra que Dewey já tinha apontado o papel do crítico de arte para

\footnotetext{
${ }^{34}$ Aqui se entende a ineficiência em relação aos objetivos declarados das políticas da padronização, mas podemos considerar a eficiência dos resultados, pois a intenção real destas políticas é fechar todo o sistema de educação pública para incluir a educação no monopólio capitalista que atualmente domina quase todas as formas de produção em poucas mãos.

35 Título do primeiro capítulo do livro What is Curriculum Theory (2008) de Pinar onde analisa de maneira crítica a transformação da escola em negócios corporativos já nos anos 90.
} 
diferenciar entre padrões e critérios. Os padrões têm três características, aponta Dewey: são coisas particulares que existem, não são valores; são medidas de coisas que existem e definem as coisas respeito a uma quantidade. Medir um objeto não é uma forma de julgamento. $\mathrm{O}$ valor da medida é que é julgada de acordo a critérios convencionais. A crítica é julgamento e isto requer um elemento hipotético centrado nas qualidades de um objeto, isto é na sua singularidade (DEWEY, 2005). A padronização não permite uma singularização ou mesmo uma pluralidade no diálogo, não permite uma conversação entre as partes nem uma avaliação qualitativa ou quantitativa real.

A conversação é de fato, e com uma linguagem altamente metafórica (SEVIGNY e FAIRCHILD, 2005), uma das formas autênticas de avaliar a aprendizagem no estúdio de arte. Mas uma 'conversação complicada', como a que acontece no âmbito de uma avaliação de estúdio artístico ou como o diálogo que o crítico de arte sustenta com o artista e o público, requerem uma experiência prolongada, um cultivo do olhar e uma reflexão constante sobre os critérios avaliativos. Eisner (2002) propõe uma transferência da maneira de operar da crítica artística para uma crítica educacional. Uma crítica educacional deve ser analogamente, segundo Eisner, descritiva, interpretativa, avaliativa e temática (extrair do particular ao geral) de maneira que haja uma comunicação entre o crítico, o educador e a sociedade.

Encontramos essa ênfase na comunicação nos escritos de Dewey, que Biesta (2010) relaciona à noção de desconstrução acunhada por Derrida. Biesta argumenta que a filosofia pragmática deweyana é uma fonte de inspiração para a filosofia da educação contemporânea porque ilumina as questões mais importantes sobre identidade e diferença, justiça social e ecológica e coexistência humana pacífica e significativa. Para ele a chave se encontra na crítica que Dewey faz da concepção da subjetividade humana centrada na consciência sobre a qual se levanta a educação moderna. Dewey aborda a educação como um processo de comunicação, onde a comunicação é entendida "como uma condição da consciência antes que a consciência como uma condição da comunicação" (BIESTA, 2010, p. 719). Mas esta ideia de comunicação "sempre envolve o risco de mudança e transformação. Em um sentido, a comunicação só existe dentro e através da transformação" (Ibidem, p.723). Dewey observa que não é a comunicação que leva à construção de algo juntos, ao contrário, é a construção de algo juntos que leva à comunicação. Freire (1987) o colocou assim: "a leitura do mundo precede a leitura da palavra". Uma "conversação complicada" envolve uma construção onde todos mudam. Há um deslocamento que pressupõe a alteridade. Da mesma maneira, a noção 
de desconstrução de Derrida é um deslocamento em direção à alteridade porque a desconstrução só é possível por meio da participação desde dentro do discurso e isto significa mudar. A transformação acontece na comunicação com o outro. Na educação se trata de uma "comunicação através de diferenças" (BIESTA, 2010, p. 724) onde a participação na construção é uma chave central.

A diferença entre um currículo padronizado e um currere que surge da comunicação através das diferenças é similar à distinção que Eisner (2002) faz entre o que ele chama de currículo in vitro e currículo in vivo. O primeiro é desenhado em condições de laboratório, o outro em condições vivas que implicam uma situação real. Nesse sentido ele compartilha com Ted Aoki a ideia de um currículo vivo (PINAR e IRWIN, 2005), isto é, um currículo que surge da vida e encontra seu sentido nela. Este pensamento está na base de toda a filosofia educacional de Dewey e Freire. Diferentemente da visão tradicional, em que os estudos curriculares são compreendidos na sua dimensão instrumental, isto é, o currículo como uma caixa de instrumentos para fazer da educação uma tarefa eficaz, Aoki defende, como Freire, o currículo como uma 'práxis situacional' onde professores, estudantes e toda a comunidade educativa dão forma à realidade da escola, ao mesmo tempo em que as pessoas se dão forma a si mesmas. Para que isto aconteça deve haver uma tensão entre um currículo planificado e um currículo vivo, como há uma tensão entre o singular e o plural, o individual e o coletivo. Ser professor para Aoki é viver neste terceiro espaço 'entre', um espaço - ponte entre a vida e o pensamento (um pensamento que não está separado da experiência sensível ou experiência estética). Nesta compreensão os estudos curriculares devem indagar sob uma ótica fenomenológica e existencial antes que instrumental para não cair na dicotomia entre teoria e prática:

Para muitos de nós, compreender a práxis requer um estranhamento da visão dicotômica entre 'teoria e prática' e abraçar aquela que vê nelas dois momentos gêmeos da mesma realidade. Antes que ver a teoria liderando a prática, necessitamos mais do que nunca ver ela como um momento reflexivo na prática. Numa linguagem orientada à ação a práxis é ação realizada de maneira reflexiva, e a reflexão é o que está se fazendo. (AOKI, apud PINAR e IRWIN, 2005, p. 3).

Da mesma maneira a práxis situacional é o coração conceitual da Pedagogia do Oprimido de Freire (1987), que concebe o currículo como uma forma de emancipação, revertendo sua instrumentalidade como forma de dominação (Fig. 23). O que é mais importante desta visão é 
que a educação não depende da implementação de um currículo, mas da sua intenção política. Temos que refletir sobre o que estamos fazendo e nesta reflexão mudar. Esta operação de 'ruptura e sutura' (GUATTARI, 1995), por ser uma questão política, tem uma dimensão ética e uma dimensão estética porque visibiliza o conflito.

Podemos pensar, portanto, que entre a teoria e a prática há fluxo, movimento e superposição. Aoki reconhece, de maneira análoga, a justaposição entre um currículo vivo e um currículo planificado que ele chama de "paisagem curricular da multiplicidade" (PINAR e IRWIN, 2005 , p. 23) onde a multiplicidade é a ideia deleuziana em que o crescimento acontece no 'meio' ou no 'entre-lugar'. Nesse sentido podemos entender um currere como uma paisagem curricular da multiplicidade onde a identidade do professor, do investigador ou do estudante estão em processo de ser, em crescimento. Devemos considerar ainda, argumenta Aoki, pensando na crítica de Derrida à metafísica da presença na tradição Ocidental, que nossa identidade não é mais uma identidade de presença, mas uma identidade como produção, uma identidade que se faz no processo, que está em fluxo. Esta ideia da identidade em fluxo, em produção, está presente também na filosofia educacional de Greene: "Eu sou...ainda não" (PINAR, 1998), a incompletude do ser que está sempre em processo de se produzir. É possível, neste aspecto, observar a conexão que existe entre essas ideias e a noção grega de poiese que jagodzinski e Wallin (2013) revisitam: à diferença da práxis, que é o fazer humano, a poiese, ou produção, se refere àquilo que está em processo de ser, não ao que é; a poiese está "no campo virtual do que pode chegar a ser" (p. 85). Poiese é, dessa maneira, uma potência que engendra outras formas de ser.

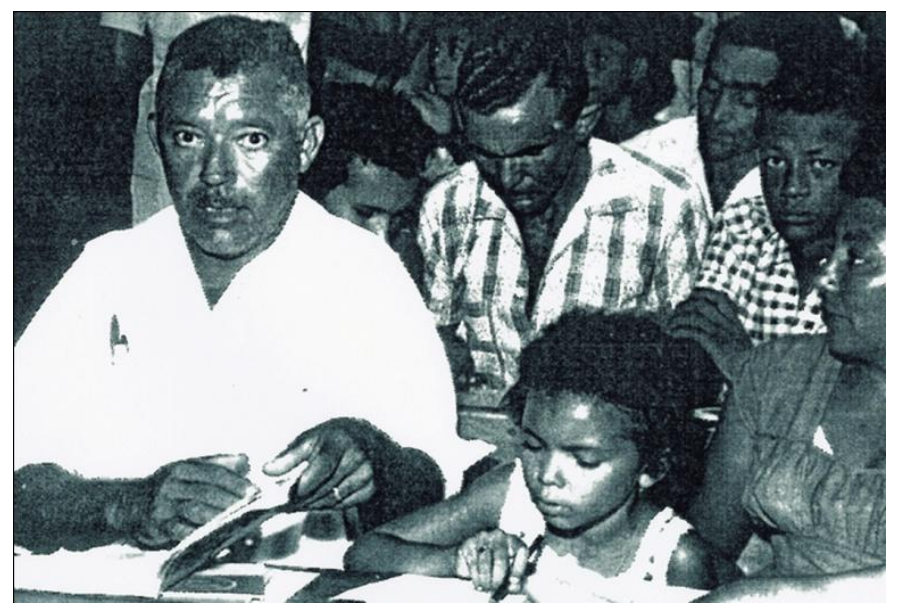

Fig. 23 Experiência de alfabetização com o método Paulo Freire, 1964. Autor desconhecido, Acervo Paulo Freire. Fonte: acervo. paulofreire.org. 


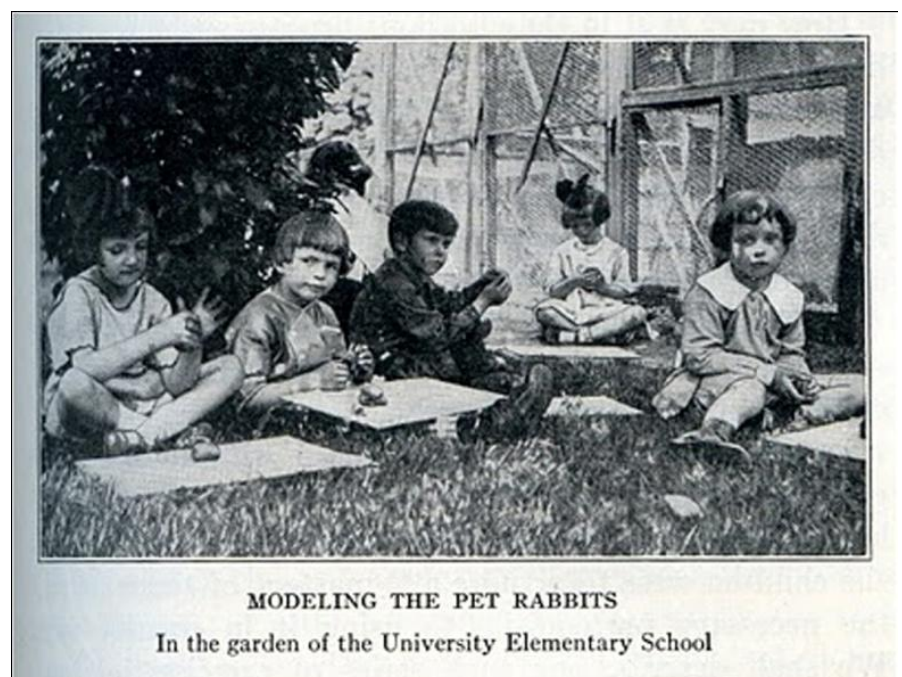

Fig. 24 Crianças modelando na Escola Laboratório da Universidade de Chicago dirigida por Dewey. Fonte: milwaukeeidscohort.wikispaces.com.

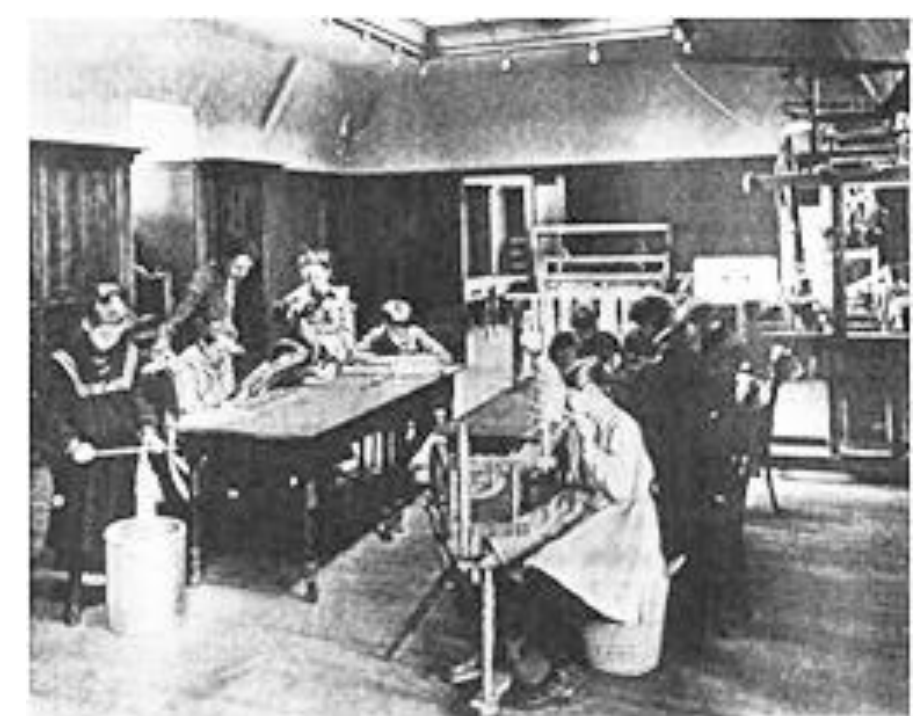

Fig. 25 Button \& Provenzo, Sala de têxteis na Escola Laboratório dirigida por Dewey, 1896. Fonte: igs.net

Essas ideias e a consequente necessidade de uma educação que acompanhe estes processos são análogas à ideia do crescimento como metáfora da educação de Dewey. O crescimento é a base conceitual da sua teoria e prática educacional. O crescimento é a base conceitual da sua teoria e prática educacional na Escola Laboratório de Chicago (Figuras 24 e 25). Ele parte da ideia de que a escola deve proporcionar além de condições saudáveis para o crescimento da criança, condições pedagógicas adequadas para um desenvolvimento físico e intelectual (MAYHEW e EDWARDS, 1936). Na metáfora do crescimento não há uma idade ou outra, há um fluxo entre o passado (o que se sabe) e o futuro (o que ainda não se sabe) em um movimento que cresce, que ele chama de organização dinâmica (DEWEY, 2005). O papel do 
professor é a do intérprete e guia dos interesses e necessidades do ser em crescimento. $\mathrm{Na}$ visão de Dewey, o professor adulto tem conhecimentos especializados que foram "sistematizados e definidos na sua experiência" (Idem. p. 250) os quais ajudam a definir e guiar o estudante no processo do presente. A experiência do professor é indispensável na hora de interpretar os interesses e necessidades dos seus estudantes e as condições em que a aprendizagem acontece:

Interpretar um fato é vê-lo no movimento vital, é vê-lo em relação ao crescimento. Mas vê-lo como parte de um crescimento normal é interromper as bases para guiá-lo. Guiar não é uma imposição externa. É libertar o processo humano em direção à sua própria realização da maneira mais adequada (grifo do autor) (DEWEY, 1902 apud MAYHEW e EWARDS, 1936, p. 252).

Compreender o currículo como um crescimento implica interpretar a paisagem na sua complexidade, na superposição de suas diversas camadas, na sua constante modificação, no processo entrelaçado em que acontece. Nesta perspectiva o currere visibiliza uma paisagem existencial em fluxo.

Sendo assim para Aoki e Pinar, da mesma maneira que foi para Dewey e Freire, a educação deve se fundamentar na experiência humana que acontece na sala de aula e na comunidade e procurar e construir sentido de maneira que se formem aberturas para a diferença. Para Guattari (1995), Rancière (2005, 2009b) e Foucault (2008) este é um processo estético justamente porque é uma questão ética e política. A experiência estética, como uma forma da "aparência da subjetividade" conduz a uma ruptura com a ordem das coisas. Estas rupturas são experiências carregadas de significado e são estéticas na medida em que se tornam eventos num processo de conexões imprevisíveis, novas, perturbadoras ou inquietantes. Por este motivo é importante revisar a ideia deweyana de experiência estética e sua relação com o conceito de evento pedagógico de Atkinson.

\subsection{A experiência estética e o evento}

A estética pragmática de Dewey permaneceu ignorada frente ao domínio da estética analítica europeia de cunho kantiano dominante em grande parte do século XX. É curioso notar que, apesar da estética analítica não ter apresentado uma proposta com um insight tão preciso 
sobre a prática artística como fez Dewey, ela dominou o campo teórico da estética moderna estabelecendo categorias ontológicas e essências supra-históricas (SHUSTERMAN, 1998). Hoje a estética analítica é insuficiente para responder à complexidade apontada pelos pósestruturalistas, marxistas, feministas e teóricos do pós-colonialismo e da cultura visual. Mas, a estética pragmática deweyana também é questionada porque está ligada ao paradigma cientifico positivista moderno. No entanto, uma análise cuidadosa revela que o pragmatismo deweyano está mais relacionado à fenomenologia da existência do que ao instrumentalismo positivista. É um pragmatismo que entende a vida como uma forma de aprendizagem e a aprendizagem como uma forma de vida. Embora ter sido um admirador da ciência do seu tempo, Dewey considera a arte, antes que a ciência, o paradigma da sociedade moderna (DEWEY, 1929), mas ele considera a continuidade entre arte e ciência antes que suas diferenças.

Shusterman (1998) nos lembra que a oposição entre a estética analítica e pragmática se origina nas diferenças entre o pensamento kantiano e hegeliano. Por um lado os filósofos analíticos associam Dewey com o idealismo hegeliano "em suas qualidades holísticas, historicistas e organicistas" (SHUSTERMAN, 1998, p. 232) e os pós-estruturalistas o veem como um pragmático moderno com um discurso não mais adequado à complexidade pósmoderna. Recusado tanto pela tradição analítica como pela filosofia pós-estruturalista o pensamento estético deweyano só voltou a ser lido pelos filósofos da educação no final do século XX. Mas, pode surpreender o quanto a filosofia de Dewey está perto de vários assuntos críticos do pós-estruturalismo que interessam ao âmbito da arte e da educação.

Entre eles está a crítica à estética do desinteresse ${ }^{36}$ que separa Dewey dos teóricos que influenciaram a estética moderna do século XIX. Para ele, esta é uma "ideia esotérica da arte" (DEWEY, 2005, p. 87) porque proclama uma autonomia respeito à funcionalidade da arte na vida colocando as discussões estéticas e artísticas no exclusivo domínio das elites culturais e longe da vida e das classes empobrecidas e dominadas. Estas premissas refletem e reforçam a divisão entre pensamento estético e trabalho prático que é por sua vez uma divisão entre

\footnotetext{
${ }^{36}$ A teoria estética kantiana do desinteresse argumenta que só a arte e a experiência estética conduzem a uma verdade pura. A política, a economia, as ciências sociais e até os sentimentos por exemplo se baseiam em ideologias e portanto mascaram a verdade. A arte despojada de ideologias, pelo contrário, é capaz de apresentar a verdade de uma maneira desinteressada. Esta pureza coloca o valor da arte na "forma pura" e não mais na representação da realidade, nas emoções ou na moral que mudam com o tempo, á diferença da forma que permanece efetiva através dos séculos. Esta ideia está também relacionada ao valor moderno de liberdade das regras acadêmicas que se estendem à liberdade das expectativas do público e à liberdade da função utilitária ou didática da arte. Desta maneira Kant divide as artes liberais do artesanato ou das artes mercantis.
} 
classes sociais, mas também entre meios e fins, entre espaço e tempo, e entre objeto e sujeito da arte. Dewey aponta assim esta relação:

[...] a separação tradicional entre algumas coisas como meros meios e outros como meros fins é um reflexo da existência isolada das classes trabalhadoras e ociosas, da produção que não é consumadora e da consumação que não é produtiva. (DEWEY, 1929, p. 367)

Outro assunto crítico se refere a indivisibilidade e intercambiabilidade entre teoria e prática, meios e fins, espaço e tempo, sujeito e objeto, matéria e forma, que para Dewey são a substância comum das artes. A cor, por exemplo, pode ser o meio ou pode ser o fim, ou mesmo meio $e$ fim. $\mathrm{O}$ tempo e o espaço na experiência se qualificam um a outro em um mesmo efeito, sujeito e objeto se tornam um na experiência estética, matéria e forma se transferem valores de acordo a direção dos nossos interesses: "[os significados] não são acrescentados só por associação, mas são igualmente a alma da qual as cores são o corpo ou o corpo do qual as cores são a alma- de acordo a nossa preocupação com a imagem" (DEWEY, 2005, p. 123, grifo nosso). Nessas bases é possível encontrar experiência estética tanto nas coisas úteis como nas ociosas, tanto na arte como no artesanato, no design ou na poesia de maneira intercambiável e em fluxo.

Sendo este um evento culminante da experiência humana "a arte faz os homens se darem conta da sua união em origem e destino" (DEWEY, 2005, p. 282) pensa o filósofo. É necessário, porém traspassar as fronteiras entre o sujeito e o objeto compreendendo a experiência estética como um encontro em que objeto e sujeito se completam e isto se estende ao encontro entre sujeitos.

Outra relação importante entre a filosofia estética deweyana e a visão de muitos artistas e teóricos da arte e da cultura contemporânea (BARTHES, 1984; FOUCAULT, 1969; BOURRIAUD, 2009; BISHOP, 2012, RANCIÈRE, 2011) se encontra na ideia da experiência estética como uma forma de produção onde tanto o artista como o espectador trabalham sobre a obra produzindo sua própria experiência. Esta produção trata de um ordenamento, reordenamento ou recriação dos elementos do todo que compõe a forma. "Em toda experiência integral", argumenta Dewey, "há forma porque há uma organização dinâmica. Chamo dinâmica a organização porque leva tempo para se completar, porque é um crescimento." (2005, p. 57). Em efeito, para ele a forma só se completa se há uma progressiva 
construção de valores, uma cumulativa conservação de experiências que é ao mesmo tempo uma preparação para o suspense, a antecipação do que ainda vai ser vivido. Fazem parte desta forma, as tensões que criam resistência na adaptação das partes, na sua interpretação, construção ou reconstrução. Por esta razão a consumação da forma é relativa, recorrente e fluida. "Continuidade, acumulação, conservação, tensão e antecipação são condições formais das formas estéticas" (Idem, p. 143) afirma Dewey. Esta dinâmica da formação está profundamente enraizada no mundo: na interação do meio ambiente com o organismo no seu crescimento.

Neste sentido as dicotomias entre processo e produto, entre sujeito e objeto, entre artista e espectador são insustentáveis. Shusterman, argumenta que:

Repensar a arte como experiência resolve o impasse conflituoso entre essas duas visões, combinando seus princípios contrários como momentos necessários e complementares da experiência. Afinal, a experiência, como sustenta Dewey, envolve tanto a atitude receptiva como a ação produtiva, [...] onde o sujeito da experiência molda e é ele próprio moldado. (SHUSTERMAN, 1998, p.47-48)

Tudo isto tem implicações para a forma como pensamos a prática pedagógica na Educação em Visualidade porque não se separa experiência de produção. A dinâmica da formação é também uma dinâmica da experiência. As práticas poéticas como as experiências estéticas são situadas porque acumulam e conservam, são complexas porque reconhecem os conflitos e ressaltam as tensões e são imaginativas porque se antecipam em direção ao desconhecido.

O conceito de experiência estética também responde às preocupações contemporâneas com a noção de arte como uma tradição histórica exclusiva de Ocidente e da estética ocidental como a única filosofia que pode validá-la. A experiência estética valida outras tradições e outras rupturas dentro de outros sistemas, pensamentos ou regimes estéticos.

Por outra parte o conceito de experiência estética dilui a suposta dicotomia entre os valores internos da arte, (valores formais e conceituais) e os valores externos da arte (valor social, econômico, cultural, político, científico, filosófico, religioso, prático) que conduzem a duas vias que são igualmente perniciosas. Se a arte se define exclusivamente pela sua própria prática (valores internos) se converte num argumento circular e se arte se define pela sua aplicabilidade ou utilidade (valores externos) se converte em instrumento para outro fim. 
Nesse caso, Shusterman (1998) encontra que o conceito de experiência estética deweyano proporciona um valor intrínseco à arte, ainda que não seja um valor exclusivo dela ${ }^{37}$ nem um valor fixo no objeto considerado arte. Ao mesmo tempo proporciona um valor extrínseco que está dado pela situação em que acontece em que se torna um evento. Desta maneira é possível responder ao problema do quê e quem determina o valor da arte:

A experiência estética não está confinada nos limites restritos da prática artística historicamente definida e não é sujeita, portanto, ao controle exclusivo daqueles que dominam essa prática e determinam seus objetivos internos. Ela pode então servir como uma pedra de toque relativamente independente ainda que não inteiramente externa, para criticar e melhorar a prática artística, especialmente quando a intenção é reorientá-la no sentido de permitir uma experiência estética mais rica e mais frequente para uma maior número de pessoas. (SHUSTERMAN, 1998, p. 38)

Shusterman (1998) nos lembra que alguns teóricos como Jurgen Habermas (2002) e Richard Wollheim (1994) argumentam sobre a insuficiência da ideia de experiência estética deweyana, por uma parte porque para eles "nenhuma experiência estética é possível separadamente da prática artística" (SHUSTERMAN, 1998, p. 38), e por outra porque a experiência estética não pode existir sem, segundo eles, "hábitos apreciativos aprendidos na prática artística moderna" (Ibidem, p. 38-39), pois foi na modernidade que a estética foi sistematizada como um dos ramos da filosofia ocidental. Mas deve-se lembrar que a experiência estética como compreendida por Dewey é muito mais do que estética e se amplia a toda experiência extraordinária, não só às peças consagradas pelo sistema da arte. A arte não poderia acontecer se a experiência estética se autolimitasse a uma determinada prática. Por outra parte, acontece independente da concepção de um nome e de uma filosofia para ela. É importante notar nesta altura que isto não significa que a experiência estética possua uma essência permanente e universal, mas que todos podem ter experiências estéticas em todo tempo e lugar e de múltiplas maneiras. A estética é principio organizacional do pensamento e da vida de todas as culturas. A estética moderna ocidental é uma entre muitas outras.

O conceito de experiência estética responde também ao problema que apresenta a teoria da arte e a filosofia estética modernas respeito às oposições binárias. Nessa visão, a atividade

\footnotetext{
${ }^{37}$ A experiência estética como compreendida por Dewey não se limita á arte historicamente estabelecida, a natureza também proporciona experiências estéticas assim como situações ou artefatos que não são considerados arte. Como aponta Shusterman (1998) podemos ter experiências estéticas em rituais, práticas esportivas, nas mídias, na cultura popular, na ornamentação doméstica e corporal, nos espaços habitáveis ou na vida cotidiana.
} 
mental está separada da atividade corporal. Os sentidos se compreendem como meros meios para veicular o significado. Assim a arte se distancia da vida, da corporalidade, mesmo quando os artefatos de arte parecem cada vez mais com o nosso cotidiano. Pretende-se que, a experiência estética, isto é, a experiência sensível, careça de apetites, sensações e prazeres corporais para legitimar a arte. Dessa maneira se separa o caráter crítico e reflexivo da arte da sua sensualidade e corporificação. Dewey, no entanto, faz uma aclaração "Fazer da patologia das sensações a base do prazer estético não é um empreendimento promissor" (2005, p. 131). A visão, o tato, o cheiro, o som, o sabor e com eles os desejos são sensações pelas quais o mundo se revela, mas não terminam nisso, o que percebemos são qualidades das coisas que experimentamos, não as sensações. A conexão entre estas qualidades e os artefatos constituem experiências significativas. Portanto, não pode haver separação entre os sentidos e o significado. Nessas bases, a distinção que Dewey faz entre arte e diversão ou entre arte e decoração é uma distinção de ênfase. E ainda assim não são diferenças intrínsecas dos artefatos ou situações, mas diferenças que se transferem de acordo as relações que se estabelecem. Aquilo que "é a forma numa conexão é matéria em outra e vice versa" (Ibidem, p. 133). O que em certo momento é pura forma ou cor que estimula os sentidos em outro momento se torna forma o matéria expressiva carregada de significado. Separar o sensível do intelectual é uma insinceridade na arte e na vida, nos lembra Dewey (2005).

Compreender a arte como uma qualidade da experiência é compreender que ela faz parte da nossa vida como uma forma particularmente expressiva. Ela pode tanto existir na práxis como na poiese ou na teoria. Em todo nosso passado humano, os ritos, as danças, a música, a pintura corporal ou rupestre, a modelagem, o performance, a intervenção na natureza e a construção de artefatos e espaços faziam parte de um vínculo que a vida e a morte compartilhavam. Eram atividades que deviam ser lembradas como experiências em que "o luto expressa mais do que a dor, as danças de guerra ou a colheita são mais do que a reunião de energias, [...] a magia é mais do que uma forma de comandar forças, [...] a festa é mais do que a satisfação da fome." (Ibidem, p. 341) Mas eram também muito mais do que atividades estéticas: todas elas "reúnem o prático, o social e o educativo em um todo integrado sob uma forma estética" (Ibidem), isto é, sob uma forma significativa, extraordinária e/ou espetacular, aquilo que Atkinson chama de evento (ATKINSON, 2008b, 2011). Nessa perspectiva podemos considerar a escola Ayllu de Warisata (Fig. 26) e as escolas zapatistas (Figuras 3,4, 21 e 22) como formas de reconstruir de maneira integrada sob uma forma estética, territórios de existência. A arte não esta associada somente ao fazer (Aristóteles e a poética), pois a 
apreciação ou leitura é também uma forma de produção onde o leitor reconstrói o sentido. Para Dewey a experiência estética acontece "tanto na produção dirigida quanto na recepção aberta" (SHUSTERMAN, 1998, p. 48).

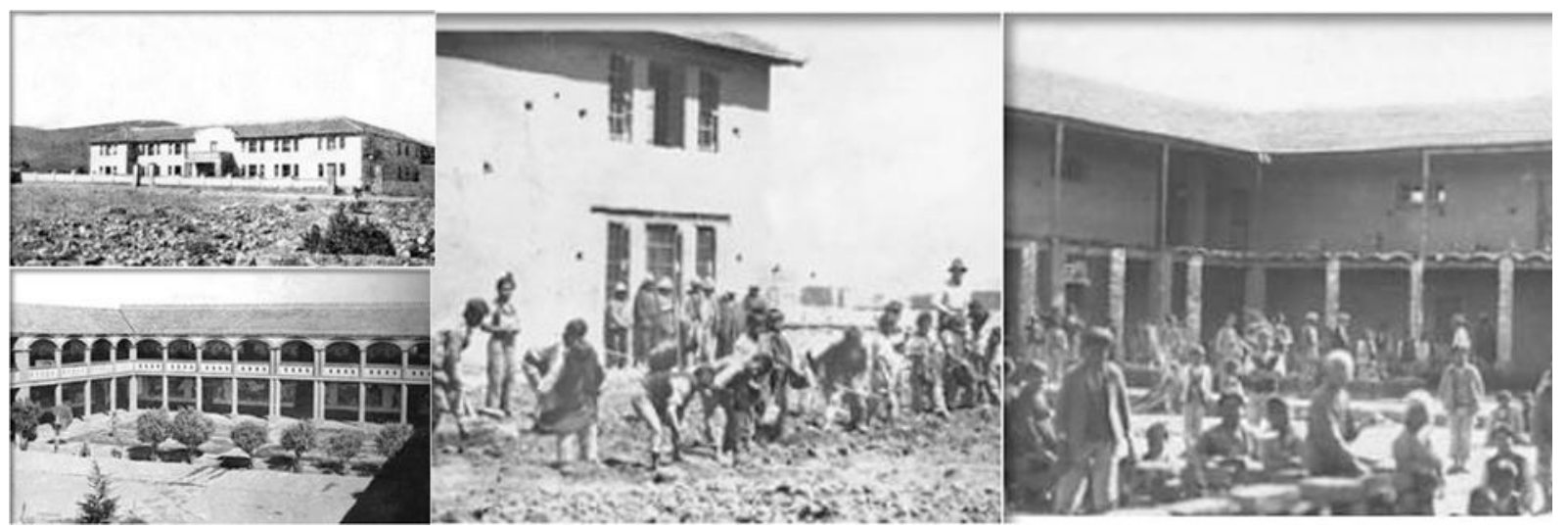

Fig. 26 Escola Ayllu de Warisata, exterior e interior, trabalho na terra e construção da escola, 1936. Warisata, La Paz, Bolívia. Fonte: sala.clacso.edu.ar

Assim, a arte pode ter tanto elementos práticos, sensoriais ou cognitivos. O conceito de experiência estética permite considerar e reconhecer que a produção cultural de todos os povos, assim como a produção industrial, as situações ou fenômenos sociais ou mesmo a produção científica e tecnológica podem ser considerados potencialmente estéticos ou artísticos. A ideia de experiência estética não substitui o conceito de arte, nem o define, apenas amplia o seu campo apontando luz sobre os processos criativos ligados à vida cotidiana. O foco desta investigação são as formas particulares em que as metodologias artísticas abrem novas possibilidades para uma aparência da subjetividade. O poder de abertura é um poder estético. Segundo Dewey "O valor da experiência não está só nos ideais que revela, mas no seu poder de mostrar muitos ideais [...] Podemos até reverter o argumento e dizer que o valor dos ideais está nas experiências a que conduziram" (2005, p. 335). Se mudarmos a palavra ideais por arte teremos que não é tão importante que as experiências revelem a arte, mas que a arte conduza a outras experiências. Encontro importante ressaltar aqui novamente que o interesse desta investigação está nestas 'outras experiências', na conversação complicada que travam os sujeitos e os objetos na sua vida e como estas experiências podem produzir novas performances epistemológicas.

Dessa maneira o conceito de experiência estética não é um conceito adequado para definir ou analisar objetos ou ações artísticas porque não constitui um conjunto de critérios estéticos: 
A experiência estética não tem sido acreditada para gerar seus próprios conceitos na interpretação da arte. Estes foram superimpostos por meio de pacotes prontos enquadrados em sistemas de pensamento que não fazem referencia à arte. (DEWEY, 2005, p. 136)

Ao invés disso o conceito de experiência estética nos proporciona um espaço para construir e reconstruir os próprios critérios. Se os critérios para definir o que é ou quando é arte estão sempre em construção, desconstrução, negociação, reconstrução, deslocamento e superposição é porque a experiência estética, que é o novo, se abre à possibilidade do que pode chegar a ser, do que está em potência. O que interessa é o que este encontro pode provocar.

A ideia de experiência estética de Dewey é por si mesma uma ideia que pode ser compreendida em face a muitas formas de relacionar arte e vida. Mas, nesta investigação é importante afinar esta ideia nas condições em que a virada da visualidade e a virada pedagógica se encontram, que são condições diferentes daquela em que Dewey pensou a experiência estética. O conceito de evento pedagógico de Atkinson (2008b, 2011), que como argumento em diante, se estende ao conceito de evento artístico, se relaciona à experiência estética deweyana na ênfase sobre o corpo em sua experiência com o mundo, isto é sobre a existência. Para ele, a ideia de existência implica em um estar (being there) em um lugar particular de tal maneira que a diferença permita estabelecer relações, estruturas, posições e identidades entre os seres. Atkinson baseia a ideia de evento na relação que Badiou (2005) estabelece entre 'o ser e o evento' como uma transição entre 'ser e se tornar', um processo continuo de existência e mudança em que a ruptura, ou o evento, torna visível a subjetividade. Nessa perspectiva é possível pensar que "a aprendizagem real pode ser vista como um problema de existência" (ATKINSON, 2011, p. 39). Como Dewey (2005), ele aponta a potencialidade que os processos artísticos têm para romper com as construções fixas da subjetividade de maneira que novas formas de 'se tornar' (becoming) possam irromper e se tornar aparentes.

Assim, a pedagogia do evento de Atkinson se reconhece como uma 'pedagogia contra o estado' porque se propõe como uma ruptura com o estado de coisas. Ele estende a ideia de experiência estética a um plano de vida em tensões extremas e mudanças sociais radicais. Neste aspecto Atkinson reflete sobre os espaços políticos e de dissenso nas situações 
educativas. Uma pedagogia do evento procura as aberturas que provocam a formação de territórios de subjetivação (GUATTARI, 1995) onde novas formas de entendimento podem emergir. Nesta linha Atkinson adota a ideia de Rancière de que a democracia não se baseia nos espaços de consenso, porque isso é reduzir a política ao policiamento (RANCIÈRE, 2009a), mas nos espaços do dissenso que possibilitam "novas subjetivações e novos caminhos de aprendizagem" (ATKINSON, 2011, p. xi).

A abordagem da pedagogia do evento de Atkinson problematiza de uma maneira mais incisiva sobre questões políticas do que a experiência estética de Dewey e permite, por uma via inversa, chegar às questões éticas da estética:

As pedagogias contra o estado é um chamado por pedagogias que trabalhem contra elas mesmas, antipedagogias, no sentido que não podem se dar o luxo de ficar presas dentro de certos valores e modos específicos de prática, não podem adotar abordagens totalitárias do conhecimento em um mundo de crescente instabilidade" (ATKINSON, 2011, p.1)

Da mesma maneira a ideia de evento artístico se compreende aqui como uma estética que trabalha contra ela mesma, uma antiestética no sentido que não se da o luxo de ficar amarrada a modos específicos de prática e a certos valores ou critérios estéticos. E isto não significa invalidá-los, mas relacioná-los nos fluxos de mudança e subjetivação. O que está por mudar é a ideia de arte e de educação e isto não significa que desaparecem as ideias inscritas pela tradição, mas que se tencionam com outras formas operar. É um movimento que vai da forma a não forma e do conhecimento ao não conhecimento. Este espaço da possibilidade do que 'ainda não é' foi compreendido na filosofia de Dewey, mas Atkinson o envolve numa pedagogia do dissenso.

Não por coincidência Atkinson (2011) observa, como Biesta (2009a, 2009b, 2010, 2012), Giroux $(2005,2012)$ e Apple $(1995,2006,2008)$ entre outros, que o maior obstáculo para pensar a pedagogia do evento são os discursos de auditoria, inspeção e controle que circulam na visão tecnocrática da educação porque valorizam práticas de padronização que perpetuam a política do consenso. Isto não acontece no sistema da arte de maneira visível como se dá na educação, mas, existem mecanismos neste sistema que, como na educação, funcionam como discursos de validação que perpetuam a ideia de que deve haver um consenso sobre o que é e não é arte. Por este motivo, a ideia de evento artístico não se estabelece numa única posição, seja esta qual for, mas flui entre as diversas formas de entender e fazer arte. Neste aspecto a 
ideia de experiência estética de Dewey permite se estender nas fronteiras da arte além do consenso: evento artístico como espaço da diferença, do dissenso e daquilo que ainda não é. 
"Se há algo que estou trabalhando em termos de educação é o desejo de explorar o afeto de um conceito: Revolução No meu caso não estou tão interessada na arte como educação mas na educação como arte Estou interessada em explorar as formas como as coisas se tornam arte Estou interessada em ver o que faz um momento ser arte, um momento que vem do âmbito da política". Tania Bruguera, Transpedagogy. Conversações com Pablo Helguera, 2009. Fonte: taniabruguera.com 


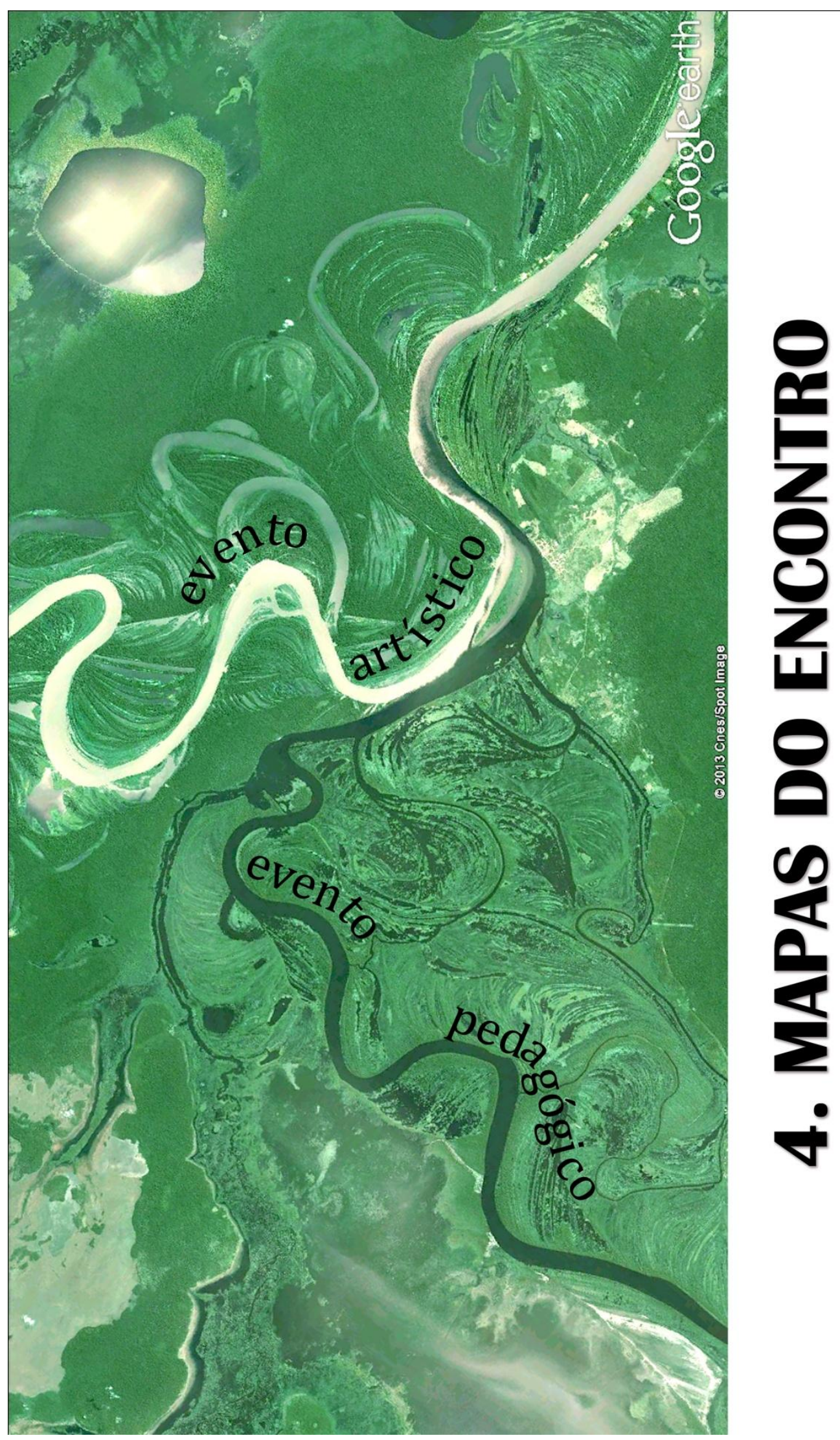

Fig. 26 Mapas do encontro. Encontro do Rio Mamoré e Rio Guaporé. Fronteira Brasil- Bolívia. Tatiana Fernández, fotografia satelital Google Earth manipulada, 2013. 


\section{MAPAS DO ENCONTRO}

Alguns anos atrás surgiram algumas perguntas na paisagem híbrida que mudou minha posição. As perguntas não surgiram da minha prática artística, mas da minha prática pedagógica. O que aprendi sobre educação nesse processo enriqueceu minha compreensão da arte. Mas, o encontro entre a arte e a educação, que é uma colisão explosiva, aconteceu dentro de mim e me fraturou. Essa interseção pressupõe um conflito, um choque que rompe o consenso e abre fendas estéticas que rompem com ordens instituídas e produzem subjetividades.

Nessas condições, parte-se da diferença e do dissenso que as pedagogias culturais promovem, porque me permitem ocupar o espaço entre no qual as coisas não são umas ou outras, mas umas $\boldsymbol{e}$ outras. Na Educação em Visualidade a arte e a educação não devem ser entendidas como territórios fixos em cenários previstos, mas como paisagens em fluxo e hibridação que produzem territórios existenciais em movimento e novas performances epistemológicas. Entre a virada da visualidade na educação e a virada pedagógica na arte há um espaço que se forma da necessidade de desfazer as hegemonias conceituais estabelecidas sob os paradigmas modernos colonialistas. Neste espaço a Educação em Visualidade se propõe emancipadora porque é localidade marginal destacada e independente em que as diferenças, estranhamentos, dissensões ou dissidências podem irromper em novas possibilidades curriculares e pedagógicas. Esta investigação se interessa por estes espaços de fronteira porque neles existe a potência para aquilo que Badiou (2005) intitula de 'procedimentos da verdade' e que aqui são entendidos como eventos.

Nesse aspecto a virada da visualidade na educação traz discussões e ações que ampliam o entendimento do papel da arte na educação, como parte do estudo das visualidades culturais. É importante entender do que se trata a 'visualidade' e o seu papel nas transformações sociais e culturais que se encontram em curso no mundo. A virada da visualidade é por este motivo uma forma de virada culturalista que se preocupa com as formas de ver, interpretar e fazer e como estas formas nos proporcionam espaços de subjetivação individual e coletiva. A 
problemática central consiste no fato de que essa virada está relacionada à virada pedagógica na arte que navega na crista da tensão entre a autonomia e a heteronímia da arte.

Sob este aspecto ganha proeminência a chamada 'arte participante' (BISHOP, 2006, 2012) uma mudança na direção do participante, que já não é mais somente público, espectador, ou estudante, mais um sujeito agente (RANCIÈRE, 2011). É uma forma de compreender a experiência estética como um evento que irrompe em direção a uma nova possibilidade de ser, que se preocupa com questões de gênero, raça, religião e acessibilidade, destacados pelas feministas, pós-colonialistas, pós-estruturalistas e teóricos queer. A arte participante muda as relações que estabelecemos na 'partilha do sensível' ${ }^{38}$, ou a maneira como se distribuem os papéis e a participação do mundo social (RANCIÈRE, 2005, 2009b), e isto requer reinventar não só a educação, mas também, e este é um ponto crucial nesta tese, a arte como o espaço da diferença e a dissidência em que novas formas de ser despontam.

O evento artístico e o evento pedagógico se encontram nestas viradas trazendo possibilidades novas a arte e a educação. E neste aspecto o encontro de águas constitui em si mesmo um grande evento capaz de provocar outros eventos e proporcionar outras experiências de vida.

\subsection{A virada da visualidade na educação}

Torna-se central lembrar que a virada da visualidade, ou virada imagética como é também conhecida, não se circunscreve somente à proliferação de imagens, nem se restringe ao visível. Refere-se antes, às maneiras de ver, aos fenômenos do olhar, ao que se faz visível e ao que permanece invisível, à vigilância óptica e à visualidade cultural. Entram nessas discussões tanto as imagens como os discursos, as palavras, os artefatos, as instituições, os corpos, os meios e as mídias. A virada da visualidade é para Mitchell (1995) uma mudança na filosofia em que, não se parte da língua como paradigma do significado, mas se aproveitam os códigos dos sistemas não linguísticos. No entanto para compreender o ponto principal de Mitchell é necessário notar que ele chama especificamente esta virada de 'pictorial turn' e não de 'image turn'. Quando Mitchell aponta uma virada da visualidade ele distingue picture de image. No inglês a palavra picture, à diferença da imagem, que é figural, denota uma mídia física na qual a imagem se sustenta fisicamente. A imagem é de natureza imaterial, "parece flutuar sem um meio visível de suporte, de aparência fantasmática, virtual ou espectral. O picture é a imagem

\footnotetext{
${ }^{38}$ N.T. le partage du sensible.
} 
mais o suporte" (MITCHELL, 2005, p. 85, grifo do autor) Assim a imagem pode aparecer em diversas mídias como a pintura, a fotografia, a escultura, cinema ou o vídeo e nesse momento passa a se chamar picture. Não se pendura uma imagem na parede, explica Mitchell (2005, 2009), o que se pendura é uma pintura, ou uma fotografia, ou o que se vê numa tela de televisão ou numa película de filme (em inglês motion picture). Quando se registram direitos de autor sobre a imagem, o que se registra é a imagem e não a mídia, por isso não podemos usar a imagem em qualquer mídia que seja, pois os direitos são sobre a sua substância figural e não sobre o meio físico que a suporta. Trata-se, então, de uma virada que acentua tanto na imagem como na mídia na qual aparece.

Por sua vez, procurando sistematizar uma ciência da imagem e num período anterior à divulgação das ideias de Mitchell o filósofo e historiador da arte alemão Gottfried Boehm também acunhou o termo 'virada icônica'. De maneira sintética para ele a imagem é entendida como um paradigma. Na perspectiva de Boehm isto não é possível sem passar pelas questões de linguagem e da tendência linguística dominante na filosofia, pois a virada icônica é uma busca por compreender o poder das imagens na vida social. A pesquisa que ele dirige estuda a imaginação como uma habilidade que nos permite entender imagens, entender novas experiências e viver como seres sociais, em suma, que nos definiria como humanos. (BOEHM e MITCHELL, 2009)

De maneira similar Hans Belting (2005) reconhece que para estudar as imagens é necessário distinguir aquilo que é o órgão da visão e a forma histórica como se constrói e como modifica culturalmente nossa visão. O primeiro é sobre o visível e o segundo sobre o visual. Ele concorda com Bernard Stiegler na ideia de que "Nunca houve imagens físicas sem a participação de imagens mentais, uma vez que a imagem é sempre algo visto (e só é algo quando é visto)" (1996 apud BELTING, 2005, p. 73) de tal maneira que as imagens mentais ou imagens endógenas estão inscritas nas imagens exógenas ou imagens objetivas e vice versa. Nessa equação entre corpo e imagem externa participa também o meio pelo qual a imagem se manifesta fisicamente visível. As imagens, pensa Belting, podem se trasladar de um meio a outro, isto inclui o corpo, como um 'meio vivo' da imagem (BELTING, 2005, p. 74).

É compreensível que Mitchell compartilhasse destas ideias. De maneira ampla a virada da visualidade "[...] é uma redescoberta pós- linguística e pós-semiótica da visualidade (picture)" (MITCHELL, 1995, p. 16 parêntese nosso) em que o espectador coloca em jogo diversas 
formas de leituras e de experiências visuais que não são explicáveis no modelo textual e "mais importante ainda, é a tomada de consciência de que, mesmo que o problema da representação visual sempre esteve entre nós, hoje pressiona todos os níveis da cultura com uma força sem precedentes." (Ibidem.) Esta força sem precedentes se encontra em primeiro lugar na nossa relação cada vez mais corporal com os artefatos das visualidades. Em segundo lugar porque nesta relação com o corpo começam a desaparecer as fronteiras entre imagem e realidade.

É importante também considerar que a história dos artefatos das visualidades tem sido sempre uma história ligada às lutas de poder e dominação/emancipação e hoje estas lutas de poder são cada vez mais visualizadas, visíveis, visuais ao mesmo tempo em que tornadas invisíveis, invisualizadas e invisibilizadas. Mirzoeff (2009), por exemplo, analisa as estreitas relações entre a aparição da fotografia e o cinematógrafo com os movimentos antiescravagistas e com os sistemas de controle social. No século XX a crítica do espetáculo de Debord (1997) aponta para preocupações como as políticas de construções do olhar e as relações que se estabelecem entre os artefatos das visualidades e espectadores sem os quais não há espetáculo. Jean Baudrillard (1991b) retoma estas reflexões na ideia do simulacro que cruza as fronteiras do real se tornando a própria realidade, o espetáculo como realidade. Dessa maneira é possível pensar as imagens e os artefatos das visualidades como uma parte da paisagem, mas também como parte do corpo.

É nesse contexto que Mitchell (1995) identifica a virada da visualidade com quatro linhas filosóficas: a indagação fenomenológica sobre a imaginação e a experiência do visual; a "gramatologia" de Jacques Derrida que aponta para uma descentralização do modelo fonocêntrico da linguagem em direção ao visível; os estudos da Escola de Frankfurt sobre cultura de massas e mídia visual e os escritos de Michel Foucault sobre poder e conhecimento que apontam para a ruptura entre o visível e o discursivo, entre o ver e o dizer que foram "linhas de fogo dos regimes escópicos da modernidade" (MITCHELL, 2005, p. 12). É pontual observar que as novas tecnologias da informação, comunicação e imagem ampliam nossa capacidade de ver de maneiras diferentes àquelas que nosso corpo é capaz (por exemplo, ver com super microscópio, com megatelescópio e micro câmeras que entram em minúsculos corpos) ademais esta relação com a imagem pode ser corporificada (como a realidade virtual ou a holografia), e permitir uma relação biológica com as imagens. A bioimagem é um dos conceitos centrais na virada da visualidade de Mitchell que inquieta o mundo acadêmico com a pergunta: o que os artefatos das visualidades (pictures) querem? (2005) Ele pensa as 
imagens 'como se fossem ${ }^{\prime 39}$ organismos vivos que tem desejos e questionam. Nós nos tornamos o meio da imagem através da qual se ela se encarna, se corporifica, logo:

O clone significa o potencial para criar novas imagens em nosso tempo novas imagens que preenchem antigos sonhos de criar uma 'imagem viva', uma réplica ou cópia que não é meramente um duplicado mecânico, mas um simulacro orgânico biologicamente viável de um organismo vivo. [...] Agora vemos que não é só um caso de imagens que parecem cobrar vida, mas que os próprios organismos vivos sempre foram imagens de uma maneira ou outra. (MITCHELL, 2005, p. 12-13)

Por conseguinte, a relação entre corpo, visualidade e meio é uma relação que muda a cultura e ao mesmo tempo é mudada por ela. Trata-se de um movimento fluído entre o ser e o mundo, que é um mundo de visualidades. O problema é que, mesmo nas academias de arte e de design, geralmente se considera o estudo da imagem e do meio como se fossem dois assuntos separados e ao mesmo tempo independentes das relações destas com o corpo e suas visualidades culturais. A metáfora das imagens vivas que usa Mitchell aponta para uma maior preocupação com as relações que se estabelecem entre as imagens os corpos, os meios e os contextos (Fig. 27). Para Rancière (2009c) a noção de virada da visualidade de Mitchell é menos sobre uma virada visual no pensamento contemporâneo do que sobre uma

[..] reversão dialética da máquina que transforma as imagens e a vida numa linguagem codificada. A máquina que quer produzir vida artificial de fato produz uma nova forma de imagem que define um novo poder de vida, uma vida que não pode mais ser separada das imagens, dos seus monstros, suas doenças e suas mitologias. (RANCIËRE, 2009c, p. 127)

Por isso, a mutação deste modo de presença viva das imagens significa para Rancière um ponto de quebra histórico. Hoje, as visualidades começam a ser entendidas como uma biosfera ao mesmo tempo em que se entende como uma iconosfera. Esta nova relação entre o bios e o ícone manifesta uma consciência do poder da imaginação na formação da espécie e da sua vida em sociedade. Como aponta Boehm (BOEHM e MITCHELL, 2009), a criação de imagens é anterior à linguagem, o ser humano faz imagens há um milhão de anos. A história destas imagens é a história da nossa existência. O poder que elas exercem sobre nossa vida e o poder que nossa vida exerce sobre elas é um fluxo contínuo. Como uma fonte de poder, a história das imagens é a história da luta pelo poder (Fig. 28).

\footnotetext{
${ }^{39}$ Mitchell fundamenta a metáfora das imagens vivas no célebre livro What do Pictures Want? (2005)
} 

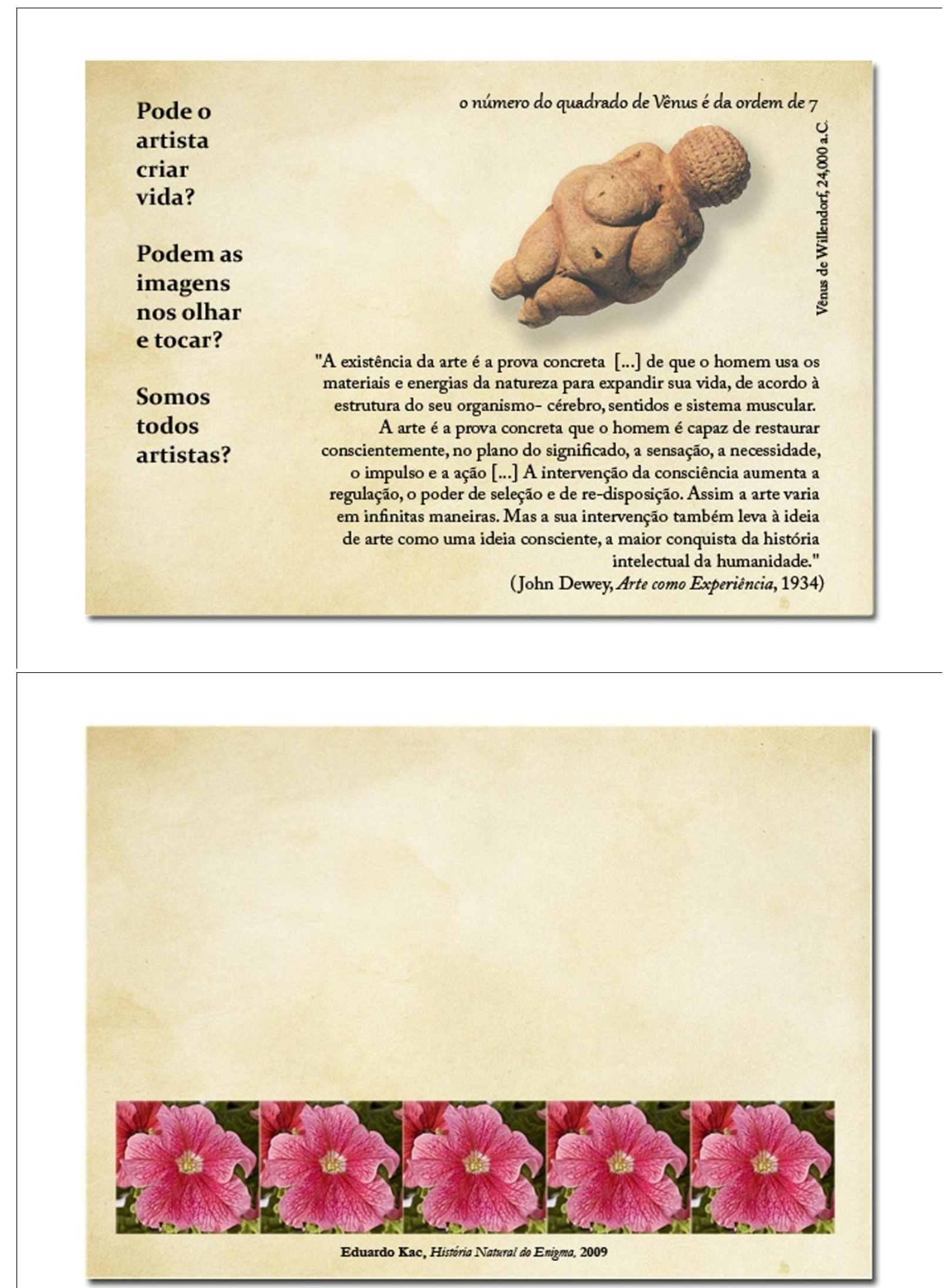

Fig. 27 Tatiana Fernández. Carta 5, frente e verso. Jogo Enigma. Objeto de Aprendizagem Poético. Curso de extensão OAP. VIS/IdA/UnB, 2013-14. 


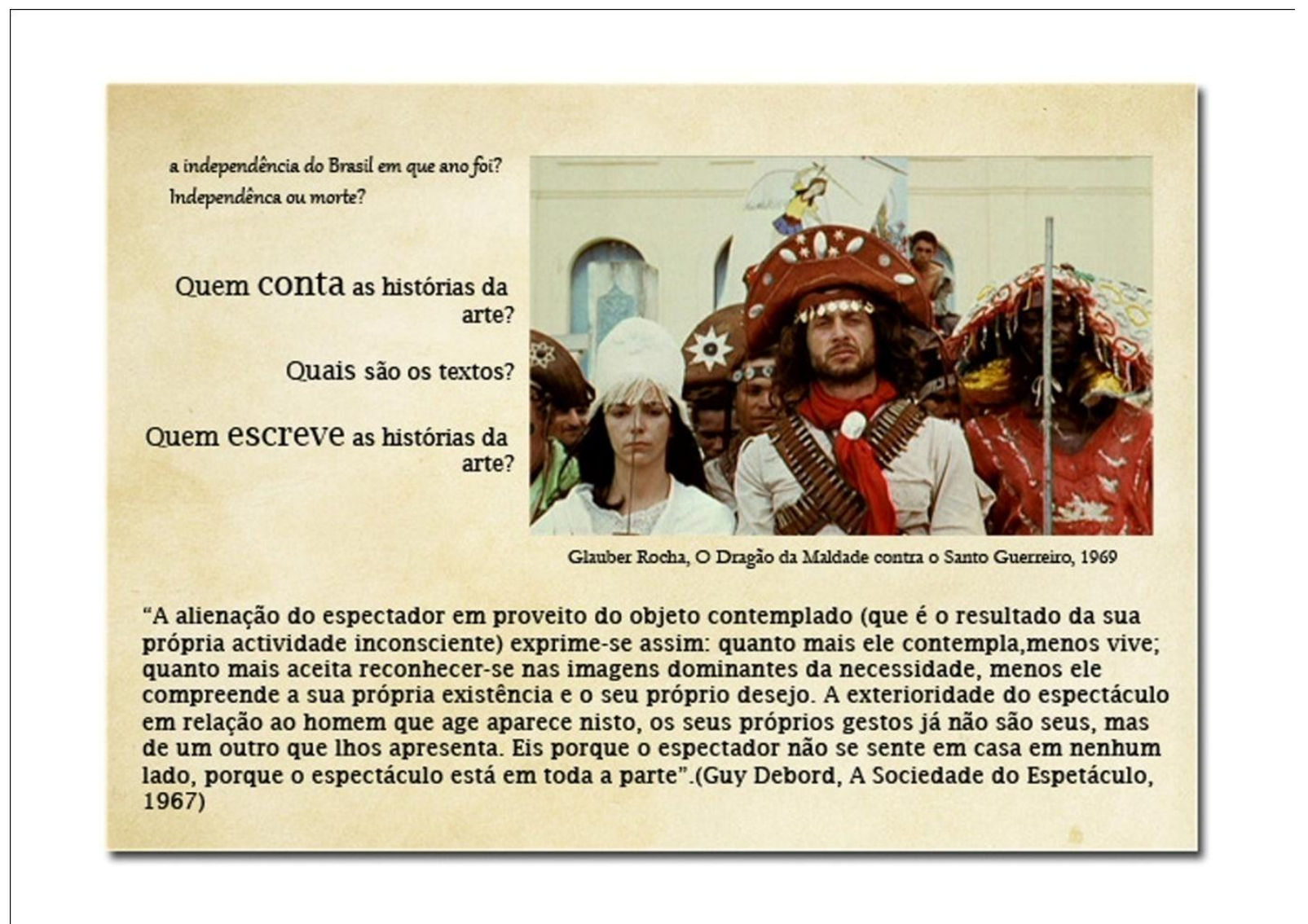

Fare la lotta di classe é perícoloso
Fare la lotta di classe é perícoloso
Fare la lotta di classe é perícoloso
Fare la lotta di classe é perícoloso
Manizio catellan, Panizione, 1991

Fig. 28 Tatiana Fernández. Carta 2, frente e verso. Jogo Enigma. Objeto de Aprendizagem Poético. Curso de extensão OAP. VIS/IdA/UnB, 2013-14. 
Tanto Mitchell (1995, 2005) como Mirzoeff (2009) destacam as implicações políticas das visualidades como uma mudança nas relações de poder e conhecimento que acompanham o pensamento de Foucault e Rancière. No entanto a ênfase sobre a relação entre estética e política de Rancière difere da ênfase sobre a visualidade de Mitchell (2009) e Mirzoeff. Rancière $(2005,2009 a, 2009 b)$ vê a relação entre estética e política como a única forma para uma 'partilha do sensível'. No mundo ocidental ele distingue três formas de organizar esta distribuição do sensível como regimes que marcam as visualidades e formas de fazer, criar e conceituar, De maneira sintética "Um regime de identificação da arte é aquele que põe determinadas práticas em relação com formas de visibilidade e modos de inteligibilidades específicos" (RANCIÈRE, 2005, p. 22). Ele identifica uma sequência histórica neles: primeiro o regime ético cujos princípios formulados por Platão procuram uma arte verdadeira que contribua aos princípios éticos da comunidade, em segundo lugar o regime representacional que é articulado por Aristóteles na sua crítica a Platão e que libera o artista das ligações morais e políticas em direção às questões da forma e do tema representacional. Finalmente o regime estético que aparece somente no século XIX na Europa trazendo a ênfase sobre o singular e com ele o sujeito da estética. Rancière afirma a capacidade que uma arte politizada teria de singularizar, de promover territórios de subjetivação porque o regime estético mantém uma tensão entre o singular e o plural, entre a autonomia e a heteronímia da arte.

Portanto, segundo Rancière (2009c), a pergunta de Mitchell $(2005,2009)$ sobre o desejo das imagens é uma crítica à crítica dos artefatos das visualidades, àquela crítica que considera as imagens como veículos de mensagens enganosas e àquela crítica que considera a imagem como um excesso ou como uma falta. A milenar proibição das imagens é uma forma de afirmar seu poder, que se estende à atualidade. Mas não se trata só de imagens ou proibições religiosas, é também sobre ausências ou excessos, aceitação ou negação. Mesmo os que negam o poder que as imagens têm sobre as pessoas, testemunham como as imagens exercem seu poder pelo mundo. Mas, para Rancière, as imagens da arte não querem nada e esta indiferença é que as torna estéticas e políticas. A ambiguidade entre os desejos e a indiferença é que constitui a força das imagens e dos artefatos das visualidades. Essa indiferença é análoga à ideia de poética defendida por Jagdzinski e Wallin (2013).

No entanto, adverte Mitchell, a virada da visualidade "não é uma resposta a nada, é meramente uma forma de colocar a pergunta" (MITCHELL, 1995, p. 24). Quando Mitchell pergunta, o que os artefatos das visualidades querem? ele tenta sair das perguntas que giram 
em torno a relação entre espetáculo e espectador no século XX e dirige a pergunta diretamente sobre os artefatos das visualidades para ver o que acontece.

\subsubsection{Visualidades e cultura}

A relação entre visualidade e cultura é uma relação complexa onde diversas camadas interagem entre si. Na construção dos artefatos, diversos fatores participam como mecanismos na formação e interpretação dos fenômenos visuais. Frente a esta complexidade Josep Català Domèmech (2011) questiona a ideia de organização linear entre percepção e semiose para debelar a natureza complexa dos processos perceptivos na relação entre os artefatos das visualidades e as culturas. Ele parte da pergunta que Umberto Eco se faz sobre semiótica e percepção: é a percepção a base da semiótica ou a semiótica a base da percepção? Nessa pergunta reconhece duas epistemologias contrapostas e lineares: a primeira, naturalista, situa a produção do significado na subjetividade do observador e a segunda, culturalista, considera que o significado previamente construído pela sociedade condiciona a subjetividade do observador de tal maneira que "não podemos ver se não através de um filtro culturalmente construído" (CATALÀ DOMENÈCH, 2011, p. 21). O autor estende ainda mais a pergunta: "a estrutura semiótica é instalada primordialmente na sociedade ou na própria capacidade perceptiva?" (Idem, p. 22). Dessa maneira ele evidencia o caráter não linear entre percepção e cultura porque "não há uma relação mecanicamente ajustada entre a sociedade e os processos perceptivos dos seus membros" (Ibidem) e não necessariamente coincidem histórica ou estruturalmente porque se movem continuamente. As "condições de visibilidade" que cada formação histórica deixa ver (DELEUZE, 1988) são condições intrincadas organicamente e em constante mudança.

Os Estudos da Cultura Visual apontam estes questionamentos sobre as condições de visibilidade modernas e pós-modernas e de diversas maneiras mostram que há coincidências com as teorias e as práticas artísticas na abordagem crítica e agenciadora sobre as visualidades. No campo da arte o interesse manifesto pelos artefatos das visualidades começa com os dadaístas e surrealistas e continua com os artistas conceituais, da Arte Pop e os situacionistas. No campo da filosofia podemos começar com Walter Benjamin e a Escola de Frankfurt, mas é na confluência de vários estudos na pós-modernidade que se configura o campo dos Estudos da Cultura Visual. 
Na década de 1980, o estudo da cultura como um sistema de representação simbólica que proliferou nos Estados Unidos e na Inglaterra nas ciências sociais, conhecido também como a virada cultural, promoveu uma metodologia de pesquisa qualitativa que enfatizou sobre a subjetividade humana, o lado subjetivo das relações sociais e o significado contextual (DIKOVITSKAYA, 2005). Para Mitchell (1995) os estudos visuais nascem do encontro, nesse contexto, entre a História da Arte e os estudos culturais nos departamentos de Nova História da Arte das universidades britânicas (DIKOVITSKAYA, 2005). Estas pesquisas se alimentaram dos estudos pós-coloniais, dos estudos críticos, das teorias feministas e dos estudos pós-estruturalistas da época. A virada cultural levou à ideia de que toda abordagem metodológica está contaminada por preconceitos ideológicos e com isto a pesquisa no campo social se afasta de uma metodologia que só reflete sobre os processos e as forças sociais e políticas em direção a uma maior capacidade de provocar processos e forças de transformação social, de maneira que a virada cultural é, como apontou Hall, um retorno aos temas sociológicos depois de um longo período dominado pelas abordagens empíricas, funcionalistas e estruturalistas (1997, apud DIKOVITSKAYA, 2005). Mas, sobretudo, a virada cultural é uma virada aos temas políticos no estudo das complexas relações entre poder e conhecimento. Os Estudos da Cultura Visual centram desde então sua atenção nestas relações entre artefatos das visualidades e poder.

Na década de 1990, a proposta da virada da visualidade levou a uma maior discussão e um maior interesse sobre visão e visualidade que Mitchell (1995) identifica na interdisciplinaridade que atravessa os estudos críticos e a filosofia. Ele usou o termo Cultura Visual para seu curso na Universidade de Chicago porque seu interesse era a construção cultural da visão e a formação social do campo visual considerando que cultura é aquilo que depende e se relaciona com o significado. Ele pensa a relação entre a cultura visual e as artes visuais da maneira em que a linguística se relaciona com a literatura, como um espaço de reflexão e crítica conceitual/formal.

Para Margaret Dikovitskaya (2005) a cultura visual é o espaço da construção social da visualidade e ao mesmo tempo a construção visual do social. Esta é uma das abordagens mais difundidas dos Estudos da Cultura Visual e uma das mais adotadas na educação da cultura visual. Já para Mirzoeff (2009) a cultura visual é a "interface entre as disciplinas que lidam com as visualidades da cultura contemporânea" (DIKOVITSKAYA, 2005, p. 58), isto é, um meio de pesquisa e agência com ênfase nas mídias não tradicionais. Alguns teóricos da cultura 
visual como Michael Ann Holly e Keith Moxey (2002) as apontam como novas abordagens teóricas na história da arte, outros incluem artefatos de todos os períodos históricos ou estudam como as diferentes noções de poder e conhecimento mudam através das diversas estratégias de visualização e expressão como David Rodowick (2001).

Os estudos culturais, críticos, visuais, tecnológicos, mediáticos e outras áreas de pesquisa das ciências humanas, sociais e mesmo naturais alimentam uma relação interdisciplinar com os estudos visuais. Mas a sua relação com a história, a teoria e a crítica da arte é mais controversa, complexa e conflituosa. Isto porque os Estudos da Cultura Visual intervém diretamente sobre os paradigmas mais caros à modernidade: "Ao estudar o caráter cambiante dos artefatos artísticos e analisá-los como artefatos sociais, a cultura visual desafia não apenas os limites, mas as práticas do sistema das belas artes" (MARTINS, 2008, p. 29). Raimundo Martins (2008) observa que o foco sobre as visualidades dificilmente se encontra com o foco sobe os valores da história da arte, pois a tarefa crítica que se propõem os estudos da cultura visual sobre as formas de representação, expressão e visualização coloca em questionamento a própria epistemologia da história da arte. É, portanto, uma situação em que, por uma parte, se fortalece o campo metodológico da teoria e a história da arte porque amplia o campo de ação e de relações entre arte e outros campos de produção visual e por outro, dilui sua importância na história das ideias como formas singulares da expressividade humana. Nesse contexto, Martins vê a necessidade de reavaliar as posições teóricas e estéticas na relação entre história da arte, cultura visual e educação.

\subsubsection{Visualidades e educação}

Esta reavaliação se dá principalmente no campo da educação da cultura visual. Trata-se de uma proposta, que de maneira geral, considera outras visualidades além da arte na educação, embora hajam diferenças de ênfase ou abordagem entre os teóricos. Alguns pensadores, por exemplo, consideram que na escola, as artes visuais constituem uma parte importante da cultura visual (FREEDMAN, 2003), outros pensam que constituem só uma pequena parte (BREA, 2003). Para outros, as artes deixaram de ser importantes como expressão visual de identidade cultural (DUNCUM, 2011) e outros ainda pensam que os Estudos da Cultura Visual substituem a arte pelo visual e a história pala cultura (FOSTER, 1996 apud AGUIRRE, 2011). A questão é que, mesmo sendo a arte uma pequena ou uma grande parte do universo das visualidades ou se sua importância relativa muda de acordo às circunstâncias, a educação em cultura visual é um espaço de conflito que conduz a um atravessamento multidisciplinar. 
Este conflito tornou-se mais evidente quando começou a se propor uma maior preocupação com os artefatos da cultura visual na educação em artes visuais em muitas partes do mundo, como foi no Brasil.

São tanto mudanças curriculares como metodológicas, mas, sobretudo, são mudanças epistemológicas que são difíceis de compreender para muitos professores de arte e artistas. A distância que se constrói entre a vida das pessoas e a arte é reforçada pelos sistemas tradicionais do ensino das artes. E mesmo quando se propõem mudanças metodológicas e de conteúdo que se abrem à cultura visual com abordagens contextualizadas, ainda permanecem estruturadas no paradigma conteudista e transmissivo. Não basta acrescentar temas ou imagens relativos à cultura visual, é necessário pensar de outra maneira a estética, a educação, a cultura, a política, o corpo, o sujeito e a sociedade em relação à vida.

Todavia no âmbito acadêmico a educação da cultura visual ganha cada vez mais atenção. No Brasil e no mundo cresceu o número de pós-graduações dedicadas à educação da cultura visual e com elas há cada vez mais estudos, pesquisas, investigações, práticas, abordagens teóricas e filosóficas que se difundem em jornais, publicações, revistas, dissertações, teses, organizações, instituições, conferências e seminários ${ }^{40}$. De toda maneira é uma abordagem que contemporiza o dissenso das pesquisas em educação e investigação em arte. Assim, as tensões entre estas duas áreas de pesquisa são análogas. $\mathrm{O}$ espaço entre o discurso da arte e o discurso da educação não é um espaço cômodo visto que o senso comum normalizado e estabelecido é de que não há um espaço de contaminação entre a arte e a educação. A Educação em Visualidade é, portanto, um espaço de atravessamentos que provocam rupturas e alteram a ordem das coisas.

Muitos dos artistas contemporâneos exploram e atravessam as fronteiras em que diversas camadas das visualidades culturais se tocam ou se tencionam, assim como fizeram também muitos artistas modernos. Na pós-modernidade como vimos, há uma maior corrosão com outras formas de visualidade. Entre os artistas que atravessaram essas fronteiras temos, para citar só alguns, Oiticica, Clarck, Meireles, Mathew Barney, Mariko Mori, Pedro Almodóvar, Martin Sastre, Cindy Sherman, Barbara Kruguer, Jenhy Holzer, Gilbert and George, Group Material, Pipilote Rist, os irmãos Chapman, Tracy Amin, Felix González Torres, Maurizio

\footnotetext{
${ }^{40}$ Entre as mais destacadas: Grupo de Pesquisa em Educação e Cultura Visual da FAV da UFG; Grupo de pesquisa Transviações: Visualidade e Educação do PPG Arte -IdA-VIS da UnB; o Grupo de Estudos e Pesquisas em Arte, Educação e Cultura da USFM. A revista eletrônica Cultura Visual do PPG Artes Visuais da UFB, a revista Visualidades e a Coleção Desenrêdos da PPG em Cultura Visual da FAV-UFG, o Seminário Nacional de Pesquisa em Arte e Cultura Visual do mesmo programa.
} 
Cattelan, Coco Fusco, Damian Ortega, Dominique Goonzalez Foerester, Efrain Almeida, Santiago Sierra, Minerva Cuevas, Francis Alys, Pierre Huyghes e Sylvie Fleury. Apesar das grandes diferenças entre uns e outros o que caracteriza estes artistas é que trabalham sobre o campo ampliado da visualidade cultural e são capazes de atravessamentos sobre as formas de experiência estética.

A virada da visualidade na educação em particular apresenta grandes desafios que colocam em debate essas problemáticas. É de se esperar que a Educação em Visualidade se coloque nas tensões que se criam com práticas pedagógicas que promovem experiências estéticas que se relacionam com os contextos, situações e formas de subjetivação. Entre elas as tensões entre o individual e o coletivo, o conhecido e o desconhecido, o currículo programado e o currículo vivo, a forma e o disforme, o cotidiano e o extraordinário, imagem e texto. Para trabalhar nestas fronteiras o educador em visualidade e o artista podem explorar os territórios que se formam nos espaços híbridos onde as diferenças e as dissidências provocam novos eventos.

Para responder a esta questão esta investigação aponta uma maior tensão entre o cotidiano e o extraordinário na Educação em Visualidade, tensões que levam a uma reconstrução mútua através de eventos que promovem experiências estéticas. Se a intenção é reconstruir uma educação que procura a emancipação do pensamento dominado é fundamental aprofundar nosso entendimento das contiguidades e contaminações entre os artefatos da visualidade e suas dinâmicas na cultura. A arte neste campo ampliado não é somente um conhecimento, mas uma forma de se relacionar com o que se conhece e o que não se conhece ainda, um saber que gera outras formas de ver, interpretar e fazer.

As formas de ver se referem às estratégias de análise, reflexão e crítica dos artefatos das visualidades que na pós-modernidade se propõem desconstrutivas no sentido que lhe dá Derrida. Mas se referem também ao que se escolhe para ver ou se deixa ver, o que se torna transparente ou invisível. Partimos de uma visão para estabelecer processos em que a verdade possa irromper. No nosso tempo estes processos favorecem, como apontam os pósestruturalistas, o ver sobre o dizer, a imagem sobre a palavra, a experiência sobre a explicação. Ademais, tomam em conta que existem muitas formas de ver e que estas estão relacionadas a diversos regimes de visualidade. $\mathrm{Na}$ sala de aula isto significa cruzar as fronteiras dos livros, das teorias, dos dogmas, das normas, dos muros, do currículo programado e do conteúdo em direção a uma maior corrosão na contingência da vida (Fig.29). 

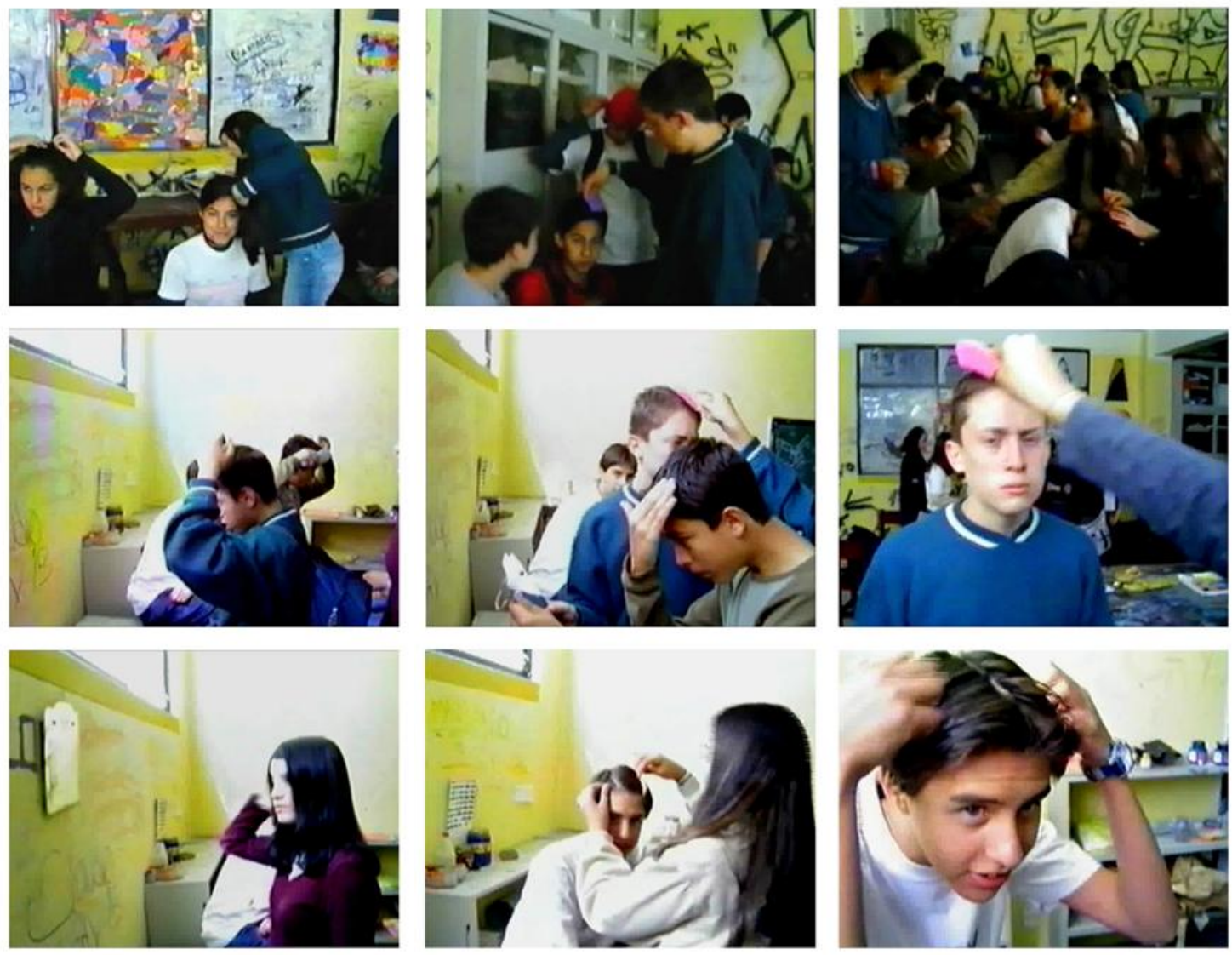

Fig. 29 Narda Fabiola Alvarado. Se penteando. Atividade de penteado com os estudantes numa aula de arte no Colégio Internacional del Sur, La Paz, Bolívia, 2003. Fotografia Narda Fabiola Alvarado.

As formas de interpretar estão ligadas ao conceito de différance de Derrida (1973) que proclama o livre jogo do significante ao invés da compreensão dicotômica saussuriana de diferenciação negativa (ROGOFF, 1998) e isto abre a possibilidade de uma construção singular na pluralidade. A ideia do intérprete como coautor na reconstrução de significados enfatiza sobre as relações que se estabelecem entre os conhecimentos, os que aprendem e os que ensinam. Como apontamos antes, e em sintonia com as ideias de Badiou e Atkinson (2011), necessitamos relações para que hajam 'procedimentos da verdade'. Assim, a verdade não emerge dos conhecimentos, mas os excede (BADIOU, 2009, apud ATKINSON, 2011), a verdade surge dos eventos provocados pelas relações. Isto significa, para o contexto educativo, que a participação como intérpretes da verdade requer pensar no público/espectador/estudante como coautor, coconstrutor, produtor e pós-produtor dos artefatos das visualidades que incluem os eventos culturais e pedagógicos. Isto muda a dinâmica da produção cultural no domínio político das representações em que é possível uma 
redistribuição do sensível (RANCIÈRE, 2005, 2007, 2009b) e uma reterritorialização e ressingularização das subjetividades, tal como a propõe Gauttari ${ }^{41}$ (1995). Aprender nesse sentido é uma tarefa interpretativa e criativa.

Já as formas de fazer constituem espaços de modelização destes territórios existenciais e aqui, como pensa Guattari, pouco importam as categorizações ou distinções formais que se fazem na arte, o "importante é saber se um artefato concorre efetivamente à uma produção mutante de enunciação" (GUATTARI, 1995 p. 131). É necessário que as pessoas possam se reapropriar da produção da subjetividade individual e/ou coletiva. Isto significa que deve haver uma transversalidade estético e ético-política no encontro entre o evento pedagógico e o evento artístico porque não se produzem só artefatos das visualidades, mas subjetividades. Para Guattari "a arte não tem o monopólio da criação, mas leva ao seu ponto extremo uma capacidade mutante de invenção de coordenadas, para engendrar qualidades de ser inauditas, jamais vistas, impensáveis" (Idem, p. 106). As formas de fazer se referem também as relações que se estabelecem com as tecnologias e como estas reconfiguram de igual maneira a subjetividade. É necessário aclarar, no entanto, que na Educação em Visualidade as formas de fazer não se referem às técnicas ou métodos porque estes são procedimentos muito específicos que respondem a situações e necessidades precisas, se referem principalmente às formas de 'se refazer', portanto, podem transitar entre o material e o imaterial, o real e o imaginário, o cotidiano e o extraordinário.

\section{2. A virada pedagógica da arte}

A virada pedagógica da arte não é uma preocupação com o valor pedagógico dos produtos ou eventos artísticos, porque este valor já é pressuposto, todo objeto poderia ser pedagogizado. Se todo artefato de arte tem uma potência pedagógica não haveria necessidade de se distinguir uma virada. A virada pedagógica da arte é um movimento que se articula na fronteira entre a autonomia $e$ a heteronímia da arte. Os artistas que investigam na virada pedagógica da arte enfatizam sobre o valor social da arte e o valor estético da educação. É um movimento que não se interessa por definições ou classificações de arte, mas pela potencia ética e estética para provocar rupturas na ordem das coisas. O que está em jogo nesta virada é o atavismo do

\footnotetext{
41 "Conjunto de condições pelas que instâncias individuais e/ou coletivas são capazes de emergir como Território existencial sui- referencial, em adjacência ou em relação de delimitação com uma alteridade por sua vez subjetiva" (GUATTARI, 1995, p. 9).
} 
discurso moderno da arte que cria dicotomias entre belo ou útil, sujeito ou objeto, teoria ou prática, corpo ou mente, forma ou substância.

A educação foi considerada por muitos séculos como uma arte, mas isso não significa que a aproximação entre arte e pedagogia seja uma aproximação fácil, especialmente na era moderna os valores da arte e da educação divergiram até ficar muitas vezes irreconciliáveis no contexto do pensamento moderno. Um dos indicadores é a persistente dicotomia que se cria na formação da identidade do artista e a identidade do professor de arte nos últimos dois séculos. Esta dicotomia se deu na situação paradoxal em que a modernidade foi construída: enquanto os valores de liberdade, individualidade e independência foram promovidos pelo Iluminismo a escravidão e a exploração laboral foram a energia que construiu essa modernidade. A estética moderna apontou então, principalmente com o idealismo alemão, à autonomia da arte e do artista para quem a liberdade era uma regra, enquanto a filosofia da educação pública apontou a uma normatização que procurou homogeneizar a subjetividade e objetivar o conhecimento da arte para a sua aplicação na indústria.

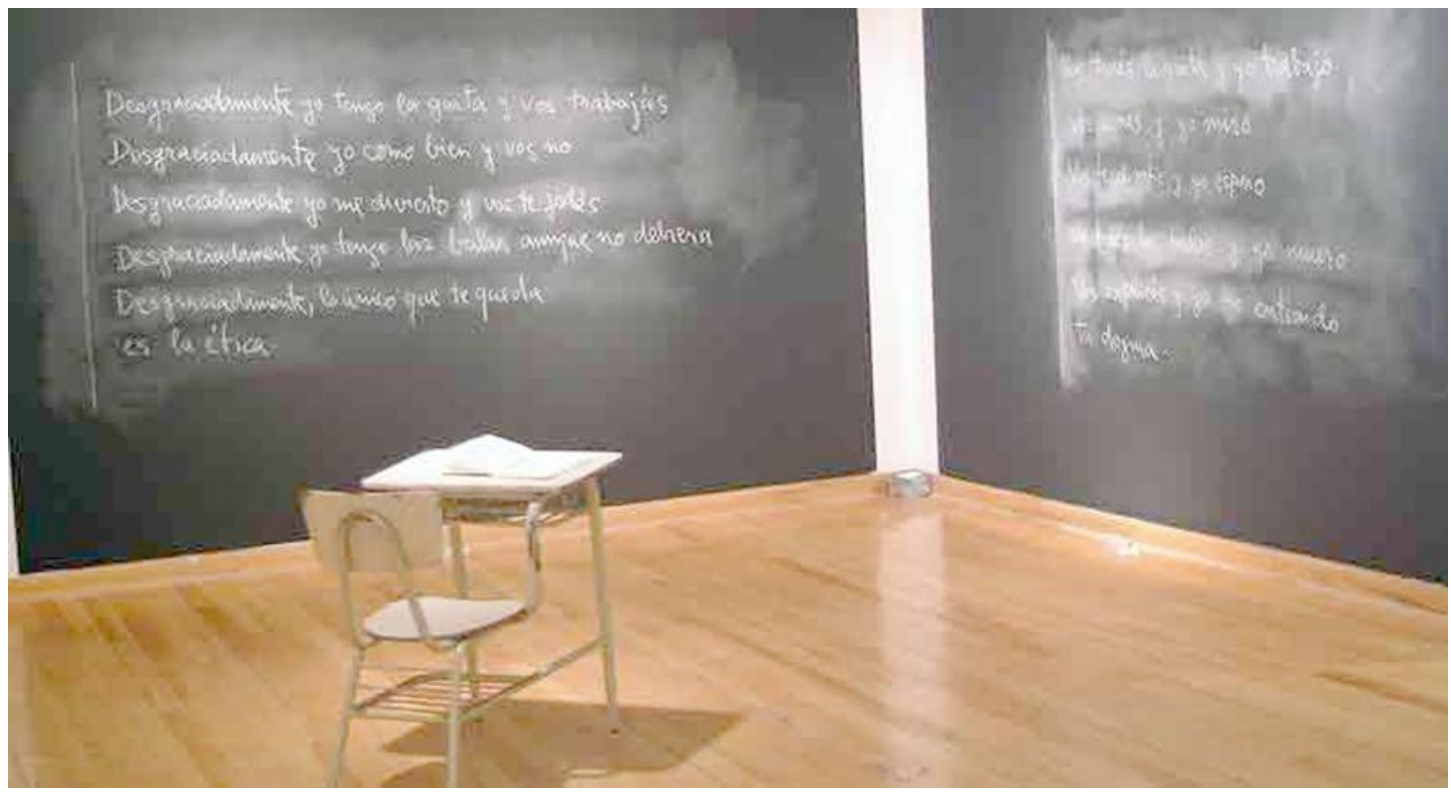

'Desgraciadamente eu tenho a grana e você trabalha, Desgraciadamente eu como bem e você não, Desgraciadamente eu me divirto e você se fode, Desgraciadamente eu tenho as balas embora não devesse Desgraciadamente o unico que te resta é a ética 
Devemos observar ainda que no século XIX estas mudanças conduziram a um conflito sobre o valor dos métodos de aprendizagem acadêmicos que datavam do século XVII. As academias de belas artes que eram escolas separadas das universidades e das escolas de artes e ofícios perderam seu valor no contexto das lutas libertárias e os artistas passaram a estudar em ateliers dirigidos por mestres artistas reconhecidos (EFLAND, 1990). As escolas de artes e ofícios cumpriam a função social que as academias de belas artes não assumiam, formando artesãos/designers preparados para cobrir as necessidades do conhecimento estético aplicado à indústria que era diretamente usado na vida cotidiana. Para formar professores(as) para estas escolas de artes e ofícios e para as escolas públicas foram criadas as primeiras escolas normais de arte na Inglaterra e nos Estados Unidos ${ }^{42}$, que como aponta Efland (1990), é uma mudança radical no mundo da ideias: por primeira vez se formariam professores de arte que não eram artistas. Estas escolas sofreram críticas por duas razões opostas, por uma parte os críticos alegavam que era desenho industrial ${ }^{43}$ e não arte o que se ensinava e por outra criticavam o custo alto de uma aprendizagem que, por não ser uma ciência, carecia de utilidade ou benefício. Foram formadas escolas de artes e ofícios e escolas vocacionais para solucionar a formação de mão de obra industrial a um custo menor. Houve desta maneira um distanciamento entre as artes visuais e o trabalho ligado à economia produtiva nos países do Norte da Europa e da América.

$\mathrm{Na}$ entrada do século XX o papel do artista no contexto das complexas relações entre o sistema da arte, a academia e as necessidades educacionais significaram uma separação abrupta entre o que era ensinado nas escolas públicas, as escolas privadas, as academias, as universidades e as escolas de artes e ofícios, constituindo assim uma realidade fragmentada sobre o papel e a importância da arte nas sociedades ocidentais. Até as primeiras décadas do século XX ainda se acreditava que ser artista era um dom com o qual se nascia, portanto não podia se formar, mas se encontrar artistas. Em termos de investigação isto significava, segundo Sullivan (2010), que os estudantes de arte indagavam sobre sua identidade artística antes que sobre as questões que interessam ao mundo científico ou ao campo social.

Os artistas e professores da Bauhaus (1919-1930) foram os primeiros a investigar sobre a contiguidade entre a criação subjetiva e a construção objetiva de uma estética moderna e o

\footnotetext{
42 South Keningston na Inglaterra e Massachusetts Normal Art School nos Estados Unidos.

${ }^{43}$ Walter Smith deu o nome de desenho industrial ao tipo de desenho que se ensinava na Normal Art School na década de 1870 nos Estados Unidos.
} 
fizeram num contexto pedagógico. Walter Gropius acreditava na importância da arte na educação e na formação da visualidade cultural alemã (mas também europeia e internacional) no cenário moderno. Entre os objetivos essenciais do programa indicava-se a "alocação e dedicação total dos artistas no sistema educacional escolar" (ARGAN, 1993, p. 340). Wassily Kandinsky e Paul Klee entre outros pesquisaram uma didática da arte diferente daquela que era praticada nas velhas academias, mas artistas como Piet Mondrian não abraçaram a ideia da contiguidade entre arte e indústria porque isto significava renunciar ao prestígio do gênio (ARGAN,1993).

Outro dos fatores que separaram as artes do âmbito da vida foi a ideia da arte pura que é uma das bases da arte moderna. Relacionada à noção kantiana do desinteresse a ideia da pureza da arte a libera de toda ideologia, de toda norma, das exigências do público e das funções utilitárias e pedagógicas. No entanto a linha da arte pura não é a única linha moderna. Ariano Suassuna (2008) nos lembra que frente aos defensores do que ele chama de 'arte gratuita' existe outra linha de pensadores que sustentam que a arte sempre tem uma tese a defender com uma função social definida à qual chama de 'arte participante'. Nos extremos destas duas linhas, pensa Suassuna, existe respectivamente o risco da desumanização e da propaganda. Estas dicotomias irreconciliáveis para artistas e teóricos modernos são parte de um conjunto de suposições que circundam a arte na era moderna. Dewey, como vimos, chama de 'ideia esotérica da arte' a essa visão que parte da suposição de que o valor que a arte possui é tão único que não tem conexão com os conteúdos de outros modos de experiência que não são estéticas. Mitchell chama isto de 'falácia naturalista' (MITCHELL, 2003 apud AGUIRRE, 2011) porque se parte da suposição de que a arte não faz parte do regime culturalmente constituído, sendo assim a arte seria parte da natureza e não algo que se debate no terreno das contingências sociais, políticas e econômicas que formam a cultura.

A separação entre valor estético e valor social da arte decorrente destas dicotomias é a crônica de uma morte já anunciada por Hegel. Como sabemos, a arte só pode ter vida dentro da vida portanto a sua morte só é possível onde existe um sistema de significados que lhe dão corpo e que podem caducar. Não basta que a arte exista sem se relacionar com a experiência da vida, como explica Arthur Danto: "[...] uma forma de vida é algo vivido e não meramente conhecido. Para que a arte tenha um papel numa forma de vida é necessário que haja um sistema complexo e justo de significados no qual se insira" (DANTO, 1997, p. 203). 

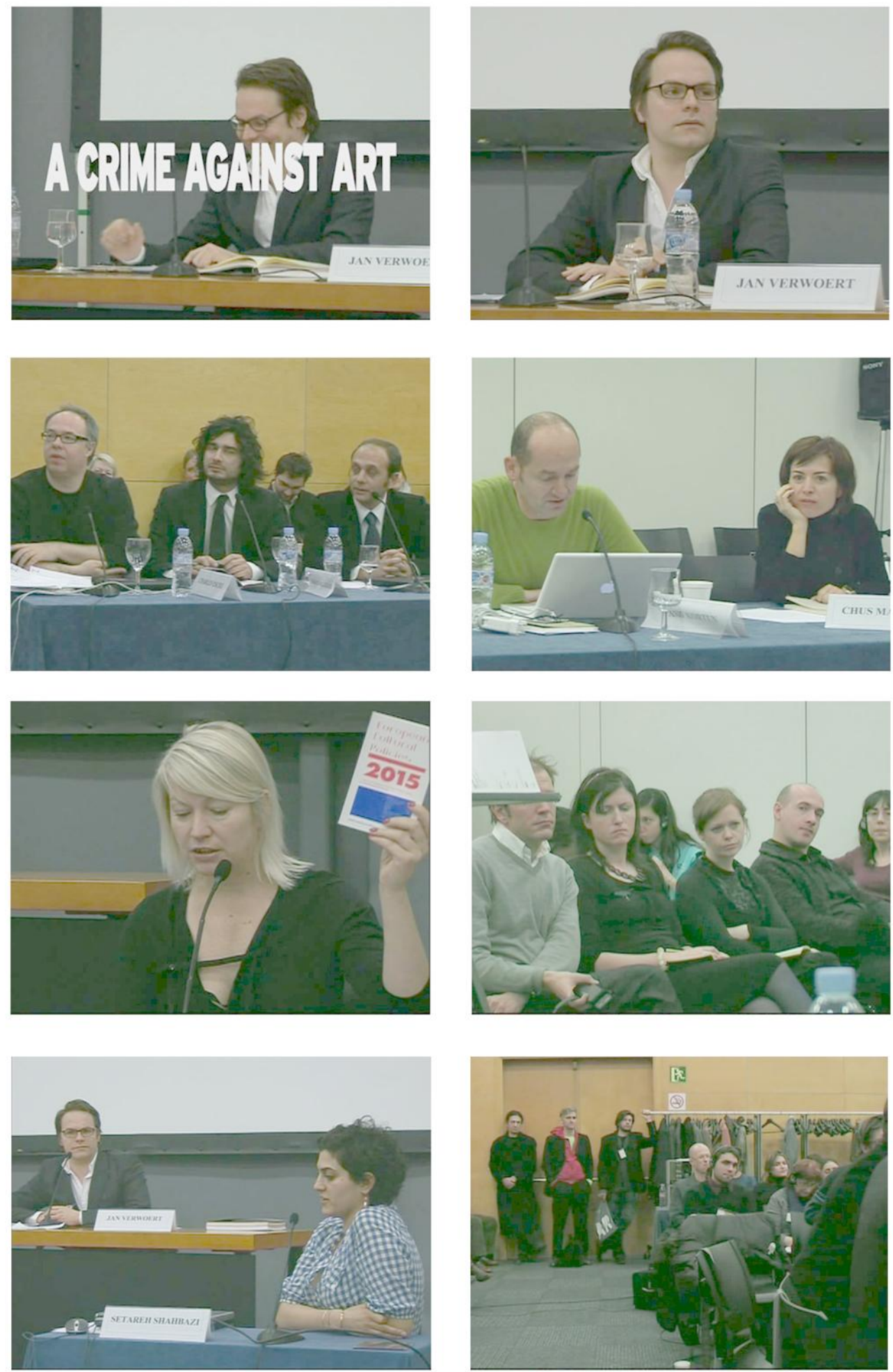

Fig. 31 Anton Vidokle, Tirdad Zolghadr, Jan Verwoert. Unitednationsplaza. O Julgamento de Madrid: Um Crime Contra a Arte. Madrid, 2007. Captions do filme de Hila Peleg, 1:40:52. Fonte: unitednationsplaza.org 
Até mesmo a ideia da 'arte pela arte' se sustenta dentro de um sistema de significados. A posição essencialista de Clement Greenberg, que distingue a arte como repositório dos valores civilizados (quando esta se concentra na especificidade do seu médium) se encontra ligada a um sistema social que distingue os artistas como repositórios dos valores ligados às classes dominantes por uma "corda umbilical de ouro" (1996, In FERREIRA e COTRIM (org.), 2001, p. 31). Assim, a pureza da arte e do seu meio procura preservar, sob um sistema de significados, a pureza da civilização branca e ocidental dos valores considerados defasados, mundanos e primitivos. Nessa visão a dificuldade não reside em compreender a arte como um produto social que tem um valor de mercado em determinado sistema econômico, mas na insistência da sua classificação em superiores ou inferiores, livres ou mecânicas, belas ou úteis, às diferenças estabelecidas com as categorias hierárquicas entre as belas artes e as artes aplicadas, as artes populares, as artes indígenas, as artes realizadas por mulheres ou os artefatos da cultura de massas ou da cultura digital. E a grande dificuldade da identidade do sujeito artista como sujeito docente é análoga. O artista moderno (e muitas vezes o artista contemporâneo) não se incomoda em produzir commodities para o sistema econômico, o que lhe incomoda é a ideia de 'reduzir' a sua prática a uma arte inferior e o seu status social a uma ruptura com o sistema de poder. É, portanto, uma questão ideológica ligada, não tanto à usabilidade da arte, mas à divisão das classes sociais e às relações de poder e dominação. A educação para o artista romântico moderno é um instrumento e não um espaço de poder.

Mas estamos frente a uma mudança dentro da arte. A virada pedagógica da arte propõe uma forma de pensar a arte e a educação como espaços de hibridação e fluxo, espaços de contaminação e rompimento ou espaços de fronteira. Bourriaud (2009) e Bishop (2012) fornecem duas linhas de análise teórica e crítica destas manifestações. Para Bourriaud se trata de uma Estética Relacional em que os artistas se propõem restaurar o vínculo social criando espaços de relacionamento humano enquanto para Bishop não se trata de espaços de consenso, mas de participação em que o dissenso é possível, em que os artistas abrem brechas que rompem com o estabelecido, isto é a arte participante (Fig. 31). Esta investigação se inscreve na linha de análise de Bishop cuja pesquisa da relação entre arte, educação e política se baseia na ideia de estética política de Rancière (2005, 2009a, 2009b) e se expressa através da noção de 'partilha do sensível'. Ele reconstrói a noção do estético no seu sentido de aesthesis, ou modo sensível, da mesma maneira que Dewey (2005) pensa a experiência estética como experiência do sensível. Rancière, à diferença de Dewey, defende a ideia de autonomia na arte, mas Bishop (2012) observa que ele considera a autonomia da nossa 
experiência em relação à arte antes que a autonomia da arte como foi para a estética moderna. Não se trata então de ser livre das exigências do público, da função utilitária ou didática da arte como promoviam os artistas modernos que defendiam uma arte pela arte, mas ser livre para questionar, imaginar novas cartografias artísticas e participar na mudança e redistribuição do sensível. A estética e a política coincidem na sua preocupação pelo compartilhamento de ideias, habilidades e experiências na vida portanto um julgamento estético é sempre um julgamento político, segundo Rancière. Essa preocupação também coincide com as preocupações da educação: compartilhar ideias, habilidades e experiências é por si mesmo um ato educativo.

\subsubsection{O ensino como meio artístico}

Os artistas que trabalham o ensino ou o processo social da educação como seu meio artístico pertencem a uma história recente e apesar das diferenças nas maneiras de questionar ou de apresentar as problemáticas se caracterizam por incluir o espectador como participante da obra. Bishop (2012) traça a história moderna da arte participante a partir dos eventos dadaístas da década de 1920 e dos Happenings e ações da década de 1960 onde prevalecem metáforas teatrais ${ }^{44}$. O ponto central de compreender o ensino como um meio artístico é compreender "a tensão entre a autoria individual e coletiva, o cultivo de uma audiência múltipla e as demandas conflituosas entre agencia e controle" (BISHOP, 2012, p. 78). Hoje muitas destas obras se caracterizam por um trabalho que não pretende ser artístico. Sob estas lentes e possível encontrar, como faz Camnitzer, o primeiro exemplo de ensino como um meio artístico na obra teórica e pedagógica de Rodríguez, e ainda, pensar nos termos de Atkinson sobre um 'evento Rodríguez' implicado no "evento Bolívar" que reverbera hoje no cenário político latino americano.

No final do século XVIII e começo do XIX, na América colonizada, Rodríguez, professor de Bolívar, pensava a educação como um ato criativo e podemos desprender dos seus escritos que a escola era para ele um espaço contínuo entre o cotidiano e o extraordinário. As suas propostas pedagógicas são, no momento das guerras napoleônicas e bolivarianas, radicais, porque enfatizam uma relação crítica, reflexiva e ativa da pedagogia frente ao objeto, que é o objeto da vida. Para ele o processo de aprendizagem podia se decompor em três partes, primeiro 'observar', que é se colocar frente ao objeto e guardar para si, se apropriar dele, depois 'refletir' que é fazer refletir a imagem entre o objeto e o "sentido que a recebe" para

\footnotetext{
${ }^{44} \mathrm{O}$ teatro da Crueldade de Antonin Artaud, o ballet Triádico da Bauhaus, por exemplo,
} 
depois 'meditar' que é "se colocar no meio do objeto e da imagem que deixa" (PALADINES, 2008, p. 165). E essa é uma aprendizagem que se situa na visualidade e cujo objeto está enfrente, está dentro e está 'entre'.

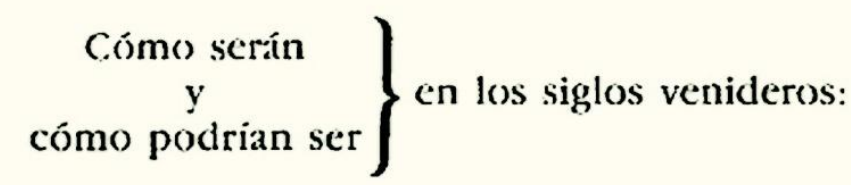

En esto han de pensar los Americanos no en PFLEAAR unos con otros.

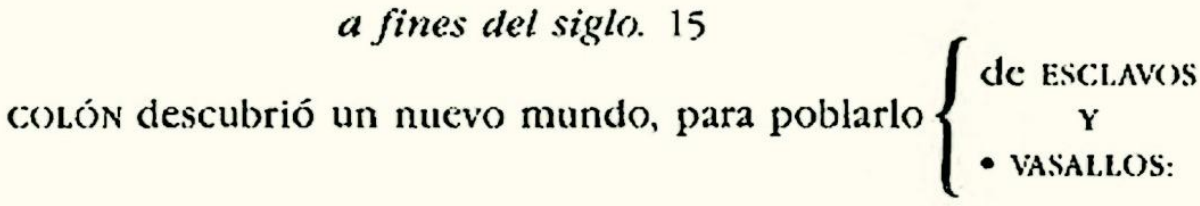

a principios del. 19 ,

la RAZÓN lo reclama, para fundar una Sociedad $\left\{\begin{array}{c}\text { de hombres L.IBRI:S } \\ \text { sometidos } \\ \text { a sus LIYYS. }\end{array}\right.$

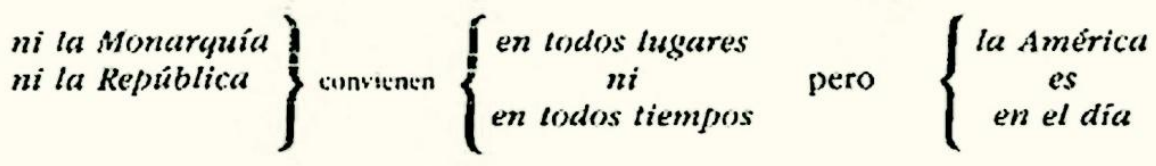
el único lugar donde CONVENGiA pensar en un Gobierno VERDADERAMENTE Republicano.

la bumanidad pide el ensayo-las luces del siglo lo facilitan 
Rodríguez rompia com a ordem estabelecida nos espaços de educação promovendo a ideia de uma educação capaz de emancipar o pensamento dominado, o pensamento colonizado, e as suas estratégias eram visuais (Fig. 32). Camnitzer considera a obra de Rodríguez, mesmo que não explicitamente, um precedente na "atitude latente na maioria das expressões culturais na América Latina" (2009a, p. 64). Os artistas nessa tradição buscam a transformação social e para tal se distanciam de uma qualidade aurática do artefato de arte que possa "interferir com uma comunicação que se supõe quer lograr uma mudança social. Como mestre, é sua claridade, não o status ou aura artísticos que estimulam o pensamento" (Ibidem). Camnitzer vê Rodríguez como um artista, mesmo que nunca tenha se definido como tal e ele pensa que sua força radica exatamente nessa atitude. Nesse sentido Rodríguez é um exemplo extemporâneo e vivido da sua tese sobre os artistas conceitualistas da América Latina: eles usam "estratégias estéticas" (Idem, p. 57) para tratar temas em que convergem arte, política, educação e poesia.

A obra de Rodríguez é pedagógica, política e estética porque institui espaços de ensino e aprendizagem onde a diferença e a dissidência engendram novas performances epistemológicas e novos estados ontológicos. Ele põe em prática no continente latino americano o que Atkinson (2011) chamaria de pedagogia do evento. As suas aulas e os seus escritos rompiam com a ordem do estabelecido de uma maneira tão radical que ele seria considerado ainda hoje um diferente. Sua pedagogia fez de Bolívar um cruzador de fronteiras e ainda que não seja possível saber de outros eventos que sua pedagogia provocou, Badiou (2005) nos lembra que, o evento está em relação a uma verdade que é imanente ao espaço de um sujeito e podem acontecer em espaços indiscerníveis.

Neste sentido é fundamental centrar-se em aspectos visíveis da história da Educação em Artes Visuais. No século XX os primeiros artistas a se apropriarem das formas pedagógicas declaradamente foram os artistas do grupo Fluxus na década de 1970. É interessante notar que as caixas Fluxus de George Maciunas (Fig. 35) guardam muita semelhança com os 'presentes' de Friedrich Froebel ${ }^{45}$ (Fig. 36) com o mesmo objetivo de provocar experiências estéticas significativas. Hannah Higgins (2002) lembra que o grupo Fluxus investigava intensamente sobre os processos cognitivos e sobre os artefatos pedagógicos. Filliou, que foi um dos artistas

\footnotetext{
${ }^{45}$ Norman Brosterman (1997) evidencia a influência dos 'presentes' de Froebel (inventor do kindergarten) na geração de artistas das vanguardas modernas, com a exposição Inventando Kindergarten, no Institute for Figurin em Los Angeles, Califórnia, em 2007. O autor lembra que Frank Lloyd Wright e Le Corbusier foram ao kindergarten, Vassily Kandinsky, Paul Klee, Piet Mondrian e Georges Branque se alfabetizaram no espectro da influencia froebeliana e apresenta presentes e ocupações que, na contiguidade com obras desses artistas, é possível perceber as estreitas relações entre a pedagogia progressista e a estética moderna.
} 
Fluxus mais interessados nas interfaces pedagógicas, elaborou um selo chamado "Princípio de equivalência: bem feito, mal feito, não feito - Criação Permanente" (Fig. 33) para avaliar seus trabalhos. Ele se perguntava se no ato de criação do universo houveram também coisas não feitas, além de coisas bem feitas e coisas mal feitas, por este raciocínio ele chega à ideia de que o Universo, o Criador, Deus e a sua Criação, inclusive nós mesmos somos o 'não feito'. A isto ele chama de 'Princípio da Equivalência' para assegurar a criação do universo. Assim fez com muitas das suas obras, apresentando três versões do que ele consideraria bem feito, mal feito e não feito e classificando estas versões com o selo do 'Princípio de Equivalência'. Esta intenção de avaliar um processo artístico e/ou 'divino' de criação toma a forma de um selo administrativo semelhante àquele que se usa para classificar ou avaliar as tarefas dos estudantes. Ele usa um artefato visual para pensar na possibilidade do terceiro espaço, daquilo que ainda não é.
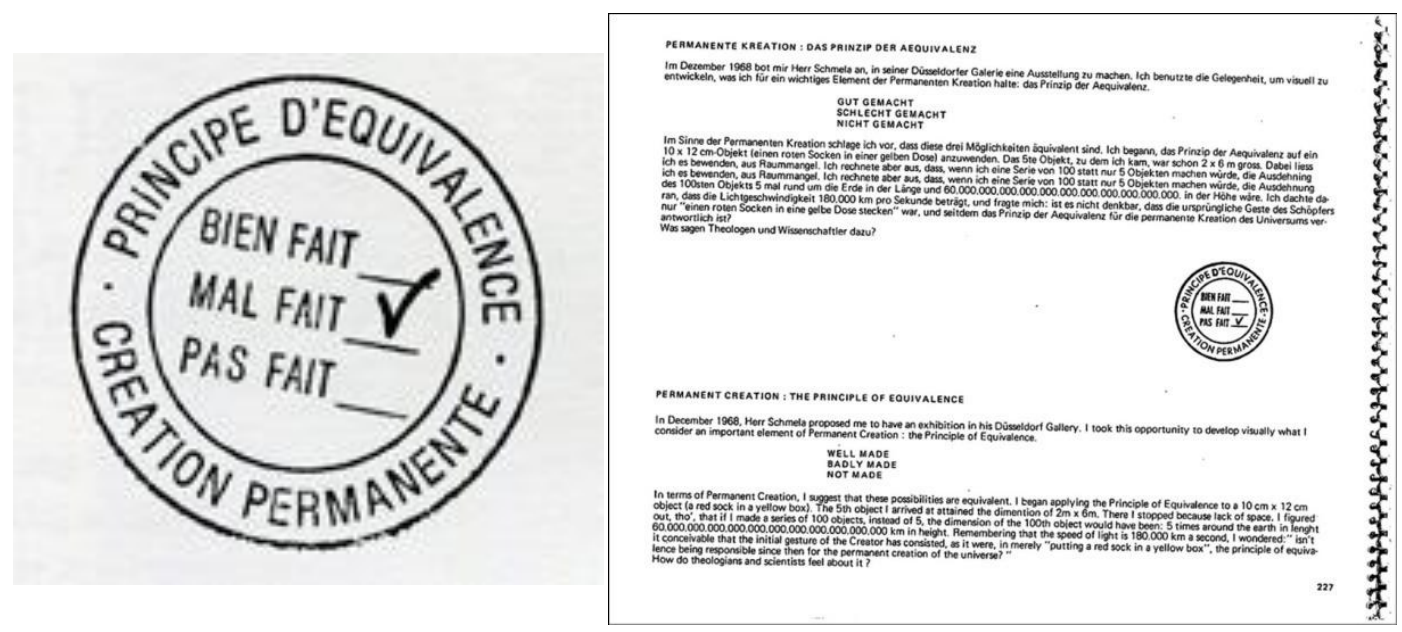

Fig. 33 Robert Filliou. Criação Permanente, selo do Princípio de Equivalência: Bem feito, mal feito, não feito. 1869. Fonte: mediation.centrepompidou.fr

Fig. 34 Robert Filliou, Teaching and Learning as Performing Arts, New York: Kasper Köning, página 227, 1970.

Em 1970 Filliou publicou um multi-livro chamado "Ensinando e Aprendendo como Arte Performática e o leitor, se ele quiser" ${ }^{46}$ com entrevistas a Cage, Allan Kaprow, George Brecht, Dieter Roth, Benjamin Patterson e Beuys entre outros, onde deixa espaços para serem preenchidos pelo leitor como coautor, "se ele quiser", propondo de maneira análoga a descentralização do professor e abrindo espaço para o que ainda não está feito. Na página 227 (Fig. 34) ele descreve o selo como um elemento de Criação Permanente para desenvolver

\footnotetext{
${ }^{46}$ N.T.. Teaching and Learning as Performing Art and the reader, if he wishes.
} 
visualmente o 'Princípio de Equivalência'. Em 1979 Filliou realizou a versão do "Ensinando e Aprendendo como Arte Performática - Parte II", usando desta vez o vídeo para explorar técnicas de participação do espectador que, segundo ele, podiam ter aplicações no ensino.

Outros artistas do grupo Fluxus também relacionaram sua prática artística às suas aulas como Cage e Ian Baxter, (Baxter\&) no final dos anos 60. Patterson apresentou no Fluxus Year Box 2 de 1965, uma carta para ser respondida cuidadosamente com duas escolhas, sim ou não (Fig. 37), colocando em evidência o pensamento binário dos processos educativos. Estes artistas estiveram muito ligados a uma prática pedagógica compreendida como prática artística que tinha uma orientação política inspirada na ideia de arte como experiência de Dewey. São eles também as fontes seminais da estética relacional e da crítica às instituições da arte.

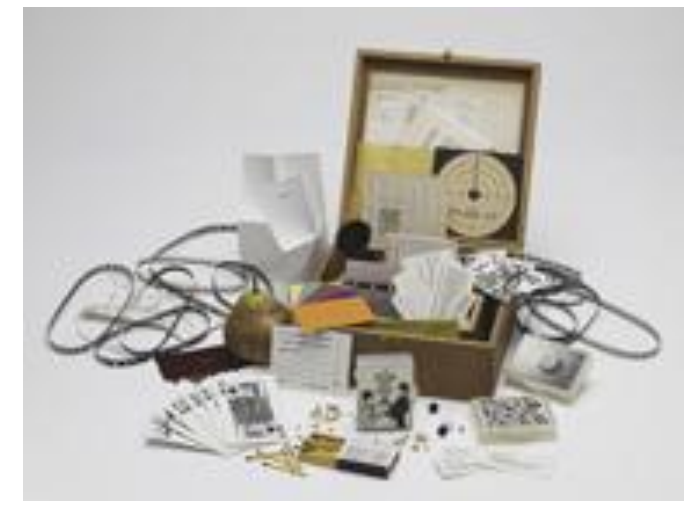

Fig. 35 George Maciunas, Flux Year Box 2, 1960.Fotografia Photograph Service President and Fellows of Harvard College. Fonte: stretcher.org

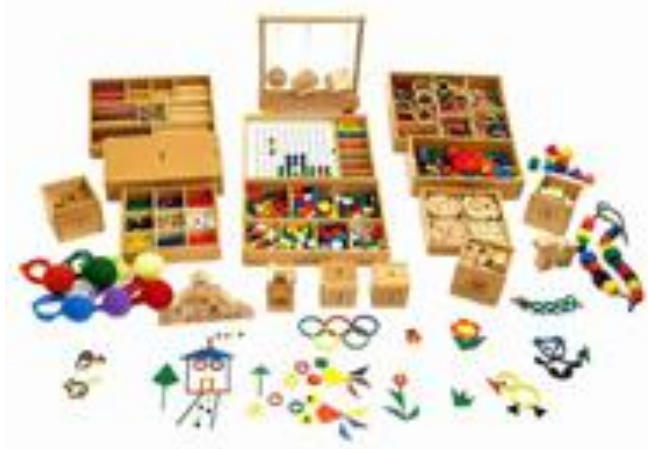

Fig. 36 Reprodução presentes de Friedrich Froebel Fonte: Picasaweb. 


\section{please answer this question carefully.}

yes

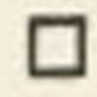

no

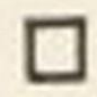

Fig. 37 Benjamin Patterson. Carta de jogo Fluxus, Fluxus Year Box 2, 1965.

por favor responda esta pergunta cuidadosamente.

$\operatorname{sim}$

não $\square$

Beuys, no entanto, foi quem levou ainda mais longe a apropriação das formas pedagógicas nas suas performances colocando a arte e o conhecimento na mesma perspectiva. Ele propôs o 'organismo social como obra de arte' na forma de uma 'conferência permanente', uma espécie de aula constante onde discutia, como se discute numa sala de aula, assuntos políticos com a sociedade. Para ele a arte era o único poder político e revolucionário e nesta linha propôs a 'escultura social' como uma disciplina. Na visão de Beuys todo ser humano é um artista na medida em que desenvolve suas capacidades, e o artefato de arte é aquele que se relaciona com as necessidades humanas e os problemas que existem na sociedade (KUONI, 1993). As suas aulas na Academia de Arte de Dusseldorf eram performances que enfatizavam o lugar da 
aprendizagem como o lugar da experiência da arte. Tanto as fotografias como os vídeos são os registros, os quadros negros onde ele trabalhava suas dissertações pedagógicas são ao mesmo tempo registros e artefatos. Em 1969 ele afirmou numa entrevista:

Ensinar é minha maior obra de arte. O resto é desperdício de produto, uma demonstração. Se você quer se expressar você deve apresentar algo tangível. Mas depois de um tempo isto só tem a função de documento histórico. Os objetos não são mais importantes. Eu quero chegar à origem da matéria, ao pensamento que está atrás dele. (KUONI, 1993, p. 85)

Na sua obra pedagógica/artística Beuys enfatizou o poder da imaginação, da transformação e da intuição que a ciência não alcança por meio do pensamento positivista ou materialista e seus postulados expandem a noção contemporânea de cocriação de significado que é a base da estética relacional das seguintes décadas. Evidentemente existem algumas contradições inerentes na obra de Beuys respeito a uma visão 'evolutiva' em que a arte teria um papel transformador em direção a uma melhor condição humana como também existem contradições na ideia de que o artista e o professor seriam os autores desta transformação (ver VERWOERT, 2008). Mesmo assim, Beuys favorece o questionamento das relações entre os artefatos de arte e sua localização que antecipa a ênfase contemporânea na especificidade do lugar, ou site especific, que pensa a obra em função específica do contexto e situação em que atua.

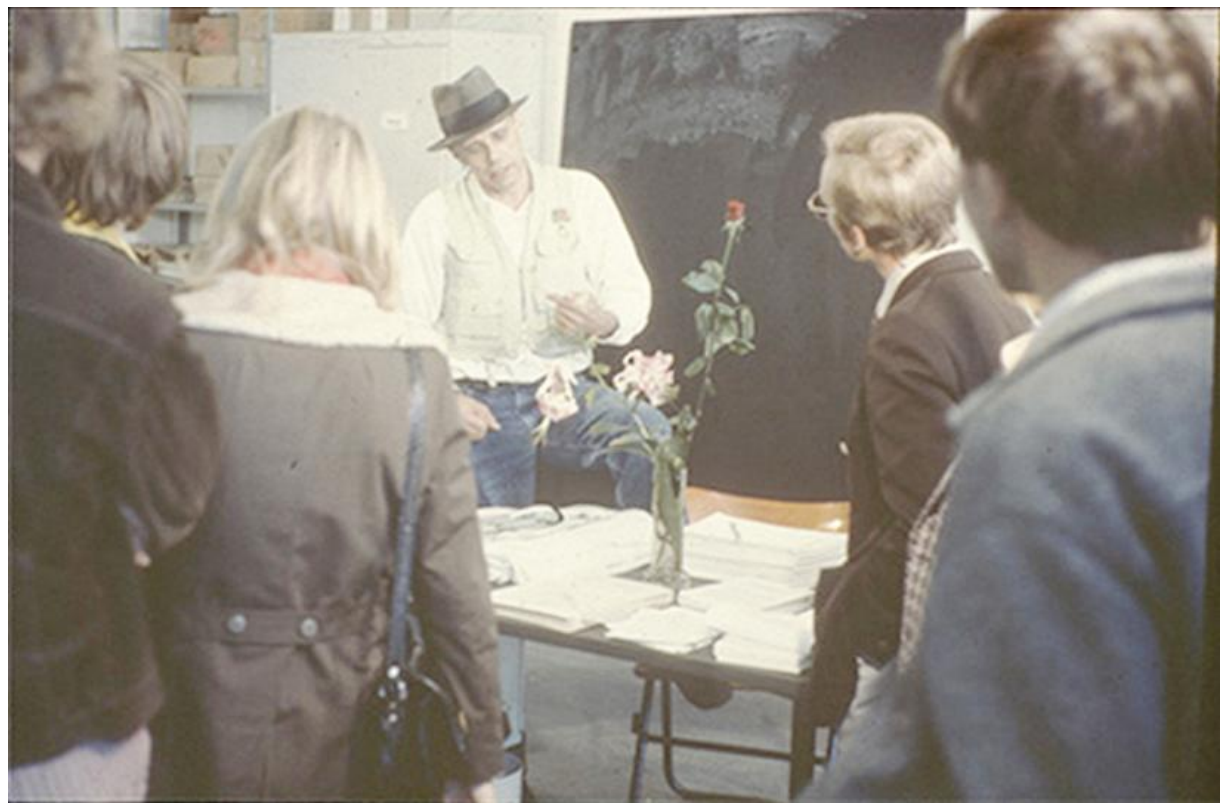

Fig. 38 Joseph Beuys, Escritório para uma Democracia Direta, Tate Londres, 1972. Fonte: Documenta 13 - d13.documenta. 

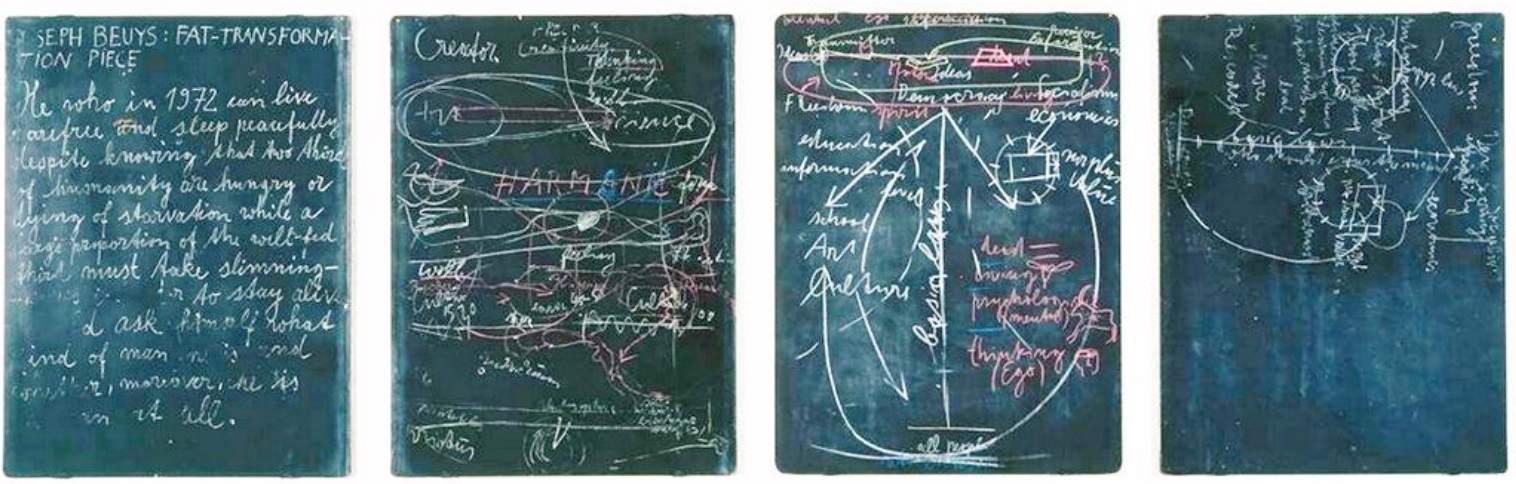

Fig. 39 Joseph Beuys, Quatro quadros negros, Tate Londres, 1972. Fonte: tate.org.uk

Em 1974, na sua luta pela democratização do conhecimento Beuys funda junto ao escritor Henrich Boll a Universidade Livre Internacional para a Pesquisa Criativa $e$ Interdisciplinar $^{47}$ (em diante FIU) que estabeleceu a preocupação do lugar institucional como intervenção crítica do pensamento (PODESVA, 2007). Esta instituição se propõe despertar a capacidade criativa das pessoas oferecendo um currículo interdisciplinar que integrava economia, sociologia e cultura. Bishop (2012) observa que antes da fundação da FIU Beuys já tinha deixado para trás as performances simbólicas e xamânicas por ações pedagógicas como seminários e cátedras sobre estruturas sociais e políticas. Em 1972 ele realizou duas açõescátedra na Tate e na Whitechapel Gallery em que conversava com o público durante horas. No mesmo ano realizou o Escritório para uma Democracia Direta ${ }^{48}$ (Fig. 38) na Documenta 5 onde se envolveu no debate com o público sobre reforma eleitoral. Os quadros negros que resultaram destas ações - cátedra se acumularam e formaram posteriores instalações da memória do intercambio intelectual (Fig.39). Em 1977, para a Documenta 6 Beuys realizou 100 dias da Universidade Internacional Livre ${ }^{49}$ onde se abriram treze workshops para o público.

Para Bishop a História da Arte e a crítica deram pouca atenção ao trabalho pedagógico de Beuys nos anos 70, mas hoje representa uma das linhas mais intensas na prática e na curadoria da arte contemporânea, afinal ele é o precursor de uma arte socialmente engajada que se cria na interseção entre arte, política e educação (2012, p. 244). Jan Verwoert (2008) é um dos únicos autores que analisam a obra artístico-pedagógica de Beuys e encontra que a diferença

\footnotetext{
${ }^{47}$ N.T. Free International University for Creativity and Interdisciplinary Research

${ }^{48}$ N.T. Boureau for Direct Democracy

${ }^{49}$ N.T. 100 days of the International Free University
} 
da ideia de mística criativa com que seus críticos o caracterizaram, como professor Beuys se destacava por um engajamento político pedagógico que o levava ao excesso, fazendo dele uma figura subversiva. As cátedras e seminários de Beuys não formam, adverte Verwoert, um metadiscurso sobre sua arte, eles são uma meio artístico em si mesmo. Naquele momento, destaca, Bishop (2012), não se entendia o discurso como um evento artístico, o próprio Beuys dividia conceitualmente seu trabalho como escultor e como pedagogo. Hoje os artistas não fazem divisões conceituais entre os diversos aspectos do seu trabalho, "Hoje podemos reconhecer não só o discurso, mas também o ensino como um meio artístico" aponta Bishop (2012, p. 245).

Logo, estas ações ampliaram o campo de ação da arte que a partir dos anos 70 irrompe com questionamentos sobre o seu sistema de circulação e de relação com o público, por exemplo, as formas em que os museus de arte apresentam e moldam a compreensão da arte e o conhecimento da história da arte. Tanto os museus, academias de arte e centros culturais se tornam lugares de interesse para a crítica institucional do sistema da arte, apesar de cair também na contradição de ser artefatos criados com o consentimento das próprias instituições. Em face a esta virada pedagógica da arte Bishop levanta uma série de problemas e questionamentos epistemológicos para os historiadores e críticos da arte: "o que significa fazer educação como arte? como julgar estas experiências? que tipo de eficácia procuramos? necessitamos participar de primeira mão na experiência para comentar?" (Ibidem).

O interesse pela educação se propaga na década de 1990 com os estudos e discussões sobre o currículo das escolas de arte, em especial na Inglaterra. O departamento de arte da Goldsmith University de Londres, onde se formaram os chamados Jovens Artistas Britânicos ${ }^{50}$ da década de 1990 foi um dos espaços em que o currículo da escola de arte era discutido entre os artistas e estudantes. Este interesse se estendeu de maneira rápida pela Europa (ver MADOFF, 2009).

Como sabemos, entre os artistas a preocupação com o uso do espaço acadêmico ou de ensinoaprendizagem ganhou maior atenção há pouco mais de uma década. Entre 1998 e 1999 Dominique González-Foerster, Pierre Huyghe e Philippe Parreno, artistas da Estética Relacional de Bourriaud, formaram a Escola Temporária com uma série de workshops em diversas escolas e universidades na Europa. Num deles alugaram um cinema e projetaram um filme narrando potenciais cenários antes de cada parte. Em outro workshop entrevistaram os 
participantes no meio de um lago congelado e em outro fizeram o workshop na cima de uma montanha. Cada situação era filmada e narrada pelos estudantes e estes registros eram vistos em outros workshops criando uma continuidade (VIDOKLE, 2006 In NOTES FOR AN ART SCHOOL, 2006).

Nessa linha empreenderam muitos artistas, como os dinamarqueses Henriette Heise e Jakob Jakobsen, que fundaram em 2001 a Universidade Livre de Copenhagen ${ }^{51}$ (CFU). Com essa iniciativa eles proporcionavam um espaço virtual e físico, do tamanho de um apartamento pequeno, para o debate e produção de processos comunitários de conhecimento enfatizando sobre áreas negligenciadas pelas instituições acadêmicas cada vez mais dirigidas ao serviço da indústria estruturada no pensamento corporativista. A CFU reconheceu a natureza ideológica do conhecimento e promoveu uma investigação politizada e socializada que não encontrava espaço nas instituições acadêmicas tradicionais. Durante os seis anos da existência da CFU e baseados na ideia da emancipação da educação dentro da academia e do mundo da arte, artistas e intelectuais investigaram sobre cinco áreas de conhecimento: organização feminista, arte e economia, subjetividade escapista, ativismo de televisão/mídia e história da arte. Os projetos de investigação na CFU foram construídos coletivamente a partir de apresentações, mostras, encontros e 'passando o tempo juntos'. As potencialidades das redes sociais e do conteúdo gerado pelo usuário como forma de construção compartilhada de conhecimento foram amplamente aproveitadas pela CFU, assim como encontros informais em ambientes domésticos onde a cozinha ou a sala com brinquedos de crianças são espaços de investigação e troca de conhecimentos. O espaço do pensamento, para eles, é um espaço público e privado ao mesmo tempo.

A CFU foi fechada em 2007, mas outras iniciativas similares surgiram em outras partes de 2004 em diante, como a Universidade Livre de Los Angeles ${ }^{52}$, a Universidade da Abertura em Londres $^{53}$, a Universidade Livre de Manoa ${ }^{54}$, a Universidade Informal de Grundung ${ }^{55}$, a Universidade Tangente ${ }^{56}$, a Academia Momentânea ${ }^{57}$, a Escola Panamericana da Intranquilidade $^{58}$ de Pablo Helguera (Figuras 40 e 41), entre outras. Algumas já estão fechadas e outras em funcionamento, mas todas se caracterizam pela produção coletiva, pela

\footnotetext{
${ }^{51}$ N.T. Copenhagen Free University

${ }^{52}$ N.T. Free University of Los Angeles

${ }^{53}$ N.T. University of Openess

${ }^{54}$ N.T. Manoa Free University

${ }^{55}$ N.T. Informelle Universität in Gründung

${ }^{56}$ N.T. L' Universite Tangente

${ }^{57}$ N.T. Momentary Academy

${ }^{58}$ N.T. School of Panamerican Unrest
} 
liberdade de acesso, pela estrutura não hierárquica onde todos são participantes, pelas abordagens experimentais e multidisciplinares, pelo foco em assuntos negligenciados pela academia tradicional, pelo uso de redes de aprendizagem colaborativa, pela natureza subversiva, ideológica e criativa do conhecimento e pela recusa de uma normatização do processo de ensino-aprendizagem (PODESVA, 2007).

Os projetos ${ }^{59}$ pedagógicos na linha da arte participante são recentes, Bishop (2012) aponta o surgimento desse interesse em 2000, mas compreende que a tendência começou a acelerar em 2006 quando a Manifesta 6 em Nicósia, no Chipre, foi cancelada por problemas políticos e em seu lugar se fez uma escola de arte em Berlim, a Escola Noturna, por iniciativa do artistacurador Anton Vidokle (Figuras 42 e 59). Hoje é a escola unitednationsplaza que dá continuidade à experiência que ele teve com a escola de arte da Manifesta 6. No mesmo ano, Rogoff iniciou o projeto Academie com outros artistas e colaboradores para pensar o museu como um espaço de educação. A ideia de academia era para eles uma metáfora da necessidade de especular, se expandir e refletir além de resultados comprovados, "Nascida da crença de que as instituições que habitamos potencialmente podem ser mais do que são, estas questões indagam como o museu, a universidade, a escola de arte, podem ultrapassar suas funções correntes" (ROGOFF, 2008, s/p). Os debates da Academie coincidiram com os debates sobre o Acordo de Bologna (1999) para a reforma educativa na União Europeia que promoveu uma educação contável, padronizada, eficiente e subordinada às exigências do mercado do capital. No entanto, Rogoff observa que o Acordo de Bologna, provocou um maior debate sobre questões como acesso e a possibilidade do diálogo. Nesse contexto numerosos fóruns independentes foram organizados fora das instituições onde se apresentou a educação como uma plataforma de ação, de política e de possibilidade criativa. Ademais, SUMMIT (Non aligned Initiatives in Education Culture) foi um fórum realizado em Berlim em 2007 que assinalou uma política e promoveu coletivos de ação. Importante notar que, o que une todas estas ações é uma ideia sobre educação: "um lugar para imaginar novas formas de pensar" (ROGOFF, 2008, s/p).

Desde então muitas outras iniciativas institucionais e corporativas levaram artistas a criar workshops e escolas ligadas a museus e galerias na Europa e nos Estados Unidos. Em

\footnotetext{
${ }^{59}$ Os projetos na arte contemporânea são um formato que permite procurar e se identificar com o trabalho colaborativo, que tem uma duração, que é situado, que tem um caráter transformador ou construtivo e que envolve uma ou várias comunidades.
} 
proximidade, no Brasil ${ }^{60}$ surgem nos últimos anos discussões sobre a formação e o papel dos mediadores e 'oficineiros' nas Bienais, nas grandes galerias, museus e nos espaços culturais institucionais onde os programas educativos ligados à exposição estão em plena experimentação das possibilidades em que arte e pedagogia se encontram. A virada pedagógica no âmbito da curadoria tornou-se assim uma tendência que cresce e se aprofunda nas políticas da relação entre o espectador, o artefato e o artista.

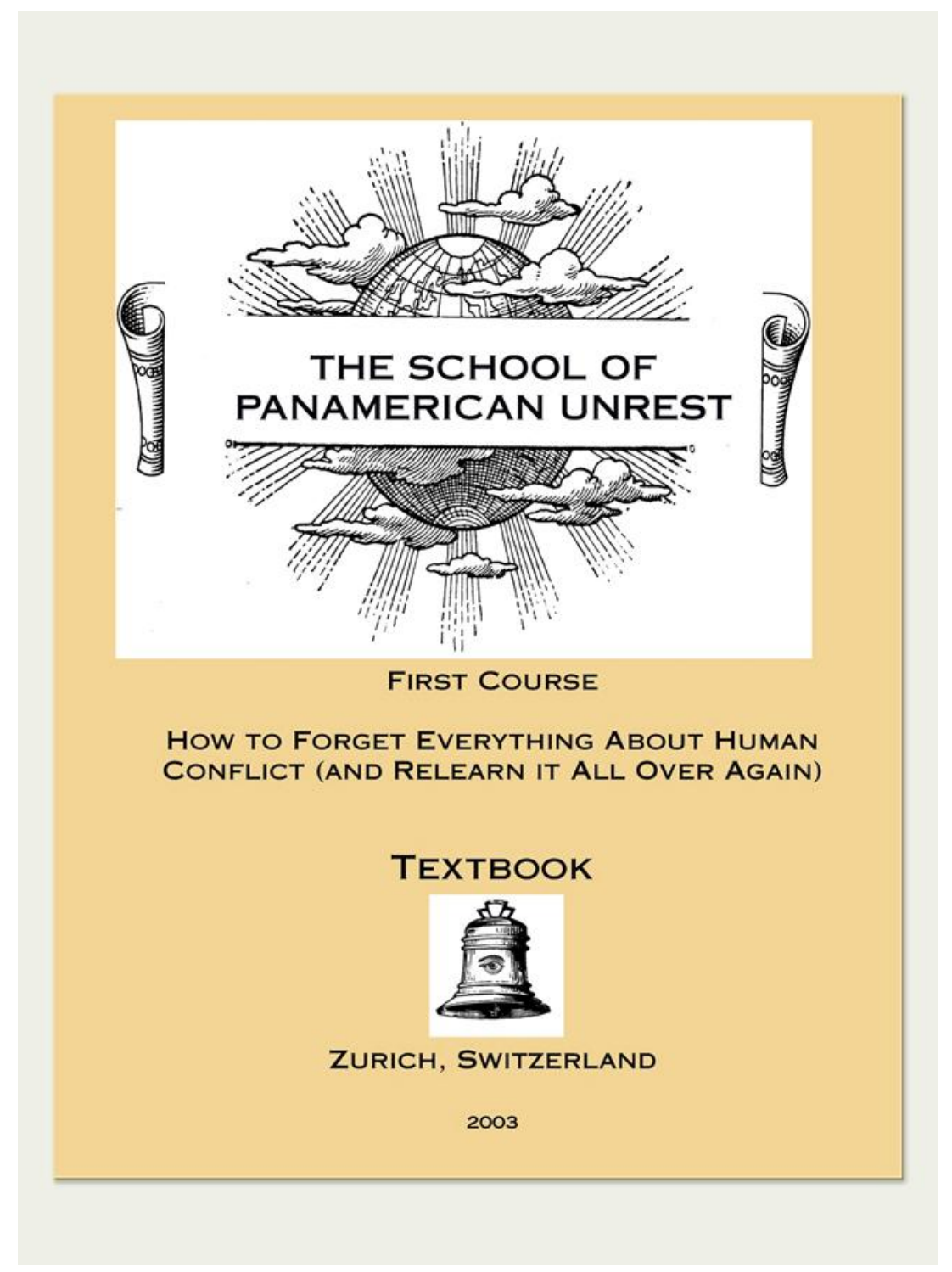

Fig. 40 Pablo Helguera. Escola Panamericana da Intranqualidade.Texto para curso, Suíça, 2003. Fonte: pablohelguera.net

\footnotetext{
${ }^{60}$ No Brasil esta preocupação pelos programas educativos nos museus surge nos anos 80 ligado às pesquisas de Ana Mae Barbosa no MAC e a implementação do DBAE no Brasil sob a forma de Abordagem Triangular e desde então se desenvolve de maneira constante e ampliada nos programas educativos das exposições.
} 
Esta preocupação levou Camnitzer (2009b), convidado para dirigir o projeto pedagógico na $6^{\mathrm{a}}$ Bienal do Mercosul em 2007, a propor uma linha de curadoria que, traspassando as fronteiras da bienal tradicional que divide a tarefa curatorial da educativa na qual a tarefa é educar o público a apreciar os artefatos de arte, se concentrasse na tarefa educativa que pensa nas relações entre o artista e o público (participantes) para incorporar o visitante no processo criativo. Desta maneira o Projeto Pedagógico se desenha junto com o Projeto Curatorial e cria-se a figura do curador pedagógico. A intenção era apontar a arte como uma metodologia para a construção do conhecimento, assim, a ênfase não era "exibir a inteligência do artista, mas estimular a inteligência dos visitantes. Em retorno esta tarefa estimularia nossa própria inteligência como artistas, muito mais do que o narcisismo tradicional." (CAMNITZER, 2009b, p. 230).

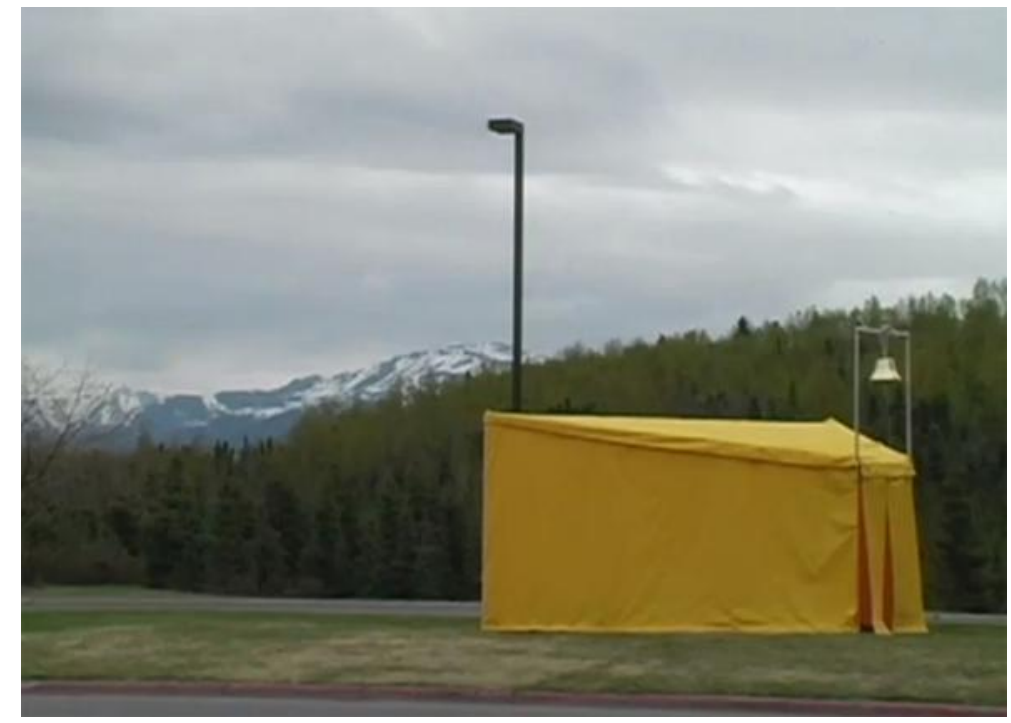

Fig. 41 Pablo Helguera. Escola Panamericana da Intranquilidade, 2003. Fonte: pablohelguera.net

Nesse sentido a Bienal do Mercosul, ou "Bienal Educativa", propôs preparar os mediadores para pensar junto com o público e não para dar informação detalhada da obra, para enfatizar sobre a especulação antes de repetir informações históricas. De maneira a manter o espaço como um lugar de criação e debate se fizeram estações pedagógicas para os trabalhos de cada artista onde aconteceriam trocas de informação e produção; criaram espaços de discussão para o público, um centro educacional com biblioteca, estúdios e aulas nos quais professores e estudantes poderiam armar suas aulas dentro do espaço da Bienal. Por outra parte prepararam materiais educativos (Fig. 43) e investiram na formação de professores como nexos da Bienal. Cinco meses antes da abertura as equipes pedagógicas trabalharam nas escolas em todo o 
Estado do Rio Grande do Sul para estimular a criação com exercícios relacionados às problemáticas que os artistas levariam à Bienal antes que informação anedótica (CAMNITZER, 2009b).

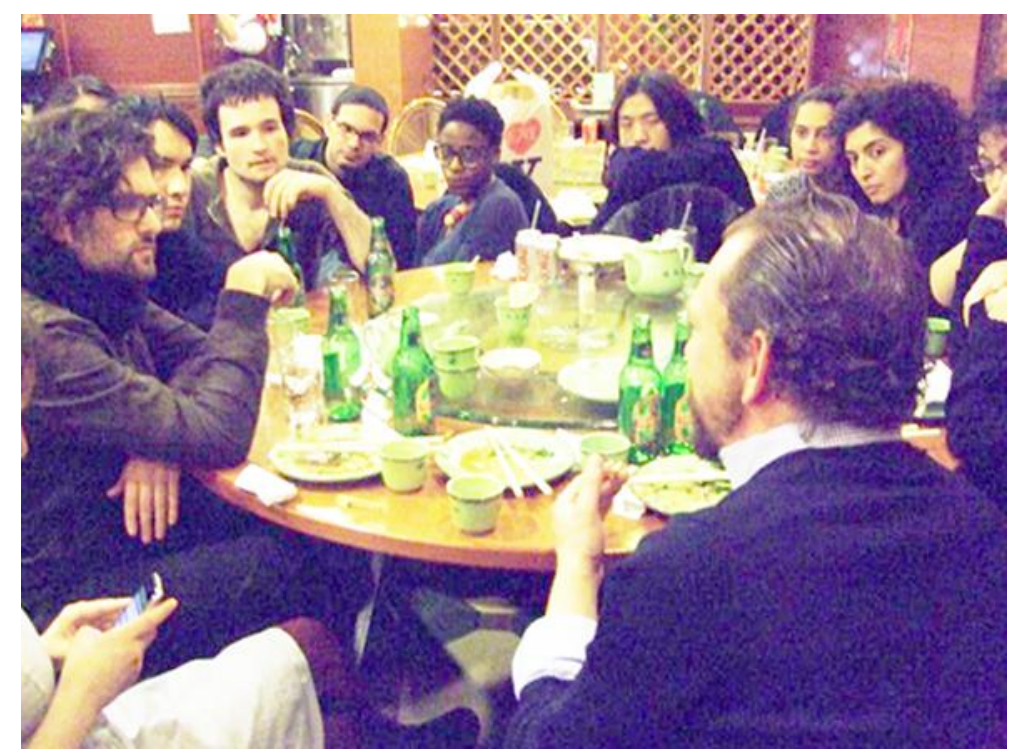

Fig. 42 Escola Noturna de Anton Vidokle. Seminário Público 3. Liam Gillick, Três Textos Curtos sobre a Necessidade de Criar uma Economia da Equivalência. 27-30 março, 2008. Foto Hatuey Ramos Fermin. Fonte: museumashub.org

Se bem a criação de espaços pedagógicos com a prática artística é antiga, pois muitos artistas hoje trabalham de maneira esporádica com projetos de residência artística em escolas, intervenções em ambientes educativos ou nos espaços expositivos por meio do contato com os visitantes; o que destaca a virada pedagógica da arte é o interesse pelo espaço da educação tanto quanto pelo espaço da arte.

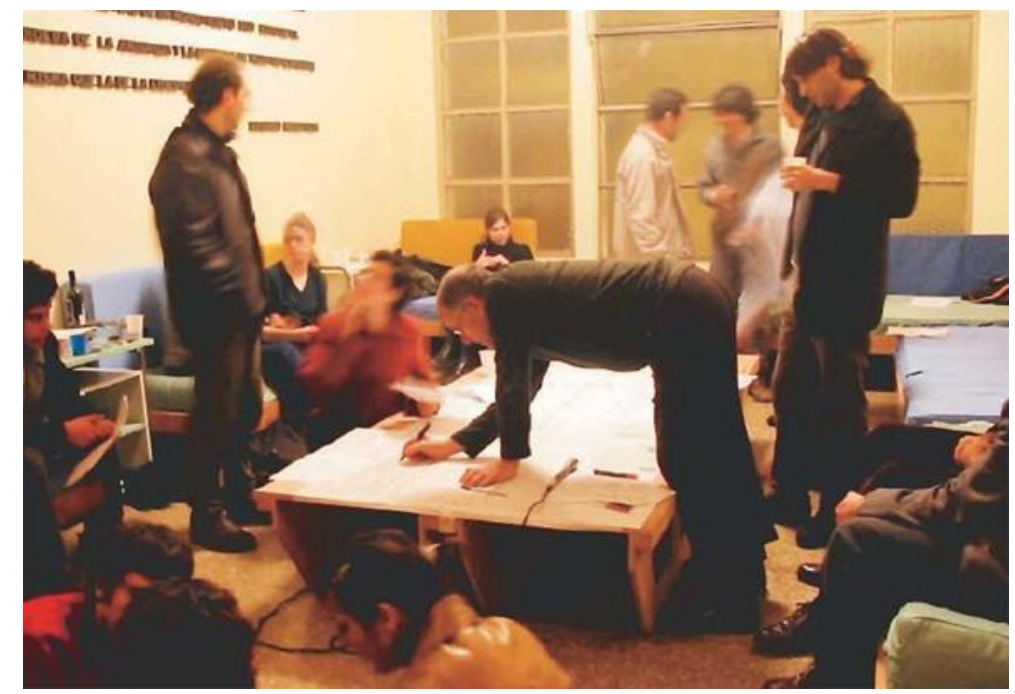

Fig. 43 M7 red, Teatro del chat, instalação - Obra em processo. Material Educativo, $6^{\text {a }}$. Bienal do Mercosur, 2007 
São muito diversas as aproximações com que os artistas contemporâneos trabalham na virada pedagógica. Rainer Ganahal, Liam Gillik, Jef Gey, Tim Rollins e Patrick Rowe, são artistas que, na sua obra, se interessam pelas contiguidades que se geram entre arte e educação. Rollins (Figuras 44, 45, 54, 55 e 56), produz elaboradas obras visuais com um coletivo sempre renovado de estudantes da escola básica nos Estado Unidos, chamado Tim Rollins \& K.O.S. (Kids of Survival) em workshops de leitura literária para crianças e adolescetes com dificuldades de compreensão leitora. Rowe (Fig. 46) criou um mini stúdio itinerante que oferece workshops para as comunidades por onde passa. Outros fizeram intervenções na sua prática pedagógica como o artista conceitual John Baldessari (Fig. 47) na suas aulas de Post Studio Art na Cal Arts. Ele trabalha com desafios que estabelecem limites arbitrários, ou 'tarefas' para seus estudantes, como as 109 'tarefas' opcionais de 1970. Narda Fabiola Alvarado (Fig. 29) usou estratégias artísticas nas suas aulas do ensino medio (embora essas ações não tivessem uma inteção artística), como proposta em que pediu aos estudantes "espelhos, acessórios para o cabelo e pentes para conversar sobre identidades atráves de um exercício estético cotidiano: se pentear" (ver entrevista Anexo III). A resposta dos estudantes foi, pelo que mostram as imagens, encarada com seriedade.

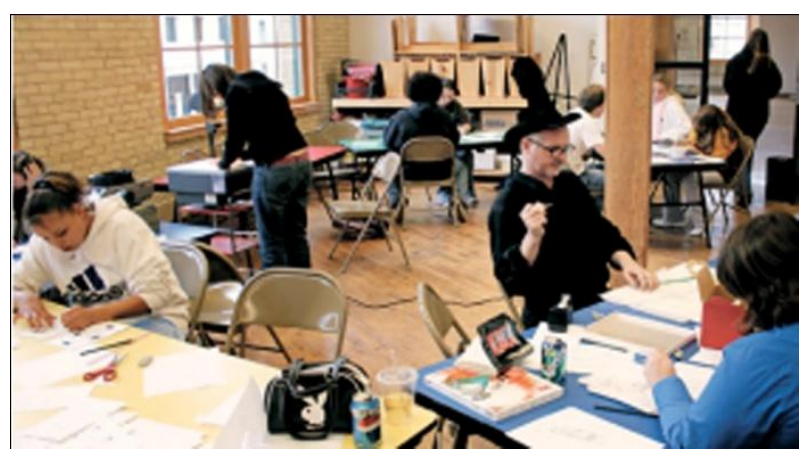

Fig. 44 Tim Rollins + KOS (Kids of Survival) workshop 2007. Fonte: gsa.gov

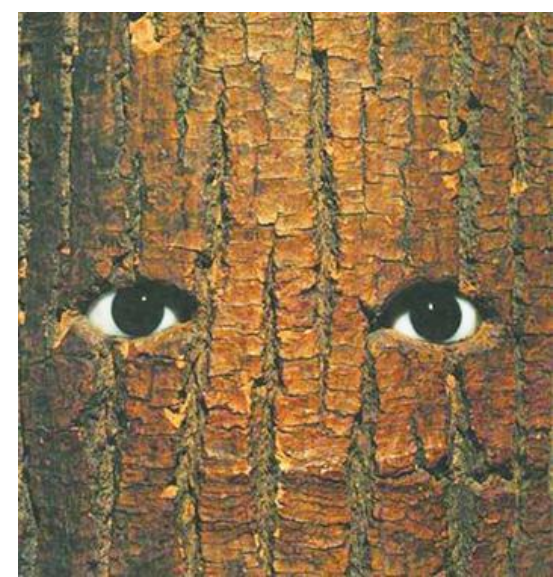

Fig. 45 Tim Rollins + KOS (Kids of Survival) Pinoquio, 1992-93. Fonte: e-flux.com 


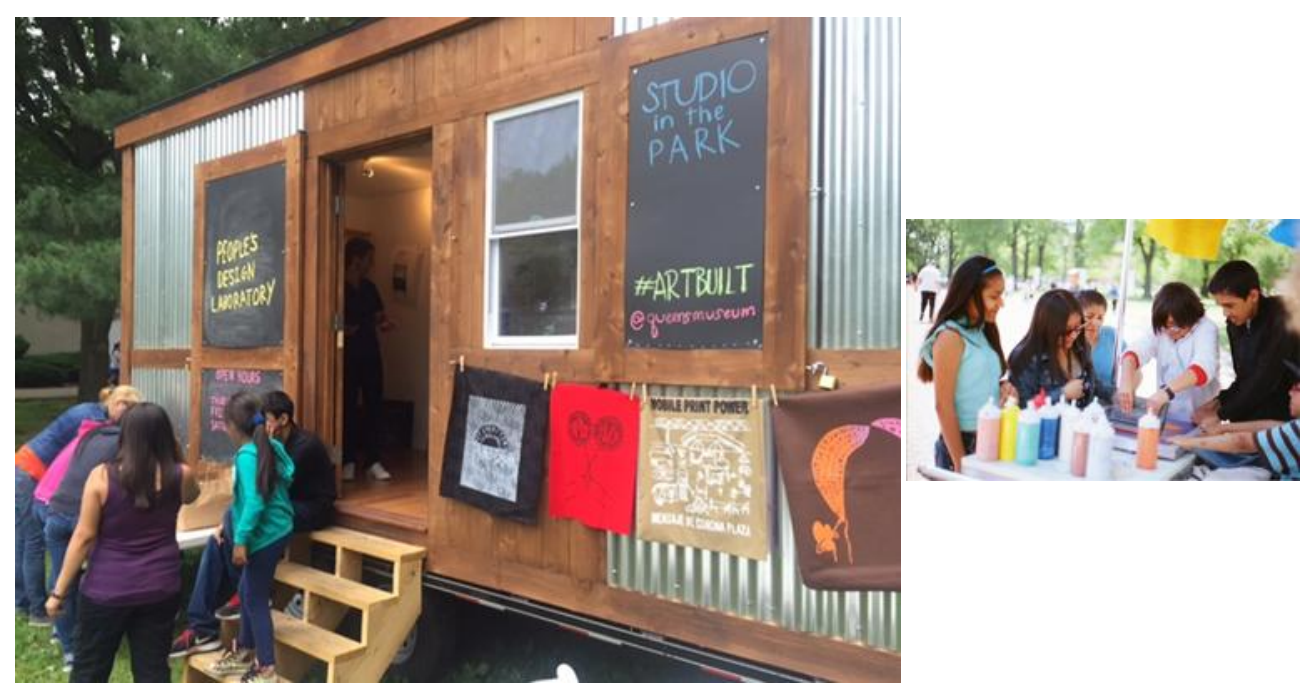

Fig. 46 Patrick Rowe. Mobile Print Power Collective, 2015. Stúdio móbil para workshops.

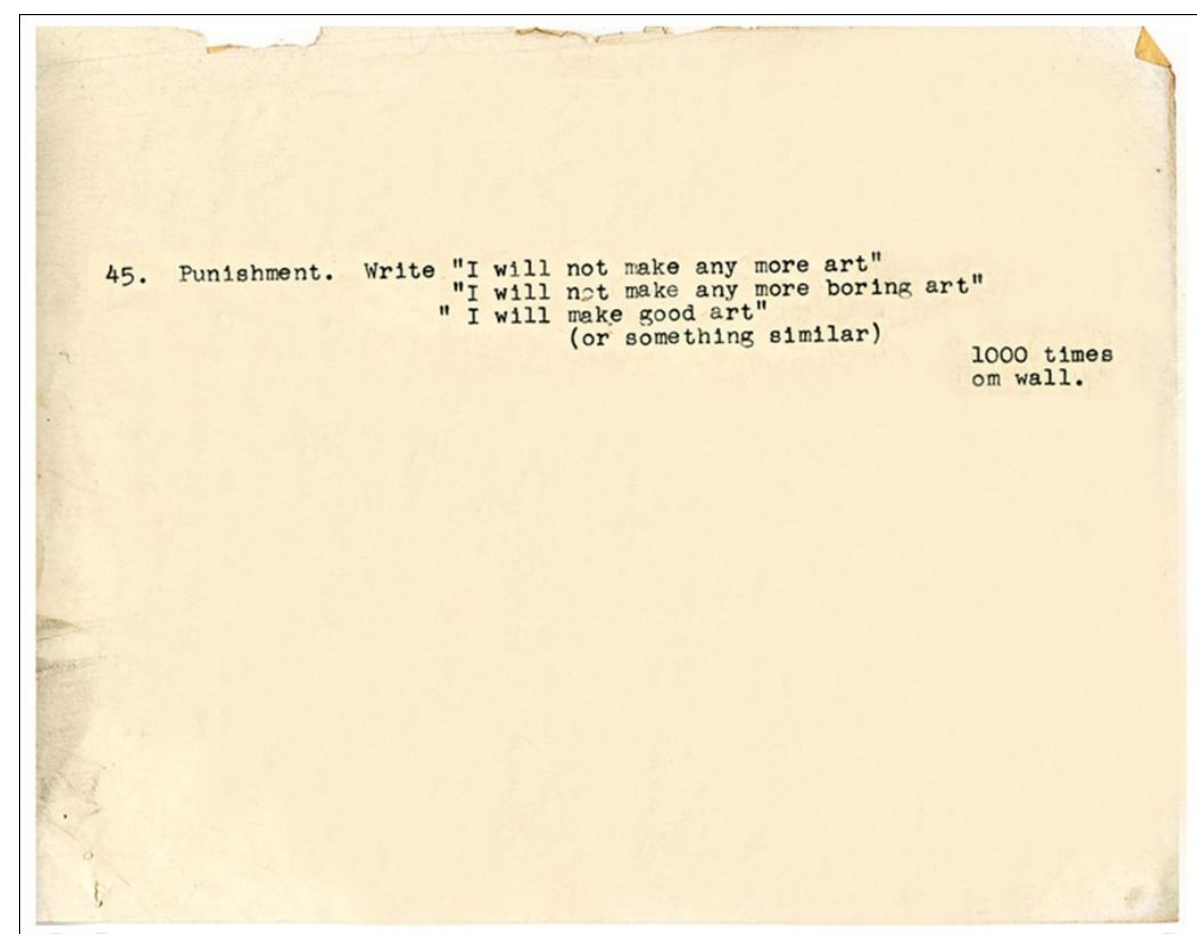

Fig. 47 John Baldessari, Class Assignments, (Optional), 1970. Fonte: wattis.org

45. Castigo. Escrever "Não vou fazer mais arte"

"Não vou fazer mais arte aborrecida"

"Vou fazer boa arte"

(ou alguma coisa similar)

1000 vezes

na parede 
O artista Paul Chan realizou em 2007, em New Orleans, um ano depois do furacão Katrina, a obra Esperando Godot em New Orleans onde organizou aulas, realizou performances e reuniu fundos para os moradores que não queriam arte, mas ajuda efetiva. Thomas Hirschhorn é um escultor que também realizou vários projetos sociais de larga escala produzindo monumentos junto a comunidades onde se situam as esculturas (Fig. 62). Outros como Althamer (Figuras 9 e 51) que há anos faz esculturas com grupos de adultos que apresentam deficiências mentais, foi comissionado para fazer uma obra comemorativa sobre Albert Einstein em Varsóvia e ao invés de fazê-la desenvolveu em 2006 uma escola de física de seis meses para sete adolescentes delinquentes da cidade que chamou Einstein Class. Na mostra Congresso de Desenhistas (Figuras 9 e 51) Althamer proporciona ao público espaços em branco e material para intervir a superfície do espaço e das formas. Da mesma forma, nos últimos anos, as galerias aderiram aos projetos educativos de forma ampla. Em 2011 a Hayward Gallery de Londres abriu pelo período de um mês a Wide Open School (Fig.48) em que os artistas convidados realizaram aulas abertas como um experimento em educação onde todos podiam participar de diversas maneiras (BISHOP, 2012).

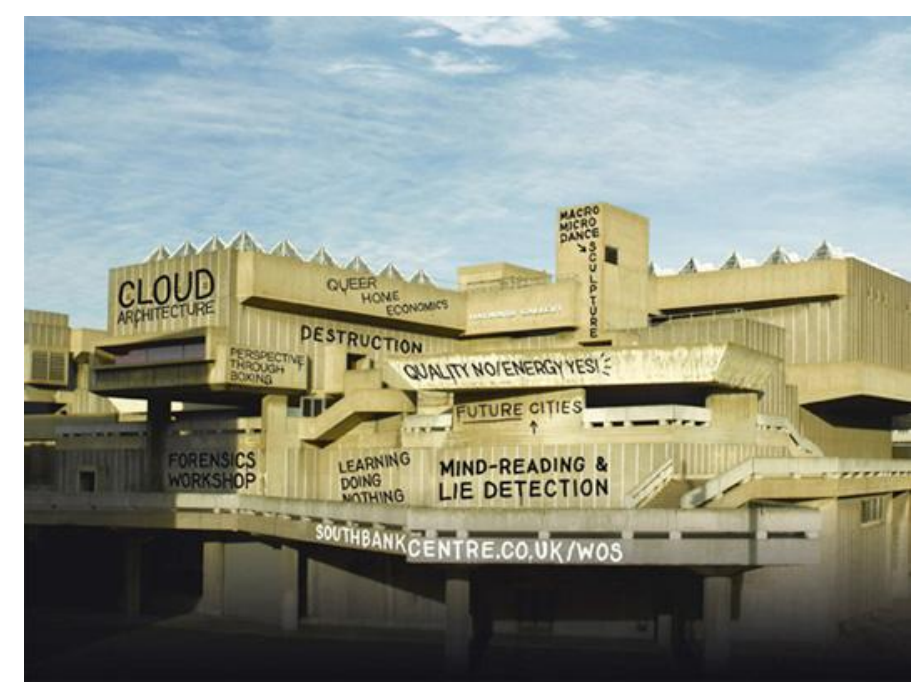

Fig. 48 Wide Open School, Hayward Gallery, Londres, $1^{\circ}$ de junho a $1^{\circ}$ julho de 2012. Fonte: wideopenschool.com

Nessa linha de escolas o trabalho de Bruguera se destaca como uma pedagogia cultural porque constitui uma das obras mais importantes e longas que investem na virada pedagógica da arte além de apresentar três conceitos importantes para o tema. Trata-se da escola de arte Cátedra Arte de Conduta pensada como artefato de arte que Bruguera manteve na Havana entre 2002 e 2009 (Fig. 49). A escola funcionou na casa de Bruguera e era organizada em 
períodos anuais com seminários, workshops e reuniões informais onde diversos artistas da comunidade internacional eram convidados junto a críticos e historiadores. Eram selecionados oito estudantes por ano e ao mesmo tempo a escola era aberta à participação livre. Bruguera considerou esta peça uma intervenção de longo alcance que pretendia criar um espaço de treinamento alternativo ao sistema de estudos de arte na sociedade contemporânea cubana. Para este projeto Bruguera (TANIA BRUGUERA, s/d) criou três conceitos importantes que são próprios dos espaços de coincidência entre o evento artístico e o evento pedagógico, a saber: Arte de Conduta, Arte Útil e Momento Político Específico.

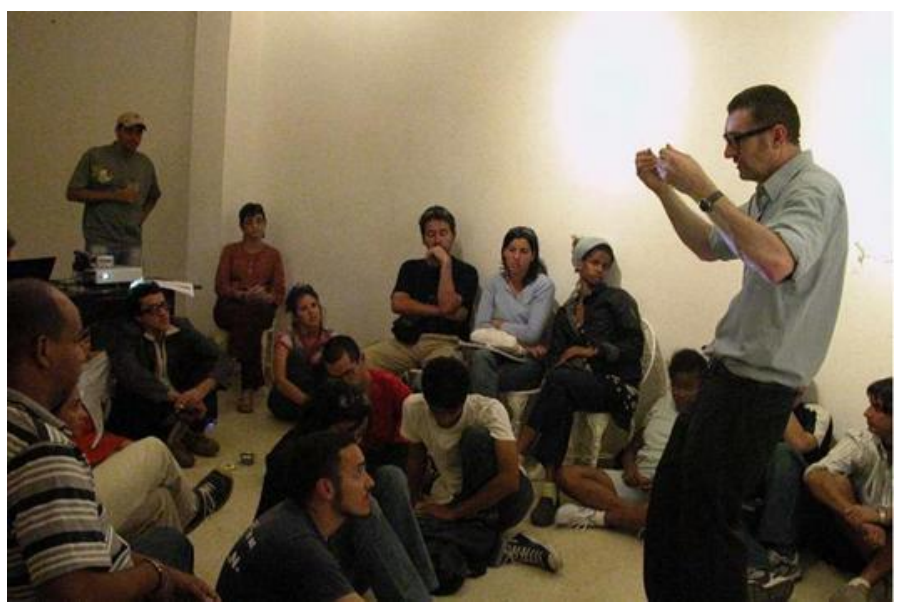

Fig. 49 Aulas. Tania Bruguera, Cátedra Arte de Conduta, Escola de Arte, Cuba, 2002-2009. Fonte: taniabruguera.com

O conceito de Arte de Conduta evidencia as tensões que fazem parte do trabalho de Bruguera, por uma parte, remete às instituições cubanas chamadas Escola de Conduta ${ }^{61}$ para reabilitar jovens com problemas de conduta social que não podem obedecer as normas do sistema onde Bruguera trabalhou como professora de arte e por outra se refere à ideia de performance como conduta social assumindo-o como material de trabalho para realizar arte público e social. À diferença da performance conceitualista a Arte de Conduta trabalha entre as interfaces do útil e o ilegal e não se foca sobre os limites da linguagem e do corpo físico mas sobre os limites da linguagem e do corpo social portanto trabalha com as reações e condutas dos que participam na obra. É sobre a qualidade do intercambio entre a arte e os participantes que se encontra a possibilidade de traspassar a fronteira entre o corpo físico e o corpo coletivo. $\mathrm{Na}$ visão de Bruguera este conceito se afasta da preocupação com a forma na arte cujo propósito estético não seja também ético e de uma arte comprometida com a aparência antes que com a

${ }^{61}$ N. T. Escuela de Conducta 
função. Arte de Conduta procura os elementos ontológicos da sociedade a partir dos quais pode modificar determinados aspectos dela. Este conceito coincide com uma pedagogia cultural que não enfatiza sobre os conhecimentos mas sobre as relações que se estabelecem com eles de maneira que se atravessam as fronteiras entre o individual e o coletivo, o privado e o público. Para Bruguera tanto a educação como a arte devem partir da vida e se dirigir a ela.

A obra de Bruguera sugere que para acercar a arte à vida é necessário pensar em acercar a vida à arte também. $\mathrm{O}$ conceito de Arte Útil aqui é crucial porque pretende transformar alguns aspectos da sociedade por meio de uma arte cujas estratégias possam ter impactos sociais com "soluções para déficits da realidade" (BRUGUERA, s/d). Este conceito se refere à necessidade de traspassar a brecha que há entre "útil e simbólico", entre "público geral e o público informado" e entre "a linguagem de vanguarda e a linguagem da política urgente, da ciência y outras disciplinas" (BRUGUERA, s/d). Bruguera formou a Associação Arte Útil em 2011 para reunir o debate em torno do que significa uma arte útil. Essa ideia coincide com a direção que esta investigação aponta. Na perspectiva de uma arte participante se entende que a utilidade da arte ou sua aplicabilidade nos artefatos e eventos da vida não anula a potência expressiva e poética, mas também não a pressupõe. Nessa visão a arte sempre foi útil a alguma coisa, mesmo quando se pensou livre de qualquer função, pois nesse movimento faz uma defesa do espaço de liberdade em que é possível dissentir. Na perspectiva desta investigação podemos argumentar que a autonomia da arte tem a função de romper com as fronteiras do que se conhece por útil, não de separar a arte da sua imanência.

O conceito de Momento Político Específico parece ser uma reformulação do conceito de site especific (LIPPARD, 1977; KRAUSS, 1998; CRIMP, 1993) formulado nos anos 70 por escultores e críticos de arte que foca a atenção sobre o espaço existencial antes que sobre o espaço físico em que o artefato se constrói. Bruguera apresenta este conceito como um método para conectar o artefato à situação política do momento específico em que se realiza de tal maneira que, passado este momento, a obra perde seu impacto restando apenas o registro como documento do evento. A situação política então define e força à obra a ser uma estrutura flexível "ao devir dos acontecimentos políticos e suas interpretações" (BRUGUREA, s/d). Este conceito é importante para pensar as coincidências entre evento artístico e evento pedagógico porque conduz a uma constante análise da situação política que acontece na sala de aula e força o professor de arte a pensar junto com seus estudantes nos eventos políticos 
que atravessam a sala de aula como elementos de trabalho poético e estético que se relacionam com a própria situação. Por outra parte aponta a uma duração, a um ritmo que pode ser cambiante.

É importante compreender que no Brasil a virada pedagógica da arte está ligada em um princípio, ainda que de maneira indireta, à obra de Ligia Clark (Fig. 65) e Hélio Oiticica (Fig. 64) que se centram (por influência da fenomenologia merleaupontyana e não deweyana como foi para o grupo Fluxus) sobre a experiência da arte e sua relação com as necessidades da vida onde os participantes são ao mesmo tempo o meio e o fim. Neste sentido Boal é entre os artistas brasileiros quem mais explorou os espaços entre a educação e as artes cênicas na interpretação da Pedagogia do Oprimido de Freire por meio do Teatro do Oprimido (Fig. 50). Em todos eles a ênfase da participação na arte como uma experiência liberadora estava ligada a um maior interesse pela sensualidade que a filosofia fenomenológica favorecia, eles "invitam o público a sentir" (BISHOP, 2012, p. 106).

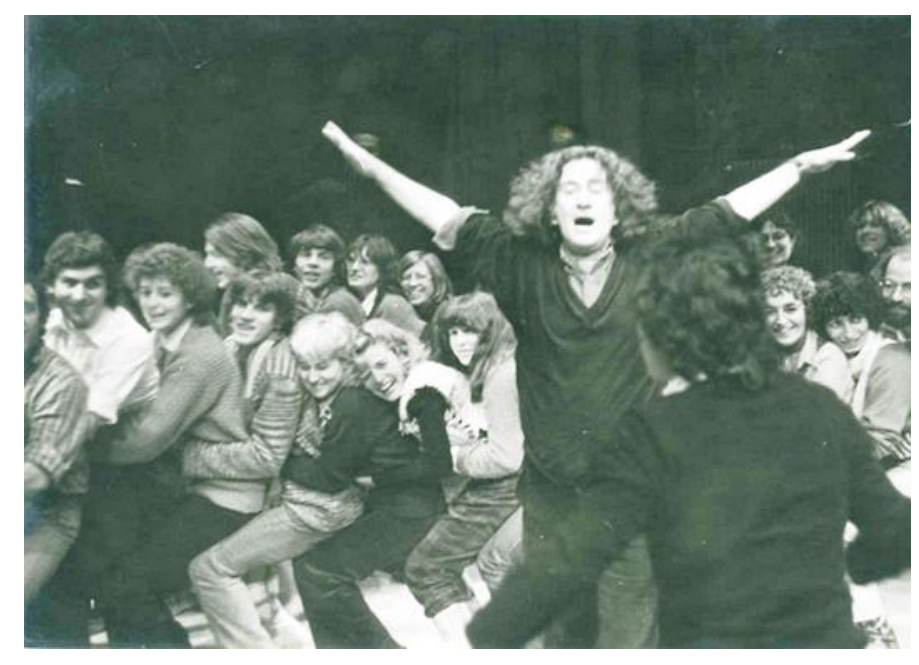

Fig. 50 Augusto Boal. Teatro do Oprimido.Paris, 1975. Fonte: Cedoc-Funarte.

De maneira similar, alguns artistas conceitualistas argentinos exploraram, de diversas maneiras entre os anos 70 e 80, no período mais repressivo e opressivo das ditaduras latino americanas, uma arte social e politicamente engajada que, mesmo não atuando diretamente em contextos educacionais usavam estratégias que procuravam a emancipação do pensamento dominado da mesma maneira que a Pedagoga do Oprimido de Freire. Mas, na Argentina, em que houve uma maior influencia da semiótica e das teorias comunicativas européias no pensamento dos artistas, era mais importante analisar do que sentir. Dessa forma realizaramse obras que, à diferença dos artistas brasileiros, procuravam performances e situações menos 
visuais e mais agressivas que sujeitavam os participantes a formas de coerção como as ações de Graciela Carnevale ${ }^{62}$. Muitos trabalhavam de maneira colaborativa como o grupo interdisciplinar argentino Tucumán Arde (Fig. 8) que produzia intervenções no tecido social. É sintomático que nesse período os setores culturais e educativos eram considerados espaços subversivos pelas ditaduras. A ideia de León Ferrari de que a arte "não seria mais beleza ou novidade, mas eficácia e perturbação [...] um ato terrorista em um país que luta pela sua liberdade" (LONGONI, 2000, apud BISHOP, 2012, p. 127), indica, não uma renuncia estética, mas um programa ético que é estético ao mesmo tempo porque visualiza o conflito e se envolve no centro dele.

A Situacionista Internacional, à diferença destes, recusava um programa artístico. Os conceitualistas norte americanos e canadenses tinham também outra preocupação, centravam seu programa na experiência estética como crítica ao sistema de consumo e do espetáculo na construção dos espaços relacionais.

Embora a produção de uma arte participante nos países latino-americanos é diversa e obedece ao seu próprio contexto, todas as obras se destacam pelas tensões entre arte e vida. Como aponta Bishop (2012), o discurso da autonomia da arte abre espaço para questionar as contradições da sociedade e o discurso da arte socialmente engajada abre espaço às provocações para uma mudança social. Nesse sentido, ambas criam tensões que alcançam pontos culminantes e recorrentes nos períodos de maior instabilidade política e social: nos anos do surgimento do Fascismo italiano, nos anos que seguiram à Revolução Russa, nos levantamentos sociais de 1968 (BISHOP, 2012) e na década pós-9/11 quando o mundo se prepara para viver uma guerra global sem fim. A história da identidade do participante é também remanejada de acordo a estas mudanças políticas: "a multidão (1910), as massas (1920), o povo (1960-1970), os excluídos (1980) a comunidade (1990) e os voluntários" (Idem, p. 277).

É importante lembrar que a participação ou a colaboração também foram conceitos intensamente usados pelas ditaduras como foi pelo fascismo e hoje é usado de maneira indiscriminada e paradoxal pelo mercado de capital. A diversidade de manifestações da arte participante obedece justamente a um Momento Político Específico que informa os propósitos

\footnotetext{
${ }^{62}$ Em 1968, como parte de uma série de ações do chamado Ciclo de Arte Experimental em Rosario, na Argentina a artista tomou prisioneiras (obrigados a participar de maneira violenta) as pessoas que foram assistir sua obra sem saberem que seriam trancados numa sala vazia cuja parede de vidro dava à rua. A artista não pretendia liberá-los até que eles conseguissem fazer isso por si mesmos. Foi uma pessoa da rua que quebrou o vidro por onde os participantes puderam se liberar.
} 
e os meios em que a arte se manifesta. A virada pedagógica da arte faz parte de um movimento de arte participante que procura responder a um momento de extrema crise política e social, mas também procura lidar com uma nova proximidade entre espetáculo e participação e ampliar a arte ao espaço da experiência estética na era da virada da visualidade.

Seria necessário também reconhecer, como Guattari (1995), que a tensão entre arte e vida é fundamental porque se a arte se funde totalmente na vida corre o perigo do seu eclipse. Para evitar esta desaparição ele sugere que a arte deve ter uma dupla finalidade: fazer parte de uma rede social que pode tanto lhe recusar ou lhe aceitar e celebrar o Universo da arte como tal porque está sempre em risco de colapso. Os projetos de arte como pedagogia contemporâneos apontam a esta dupla ontologia de tensões entre arte e sociedade, arte e educação, arte e cultura, arte e ciência, arte e política e arte e vida. Na Educação em Visualidade significa manter uma tensão entre a visão crítica e produtiva das visualidades.

\subsubsection{O evento artístico como pedagogia}

Pensar no evento artístico como uma pedagogia não significa converter uma na outra, mas provocar tensões e cruzamentos para que a mútua contaminação possa irromper a ordem das coisas. Esta contaminação pode trazer a ambos discursos força crítica e maior poder de agência sobre a construção da visualidade. Mas a pergunta se estende, o que torna um evento artístico uma pedagogia?

Na paisagem conceitual contemporânea, é muito difícil e muito perigoso embarcar em uma categorização das manifestações artísticas ou em uma distinção cartesiana de movimentos porque não há uma "relação mecanicamente ajustada" entre os artefatos de arte, as situações, os contextos, as linguagens e a sua especificidade. O importante, portanto não é classificar ou distinguir uma forma de evento artístico como pedagogia, mas indagar nas possibilidades que se abrem nestes cruzamentos.

Por esse motivo são necessárias novas formas de pensar e fazer, isto é, novas performances epistemológicas. Ainda, é necessário compreender tanto o discurso da arte como o discurso da educação e pensar no que uma significa para a outra. Como em todo choque cultural existe uma tensão difícil de atingir sem atravessar fronteiras. O paradigma da transversalidade de Guattari (1995) aponta a possibilidade que a arte tem de atravessar e entrar em outras disciplinas colocando tanto o discurso artístico como o discurso social (para nós o discurso da educação em especial) em constante questionamento mesmo reafirmando a arte como um 
"universo de valor". Para Rancière o regime estético rege tanto a ideia de uma estética como a ideia de uma antiestética, é necessário, portanto, a mediação de um terceiro termo para manter a tensão entre a autonomia e a heteronímia da arte, entre o artista e o espectador (se referindo principalmente à relação entre teatro e educação):

[...] o espetáculo é o terceiro termo, ao qual os outros dois podem se referir, mas que impede qualquer tipo de transmissão igual ou não distorcida. É uma mediação entre eles, e essa mediação do terceiro termo é crucial no processo da emancipação intelectual (RANCIÉRE, 2007 apud BISHOP, 2012, p. 278).

De maneira análoga deve haver uma tensão entre a necessidade que o artista tem da exploração criativa do participante e a necessidade que o participante tem da direção do artista. É, portanto, uma relação de tensão, reconhecimento e dependência. Neste assunto, e diferentemente de Rancière, Freire pensa que é necessário que exista uma hierarquia entre o estudante e o professor (podemos pensar aqui analogamente na relação espectador/artista) para que haja um programa, uma direção, um contexto: "O diálogo requer uma tensão permanente entre autoridade e liberdade. Mas nesta tensão [...] a autoridade e a liberdade aprendem a se autodisciplinar" (FREIRE e SHOR, 1987b, p. 102). Bishop destaca que na sua pesquisa sobre arte participante considera melhores as obras que mantém esta tensão entre o discurso artístico e o discurso social porque existe um programa e um contexto sob uma direção autoral (seja individual ou coletiva). De maneira análoga, quando se analisam as coincidências entre o evento artístico e o evento pedagógico é importante tomar em conta que um programa e um contexto pedagógico requerem uma direção autoral que pense naquilo que Freire chama de 'horizonte':

No momento em que o professor começa o diálogo, ela ou ele sabe muito, primeiro em termos de conhecimento e segundo em termos do horizonte aonde quer chegar. O ponto inicial é o que o professor sabe sobre o objeto e aonde o professor quer chegar com isso. (FREIRE e SHOR, 1987b, p. 103)

Da mesma maneira, para determinar quando é um evento pedagógico é necessário se posicionar nas relações que se estabelecem entre os que aprendem, os que ensinam e o que se aprende. A diferença e a dissidência são dois conceitos que permitem pensar na tensão entre a 
singularidade e a pluralidade tanto para uma sociedade democrática (política) como para uma pedagogia emancipadora (educação) e uma poética - estética da resistência (arte).

No encontro entre esses dois eventos há uma preocupação por atravessar as fronteiras entre o discurso artístico e o discurso social e as fronteiras entre o discurso da arte e o discurso da educação. Bishop (2012) observa, no entanto, que a ideia de 'partilha do sensível' se abre às possibilidades de toda arte ser política e, portanto, submetida a julgamentos morais. Hoje a tendência no âmbito dos incentivos culturais é apoiar projetos artísticos ou culturais que tragam ideias moralizantes e civilizatórias. Os artefatos artísticos que obedecem estas diretrizes são muitas vezes entendidos como parte de uma 'virada social da arte'. Mas, na maioria dos casos esta tendência indica que se parte de um princípio de inferioridade dos participantes porque trata-se de lhes ensinar o que não sabem sem considerar o que sabem.

Para Rancière isto denota o "colapso do dissenso na arte e na política em novas formas de ordem consensual" (2004, apud BISHOP, 2012, p. 28). Ele afirma que assim como na política da guerra (norte americana) o discurso dominante tende a distinguir uma 'maldade infinita' de uma 'justiça infinita' assim na arte o discurso dominante tende a distinguir uma arte que procura a restauração do vínculo social (ver BOURRIAUD, 2009), de uma arte que apresenta a visão da catástrofe. A arte para Rancière deve procurar a tensão que a faz existir em si mesma e além de si mesma:

A estética para Rancière assinala uma habilidade para pensar a contradição: a contradição produtiva da relação da arte com as mudanças sociais, que se caracteriza pela paradoxal crença na autonomia da arte e em seu inextricável vínculo com a promessa de um mundo melhor a vir. Em quanto esta antinomia é a aparente em muitas práticas vanguardistas no último século, parece particularmente pertinente analisar a arte participante $\mathrm{e}$ as narrativas legitimadoras que atrai. Em resumo, o estético não necessita ser sacrificado no altar da mudança social, porque ela sempre contem a promessa da melhoria. (BISHOP, 2012, p. 29)

Não é de se surpreender que apesar de ser ainda uma tendência marginal no mundo da arte atualmente existe um maior interesse dos artistas pela relação entre arte e academia e se antigamente a academia era associada a uma instituição já estéril hoje se converte em uma aliada num contexto em que o espaço público se torna cada vez mais privado (BISHOP, 2012). Ademais, Rogoff observa que diversos termos como "'educação', 'pedagogias auto- 
organizadas', 'pesquisa' e 'produção de conhecimento' começam a atravessar os discursos. O problema é que, no discurso neoliberal, os mesmos termos têm outra intenção: fazer da educação uma ferramenta para a nova 'economia do conhecimento'" (ROGOFF, 2008, s/p). Os projetos educativos que se apresentam nos museus e espaços culturais institucionais se restringem na sua maioria a projetos politicamente corretos que satisfazem somente os objetivos institucionais e corporativos dos patrocinadores. Partindo desta perspectiva Bishop (2012) questiona como seria possível reconhecer neste contexto a diferença entre uma pedagogia estética e as interseções generativas entre arte e educação? Ela lembra que a literatura em arte e pedagogia evita tratar das interseções e das diferenças entre os discursos da arte e da educação.

Nesta investigação, isto significa procurar eventos artísticos que consigam negociar a tensão entre uma arte que tende à vida e uma arte que se abre à experiência estética distinta de outras formas de experiência. Por outra parte estes eventos artísticos devem ser em si mesmos eventos pedagógicos porque pensados para contextos de educação. Isto significa procurar pedagogias do evento, como as concebe Atkinson. Em base a uma extensa pesquisa sobre arte participante e sobre os projetos pedagógicos da última década Bishop (2006, 2012) observa o que acontece quando artistas trabalham com interfaces pedagógicas. Isto pode ser importante para observar o que acontece quando o evento artístico coincide com um evento pedagógico em contextos de educação básica:

- Não são, na maioria das vezes, trabalhos coesos, completos e pensados para uma exposição. A obra, a menos que esteja densamente documentada, não resulta em imagens, e se tem, dificilmente apresenta uma unidade estética.

- São processos longos porque reivindicam relações, procuras, indagações, experiências, experimentos e longas reflexões. Muitas vezes são processos fechados no circulo social dos participantes, como os adolescentes de Einstein Class de Althamer (Figuras 9 e 51).

- Os registros são escassos porque são processos longos e é difícil dar uma imagem clara da estrutura e da narrativa a um intercambio invisível e sem forma.

- Estes projetos pedagógicos realizados por artistas não são projetos pré-fabricados que se aplicam em qualquer lugar, ao contrário, respondem a diversas urgências do momento, surgem da relação que estes artistas estabelecem com seu meio social. Por este motivo todos esses projetos têm um objetivo político de emancipação. 
- Nos países do norte europeu e americano, a virada pedagógica na arte é mais uma reação ao constante e crescente fechamento do espaço público e à padronização da educação, enquanto nos países do centro e sul americano se trata mais de compensar aquilo que falta nas instituições sociais, políticas, culturais e educativas.

- A coincidência destes eventos tem um status ontológico duplo: é uma forma de manter a tensão entre estar no mundo e ao mesmo tempo estar fora dele por isso se dirige tanto aos participantes (primeira audiência: estudantes) como a espectadores (segunda audiência: público). Helguera (2011a) reconhece para os artistas ainda uma terceira audiência que é a crítica de arte.

- Portanto, estes eventos enfrentam um duplo dilema: devem manter a tensão entre o que é ideal e o que é real na educação e devem manter a tensão entre dirigir o artefato artístico a um público universal e a estudantes específicos. A educação é um processo social fechado que não necessita e não pode ser comunicável de maneira efetiva a um público externo (os testes de qualidade são instrumentos apenas quantitativos, inexpressivos e muitas vezes inadequados) e a arte é um processo social aberto que requer de uma comunicabilidade com o mundo. Poucos projetos, observa Bishop, conseguem lidar com essa distância entre os processos da primeira e a segunda audiência.

- A coincidência destes eventos requer de uma grande habilidade para trabalhar com formas, experiências e significados e de muita imaginação e coragem.

Bishop destaca que o domínio da linguagem é muito importante, quando se trata de uma 'pedagogia como arte' os projetos pedagógicos mais artísticos se apresentam de uma maneira tal que podem comunicar essa experiência a uma segunda audiência, seja por meio de vídeo, performance, exibição, cátedra ou publicação. Sobretudo, são projetos que, segundo Bishop,

[..] cristalizam um dos problemas centrais de toda prática artística no campo social: nos pedem examinar nossas suposições sobre ambos campos de operação e ponderar as sobreposições produtivas e incompatibilidades que posam surgir de sua conjunção experimental, com as consequências de perpetuar a reinvenção de ambas. (BISHOP, 2012, p. 274)

O encontro entre a virada pedagógica na arte e a virada da visualidade na educação criou um espaço de interseção, colisão, contaminação, coincidência e hibridação entre arte e educação que pode mudar ambas no século XXI. É necessário identificar instrumentos metodológicos 
que nos ajudem a compreender e desenhar práticas que atravessem estas interseções na complexidade do mundo contemporâneo. O território da investigação é o espaço de interseção em que os conceitos e os eventos podem fluir.

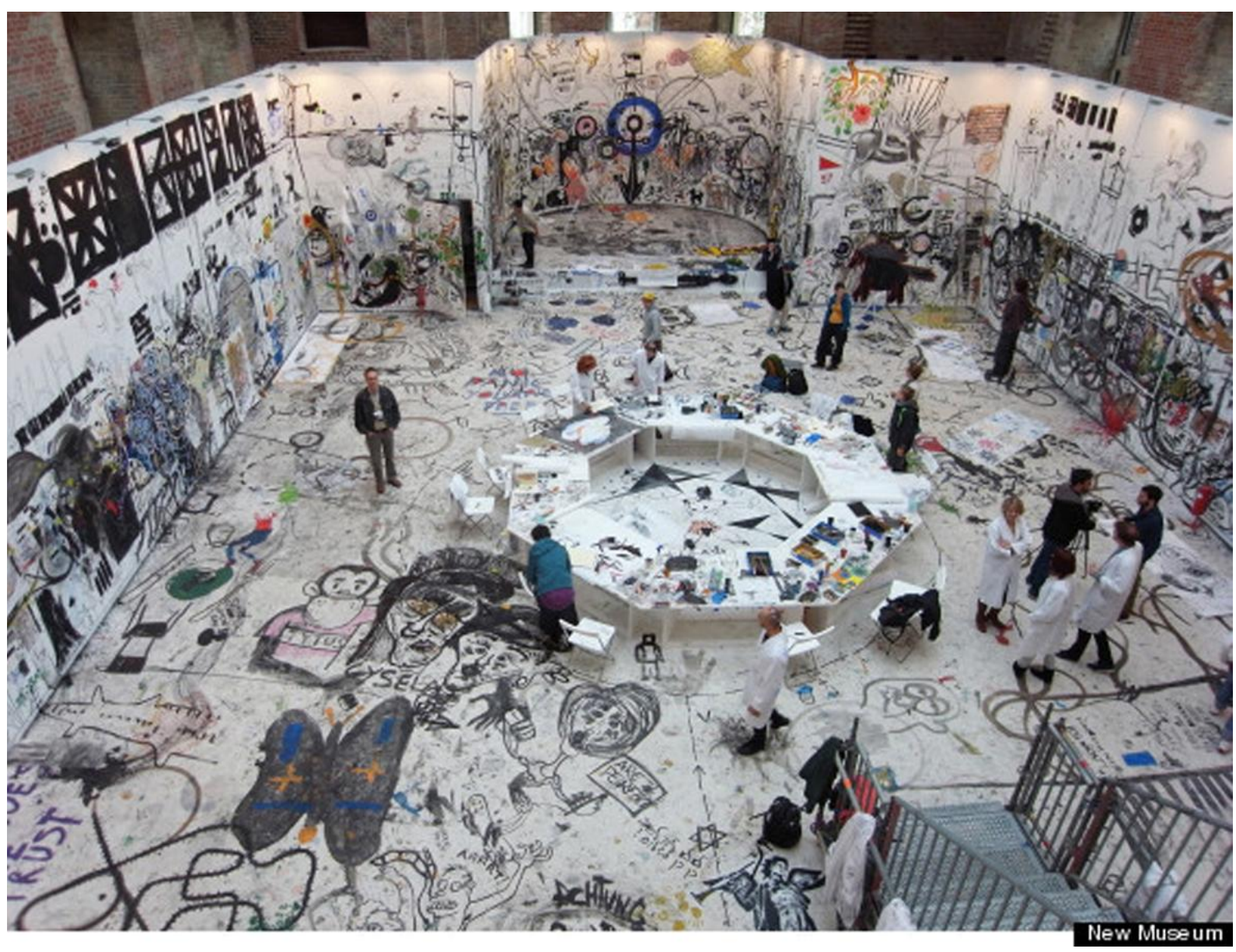

Fig. 51 Pawel Althamer, Congresso dos Desenhistas, exposição Os Vizinhos, New Museum, New York, 2012. Fonte: huffingtonpost.com.

Mas, como sistematizar uma (ou várias) pedagogia(s) cultural(ais) na Educação em Visualidade? Guattari (1995), Bishop (2012), Atkinson (2002, 2008a, 2011, 2012), Eisner (2002) Giroux (2005) Sullivan (2002, 2010), Rancière (2005, 2007, 2009a, 2011), Camnitzer (2009a, 2009b) entre outros, sugerem que os processos ético-estéticos promovem explorações que abrem fendas por onde os eventos podem atravessar e gerar novas formas de saber, novas formas de ser, novos territórios existenciais. No caso desta investigação é importante então estudar como funcionam estes processos, as maneiras de operar dos artistas contemporâneos que trabalham com interfaces pedagógicas, observar a complexidade em que se situa a ação, como estabelecem ligações com à vida e como abordam as relações entre poder e emancipação. Da mesma maneira é importante estudar o que significa isto para educadores 
em visualidade e para os estudantes do ensino básico. As explorações que os artistas contemporâneos realizam com os contextos de educação podem contribuir de maneira importante na filosofia educativa, "Se as visões da educação continuam despojadas de imaginação, tal vez sejam as áreas culturais antes que os modelos de fábrica ou as estruturas de administração que tem o potencial para mudanças profundas e equitativas." (SULLIVAN, 2010, p. 25).

A imaginação é no caso desta investigação um dos pilares metodológicos que sustentam todos os processos e sobejassem em todos os artefatos que resultam dele. É importante reconhecer que é necessário estabelecer percursos de investigação. Estes estão dados na medida em que debelam as coincidências, contaminações, contiguidades e hibridações que acontecem no encontro entre o evento artístico e o evento pedagógico em contextos escolares. 


\begin{tabular}{|l}
\hline "Embora se expande num espectro eclético, a Wide Open \\
School compartilha um mesmo objetivo: oferecem aos \\
participantes uma experiência direta de como os artistas pensam \\
e questionam as coisas. Os artistas geralmente são grandes \\
auto-educadores. O trabalho deles demanda que estejam sempre \\
aprendendo e inventando novas formas de aprender [...] Como \\
um dos artistas participantes sugeriu, é uma escola para pessoas que \\
adoram aprender mas não necessariamente gostam de \\
escolas". WebSite da Wide Open School \\
\hline
\end{tabular}




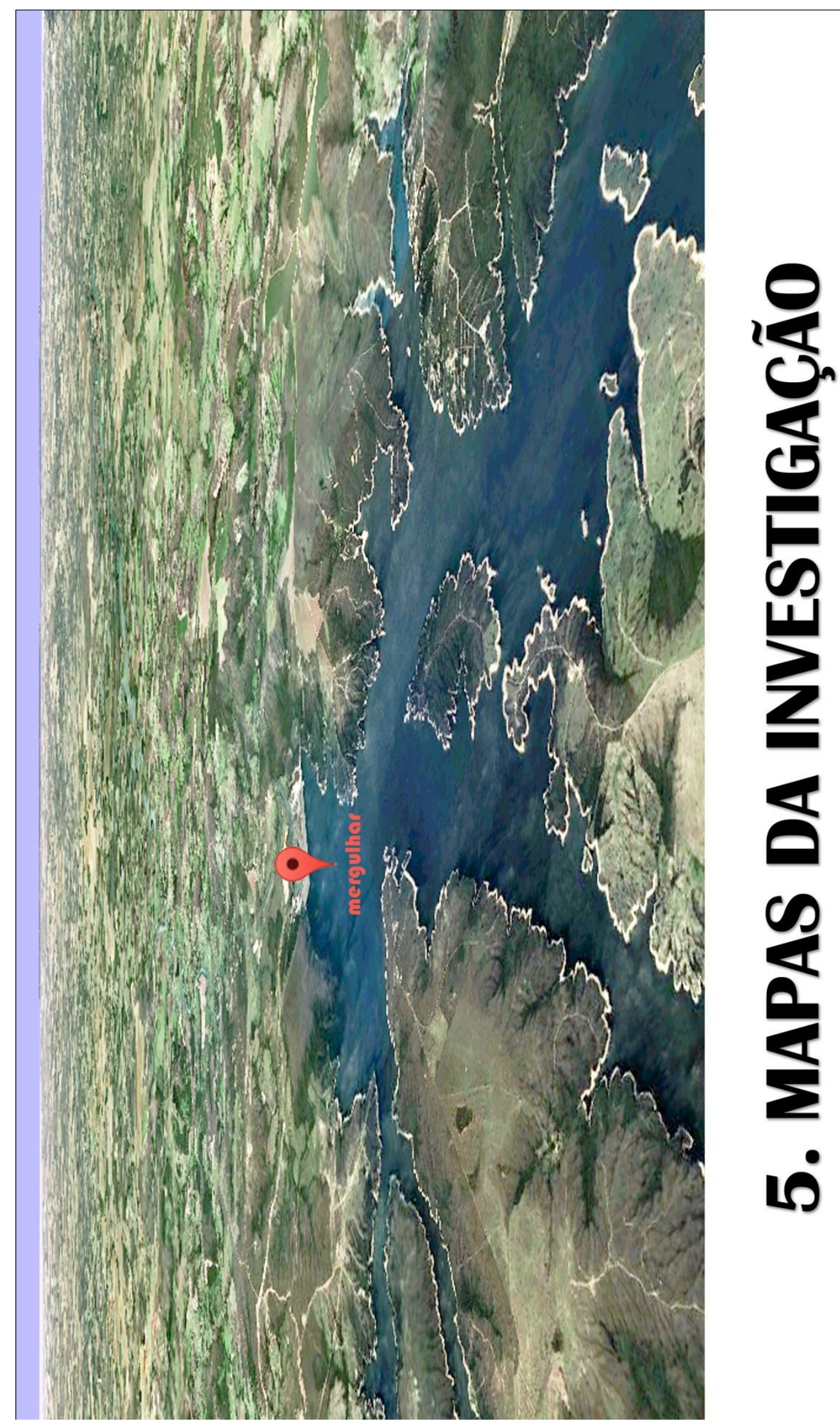

Fig. 52 Mapas da investigação. Tatiana Fernández, fotografia satelital Google Earth manipulada, 2013. 


\section{MAPAS DA INVESTIGAÇÃO}

Entre a investigação e a arte há uma relação muito antiga. Toda arte requer de um processo de investigação e os processos criativos constituem em si mesmos um corpo de conhecimentos, contextos e práticas que unem a subjetividade singular do artista ou da comunidade de artistas à pluralidade do mundo sempre na beira do crescimento. A "prática artística é de muito tempo um meio criativo e crítico que encoraja novas formas de pensar o que é ser humano dentro do mundo incerto em que vivemos" (SULLIVAN, 2010, p. 4). A investigação é, portanto, um percurso em que se envolve a própria vida, que vá se transformando na contiguidade e contingência dos eventos e dos fluxos. Pode-se dizer de maneira semelhante para a arte.

$\mathrm{Na}$ sua análise da arte como experiência Dewey (2005) reconhece que o artista é um experimentador, um aventureiro que expressa a sua intensa experiência individualizada através de meios e materiais que correspondem ao mundo público e comum, assim como o cientista. Ele reconhece também que uma "qualidade estética é inerente ao trabalho científico" (Idem, p. 206). Sugere com isto que toda atividade humana encontra seu sentido na indagação estética.

Com o projeto Iluminista do século XVIII a pesquisa científica foi valorizada através de uma filosofia racional e de uma indagação empírica que se aplicou a todos os campos do conhecimento inventando métodos que pudessem conduzir à compreensão da natureza. Com esta transformação a teoria passou a ser base de toda prática que aspira ao reconhecimento acadêmico. A arte não escapou ao que Sullivan chama de "nova religião da racionalidade" (2010, p. 6) apesar da resistência que opuseram artistas e intelectuais românticos no século XIX, como John Ruskin, William Morris ou os Pré-Rafaelitas. Tanto a nova corrida pela modernização da indústria como a institucionalização da educação pública ofereciam uma expansão do universo das artes a outras formas de produção, exposição e interpretação. Os conhecimentos da arte se tornaram cruciais para o desenvolvimento industrial que era uma política prioritária para as potências européias daquele século (ver EFLAND, 1990; MACDONALD, 2004). Como aponta Sullivan, o papel da arte se estendeu a uma ferramenta visual para o raciocínio e o papel do artista ganhou maior autoridade na ordem social: 
O inicio da era da máquina viu a academia se tornar mais uma agência ao serviço das novas industrias manufatureiras onde desenhar se alinhava nas destrezas do design. Assim as técnicas da arte eram como uma escritura que pode ser ensinada a todos como uma destreza para a vida e não somente como uma ocupação cultural. Esta vocação viu a prática artística se ampliar consideravelmente para abraçar outros papéis como o de artista como tecnólogo, analista, ilustrador, comunicador e pesquisador. (SULLIVAN, 2010, p. 7)

No entanto, à medida que a arte e os artistas ampliaram suas funções na nova sociedade as relações entre os artistas, os artefatos e o público também mudaram. Como vimos antes, esta separação resultou em diversas dicotomias que serviram aos sistemas de poder e dominação. Com a institucionalização das práticas educacionais e sob o paradigma cientificista, a arte entrou no século XIX numa situação instável e controversa. O papel da arte ficou cada vez mais confuso nesta competência e tensão de interesses entre as academias de arte, as escolas de formação profissional e as universidades privadas. Artistas e professores de arte, aponta Sullivan "não conseguiam decidir o que deviam estar fazendo" (2010, p. 10): buscando ideais de uma base ampla de conhecimento, conhecimentos fundamentais ou conhecimentos técnicos e profissionais (Fig. 53).

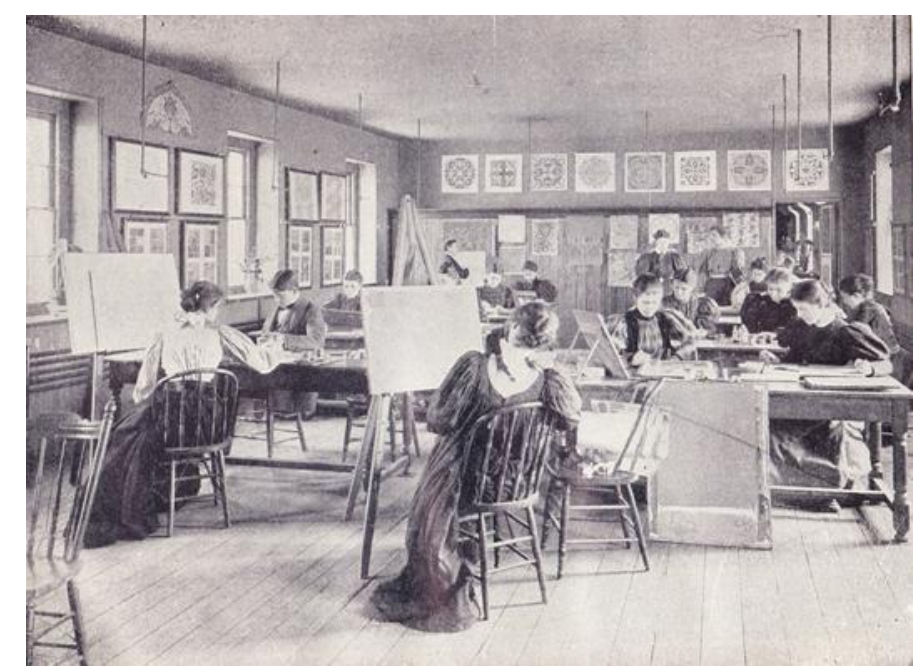

Fig. 53 Estudantes em aula prática de desenho, possivelmente na Escola de Arte e Design de Massachusetts, em Boston. 1908. Fonte: papergreat.com

Hoje é necessário se perguntar, na tensão das fronteiras, como os artistas/professores de arte buscam e geram conhecimentos estéticos? a IBA e a IEBA, que ganham cada vez mais importância no âmbito da pesquisa qualitativa, proporcionam os fundamentos metodológicos 
com os quais se desenham as estratégias, os critérios de análise e interpretação dos eventos artístico/pedagógicos e artefatos resultantes destes encontros. Nesta perspectiva a metodologia a/r/tográfica alcança um espaço de indagação existencial onde é possível uma epistemologia de fronteira.

Por outra parte, esta indagação me leva a procurar não somente como se geram conhecimentos estéticos, mas também como se constrói sentido nos processos artísticos/pedagógicos. Essa dimensão é particularmente importante para uma Educação em Visualidade que se propõe emancipadora porque aborda esses processos como indagações vivas. Nessa direção, o conceito de prática transcognitiva de Sullivan (2010) oferece uma lente amplificadora da complexa forma em que os artistas operam na construção do sentido estético.

\subsection{A Investigação Baseada nas Artes e a Investigação Educacional Baseada nas Artes}

A institucionalização da prática artística na formação de artistas e professores de arte de maneira separada criou uma cisma entre os que procuravam manter regras claras e marcadas e os que queriam desafiá-las. Esta cisma é também uma forma de conservar e reproduzir as relações entre poder e conhecimento e constitui atualmente o coração do dilema da metodologia de IBA e da IEBA. Isto porque os conflitos entre a identidade do sujeito artista, do sujeito docente e do sujeito investigador são conflitos políticos que revelam uma situação ainda não resolvida no século XXI, mas que se encontra em plena mudança no contexto das transformações políticas, culturais, filosóficas e tecnológicas do nosso tempo.

Da mesma maneira, a investigação no campo das artes, que em muitos casos obedecia à necessidade de aplicar os conhecimentos da arte à vida, isto é, à sua usabilidade, esteve subordinada ao paradigma cientificista do positivismo durante todo o século XX. Hernández (2008) nota que a hegemonia da racionalidade na pesquisa científica se projetou em todos os âmbitos de conhecimento e isto fica evidente na denominação de Ciências da Educação, Ciências Sociais, Ciências da Linguagem ou Ciências Humanas em que o prefixo ciência, e por extensão seus métodos de pesquisa, se usam para legitimar o campo de conhecimento.

No final do século XX o paradigma cientificista que dominou a maneira de se aproximar, experimentar, indagar, validar e legitimar o conhecimento começa a ser questionado. Segundo 
Sullivan (2010) o legado positivista da pesquisa científica procura a resolução de problemas e conduz à assunção de que os resultados de uma pesquisa devem ser observados em relação ao que já se sabe, sendo, portanto, uma mudança em grau ou quantidade respeito a algo anterior. Assim se constrói a teoria da probabilidade. Para a pesquisa de contextos complexos em que se procura não resolver problemas, mas abordá-los, como é nas ciências sociais, as diferenças são de tipologia com abordagens locais e particulares. Assim, pensa ele, se constrói a teoria do plausível. Restam as perguntas, "Mas como criamos conhecimento e teoria que explore o que é possível? [...] Como a pesquisa pode ser vista como uma prática criativa e crítica onde a compreensão imaginativa confirma, desafia ou muda nosso entendimento?" (SULLIVAN, 2010, p. 31). Se a pesquisa procura criar novas concepções do que sabemos, adverte Sullivan, então é necessário pensar como a pesquisa pode ser uma procura pelo provável, o plausível e o possível e para isto, investigar deve ser uma prática criativa e crítica ao mesmo tempo.

Ele pensa que uma forma de lidar com as limitações das linhas tradicionais de pesquisa é usar as artes como instrumentos de investigação. Desde os anos 90 há um crescente interesse por uma metodologia de investigação que dê conta da "virada da visualidade" (MITCHELL, 1995) na cultura contemporânea, em especial no campo da educação, da antropologia, da comunicação e das ciências sociais. Tom Barone e Elliot Eisner (1997, apud Sullivan 2010) lembram que a IBA começou a ser citada na metade da década de 1990 e desde então seu impacto foi muito grande na investigação educacional com muitos manuais, antologias, artigos, seminários e jornais especializados. Eisner inspirou entre os educadores a IEBA como uma forma engajada de abordar os processos de reflexão e ação que proporcionam novos significados e possibilidades na educação em base à forma como se constrói a crítica da arte e como esta metodologia permite uma avaliação qualitativa no ensino das artes visuais. A IEBA, como a IBA, são sobretudo, formas de criar significados, questionar e problematizar antes que formas de encontrar significados, respostas ou soluções.

Hernández (2008) vê duas relações na IBA, a primeira, que ele chama de tautológica, é aquela que compreende que a arte é um processo de investigação em si mesmo porque sempre há um propósito indagador. A segunda é a que considera os elementos estéticos e aspectos do design que afetam a investigação, elementos esses que se encontram, segundo Hernández, nas atividades educativas. Esta definição que se origina com Barone e Eisner (HERNÁNDEZ, 2008) identifica a IBA como uma investigação qualitativa que usa 
procedimentos artísticos (literários, visuais e performativos) para dar conta de práticas de experiência em que tanto os diferentes sujeitos [...] como as interpretações sobre suas experiências debelam aspectos que não se fazem visíveis em outro tipo de pesquisa. (HERNÁNDEZ, 2008, p. 92)

Hernández (2008) a partir das ideias de Barone e Eisner (2006) identifica assim as características de uma IBA:

- Centralidade de elementos estéticos e artísticos.

- Procura outras maneiras de ver e representar a experiência. Não procura certezas, mas realça perspectivas e lugares não explorados.

- Tenta debelar aquilo do qual não se fala. Não oferece soluções ou alternativas, mas conversações mais amplas.

Além destas características, Barone e Esiner (2006) consideram que a IBA promove a transformação dos sentimentos, pensamentos e imagens de forma estética e aponta questionamentos antes que respostas. Para eles a IBA considera três tipos de textos: evocativos, contextuais e vernáculos; não com uma intenção ornamental, mas para despertar uma empatia que amplie a compreensão do conhecimento e permita maior relação com a experiência do leitor. Os textos também podem usar diferentes formas literárias como a narrativa, a poesia ou a ficção para permitir que os leitores encontrem seu espaço na investigação e que promovam o desencadeamento de outros relatos.

Nesse aspecto, a A/r/tografia, que é uma tendência importante dentro da IBA, não só aborda a arte e o processo criativo como uma forma de investigação e enfatiza a contiguidade entre o texto e as formas artísticas, mas incorpora formas de investigação que incluem e criam relações entre visualidade, musicalidade, performance, poética, drama e narrativa e as expandem a outras áreas de pesquisa como educação e sociologia. Os a/r/tógrafos indagam também como são apresentadas, publicadas e representadas as pesquisas nos âmbitos acadêmicos, profissionais e da vida.

A A/r/tografia se centra em conceitos antes que em métodos para guiar o processo de investigação: contiguidade, indagação, pesquisa viva, metáfora/metonímia, aberturas, reverberações e excessos (IRWIN e COSSON, 2004; IRWIN et al., 2006; SPRINGGAY et. al., 2008; AGUIAR, 2011, DIAS e IRWIN, 2013) entre os mais importantes. Estes conceitos 
estão relacionados às epistemologias de fronteira e, portanto, à estética contemporânea que se forma na tensão das dobras fronteiriças.

Irwin ressalta que os a/r/tógrafos são habitantes das fronteiras em que recriam, reaprendem e investigam maneiras de entender, apreciar e representar o mundo. Esta existência mestiça integra o conhecer, o fazer e o produzir, uma "existência que deseja uma experiência estética que se encontra no elegante fluído entre o intelecto, os sentimentos e a prática" (IRWIN e COSSON, 2004, p. 29). Dessa maneira as pessoas não só tem acesso ao que pensam os teóricos e seus assuntos de estudo, mas também ao que fazem, "Neste sentido as artes levam 'o fazer' ao campo da pesquisa" (SILVERMAN, 2000, apud HERNÁNDEZ, 2008, p. 93).

Dessa forma não há prioridades, separações, limites ou dicotomias entre escrever, imaginar, criar e investigar numa pesquisa a/r/tográfica, pelo contrário, são estados fluidos que se influenciam, se complementam, criam tensões e se alimentam mutuamente. Como argumentam os a/r/tógrafos (WILSON, In IRWIN e COSSON de, 2004) estes espaços fluidos definem a IBA como uma metodologia de pesquisa mais complexa, multiforme, rizomática, aberta e multimodal.

Para a tradição cientificista estes são caminhos de pesquisa inversos aos da ciência que exige rigor, claridade, objetividade, precisão e universalidade dos métodos científicos. Por uma parte é necessário lembrar que a IBA tem mostrado que é possível uma tensão entre rigor e abertura, claridade e complexidade, subjetividade e objetividade, precisão e ambiguidade, relatividade e universalidade. São justamente esses espaços do paradoxo em que se geram as possibilidades da transformação. No âmbito acadêmico tradicional esta abertura cria uma incômoda incerteza em face a um sistema que vem se acomodando há séculos nas certezas da razão e da ética dogmática. Lidar com o desconhecido, o diferente, o paradoxal e o divergente é algo novo no campo da pesquisa acadêmica. Este é um problema que não é só da ciência, mas de toda a sociedade ocidental moderna.

Shaun McNiff (1998) prefere valorizar na investigação os encontros com a incerteza por meio da imaginação. A ciência e a arte são modos complementares de conhecimento e formas de investigação, portanto não podemos "reduzir uma à outra assumindo que uma tem maior credibilidade que a outra" (McNIFF, 2007, p. 34). Quando as duas se alimentam mutuamente a arte ganha uma forma de sistematizar a investigação e a ciência uma forma de abordar "responsivamente ao inesperado" (Idem, p. 39). Para ele, aprender dos artistas e da própria 
prática artística "imbui o processo de investigação com uma tensão criativa que não é menos rigorosa ou relevante que processos de pesquisa mais tradicionais" (SULLIVAN, 2010, p. 57). Por outra parte também é necessário lembrar que o artista, como pensa Dewey, "joga o jogo intensamente porque o joga estritamente" (2005, p. 208). O rigor, a claridade a e precisão que um artista exige da sua obra pode chegar a extremos que surpreendem os próprios cientistas, muitas vezes abrindo caminho para a ciência.

É de se esperar que a imaginação como uma abordagem da possibilidade, do que está em potência ou do que traspassa as fronteiras do conhecido, entra na pauta das discussões conduzidas nos últimos anos pela IEBA, a IBA, a Pesquisa Baseada na Prática (em diante PBP) (Practice Based Research ou PBR) e a investigação A/r/tográfica em particular. São poucos e recentes os autores que valorizam a ação da imaginação na investigação e desde campos diversos como o esoterismo ou a economia. É importante notar que mesmo no contexto de uma pesquisa científica a imaginação é imanente à indagação ainda que não se considere seu peso no rumo da pesquisa. Um cientista reconhece que pesquisa sobre os indícios da realidade observável, mas não reconhece que procura sobre os traços da sua imaginação ainda que ela esteja ali o tempo todo na construção do conhecimento.

Uma das primeiras tarefas para a IBA é, sugere Elizabeth Grierson (2003, p. 6), testar os limites epistemológicos da imaginação no campo estético, social e político. A palavra Imaginação se origina em im-ago: "eu atuo de dentro". Grierson entende que a origem etimológica da palavra conduz a uma "imagem para se" antes que a uma "visão da mente". Imaginar nesta perspectiva é uma parte ativa no processo da construção do conhecimento. A compreensão de qualquer fenômeno depende da "imagem que fazemos para nós" porque é ela que forma nossa estrutura mental.

\subsubsection{Imaginação na investigação}

Terence Rosenberg (2000) que estuda a metodologia de investigação poética no design adverte que na metodologia de pesquisa tradicional a imaginação é compreendida como um "palpite" antes que como processo criativo. Para ele a imaginação deve ser compreendida como uma metodologia em si mesma que a diferencia da pesquisa tradicional porque provoca uma perturbação poética na direção de uma linha errante de descobrimentos, não na direção da certeza. A investigação poética para Rosenberg abre o diálogo entre o racional e o irracional, abre a possibilidade do desvio, tecendo elementos díspares em uma estrutura 
complexa e crescente. Outros como Paul S. Gray et al. (2007) acreditam que a imaginação proporciona vida e propósito à investigação. $\mathrm{Na}$ suas analises estes autores apontam a Investigação Imaginativa (Imagination Research, IR) entre os métodos qualitativos de investigação. Iain Ross Edgar (2004) aponta uma metodologia de investigação baseada na imaginação no âmbito da antropologia social.

No âmbito da IBA, McNiff (1992, 1998, 2003, 2007) indaga a ficção como forma de penetrar com maior liberdade e intimidade em um tema particular, de nos identificar com as situações e personagens de maneiras novas e desde outras perspectivas (2007, p. 38). Como artista e professor McNiff desenvolveu a prática do diálogo imaginativo como forma de IBA, um diálogo que pode se dar através do movimento, do performance, da improvisação vocal, do ritual, a poesia ou de outra natureza artística. McNiff encoraja a seus estudantes desenvolverem investigações através explorações ficcionais. Para ele (Idem, p. 39-40) o conhecimento artístico pode ser heurístico, fenomenológico, hermenêutico, imaginativo, arquetípico, empírico, estatístico e mais, mas em contraste com a pesquisa cientifica a investigação artística tipicamente começa na incerteza do resultado

No processo artístico a imaginação é o modus operandi constante em todas as fases do processo e requer uma atenção, uma abertura muito maior dos sentidos ao mundo do que em situações não criativas. É necessário ver para imaginar e imaginar para ver, se abrir a uma percepção que exige muitas vezes uma dolorosa relação com o mundo. A imaginação exige se desprender dos limites da realidade, como um fluído que se expande e se movimenta tomando as formas do espaço que percorre.

A IEBA pode conduzir também uma forma imaginativa de abordar o processo de observação, interpretação e ação que proporcionam as artes na investigação e na metodologia de ensino. Para os professores, como para os artistas a imaginação e a contingência da situação são elementos que se complementam para dar forma à expressão. Sem imaginação o ensino é um fingimento e a arte uma insinceridade (DEWEY, 2005). A qualidade imaginativa funciona como uma apertura constante a novas possibilidades de ser, se abre sempre a novos questionamentos. Uma investigação e um ensino imaginativos favorecem uma apertura a questionamentos. A filosofia, argumenta Dewey, "começa com um questionamento e termina na compreensão, a arte começa pela compreensão e termina no questionamento" (2005, p. 281). 
Os questionamentos vivos são a razão da metodologia de situações para os a/r/tógrafos (IRWIN e COSSON, 2004; IRWIN et al., 2006; DIAS, 2007; SPRINGGAY et al., 2008; HERNANDEZ, 2008; SULLIVAN, 2010; AGUIAR, 2011; DIAS e IRWIN, 2013). Essa metodologia se propõe investigar em contextos vivos como forma de PBP. Eles a denominam "investigação viva", em inglês living inquiry. Essa perspectiva denota uma investigação questionadora, onde se teoriza através de um processo que envolve uma "evolução de questionamentos" (IRWIN et al., 2006, p. 71).

Adotar a imaginação como uma metodologia de investigação amplia as possibilidades de transformação porque se abre às possibilidades do diferente, do inesperado, do não antecipado, do aberto, do fluido, do horizonte que retrocede a medida que buscamos e vivemos, a medida que nos fazemos novos questionamentos, a medida que nos reconstruímos. O processo de estar se tornando requer de espaços de possibilidade e conexão, onde a imaginação ou "imagem para se" (GRIERSON, 2003, p. 6) possa se formar e transformar. Nesta investigação dou crédito à imaginação como uma forma de ver, observar, indagar, criar e produzir; em direção a uma prática onde a investigação é emergente, generativa, reflexiva e responsiva (IRWIN, 2006, p. 71).

\subsubsection{Imaginação na Educação}

Assim como é para a pesquisa, a imaginação é crucial na educação. Eisner (2002) apontava entre as lições que a educação pode aprender da arte a importância da imaginação para ver nas coisas outras coisas daquilo que são, para perceber o que são e imaginar o que podem ser (p. 198 -201). A importância da arte está no exercício da imaginação que relaciona o ser com o mundo.

Dewey (2005) encontra evidencia desta relação na arte. Uma experiência imaginativa, diz ele, "acontece quando variados materiais, emoções e significados se unem marcando um novo nascimento no mundo" (2005, p. 279). Na arte há uma corporificação (embodiment) das possibilidades entre a matéria e a mente. Esta corporificação é para ele a melhor evidencia da verdadeira natureza da imaginação. Quando a mente somente brinca com a matéria sem corporificá-la não há uma interpenetração e o imaginativo se torna facilmente imaginário (Ibidem):

A qualidade peculiar do imaginativo é melhor entendida quando a comparamos com o efeito obtuso do habitual. O tempo é a prova que discrimina o imaginativo do imaginário. $\mathrm{O}$ último passa porque é arbitrário. $\mathrm{O}$ 
imaginativo perdura porque, enquanto é primeiramente estranho a nós, é familiarmente persistente a respeito da natureza das coisas. (DEWEY, 2005, p. 280)

Nessa linha Greene (2000) destaca a estreita relação entre a realidade em que vivemos e o ato imaginativo. Para ela a imaginação é uma forma de consciência que permite a mudança social. A arte, na sua exploração imaginativa, aponta um horizonte cujos limites se expandem à medida que exploramos o mundo. Imaginar é caminhar nos limites, nas fronteiras do habitual e normativo. A prática artística como experiência estética leva a imaginar a vida de outras maneiras. Nas palavras de Greene:

A imaginação nos permite particularizar, ver e escutar as coisas na sua concretude. (...) É a imaginação que nos conduz, nos torna capazes de fazer novas conexões entre as partes da nossa experiência que sugerem a contingência da realidade que concebemos. (GREENE, 2000, p. 29-30)

Mas para ela, o papel da imaginação não é resolver, não é apontar o caminho, não é melhorar, é acordar, descobrir o ordinário não visto, não escutado, não esperado (Idem, p. 28). O aspecto principal na visão de Greene sobre o papel da imaginação na educação está na sua capacidade para transformar as pessoas que transformam a realidade. Ela propõe recuperar a imaginação "para tirar a sociedade da sua paralise e restaurar o sentido de que alguma coisa pode ser feita em nome do que é decente e humano" (GREENE, 2000, p. 35). Quando imaginamos acordamos à vida, tecemos nossas experiências passadas e presentes às possibilidades que concebemos e assim crescemos no processo de ser. "Para aprender e ensinar devemos ter consciência de deixar alguma coisa para trás enquanto vamos em direção a algo novo, este tipo de consciência está ligada à imaginação" (Idem, p. 20), argumenta Greene. Da mesma maneira Dewey aponta que "quando as coisas familiares e velhas se tornam novas na experiência, ali há imaginação" (2005, p.278). A educação em todas as suas formas e graus de complexidade pode constituir uma cadeia entre o conhecido e o desconhecido, um espaço onde a imaginação cria possibilidades novas de experiência. E mais ainda, um espaço onde a imaginação trabalha na contingência da sua sociabilidade.

Para esclarecer a natureza da imaginação Dewey analisa o conflito que os artistas enfrentam entre visão interna e visão externa. A visão interna não é uma 'visão da mente' porque não é uma propriedade nem está separada da visão externa, ambas se realizam no corpo todo ao 
mesmo tempo e com os mesmos estímulos. A visão interna é muitas vezes mais rica e fina que sua manifestação externa, mas esta última obriga o artista (e no caso que toca o espectador) a tomar consciência de que suas especulações devem tomar corpo, peso e perspectiva. Ainda assim a visão interna não é descartada, ela guia e controla a visão externa que assimila a estrutura na medida em que é incorporada ao objeto. "A interação entre os dois modos de ver é a imaginação" (2005, p. 280). São duas qualidades que juntas estruturam nossa imagem do mundo. Na perspectiva de Dewey a imaginação "é uma maneira de ver e sentir as coisas que compõe um todo integral [...] é a generosa e ampla fusão de interesses onde a mente entra em contato com o mundo" (2005, p. 278) (Fig. 57).
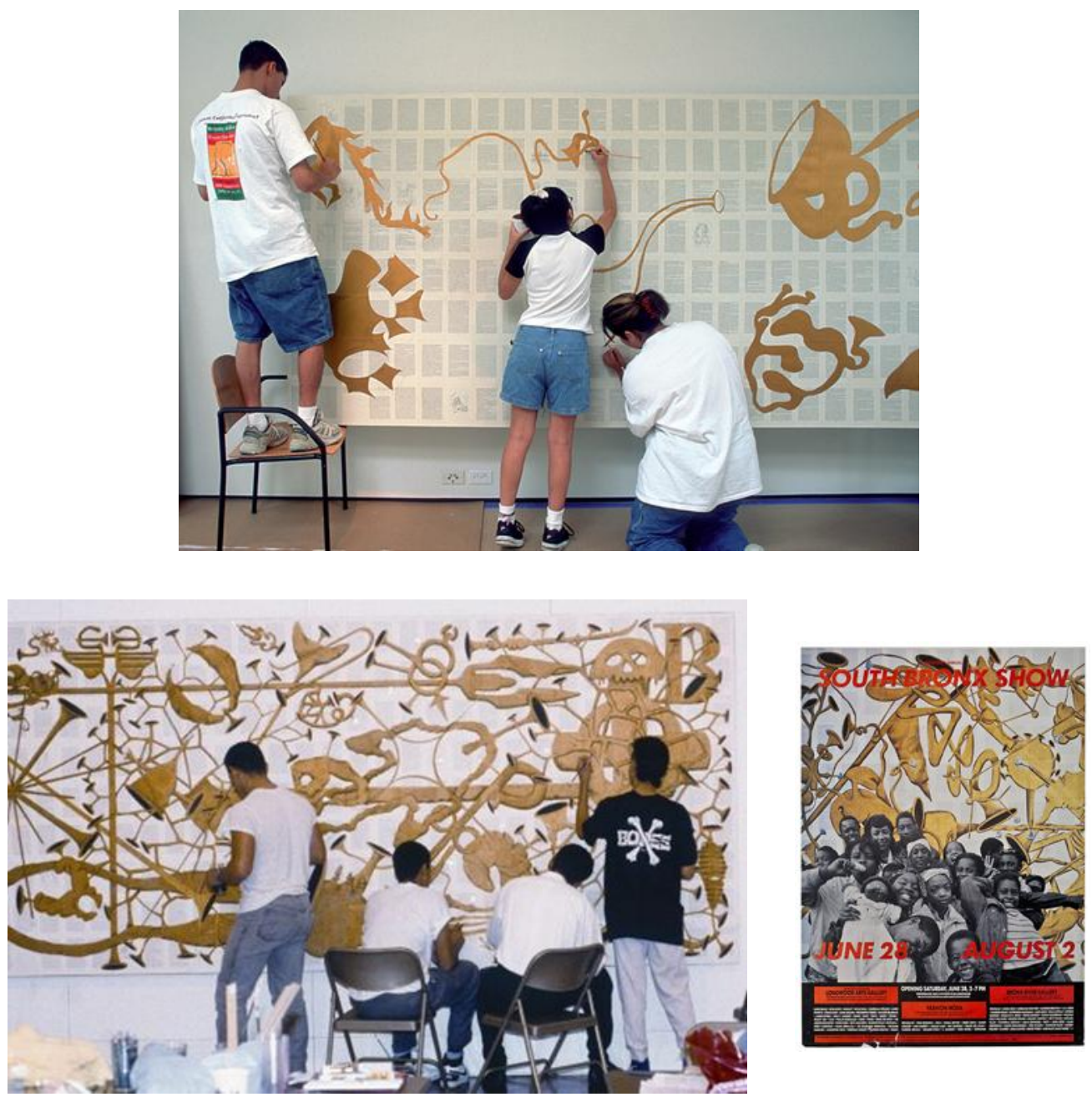

Fig. 54 Tim Rollins + K.O.S. Fonte: barbarayontzatstac.com

Fig. 55 Tim Rollins + K.O.S. "As crianças de Lyman Place” Design de Stephan Neuman e fotografia de Michael McKenzie, Cartaz para exposição no Bronx 1986. Fonte: gallery.98bowery.com

Fig. 56 Tim Rollins + K.O.S. "Workshop para Amerika IX," 1987. Mint Museum of Art, Charlotte, North Carolina. Fonte: fryemuseum.org 
Isto nos permite entender que a imaginação não é uma projeção em direção ao abismo ou à inconcretude. Essa dupla direção da imaginação que permite o fluido entre o interno e o externo, entre o sujeito e objeto, entre o ser e o mundo permite também um fluido entre a teoria, a práxis e a poiese. A tensão entre a teoria, que reflete sobre os eventos, a prática, que toma a forma do mundo, e a poética, que amplia o horizonte, é uma tensão existencial. A imaginação é o elo que flui entre sentir, pensar, fazer e ser.

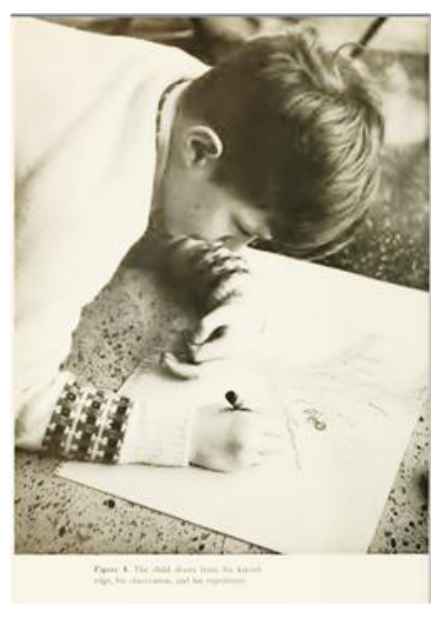

Fig. 57 Criança desenhando. Imagem do livro Creative and Mental Growth de Viktor Lowenfeld, 1947.

Nessa perspectiva a pesquisa viva é existencial porque não separa os espaços teóricos dos ativos e produtivos. Quando há um fluxo entre eles as relações de poder e dominação, que se sustentam justamente na divisão desses espaços, perdem seu sustento. É por este motivo que a pesquisa viva é também uma investigação crítica e política. $\mathrm{O}$ conhecimento não é algo que está inteiramente fora nem inteiramente dentro dos sujeitos. Ele flui entre o 'dentro e o fora' na sua relação de tensão com o mundo. Sullivan (2010) estuda este fluxo na prática de artistas visuais sob um viés cognitivo que nos ajuda a entender as diversas maneiras de operar das artes na construção do conhecimento e do significado proporcionando um marco metodológico para compreender o encontro entre eventos artísticos e pedagógicos.

\subsection{A prática transcognitiva}

Esse encontro acontece no espaço da investigação viva. É necessário apontar, no entanto, duas questões que destacam nas discussões sobre o status da prática artística como uma forma de investigação, a primeira debate sobre o que constitui o conhecimento das artes visuais e a 
segunda sobre as suas metodologias de investigação (SULLIVAN, 2010). As duas conduzem revisões epistemológicas sobre o que se considera conhecimento e sobre "como se conhece, sobre o que se conhece e por que se conhece" (Idem, p. 83). Estes questionamentos epistemológicos levam a outra questão importante: o conhecimento se encontra no objeto da arte ou se cria na mente dos sujeitos que se relacionam com o objeto de arte? Os artistas veem estas relações de múltiplas maneiras integrando a teoria com a prática, observa Sullivan: "A capacidade de criar entendimento e, portanto, criticar o conhecimento é central na prática artística e os artistas estão ativamente envolvidos com processos de investigação reflexivo" (Idem, p. 96).

Nesse cenário a forma como fazemos os questionamentos tem implicações sobre o que sabemos. Da mesma maneira, na investigação educacional, a forma como fazemos as perguntas tem importantes implicações sobre como abordamos as metodologias e o currículo. Sullivam lembra que inclusive um destacado pesquisador educacional como Jerome Bruner passou de se perguntar como aprendem as crianças? a se perguntar, como as crianças constroem os significados? (Ibidem). A primeira revela a ideia do conhecimento como algo que é adquirido de fora para dentro. A segunda entende que os conhecimentos se formam na relação orgânica e construtiva entre o ser e o mundo. E isto implica em mudanças metodológicas e curriculares.

A compreensão da arte como uma forma de conhecimento, argumenta Sullivan (2010), exige localizar a investigação artística nas teorias e práticas que se desenvolvem no âmbito do fazer artístico, reconhecer que o pensamento e fazer artístico são processos cognitivos e que estas formas de construir o conhecimento têm um papel crucial na crítica cultural, na indagação histórica e no desenvolvimento educacional, porque se dirigem a preocupações humanas e culturais de amplo alcance. Com esse objetivo ele elabora uma cartografia dos processos artísticos como formas de investigação e estabelece relações entre as diversas formas de pesquisa validadas pela ciência e as metodologias do artista.

Para isso Sullivan estuda as camadas que se superpõem na maneira de operar de artistas contemporâneos, como estratos que compõem o território da arte como investigação. Nesse processo ele identifica as relações entre a teoria e a prática em três marcos ${ }^{63}$, ou camadas, para desenvolver investigação em artes visuais baseados em indagações que surgem no contexto

\footnotetext{
${ }^{63}$ Sullivan apresenta 5 marcos para investigação: marco de persquisa, marco de saberes, marco de contexto, marco de prática e marco de projetos nas artes visuais, mas desses 5, somente interessam os primeiros 3 nesta investigação.
} 
do estúdio, ou do espaço onde acontece a prática artística. O primeiro marco destaca as práticas de investigação em estúdio onde surgem as questões de pesquisa, o segundo estuda as dinâmicas do saber visual, ou as maneiras de pensar o visual, ou o que o autor denomina de transcognição; o terceiro destaca a densidade teórica da investigação de estúdio em referência aos contextos de investigação.

Nesse processo ele analisa em cada marco ou camada a relação entre quatro áreas interconectadas da investigação artística. A primeira, no centro delas, localiza a prática artística onde se origina o contexto, os assuntos e os problemas da investigação. As outras três localizam as práticas de pesquisa tradicionais das ciências das quais os artistas também se valem para sua prática.

Na primeira camada ou marco de práticas de investigação ele identifica o centro da prática artística como o lugar de onde se desdobram os domínios da IBA ou ICA e as práticas relativas aos domínios de pesquisa interpretativista ${ }^{64}$ empiricista $^{65}$ e crítica $^{66}$, da tradição científica que, na prática artística, Sullivan identifica como agencia, estrutura e ação respectivamente. (Ver Anexo IV Fig. 58, Marco das práticas de investigação em artes visuais em relação aos domínios de pesquisa tradicionais segundo modelo de Sullivan, 2010, p. 102).

Ele refere esses domínios de pesquisa ao esquema tripartite de Habermas (1971) que os considera ligados a três interesses específicos respectivamente:

1) a dimensão hermenêutica - é histórica: o interesse é o de interpretar qualitativamente e compreender estas realidades;

2) a dimensão analítica - é empírica: o interesse é o de controlar realidades sociais ou naturais;

3) a dimensão crítica - é emancipadora: o interesse é o de transformar a consciência individual e coletiva da realidade para a liberdade e democracia.

Nesse marco os domínios de investigação artística podem ser lidos em três diferentes camadas. A primeira (Anexo IV Fig. 58, texto cor laranja) corresponde ao caráter conceitual e

\footnotetext{
${ }^{64}$ Sullivan entende o interpretativismo dentro da visão hermenêutica de Jurgen Habermas (1971), de Paul Ricoeur (1981) para quem a interpretação de um texto é aberta e de Egon Guba e Yvonna Lincoln (1998) que pensam a construção dialética do significado.

${ }^{65}$ Sullivan prefere o termo empiricista ao invés de empírico porque este é comumente usado para descrever a pesquisa qualitativa, enquanto empiricista reflete uma situação em que a evidencia deriva da experiência e é coletada de diversas maneiras.

${ }^{66}$ Sobre o domínio da pesquisa crítica, que é característico da teoria e prática das artes visuais, Sullivan defende a perspectiva revisionista e desconstrutiva.
} 
teórico em que a investigação acontece, onde as ideias são geradas e os problemas identificados conceituados e definidos, pudendo, neste caso, ser dialética, conceitual ou crítica. A segunda camada (Fig. 58, texto cor azul celeste) corresponde ao nível operacional e metodológico em que as ideias tomam uma forma que permite intervenções e avaliações, pudendo ser construtivista, reflexiva ou colaborativa. A terceira camada (Fig. 58, texto cor verde) se refere aos contextos e situações que se localizam nas fronteiras das estruturas disciplinares onde se aplicam as interpretações, seja de uma perspectiva pessoal, social, educacional ou cultural de tal maneira que pode ser interdisciplinar, disciplinar e transdisciplinar. A prática artística como investigação tem, na sua camada conceitual e teórica um caráter criativo e crítico; a metodologia é reflexiva e se dá num contexto pós-disciplinar (além das estruturas disciplinares).

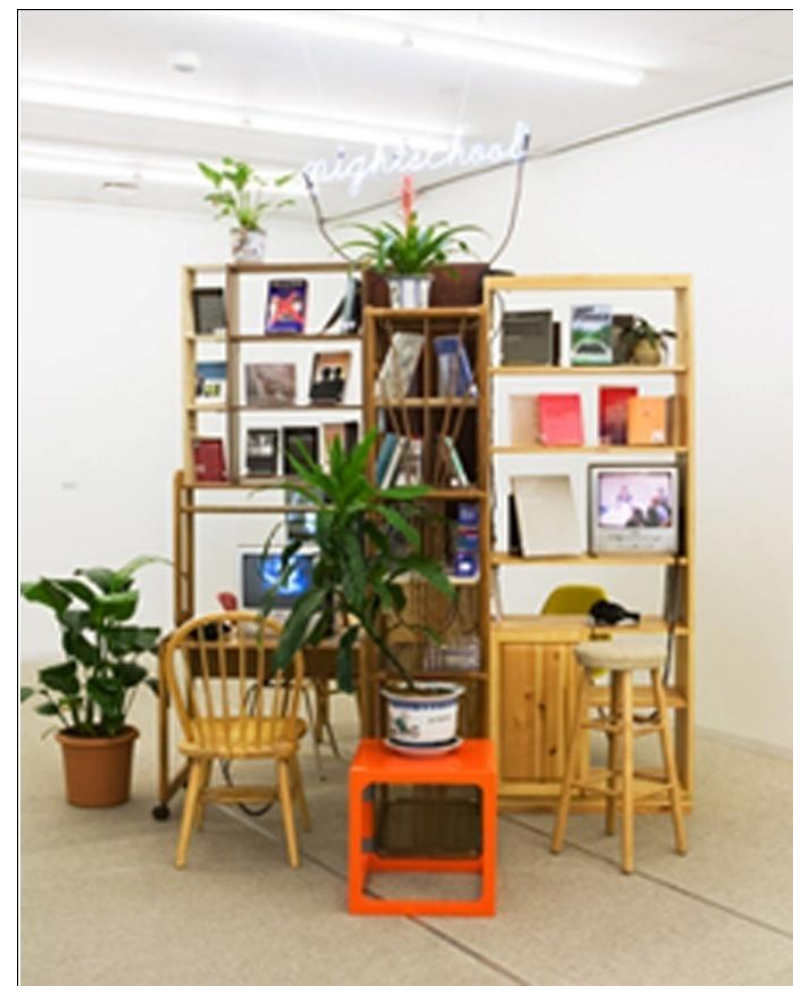

Fig. 59 Anton Vidokle, Escola Noturna, 'Night School', New Museum, New York. 2008 a 2009. Fonte: e-flux.com.

Paralelo a este marco teórico, Sullivan explora as condições que influenciam o processo artístico. Ele examina a cognição visual e os diferentes níveis de entendimento que surgem da virada da visualidade baseado nos estudos cognitivos que esclarecem as relações entre ver, sentir e conhecer. Nesses estudos identifica três maneiras de pensar associadas aos três domínios de pesquisa: pensar na linguagem (relativo ao domínio interpretativista), pensar no 
meio (relativo ao domínio empiricista) e pensar no contexto (relativo ao domínio crítico) (Ver Anexo IV Fig. 60, Marco do saber visual na prática transcognitiva segundo o modelo de Sullivan, 2010, p. 134). Considerando que estas práticas de pensamento são construtos biológicos e culturais, elas se emolduram, estruturam e corporificam.

Ele observa que assim como da pesquisa científica resultam teorias, dos processos artísticos resultam ideias, formas e situações que constituem o saber visual e que alimentam ao mesmo tempo a prática artística.

$\mathrm{O}$ autor distingue três camadas que permeiam estas formas de pensar. Na primeira camada (Fig. 60, texto cor marrom claro e escuro) identifica os processos cognitivos: pensar na linguagem enfatiza sobre a metacognição, pensar no contexto favorece uma cognição situada no tempo e no espaço e pensar no meio enfatiza as relações entre as formas e conteúdo do pensamento que constituem uma cognição distribuída. Esses processos nas práticas artísticas interatuam na construção do saber visual. É o que Sullivam denomina de práticas transcognitivas.

Na segunda camada (Fig. 60, texto cor azul cerúleo) Sullivan distingue os processos de entendimento que permeiam as práticas de construção do saber nas artes visuais. Encontra que, analogamente à tradição interpretativista, os processos reflexivos do pensar na linguagem são dialógicos; pensar no contexto requer processos de pensamento responsivos e pensar no meio, requer processos de pensamento que trabalham com estruturas simbólicas. Observa também que o pensamento visual requer de processos prático- teoréticos.

Na terceira camada (Fig. 60, texto cor verde) afirma que estas práticas se realizam entre, através, dentro e sobre o espectador, o artefato, a situação e o artista onde cada um tem um papel na construção do sentido criando diversas formas de diálogo.

Os artistas contemporâneos, lembra Sullivan, adotam diversas abordagens que rompem com as "fronteiras disciplinares, as convenções sociais e os interesses políticos, no entanto fazem isto no âmbito da experiência estética, o comentário cultural e a relevância educacional" (2010, p. 156). A Escola Noturna de Vidokle (Fig. 49 e 59), por exemplo, é uma comissão artística que toma a forma de uma escola temporária com uma programação de seminários e oficinas que produz ideias, formas e situações através do engajamento em debates com o público sobre temas/objetos de estudo. Ao longo de um ano, em cada versão, os seminários e 
as oficinas constroem processos transcognitivos em que é necesário pensar na linguagem, no médio e no contexto (Fig. 49).

Como nesse caso, nas últimas décadas a contribuição dos artistas tem se ampliado além do campo cultural e político, hoje os artistas são também ativistas, críticos, cientistas, teóricos, pesquisadores e educadores. É necessário relacionar esta diversidade de práticas artísticas com os contextos em que eles hoje atuam. As investigações sobre práticas artísticas contemporâneas revelam a maneira como os eventos artísticos são lugares de possibilidade para fazer arte, pensar a arte e ensinar arte, são "espaços e lugares que rompem com as fronteiras existentes" (Idem, p. 158) e que tem relevância pessoal e social.

Por esse motivo, além de um marco de investigação em artes visuais e de um marco de saber visual, Sullivam oferece um marco dos contextos (Ver Anexo IV Fig. 61 Marco dos contextos em que se dá a investigação visual em relação aos domínios de pesquisa tradicionais em base ao modelo de Sullivan, 2010, p. 159) em que acontece a prática artística examinando padrões e situações da investigação em artes visuais. Neste marco Sullivan reconhece o artista contemporâneo como um teórico que aporta às políticas culturais importantes fontes visuais e auditivas assim como abordagens que reclamam maneiras diferentes de pensar a prática artística. Ele relaciona este marco de contextos às práticas interpretativistas, empiricistas e críticas da pesquisa tradicional da mesma maneira que faz com o marco do saber visual. Ele aponta três temas que revelam a dinâmica do movimento nas artes visuais: fazer nas comunidades, fazer nos sistemas e fazer nas culturas.

As práticas artísticas que se fazem nas comunidades são, segundo Sullivan, práticas reinterpretativas que exploram a interatividade e a comunicabilidade das artes visuais para gerar novas conexões entre ideias, conhecimentos ou saberes, sejam estes individuais ou comunitários. Por este motivo as pessoas e os lugares são essenciais para os artistas que fazem nas comunidades. A especificidade do lugar (site specific) e da situação é um importante dado no processo criativo para muitos artistas e curadores porque isto abre maiores possibilidades de comunicação e interação.

Para Sullivan este envolvimento crescente dos artistas com as comunidades revela que assumem uma maior responsabilidade como teóricos em que o espaço entre a teoria e a prática se tornam o lugar para fazer arte e investigação. Para eles o conhecimento local e situado promove uma forma dialética de construir o conhecimento porque o passado e o 
presente se encontram nas tradições, nas histórias e nas relações que se estabelecem entre as gerações, as culturas e as camadas subjetivas de tal maneira que podem visualizar e fazer visíveis estas relações para formar um diálogo dentro do contexto comunitário (SULLIVAN, 2010). Restabelecer os laços da comunidade é um dos objetivos principais dos artistas da Estética Relacional (BOURRIAUD, 2009) ou arte participante (BISHOP, 2012; SUASSUNA, 2008). O conceito de Momento Político Específico de Bruguera amplia esta ideia à situação política que rege o momento e que envolve as pessoas e suas relações sociais. Trata-se de uma estética que investe nas relações entre o(s) artista(s), o público, o artefato, a situação e os conhecimentos, onde a forma se configura no processo destas relações. Mas, sobretudo tem uma intenção política porque entende que sendo a experiência estética uma experiência relacional distribui e redistribui o poder constantemente. Dessa maneira sua principal mídia são as pessoas e os lugares por onde os eventos artísticos fluem.

Nesse sentido os contextos educativos constituem hoje uma espaço poético em que o significado pode ser construído e o poder redistribuído. Bishop nota que "por décadas os artistas intentaram forjar uma conexão mais próxima entre arte e vida, se referindo às suas intervenções nos processos sociais como arte; mais recentemente estes incluem experimentos educacionais" (2012, p. 241, grifo nosso). Sullivan lembra, no entanto, que poucas universidades exploram a experiência em comunidades e espaços públicos e conclui que "Tal vez é a reconfiguração do estúdio privado e o espaço público como lugares colaborativos de investigação que pode ajudar os investigadores em artes visuais a responder ao (este) desafio" (Idem, p. 170).

Já as práticas artísticas que fazem nas culturas enriquecem as práticas críticas e "desafiam percepções através de encontros visuais" (Idem, p. 156) porque se estabelecem nas relações culturais. $\mathrm{O}$ interesse se foca nas situações e ações transformadoras, portanto se trata de investigar novas ideias de como fazer as coisas. Os artistas que fazem nas culturas preferem focar sobre as dissonâncias, conflitos, paradoxos ou aporias e estabelecer diálogos que procuram formas de experiência estética que revelem, critiquem e transformem o que sabemos. O papel do artista é, neste contexto, "investigar como os criadores de imagens e criadores de sentido sabem as coisas que sabem. [...]. Este imperativo crítico implica que a imagem visual é mais do que um produto que pode ser isolado ou contextualizado". (SULLIVAN, 2010, p. 173). Nessa visão os significados não só são criados mais questionados. 
Sullivan lembra que no pensamento moderno 'ver era saber' porque na perspectiva empírica a experiência visual direta era necessária ao conhecimento. Numa sociedade visualmente midiatizada como a pós-moderna 'saber é ver' porque se compreende que há várias formas de ver e interpretar o mundo (Idem, p.171). A nossa tarefa seria então, argumenta ele, determinar o impacto social destas diversas visões e usar o potencial das imagens para criar formas de representação que transformem nosso conhecimento. Os artistas que fazem na cultura estão interessados em questionar as formas de representação e revelar nelas as relações entre poder e conhecimento onde assuntos críticos como gênero, raça, religião, excepcionalidade e colonização irrompem. O valor educacional destas abordagens reflexivas sobre as formas de representação visual são importantes numa era de grandes tensões culturais.

Estas afirmações requerem, no entanto, uma aclaração: na linha desta investigação o que interessa não é o que os artefatos da visualidade significam, mas como os artistas e os participantes constroem, negociam e desconstroem estes significados na experiência estética. Isto requer pensar a arte não só como uma forma de representação, mas como um processo vivido ao qual se atribui um significado. Aqui se compreende, na linha de Badiou, pensar a arte como um evento.

Essa posição é análoga à ideia que existe nas comunidades indígenas de Norte América de que é mais importante estabelecer uma relação com os conhecimentos do que dominar eles (SEMALI e KINCHELOE, 1999, apud SULLIVAN, 2010). Fazer na cultura é desta maneira criar eventos que nos levem a pensar na nossa relação com os significados e não uma leitura decodificadora de imagens. Dessa maneira muda a situação e a forma como o conhecimento é criado e comunicado. Quando nos relacionamos com os conhecimentos se estabelece um espaço de interseção entre o particular e o universal, (pode ser entre o local e o global, entre periferia e centro) atravessando assim as fronteiras culturais porque o poder da visão e da voz se distribui e redistribui. A ênfase sobre a relação que estabelecemos com os conhecimentos e os significados é uma ênfase política porque, em quanto não houver uma relação com o conhecimento ele pode ser instrumento de dominação.

Fazer na cultura, no entanto, não significa um acento sobre políticas nacionalistas, tradicionalistas ou chauvinistas ligadas a uma geografia. Estamos frente a uma nova geografia em que o local e o global se fundem. Inclusive não é mais sobre uma geografia, como aponta Camnitzer (2009b), mas sobre uma 'infografia' porque é um mundo que se organiza de acordo 
a como é informado e como informa. Nesse aspecto e para esta investigação fazer na cultura tem um acento sobre os espaços pedagógicos como espaços de conflito.

A virada da visualidade na educação impregnada das mudanças e conflitos culturais é, por este motivo, uma virada política que coloca em xeque as relações entre poder e dominação por meio da "redistribuição do sensível". Tanto para artistas como para educadores e investigadores da Educação em Visualidade fazer na cultura significa ampliar o poder de pensar, de fazer e de ser junto com o outro.

Já as práticas que se fazem nos sistemas exploram as diversas formas em que o conhecimento se constrói baseados em conhecimentos e destrezas disciplinares e práticas pós-disciplinares, criando também interseções com outros domínios de pesquisa e investigação. Para os artistas que trabalham nestes contextos os sistemas oferecem estruturas e formas dinâmicas e estáticas com as quais eles interatuam de maneira complexa. Ao mesmo tempo nestes contextos os artistas permitem a interação entre o evento artístico, o público, o artista e o contexto histórico que caracteriza um processo de intercambio e desenvolvimento. As instalações, as intervenções, os performances e a estreita relação entre arte, tecnologia e ciência hoje evidenciam estas práticas que se fazem nos sistemas onde os ambientes, as situações, as ações e eventos são "espaços interativos e sistemas de referência, inferência e significado" (SULLIVAN, 2010, p. 163). Por esse motivo a camada teórico conceitual em que os artistas atuam quando fazem nos sistemas é a interação. Os questionamentos que atravessam as investigações artísticas daqueles que fazem nos sistemas procuram o entendimento na experiência da forma com a qual trabalham e isto sempre estabelece relações com outros sistemas. Destarte a camada operacional e metodológica é multimodal para permitir um entrelaçamento com outros sistemas e contribuir com os conhecimentos humanos tanto nos aspectos técnicos, conceituais, científicos e éticos como na criação do sentido. Para estes artistas, as mídias são os contextos reais e virtuais onde estas relações sistêmicas se estabelecem.

Por outra parte as práticas artísticas que fazem no sistema tendem a trabalhar em sistemas interativos de investigação que abrem novas maneiras de pensar o ensino das artes visuais. É possível observar que o que há de estético nos sistemas há também de pedagógico se pensamos que:

Embora o status do ensino como uma prática dentro das artes visuais foi caricaturada no passado como intrusiva ou irrelevante, quando os artistas 
assumem ativamente um papel pedagógico como uma parte natural da sua prática artística, estes caracterizam os períodos mais radicais e inovadores da história da arte. (SULLIVAN, 2010, p. 164)

As pedagogias culturais se propõem atravessar os contextos do fazer nas comunidades, fazer nos sistemas e fazer na cultura na concepção do artista/investigador/professor como um teórico que imagina, argumenta, propõe, interpreta, experimenta, critica, faz e produz eventos artísticos e pedagógicos. A prática transcongnitiva é desta maneira um marco metodológico em que as coincidências, contaminações, hibridações e contiguidades entre estes eventos podem ser reconhecidas.

Nessas bases é possível identificar competências artísticas em situações não artísticas como as da sala de aula na confluência dos eventos artístico/pedagógicos e apresentar a investigação com um artefato integral desse processo.

\subsection{Competências artísticas em situações não artísticas}

Evocando Stephen Wright, Atkinson pensa que os artistas contemporâneos desafiam as noções tradicionais de arte sacrificando como Marcel Duchamp o "coeficiente de visibilidade artística" para conseguir uma maior capacidade de "corrosão e dissenso na ordem semiótica dominante" (WRIGHT, 2008, apud ATKINSON, 2012, p. 7). Isto significa cruzar as fronteiras da arte, não para invalidar os eventos artísticos, nem a singularidade da experiência estética, mas para empregar o que Wrigth chama de "competências artísticas" em contextos e situações não artísticos. Se compreendemos a prática artística como uma 'prática transcognitiva' podemos pensar nos contextos educativos e situações pedagógicas como espaços potencialmente artísticos e os espaços artísticos como espaços potencialmente pedagógicos. Tudo isto chama a reconsiderar noções sobre prática, objeto de arte e o papel do artista na sociedade (Ibidem). Sobre os artistas contemporâneos que trabalham com interfaces pedagógicas Atkinson considera que a intenção deles é intervir na economia do conhecimento para redistribuí-lo imaginando o que a arte pode ser e o que aprender pode ser "além de parâmetros de reprodução, empacotamento de conhecimentos, habilidades tradicionais e a pragmática e previsível aplicação de conhecimento" (ATKINSON, 2012, p. 8). 
As coincidências, contaminações e hibridações entre o evento artístico e o evento pedagógico revelam não só uma expansão da prática artística como uma prática de investigação transcognitiva que invade e contamina outras práticas quando suas metodologias se democratizam, mas também uma expansão do poder estético da criação quando se reforça na participação da vida: "se podemos fazer que uma pessoa perca contato com sua capacidade criadora, perca a visão do seu desejo e poder de fazer arte, então a obra da subjugação, da colonização estará completo" (HOOKS, 1995, apud SULLIVAN, 2010, p. 176). Logo, é crucial democratizar as forma de operar da arte.

É importante destacar que esta democratização não é 'civilizatória'. Não se trata, mais uma vez, de pensar que levamos a arte aos que não têm, de canonizar ou sacralizar uma prática artística determinada em contextos educativos, se trata de explorar formas estéticas na construção de espaços de existência. Dewey (2005) lembra que o poder de fazer é o primeiro conhecimento importante para a vida e este poder se fortalece na arte como potência de toda linguagem. Se as metodologias artísticas constituem formas de encarnar o poder de fazer, são formas potencialmente pedagógicas. São, o que Hirschhorn chama de 'pensamentos bomba' (Fig. 62). Aqui concordo com o argumento de jagodzinski e Wallin (2013) de que a arte é mais do que um objeto para ser lido, seu poder não é epistemológico ou representacional, seu poder está na sua dimensão ético - política: "não o que arte significa, mas o que a arte faz" (Idem, p. 170).

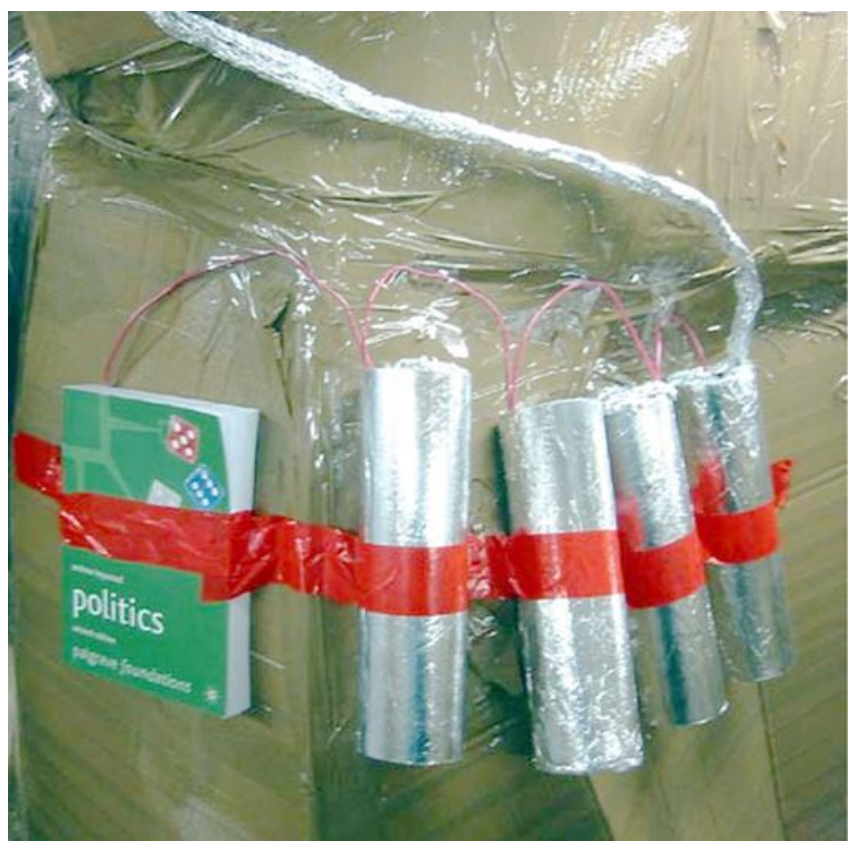

Fig. 62 Thomas Hirschhorn. Cavermanman. Instalação, 'pensamentos bomba'. $5^{\circ}$ Carnegie International, Carnegie Museum of Art, Pittsburgh, 2002. Fontes: artnet.com; spainmolly.wordpress.com; flickr.com 
De maneira similar Camnitzer vê na relação entre arte e pedagogia uma expansão além das noções de arte e de educação em artes visuais dominantes:

O fato é que temos que introduzir a arte na educação como um método pedagógico, como uma metodologia para adquirir conhecimento. O fato é que temos que introduzir noções pedagógicas na arte para polir o rigor na criação e melhorar a comunicação com o público. O fato é que não há educação real sem arte e não há arte verdadeira sem educação. $O$ fato é que os artistas que não podem sobreviver no mercado vão ensinar sem saber como. $O$ fato é que o professor que fica sem ideias não se atreve a ir na arte para tê-las. O fato, o trágico fato, é que aceitamos socialmente que se ensina sem rigor e se faz arte por divino desígnio. [...] arte e educação são o mesmo, somente tomam forma em diferentes mídias. (CAMNITZER, 2009b, p. 235-236)

É sobre a exploração dessas mídias que é possível encontrar as coincidências, contaminações e hibridações e indagar como se dão estas relações entre a identidade do sujeito artista e do sujeito docente para permear as formas de ver, interpretar e fazer.

Nessa linha observo que o evento artístico como pedagogia requer três tipos de questionamentos análogos às três dimensões de investigação numa prática transcognitiva. Por uma parte estão os questionamentos filosóficos da arte e da educação para analisar e interpretar os discursos, artefatos, fluxos e contextos em que o evento artístico se encontra com o evento pedagógico; para imaginar outros discursos, artefatos, fluxos e contextos e compreender de que maneira e o que acontece quando estes eventos se tornam híbridos.

Por outra parte, é necessário levantar questionamentos sobre as considerações curriculares e metodológicas em que o evento artístico se encontra com o evento pedagógico. O importante é se aventurar na experimentação e procurar o rigor quando se trabalha entre o conhecido e o desconhecido, como é no caso do currere que propõe Pinar. Estes questionamentos articulam o processo de construção, experimentação, valoração e reconstrução de acordo a uma intenção expressiva e criativa. Cada processo pode ter uma série diferente de metodologias que aproximem ideias, situações e formas. $\mathrm{O}$ artista e os educadores em visualidade são também inventores de metodologias.

Por último os questionamentos culturais e políticos que são produto de uma situação e um contexto nos levam a um processo de crítica em que se julgam e valorizam os eventos. Nesse processo, a reflexão da prática se aprofunda na contingência da vida cotidiana. Porque 
transformar não é ir de uma situação estática a outra, transformar aqui se entende como uma mudança na direção dos eventos em constante fluxo.

Para compreender esta metodologia como uma metodologia do fluxo se procura um marco epistemológico onde as relações entre teoria, prática e poética sejam fluídas. Nesse marco a textualidade e visualidade constituem metalinguagens com as quais se pode estabelecer um diálogo, uma 'conversação complicada' entre narrativas, disciplinas, pessoas e lugares. Da mesma maneira o artefato e a aula ${ }^{67}$ constituem os meios pelos quais a forma se manifesta, onde as representações se constroem e o campo simbólico se cria. A matéria sobre a qual o evento artístico e o evento pedagógico se encontram podem ser em um dado momento o artefato do evento artístico e em outro a aula do evento pedagógico. Por outra parte o evento pedagógico como evento artístico carece de significado sem um contexto que proporcione o espaço das relações entre arte e vida. É na práxis que se criam e recriam os significados e se estendem de diversas maneiras a outros campos do conhecimento. Para uma aprendizagem significativa a teoria a práxis e a poiese devem compartilhar um fluxo de eventos. Nesse encontro de eventos a identidade de artista/investigador/professor e de estudante/participante se fundem também no sentido da autopoiese porque todos mudam quando participam na construção simbólica do evento artístico/pedagógico. Esta é, portanto, uma metodologia do fluxo entre identidades e ademais entre textualidade e visualidade, artefato e aula, educação e arte.

Essas dimensões epistemológicas não só se complementam, mas se fundem em outras novas ou criam tensões e conflitos que reconfiguram o evento artístico e o evento pedagógico em uma nova investigação ou em novas performances epistemológicas. Na prática artística, como na pratica pedagógica e de investigação o artista/investigador/professor $\mathrm{e} \quad \mathrm{o}$ estudante/participante pode se mover "dentro, através, entre e arredor" (SULLIVAN, 2010, p. 108) das dimensões de investigação.

De toda maneira a análise e reflexão sobre contiguidade, contaminação, hibridação e coincidência entre evento artístico e evento pedagógico se baseia no estudo de artefatos artísticos que usam a educação como um médio e na observação da prática pedagógica de professores de arte porque a intenção é conhecer o que acontece quando estes encontros se tornam uma pedagogia. Por este motivo os produtos destes encontros são sistematicamente

\footnotetext{
${ }^{67}$ Nesta pesquisa a aula é entendida não só como espaço físico da aprendizagem, mas também 1) como uma estrutura de competências, objetivos e metodologias de aprendizagem de algo, para algo, para alguém e em uma dada circunstância. 2) Uma comunidade de aprendizagem. 3) Os recursos e objetos de aprendizagem que mediam a educação.
} 
registrados e estudados nos parâmetros de uma investigação transcognitiva que enfatiza sobre o saber visual produzido e que se estuda tanto na perspectiva do fazer em sistemas como do fazer na cultura e em comunidades.

De que forma as metodologias
pedagógicas que tem por objetivo
a compreensão das reações do
público, podem beneficiar a prática da arte
(caso isso aconteça)?
que o público não é um mero acidente,
mas sua razão de ser, Que o conhecimento e seu efeito tem data de
validade, Que o tempo é necessário para a transformação social, Que a
criatividade não é um objetivo, mas uma ferramenta, Que a utopía é
um estágio acessível da realidade e não sua fatalidade, Que todos querem
entender Tania Bruguera em entrevista com Pablo Helguera. In
HELGUERA e HOFF, 2011.




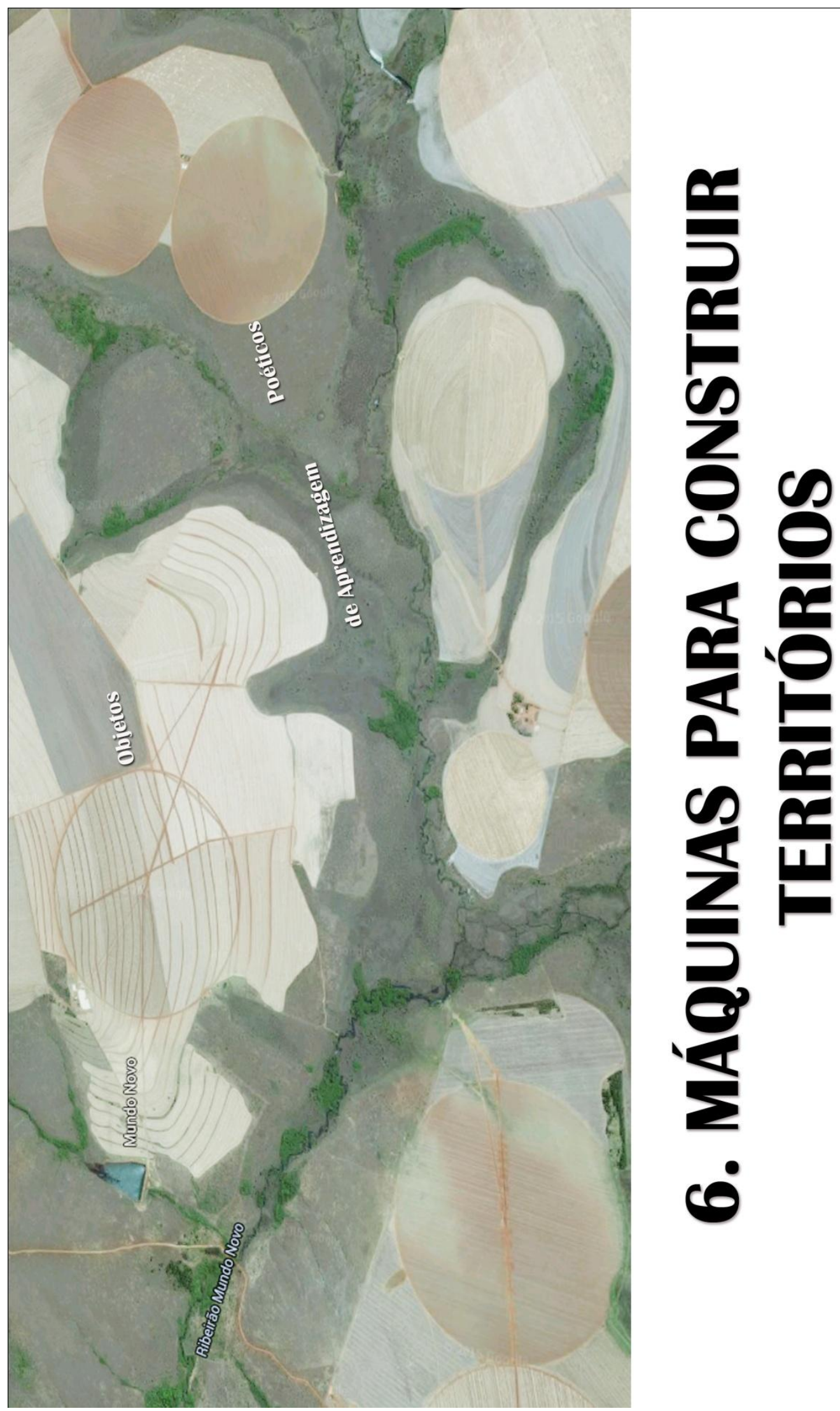

Fig. 63 Máquinas para construir territórios, Tatiana Fernández, fotografia satelital Mundo Novo, Minas Gerais, Brasil, Google Earth manipulada, 2015. 


\section{MÁQUINAS PARA CONSTRUIR TERRITÓRIOS}

O caminho da investigação não concreta-se nos rastos e marcas que deixa, mas, sobretudo nos novos processos que deflagra. Uma investigação como esta deve criar espaços que favoreçam o encontro entre a prática artística e pedagógica, estruturar processos em que estas práticas sejam produzidas e experimentadas, e gerar registros visuais que possam ser vistos por uma terceira audiência, portanto devem se constituir em artefatos e contar com um espaço de experimentação. Nessas bases, propus o que denominei de Objetos de Aprendizagem Poéticos (em diante OAP), apresentados na forma de um curso de extensão realizado no Instituto de Artes, IdA, no Departamento de Artes Visuais, VIS, através do Decanato de Extensão da Universidade de Brasília, DEX-UnB dirigido a professores de arte e estudantes das licenciaturas.

Os OAP são, como veremos adiante, a investigação como artefato. Constituem uma forma de conceber a Educação em Visualidade que se modula em diferentes formas e cria situações singulares. Manifestam-se de forma material em um curso de extensão que produz outros artefatos e de forma imaterial no conceito que se forma para a Educação em Visualidade. Assim como os cientistas criam teorias, como vimos com Sullivan, os artistas criam ideias, formas e situações. Nessa perspectiva os OAP constituem uma ideia para cruzar as fronteiras entre a arte e a educação, uma forma que produz outras formas e cria situações em que se produzem eventos artísticos como pedagogia.

Pensar a investigação como um artefato, dessa maneira, exige atenção às dimensões teóricas quando um evento artístico coincide com um evento pedagógico. Nesses termos, a investigação se propõe contribuir na construção do saber visual porque, como uma abordagem a/r/tográfica "[...] indaga no mundo por meio de um processo contínuo de fazer arte em qualquer forma artística e escrita não separadas ou ilustrativas uma da outra, mas interconectadas e tecidas entre elas para criar significados adicionais ou novos" (IRWIN, 2006, s/p). É importante remarcar, no entanto, que estes significados estão sempre em constante negociação e fluxo. 
Os encontros entre os eventos artísticos e pedagógicos, na forma dos OAP, têm por outra parte, implicações culturais, educativas, políticas e artísticas que remapeiam os territórios. A indagação sobre a virada da visualidade na educação e a virada pedagógica na arte tem implicações culturais porque envolvem questionamentos sobre as formas de representação visual, a construção e o fluxo das identidades, as fronteiras nacionais, religiosas e ideológicas, a homogeneização e normalização de padrões culturais pela sociedade e pela indústria cultural e as relações entre tecnologia e subjetividade.

Investigar na linha das pedagogias culturais e sob a ideia de um currere tem implicações educativas porque situa a discussão não mais sobre a instrumentalização do currículo e da metodologia delimitada em fronteiras disciplinares da arte, mas sobre uma prática curricular e metodológica que se estende em, entre, arredor e através de artefatos da visualidade cotidiana e extraordinária, isto é, além de limites disciplinares.

As discussões levantadas pelos artistas contemporâneos que trabalham ao redor de uma arte participante conduzem a questionamentos que tem implicações políticas importantes. Eles centram a estética na experiência do mundo e se propõem produzir eventos que promovam novas performances epistemológicas. Muitos artistas, teóricos e filósofos ${ }^{68}$ concordam que o projeto de uma arte participante rehumaniza a sociedade hoje "insensível e fragmentada pela instrumentalidade repressiva do sistema capitalista" (BISHOP, 2012, p. 11). Essa direção e preocupação com novas formas de organização social e cultural que resistem à pressão dos sistemas sociais rígidos conduzem à chamada 'virada social' ou 'virada cultural' que em muitos casos está relacionada também à virada pedagógica da arte. Essas viradas são sintomas da estrangulação dos espaços públicos, dos direitos humanos e das políticas democráticas em escala global. A arte participante atualiza o debate filosófico da relação entre estética e ética criando rachaduras no sistema de dominação instituído porque dá visibilidade a uma nova forma de política na distribuição do sensível em que o espectador se emancipa e se torna um participante.

As implicações artísticas desta investigação como artefato também são importantes porque se evidencia uma crescente dissidência com as noções de gênio artístico, com a ideia dicotômica entre arte e estética (JAGODINSKY, 2009) e com a construção das identidades de artista e

\footnotetext{
${ }^{68} \mathrm{O}$ historiador de arte Grant Kester no livro Conversation Pieces:Community and Communication in Modern Art, Berkeley: University of California Press, 2004. O artista-ativista Blake Stimson e o historiador da arte Gregory Sholette (eds) no livro Colletivism After Modernism: the Arts of Social Imagination after 1945, Minneapolis: University of Minnesota Press, 2007. O curador, crítico e teórico N. Bourriaud, o filósofo J. Rancière, a crítica de arte C. Bishop, o artista L. Camnitzer listados na bibliografia, são só alguns entre os que apontam o movimento.
} 
professor de arte como identidades antagônicas. A ideia de prática transcognitiva de Sullivan permite, por outra parte, pensar numa maior contaminação disciplinar que hoje começa a ter consequências sobre a historiografia, a crítica e a curadoria da arte e, portanto, nas formas de coletar dados, mostrá-los, analisá-los, refletir e criticar a arte (BISHOP, 2012). As relações entre arte e cultura visual também conduzem a repensar a arte como experiência estética onde a noção de evento marca o caráter transitivo, fluido e permeável que dá conta do processo contínuo e mutante da experiência e da sua significação cultural.

Nesse marco, a investigação se apresenta na sua dimensão teórica com uma indagação interpretativa e crítica das coincidências entre o evento artístico como evento pedagógico nos artefatos de artistas e professores de arte que cruzam essas fronteiras. Na sua dimensão prática se apresenta com a exploração de OAP em contextos de formação em cursos de extensão para professores de arte atuantes na rede pública e particular do ensino básico em Brasília. Na sua dimensão poética se apresenta como uma apropriação de outro sistema de produção (educação) como forma de ocupação de outros territórios existenciais cujas consequências são imprevisíveis. Nessas dimensões os OAP são máquinas para construir novos territórios de existência.

Por outra parte me aproprio, nos termos que se colocam no capítulo, de uma denominação e de uma concepção de educação inserida na formação do conceito de Objetos de Aprendizagem, conhecidos pela sigla OA, (Learning Object, LO, em inglês) para virá-lo e transformá-lo em Objetos de Aprendizagem Poéticos, um conceito que se posiciona em outro território. Por este motivo se trata de uma apropriação que ocupa territórios epistemológicos não explorados em espaços que se abriram para outros fins. Os OA se usam, como se verá adiante, como instrumentos de hegemonização nos sistemas de 'educação bancária' (FREIRE, 1987a). O que faço é ocupar o espaço conceitual que os OA abrem na educação por caminhos invisibilizados que se tornam visíveis no encontro entre o evento artístico e o evento pedagógico.

OA é uma denominação que aparece no começo do século XXI na literatura associada ao $e$ learning, com o uso de novas Tecnologias de Informação e Comunicação, TIC, na educação, geralmente por pesquisadores do campo das mídias digitais, tecnologia e educação. Os estudos sobre OA predominam no campo da tecnologia educacional, do design instrucional e da capacitação e treinamento empresarial e comercial. Se referem a pequenas unidades de aprendizagem em formato digital que são reutilizáveis e que favorecem a autonomia da 
aprendizagem. A concepção de OA faz parte também de um discurso associado à denominada Economia da Aprendizagem (Learning Economy) ${ }^{69}$, defendida pelos interesses econômicos neoliberais para facilitar cortes no custo da educação através de um sistema que dispensa professores e facilita políticas de avaliação e padronização da educação. É importante, portanto, observar como se colocar frente ao desafio que os OA representam na perspectiva das pedagogias culturais.

Nesse marco se desenha a proposta dos OAP, que condensam na poética, ou poiese, o espaço de fronteira em que as pedagogias culturais podem ser possíveis. Da mesma maneira, e com a mesma importância, neste capítulo, observam-se as relações que existem entre os fundamentos conceituais que regem os OA, a proposta dos OAP e as questões relativas aos projetos artísticos que trabalham com interfaces pedagógicas na arte participante.

É importante observar neste ponto que realizar uma investigação como artefato artístico exige a possibilidade de abarcar outros sistemas de produção, a arte não é uma atividade específica ou um ofício particular, como pensa Guattari, a arte pode funcionar em diferentes planos. A investigação produz diversos artefatos relacionados entre si: a dissertação, o curso de extensão, os OAP, o vídeo, a página web e um livro didático. Mas o que se apresenta como artefato artístico é imaterial: é somente a ideia de que possam existir objetos poéticos para aprender qualquer coisa. Em referência a essas ideias, Bourriaud conclui que "A obra materializa territórios existenciais, onde a imagem assume o papel de vetor de subjetivação, de shifter capaz de desterritorializar nossa percepção antes de 're-ramificá-la' para outros possíveis: papel de um "operador de bifurcações na subjetividade" (2009, p.138-139, itálicas do autor). Os OAP têm esse propósito, funcionar como shifters, como máquinas para construir territórios de subjetivação, isto é, como máquinas provocadoras de eventos artísticos/pedagógicos.

\subsection{Máquinas para construir territórios de subjetivação}

O evento artístico e sua maneira de operar na construção de territórios de subjetivação, como um 'operador de bifurcações na subjetividade', é o aspecto mais significativo para as

\footnotetext{
${ }^{69}$ A Economia da Aprendizagem ou Learning Economy é a tendência a ver a educação em termos puramente econômicos. Nesse tipo de política se incentiva as pessoas a aprender para ganhar dinheiro, para ser competitivas e/ou para o crescimento econômico de um grupo social. Para Biesta o aspecto econômico deve se equilibrar com os aspectos pessoais e democráticos. As políticas neoliberais tendem a eliminar as questões pessoais e democráticas na equação. (BIESTA, 2006)
} 
pedagogias culturais. É possível observar que esse operador é uma máquina e que essa maneira de operar situa a experiência estética na dobra que se estabelece entre objeto e sujeito. Guattari (1995) reconhece, como Maturana e Varela, que os sistemas dos seres vivos são máquinas autopoiéticas, mas à diferença destes, pensa que as máquinas também são sistemas autopoiéticos ${ }^{70}$ porque têm um poder enorme de enunciação (com componentes materiais, cognitivos, afetivos e sociais que podem formar o que ele e Deleuze denominam como agenciamento maquínico ${ }^{71}$ ) e uma filogênese (história genealógica de uma espécie) contígua à dos seres vivos. Em decorrência disso é importante, como pensa Guattari, entender os artefatos como máquinas de subjetivação. Se pensamos numa relação de alteridade entre objeto e sujeito podemos pensar como o autor que "as instituições ou máquinas técnicas parecem ser alopoiéticas, mas quando as consideramos no contexto dos agenciamentos maquínicos que constituem junto aos seres humanos, se tornam autopoiéticas ipso facto." (1995, p. 40). É impossível, argumenta Guattari, negar a participação humana na essência do maquinismo, nem a capacidade de enunciação e relações de alteridade das máquinas (com outras máquinas).

Nessas bases podemos compreender os artefatos como máquinas de subjetivação porque tem um papel intrincado na construção da subjetividade. jagodzinski e Wallin nos lembram que,

Faculdades internas como a alma, as relações impessoais, os complexos intrafamiliares não são exclusivamente esses que produzem subjetividade. Ela é também produzida por meio de máquinas não humanas, como agenciamentos sociais, culturais, meio-ambientais ou tecnológicas que entram na mesma produção de subjetividade. (JAGODZINSKI e WALLIN, 2013, p. 47)

A disposição de 'objetos para aprender' é maior com a rede e Internet. Essas novas formas em que se estabelecem relações de ensino-aprendizagem produzidas por máquinas humanas e não humanas são formas de produção de subjetividades. Na coincidência entre o evento artístico e o evento pedagógico os OA e OAP funcionam dessa maneira. Ou seja, produzem espaços atuais ou virtuais em que se re-constrói o ser e se re-constrói o objeto. Para os autores o

\footnotetext{
${ }^{70}$ Para Maturana e Varela existem dois tipos de máquinas, as autopoiéticas, que são as que produzem seus próprios componentes e os organizam de acordo a suas especificações e limites; e as máquinas alopoiéticas que produzem outros componentes diferentes de si mesmo e dependem de máquinas autopoiéticas o de outras máquinas alopoiéticas para funcionar.

${ }^{71}$ Em Mil Platôs, Deleuze e Guattari (2002) definem os agenciamentos maquínicos como simbioses ou amálgamas de corpos que se atraem ou repulsam, se alteram, se aliam, se penetram e se expandem entre si. Da mesma maneira ferramentas, tecnologias, ou artefatos, "só existem em relação às misturas que tornam possíveis ou que as tornam possíveis. O estribo engendra uma nova simbiose homem-cavalo, que engendra, ao mesmo tempo, novas armas e novos instrumentos" (p. 94). As sociedades se definem não pelas suas ferramentas, mas pelas suas amálgamas, selecionam a tecnologia para incorporá-la à sua genealogia, argumentam os autores. Nessas condições se produzem ensambladuras entre os seres vivos e suas máquinas.
} 
evento incorporal é aquele que nos acontece vindo do lado de Fora (o Real virtual de Lacan) de tal maneira que "o encontro com o objeto" (2013, p. 47) se torna o lugar da aprendizagem e do 'se tornar'. É necessário se encontrar com os artefatos para detonar transformações. Por isso, aqui compreende-se que a aula se encontra conceitualmente no artefato e não necessariamente no espaço físico da sala de aula. Esses espaços podem existir por meio de artefatos com os quais nos relacionamos.

Os artefatos artísticos também funcionam dessa maneira, seja da perspectiva semiótica, histórica, formal ou cognitiva: são máquinas de subjetivação. Na arte, a orientação sobre o objeto, que aparece com Duchamp, se estende com o grupo Fluxus nos Estados Unidos, os Neoconcretos no Brasil, especialmente com Hélio Oiticica (Fig. 64) e Lygia Clark (Fig. 65), e a arte conceitual na Europa, evidencia uma preocupação com o participante da obra antes que sobre o objeto da obra. Clarck, por exemplo, chama de 'objeto relacional' os artefatos que usa na suas ações e considera o artista um 'propositor'. Mas, por que é tão importante o objeto na construção do sujeito? jagodzinski e Wallin (2013) apresentam um argumento que ajusta este aparente paradoxo: em base às ideias de Deluze e Guattari, sobre maquinas de subjetivação, eles observam que é necessário pensar na passiva vitalidade maquínica do objeto em oposição ao antropocentrismo transcendental animista.

O antropocentrismo se baseia na divisão do sujeito do mundo por meio de um 'interior' e um 'exterior' ao ser. Nesse modelo de pensamento a construção da subjetividade é algo que acontece no interior. Compreende-se que há uma influência exterior, mas ela não se considera como uma continuidade do interior. Entretanto, na perspectiva de Deleuze e Guattari, não há objetos nem sujeitos, nem distinções entre ambos, portanto não há cisão entre o interior e o exterior. A própria condição de sujeito e objeto é flutuante, muda de acordo ao contexto ou situação. Nessa perspectiva não pode haver uma ontologia do sujeito sem objeto, nem do objeto sem sujeito, mas da relação que se estabelece entre eles. Para Deleuze e Guattari, segundo jagodzinski e Wallin,

[..]o que é ontogênico é o relacional. A inteligibilidade é uma estrutura relacional e as relações em si mesmas são simplesmente multiplicidades que não tem 'nem sujeito nem objeto'. Estas multiplicidades intensas não podem ser enumeradas sem ser traduzidas em relações extensivas (objetos) que são necessariamente redutíveis. (JAGODZINSKI e WALLIN, 2013, p. 32 itálicas e aspas do autor) 

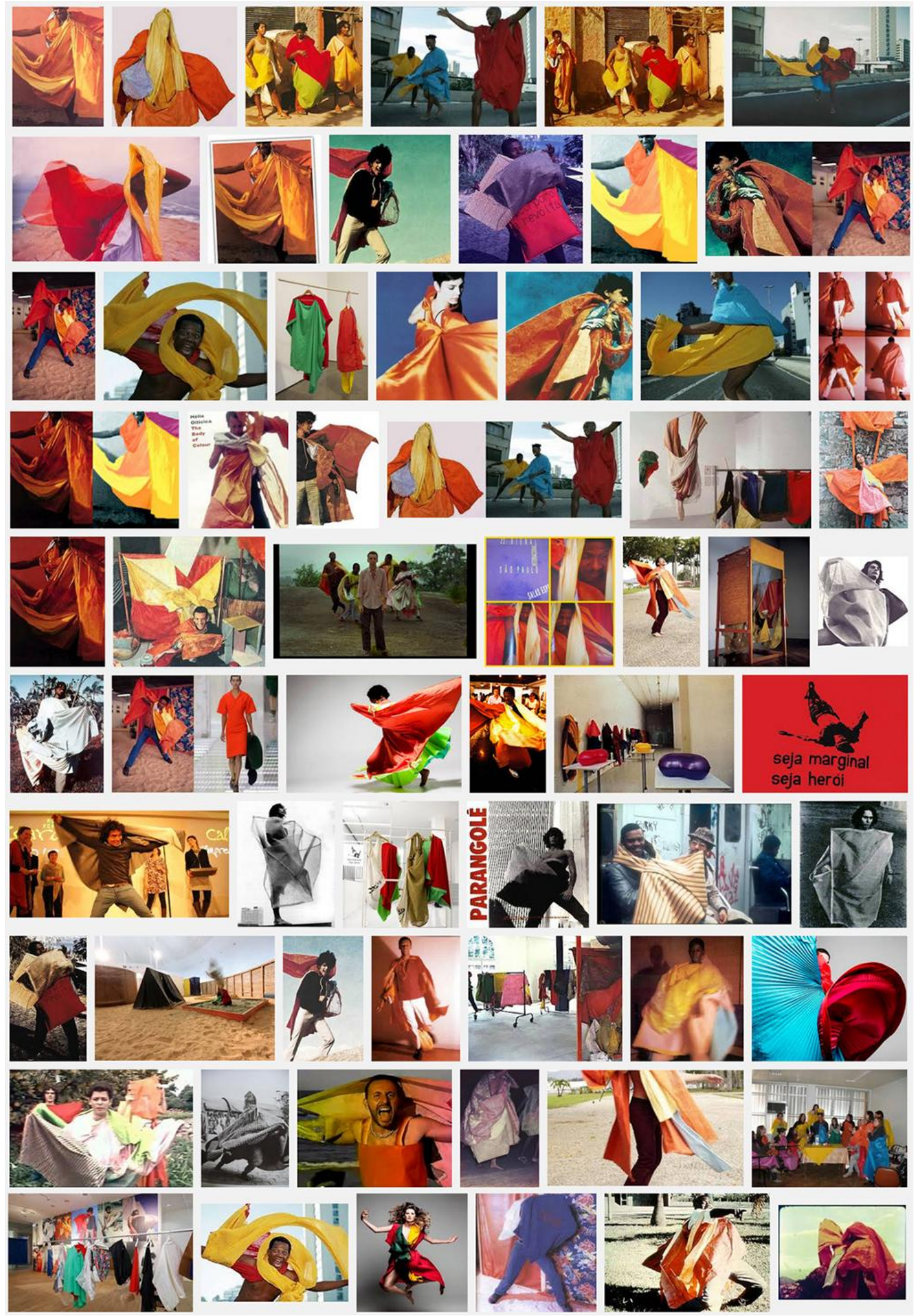

Fig. 64 Página seguinte. Hélio Oiticica, Parangolé. Captura e edição de imagens que aparecem no buscador de Google com a chamada de "Parangolé Hélio Oiticica", 2015. 
De maneira a fazer mais visível estas relações os autores recorrem à diferença entre as premissas de trabalho de Wassily Kandinsky e Paul Klee. Para Kandisnsky há duas formas de experimentar os fenômenos: interna e externa (HENRY, 2009). Nessas bases a distinção objeto-sujeito permanece, em virtude de figuras "geométricas fechadas, pontos e cores que só podem se mover por forças externas" (JAGODZINSKI e WALLIN, 2013, p. 33). Para Klee não há distinção entre formas, mas linhas que mudam de direção. A linha curva de Klee não reconhece divisão entre objeto e sujeito, ela se torna um caminho que dobra em um ponto de inflexão em que aparenta ir de dentro para o fora sem deixar de ser a mesma linha. Sobre essa ideia de dobra Deleuze (2007) desenvolve a noção de "inflexão". A relação entre objeto e sujeito, entre objeto e objeto, entre sujeito e sujeito é, nessa perspectiva, uma relação de continuidade em formação. Entre eles há dobras.

Em base a ideia da dobra, Deleuze aponta a arte não como um objeto, mas como o que ele denomina de objétil, uma concepção de objeto tecnológico que remete

[...] a nossa situação atual quando a flutuação da norma substitui a permanência de uma lei, quando o objeto ocupa lugar em um contínuo por variação [...] Pelo seu novo estatuto, o objeto é reportado não mais a um molde espacial, isto é, a uma relação forma - matéria, mas a uma modulação temporal que implica tanto a inserção da matéria em uma variação contínua como um desenvolvimento da forma. (DELEUZE, 2007, p. 38)

A arte é um objétil, não no fato da sua atualidade (o que é), mas da sua potência (o que pode ser), isto é, um objeto que está em constante formação pelas forças que o modulam ${ }^{72}$. Estas modulações, ou inflexões em um ponto indiscernível, são o lócus do evento (em flutuação e fluxo). Isso acontece também com o su-jeito (sub-ject) que Deleuze denomina de super-jeito (super-ject) porque a inflexão nesse caso se refere ao ponto de vista que é "a condição sob a qual um eventual sujeito aprende uma variação" (DELEUZE, 2007, p. 40). Se consideramos, como Deleuze e Guattari, que entre objeto e sujeito não há divisões, mas dobras, a divisão entre natureza e cultura sofre a mesma alteração. Deleuze e Guattari (2010) consideram que a arte começa na construção do habitat, como território, caracterizado pelas qualidades sensoriais que os animais (os humanos entre eles, evidentemente) distribuem no território que ocupam com o cheiro, as cores, os sons, as posturas corporais ou os objetos. A criação nessa

\footnotetext{
${ }^{72}$ Para Deleuze, no nosso tempo em que "o objeto já não se define por uma forma essencial" que mantém uma lei de constância (como os objetos da revolução industrial) se trata não de moldar, mas de modular, e nesse sentido cita Gilbert Simondon "Moldar é modular de maneira definitiva; modular é moldar de maneira contínua e perpetuamente variável". (DELEUZE, 2007, p. 38)
} 
perspectiva está mais relacionada a uma força interna (Zö̈), do que a uma coisa. Por outra parte, no objeto há uma intencionalidade que vai além do pensamento humano, que Deleuze denomina de vitalismo passivo. É na dobra entre a potência do sujeito e o vitalismo passivo do objeto que se abre o caminho para uma interação no nível inconsciente de um agenciamento maquínico (JAGODZINSKI e WALLIN, 2013). É, pois, uma abordagem póshumanista que aponta a relação entre o sujeito e os artefatos da visualidade como agenciamentos maquínicos.
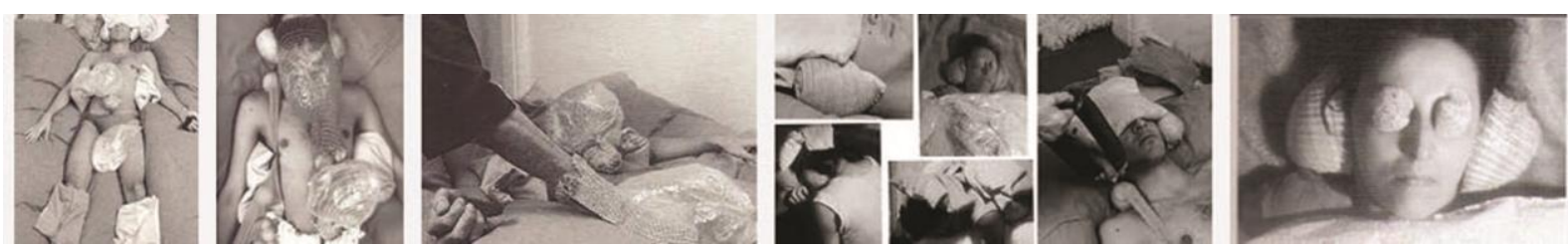

Fig. 65 Lygia Clark Captura e edição de imagens que aparecem no buscador de Google com a chamada de "Lygia Clark objetos relacionais”, 2015.

Se analisarmos com essas premisas veremos que os OA apresentam ou representam as coisas (o que é) em relação a uma visão fixa de mundo porque, apesar de serem essencialmente interativos, mantém uma distinção entre sujeito e objeto. Enquanto os OAP se propõem como inflexões, objétis que estão em potência na modulação com os sujeitos ou superjeitos, de tal maneira que se abrem possibilidades de transformação em novos agenciamentos maquínicos. Esses objetos devem ser pensados como máquinas para construir outras formas de ser, outros territórios existenciais. A intenção desses objétis é o de provocar movimentos para que aconteçam eventos artísticos como pedagogias.

\subsection{Os Objetos de Aprendizagem}

Os OA fazem parte de maneira crescente dos artefatos da visualidade com que os estudantes aprendem na educação formal, não formal e informal. São parte dos agenciamentos maquínicos em processo de amálgamas. Dos simuladores aos tutoriais, os OA são tanto formas de automatizar e hegemonizar o processo de aprendizagem, como de aperfeiçoar formas que de outra maneira seriam muito difíceis ou arriscadas de aprender. São também formas de democratizar os processos de aprendizagem para pessoas que de outra maneira não poderiam ter. Seja qual for o caso, é importante entender o que são e o que representam estes artefatos. 
Os OA se definem como objetos especialmente desenhados para aprender. É, de fato, uma definição muito ampla que pode incluir planos de aula até livros didáticos. O que distingue estes artefatos de outros recursos educacionais (livros, revistas, filmes, mapas, móveis, equipamento, material, instrumentos) é que são objetos que contém em si um processo pedagógico. São, portanto, criados com uma intenção pedagógica, pensados para um determinado processo de aprendizagem. Os OA são dessa maneira, recursos especializados. Por este motivo se reconhecem como objetos de aprendizagem e, embora o termo seja aberto a muitas possibilidades, existem diversas propostas para denominar, definir e estabelecer parâmetros.

Alguns autores como Robson da Silva (2011) argumentam que os OA são objetos exclusivamente digitais enquanto outros defendem a ideia de que podem ser tanto objetos digitais como objetos corporais (jogos de mesa, cartas) e incorporais (proposta de ações a se realizar) (IEEE/LTSC, 2000; WILEY, 2000a, 2000b; HODGINS, 2000). Alguns autores denominam esses artefatos de 'objetos educacionais' (TAROUCO; FABRE; TAMUSIUNAS, 2003), outros de 'objetos de conhecimento' (MERRILL, 2000), 'objetos de aprendizado' (BETTIO e MARTINS, 2004), 'materiais de aprendizagem on-line' (MALOY e HANLEY, 2001), entre outras mais (AUDINO e NASCIMENTO, 2010).

Mas a natureza e origem do conceito de OA é a dos objetos instrucionais: "o objeto instrucional foi proposto dentro de diferentes campos de especialidade para o beneficio na produtividade, para a padronização dos benefícios e como um meio para ter um design acessível para um exército em crescimento de desenvolvedores não treinados" (GIBBONS e NELSON, 2000). Quem encarna a história dos OA é Wayne Hodgins (2000) porque ele pensou no conceito de OA a partir dos blocos de LEGO, vendo os filhos construir brincando. Ele observou que o tamanho de cada peça poderia ser um 'dado molecular', independente, que pode se ensamblar em quase qualquer outra peça, para qualquer outro propósito de aprendizagem. A partir dessa observação ele conceitua a ideia central dos OA. Para fazer possível um sistema como esse, o autor argumenta, é importante que estas peças sejam universalmente padronizadas, de maneira que possam se acoplar a outras de qualquer tamanho, forma ou função, como as peças do LEGO, e oferece uma comparação com a padronização do sistema elétrico, dos trens, ou para os sistema da internet e argumenta que os "Padrões comuns para os metadados, objetos de aprendizagem, e arquitetura de aprendizagem 
são obrigatórias para um sucesso similar para a economia do conhecimento do futuro." (2000, p. 15)

O discurso de Hodgins (2000) revela a estreita relação entre o conceito original de OA, o conceito de e-learning e as políticas neoliberais da Economia da Aprendizagem. Ele defende os OA para um futuro em que a aprendizagem se funde na vida cotidiana e laboral, mas, destaca a eficiência, produtividade e competitividade como valores potenciais destes artefatos, deixando clara a prioridade sobre valores de mercado, antes que valores pedagógicos. Embora declare que sua principal premissa é o desenvolvimento humano, as projeções que ele faz são favoráveis aos grupos econômicos dominantes que servem o mercado, pois aponta não aos sujeitos da aprendizagem (não há referências à educação), mas a uma "massa" (Idem, p. 19) que deve ser mais "efetiva e eficiente como os objetos de aprendizagem" (Idem, p. 24). O autor prevê que dessa maneira os $\mathrm{OA}$, como em anteriores criações revolucionárias, trará um incremento na produtividade e na performance. Ele projeta uma economia em que os OA são uma fonte de energia de uma nova economia do conhecimento onde a nova ideia de aprender a vida (ao invés de ganhar a vida) é já uma realidade. No entanto, não é difícil concordar com o autor que a realidade do trabalho exige cada vez mais expertise dos trabalhadores, redefine a aprendizagem, o trabalho e o conhecimento em uma continua capacitação. Aprender e aplicar imediatamente o que se sabe é uma vantagem competitiva. Mas, para quem? Quem ganha com isso? Que grupos se beneficiam realmente?

A perspectiva da Economia da Aprendizagem, ou da Economia do Conhecimento, como a chama Hodgins, é sempre a perspectiva do mercado, por isso pensada na dimensão econômica. Biesta (2006, 2009a, 2009b, 2012) observa que a promoção da ideia de 'aprender para viver' está na base de políticas que procuram crescimento econômico e competitividade global. Mas, geralmente os que mais ganham com isso não são os que 'aprendem para viver', mas os que controlam o lucro da produtividade e a economia como um todo. Biesta reconhece que a dimensão econômica é importante para a aprendizagem ao longo da vida (aprendizagem continuada), mas que deve se basear também em outras duas dimensões: a dimensão pessoal e a dimensão democrática da aprendizagem. Na triangulação entre a dimensão econômica, pessoal e democrática é possível pensar esses processos de maneira que seja significativo para muitos.

Eu me aproprio do termo OA tanto para reverter a intenção original como para discuti-la na perspectiva do paradigma ético-estético. Os OA apresentam potencialidades, por uma parte, 
no espaço epistemológico porque destacam o artefato (objeto e evento), os participantes, o processo e o resultado da aprendizagem em um novo espaço de coincidências, hibridações, contágios e contaminações que mudam as formas de conhecer. Por outra parte, no espaço ontológico, porque pode funcionar, sendo artefato, como operador de bifurcações de subjetividade nas possibilidades poéticas dos objetos e das experiências estéticas. É também o termo que mais tem sido utilizado na literatura brasileira (BRASIL, MEC, SEED, 2007).

Nessa linha é imperativo reconhecer que, no esforço dos investigadores por encontrar parâmetros de padronização universal para OA, se ampliam os campos de discussão sobre quais objetos podem ser considerados. Esta investigação participa também na construção do que podem ser os OA na educação em visualidades, que dadas as formas de operar da arte na cultura visual, devem fazer outras considerações.

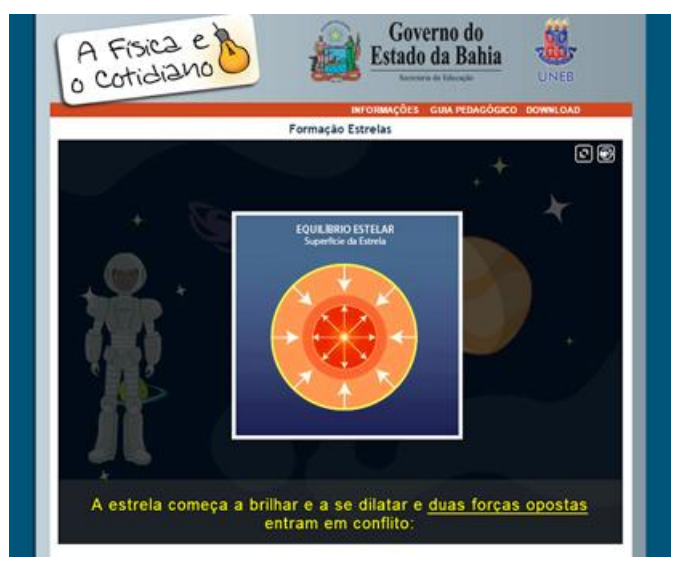

Fig. 66 Projeto Condigital MEC - MCT; Grupo de Trabalho de Produção de Conteúdos Digitais Educacionais da Secretaria de Educação do Estado da Bahia, A física e o cotidiano - Fique sabendo! - A vida das estrelas ( Formação das estrelas). Animação/simulação. Compreender como ocorre o processo de formação das estrelas e dos buracos negros. Ensino Médio: Física. MEC. URL: objetoseducacionais2.mec.gov.br/handle/mec/14346. Banco Internacional de Objetos Educaionais, SEED, Brasil.

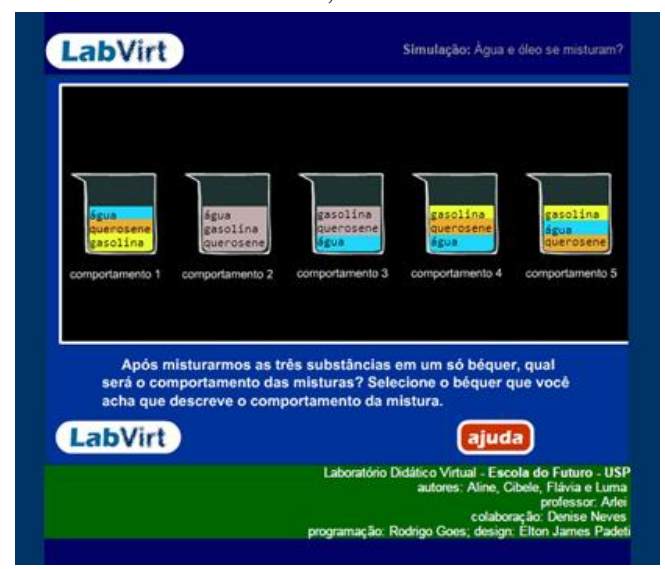

Fig. 67 Aline; Luma; Arlei; Cibele; Flávia, Água e óleo se misturam? Animação/simulação. Verificar as propriedades das ligações químicas das moléculas, entender o porquê água e óleo não se dissolvem um em outro. Ensino Médio:Química.URL:www.labvirtq.fe.usp.br/simulacoes/quimica/sim_qui_aguaeoleo.htm. Banco Internacional de Objetos Educaionais, SEED, Brasil. 

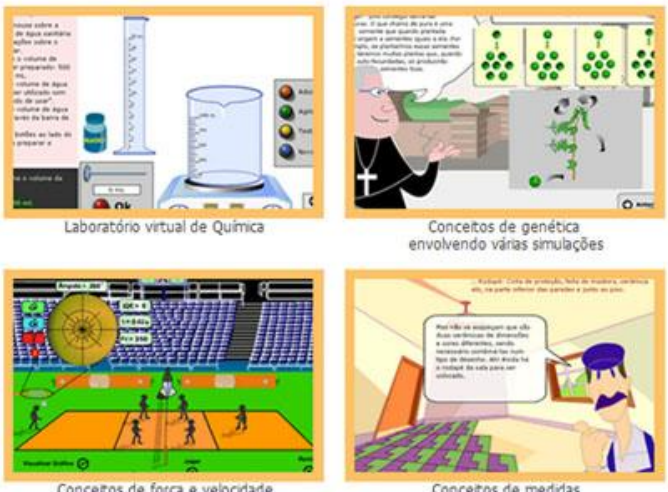

Fig. 68 Objetos de Aprendizagem e Banco Rived do Ministério de Educação. Fonte: rived.mec.gov.br

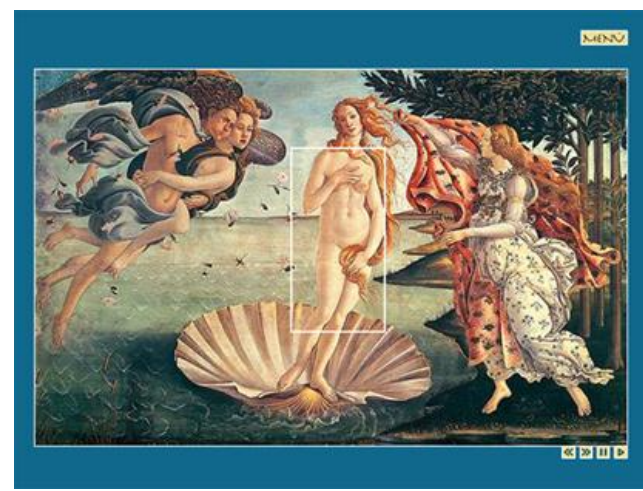

Fig. 69 Adolfo Gomes. O Nascimento de Vênus de Sandro Botticelli. Animação. Frame da imagem de análise formal e simbólica da peça. CD interativo apresentado com o livro História da Arte de M. Alvaro, Madrid: Anaya, 2003.

Fonte:www.ub.edu/histodidactica.

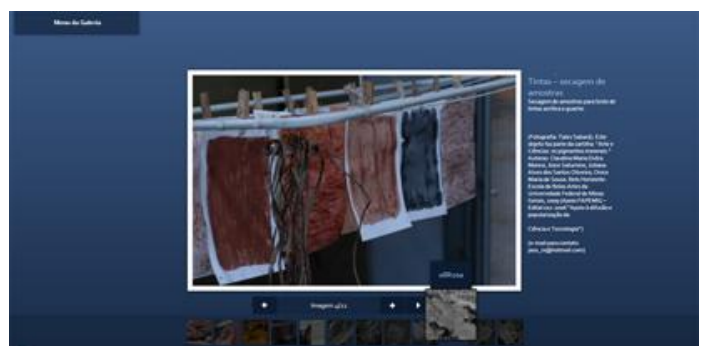

Fig. 70 Oliveira, Juliana Alves dos Santos; Saturnino, Joice; Moresi, Claudina Maria Dutra; Sousa, Onice Maria de.

Pigmento in Natura. Apresentação visual de um pigmento. 2011. Galeria Portal Pontociência. MEC. URL:

bjetoseducacionais2.mec.gov.br/handle/mec/24526. Banco Internacional de Objetos Educaionais, SEED, Brasil.

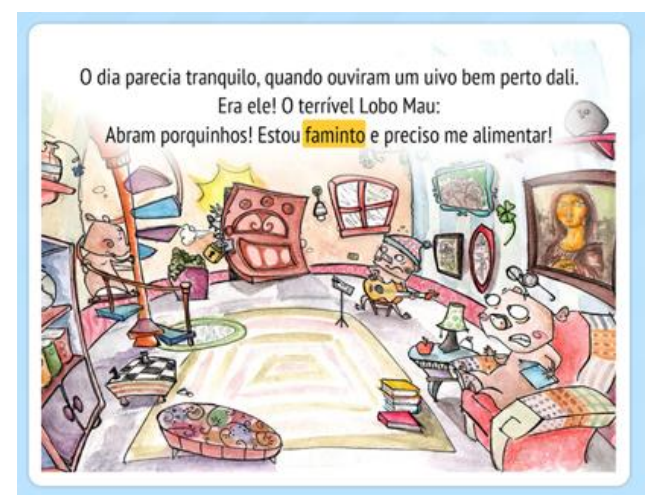

Fig. 71 Christiane Ávila, Gabi Moraes. Os Tr es Porquinhos. Escola Games. Livro infantil com narração, texto e imagens que estimula a leitura. URL: escolagames.com.br/livros/osTresPorquinhos/ 
Entre as características dos $\mathrm{OA}$ os pesquisadores identificam os mais importantes: são unidades pequenas de aprendizagem, estruturadas para exercício ou aprendizagem autônoma que podem ser reutilizados, que estabelecem interações ou relações no processo de aprendizagem e que constituem ao mesmo tempo uma forma de avaliação. Mas nem todas essas caracterísricas são constantes, pois podem haver OA não interativos, ou não reutilizáveis da mesma maneira, ou sem de mecanismos de avaliação como apresentações ou vídeos, ou que requerem de um processo guiado. Geralmente os OA fazem parte de um planejamento maior, onde funcionam como peças modulares e se organizam de diversas formas no planejamento de aula ou na organização dos participantes.

Daniel Audino e Rosemy Nascimento (2010) apresentam uma série de parâmetros que aparecem na literatura sobre OA e que tem guiado as avaliações de qualidade destes produtos. Entre eles os autores identificam a facilidade de utilização ou acessibilidade; a durabilidade; a flexibilidade de uso e adaptação; assim como a capacidade de customização, atualização e portabilidade. Por outra parte os OA se apresentam com uma série de metadados que ajudam à sua classificação e busca em repositórios ou bancos digitais de OA. São ainda objetos autoconsistentes, isto é, que se explicam por si mesmos sem precisar de outros para fazer sentido, e são autocontidos, (restritos a si mesmos) ou contidos (apresentam links externos com outros objetos pela Internet). São também interoperáveis porque podem funcionar em diversos sistemas, interfaces ou componentes. Nesse contexto, estes parâmetros se apresentam em maior ou menor grau na complexidade funcional e densidade de processos de um OA, que nos parâmetros internacionais se denomina de granularidade, e dependem da intenção dentro do processo pedagógico.

Outra característica que é pouco mencionada é a sua disposição para o livre uso (Creative Commons) em bancos ou Repositórios de OA (ROA) em muitas línguas, onde podem ser gerenciados. Há uma indústria de OA digitais para diversas áreas de estudo que apresentam software para aprendizagem ou Recursos Educacionais Abertos ${ }^{73}$, REA, que permitem criar atividades educativas como palavras cruzadas ou pequenos jogos até cursos inteiros (SILVA, 2011) e plataformas ou ambientes virtuais de aprendizagem como o Moodle ou o Scholar, desenhadas por equipes de designers instrucionais, professores, pedagogos, produtores e editores. A maior parte dos OA são financiados por projetos que amparam os custos e o

\footnotetext{
${ }^{73}$ Os REA são ferramentas de autoria para criação de conteúdo e-learning. Se trata de estruturas prontas, como palavras cruzadas ou espaços para perguntas e respostas, que podem se tornar OA, como o programa QUIZZ, Course Bilder, Quedoc Quiz Maker e Hot Potatoes entre outros.
} 
tempo de produção. Esses requerem uma produção de design instrucional altamente qualificado, mas outras formas de OA podem ser facilmente fabricadas pelos professores com alguns conhecimentos de edição e software livre. Muitos professores produzem seus próprios OA de maneira independente e com alta qualidade técnica, criando também seus próprios repositórios, disponíveis a todo público na rede de Internet ou restritos ao ambiente educativo. É possível então, buscar, identificar e usar OA criados por outros professores ou profissionais do design instrucional, adequados ao contexto de educação que procuramos em um repositório institucional ou pessoal. Por este motivo os metadados são tão importantes para os OA.

$\mathrm{Na}$ última década se desenvolveram diversos tipos de $\mathrm{OA}$, dos mais sofisticados como os simuladores de voo, até os mais simples, como apresentações Power Point. Portanto tem aqueles que não são acessíveis a todo público, pois funcionam em contextos complexos e aqueles que estão disponíveis de maneira gratuita. Para a educação básica há uma quantidade considerável, tanto no mercado como nos bancos disponíveis na Internet. Mas sua grande maioria é dirigida às ciências exatas, em especial para a aprendizagem da física e química (Figuras 66, 67 e 68) que requerem simuladores para visualizar os fenômenos de forma complexa e na matemática para efetuar cálculos complexos. Esses, de maneira quase total, se estruturam em um modelo cientificista que 'transmite um conteúdo' e testa a capacidade de 'fixar' ou 'lembrar' alguma informação que pode ser textual ou visual, com atividades que consideram ações corretas e ações incorretas. O modelo cientificista mantém uma visão dicotômica e reducionista que evidencia o interesse em resultados antes que em processos educativos de qualidade. Nesse modelo a subjetividade existe apenas como receptáculo. A imaginação não é tomada em conta, não se consideram as diferenças, nem há espaço para uma forma de dissidência, portanto para a singularidade e pluralidade do mundo.

Uma cuidadosa procura nos bancos de OA evidencia que as áreas de maior produção e uso são as ciências, tanto na educação básica como na educação superior. O Banco Internacional de Objetos Educacionais da Secretaria de Educação à Distância, SEED, por exemplo, possuía até abril de 2015 para o Ensino Médio, 79 objetos para o ensino das artes, enquanto para o ensino da física ofertava 2,192 objetos, para o ensino da química 1,723 objetos; para o ensino da matemática 1,814 objetos e para o ensino da Biologia 1,590 objetos. No ensino da sociologia, literatura, história e geografia os números variam entre 200 a 400 objetos. O Repositório da Rede Interativa Virtual de Educação, Rived, do Ministério da Educação, 
possuía, até a mesma data, no mesmo nível de ensino, 1 objeto para o ensino das artes, enquanto para o ensino da física contava com 32, para o ensino da química 18 e para a matemática 14. A mesma desproporção também acontece no ensino fundamental.

Embora nas áreas humanas esses artefatos sejam mais flexíveis e promovam maiores reflexões críticas (quando envolve projetos de trabalho, por exemplo), os modelos oferecidos tanto pelas ciências exatas como as humanas, são pouco adequados à aprendizagem das visualidades se não favorecem espaços de diferença, dissidência ou potência (abertura ao desconhecido). A maioria dos OA disponíveis nos bancos no Brasil e no mundo para o ensino das artes visuais entra nesse modelo ou se limita a exposição de imagens (Figuras 69, 70 e 71). O jogo interativo A Mansão de Quelícera realizado pelo Digital Art Studio Casthalia, dirigido por pesquisadores do Centro de Artes da Universidade do Estado de Santa Catarina UDESC e da Universidade Federal de Santa Catarina, UFSC (Figuras 72 a 75), é um dos poucos artefatos elaborados para atender os Parâmetros Curriculares Nacionais de Arte e recomendado pelo Ministério da Educação. No percurso de jogo os participantes se deparam com 'desafios' para atravessar os diversos ambientes da Mansão desenhada com múltiplas referências a obras destacadas da história da arte de Ocidente. Estes desafios por vezes são relacionados a uma obra de arte na forma de quebra-cabeças (Fig. 73), mas na maioria deles são desafios comuns nos jogos virtuais, como lutar com um monstro, ou estabelecer diálogo com um personagem, ou coletar o maior número de folhas de uma árvore antes de acabar o tempo determinado.

Por outra parte, o enredo ao redor do qual o jogo se desenvolve e dentro do qual os participantes constroem seu percurso, é o da bruxa Quelícera, uma menina morena que se torna malvada por causa da inveja que sente pela sua irmã Estrela, loira e bela, segundo o relato na animação que inicia o jogo. O jogo estabelece assim, uma visualidade que tradicionalmente associa as moças loiras ao bem e a beleza, enquanto as morenas representam o mal e a inveja. Ainda que o jogo faça referência a obras de arte, e a pesar da grande qualidade gráfica e visual do design, se pauta por uma visão acrítica da arte e da sua maneira de operar e se estrutura no modelo de certo e errado no processo do jogo, pois se limita a resolver quebra-cabeças das imagens.

Embora esses parâmetros e características pareçam se ajustar a um sistema digital e a um modelo cientificista há muitas possibilidades fora deles para a criação de OA. Se pensarmos em sistemas flexíveis, adaptáveis, customizados, atualizáveis, interativos estamos abrindo a 
possibilidade de uma dobra na direção da experiência estética. Ainda mais se considerarmos os formatos digitais, hipertextuais e multimediáticos como espaços fecundos para o trabalho com a cultura visual e atividades que promovam processos críticos e autoreflexivos.

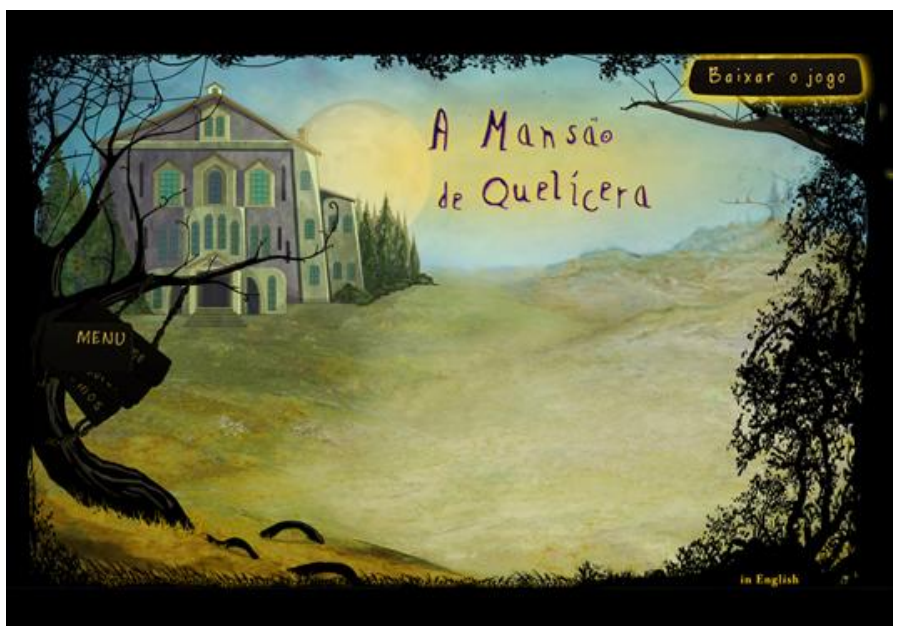

Fig. 72 Estúdio Casthalia, A Mansão de Quelícera, jogo interativo. Fonte: casthalia.com.br
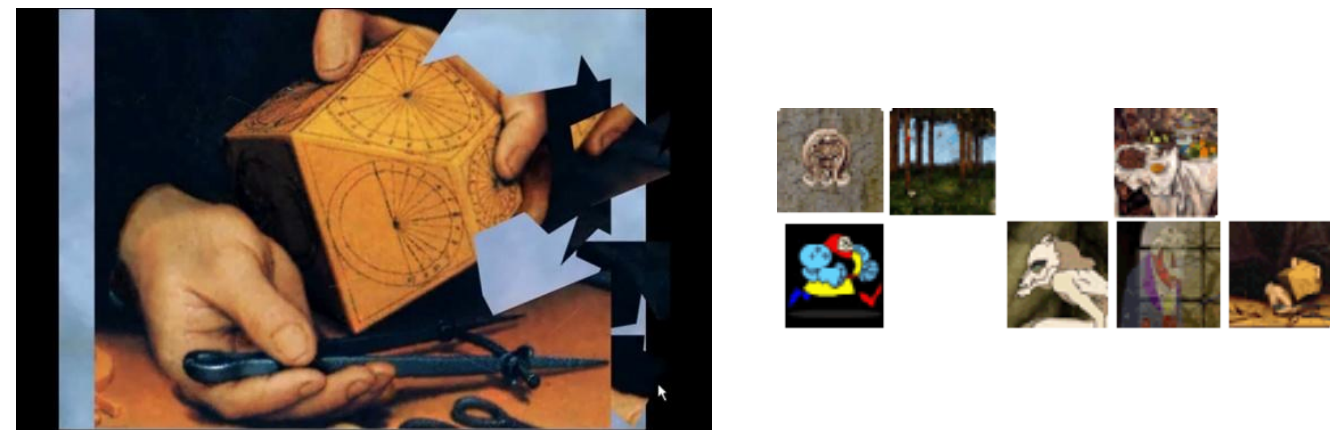

Fig. 73. Estúdio Casthalia, A Mansão de Quelícera, jogo interativo. quebra-cabeça em base ao Retrato de Nicolas Kratzer de Hans Holbein. Fonte: casthalia.com.br

Fig. 74 Estúdio Casthalia, A Mansão de Quelícera, jogo interativo. Ícones dos desafios. Fonte: casthalia.com.br
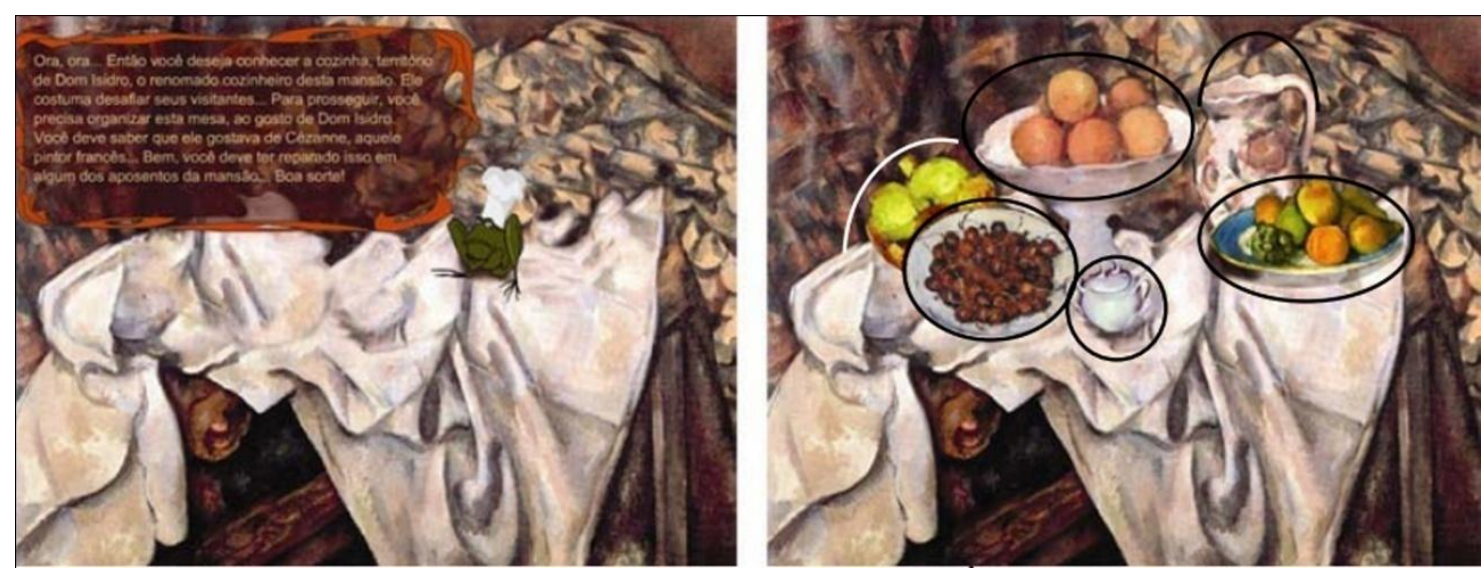

Fig. 75 Estúdio Casthalia, A Mansão de Quelícera, jogo interativo. quebra-cabeça em base a Natureza Morta com Maçãs e Laranjas de Paul Cézanne onde o jogador deve organizar os elementos da mesa que correspondem aos elementos da obra na ordem do quadro original. Fonte: casthalia.com.br 
Mas, além dos parâmetros e características, nesta investigação é importante considerar os usos e acima de tudo, a intenção pedagógica e poética, pois, como vimos antes, esses artefatos estão associados às políticas neoliberais na educação. Quando pensamos na equação econômica- pessoal- democrática, outros parâmetros e características se destacam porque servem a outras intenções e usos. Além do mais, quando são pensadas para o ensino das visualidades na linha das pedagogias culturais as possibilidades se ampliam. É necessário, então, inventar um novo conceito que possa denominar o espaço de apropriação, o novo território ocupado que está se tornando (becoming) no processo de aprender.

\subsubsection{Os Objetos de Aprendizagem Poéticos}

A minha relação com os OA é antiga. Já produzi muitos para os meus estudantes na Bolívia, entre 2004 e 2007 dentro da página web de história da arte que escrevi e produzi para eles ao longo de quatro anos. Além de produzir selecionei muitos OA para o ensino das artes visuais disponíveis na internet em bancos de OA para todas as últimas séries da escola primária (equivalente ao ensino fundamental no Brasil) e todas as séries da escola secundária (equivalente ao ensino médio no Brasil). Mas, o entendimento que procurava nestes artefatos que produzi para aprender me exigia uma posição de diferença. Alguns constituíram projetos colaborativos em longo prazo, outros, pequenas atividades de reflexão sobre imagens ou com imagens, mas todos mantinham aberturas a resultados singulares. Ao longo dos anos observei na minha sala de aula a forma como os estudantes se relacionavam com estes artefatos. Aprendi, entre outras coisas, que as relações entre os sujeitos e os objetos poucas vezes são iguais para todos. Essa experiência me levou a considerar as aperturas à diferença e à dissidência que não encontrava nos $\mathrm{OA}$ que ofereciam no mercado e que eu devia desenhar e produzir. Com essa familiaridade posso me apropriar do conceito e transformá-lo em OAP.

A experiência com estes artefatos é longa, mas a criação do termo OAP só se concreta no trânsito entre a arte e a educação no curso desta investigação, para uma das minhas aulas de História da Arte Contemporânea em 2012, no ensino superior. Trata-se de uma série de intervenções em livros de história e teoria da arte da biblioteca da Universidade de Brasília que pedi a meus estudantes pesquisar. Nas páginas indicadas para ler nos livros se encontram folhas inseridas no ritmo do discurso do autor, que imitam a diagramação e o estilo do livro, como se fossem uma página a mais. Neles, o texto e as imagens apresentam Domitila Huanca, uma artista impossível, com obras impossíveis para as condições que tem: indígena, vendedora de mercado e empregada doméstica, na terceira idade, vivendo em um povoado de 
fronteira no altiplano boliviano. As obras, que são fotografias e capturas de vídeos, não poderiam ser de uma artista nessas condições. São cenas que retratam figuras em tinta acrílica em espaços cotidianos da artista, como a cozinha, a roça ou a lavanderia.

Nesse ponto a intervenção contrasta com a narrativa coerente dos livros, de uma história que se escreve quase sempre sobre a mesma linha. Os textos que interferem nos livros funcionam como uma dobra: em certo ponto conveniente do livro a página inserida continua o discurso anterior, que é do autor, e faz uma bifurcação em direção do impossível. A contradição entre a situação impossível e a semelhança da configuração visual pode deixar o leitor incomodado. Essas peças foram apresentadas como experiência na aula de Poéticas Contemporâneas do Programa de Pós-Graduação do IdA na UnB, com o nome de History Intervention: Objetos de Aprendizagem Poéticos (Fig. 76 a 78). Depois, as páginas foram deixadas nos livros da biblioteca para ver se em algum momento do tempo/espaço criam uma camada de intriga na história da arte. Os leitores participantes podem se dar conta em certo ponto, que são páginas falsas e poderão se apoderar delas, rasgá-las ou intervi-las, mas tal vez, nunca saibam do que se trata. Eu não saberei além dos nomes na lista dos empréstimos, quem leu ou como interpretou estas páginas (filhas) ilegítimas da história da arte, mas também páginas (filhas) ilegítimas da educação. Esses artefatos de intervenção, pensados como objetos de aprendizagem poéticos, estão na base da forma em que capturo o evento artístico em colisão, contaminação, hibridação ou interseção com o evento pedagógico.

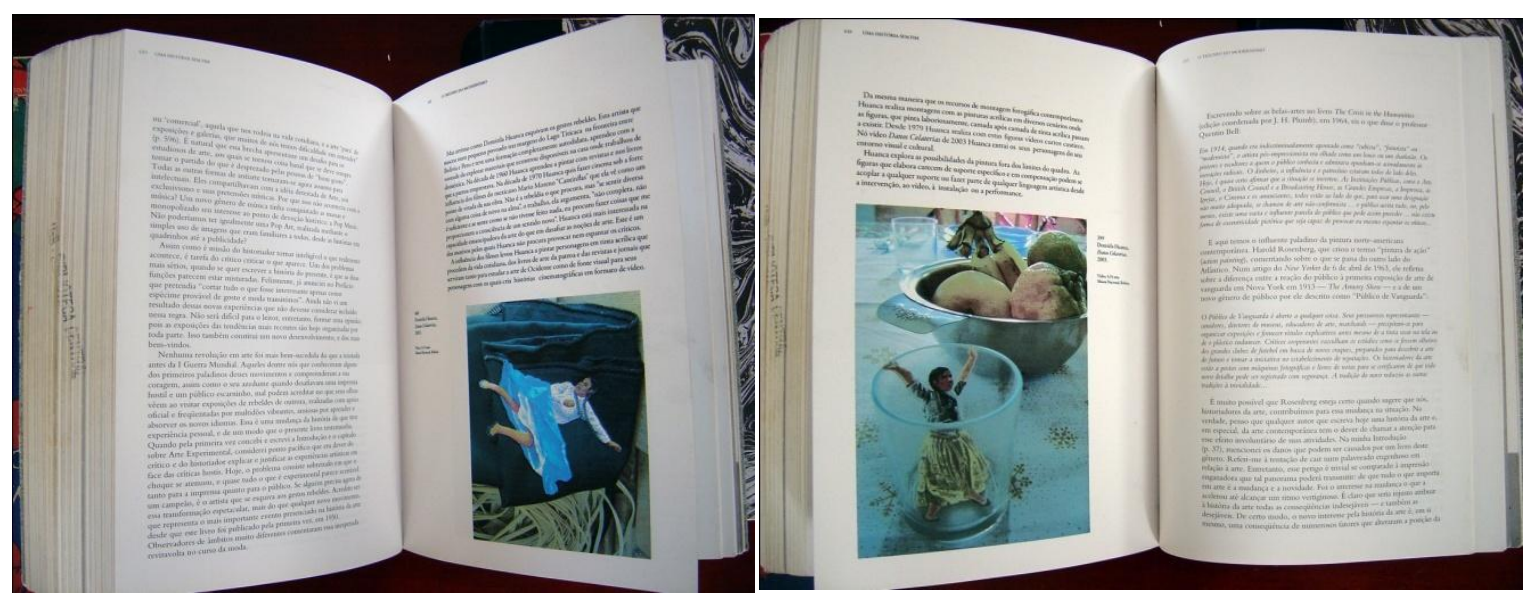

Fig. 76 Tatiana Fernández. Art History Intervention: Gombrich “A História da Arte”. Página inserida em livro da biblioteca entre páginas 610 e 611, № de chamada 7(09) G632s 16ed.=690L. UnB, Brasília, 2012.

Página ao lado e posterior imagem em tamanho original.

Fig. 77 Página 610;

Fig. 78 Página 611 
Mas artistas como Domitila Huanca esquivam os gestos rebeldes. Esta artista que nasceu num pequeno povoado nas margens do Lago Titicaca na fronteira entre Bolívia e Peru e teve uma formação completamente autodidata, aprendeu com a vontade da explorar materiais que econtrou disponíveis na casa onde trabalhou de doméstica. Na década de 1960 Huanca aprendeu a pintar com revistas e nos livros que a patroa emprestava. Na década de 1970 Huanca quis fazer cinema sob a forte influencia dos filmes do mexicano Mario Moreno "Cantinflas" que ela vê como um ponto de virada da sua obra. Não é a rebeldia o que procura, mas "se sentir diversa com alguma coisa de novo na alma”, o trabalho, ela argumenta, "não completa, não é suficiente e se sente como se não tivesse feito nada, eu procuro fazer coisas que me proporcionem a consciência de um sentido novo." Huanca está mais interessada na capacidade emancipadora da arte do que em dasafiar as noções de arte. Este é um dos motivos pelos quais Huanca não procura provocar nem espantar os críticos.

A influência dos filmes levou Huanca a pintar personagens em tinta acrílica que procedem da vida cotidiana, dos livros de arte da patroa e das revistas e jornais que serviram tanto para estudar a arte de Ocidente como de fonte visual para seus personagens com os quais cria histórias cinematográficas em formato de vídeo.

400

Domitila Huanca, Danos Colaterias, 2003.

Video, 5:35 min. Museu Nacional, Bolivia

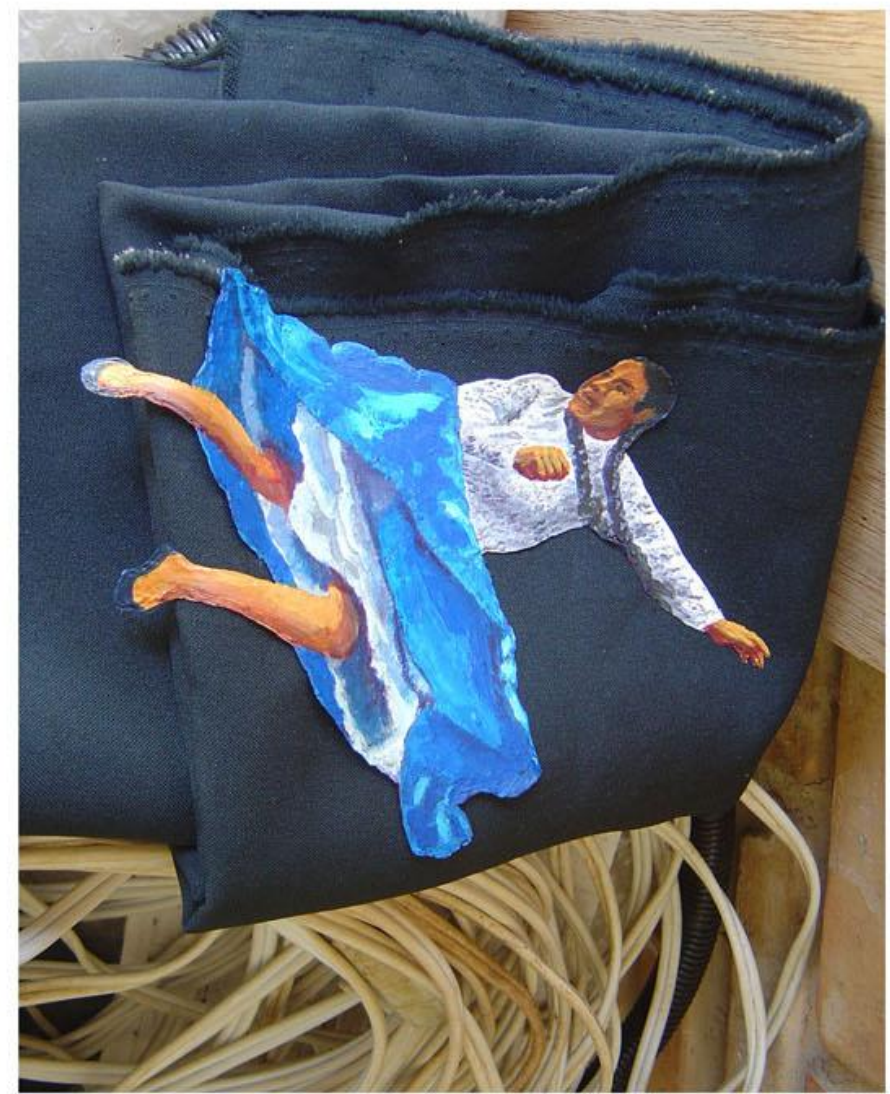


Da mesma maneira que os recursos de montagem fotogáfica contemporâneos Huanca realiza montagens com as pinturas acrílicas em diversos cenários onde as figuras, que pinta laboriosamente, camada após camada de tinta acrílica passam a existir. Desde 1979 Huanca realiza com estas figuras vídeos curtos caseiros. Nó vídeo Danos Colaterias de 2003 Huanca extrai os seus personagens do seu entorno visual e cultural.

Huanca explora as possibilidades da pintura fora dos limites do quadro. As figuras que elabora carecem de suporte específico e em compensação podem se acoplar a qualquer suporte ou fazer parte de qualquer linguagem artística desde a intervenção, ao vídeo, à instalação ou a performance.

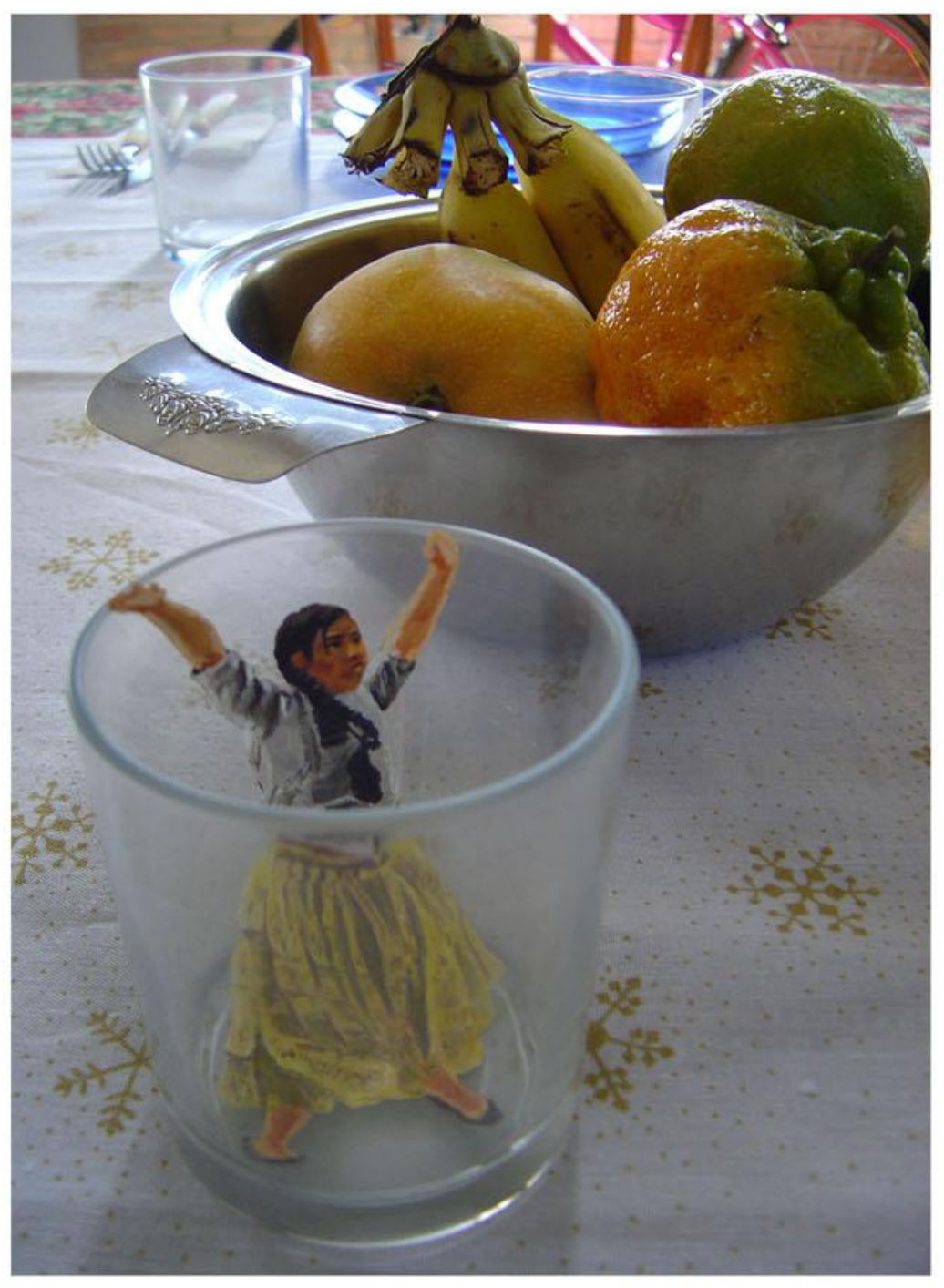

Danos Colaterias,

2003.

Vídeo, 5:35 min.

Museu Nacional, Bolivia 
A partir desse germe começo por analisar a denominação de OAP no aspecto epistemológico: como conhecemos o poético e sua diferença da práxis. Esse aspecto conduz nossa atenção para o que está além da intenção artística, isto é, o que é pós-humano ou inumano na poética. Os OAP vão além da práxis, que se refere ao fazer, ao método; mas também vão além da teoria porque se referem a algo que está fora do conhecido. Na contiguidade entre teoria/práxis/poiese, que constitui um dos pilares metodológicos desta investigação, é imperativo situar o sentido da poética como poiese e observar os riscos que ela apresenta. E é nesse sentido que aponto a investigação teórica no âmbito das pedagogias culturais: os desafios de uma pedagogia cuja direção é cruzar fronteiras e ocupar outros territórios a torna uma pedagogia de riscos.

Mas o risco é, para a poética, uma condição. Da mesma maneira que acontece com a noção de estética, associamos poética e arte, mas o caminho entre estes dois conceitos nem sempre foi contiguo ou relativo. Para os gregos a poética estava mais perto da filosofia ou da música (que era entendida em termos de canto do poema e dança). As artes estavam, para eles, ligadas a uma produção material, regida por regras e leis e a poética estava condicionada à inspiração de Apolo e das Musas. Em poucas palavras, a poesia não dependia da vontade do poeta nem estava sob seu controle. Inclusive viam a poesia como uma forma de profecia. Enquanto o poeta era então animado pelo espírito dos deuses, entregue ao que ele mesmo não conhecia, o artista era quem conservava o conhecimento dos antepassados, com um controle cada vez mais apurado e atualizado sobre sua prática. A palavra arte na origem é, assim, o domínio de um conhecimento através de uma prática que se aprimora a cada geração. Por este motivo arte era tudo aquilo que era feito (e não produzido) com excelência de técnica e esse era o abismo com a poesia. A diferença se dá também nas esferas sociais, os poetas eram mais admirados e respeitados que os artistas, e alguns deles, como Homero, eram reverenciados como semideuses. Somente na Idade Moderna com a visão da pintura como uma arte superior, prestígio alimentado no Renascimento, a poiese se acerca ao que os artistas almejam fazer. No final do período Barroco a pintura e a poesia se classificavam juntas entre as Belas Artes (TATARKIEWICZ, 1996) e já no século XIX e XX poetas e artistas plásticos compartilhavam movimentos artísticos.

Nas últimas décadas do século XX a poética começa a ganhar um espaço epistemológico nas artes visuais. A poética da imaginação de Gaston Bachelard (2000), que contribui nesta aproximação, está relacionada à imaginação criativa na perspectiva da filosofia 
fenomenológica. Richard Kearney observa que a poética fenomenológica de Bachelard "descreve a imaginação como uma interação perpetua entre o sujeito humano que imagina e a imagem em si" (1998, p. 97). Para Bachelard (2000) o problema da poética da imagem na filosofia é o da fenomenologia da imaginação. Embora o autor se refira às imagens da poesia, o seu pensamento teve forte influência sobre artistas contemporâneos que trabalham nas artes visuais, desde a década de 1960, com intervenções e instalações que tem foco sobre o espaço ou o evento. Bachelard é abrangente: "A poesia aparece [...] como um fenômeno da liberdade" (2000, p. 15) se referindo a um passado em que as artes poéticas codificavam as licenças e a um presente em que a liberdade é o corpo da linguagem. A ideia de liberdade na arte aparece na modernidade e com ela a poética nas artes visuais. Giulio Carlo Argan situa historicamente as poéticas visuais na Ilustração. Ele identifica a poética na intencionalidade romântica, em oposição à certeza teórica do clássico. O pensamento clássico, explica o historiador, implicava um modelo binário entre o modelo e a imitação. Com o surgimento da estética como filosofia da arte é questionado o dualismo entre teoria e práxis, ou intelectualismo e tecnicismo, e favorecida a "estrutura monista da poiese, isto é, do fazer artístico" (1993, p. 11) em que prevalece a autonomia da arte, que, nessa visão, não tem outro fim que si mesmo. Essa abordagem compreende a poética como práxis artística que contém todo o valor da arte. Assim, as poéticas artísticas estão na potência do sujeito de atuar sobre a matéria.

A ideia de poética nas artes visuais atualmente é associada às estratégias discursivas e à pluralidade e multiplicidade das linguagens e das narrativas nas artes visuais. Andre Severo, um dos curadores da $30^{\circ}$ Bienal de São Paulo de 2012, titulada A iminência das poéticas, define por poético "o repertório instrumental que permite a um individuo ou coletividade estabelecer de forma intuitiva, intencional ou inconsciente, estratégias e plataformas para atos discursivos" (FERNANDES, 2012, s/p). A poética se entende, portanto, como "aquilo que se expressa, que se cala, que se transforma e que ganha potência comunicativa por meio da linguagem das artes" (Ibidem). Nessa perspectiva se estabelece uma relação entre poiese e intenção comunicativa, ainda que não necessariamente linguística. Por outra parte, a poiese se entende como a articulação do repertório singular nos discursos da arte, que se movem entre as camadas de significação, tendo assim uma intenção semiótica. Nessas perspectivas, de uma forma ou outra, a poiese é pensada como a intencionalidade do artista. 
Diferentemente, Cauquelin identifica "Outra maneira de conceber, não mais o que é poético, mas uma poética: a arte poética, isto é, um conjunto de regras que circunscrevem um território singular cujos princípios estão postos e devem ser seguidos" (2008, p. 184). Esse território singular é o do espaço em que a poética acontece: a poética da cidade, a poética da interface (a que ela se refere), a poética da noite, da gravura, da fotografia ou de qualquer outro território. Nesse caso a poética não reside no sujeito, mas no território que subverte as prioridades, que tem uma poética própria.

Mas nesta investigação a poiese não é equacionada com as formas de operar da arte que se referem à práxis, nem com um conjunto de regras que circunscrevem territórios, mas com a possibilidade de ocupar novos territórios de subjetivação. Esse é o espaço do que está para ser. Isso significa que os OAP não são poéticos porque evidenciam um discurso, ou o discurso do autor. Nem se atentam a circunscrever o que poderia ser uma poética do pedagógico. São poéticos porque movimentam eventos.

Embora a poética nas artes visuais esteja associada à produção, criação e formação, estes são compreendidos nesta investigação na perspectiva de jagodzinski e Wallin (2013), na sua origem grega poiese, que é o ato de transformar e continuar o mundo. Entende-se, portanto, como um devir, um processo de vir a ser e não de algo já feito. O acento é sobre o que ainda não é. Os autores observam que, à diferença da práxis, que se refere ao fazer, a poiese "se refere ao descobrimento da verdade que não está conectada nem às considerações práticas nem à intenção voluntária" (Idem, p. 85). Portanto, não se trata do mesmo sentido de produção que concebemos no mundo ocidentalizado contemporâneo. E também não se trata do sujeito da arte, apontam os autores, "a poiese se refere à obra de arte como aparece sem um artista" (Idem, p. 104). Nesse marco conceitual os autores definem a poiese como pro-dução, ou seja, um tornar-se "que dilata o que é, no plano virtual do que pode ser" (Idem, p. 18, itálicas dos autores). A poiese é assim o que escapa á vontade do artista, ao seu controle,

[...] a conceituação clássica de poiese se refere a um fazer nascer, ou mais acertadamente, um trazendo à vida (bringing into being). Em contraposição a uma práxis estética de ação, entretanto, o se tornar poiético (poietic becoming) não se faz presente na obra [...] a pro-dução poiética não é o resultado do fazer. (JAGODZINSKI e WALLIN, 2013, p. 104, itálicas dos autores e parêntese nosso) 
Dessa maneira a poética é para os OA uma dobra perturbadora, da qual não se tem controle uma vez colocada em ação. Ela contém a possibilidade de um evento. A ação e sua experiência, que podem ser estéticas, se referem à prática, isto é, às metodologias, métodos, estratégias ou táticas $^{74}$ (Fig. 79). Mas a poética é o espaço da potência, "marca uma abertura de mundo em que pensamento e ação devem recomeçar diferentemente" (Ibidem). Por esse motivo a poética não pode ser uma representação, no ato poético não há criação de significado. Criar significado tem implícita uma intenção, mas jagodzinski e Wallin preferem pensar em uma in-tensão, (2013, p. 123). Isso tem riscos no caso de uma IBA: sendo que a poiese está entre os três pilares metodológicos nesta investigação, ela não pode se apresentar como fato consumado, qualidade intrínseca do artefato, espírito do artista, significante ou significado, estética ou método. A poética é o que não pode se manifestar, nem ser antecipado ou programado. jagodzinski e Wallin advertem que a IBA, e aqui estendemos a observação à IEBA, está

[...] necessitando uma maneira de pensar a arte que não se respalde na prática vital do artista. Pelo contrário, para que a investigação baseada nas artes permaneça politicamente carregada, deve orientar sua tarefa na criação de uma vanguarda capaz de detectar o evento poiético sem reterritorializá-lo dentro de uma imagem de pensamento a priori. Pelo contrário, a investigação em artes deve extrair da pro-dução poiética aquelas forças capazes de pensar em pessoas que estão por vir, ou melhor, pessoas sem imagem. (JAGODZINSKI e WALLIN, 2013, p. 106, itálicas dos autores)

Embora a poética seja o espaço da incerteza, estes são justamente os espaços que interessam às pedagogias culturais, como vimos anteriormente. Para a investigação são importantes, sobretudo, porque a poética é o espaço do indeterminado que alimenta a arte. Não poderiam, por este motivo, se tratar de Objetos de Aprendizagem Artísticos. O artefato deve permanecer em um plano indefinido para não "reterritorializá-lo dentro de uma imagem de pensamento a priori". Por outra parte, tanto a arte como a estética e a poética são conceitos relacionados, mas nem por isso intercambiáveis ou subordinados.

É nesse marco conceitual que a poiese, ou o poético, abre a possibilidade de uma pedagogia do evento: "o conceito de evento pode ser chamado de poiético na medida em que cada um se

\footnotetext{
${ }^{74}$ Aqui a distinção entre estratégia e tática é a que Certeau apresenta em A invenção do cotidiano (1998): estratégia é o calculo das relações de forças que se dão quando há sujeitos em "lugares capazes de ser circunscritos como próprios"e portanto podendo negociar com uma entidade externa, e tática é um "cálculo que não pode contar com um próprio, nem portanto com uma fronteira que o distingue do outro como totalidade visível. A tática só tem por lugar o do outro. A tática joga com os acontecimentos para os transformar em 'ocasiões'" ( p. 46).
} 
refere ao processo de surgimento de forças não pensadas" (Idem, p. 105-106, itálicas dos autores). Mas então como saber como e quando são OAP se não podemos programá-los?

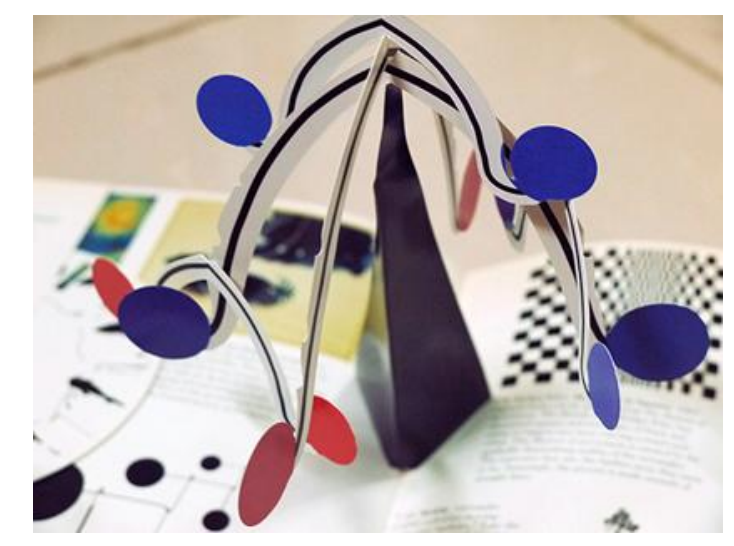

Fig. 79 Ron van der Meer, The Kids' Art Pack, páginas pop-up. Livro com atividades e objetos Fonte: vjjoson.com/

A poética nos OAP se refere a situações poéticas de aprendizagem. Isso requer aberturas que na educação conservadora são inconcebíveis. Considerando que a investigação se localiza em espaços de fronteira, a poiese que se lhes atribui se encontra no espaço do que está em transformação, do que ainda não é, ou do que ainda não se conhece. Nesse ponto é crucial observar que as aberturas ao que está em transformação não constituem um método porque não são controláveis. As aberturas são formas de operar na arte que provocam bifurcações. Essa é uma condição poética. O que se propõe, então, é deixar cinco aberturas por onde seja possível a experiência estética, à singularidade e pluralidade de subjetividades, a criação de territórios de subjetivação, a aparição da diferença e da dissidência e a imaginação. Essas cinco aberturas não garantem o que o participante possa fazer. Por isso não é um método. As aberturas só estabelecem espaços de emancipação, que são espaços ético-estéticos.

As cinco aberturas, no entanto, podem servir como parâmetros para pesquisar, para selecionar, para produzir e para avaliar objetos de aprendizagem poéticos. São aberturas que são possíveis de observar de maneira concreta, são possíveis de analisar e avaliar em diversas situações e em relação aos conceitos e investigações que nutrem as pedagogias culturais. São estas,

1) Abertura dos espaços de experiência estética: Os OAP são pensados em termos de experiências estéticas que requerem a corporificação dos processos de aprendizagem, mas vale ressaltar que, a experiência é algo a ser criado, não se situa nem fora nem dentro do sujeito, mas nas relações "entre". Sentir se refere a todo o processo que é intelectual, 
perceptivo e emocional em relação ao mundo (DEWEY, 2005). Os OA, de maneira geral, por serem objetos visuais e da visualidade, tendem a provocar experiências estéticas porque favorecem a interatividade e o envolvimento emocional, como acontece nos jogos. Mas, além disso, e diferentemente dos OA, os OAP abrem rachaduras por onde se faz visível aquilo que ainda está para ser, aquilo que pode provocar outras experiências (Fig. 79).

2) Abertura à singularidade e pluralidade das subjetividades, dos eventos e produtos de aprendizagem: à diferença dos OA que procuram resultados homogêneos e mensuráveis de acordo a um sistema de avaliação de qualidade onde se propõem parâmetros universais de OA, os OAP podem se propor de maneira que os sujeitos possam participar da sua construção e dos resultados e portanto, se manifestem na sua singularidade e em uma pluralidade de visualidades. Para isso é necessário que os OAP favoreçam ferramentas, processos, critérios e espaços em que os sujeitos da aprendizagem possam ser visualizados.

3) Abertura à criação de territórios de subjetivação: Os OAP se propõem como máquinas para criação de espaços de subjetivação com as quais os participantes possam experimentar outras formas de ser, de se relacionar e de produzir agenciamentos maquínicos. Os OAP devem incentivar a percepção da simbiose entre sujeito e objeto na experiência estética. A maior parte dos $\mathrm{OA}$ dirigidos às ciências mantém uma distinção entre sujeito e objeto através de formulações que ignoram as relações que estabelecemos em uma determinada realidade. Essa distinção impede a corporificação da experiência estética. Quanto mais homogêneos e programados são os resultados desejados de um $\mathrm{OA}$, menos possibilidade existe para a criação de territórios de subjetivação onde a diferença e da dissidência possam ser visíveis.

4) Abertura à aparição da diferença e da dissidência: Na sua estrutura básica os OA não favorecem a aparição das diferenças ou das dissidências. Pelo contrário, são, na sua maioria, impermeáveis às diferenças culturais, sociais, pessoais, de acessibilidade, de gênero, de ou de qualquer outra natureza, ou pior, perpetuam ou incentivam relações hegemônicas de poder. As dissidências, divergências, paradoxos ou aporias, que são as resistências e tensões, são ignoradas pelos OA porque não são possíveis de controlar ou medir ou porque desafiam o estabelecido. Nessas condições não há possibilidade de se movimentar eventos. Os OAP, à diferença dos $\mathrm{OA}$, se propõem visualizar aquilo que, na sua diferença e dissidência, se tornam evento. 
5) Abertura à imaginação: o espaço do encontro entre o sujeito e o objeto, entre o ser e o mundo é o espaço da imaginação. É o espaço que se abre ao que está por ser. É crucial reconhecer o papel da imaginação em percursos poéticos que se aventuram no que ainda não se conhece, na investigação do que é possível, e na criação de territórios de subjetivação. A imaginação deve ser o pivô de todo OAP como é, de certa maneira, também para a maioria dos OA no mercado. Os OAP, no entanto, não se limitam a proporcionar situações imaginárias, como a maioria dos $\mathrm{OA}$, mas precipitam o imaginário dos participantes.

Nessas bases os OAP podem condensar em si tanto qualidades dos OA, como aquelas que lhe são próprias e com elas constituir parâmetros flexíveis que orientem as possibilidades de caminhos para sua criação, uso e avaliação. Os OAP são, portanto, objetos especialmente pensados para reinventar e re-construir conhecimento que continuam a se transformar. Devem ser por este motivo objetos que provoquem novas formas de pensar e se relacionar com os conhecimentos. Pensar na construção de OAP já é, em si mesmo, um ato poético porque exige pensar nas dimensões em que acontece a experiência estética e pedagógica e tomar os riscos (Fig. 79).

Por outra parte estas aberturas constituem as dimensões em que são analisados os OAP criados pelos participantes no curso de extensão Objetos de Aprendizagem Poéticos (em itálicas e por extenso para se referir ao título do curso). Além destes parâmetros, são também usados aqueles que se estabelecem internacionalmente quando os critérios que se delimitam favorecem a perspectiva das pedagogias culturais.

Mas, me apropriar de um conceito e lhe dar forma não basta, era necessário criar diversas situações pedagógicas e isso requer de um espaço e de participantes. Nesse processo deve-se privilegiar uma triangulação entre as ideias, as formas e as situações. A abertura do curso para professores e estudantes das licenciaturas visou também a participação da comunidade na construção de metodologias mais situadas. Trata-se, então, de uma apropriação do conceito e do espaço pedagógico onde ele poderia ser possível.

\subsection{Apropriação: ocupação dos territórios pedagógicos}

$\mathrm{O}$ conceito de apropriação na arte se consolida no século $\mathrm{XX}$, primeiro em base às experiências das vanguardas modernas e posteriormente ao questionamento sobre as noções 
de autoria e originalidade apontadas pelos pós-estruturalistas, e na última década com as novas formas de edição, publicação e compartilhamento digital. A apropriação não é um método novo na arte, como os historiadores e artistas sabem, mas uma forma de operar que interessa no contexto contemporâneo em que o mito da originalidade é dissecado. Verwoert (2007), no entanto, observa que a noção de apropriação na arte tem diferentes momentos de acordo à situação histórica. Na história mais recente, na década de 1980 a apropriação na arte estava ligada ao discurso crítico e a um senso de estagnação, de interrupção histórica onde os artistas se apropriavam de material visual dos restos da história, uma história considerada morta. Mas, na década de 1990, argumenta Verwoert, os eixos temporais e espaciais mudaram de tal maneira que se apropriar de fetiches da cultura material hoje é "como saquear uma loja vazia momentos antes da destruição" (2007, s/p). Existem muitos eixos temporais e espaciais que hoje se entrecruzam,

O desafio do momento é, então, re-pensar o significado de apropriação em relação a uma realidade constituída por uma multiplicidade de temporalidades espacializadas. $O$ ponto de partida para tais considerações - e também a razão pela qual a apropriação continua sendo relevante como uma prática (artística) crítica- é o não pequeno, mas crescente poder da cultura da mercadoria capitalista para determinar a forma da nossa realidade cotidiana. A força que está sob a crença no potencial da apropriação é a esperança de que pode cortar uma fatia da substância da cultura da mercadoria para expor as estruturas que lhe dão forma em todas suas camadas. É também a esperança de que esse corte possa, pelo menos parcialmente, liberar a fatia de cultura material da segurança da sua lógica dominante e colocá-la a disposição de um uso diferente. (VERWOERT, 2007, s/p, parêntese do autor)

É nesse sentido que, a apropriação do conceito de OA para torná-lo um OAP, é um método de investigação que permite indagar nas camadas que se formam no encontro entre a virada da visualidade na educação e a virada pedagógica na arte. Evidentemente, não é possível indagar em todas as camadas que se formam e que se transformam constantemente, mas é possível analisar os traços visuais, os rastros de pensamento, as marcas das fronteiras e os cursos dos eventos que se imprimem nas construções que se fazem dos OA ou dos OAP.

Mas Verwoert (2007) também adverte que quem se apropria, o faz de algo que não é uma propriedade (legalmente constituída). Dessa forma se apropriar é, como reflete o autor, uma escolha consciente de que o objeto apropriado não será nunca próprio, porque não faz parte de uma propriedade. $\mathrm{O}$ artefato poderá ser apropriado e transformado por outros de igual 
maneira. A apropriação é, portanto, "invocar algo que vive através do tempo" (JAGODZINSKI e WALLIN, 2013, p. 114) antes que tomar para si.

Na perspectiva de Bourriaud "[...] a apropriação é a primeira fase da pós-produção: não se trata mais de fabricar o objeto, mas de escolher entre os objetos existentes e utilizar ou modificar o item escolhido segundo uma intenção específica" (2004, p. 22). Mas, a apropriação não se reduz a escolher, utilizar ou modificar. A metáfora de Barthes do "tecido de signos" (1984, p. 52) que se cria no imenso dicionário que é o mundo, nos ajuda a imaginar a apropriação como um processo intertextual, interligado de tal maneira que não é possível dizer onde começa e termina uma autoria. De maneira similar Bourriaud pensa que,

[...] agora todo artista se move numa rede de formas contíguas que se encaixam ao infinito. $\mathrm{O}$ produto pode servir para fazer uma obra, a obra pode voltar a ser um objeto: instaura-se uma rotação, determinada pelo uso dado às formas (BOURRIAUD, 2004, p. 41-42).

$\mathrm{Na}$ perspectiva dos estudos culturais Deborah Root (1998) contribui na discussão da perspectiva da apropriação cultural. Diferentemente da ideia de Bourriaud, que pensa a apropriação como uma escolha e modificação para diferentes fins, Root nos lembra que no caso da apropriação cultural as questões são mais complexas. A autora analisa a apropriação que o mercado faz do design nativo no Canadá e as consequencias para as culturas nativas. A partir desses estudos observa que a apropriação ocorre quando a diferença cultural se torna uma mercadoria, processo que ela denomina Mercantilização da Diferença (Commodification of Difference). Para ela, a apropriação não é uma partilha ou empréstimo "porque envolve tomar para si e mercantilizar as formas estéticas, culturais e recentemente espirituais de sociedade" (1998, p. 70). Assim, a apropriação pode ser vista como um roubo. Ela observa que "apropriação ocorre porque a diferença cultural pode ser vendida e comprada no mercado" (Idem, p. 68,). A apropriação nesse caso se entende como um "consumo de diferenças culturais que podem neutralizar a ambivalência que a diferença cultural pode gerar" (Idem, p. 69). Root encontra que o que vende é a ideia de autenticidade da diferença cultural, sendo que o desvio como mercancia destrói não só a pretendida autenticidade, mas a integridade das formas estéticas, culturais e espirituais.

Não podemos deixar de notar que a noção de apropriação na arte na era digital é parte de uma reação à superprodução de imagens, como pensa Bourriaud (2004) e às facilidades que surgem do acesso às tecnologias audiovisuais, edição, produção e publicação, mas também 
faz parte das estratégias de neutralização da diferença cultural, como pensa Root (1998), por parte das políticas capitalistas e colonialistas. A autora inclusive identifica os sistemas de poder econômicos como os únicos que exercem o poder da apropriação sobre outros sistemas sujeitos a este poder.

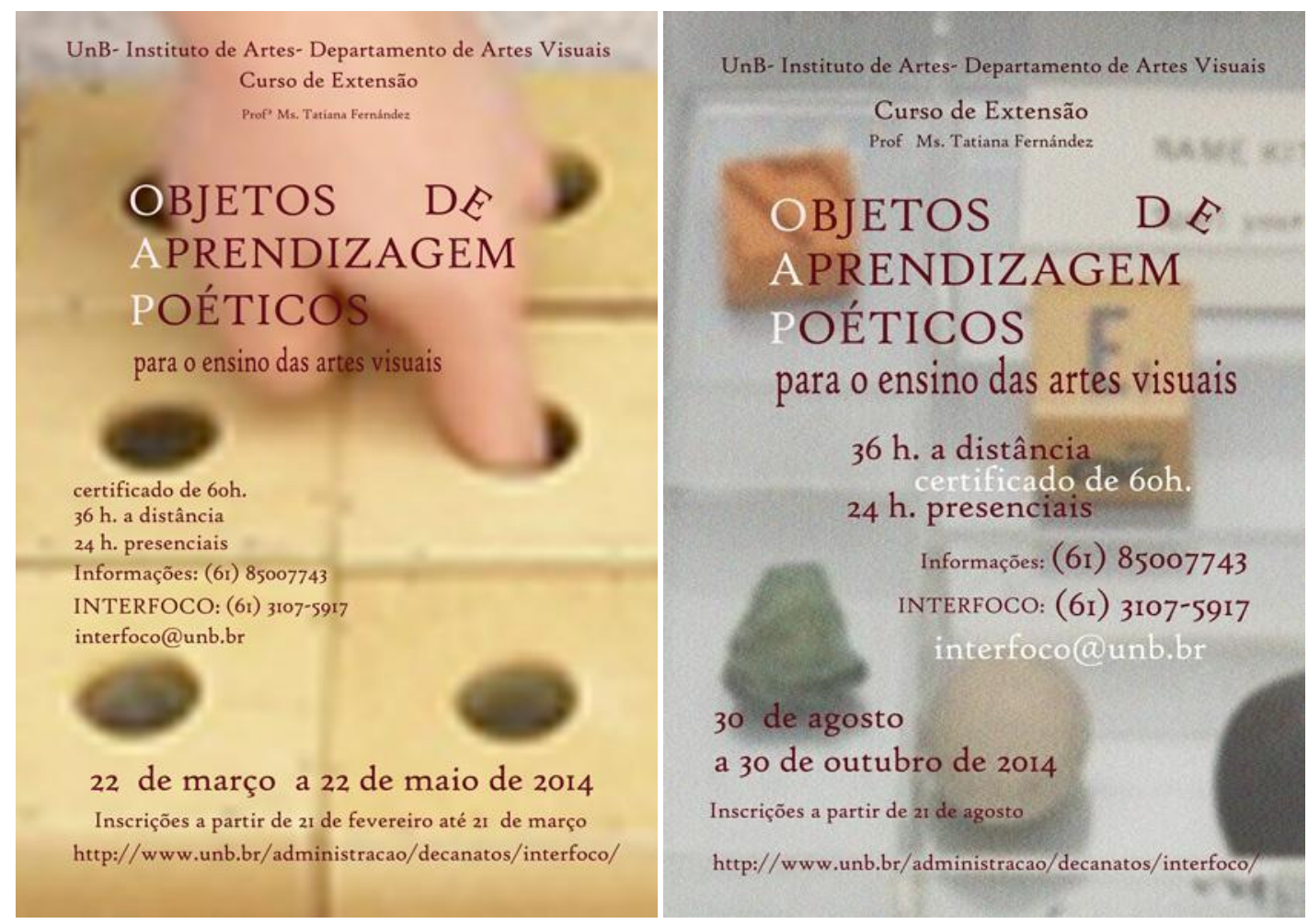

Fig. 80 Cartaz para curso de extensão Objetos de Aprendizagem Poéticos para sua segunda versão de 22 de março a 22 de maio. Criação com apropriação de fragmento de fotografia da 'Caixa de dedo' de Ay-O. 2014.

Fig. 81 Cartaz para curso de extensão Objetos de Aprendizagem Poéticos para sua terceira versão de 30 de agosto a 30 de outubro. Criação com apropriação de fragmento de fotografia da 'Kit do nome' do Fluxkit de 1965 de George Brecht, 2014.

Nesse sentido podemos argumentar que também os colonizados se apropriaram de diversas formas estéticas, culturais e espirituais dos colonizadores, muitas vezes como uma estratégia de resistência e muitas outras como uma forma de se relacionar com a nova situação. Para Michel de Certeau (1998) o uso que fazemos dos artefatos está ligado a um contexto (contexto de uso). A apropriação é parte de um processo maior no uso que fazemos dos artefatos ou da língua que inclui: "realizar, apropriar-se, inserir-se numa rede relacional, situar-se no tempo" (CERTEAU, 1998, p. 96) e por outra constitui um nodo entre outros que abrem uma rede de possibilidades de uso impensáveis e, portanto, de produção nova. Sobre as inversões de uso provocadas pelo consumo, Certeau argumenta que, 
[...] o espetacular sucesso da colonização espanhola no seio das etnias indígenas foi alterado no uso que delas se fazia: mesmo subjugados, ou até consentindo, muitas vezes esses indígenas usavam as leis, as práticas ou as representações que lhes eram impostas pela força ou pela sedução, para outros fins que não os dos conquistadores. (1998, p. 94)

Certeau identifica as mesmas táticas na cultura popular que se apropria da produção para consumo em massa nos diversos usos que lhes dá. A apropriação indica um uso, entre muitos, que podem surgir da situação. No caso que Root apresenta há uma diferença colonial ${ }^{75}$. No Canadá não houve hibridação cultural como aconteceu nas colônias espanholas e portuguesas. A apropriação nestas ultimas é uma forma de fazer e de viver um com o outro em constante antropofagia. E ainda devemos tomar em conta que na concepção indígena (americana) não há autores de ideias, nem donos de terras, nem proprietários de artefatos. O senso de comunidade é central e, portanto, o senso de autoria é comunitário. A apropriação é uma forma de viver com o outro como parte de um mesmo corpo.

Mas, um argumento resta nessa discussão que outorga a Root uma posição crítica: a apropriação, quando é entendida, como acontece no campo do ensino da arte, como uma releitura das obras de arte, em que se acrescentam algumas intervenções ou desvios como sendo uma atividade ao mesmo tempo criativa e reflexiva, o que acontece geralmente é que se neutraliza qualquer possibilidade de diferença do próprio leitor. A releitura não se desloca do próprio espaço/tempo, portanto não estabelece uma relação de diálogo em que ambos se transformam. "A arte não é um simples objeto para ser lido, mas uma força do que está se tornando que escapa territórios de uso e referência, A qualidade poética da arte é autônoma do artista, do professor ou do pesquisador" pensam jagodzinski e Wallin (2013, p. 98). A apropriação então deve envolver uma leitura ativa, isto é, um diálogo, uma conversação que requer envolvimento em outros espaços e tempos, e transformação não só do artefato apropriado, mas principalmente daqueles que se apropriam. Onde não há transformação não há apropriação, há subtração, deixando um espaço vazio. Apropriação requer uma soma, uma multiplicação, uma divisão, uma superposição ou uma hibridação.

Se compreendemos como Emerson de Oliveira que a apropriação na arte não é uma forma de se apoderar e reformular um artefato, mas "o 'consumo' cultural ou intelectual como uma forma de produção" (2010, p. 6, aspas do autor), que não suprime o autor nem o contexto em

\footnotetext{
${ }^{75}$ Termo usado por Mignolo (2012) para indicar as diferenças culturais entre colônias e entre períodos coloniais que produzem diferenças nas tensões que se estabelecem entre colonizadores e colonizados.
} 
que ele é produzido ${ }^{76}$, temos que pensar a apropriação como um diálogo entre o autor e o coautor, que, no mínimo, requer de uma compreensão do que foi apropriado, do contexto em que este foi produzido, e do que foi estudado sobre e produzido a partir dele. Isso significa que, como Oliveira aponta em referência ao historiador da arte Michael Baxandall,

[...] resumir, mais uma vez no caso da arte, tudo à influência ou à mera assimilação é esquecer-se que aquele que se apropria do passado não o faz apenas da obra ou do procedimento do outro, mas o faz por meio daquilo que já se escreveu, se interpretou, se criticou, se copiou etc., desses mesmos objetos e procedimentos. (OLIVEIRA, 2010, p. 7).

Essa perspectiva contribui na compreensão dos critérios com que se analisam os artefatos considerados OAP nesta investigação, porque proporciona um marco epistemológico para entender esses, como espaços de apropriação (e não de influência ou mera assimilação). Mas também para entender que se apropriar é estabelecer uma relação dialógica com o artefato apropriado e suas implicações situacionais. A relação entre os artefatos pedagógicos e os artefatos artísticos no final do século XIX e em todo o século XX é uma relação de apropriação, como vimos no capítulo IV, porque é uma relação de diálogo entre a arte e a educação.

A virada pedagógica na arte é de fato uma apropriação de matrizes pedagógicas para produzir eventos artísticos, mas são experiências, como aponta Helguera (2011b), claramente diferentes das experiências nas academias ou na educação formal. E os produtos são visualizados e valorizados somente na perspectiva do campo artístico. Não entram nas discussões do campo pedagógico. Acontece, como vimos, que os pedagogos poucas vezes se apropriaram de artefatos ou processos estéticos para os processos pedagógicos como o fizeram Rodríguez, Froebel, Maria Montessori e Dewey. Diferentemente, muitos artistas se apropriaram de artefatos e processos pedagógicos no século XX.

A apropriação, por outra parte, é compreendida nesta investigação na perspectiva de Mignolo (2012) como uma forma de pensamento de fronteira. Para o autor, a rearticulação e apropriação dos designs globais, que é o sentido do pensamento de fronteira, passa pela noção de cultura mundial , que ele toma da escritora e filósofa Hélé Béji para distinguir do conceito de cultura global onde o acento é sobre a ideia de civilização. A civilização para Bèji, destaca

${ }^{76}$ Oliveira se baseia nas ideias de Roger Chartier, em A História Cultural: entre práticas e representações, Lisboa: DIFEL, 1988. 
Mignolo, está ligada à modernidade, ao progresso e a tecnologia enquanto a cultura está ligada à tradição, às esferas da vida que a civilização tende a eliminar. Nesse sentido argumentar por uma cultura mundial frente a uma cultura global é favorecer o que é da cultura em relação ao que é da civilização. Rearticular e se apropriar dos designs globais, como é o caso dos OA, e usá-los em processos de emancipação na cultura mundial é um ato político, que, de diversas maneiras se relaciona à minha prática artística. Como artista boliviana da última década do século XX e começo de século XXI o espaço/tempo que ocupo é o de fronteira, onde a apropriação é uma estratégia necessária. Meu trabalho se da, como é com muitos artistas do continente, na rearticulação da experiência que acontece na tensão entre cultura e civilização. Para mim a apropriação é uma condição de vida e de trabalho. Com os OAP me aproprio de espaços abertos pela civilização para favorecer os espaços da cultura que a civilização tende a fechar (Fig. 82).

Em uma IEBA a apropriação artística como método visa a compreensão dos espaços pedagógicos ocupados onde possa ser efetivo um diálogo entre arte e educação. Por outra parte a apropriação tem um duplo movimento: pode se tornar um evento artístico porque atua como "dispositivo de existência que incluem métodos de trabalho e formas de ser, em vez de objetos concretos que até agora delimitavam o campo da arte" (BOURRIAUD, 2009, p. 145) e é ao mesmo tempo um método para ocupar os espaços pedagógicos de diferença e dissidência.

Para este estudo é importante ocupar o espaço pedagógico como espaço gerador do evento artístico, onde ele pode se tornar uma pedagogia em si mesma. É, portanto, uma apropriação em mão dupla em que, como artista, me aproprio do espaço pedagógico e, como educadora em visualidade, me aproprio das formas de operar da arte.

\subsubsection{O curso de extensão Objetos de Aprendizagem Poéticos}

O caráter poético dos OAP requer ir além da sua mera fabricação. E eles só tem sentido em contextos de aprendizagem. Assim sendo, os artefatos só podem ser de aprendizagem e ser poéticos na medida em que possam ser eventos artísticos como pedagogias onde os participantes têm um papel formador e produtor e onde existam possibilidades de novas conexões, novos territórios de subjetivação. O primeiro OAP criado para minha aula de História da Arte Contemporânea não teria consequências em longo prazo que eu pudesse registrar e estudar. Ele funciona como uma marca, um precedente para a conceituação dos 
OAP. Por outra parte era necessário, por uma questão metodológica, criar um espaço em que professores de arte pudessem experimentar e produzir para seu próprio contexto de maneira a multiplicar as experiências. A diversidade de participantes permite uma pluralidade de necessidades, interesses, abordagens, inquietações ou razões para conhecer Objetos de Aprendizagem Poéticos (Figuras 80 e 81). O curso se abre também à possibilidade do participante escolher entre realizar um $\mathrm{OA}$ ou um OAP, de acordo às relações que o participante quiser estabelecer com esses artefatos pedagógicos. Mas, isso também contribui na investigação, pois não se trata de prescrever fórmulas, mas de investigar o que acontece nos espaços que abrem caminhos potenciais na educação em artes visuais. $\mathrm{O}$ curso se propõe construir com os participantes ferramentas conceituais, metodológicas e técnicas que ampliem as possibilidades de se apropriar das formas de operar da arte na prática pedagógica do Ensino Básico. Por este motivo está dirigido principalmente a educadores em visualidade e estudantes das licenciaturas.

A minha investigação viva, no entanto, se dirige aos meus antigos estudantes da escola, que hoje são adultos. Mas, não são eles que participam, o tempo já se foi. Eles são o motivo da minha ocupação dos territórios da educação. É importante apontar que, no inicio da investigação, pensava realizar experiências diretas no espaço que é de interesse da minha indagação: os estudantes do Ensino Básico. Mas, minha atuação na formação de educadores em visualidade me proporciona um espaço em que posso observar a prática de diversos profissionais em diferentes contextos educativos de tal maneira que se amplia o campo para analisar e refletir sobre o evento artístico como pedagogia.

Outra razão para dirigir o curso a educadores em visualidade, é que o processo de investigação passa pela discussão das pedagogias culturais, pela análise dos artefatos (aqui entendidos como objeto/evento - matéria/duração) que tornam visível o espaço de hibridação entre arte e educação e pela reflexão sobre a identidade do educador em visualidade como artista/pesquisador/professor. O educador como criador, como propositor (MARTINS, 2006), não mais como explicador e transmissor de informação é central nas mudanças que se estudam e isso deve ser observado e debatido na investigação se tratando de uma pesquisa qualitativa que trabalha na tensão entre teoria, prática e poética. A diversidade de participantes do curso de extensão contribuiu com elementos diferentes para investigar as interseções entre arte e educação e abriu espaços de enriquecimento a todos, além da investigação em si (Figuras 83 e 84). 
A criação do curso de extensão Objetos de Aprendizagem Poéticos para o ensino das artes visuais é, assim, uma estratégia para explorar coincidências, contaminações, hibridações e/ou contiguidades entre arte e pedagogia. $\mathrm{O}$ curso teve três versões no formato semipresencial de 60 horas, de tal maneira que se estenderam certificados de participação com valor curricular de 4 créditos. O primeiro aconteceu entre 14 de setembro e 14 de novembro de 2013 com 5 participantes, o segundo foi realizado entre 22 de março e 22 de maio de 2014 com 12 participantes e o terceiro entre 30 de agosto e 30 de outubro de 2014 com 3 participantes, todas realizadas no Laboratório LIGO; Educação e Visualidade do IdA/VIS, UnB. As aulas foram $40 \%$ no modo presencial e $60 \%$ no modo a distância através da plataforma Moodle do Aprender $^{77}$. (Anexo I)

Os estudos, as investigações e as práticas pedagógicas que permeiam o curso de extensão se basearam em três dimensões teóricas: a dimensão pedagógica, a dimensão estética e a dimensão metodológica. A dimensão pedagógica seguiu a linha das pedagogias culturais e destacou os artefatos que cruzam fronteiras entre educação e arte. A dimensão estética se baseou no conceito de arte participante e a dimensão metodológica se baseou na ideia de prática transcognitiva.

Foram apontados dois objetivos gerais para o curso: proporcionar espaços para participar em OAP especialmente desenhados para professores de arte onde se abordaram questões das pedagogias culturais e proporcionar espaços para que eles pudessem criar seus próprios artefatos para o ensino das artes visuais dirigidos a contextos específicos de educação formal, não formal ou informal, aplicando e avaliando experiências. O modelo híbrido de encontros presenciais e a distância, exige ademais dos espaços físicos, espaços virtuais. Com esses objetivos e em razão dessa exigência foi construída uma página web (Fig. 85) onde foram dispostos os textos e imagens, os recursos e os OAP criados para os participantes. O ambiente da plataforma Moodle foi o espaço de sala de aula virtual onde se realizaram atividades de debate, exposições, onde se construíram as relações em comunidade e as conexões com a página web do curso e outros espaços virtuais. Trata-se então de uma estrutura de hipertexto e hipermídia conectada a um AVA que funcionou ao mesmo tempo como conector de outras estruturas hipermídia.

\footnotetext{
${ }^{77}$ Aprender é o nome do Ambiente de Aprendizagem (em diante AVA), do Decanato de Ensino e Graduação a Distância, DEGD- UnB.
} 


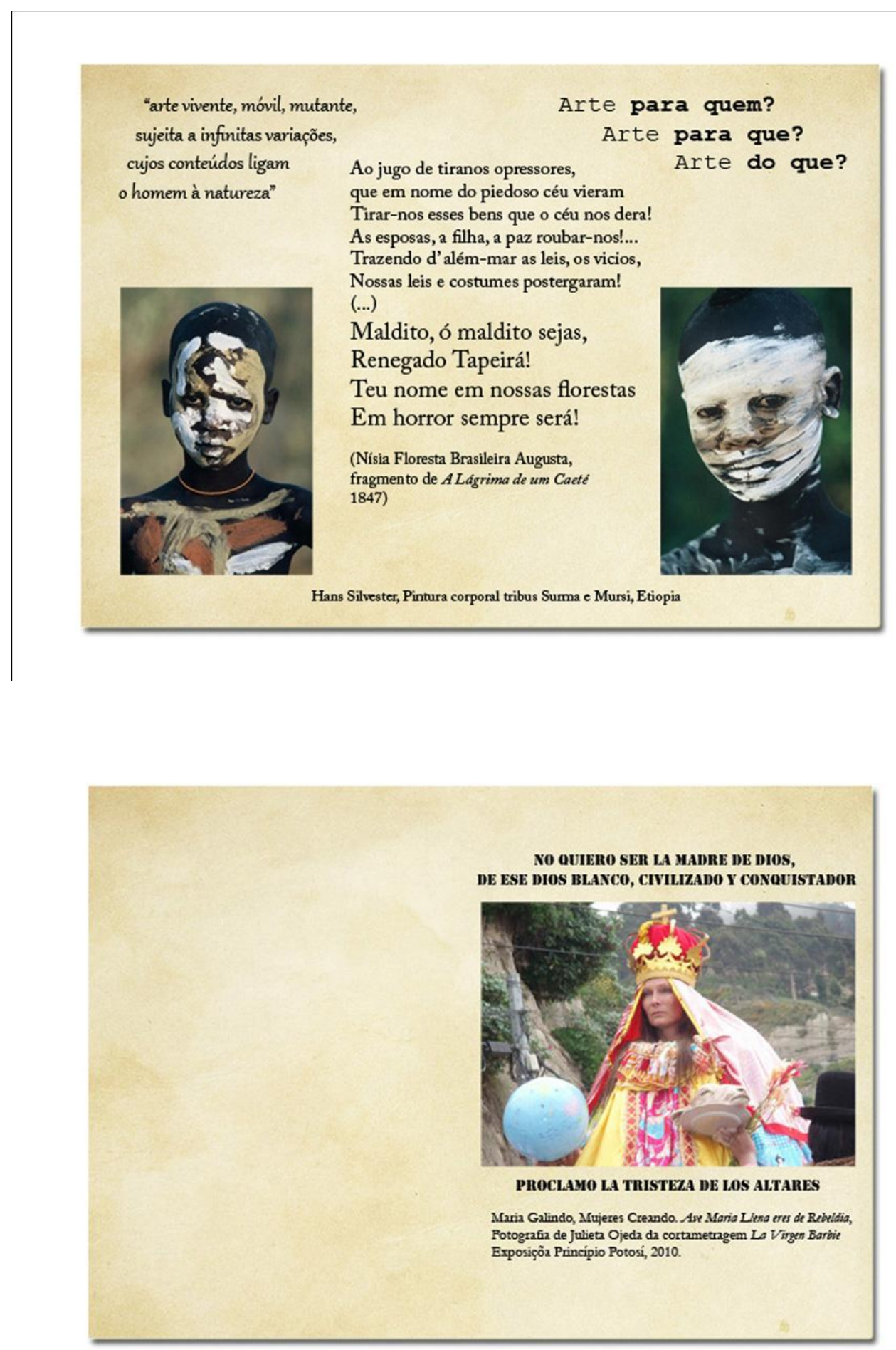

Fig. 82 Tatiana Fernández. Carta 7, frente e verso. Jogo Enigma. Objeto de Aprendizagem Poético. Curso de extensão OAP. VIS/IdA/UnB, 2013-14.

A página web do curso Objetos de Aprendizagem Poéticos, que constitui em si mesmo um $\mathrm{OA}$, se divide em quatro capítulos, correspondentes às quatro fases do curso:

I. O que são OAP? 


\section{Explorar OAP}

\section{Desenvolver OAP}

\section{Avaliar OAP}

A primeira fase e capítulo aponta à observação dos traços visuais e fundamentos conceituais do que são os OA e do que poderiam ser os OAP. Evidenciam-se nessa fase as dificuldades que os OA representam para o ensino das artes visuais quando são pensados dentro dos modelos para as ciências. Observam-se artefatos criados por pedagogos e artistas que cruzam as fronteiras entre arte e educação e as tensões que existem entre as subjetividades de artista e professor de arte. Essa fase contou com 4 horas presenciais no curso onde se dava o primeiro contato com os participantes. $\mathrm{O}$ tempo dedicado a esta primeira fase foi curto, mas atendeu à necessidade de dar maior tempo às fases de experimentação, desenvolvimento e avaliação. A página conta com um texto hipermídia central conectado a outros textos, imagens e diversos recursos. Os participantes têm a página à disposição para aprofundar no espaço teórico de maneira autônoma durante e depois do curso.

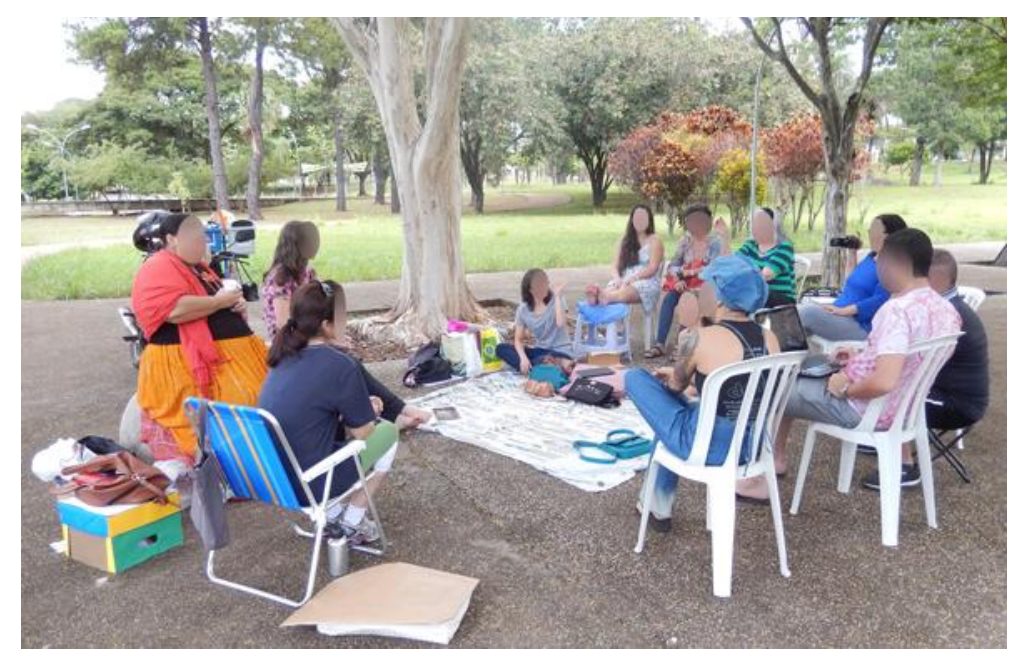

Fig. 83 Curso de extensão Objetos de Aprendizagem Poéticos. aula pic-nic da segunda versão, UnB. 2013-2014. Fotografia Denise Munhoz e Tatiana Fernández

A segunda fase, que corresponde ao segundo capítulo, teve duração de 24 horas e ofereceu um panorama de quatro plataformas em que os OA e OAP podem ser potenciais para o ensino das artes visuais: as mídias e meios contemporâneos, a investigação, o jogo e a participação. Em todos eles se proporcionam exemplos de OA disponíveis em bancos de OA do Brasil e outros 
países. Nesse panorama se identificam também os raros OAP disponíveis para o ensino das artes visuais no Brasil (e no mundo) e se traçam analogias com a forma de operar da arte por meio da observação de artefatos artísticos. Esse capítulo tem muitos exemplos com acesso a leituras, tutoriais, ferramentas e bancos de OA, de maneira que é muito difícil ver, ler, estudar tudo que é elencado entre os recursos no tempo do curso. O participante deve escolher um percurso próprio. Mas, sendo que a página web do curso Objetos de Aprendizagem Poéticos tem a intenção de permanecer no ar durante anos, se transformando e crescendo, os participantes podem continuar pesquisando no futuro. No caso do curso, os participantes foram orientados a selecionar o que lhes interessava. Se quisessem aprender a fazer vídeos interativos, por exemplo, contavam com recursos para edição de vídeo, tutoriais para se iniciar na produção de vídeos interativos, para entender como funciona e os conceitos que se projetam neles, conhecer artistas que trabalham com essa linguagem, etc.

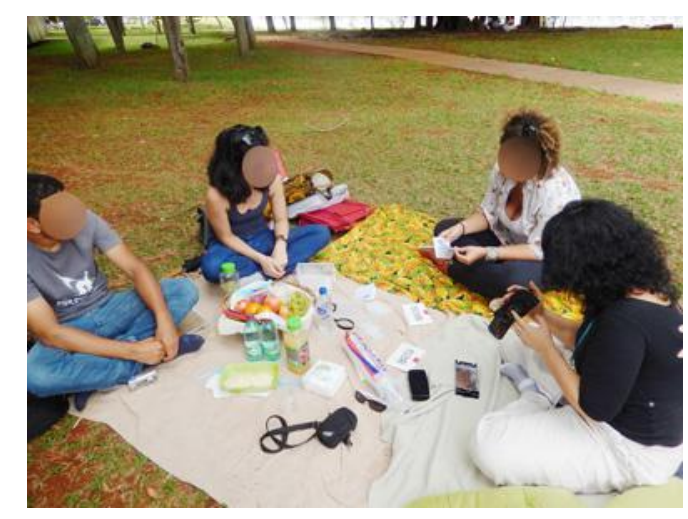

Fig. 84 Curso de extensão Objetos de Aprendizagem Poéticos. Acima esquerda: aula pic-nic da terceira versão. Acima direira: jogo na aula presencial da segunda versão. Embaixo: aula da terceira versão no prédio das Artes Cênicas, UnB, 2014. Fotografia Tatiana Fernández.

Estas plataformas respondem a diversas necessidades pedagógicas na educação em visualidade, mas também às formas de operar dos artistas na sociedade:

a) A plataforma das mídias contemporâneas. As mídias e meios contemporâneos produzem uma mutação nas formas como nos comunicamos e consequentemente em como pensamos. Os artefatos podem explorar o uso dessas mídias e meios em formas de apresentar informações ou formas de interagir com elas, as possibilidades vão dos impressos aos hipermídia, do texto à imagem em movimento e áudio, até o uso de meios e tecnologias antigas e modernas como é o caso das animações. As ferramentas 
e interfaces são múltiplas e estão ao alcance de muitos. As preocupações com a apresentação de artefatos, ideias, conceitos, conteúdos ou informações são tão importantes para artistas como são para professores e investigadores. Tanto o artista como o professor devem pensar como vão estruturar, construir, produzir, apresentar ou veicular seus artefatos e de que maneira avaliar as relações que o público ou os estudantes vão estabelecer com esses. Os artefatos são os que vão estabelecer relações com o participante mediados pelas formas em que se dispõem no espaço/tempo. A virada da visualidade na educação nos obriga a pensar não só na imagem, mas na mídia que a suporta, porque muda a situação em que nos relacionamos com os artefatos da visualidade.

b) A plataforma investigativa. A investigação também condensa qualidades que são tão valiosas para a arte como para a educação. Mas é importante observar que no tempo/espaço que ocupamos mudam as formas de investigar. Novas vantagens, mas também desafios novos se projetam com as TIC. Estamos apenas na madrugada das tecnologias que estão revolucionando a forma como construímos o conhecimento. A direção não é mais sobre a acumulação de informação, mas sobre saber procurar, selecionar e, sobretudo, saber o que queremos fazer com o que sabemos. Os artefatos que se propõem com dispositivos de investigação provocam práticas que identificam, mapeiam, interpretam, aprofundam e criam novas posições na visualidade.

c) A plataforma participativa. Os artefatos que privilegiam os processos participativos na construção do conhecimento promovem processos democráticos porque trazem neles a singularidade/pluralidade, a diferença e sua posição. Os OA que atuam como dispositivos de participação favorecem práticas que corporificam, porque se estabelece em relação a uma situação e à existência dos participantes. Nesse caso o artefato se coloca no tempo/espaço do evento. Os OAP de participação são aqueles que procuram espaços comunitários de construção e agência. É uma plataforma usada por artistas contemporâneas que trabalham com arte participante ou Estética Relacional. Na educação é também conhecida como aprendizagem colaborativa. Os processos colaborativos, ou como se prefere nesta investigação, processos participantes, baseiam-se na ideia de que o conhecimento só se constrói no "ser com o outro". 
d) A plataforma lúdica. A dimensão lúdica evidencia muitas qualidades apreciadas tanto na arte como na educação: o lúdico condensa na sua estrutura a imaginação, a emoção e os sentidos de tal forma que se corporificam as experiências. O jogo também coloca sua atenção sobre os participantes, antes que sobre os autores. Só faz sentido quando alguém participa. Por isso os OAP lúdicos são sempre participativos, além de poder ser investigativos, ou como forma de apresentar ou interatuar com certas informações, ideias, conceitos, conteúdos, etc. Os OA ou OAP que envolvem jogos podem ter diversas orientações: podem ser para apresentar e interatuar, podem ser para provocar investigações ou para promover a participação em uma ação. Mas, geralmente favorece várias dessas orientações ao mesmo tempo. O lúdico é para os OA, uma qualidade antes que uma plataforma de criação, uso ou avaliação, mas devido ao interesse crescente que existe ao redor dos jogos na educação e na arte, era necessário criar um espaço específico para os OAP e os jogos porque eles favorecem uma experiência entre, através, dentro e sobre o papel do espectador, da situação e do artefato.

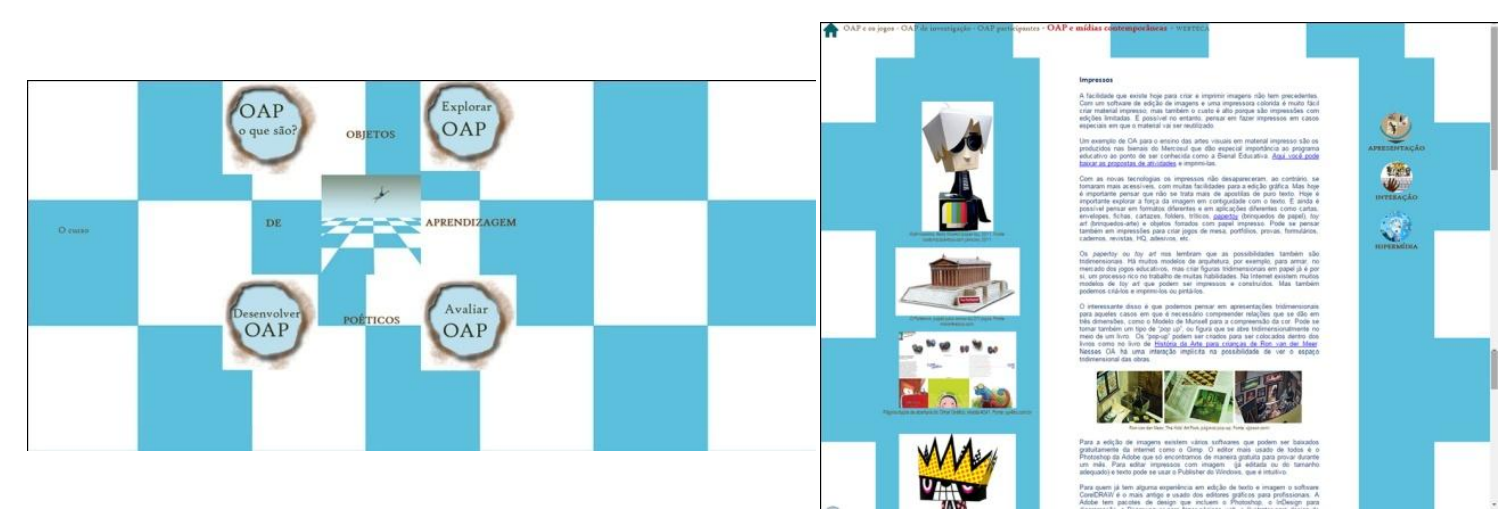

Fig. 85 Página web Objetos de Aprendizagem Poéticos. Início e Capítulo 2. Tatiana Fernández, 2012.

Por outra parte, na segunda fase do curso, os participantes escolheram um dos OAP disponíveis no capítulo II criados epecialmente para eles com temas relativos às pedagogias culturais. Entre eles o mais explorado foi o HQ 'Controle de Danos' (Fig. 87) em que o participante estabelece uma conversação com teóricos e com o autor do artefato. Cada participante teve uma relação diferente com o discurso dos teóricos apresentados no artefato. As cartas dos 'Enigmas' também foram exploradas com intervenções de imagens e textos (Fig. 88 e 89), o jogo 'Conexões' teve resultados interessantes em termos de debate, o Webquest foi realizado e o vídeo Imagens Cegas foi produzido com o desafio performático 
dos 'Corpos que Olham' (Fig. 86). Esses artefatos foram criados considerando aberturas à experiência estética, à imaginação, ao singular e plural, à criação de espaços de subjetivação e espaços para o diferente e o dissidente. Foram desenhados para um participante que vai conhecer, questionar, se posicionar, criticar, refletir e criar. Eles proporcionam ao participante a oportunidade de se envolver com a teoria, a práxis e a poiese na própria experiência de se relacionar com os artefatos e fazer isso de uma maneira muito particular.

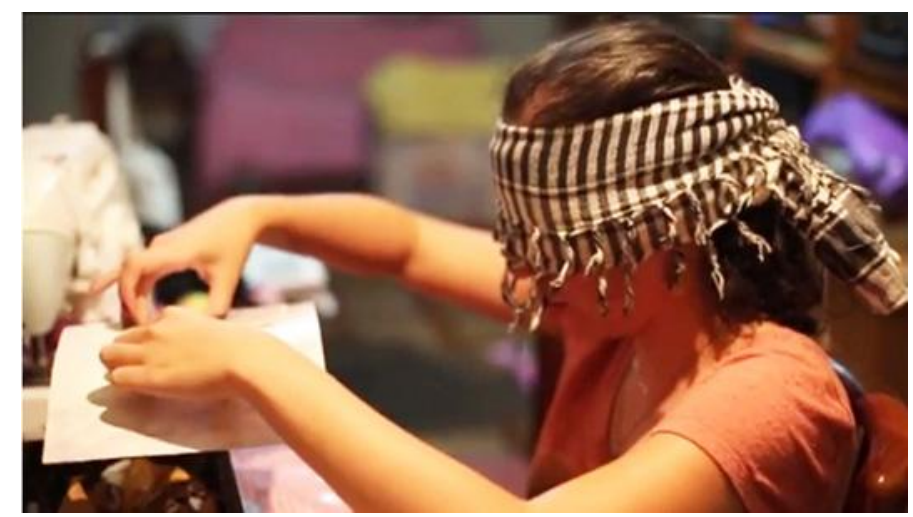

Fig. 86 Participante ' $B$ ', OAP 'Imagens cegas' produzido no âmbito da primeira versão do curso de extensão Objetos de Aprendizagem Poéticos, VIS/IdA/UnB $2^{\circ}$ semestre de 2013. Still de vídeo.

Na terceira fase, relativo ao capítulo III, e com duração de 16 horas, os participantes foram chamados a criar seus próprios artefatos. O capítulo oferece parâmetros de avaliação que orientam a qualidade para a educação. Nele também se dispõem métodos e estratégias de produção para criar OA e/ou OAP, entre os quais o modelo ADDIE; o modelo Sophia da Universidade do Vale do Itajaí, UNIVALI; o modelo Lavirt; o modelo Rived; a metodologia projetual de Bruce Archer; o método $5 \mathrm{~W}+2 \mathrm{H}$; a metodologia de Bruno Munari e se propõe um método simples para a ocasião: uma fase de planejamento, outra de desenvolvimento das ideias e uma final de aplicação que contempla a avaliação. Nessa fase os participantes receberam na plataforma Aprender, por meio de fóruns que se estruturaram para o curso, o suporte técnico para o design e a construção dos artefatos, mas também o suporte pedagógico no que se refere a questões conceituais e metodológicas no ensino das artes visuais.

Os participantes desenharam e construiram seus OA ou OAP de acordo ao contexto de educação em que estão inseridos ou com quem planejavam experimentar. Podiam trabalhar de maneira individual ou coletiva. O processo de cada um foi orientado nos fóruns onde a coletividade proporcionou uma ajuda valiosa no processo pessoal. Nessa fase foram 
programados dois encontros, um para limar dúvidas na produção e outro para apresentar o artefato.
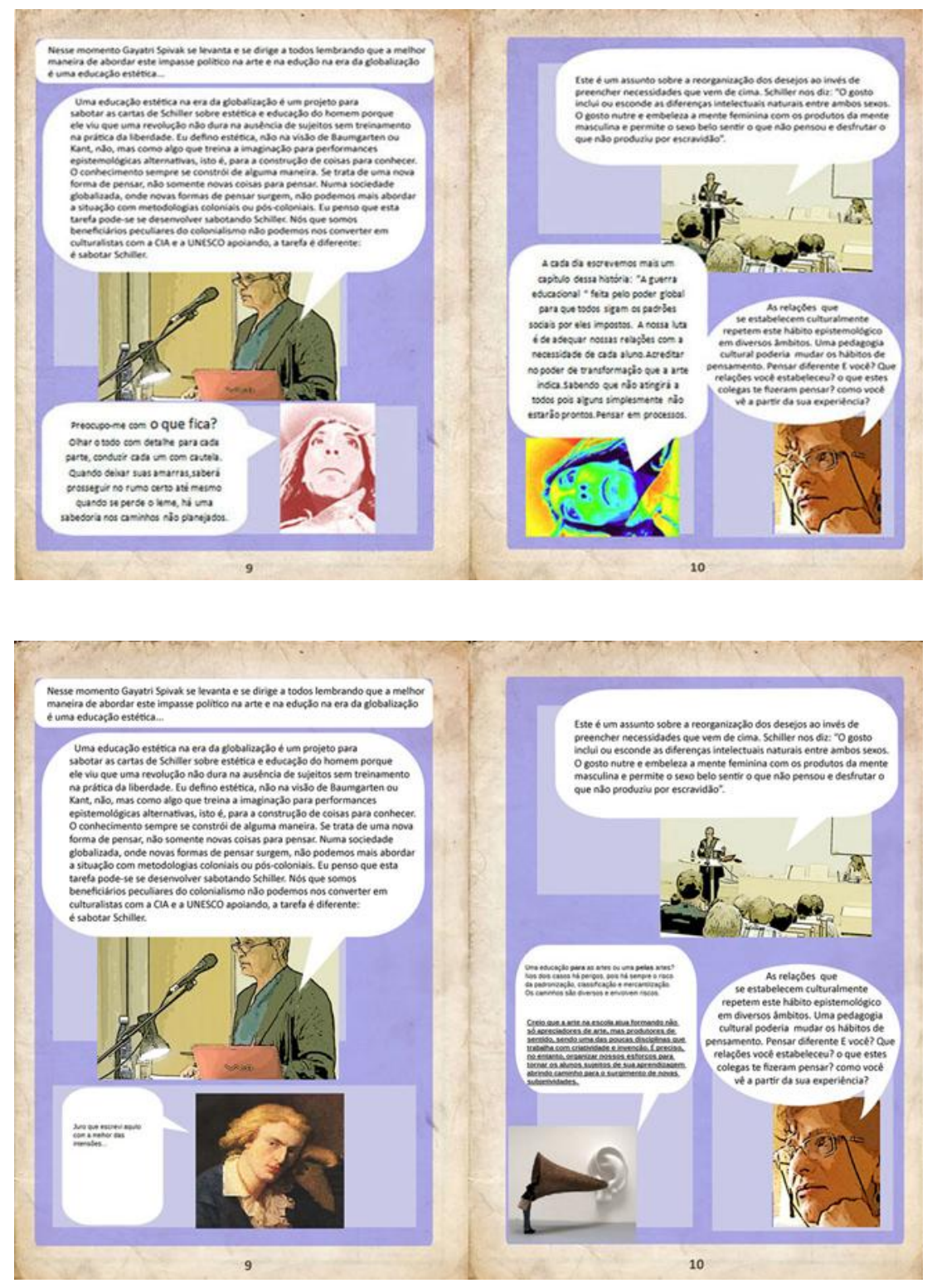

Fig. 87 Tatiana Fernández e Participantes. História em Quadrinhos Controle de Danos' páginas 9 e 10. Objeto de Aprendizagem Poético. Curso de extensão de Objetos de Aprendizagem Poéticos, VIS/IDA/UnB, 1\%semestre 2014. Intervenção sobre conferências de Henry Giroux, William Pinar, Anton Vidokle e Gayatri Spivak com tradução livre, edição e adpatação de Tatiana Fernández com a participação dos cursistas estabelecendo um diálogo fictício e real ao mesmo tempo.

A quarta fase, relativa ao capítulo final sobre avaliação, tem duração de 16 horas. Esse espaço de tempo foi planejado para que os participantes pudessem estender suas práticas no ambiente de educação, fazer observações, registrar, analisar e, se fosse necessário, fazer modificações. No final dessa fase os participantes apresentam uma avaliação final dos seus artefatos em um 
encontro presencial. Depois disso os participantes elaboraram um pequeno ensaio sobre a experiência do curso e o avaliaram. No último encontro presencial, os resultados forma apresentados e um espaço de exposição foi criado para manter estes artefatos visíveis.

Os fóruns que se criam em cada fase são espaços importantes de discussão onde acontece a maior parte do curso. Esses espaços tomam a forma de conversações escritas muito similar às conversações nas redes sociais. Nessa dinâmica de conversações virtuais e encontros presenciais os assuntos vão tomando a forma dos artefatos. A conversação é uma estratégia para tornar visíveis os processos de construção do conhecimento que são ao mesmo tempo individuais e coletivos. Mas para dar contexto às conversações é vital conhecer antes, o papel dos participantes nesse processo.

\subsubsection{Os participantes}

No contexto dos OAP aqueles que participam do processo, são chamados de participantes. Podem ser estudantes, diletantes, público, pesquisadores ou professores, não há diferenças, quando participam de um OAP, são participantes. A denominação presupõe a emancipação de todos os envolvidos no ponto de partida porque compreende o participante como um sujeito agente (RANCIÈRE, 2011) em todo o processo. A participação distingue uma apropriação, no sentido mencionado acima e, por definição, se propõe uma partilha do sensível como invoca Rancière $(2005,2009 b)$ porque não há restrição à diferença ou à dissidência, nem uma divisão pressuposta de poder. Por outro lado, a noção de participante sugere uma relação entre o sujeito e o artefato (que pode incluir uma situação) do qual participa. Isso sugere que podemse criar agenciamentos maquínicos. Nesse sentido os participnates são o território do evento artístico como pedagogia, o território do evento híbrido. Como efeito, quando se trata de OAP, a identidade do participante é ao mesmo tempo de estudante/espectador/produtor.

A noção de participação está também relacionada à arte participante (BISHOP, 2006, 2012; SUASSUNA, 2008), à Estética Relacional (BOURRIAUD, 2009) e, evidentemente, às preocupações democráticas das pedagogias culturais como vimos antes. O papel do público em relação à arte foi muito variado de acordo ao conceito de arte e artista em cada tempo e lugar. Como vimos no capítulo III, o papel do público é cada vez mais, hoje, o de co-produtor e produtor de visualidade. Rancière se refere a esta mudança como a emancipação do espectador. Para ele, a emancipação é o "apagamento do limite entre aqueles que atuam e aqueles que olham, entre os indivíduos e os membros de um corpo coletivo" (2011, p. 19). 


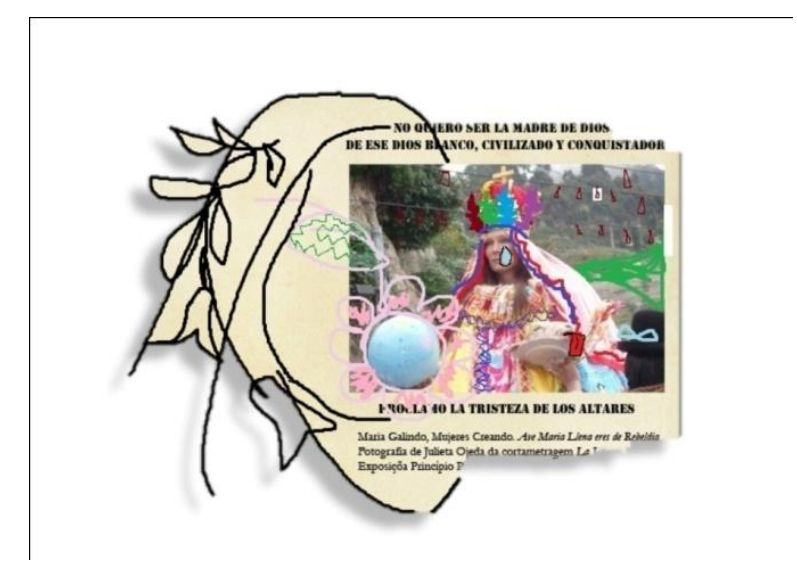

Fig. 88 Participante ' $Q$ '. Intervenção em carta 7. Jogo Enigma. Objeto de Aprendizagem Poético. Curso de extensão OAP. VIS/IdA/UnB, $1^{\circ}$ semestre 2014.

A concepção do espectador como um participante da obra é uma procura moderna, especialmente no âmbito do teatro, mas, na perspectiva de Rancière (2011) podemos considerar que inclusive o expectador considerado passivo pelas teorias críticas, é de muitas maneiras um participante ativo na reconstrução subjetiva da sua leitura do mundo, com consequências práticas e concretas na sua vida. Podemos afirmar como Rancière que os artistas contemporâneos não querem 'instruir' o espectador. Podemos afirmar a mesma coisa de muitos pedagogos contemporâneos, que não querem 'instruir' o estudante: "Eles simplesmente querem produzir uma forma de consciência, uma intensidade de sentimento, uma energia para a ação" (Idem, p. 14). Nessa perspectiva tanto os artistas como os professores são criadores de situações, não instrutores. Esse espectador, que agora é um participante, é uma das partes mais importantes de um evento artístico em que se cria uma situação. Ou mesmo quando são os espectadores que criam a situação a pedido do artista, é sempre a parte da dobra que constitui o evento artístico e agora o evento pedagógico. 

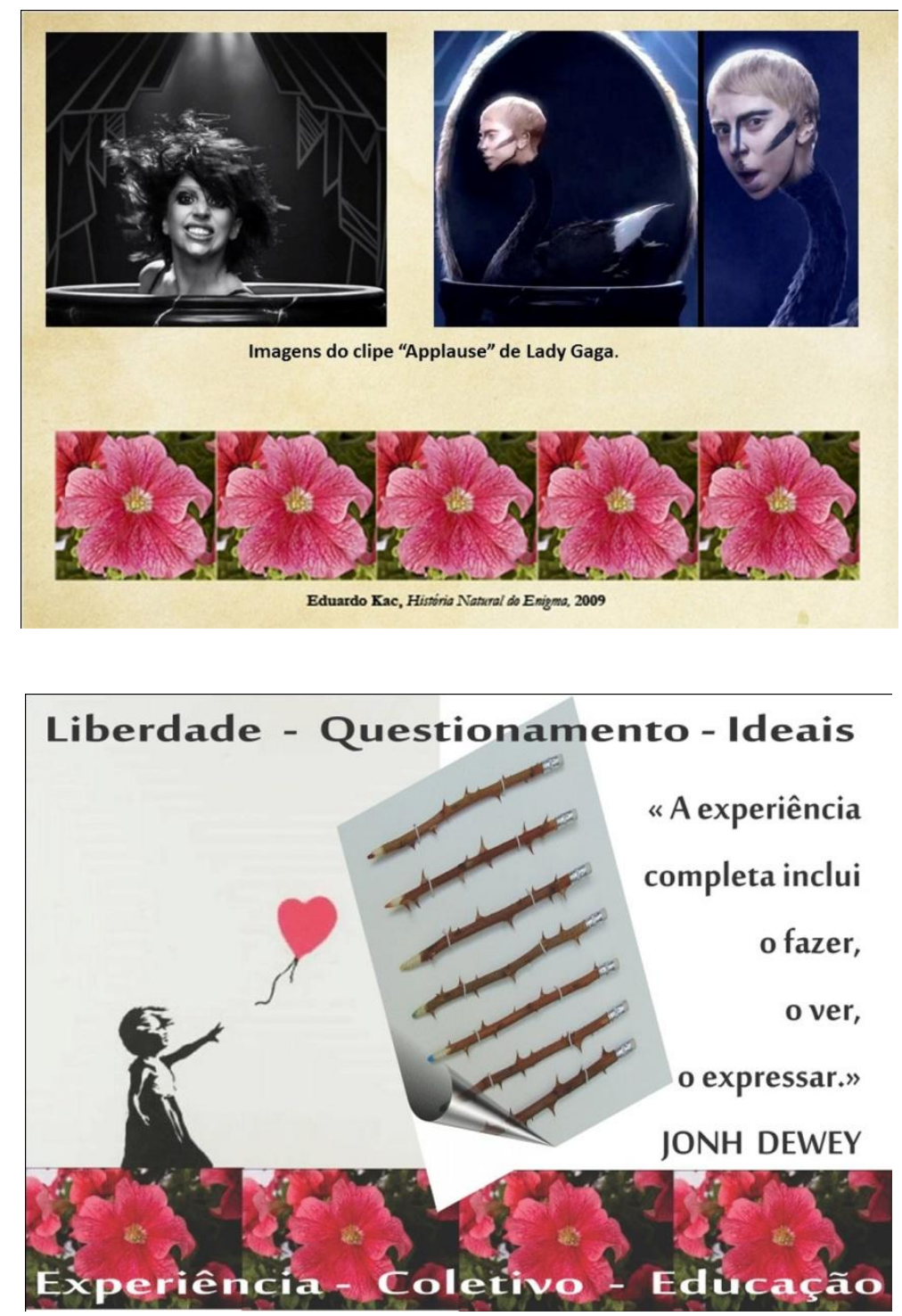

Fig. 89 Participante ' $F$ ' e participante ' $I$ 'Intervenção em carta 5 com imagem e texto. Jogo Enigma. Objeto de Aprendizagem Poético. Curso de extensão OAP. VIS/IdA/UnB, $1^{\circ}$ semestre 2014.

Como vimos antes, Bishop (2012) destaca que, a ideia de participação na arte no século XX traz tensões entre a autoria individual e coletiva, coloca questões sobre múltiplas audiências (por exemplo, quem não participa pode ou não ver a obra?) e se encontra com o conflito entre as demandas dos participantes e a direção ou controle da obra. Essas tensões conduzem ao cruzamento de fronteiras nos territórios do que ainda estar por ser. No caso da arte participante as indagações dos artistas coincidem com as indagações no campo da pedagogia. Jacotot, o mestre ignorante de Rancière, reforça as discussões sobre a emancipação do espectador. Do lado latino americano, Camnitzer aponta Rodríguez como o primeiro conceitualista cuja obra foi um projeto de educação pela emancipação do pensamento 
dominado. Em Artificial Hells (2012) Bishop destaca os projetos educativos na arte participante evidenciando a contribuição decisiva da pedagogia tanto na dimensão teórica como prática. Em todas essas contribuições está a ideia do noviço emancipado. O participante é, portanto, o emancipado.

Mas, nas relações que os artistas estabelecem com seus participantes há necessidade de aproximações que cheguem a fazer contato. Rancière aponta duas distâncias que os artistas hoje tentam cruzar. Por uma parte a distância entre o artista e o espectador, que é similar à distância entre o professor e seu estudante. Por outra, a distância entre o espectador/estudante e o artefato artístico ou pedagógico. Não basta, na perspectiva do autor, deixar o espaço para que o espectador tome a cena (Rancière se refere ao caso do teatro, mas podemos bem estender a todo o discurso da arte e da educação). Ele nos lembra que pela lógica da emancipação, entre o mestre ignorante e o noviço emancipado sempre há "uma terceira coisa um livro ou uma peça de escrita- alienado de ambos e ao qual possam se referir em comum, o que a aluna viu, o que diz sobre isso, e o que pensa sobre isso" (Idem, p. 14-15). Nessa perspectiva, a terceira coisa entre o artista e o espectador e entre o professor e o estudante "não é propriedade de nenhum dos dois, seu significado não é propriedade de ninguém, mas subsiste entre eles, excluindo toda transmissão uniforme ou identidade de causa e efeito" (Idem, p. 15).

Em outras palavras, se trabalhamos na lógica da emancipação, não podemos partir de uma suposta distância entre o professor e o estudante, ou entre o artista e o espectador, mas também não podemos partir de uma suposta distância entre o espectador/estudante do artefato. Não podem mais, nem o artista, nem o professor 'ensinar' ou 'apontar' o que o espectador ou o estudante deve entender do artefato, nem o que deve fazer com esse entendimento. Se o mestre ou o artista explica o que um dado artefato significa ou é, parte do princípio de que há uma distância entre o espectador ou estudante e o artefato. Já o participante cruza ambas distâncias: espectador-artista; espectador-objeto, ele participa. Assim, na perspectiva da Estética Relacional "toda obra de arte pode ser definida como um objeto relacional" (BOURRIAUD, 2009, p. 37) que se encontra entre o artista e o espectador.

Marcel Duchamp, observa Bourriaud (2009), abriu o espaço do participante na obra de arte com a ideia do coeficiente de arte pelo qual o artefato de arte escapa ao artista: sempre vai além do controle com elementos que não saem como se quere ou que surgem sem intenção. $\mathrm{O}$ 
participante faz parte desse coeficiente da arte porque faz da obra outras leituras. Bourriaud denomina isso de transitividade. Com as performances, intervenções, ações e happenings do grupo Fluxus e no Brasil dos Neoconcretos, a participação do espectador na obra de arte se tornou uma constante. Hoje essa participação, Bourriaud observa, "consiste numa cultura interativa que apresenta a transitividade do objeto cultural como fato consumado" (Idem, p. 36). De fato, a importância do participante e de sua capacidade de intervenção se estende em quase todas as esferas da vida. Dos objetos de consumo que são customizados pelo consumidor à Web 2.0 e 3.0, o participante é quem constrói, quem determina, quem imagina. As novas TIC ampliaram a capacidade de interação com os artefatos. Mas Bishop distingue entre participação e interação. A participação é uma construção que geralmente é comunitária, a interação é limitada a espaços já delimitados a priori que podem ajudar na participação, mas ambas são formas de comunicação. A autora adverte o paradoxo da participação como um dispositivo artístico que, "dá abertura do trabalho à manipulação ou alteração pelo espectador, se torna rapidamente uma convenção altamente ideologizada, uma em que o espectador por sua vez é manipulado para que possa completar o trabalho 'corretamente'" (2012, p. 93). O espaço do participante é um espaço de risco em que podem acontecer ou não situações de aprendizagem.

Para Helguera a participação na arte pode ser um termo muito amplo se não distinguimos as condições de participação. Ele propõe, nos seus estudos sobre as técnicas e materiais de Arte Socialmente Engajada, ASE, uma configuração das diversas camadas que compõem as estruturas de participação do público em um artefato de ASE:

- participação nominal: aquela em que o público participa somente pela contemplação ou pela percepção - geralmente de pequena duração.

- participação direta: aquela em que o público completa uma tarefa simples para contribuir na construção da obra - geralmente de curta duração.

- participação criativa: aquele em que o público produz conteúdo dentro da estrutura que o artista proporciona - geralmente de longa de duração.

- participação colaborativa: aquela em que o participante compartilha responsabilidade na construção da obra em diálogo direto com o artista - geralmente de longa duração. (HELGUERA, 2011a, p. 14-15) 
Helguera ressalta a importância de considerar o grau de participação de acordo a objetivos comunitários e da disposição dos participantes, pois é possível que seja voluntária, não voluntária ou mesmo involuntária. O autor argumenta ainda que, as novas tecnologias de informação e comunicação ampliaram canais de participação como as redes sociais, embora muitas das obras participativas, como acontece com os artistas da Estética Relacional, surgiram como uma reação aos encontros virtuais.

Nesta investigação os estudantes do curso de extensão foram considerados participantes voluntários e sua relação é criativa e colaborativa porque produzem conteúdo, ocupam novos territórios e compartilham responsabilidade na criação de novos territórios de subjetivação em uma área que lhes é comum: a educação em artes visuais. Nesse sentido formaram parte de uma comunidade e esse sentimento teve uma importância vital no grau de envolvimento dos participantes. Essas relações por outra parte se construíram em períodos de longa duração (dois meses) e se deram no espaço presencial e virtual onde a interação se mantém síncrona e assíncrona.

Esse é um quadro geral dos participantes nas três versões do curso de extensão (Fig. 90), usando para efeito de identificação as letras do abecedário e a cor da sua ocupação, vermelho para os professores de arte, amarelo para estudantes de arte, azul para profissionais de outra área de atuação diferente das artes visuais, verde para estudantes da licenciatura e roxo para o participante imaginário:

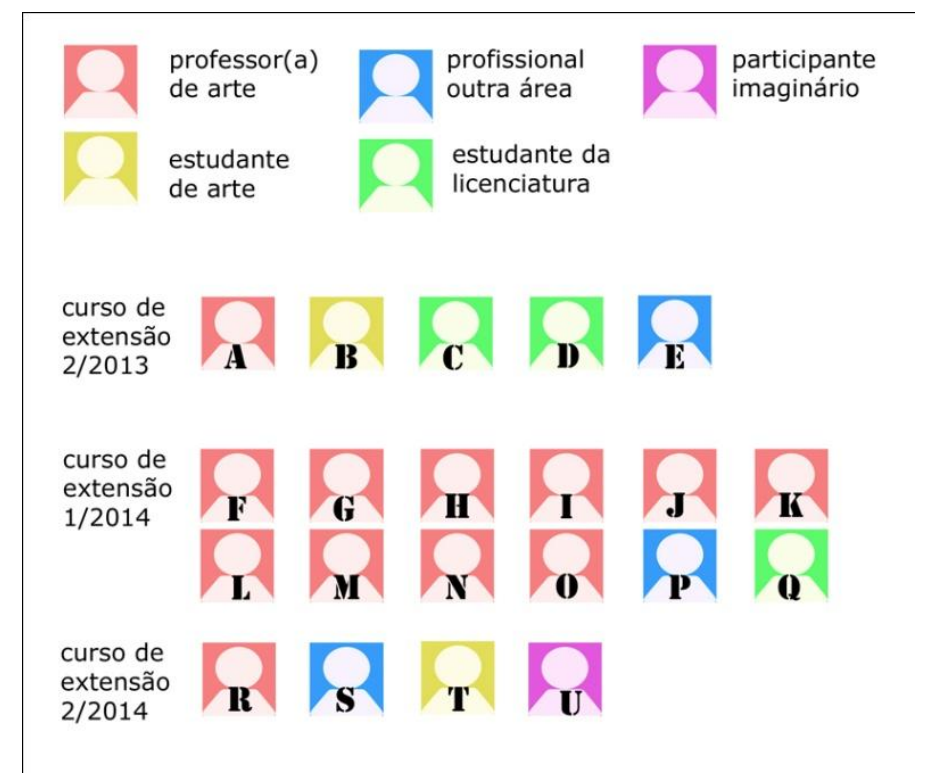

Fig. 90 Quadro de participantes no curso de extensão Objetos de Aprendizagem Poéticos nas três versões. 
Todos os gráficos referidos à amostragem de dados do curso, como os quadros de conversações nos fóruns, o mapa da produção e os quadros de análise de obras foram configurados tomando em conta a codificação das letras a fim de preservar a identidade e ao mesmo tempo relacionar o percurso e a produção dos participantes.

Nas suas três versões o curso contou com vinte um participantes. Desses, onze são professores de arte de escolas públicas e particulares do D.F. em Brasília, um é professor de ensino infantil em São Paulo que fez o curso inteiramente a distância, dois são estudantes do Bacharelado em Artes Plásticas na UnB, três são estudantes da Licenciatura em Artes Plásticas na UnB, três são profissionais de outras áreas (Artes Cênicas e Pedagogia) e, na terceira versão um participante imaginário que aqui se identifica com a letra ${ }^{\prime} U^{78}$. O personagem apareceu como um participante a mais do curso levado à vida pela autora, a tutora que atuou no curso. A identidade de ' $U$ ' nunca foi revelada no curso. Mas efetivamente, o participante imaginário se tornou um elemento de provocação à conversação e à ação no AVA. Aportou situações de grande valor para as dinâmicas de conversação na terceira versão do curso de extensão. Tornou-se um OAP.

No contexto desta investigação os participantes são considerados co-produtores do que podem ser os Objetos de Aprendizagem Poéticos com suas propostas, suas formas de pensar, de organizar e de projetar o artefato. Todos os vinte um participantes, incluído o participante imaginário, aportaram de uma maneira ou outra na construção das ideias, formas e situações ao redor dos OAP. O mesmo interesse que os moveu a participar de um curso de extensão sobre estes artefatos os uniu em um corpo comunitário. Nas três versões os participantes compartilharam experiências que alimentaram suas práticas e processos de produção. Isso promoveu um espaço de ação comunicativa intensa, especialmente na segunda versão. Os artefatos produzidos foram aplicados em diversos contextos de aprendizagem e apresentados em suas diversas fases. As conversações que surgiram destas interações e os artefatos que se experimentaram e se criaram são os territórios que se ocuparam e que formam a investigação como artefato.

\footnotetext{
${ }^{78}$ Personagem fictício, alter-ego da professora tutora cuja obra inclui a poesia. A participante ' $U$ ', é uma poetiza que procede de um contexto pobre, tem uma graduação e vive de empregada doméstica em casa de gente rica.
} 
"Esta viagem era parte de um projeto de arte público, a Escola Panamericana da Intranquilidade, que consistia em dirigir através do Norte e Sul América com uma grande instalação - uma casa/escola- e erguê-la em praças públicas, universidades, instituições de arte [...] Uma variedade de eventos ocorreram em cada parada - painéis de discussão, eventos cívicos e cerimônias, projeções [...] Em cada encontro, vários símbolos, como bandeiras e hinos elogiavam "Panamerica", o país fictício". Pablo Herguera, In ALLEN, 2011. 


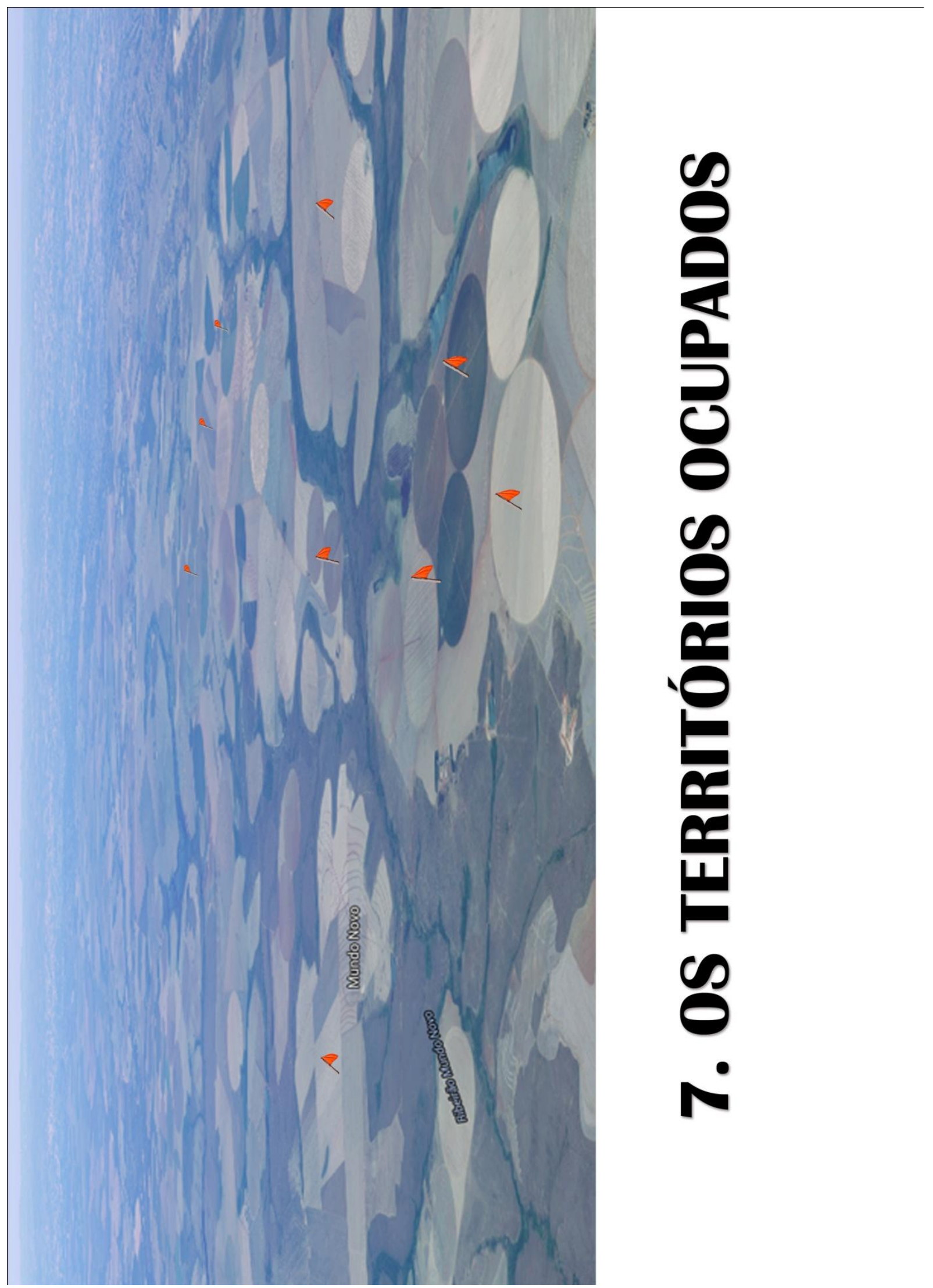

Fig. 91 Mundo Novo, Os Territórios Ocupados, Tatiana Fernández, fotografia satelital Google Earth manipulada, 2014. 


\section{OS TERRITÓRIOS OCUPADOS}

O território é um espaço de existência onde, como animais, não só habitamos como também criamos para ter um espaço estável no caos, pensam jagodzinski e Wallin (2013). Para eles, como era para Guattari (1995), a arte é uma das formas de criar territórios de existência. Esses espaços são criados e ocupados, mas também desocupados, territorializados e desterritorializados em todo tempo e lugar. Nesse caso, o evento artístico como pedagogia é uma ocupação dos espaços educativos, artísticos e políticos que formam novos territórios de existência para os educadores em visualidade. E é a partir dos territórios ocupados pelos professores que os estudantes criam e/ou ocupam outros territórios de existência. Os OAP são provocadores de eventos que provocam outros eventos. Por este motivo o espaço que esta investigação ocupa é um espaço em que os eventos artísticos se encontram com os eventos pedagógicos no coração das identidades em trânsito de professor/artista/pesquisador/estudante/participante.

A observação e análise dos OAP em contextos educativos teve por objetivo identificar como se reconfiguram esses territórios e como se movem seus atores. Os dados levantados foram organizados e analisados com parâmetros e critérios baseados na reflexão da experiência estética e a prática transcognitiva tanto no papel de estudante/participante como no papel de artista/investigador/professor que nas experiências tendem a se fundir. Os instrumentos de valoração dos processos são os próprios OAP que os estudantes realizaram a partir da experiência com o evento artístico/pedagógico.

Nesta investigação as principais estratégias de ocupação dos territórios educativos, artísticos e políticos passam por dois eixos que atravessaram o curso: a conversação e a singularização. A conversação é temporal e imaterial porque aconteceu através dos participantes nos fóruns do curso com certos ritmos (relativos aos quatro capítulos ou fases). Esse eixo registra indícios da experiência dos participantes. Essa experiência se apresenta em um mapa de conversações que destacam trechos relevantes às análises dos artefatos e dos eventos (Figuras 93 a 96). A partir desse eixo pode-se fazer um seguimento por fase, por assunto, por data ou por participante. O quadro de conversações ajuda a visualizar de maneira concreta os ritmos de participação e o destaque dos temas relacionados a cada fase. Já o eixo da singularização 
se manifesta de maneira concreta com os objetos de aprendizagem que apresentam aberturas para ocupar um espacio existencial, pois devem ser pensadas como máquinas desenhadas para construir territórios de subjetivação, que funcionam em um determinado espaço/tempo e que se apresentam de maneira singular. Os artefatos produzidos pelos participantes se apresentam no mapa de objetos de aprendizagem (Fig. 97) realizados no curso de extensão. Esse eixo permite ver toda a produção na sua singularidade. A partir da análise cruzada desses mapas e das conversações e textos escritos é possível identificar coincidências, contágios, contaminações, hibridações e/ou superposições que acontecem no encontro entre o evento artístico e o evento pedagógico.

Todos os artefatos realizados no curso de extensão foram tomados em conta, embora o maior interesse fossem somente os artefatos produzidos pelos educadores em visualidade para o ambiente escolar. No processo de análise dos trabalhos se tornou evidente que a contribuição dos participantes de outras áreas profissionais ou com intenções diferentes a da educação, proporcionaria uma maior percepção da intensidade nas potencialidades das pedagogias culturais. Os diferentes interesses que movem as pessoas para saber o que são os OAP criaram um espaço maior de interação e troca.

Dessa forma foram consideradas as experiências e artefatos de todos os participantes que concluíram o curso de extensão como contribuições à construção das ideias, formas e situações dos OAP proporcionando uma visão da extensão e diversidade. Do conjunto de trabalhos produzidos foram analisados em profundidade aqueles que foram finalizados, experimentados, avaliados e apresentados e que proporcionavam, não um padrão típico de resultados, mas diferenças ou intensidades (FLICK, 2009). No contexto de uma investigação que se move dentro das pedagogias culturais é necessário favorecer a singularidade para uma pluralidade de resultados dos quais interessam os extremos, desvios e intensidades.

Por esse motivo foi importante para esta investigação adotar estratégias de singularização da produção. O curso de extensão propôs situações em que os participantes deviam construir seu percurso em relação a sua prática artística (se houvesse uma produção) e a sua forma de ocupar os territórios pedagógicos. O apoio técnico, teórico e pedagógico fica a disposição dos participantes no percurso do seu estudo através dos fóruns e nos encontros presenciais. A metodologia, teórico/prática/poética, favorece diversos interesses e promove uma abertura onde é possível aprender na tensão entre o que sabemos e o que não sabemos ainda. A diversidade da amostragem pode ser um problema metodológico para o processo de análise, 
mas no caso desta investigação a proposta se abre à singularidade e com isso às possibilidades de casos extremos, desviantes e intensos aumenta e enriquece as reflexões.

Evidentemente para uma análise dos dados que se apresentam dos mais variados é necessário cruzar informação com outras fontes. Para este efeito nas três versões do curso foram realizados registros fotográficos, vídeo, participação escrita nos fóruns, ensaio individual e questionário de avaliação do curso e do DEX/UnB (Anexo II), constituindo assim uma ampla base de dados multifocais para análise.

\subsection{A conversação como forma de construção coletiva}

A conversação é um método de investigação muito usado na Pesquisa Qualitativa para analisar e entender enunciados, geralmente usado na etnometodologia. O que caracteriza a conversação como método de investigação é que acontece em um contexto específico de tal maneira que, na análise não pode se separar o discurso do contexto. No caso desta investigação, a codificação é aberta ${ }^{79}$, mas se centra na análise da interação dos participantes e do contexto real em que os OA e os OAP são construídos:

O objetivo dessa abordagem é determinar os princípios e os mecanismos constitutivos por meio dos quais os atores, na realização situacional das suas ações e na reação recíproca a seus interlocutores, criam estruturas significativas e a ordem de uma sequencia de eventos e de atividades que constituem esses eventos. (BERGMANN, 2004, apud FLICK, 2009).

As conversações proporcionaram uma maior liberdade para os participantes nas reflexões sobre o que estamos construindo como comunidade. Delas foi possível analisar episódios selecionados em que podem se identificar elementos de ordenação que nos ajudam a entender como aconteceu o processo. Mas, no caso desta investigação, além ser um método de investigação, a conversação foi um processo de construção, um meio para construir junto à comunidade de educadores em visualidade, estudantes da licenciatura e outros interessados na ideia de OAP. As conversações aqui proporcionam leituras e conexões mais complexas para a análise. Sendo que os OAP pertencem a um espaço educativo sem o qual carecem de sentido, o espaço em que eles são construídos é o espaço da conversação.

\footnotetext{
${ }^{79} \mathrm{Na}$ codificação aberta não há códigos específicos para a interpretação dos dados, pois se espera que as conversações revelem dados inesperados, inflexões diversas, aberturas ao que ainda não é.
} 
A conversação é um método muito usado em diversas áreas de investigação, mas na arte ganhou maior destaque desde finais dos anos 90. É uma estratégia muito usada por artistas contemporâneos, como vimos no capítulo IV. Geralmente são os que trabalham com interfaces pedagógicas, ou de uma maneira geral com ASE (ou Social Engaged Art, SEA ) ou, com Estética Relacional. Para muitos deles a conversação é o meio com que se faz a obra. E alguns deles tomam a forma de discussão em espaços pedagógicos, como os trabalhos de Beuys, Filliou e mais tarde Gillick, Vidokle, Bruguera, Helguera e Rogoff entre outros. Para Rogoff (2008) a noção de "conversação" é uma das mudanças mais significativas na arte da última década e considera as conversações promovidas pela Documenta X (1997) com um fórum de 100 dias em que participaram 100 convidados e depois as quatro plataformas de discussão que se realizaram no mundo todo antes da Documenta XI (2002) como grandes contribuições à cultura contemporânea.

Então o mundo da arte se converteu no lugar da conversação extensivaconversar emergiu como uma prática, como uma forma de se encontrar, como uma forma de ter acesso a algum conhecimento e alguns questionamentos, como estabelecendo conexões, organizando e articulando alguns questionamentos necessários. Mas demos algum valor àquilo que de fato dissemos? Ou privilegiamos juntar as pessoa em um espaço e acreditar que os formatos e a substancia emergiriam deles? (ROGOFF, 2008, s/p)

As práticas às que Rogoff se referem se estendem também em diversos campos de estudo e prática relacionados às narrativas particulares. Nos últimos anos o questionamento se torna mais urgente. Em um panorama em que essas práticas se multiplicam no âmbito da arte, Rogoff (2008) se pergunta qual o papel da conversação no mundo da arte a partir da reflexão de Foucault (2001) sobre a noção de parrésia $^{80}$ : é importante não só conversar, mas principalmente se dar conta de "quando e por que algo importante foi dito" (ROGOFF, 2008, s/p). Na parrésia se trata de conversar de forma destemida, franca, aberta e corajosa em público. No panorama contemporâneo a revista de arte online $e$-flux favorece esses espaços de conversação com programas como e-flux Conversations ou Supercommunity em base a uma nova plataforma em modo editorial livre que permite a participação aberta moderada por um editor com centos de temas, diversos convidados e participantes, tudo online. Nesse sentido se reconhece a conversação como uma forma de construção coletiva. Mas, é importante tomar em conta como Monika Szewczyk que

\footnotetext{
${ }^{80}$ Em grego significa expressão livre, franca e ousada. Foucault a chama de fala destemida (2001).
} 
[...] se, como uma arte, a conversação é a criação de mundos, poderíamos dizer que escolher ter uma conversação com alguém é admitir ele no campo em que os mundos se constroem. Isso basicamente aponta o risco de redefinir não só o 'outro', mas nós também. A arte e a conversação compartilham esse espaço de invenção, mas só a conversação vem com a precondição da pluralidade que pode desmontar totalmente a noção do agente criativo. (SZEWCZYK, 2009, s/p)

Favorecer a conversação como um eixo de construção do conhecimento é parte de uma metodologia baseada nas artes, mas é principalmente a/r/tográfica porque no risco da parrésia, como um elemento que modula o espaço de conhecimento, há uma escolha política que se refere ao outro. Nesse caso a conversação não é só com palavras ou discursos, mas com imagens, sons, corpos, visualidades.

Entre os poucos autores que estudam a conversação como um meio artístico está Helguera (2011a), que usa a conversação em várias das suas peças. Aqui interessa em especial a Escola Panamericana da Intranquilidade que ele levou por diversos lugares estabelecendo conversações com as comunidades onde passou. Ele vê a conversação como uma forma de pesquisa, uma estratégia para construir "conclusões coletivas" (2011a, p. 40) sobre experiências e assuntos comunitários. Helguera observa que essas práticas, também conhecidas como práticas dialógicas no campo da arte, não chamam a atenção dos pesquisadores enquanto o conteúdo ou a estrutura nem o que estas conversações produzem, mas somente sobre o fato de ser uma conversação. Em contraste, ele identifica, na educação, uma tradição da discussão como processo de emancipação: da hermenêutica de Hans-George Gadamer ao pragmatismo de Dewey, ao neo-pragmatismo de Habermas e Richard Rorty à pedagogia de Paulo Freire. Para Dewey e Freire a conversação não se resume ao diálogo verbal, mas uma conexão com o mundo. Dewey adianta, como vimos antes, que é necessário construir juntos para haver uma comunicação. Isso pode dar uma ideia de como a conversação é uma estratégia potencial para as pedagogias culturais. Desse modo, é importante ver como estas conversações acontecem, como elas se constroem e como formam as subjetividades coletivas, que Guattari (1995) denomina de agenciamentos coletivos de enunciação.

Helguera aponta que, como a conversação, todas as formas de discurso tem potencial comunicativo, sejam debates, colóquios, conferências, chat, etc. Essas formas têm dois objetivos: a verdade e o aprofundamento que se forma sobre o tema no processo. Mas as 
conversações informais são as mais usadas pelos artistas da ASE ou da arte participante, ou da Estética Relacional. Como neste caso, os artistas formam espaços comunitários onde as pessoas são convidadas a debater, discutir, conversar sobre temas específicos. Para o curso de extensão Objetos de Aprendizagem Poéticos, os temas de conversação se referem aos processos ao longo do curso, portanto, são conversações que começam com as perguntas que os participantes são chamados a fazer sobre suas leituras e experimentações. Essas conversações acontecem nos fóruns onde se estruturam os debates sobre diversos aspectos do processo, inclusive os inesperados, os emotivos, os pessoais, os que estão perdidos, etc.

Helguera também proporciona um diagrama (Fig. 92) de duas variáveis para ser consideradas pelos artistas interessados em práticas dialógicas como um meio, que como ele argumenta, são práticas já estabelecidas na educação: especificidade de conteúdo (assunto) e especificidade do formato:

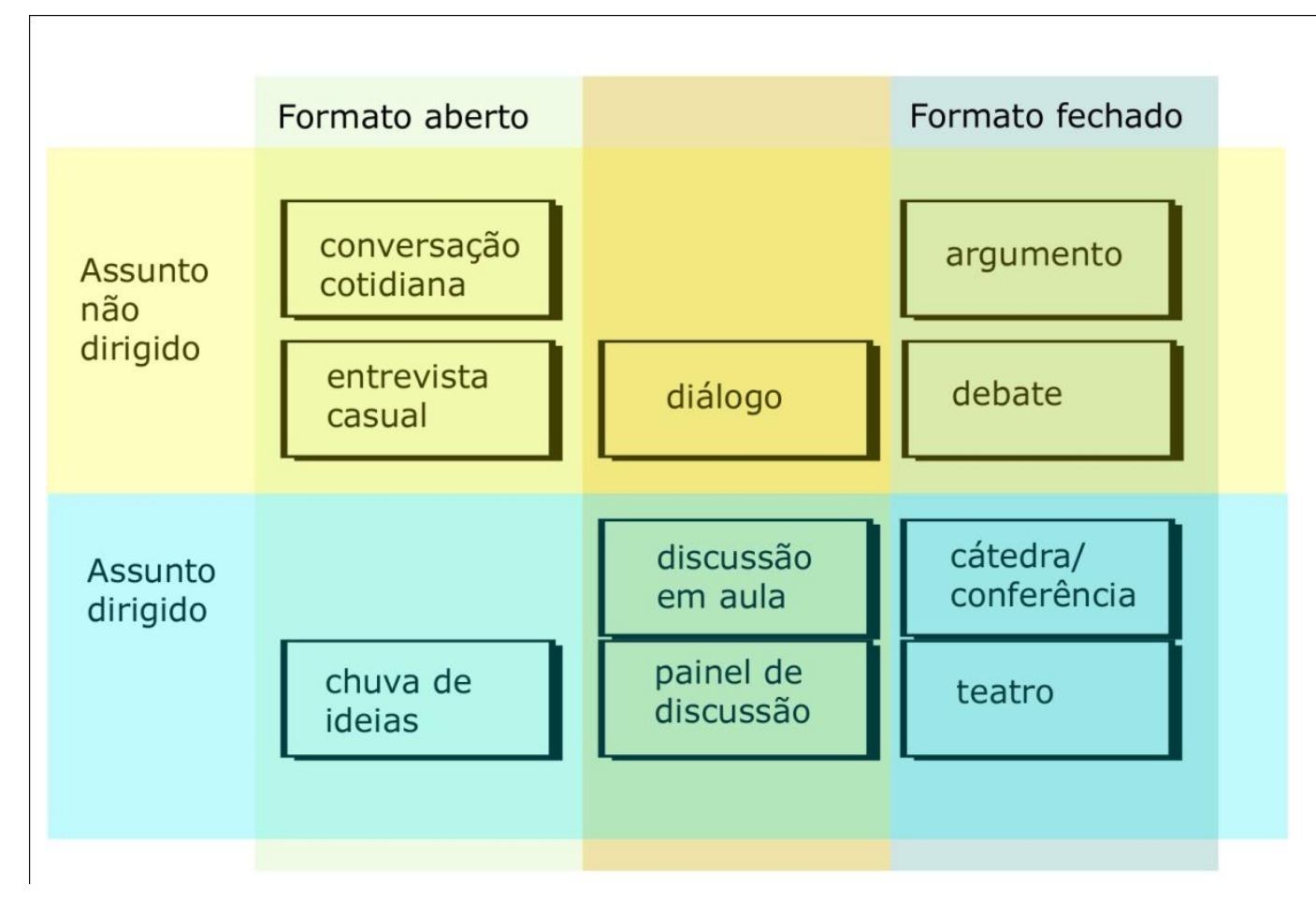

fig. 92 Diagrama de formatos de conversação a partir de Pablo Helguera, 2011a, p. 45

Nesse sentido, as conversações que aconteceram no curso de extensão Objetos de Aprendizagem Poéticos foram discussões em aula virtual e presencial e painéis de discussão, de maneira que as conversações se encontram em um formato semiaberto ou semifechado com assuntos dirigidos. Esses formatos permitiram aos participantes se inserir no diálogo de uma comunidade, no caso de educadores em visualidade, estudantes de educação em artes 
visuais e outros interessados e conversar sobre as dificuldades e potencialidades da sua prática pedagógica ou artística, ou ambas. Os formatos abertos e semiabertos de conversação com assunto dirigido favoreceram uma maior percepção do campo de ação e uma visão mais clara da sua posição no contexto do encontro entre a virada da visualidade na educação e a virada pedagógica na arte. Com esse formato e dentro de um assunto central, a singularidade dos participantes fez parte do diálogo e ficou impressa na estrutura de uma construção coletiva. Cada um contribuiu com a modelização das dobras que as conversações formam. Como aponta Helguera, as conversações requerem uma maior atenção, de parte do artista, aos interesses das comunidades onde trabalha, mas também é necessário que sejam organizadas, ativadas e mediadas por ele. A relação que se estabelece na conversação como estratégia artística, entre o artista e os participantes e entre os participantes é a mesma relação que se estabelece entre o professor e os estudantes e entre os estudantes. Os participantes do curso de extensão são, nessa perspectiva, protagonistas no processo de construção.

Os fóruns são, na educação a distância, um dos espaços mais usados pelo seu formato de debate ao redor de alguma questão. No curso de extensão Objetos de Aprendizagem Poéticos os fóruns são espaços de conversação e exposição. As conversações que se deram nesses espaços traçam os percursos na construção dos artefatos e na valoração dos produtos. Os fóruns foram conduzidos com perguntas ou tarefas, mas também foram espaços para tirar dúvidas, procurar ideias, compartilhar achados, ou postar imagens (Ver Anexo V Figuras 93 a 96, Quadro de conversações dos Fóruns 1, 23 e 4)

Durante o curso cada fase teve um ou dois fóruns. Os que interessava para análise nesta investigação eram aqueles que traziam discussões centrais sobre a relação entre arte e educação. $\mathrm{O}$ fórum de discussão da primeira fase se abria às perguntas que surgiam sobre OA e OAP. A discussão que acompanhou a segunda fase versou sobre a exploração dos OA para ensino das artes visuais, onde houve troca de pesquisas, de ideias e experiências. Na mesma fase exploraram-se os OAP preparados para o curso e houve um encontro presencial em que se estabeleceu uma conversação sobre as experiências. Na terceira fase as discussões nos fóruns ficaram intensas, pois foi a fase da construção do próprio artefato. As dúvidas giraram em torno das ideias que surgem de acordo às necessidades do contexto da sala de aula, ou quando é o caso, em torno da poética dos participantes. Na quarta fase o fórum foi dedicado à avaliação da experiência do OA ou OAP desenvolvido e aplicado em contexto de educação formal ou não formal. Nesse último fórum, que foi de discussão sobre os resultados 
alcançados, os participantes apresentaram também um pequeno ensaio sobre a experiência, responderam um questionário para avaliação interna do curso e um questionário de avaliação on-line do DEX (Anexo II).

Para ter uma visualização do tom destacado das conversações no processo de construção a apropriação do conceito de OAP os Quadros de Conversações (Figuras 93 a 96) foram estruturados por fase associada ao capítulo do curso de extensão. Mas o formato de fórum produziu conversações que se superpuseram ou se distanciaram. Por este motivo os ruídos externos à conversação e as repetições foram editados para melhor compreensão e foram selecionados trechos que condensam o nodo das ideias guardando em parte uma sequencialidade de postagens, interesses e eventos. Esses trechos são apenas amostras das camadas que se superpõem na construção do curso. Os vídeos realizados dos encontros presenciais proporcionaram também um registro das conversações que aconteceram, em especial no momento da apresentação dos artefatos. Por outra parte o material textual escrito pelos participantes, seja no ensaio ou nas avaliações do curso, é rico em indícios que ajudam a compreender a dimensão do que pode acontecer quando o evento artístico se torna pedagogia.

A riqueza das conversações depende de muitos fatores, a quantidade nem sempre é qualidade. Como se pode ver nos Quadros de Conversações (Anexo V Figuras 93 a 96), onde há mais espaços vazios aparecem as dificuldades para conversar. Esses espaços de silêncio se tornam maiores quando os grupos são menores, como acontece com a primeira e terceira versão do curso de extensão. E acontece também uma menor participação nos fóruns iniciais e finais. $\mathrm{Na}$ seleção que apresento nesses quadros de conversações aponto somente enunciados que não se repetem de alguma maneira pelos colegas, a menos que seja para ampliar ou fazer contraponto. Inclusive o silêncio de alguns fóruns foi selecionado na forma de uma conversação iniciado pelo participante imaginário ' $U$ ' que provoca a reflexão do colega ' $R$ '. Como acontece em toda conversação que é editada o sentido de um trecho pode mudar se a conversação não está completa. Nesse caso somente seleciono trechos que possam ser claros em si mesmos. É necessário apontar que estes trechos selecionados para o Quadro de Conversações (Anexo V Figuras 93 a 96) não são os únicos que uso na análise dos discursos. Os quadros se propõem sintetizar de maneira visual os nodos principais, as ideias que fluíram, os conceitos que se formaram e a construção que houve. 


\subsection{Singularização da produção maquínica}

Os OA e OAP realizados pelos participantes do curso de extensão Objetos de Aprendizagem Poéticos constituram os principais dados a ser analisados. O caso é que esses artefatos conservaram as marcas da pro-dução maquínica de tal maneira que fizeram visíveis as construções singulares e ao mesmo tempo plurais da arte e sua educação no tecido social, assim como os pontos de mutação nas subjetividades e nos processos. As questões sobre a singularidade subjetiva, lembra Guattari (1995), tem um papel dominante nas condições contemporâneas (ainda que isso não signifique necessariamente em direção à emancipação). A situação é muito mais radical duas décadas depois das reflexões de Guattari. Hoje, com o ressurgimento dos nacionalismos extremos, vivemos o que ele denominou de "coquetel subjetivo" (1995, p. 4). A singularidade subjetiva é uma reação à globalização que tem combinações excludentes, mas é também uma forma de conquistar espaços democráticos. No âmbito das pedagogias culturais singularizar é visualizar o outro nos espaços coletivos que comporta por sua vez uma série de transformações pedagógicas e culturais. Singularizar é, na perspectiva de uma estratégia, proporcionar material de provocação para que uma coletividade (pluralidade) de singularidades produza seus próprios territórios de subjetivação. Em referência à aula como obra de arte, Guattari se pergunta que caminhos seriam possíveis "para a sua singularização" (Idem, p. 133). Esses caminhos foram explorados pelos participantes do curso.

A importância da singularização no processo de construção de OA ou OAP decorre por uma parte, da vantagem de proporcionar uma pluralidade de visões e contextos em que podem ser produzidos e analisados. Por outra, decorre das abordagens pedagógicas e estéticas que privilegiam a diferença e a dissidência como produção poética. Ainda, a singularização coloca o acento nas relações entre sujeito, objeto e contex to e não exclusivamente sobre o sujeito ou exclusivamente sobre o objeto. Singular é o contexto, o objeto e o sujeito. Para a investigação a singularização da produção maquínica reflete o potencial múltiplo dos médios em relação ao contexto, aos participantes e aos autores, porque, como a arte, "mobiliza afetos e encontros potenciais" (COLEBROOK, 2006 apud JAGODZINSKI e WALLIN, 2013 p. 168). Em outras palavras, se trata de promover produções singulares capazes, não de representar ou significar (sempre em relação aos sujeitos, contextos e à sua memória), mas indicar, anunciar ou fabular a potência do que está em formação, ou mais precisamente, do que é poético. Isso significa que a singularização da produção maquínica não é a personalização dos artefatos, como 
esperaríamos se pensamos que ela está na intenção poética do artista (como vimos, a poética não pode ser intencional).

Por esse motivo não se trata de assinaturas, estilos, marcas da individualidade ou da personalidade. Pelo contrário, a singularização é uma estratégia que mobiliza bifurcações em outros territórios para que, assim, novos significados possam ser formados. Assim, singularizar a produção de máquinas de subjetivação é, no âmbito desta investigação, uma maneira de observar, através do outro, o que acontece nos espaços de fronteira na pluralidade de contextos, afetos, sensibilidades e conhecimentos.

Para este efeito na terceira fase do curso de extensão os participantes exploraram o que significa criar artefatos pedagógicos e poéticos ao mesmo tempo, e depois aplicar e avaliar no seu contexto educativo. O tempo para o processo de criação e avaliação foi limitado e isso influencia sobre algumas decisões, mas responde também à velocidade dos processos em sala de aula. Os artefatos que os participantes produziram resultam dos mais variados porque respondem a processos diferentes, são estruturados em diversos níveis de complexidade e pensados para diferentes contextos. No curso, alguns artefatos foram concluídos, mas não foram aplicados a tempo e outros ainda ficaram na forma de projetos. Ainda, nessa paisagem, é possível identificar a intensidade dos artefatos, o caminho de reflexão na sua construção, a plataforma em que foram pensadas, as maneiras de operar os processos de aprendizagem e as formas como os participantes singularizam a produção em todos eles.

A quantidade de artefatos produzidos no curso de extensão resultou em uma pluralidade que requer cruzar dados multifocais. Por esse motivo, para a análise dos artefatos se consideraram as apresentações verbais em encontro presencial registrado e editado em vídeo; ensaios escritos e apresentados no final do curso, avaliações do curso feitas pelos participantes (Anexo II) e as conversações nos fóruns.

Os artefatos são apresentados em um primeiro momento em um mapa dos OA e OAP produzidos pelos participantes (Ver Anexo VI Fig. $971^{\circ}, 2^{\circ}$ e $3^{\circ}$ versão Mapa dos OA e OAP) com uma visão geral dos trabalhos realizados nas três versões do curso de extensão. Para mapear de maneira objetiva e pontual, os dados básicos aparecem com codificações que identificam o nome do artefato, a letra do participante, a plataforma em que foi construído (mídias, jogos, investigação ou participação), se é OA ou OAP, a que segmento da educação 
está dirigido, do que se trata o artefato, um breve apontamento do que há de estético e pedagógico nele e finalmente em que versão do curso de extensão foi realizado.

De todos esses artefatos realizados era necessário considerar para análise aqueles que se apresentaram completos em base aos dados verbais, às narrativas sobre a produção nas conversações dos fóruns, aos registros videográficos, imagéticos, ensaios e avaliações. A identificação desses artefatos foi estruturada em quatro fases. Na primeira foram identificados os artefatos concluídos. Nesse ponto, os que ficaram em uma fase anterior sem concluir por razões de tempo, condições ou recursos, mesmo tendo potencial para contribuir na construção do que pode ser um OAP, não foram analisados por falta de elementos. Dos vinte artefatos, nessa primeira identificação, onze foram selecionados como artefatos concluídos. Na segunda fase foram identificados os artefatos que foram aplicados em um contexto de educação formal ou não formal, de maneira a ter um feedback. Dos onze artefatos concluídos, nove cumpriam com esse critério. $\mathrm{Na}$ terceira fase foram identificados os artefatos que foram apresentados em encontro presencial no final do curso, de tal forma que apresentam dados sobre o artefato. Dos nove artefatos concluídos e experimentados, sete foram apresentados pelos autores no encontro presencial final.

Para analisar esses artefatos os identifico como casos de intensidade, extremo, desvio e relevância no contexto pedagógico e/ou artístico em base aos seguintes critérios:

a) Intenso: a intensidade se refere ao grau de aberturas que o artefato apresenta para ser OAP de acordo aos critérios apresentados anteriormente: sentir é igual a saber (abertura à experiência estética), resultados singulares, inesperados, diferentes (abertura à singularidade e à pluralidade), outras formas de ser (abertura à subjetivação), tendência à fabulação (abertura à imaginação) e lidar com paradoxos e aporias (abertura à diferença e dissidência). Além das aberturas considera-se a qualidade funcional e formal, a sua interação com os participantes e os registros e as análises realizadas pelo autor a partir de experiência. Dentre os sete artefatos, um apresentou as qualidades de um caso intenso.

b) Extremo: o extremo se refere à tendência do artefato em direção a um evento puramente artístico ou pedagógico. Os casos extremos nos ajudam a entender as dificuldades que existem em todo espaço de hibridação. Dos sete artefatos, um apresenta um caso extremo em direção ao campo de ação da arte. 
c) Desviante: o desvio se refere à escolha de um caminho diferente ao que se propõe e tem a qualidade de ampliar a compreensão sobre o objeto de investigação. Entre os sete artefatos, um foi considerado desviante porque faz uma inflexão e toma um caminho diferente com alta qualidade e relevância no contexto pedagógico ao qual se dirige. A sua diferença nos ajuda a compreender os OAP.

d) Relevante: São casos que apresentam parâmetros de qualidade altos, apontam processos pedagógicos em curso e evidenciam como os artefatos se inserem nesses processos. À diferença do caso de intensidade, esses processos ainda não apresentam resultados claros no contexto de aplicação ou não alcançaram suficiente intensidade. Também não se configuram como casos extremos, nem como desvios.

Em base a esses critérios de identificação posso abrir o espaço de análise dos registros visuais (em fotografias e vídeos), textuais (Anexo V, Quadros de Conversações de Fig. 93 a 96) e verbais (em apresentações registradas em vídeo) sobre cada artefato. Nas análises que seguem a voz dos participantes se mantêm ativa, no plano da memória e do registro, visualmente destacadas em caixas cinzas para uma leitura descentralizada do corpo do texto.

As conversações e a produção maquínica dos participantes registradas em vídeo, fotografia, imagem e texto nas três versões do curso de extensão se tornaram dados centrais para observar o que acontece no encontro das águas. Esses artefatos são os indicios do que ocorre no encontro das viradas no contexto de uma experiência com educadores em visualidade e estudantes de arte, de licenciatura em artes visuais, em artes cênicas e pedagogia.

\subsection{O encontro das águas}

O encontro entre a virada da visualidade na educação e a virada pedagógica na arte, como um encontro de águas, é vigoroso, pleno de potencialidades e denso. Sua força modula novos territórios que estão em formação. De um lado as experiências pedagógicas na arte, que já tem mais de uma década, trazem consigo paradoxos, aporias, dobras, desafios e novos questionamentos em violento movimento. De outro lado, a visualidade na educação traz mudanças que conflitam o estabelecido, que indagam em espaços de emancipação, que criam 
novos mundos. No meio do encontro, as águas colidem, se misturam, se contaminam, mudam e geram nova força e novos campos. Mas também continuam ocupando seu próprio espaço. No encontro, as águas são singulares e plurais ao mesmo tempo e são sempre águas novas porque estão em movimento, em fluxo. Dessa forma, o espaço criado é turbulento, tem muitas dimensões e alcances e é sobretudo um espaço de potência. Entre as questões que trazem ambas viradas (que não é só o que aqui se investiga) há uma relação de intensidade capaz de gerar mutações em seus próprios campos (educação e arte). O que temos é, como nas águas, uma continuidade, de algo que está sempre 'se tornando', eis o que explica a força. Águas em movimento geram energia. Mas, como interpretar algo que está sempre mudando? Que está em movimento, em fluxo? Que parte tomamos para analisar? Essa parte representa o todo que sempre muda, que sempre é diferente? Como cortar o curso de um rio e isolá-lo para compreendê-lo? Para compreender haveria que entrar no rio e mergulhar no encontro. Para compreender haveria que se tornar rio, ser rio, e tudo que isso significa.

Verwoert sintetiza a imagem que trago em mente em referência ao gesto de Aby Warburg ${ }^{81}$ para demonstrar que a história da arte está atada às práticas mágicas "onde o significado se torna animado, porque você dança e dança e no percurso coisas e espíritos vem falar através e entre si (e as pinturas deixam de ser meramente algo de óleo sobre tela)." (2011, p. 3, parêntese do autor). É nesse sentido que, para interpretar os dados da investigação, que procedem de um espaço vivo e em movimento, devo me abrir à agitação que pressupõem, à qualidade transitória dos resultados, à impermanência dos achados, à volatilidade dos eventos e às camadas inapreensíveis que se deslizam e se hibridizam. É necessário entrar na dança e conversar com os espíritos.

No caminho, as águas trouxeram questões relacionadas à pedagogia cultural, por uma parte, e à arte participante, por outra. A ideia principal entre estas duas vertentes que alimenta o encontro é a emancipação, que coincide com as transformações históricas, sociais, culturais e naturais em curso no planeta em direção à emancipação em relação aos sistemas opressivos, insustentáveis e (auto)destrutivos. Como vimos antes, a emancipação não é uma ideia nova nem na arte nem na pedagogia, mas ganha uma nova perspectiva e uma renovada força na educação em visualidade. Ligadas à ideia de emancipação, tanto na arte como na educação, a literatura investigada aponta aos conceitos de pensamento de fronteira (MIGNOLO, 2012), de

\footnotetext{
${ }^{81}$ Em 1923 Warburg dá uma cátedra sobre o ritual da cobra da tribo Hopi, apontando como ele compreendia a forma em que a arte e a cultura obram (VERWOERT, 2011).
} 
partilha do sensível (RANCIÈRE, 2009b) e do paradigma ético-estético (GUATTARI, 1995; DELEUZE e GUATTARI, 2002, 2010), que são ideias políticas. Podemos argumentar, como Camnitzer, que a arte e a educação são "ambas, formas de ação política" (2015, s/p), porque fazem parte do espaço coletivo onde se forma o singular e o plural. O espaço do encontro é, portanto, político.

Por outra parte, no encontro destas vertentes, a arte e a educação apontam metodologias e formas de operar na formação de novos territórios de subjetivação e novas performances epistemológicas que incluem "o ilógico, a suspensão das leis, o absurdo, o que não pode ser repetido, a impossibilidade, e a procura por uma ordem alternativa que ainda não existe" (CAMNITZER, 2015, s/p) em contraste à ciência, que apresenta "sérias limitações por ter que usar a lógica, a causalidade e a experimentação repetível", (CAMNITZER, 2015, s/p). A arte, defende Camnitzer, é uma metodologia geral, uma metadisciplina, o espaço de todas as formas de investigar, onde as ciências são apenas "um acidente menor na construção do conhecimento" (2015, s/p). Nesse sentido "[...] a arte é educação. Mesmo se como artistas continuamos a atuar como produtores de objetos, temos que nos dar conta de que educamos outros com o propósito de desafiar, reorientando e expandindo conhecimento." (2015, s/p). O espaço do encontro entre as viradas é também metodológico e se orienta ao paradigma éticoestético.

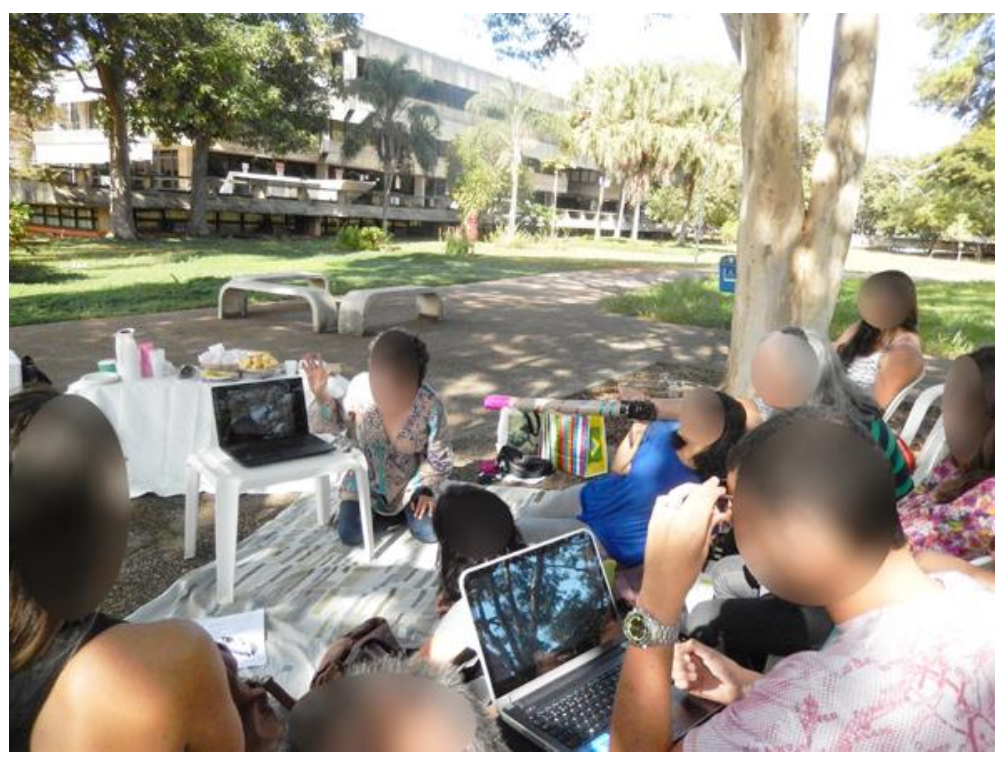

Fig. 98 Aula Pic Nic de apresentação de artefatos do curso de extensão 'Objetos de Aprendizagem Poéticos' no $1^{\circ}$ semestre de 2014, VIS/IdA/UnB. 
Esse encontro das viradas também evidencia a coincidência da centralidade da experiência estética, como evento. jagodzinski e Wallin advertem que não se trata mais da experiência individual do sujeito, nem da experiência metafísica da presença, nem das experiências compreendidas como modos de percepção técnico- científicos, "a experiência não pertence pessoalmente ao sujeito, paira no espaço intermediário entre o sujeito e o objeto, é uma dimensão do afeto que é o trazer à vida em um nível molecular" (2013, p. 194). É a experiência estética de Dewey (2005) entendida hoje no seu sentido político de evento. O evento é relacional, fluído, mutante e corporificado, onde não há mais distinções entre sujeito e objeto. O espaço do encontro é, portanto existencial onde ser não é, só, ser singular, mas, ao mesmo tempo, ser plural, ou, em outras palavras, ser com. Ser singular-plural não se limita à relação humano-humano, mas também a relação humano-inumano.
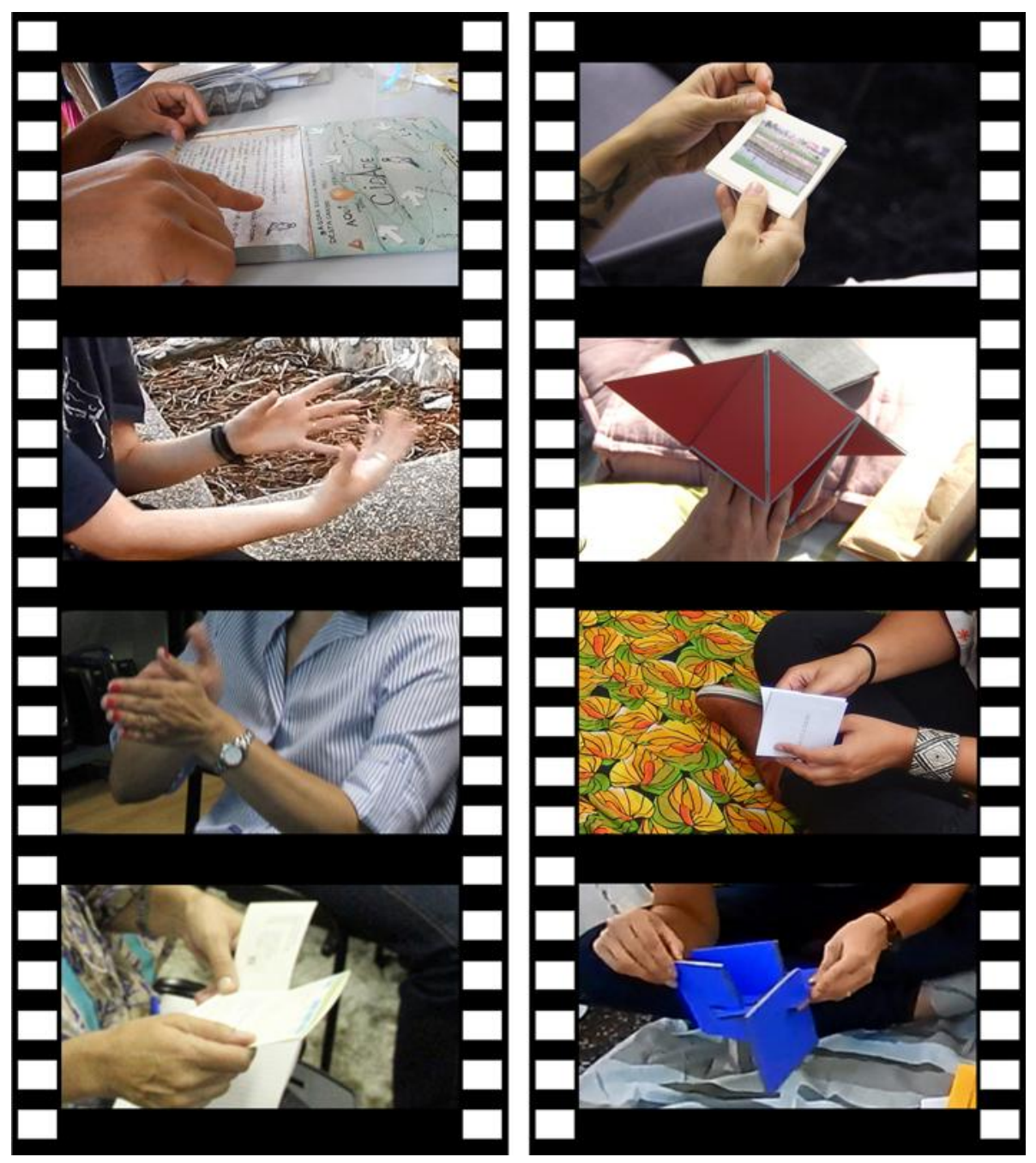

Fig. 99 Mãos. Detalhes dos filmes produzidos nas três versões do curso de extensão Objetos de Aprendizagem Poéticos. Tatiana Fernández e Denise Munhoz. 2013-2014. 
Para ver o que acontece no encontro entre as viradas e nas condições que proporcionaram as três versões do curso de extensão, analiso em três partes os territórios ocupados. A primeira parte se ocupa de analisar os OA e OAP produzidos pelos participantes do curso de extensão Objetos de Aprendizagem Poéticos, identificados em termos de relevância, intensidade, extremo e desvio, no marco de uma pedagogia cultural e de um arte participante. O objetivo é compreender o que acontece quando o evento artístico se torna uma pedagogia, em termos de superfície e profundidade, para saber que práticas investigativas e que formas de pensar provocam ou promovem os OAP, ou ao contrario, como os OAP provocam outras práticas investigativas ou formas de pensar. Nessa primeira parte os instrumentos de análise são filosóficos e a pergunta que nos guia é, o que os OAP podem fazer?

A segunda parte incursiona na análise dos processos e estratégias na produção dos artefatos artístico-pedagógicos de todos os participantes que finalizaram o curso. O objetivo é compreender as formas de operar da arte e da educação quando se encontram em colisão, contaminação, interseção ou hibridação para saber de que maneira se relacionam os OAP com os contextos de investigação. Para essa segunda parte os instrumentos de análise são os marcos de investigação de Sullivan (2010) e a pergunta que nos guia é, o que se produz com os OAP?

A terceira parte da análise aborda os territórios de subjetivação que se constroem, ou, como os participantes se vêm a si mesmos e aos seus estudantes, no coração do encontro das águas. Nesse sentido a análise inclui diversos participantes. O objetivo é entender as relações fluídas entre arte, educação e existência, para saber em que medida as identidades se fundem, hibridizam, ou tencionam. Os instrumentos de análise nesta última parte são narrativos em decorrência da necessidade de capturar os traços inapreensíveis do que se move, daquilo que não tem um começo ou um fim, do que está em processo de ser com. As perguntas que aqui nos guiam são, que afetos formam os OAP? Que afetos são formados pelos OAP?

\subsubsection{O que um OAP pode fazer?}

A seleção apresentada aqui para análise baseia-se em dados escritos, visuais e audiovisuais. Os conceitos, que atravessam as análises de todos os artefatos selecionados, partem dos fundamentos conceituais apresentados nos primeiros capítulos. Com a intenção de ter uma visão em superfície e em profundidade, cada um dos artefatos é analisado de maneira separada, tomando em conta que foram identificados, justamente, em função das suas 
diferenças e não das semelhanças. No caso dos artefatos apresentados aqui, interessa analisar as suas potências pedagógicas para Educação em Visualidade, mas também identificar os desafios que se apresentam com eles.

Um desses desafios é pensar a educação não mais como uma transmissão de pacotes de informação, ou 'educação bancária' (FREIRE, 1987a, 1987b), que condiciona as imagens a processos de fixação na memória, a processos de codificação e decodificação desviculados de contextos específicos, a processos de imitação ou modelação a partir de uma obra para a prática criativa. Nessa perspectiva não interessa outra coisa que o objeto de arte. Mas, na pespectiva das pedagogias culturais, interessa mais saber o que a arte faz para a vida das pessoas. A arte como um detonante de experiências estéticas e pedagógicas. Estes artefatos trazem alguns indícios.

A potência pedagógica dos artefatos que se realizaram nos cursos de extensão são muito maiores do que parecem na realidade e diferentes daquilo que podemos esperar. Aprender não é algo que ocorre necessáriamente no instante em que se conhece um fato, nem se aprende exatamente o que foi ensinado ou a mesma coisa que todos os que compartilham um processo de aprendizagem e nem todos conseguem exteriorizar tudo que aprenderam. A maior potência se manifesta, portanto, no que ainda podem se tornar ou nas outras experiencias a que podem conduzir. O que existe em potência nos artefatos que resultaram do curso de extensão Objetos de Aprendizagem Poéticos, se apresentam aqui, de maneira intensa, extrema, relevante e desviante. Mas é importante destacar que estes critérios foram estabelecidos em relação a todos os trabalhados realizados nas três versões do curso de extensao e não a padrões externos ao curso e aos seus participantes. Também não se trata de um ranking, ou avaliação em relação a um "certo" ou "errado" dos artefatos. Isso todos os participantes podem fazer na sua própria prática julgando em relação ao seu contexto, o curso proporciona vários parâmetros profissionais para guiar uma avaliação.
A) Intensidade

Título: Queres Quanto? Autor: Participante ' $N$ ' - curso 1/2014. Dirigido a: estudantes do $4^{\circ}$ ano do Ensino Fundamental. Modalidade: jogo com dobradura de papelão. 


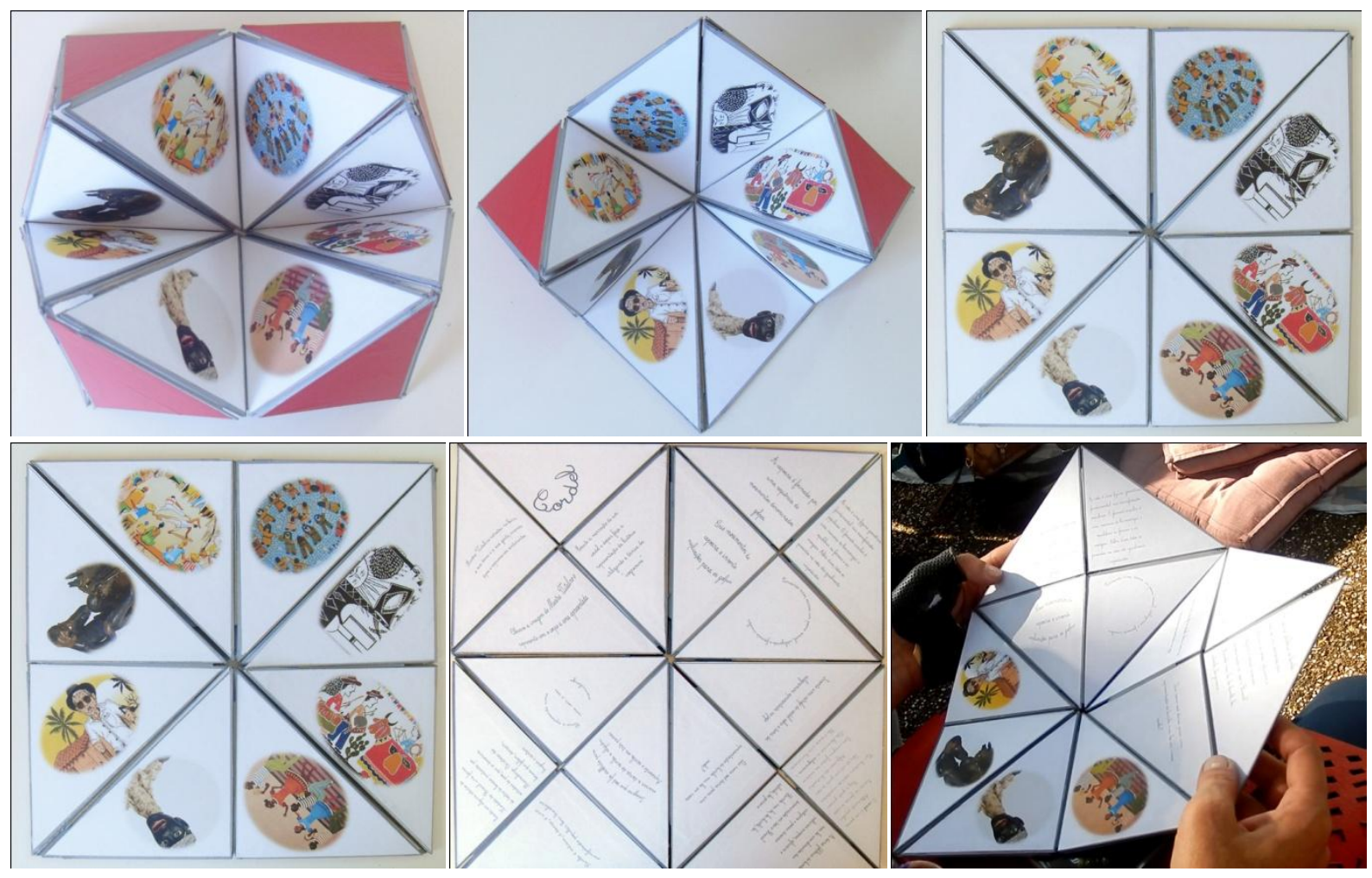

Fig. 100 Participante ' $N$, “Queres-quanto" jogo para aprender sobre Cultura Popular para crianças do $4^{\circ}$ ano do Ensino Fundamental produzido no âmbito do curso de extensão 'Objetos de Aprendizagem Poéticos' no $1^{\circ}$ semestre de 2014, VIS/IdA/UnB. Fotografia do participante ' $N$ '.

O participante ' $N$ ' trouxe da memória de infância o jogo 'Queres Quanto?' ${ }^{82}$ e revelou o potencial da estrutura do jogo para criar OAP. Se apropriando dessa estrutura desenvolveu um jogo em que trabalha a Cultura Popular com imagens e desafios poéticos que podem resultar em desenhos, performances, poemas ou narrativas realizadas pelos estudantes/participantes da sua aula. $\mathrm{O}$ artefato tem a intenção de complementar e avaliar o trabalho que ' $N$ ' vinha realizando em sala de aula com o tema. O jogo trabalha habilidades para relacionar artefatos, narrativas e costumes à compreensão poética da cultura. A peça, feita de material firme e leve com impressões de imagens e texto (trabalhado como imagem), se apresenta em um tamanho e qualidade estética ideal para o uso dos seus participantes (Fig. 100).

No fórum do capítulo III, ' $N$ ' explicou suas intenções e descreveu quais as regras do jogo que imaginava (ver fig. 95, Quadro de Conversações do Fórum do capítulo III). No fórum do capítulo IV, ' $N$ ' narrou o processo de construção do OAP, se entusiasmou com as

\footnotetext{
${ }^{82}$ Jogo que se realiza com uma peça feita de papel com uma dobradura especial, que um jogador move tantas vezes quanto um outro participante quiser (Quanto queres?). O número determina o lugar onde se abre a peça e onde se encontram as perguntas ou consignas do jogo para que o participante que deu o número faça.
} 
possibilidades que se abrem na frente e apontou uma mudança nas modulações da sua identidade (ver fig. 96, Quadro de Conversações do Fórum do capítulo IV).

A proposta apresentada por ' $N$ ', desde um começo, mostrava claramente a potencialidade do artefato (ver fig. 95, Quadro Conversações, fórum do capítulo III). ' $N$ ' deixou evidente que sua preocupação se centrava no que poderia ser realmente poético no artefato para permitir o espaço de subjetivação dos seus participantes. As palavras e as imagens com que descreveu as ideias evidenciaram a intensidade com que ' $N$ ' abordou o desafio de fazer um OAP. A apropriação de um jogo popular que, justamente, se coloca a disposição para ser reinventado, foi muito adequado para a faixa etária e para a atividade. A dobradura do jogo pode ser adaptado e customizado. O que era interessante na ideia é que era uma estrutura ideal para apresentar desafios (são as consignas que indicam o que o participante deve fazer no jogo) e ' $N$ ' trabalhou muito nisso. $\mathrm{O}$ importante era saber que tipo de desafios. $\mathrm{O}$ assunto do artefato proposto, a Cultura Popular, era também uma oportunidade de provocar eventos. O contexto em que ' $N$ ' se propunha aplicar era a própria turma na escola, constituindo assim um caldo com os melhores ingredientes para a criação de um OAP.

' $N$ ' construiu um protótipo de qualidade, com material firme e permanente, de tamanho grande o suficiente para conter os desafios escritos e as imagens e ao mesmo tempo ser manipulável para as mãos das crianças. Desenhou a estrutura da figura geométrica onde configurou as imagens e os textos. E os textos eram desenhos. Pensou nestes textos como formas em movimento e os editou. Esse trabalho requer cuidado na elaboração e conhecimento de edição e impressão de imagem. A qualidade da forma foi pensada para dar espaço à qualidade das ideias que estão incorporadas nos desafios. Os desafios são, então, textos dançantes. São desafios para que os estudantes participantes realizem tarefas poéticas apresentadas de maneira poética. As propostas de ações para seus estudantes são abertas à imaginação: "crie movimentos de capoeira e invente explicações para os golpes". ' $N$ ' manifestou a ansiedade que sentiu no momento que os estudantes-participantes simularam um enfrentamento que poderia parecer uma briga para quem entrasse na sala de aula sem saber o que ali estavam aprendendo.

No dia da apresentação final do curso de extensão ' $N$ ' apresentou o OAP e alguns dos resultados: "[...] eu peguei um conteúdo que foi trabalhado durante o trimestre, e ai, criar um desafio que fosse ao mesmo tempo poético e 


\begin{abstract}
que permitisse a singularidade... eu achei, assim, que foi bem mais dificil, [...] porque [...] eu não podia imaginar um resultado, se não, não seria poético, [...] cada aluno tinha que criar do seu jeito, [...] apliquei com um grupo de oito alunos, depois vou arriscar com uma turma de 35, [...] então, dividi a turma em grupos, e ai, para cada grupo, eles manipularam, e foi sorteado um desafio, e alguns foram até repetidos, mas eu achei bem interessante que mesmo os repetidos surgiram coisas diferentes. Alguns desafios eram por exemplo, dar um nome para o Boi Bumbá [...], então aqui tem alguns registros do que eles foram escrevendo, trabalhei também com xilogravura, eu tinha um desafio que era ouvir a narração, de um cordel de Patativa do Assaré, que é o Cabra da Peste, ai uma aluna foi sorteada, ela ouviu e tinha que representar por meio de uma xilogravura [..] dai a menina é louca por desenho, então caiu direitinho com ela, que ela se apaixonou, e, também tive poesia, eles tinham que escrever uma poesia a partir uma xilogravura de Brasília [...] e dos vídeos [...] em geral eu não tinha gostado muito do resultado não [...] alguns desafios [...] um era para criar um passo de capoeira, e dai, eles tinham que explicar o passo de capoeira, [...] eles começaram a se bater, como se estivessem ensaiando [...] mas assim, você via que estava no controle, mas a impressão é que, se alguém chegasse de fora, ia falar 'eles estão brigando', e o outro foi do samba, eles tinham que apresentar o samba para uma pessoa e apresentar o samba em três passos." (Participante $\mathrm{N}$, transcrição de trecho do vídeo da apresentação de resultados, encontro presencial, curso de extensão Objetos de Aprendizagem Poéticos, 1/2014)
\end{abstract}

Os resultados que ' $N$ ' apresentou foram intensos, embora as práticas que realizou fossem somente com um pequeno grupo e estivessem limitadas em tempo. Os resultados, tanto do material escrito (poemas e narrativas) (Fig. 101), como do material visual e audiovisual (xilogravuras e performances) foi sistematizado por ' $N$ ' com registros. A apresentação dos registros à turma do curso de extensão, no dia do último encontro presencial, teve uma força particular que tocou todos: leu um poema escrito por um dos participantes do seu jogo, mostrou uma cópia da xilogravura realizada por outro e mostrou as imagens das performances. O que ' $N$ ' fez foi colocar a disposição um artefato que provoca corporificar aquilo que se propõem aprender. 
Pensar nos desafios e selecionar as imagens, construir, testar, pensar em outros artefatos é um processo difícil, admite ' $N$ ', (Quadro de Conversações do Fórum do capítulo IV) mas suas palavras sugerem que, justamente, é esse processo que encanta, que estimula. É um processo que se atreve a mergulhar na experiência estética. $O$ objeto não finaliza ali, cria uma expectativa, ele promete, se abre a outra forma. Não importa quantas vezes seja aplicado, provocará resultados singulares, pois ' $N$ ' elaborou os desafios com aberturas à poética dos eventos sem perder de vista o tema de estudo nem o contexto em que se aprende. Produzir o OAP é, como aponta ' $N$ ', um processo de investigação, de construção de conhecimento, é um processo pedagógico e estético.

Na fase final, 'N' avalia seu trabalho da seguinte maneira: "'Queres quanto
' apresenta caráter participativo, avaliativo e, ao mesmo tempo, lúdico. Os
alunos puderam interagir com o material produzido, mesmo sendo apenas um
único objeto. A turma foi dividida em cinco grupos e cada grupo recebeu um
desafio. Eles tiveram um tempo para a produção, acordado previamente, e
depois apresentaram o resultado. Vale ressaltar que todos os assuntos
abordados nas imagens e nos desafios foram desenvolvidos anteriormente.
Penso que o objeto é reutilizável: altere o conteúdo e as imagens, e novos
desafios surgirão. O objeto foi provocativo e instigante. Alguns alunos
demonstraram interesse em realizar outros desafios. Até os mais tímidos se
envolveram com as tarefas. Os resultados foram singulares." (participante 'N',
Fórum dos resultados da Aplicação, Fórum do capítulo IV, curso de extensão
Objetos de Aprendizagem Poéticos, 1/2014).

No aspecto pedagógico o jogo Queres Quanto? se abre a uma forma estética de se relacionar aos conhecimentos que se propõem. É um artefato em cujo processo pode se aprender sobre cultura popular brasileira (embora no caso da turma, os temas já tinham sido trabalhados) e ao mesmo tempo, pode constituir um instrumento de avaliação qualitativa. De fato o participante ' $N$ ' pensa ele para avaliar um processo. É, por outra parte, um artefato que perfeitamente pode ser trabalhado de maneira inter-trans e pós-disciplinar. O design é claro, estimulante e pensado em todos seus aspectos visuais e textuais, muito apropriado para a idade e o contexto de ensino. O Queres Quanto? se insere dentro de um processo pedagógico como parte de uma unidade maior. Os desafios abrem espaços para resposta singulares no processo de construção de uma relação com os assuntos da Cultura Popular. Nesse processo a singularidade dos 
estudantes/participantes é chamada a imaginar, inventar, pretender, poetizar, criar e produzir mundos outros. Nesses desafios há espaço para processos de interpretação e de invenção de outras formas de fazer e ver.
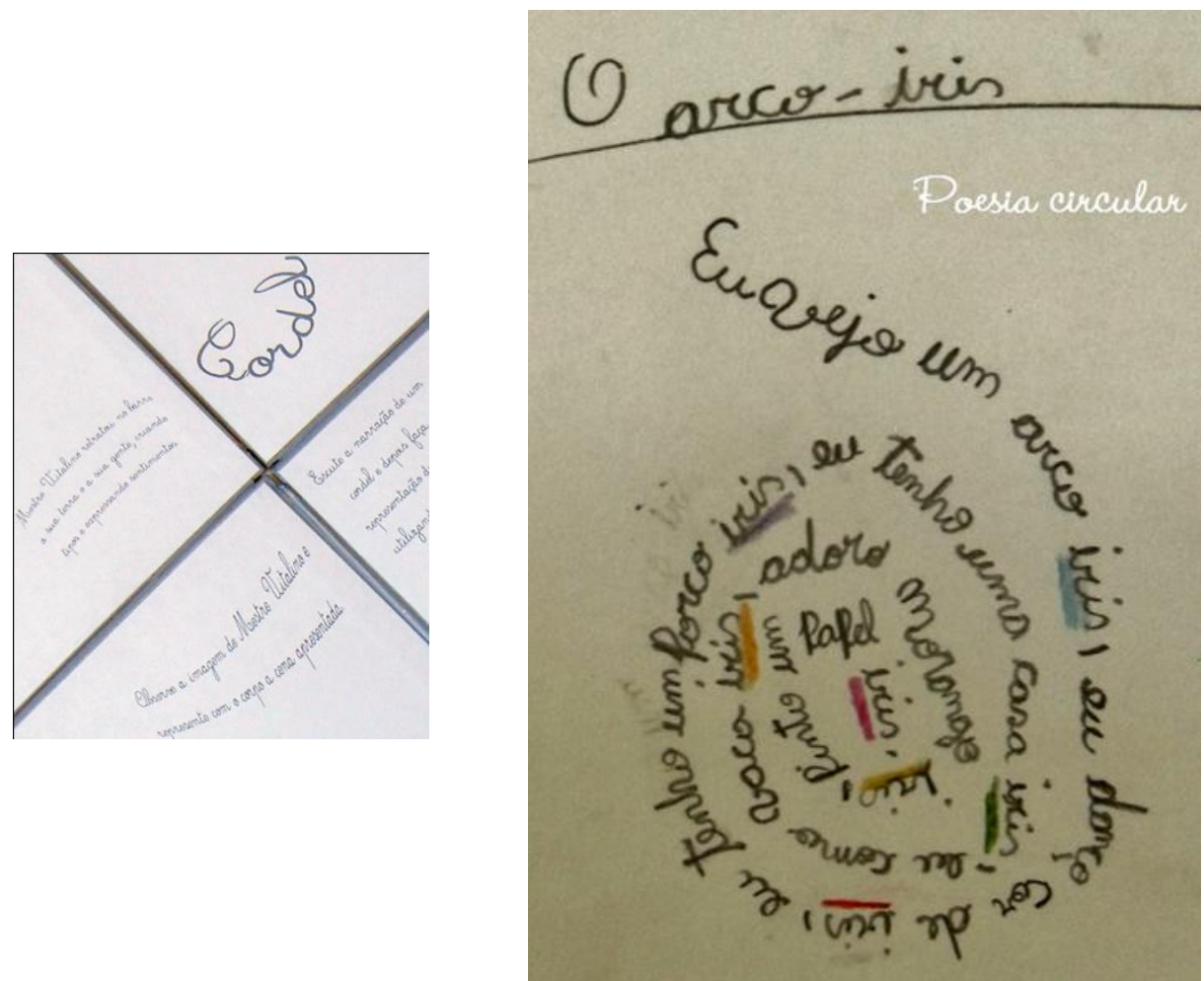

Fig. 101 Detalhe dos desafios e O Arco Iris, poema de estudante/participante do OAP Queres Quanto?, 1-2014. Fotografia do participante ' $N$ '.

Podemos dizer, como Deleuze (2007), que se trata de um objétil, porque o artefato projeta as possibilidades singulares dos participantes, e ai incluo as possibilidades que se abrem para o participante ' $N$ ' na sua prática pedagógica. Isso depende tanto da configuração e material quanto dos desafios que apresenta o artefato. Como aponta ' $N$ ', mesmo com desafios repetidos, os resultados foram diferentes. Os estudantes se tornam então, participantes na construção dos eventos. É importante notar que tanto a interface visual como as propostas ou desafios abordam a experiência estética como um evento e não como um processo de leitura de imagens. O desafio pede, por exemplo: "escute a narração de um cordel e depois faça a representação da história na técnica da isogravura". Isso significa que os desafios favorecem processos de interpretação que são, ao mesmo tempo, processos de produção. Não se separa na experiência o que é do sujeito e o que é do objeto. 
No ensaio final do curso, ' $N$ ' escreve: "[...] a relação que o objeto cria entre o aluno e o conhecimento é singular. Da para notar no brilho dos olhos dos alunos que eles estão criando, reinventando, brincando, participando, avaliando e aprendendo! Dependendo do objeto, ele pode ser reutilizável e autônomo. [...] utilizar OAP em aula é [...] a educação [...] reflexiva, emancipadora, democrática e política". (Participante ' $N$ ', ensaio final, curso de extensão Objetos de Aprendizagem Poéticos, 1/2014).

O jogo indica (na sorte) o desafio e o participante deve se relacionar de alguma maneira particular com o objeto de conhecimento. Essas bases são análogas ao princípio da emancipação no ponto de partida. O participante do jogo poderia criar um território de existência, produto da sua relação com a imaginação e com o artefato: "[...] eu danço cor de íris,[...]" (Fig. 101). Um poema que dança é o resultado de um dos desafios relacionados à roda e à capoeira. O desafio pede ao participante, "Pensando nisso, escreva um poema visual, utilizando a forma circular". E o participante escreve isso de forma circular. Essa forma estabelece, metaforicamente, a relação circular entre o criador do artefato, o artefato e o participante.

Essa 'dança cor de íris' é um rastro do evento, do encontro entre o sujeito e o objeto, que é um encontro estético. Os participantes encontram território fértil para inventar cartografias de existência onde se fazem visíveis. Nesse ponto, entre todos os artefatos finalizados, o jogo 'Queres quanto?' alcança intensidade como um OAP pelas aberturas que apresenta à diferença.

B) Extremo

Título: Identidades. Autor: Participante 'T'- 2/2014. Dirigido a: Ensino Médio. Modalidade: Caixa com diversos artefatos.

'Identidades' é um OAP que explorou as mídias contemporâneas na formação de identidades. Compõe-se de uma caixa com uma série de papéis transparentes com palavras (no caso foi escolhida a palavra REFLEXO) e letras impressas que, superpostas, formam palavras chave a partir das quais se fazem reflexões coletivas sobre identidade, um caderno de perguntas que guiam as discussões, uma série de impressões de uma imagem de identificação usada em redes sociais impressa em papel transparente, o recorte da forma de um espelho, e uma lupa 
(Fig. 102). A proposta faz uso de telefones celulares para fotografar e trabalhar navegando nas redes sociais. Resulta num Caderno de Navegação dos participantes (ver fig. 95, Quadro de Conversações do Fórum do capítulo III).

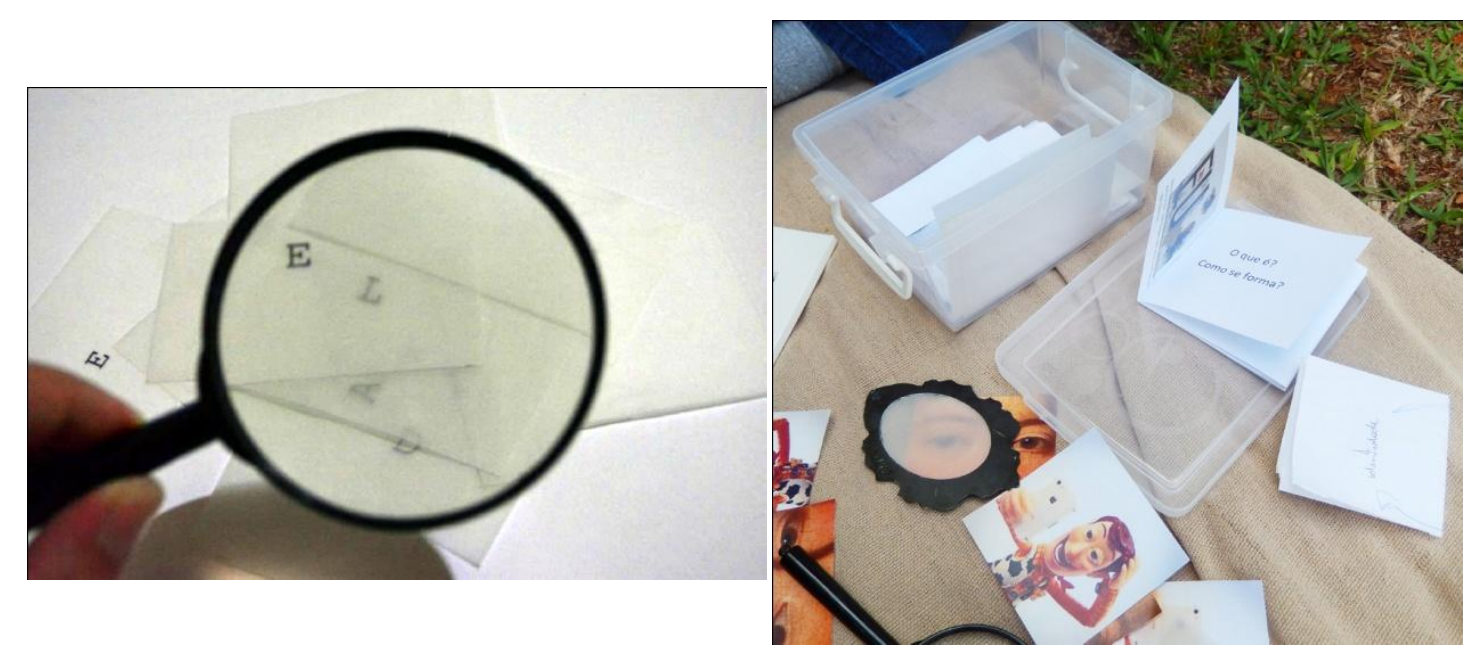

Fig. 102 Participante ' $T$ '. Identidades. Artefato para refletir sobre conceitos que se relacionam às identidades dirigido ao ensino médio, produzido no âmbito do curso de extensão 'Objetos de Aprendizagem Poéticos' no $2^{\circ}$ semestre de 2014, VIS/IdA/UnB.

Neste ponto é conveniente observar que os participantes que vinham do âmbito da arte tiveram dificuldade para estruturar um projeto pedagógico, da mesma maneira que os participantes que vinham do âmbito da educação tiveram problemas para estruturar projetos poéticos. Houve vários projetos que se mostravam como extremos no sentido em que tendiam para uma forma de evento mais do que para outra. Mas, somente 'Identidades' se completou em todas as fases. Tanto o artefato 'Regalo' como 'Vivências Estéticas do Maracatú' levaram ao extremo o caráter poético do OAP, mas não se completaram e a estrutura pedagógica não ficou definida. Eles partiram do espaço da arte em direção ao espaço pedagógico, pois prevaleceram os projetos artísticos que levavam em curso. Os objetos surgiram da sua investigação artística. Com os professores os objetos surgiam da sua investigação pedagógica e apresentaram resistência para sair do pensamento dicotômico entre certo e errado. Essas diferenças constituem extremos que nos ajudam a entender os territórios de subjetivação.

'Identidades', no entanto, é um artefato que 'T produziu com uma grande preocupação sobre as questões pedagógicas, e, embora não tivesse um grupo de estudantes, conseguiu aplicar e observar o OAP com um grupo de estudantes de arte e um grupo de estudantes do ensino médio, o que contribuiu para fazer comparações. 


Pensando de maneira crítica, a intenção de 'T parte da corrente dos
selfies nas redes sociais na Internet, que molda a identidade das
pessoas e suas formas de relacionamento. 'T observa que no "currículo
escolar do Distrito Federal do nível médio" se encontra "uma
possibilidade de dialogar sobre a formação da identidade a partir da
dialogo com estudantes sobre a produção e reprodução de imagens
distribuídas na rede, tendo como ferramenta de pesquisa os aparelhos
eletrônicos (celular ou tablet) de cada estudante, essa observação
levou-me a elaborar meu OAP" (Participante 'T, Ensaio final, curso de
extensão Objetos de Aprendizagem Poéticos, 2/2014).

O que ' $T$ tinha em mente desde o começo eram indagações sobre o que os selfies e os autoretratos nas redes sociais significam no contexto da formação de identidades. Encontrou relações que poderia estabelecer com a matriz curricular do ensino médio e pensou a partir desse contexto. Para ' $T$, a figura principal era a dos fragmentos que se superpõem, que se movem e formam outros significados. Usou palavras chave relativas à identidade, como Reflexo, impressas em papel transparente. Com esse artefato 'T" queria "discutir a construção da identidade através de palavras chaves e imagens produzidas e reproduzidas na rede. produzir um Caderno de Navegação em equipe, analisar os diferentes pontos de vista, intervir e trocar a partir do Caderno de Navegação" (Participante 'T, proposta de trabalho, Fórum do capítulo III, curso de extensão Objetos de Aprendizagem Poéticos, 2/2014). Nesse ponto tínhamos um objeto poético que ainda pedia um suporte para manipular os fragmentos (palavras chave, imagens, cadeno de navegação) e um detonante de aprendizagem.

'T Apresenta o OAP da seguinte maneira: "A partir da Cibercultura proponho um diálogo sobre a construção da identidade entre os estudantes do ensino médio [...]". No processo se estabelece um "Diálogo sobre a construção da identidade para gerar uma série de palavras chaves, conexões" e se realiza uma "Análise das imagens produzidas e compartilhadas na rede digital. Como uma imagem, um recorte fotográfico participa da construção da sua identidade?". Logo depois "o grupo irá organizar o caderno que é composto das palavras chaves e imagens, lembrando que tudo será impresso em papel 


vegetal. Com orientação sobre encadernação os grupos iram
confeccionar os Cadernos de Navegação (um caderno por grupo). O
objetivo dessa etapa é fortalecer a troca e a construção em equipe.
Depois de prontos os Cadernos de Navegação cada grupo irá falar
como conceberam o processo de construção de identidade (pontos de
vistas diferentes)". Finalmente haverá uma "Troca de Cadernos de
Navegação entre os Grupos para intervenção (escrita, colagem,
recorte) de outras pessoas" (Participante 'T, proposta de trabalho,
Fórum do capítulo III, curso de extensão Objetos de Aprendizagem
Poéticos, 2/2014).

Mas, não que o artefato de ' $T$ não tivesse detonantes, ao contrário, era aberto a muitas possibilidades. A questão era então apontar um horizonte de aprendizagem. Um horizonte é amplo, mas determina uma certa direção, sentido e metodologia. Um OAP deve calibrar as aberturas de tal maneira que se abra a possibilidades singulares, mas por outro lado deve apontar um horizonte.

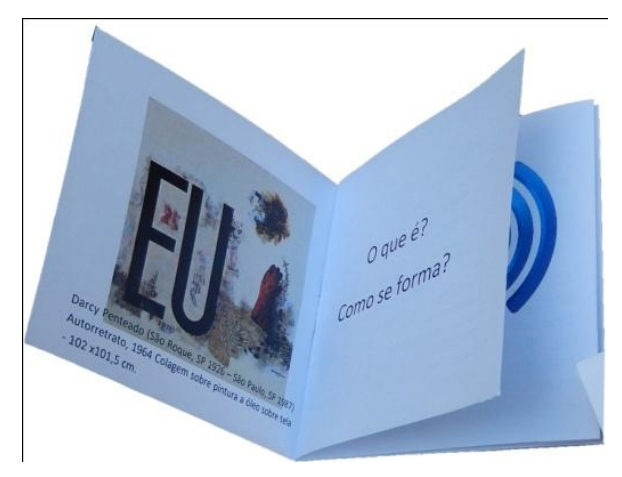

Fig. 103 Livreto de perguntas e conceito fragmentado em transparências para discussão. 'Identidades', curso de extensão 'Objetos de Aprendizagem Poéticos' no $2^{\circ}$ semestre de 2014, VIS/IdA/UnB.

'T encontrou nas caixas Fluxus (Quadro de Conversações do Fórum do capítulo III), um caminho para dar forma pedagógica à ideia das palavras chave fragmentadas e ao mesmo tempo pensar esse dispositivo como uma parte entre outras. O pequeno livreto de perguntas surgiu da necessidade de estruturar a proposta pedagógica como um guia do processo (Fig.103). Os acessórios, como o recorte em forma de espelho, a lupa e as imagens de selfies impressas são elementos alegóricos que podem ser elaborados. Mas é importante considerar que o projeto se apresentou em processo de construção. 


No seu ensaio, 'T descreve o processo de construção e experimentação:
"O primeiro protótipo do OAP foi realizado com base em uma folha
lendo cada passo que orientava o dialogo sobre a formação da
identidade para que ao final elaborasse em grupo um livro que seria
trocado com outro grupo diferente para que todos tivessem a
oportunidade de intervir no trabalho do outro. Porém quando testei a
estrutura do papel dobrado com um grupo de amigos, essa estrutura
não favoreceu a dinâmica da proposta. Então mudei o formato para
um livreto o qual teve uma analise positiva." E sobre as palavras chave
aponta que, "Ao propor palavras chaves que façam conexão com a
formação da identidade há a possibilidade de fragmentar essa palavra
e construir outras. Isso é possível devido à transparência do papel
vegetal que revela até certo ponto as sobreposições. Essa parte das
palavras desfragmentadas será organizada como baralhos dispostos
em uma caixa metálica." (Participante 'T, Ensaio final, curso de
extensão Objetos de Aprendizagem Poéticos, 2/2014)

O artefato poético, 'Identidades' aponta a uma mudança nas formas de se ver e ver os outros, assim como as formas de construir as identidades. Como uma nova espécie de espelho que reflete fragmentos de algo que não consegue se definir. Os celulares, com suas funções fotográficas e videográficas anunciam um ser que se vê na sua indefinição, na sua fabulação e na sua capacidade mutante. Vê-se porque se mostra nas redes sociais, (o espelho ou espaço heterotópico) onde passa a existir de uma outra maneira. ' $T$ sabe que as rachaduras que se criam nesses processos levam a um denso mar para explorar na arte (a lupa), e isso além do mais, tem um valor pedagógico incalculável porque foca nas fronteiras e fluxos entre imagem e realidade, entre objeto e sujeito, ao mesmo tempo em que pode conduzir a reflexões políticas, sociais e culturais relevantes.

Na hora de avaliar 'T escreve no seu ensaio: "Acredito que quando pensamos nossas propostas de ensino de arte em forma de objeto palpável ou digital estamos oferecendo possibilidades de uma integração mais eficiente com o estudante e o conteúdo sem repetir 
uma estrutura mecânica, mas uma estrutura que privilegia a reflexão, as conexões entre o mundo de cada estudante e a escola ou espaço de ensino." (Participante 'T, Ensaio final, curso de extensão Objetos de Aprendizagem Poéticos, 2/2014)

Embora ' $T$ tenha tido dificuldade para estruturar o eixo pedagógico o artefato alcançou qualidade nesse aspecto. As possibilidades reflexivas são só uma pequena parte dos possíveis desdobramentos pedagógicos. $\mathrm{O}$ artefato apresentou muitas possibilidades de exploração na Educação em Visualidade: questões da cultura visual como os autorretratos ou o fluxo de identidades, ou questões de produção fotográfica, videográfica e edição de imagem, ou questões metodológicas nas relações inter-trans e pós-disciplinares. No caso, o livreto pauta as orientações e consignas que permitem que o OAP seja usado em qualquer outro contexto semelhante. O Caderno de Navegação é um dos resultados esperados no caso de ser aplicado no âmbito da educação formal. Mas ' $T$ não chegou a esta fase. Os grupos com os que trabalhou completaram dois dos três passos do OAP: debateram sobre as palavras chave e sobre os fragmentos da identidade nas redes sociais.

O que ' $T$ ' apontou com essa proposta foram situações de reflexão crítica de uma maneira poética que não é comum no espaço pedagógico. Como artefato de aprendizagem, cruza as fronteiras do estabelecido (mas que por esse motivo, se torna eminentemente pedagógico). Evidentemente, faltaram fases para completar a experiência, os Cadernos de Navegação poderiam revelar aspectos importantes do processo. Mas, se considerarmos que os participantes poderiam aprender com este artefato e que, nesse ato há uma forma de criar novos territórios de subjetivação, nesse sentido, 'Identidades' aponta em direção a um espaço poético - pedagógico possível.

C) Desvio

Título Arte Popular Brasileira. Autor: Participante 'P' - 1/2014. Dirigido a Ensino Fundamental na Educação de Jovens e Adultos, EJA, na modalidade de Educação a Distância, EaD. Modalidade: jogo interativo digital na internet. 


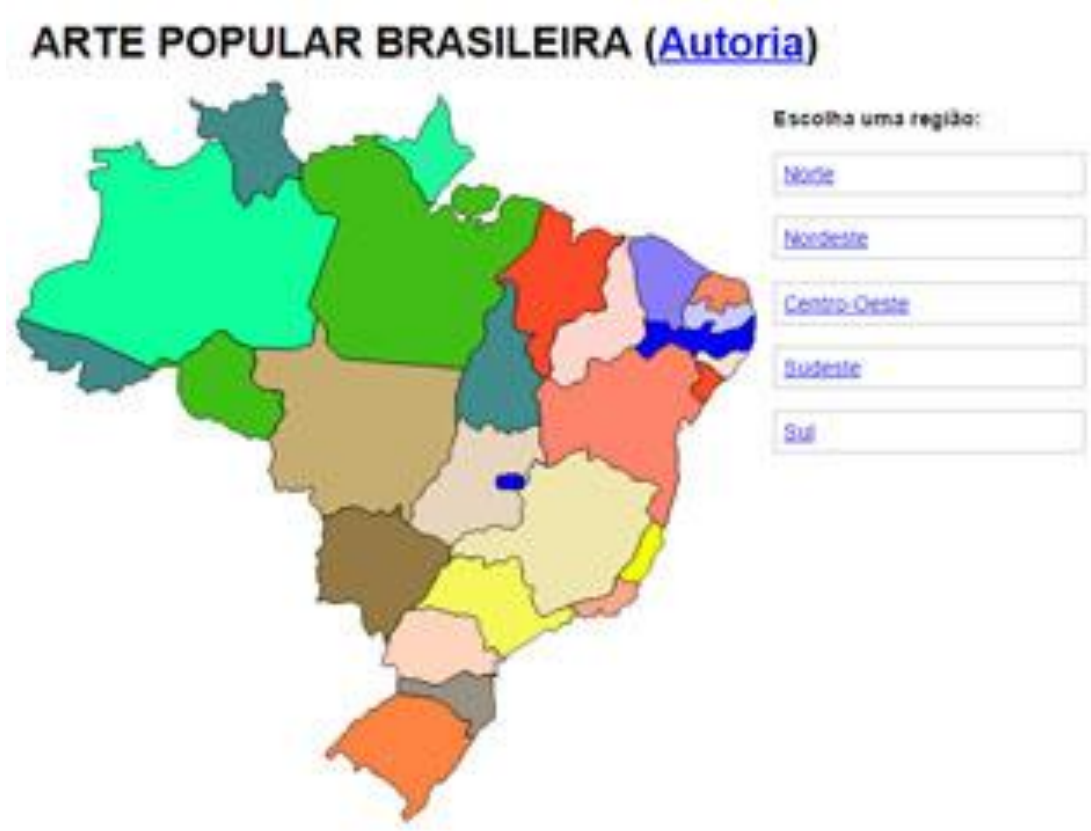

Fig. 104 Participante 'P'. Arte Popular Brasileira. Jogo Interativo para EJA a distância. Escolha e contagem dos acertos e erros. Produzido no âmbito do curso de extensão 'Objetos de Aprendizagem Poéticos' no $1^{\circ}$ semestre de 2014, VIS/IdA/UnB. 2014. Fonte: jogadenovo.com.

O objetivo do jogo interativo ${ }^{83}$ do participante ' $P$ ' em formato digital foi estudar e avaliar o tema da Arte Popular Brasileira sobre a estrutura de um mapa das regiões no Brasil (Quadro de Conversações, Fórum do capítulo III). No jogo, o participante aprende e avalia seu percurso pela relação que estabelecem as imagens apresentadas com as regiões no mapa do Brasil (Fig. 104).

Na entrada do jogo, apresenta-se o mapa do Brasil e as opções para
escolher a região: "a estratégia do jogo é estabelecer a relação entre a
imagem da arte popular brasileira com o estado correspondente à imagem,
já separado por região". Uma vez escolhida a região aparecem pintados
somente os Estados que a compõem e do lado direito, imagens de
"costumes, religiões e festas, lendas, contos populares, brincadeiras,
provérbios, adivinhações, orações, maldições, encantamentos, juras,
saudações, despedidas, trava-línguas, artesanato, medicina popular,
danças, música, canções (inclusive as baladas e canções de ninar) e muitas
outras" (Participante 'P', Ensaio final, curso de extensão Objetos de
Aprendizagem Poéticos, 2/2014).

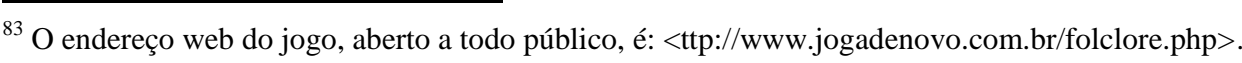




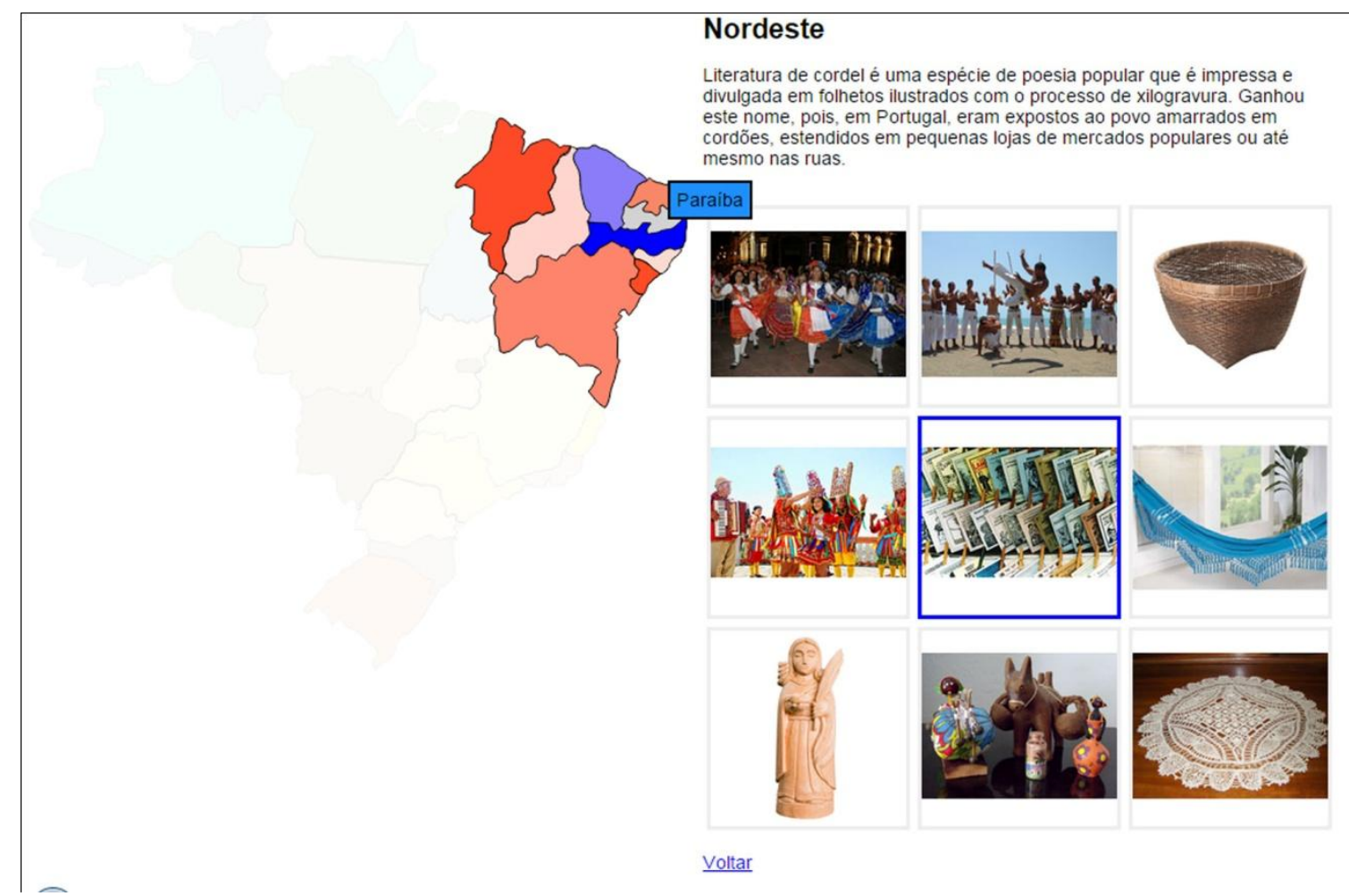

Fig. 105 Participante 'P'. Arte Popular Brasileira. Jogo Interativo para EJA a distância. Região Nordeste. Produzido no âmbito do curso de extensão 'Objetos de Aprendizagem Poéticos' no $1^{\circ}$ semestre de 2014, VIS/IdA/UnB. 2014. Fonte: jogadenovo.com.

O participante deve escolher uma imagem. Na hora de clicar a imagem uma moldura verde e um texto com informações da imagem aparece (Fig. 105). Imediatamente o participante deve escolher o Estado ao qual pertence a imagem. Se o participante acertar, a imagem muda a sua moldura para cor azul e o contador de acertos marca os sucessos. Se o participante errar, a imagem perde a moldura e deve-se escolher novamente uma imagem. $\mathrm{O}$ contador de erros faz também a conta de cada erro. Dessa maneira o artefato se baseia no modelo de respostas certas ou erradas porque visa desenvolver uma estratégia de memorização visual, que no caso é a correspondência entre a região e o artefato.

O participante ' $P$ ' apontou os seguintes objetivos para seu artefato: "Identificar a relação histórica da arte popular brasileira à região de natureza" e "compreender com os temas transversais a Arte com a arte popular brasileira, a Geografia com as regiões brasileiras e a História com os valores históricos das regiões". Com o jogo "Os alunos desenvolvem estratégias de memorização com a arte popular, as regiões e o valor histórico das regiões" (Participante P, Ensaio final, curso de 
extensão Objetos de Aprendizagem Poéticos, 2/2014).

Embora a natureza visual da relação que estabelece entre o mapa e os artefatos da arte popular brasileira seja efetiva, uma estrutura que favorece respostas certas ou erradas pode ser considerada um desvio da proposta de OAP. No mapa dos artefatos criados no curso podemos ver que sete dos vinte artefatos criados se estruturaram como OA, de maneira que este não é o único desvio da proposta. Os participantes poderiam optar por fazer um OA, segundo as suas necessidades e convicções. Mas, o artefato 'Arte Popular Brasileira' apresentou alta qualidade técnica e pedagógica e, embora não tenha apresentado resultados com estudantes na época, foi finalizado e provocou desdobramentos importantes para ' $P$ ' no âmbito do trabalho e da investigação. Dessa maneira, aqui o desvio é considerado uma inflexão que conduz a um caminho fértil da mesma maneira.

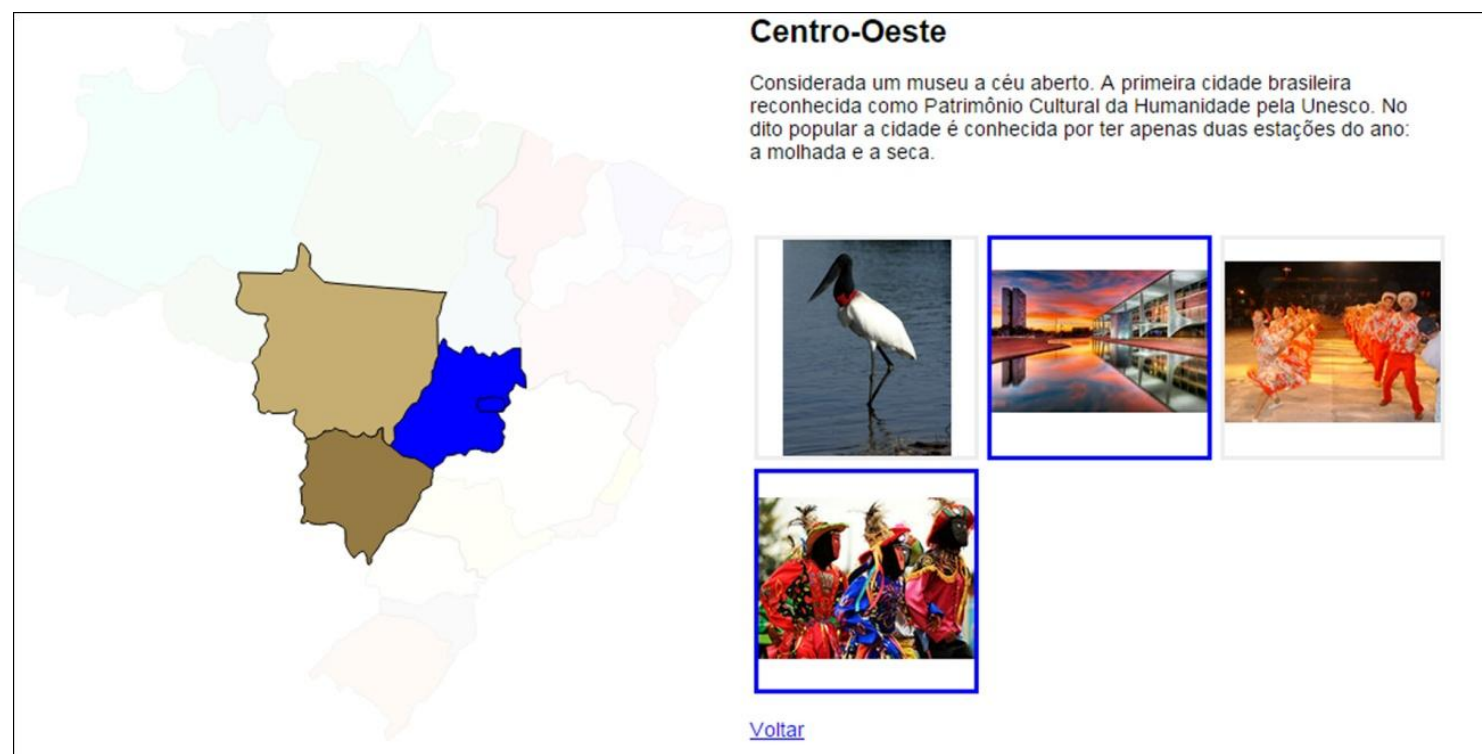

Fig. 106 Participante ' $P$ '. Arte Popular Brasileira. Jogo Interativo para EJA a distância. Centro- Oeste. produzido no âmbito do curso de extensão 'Objetos de Aprendizagem Poéticos' no $1^{\circ}$ semestre de 2014, VIS/IdA/UnB. 2014. Fonte: jogadenovo.com.

A dificuldade para pensar em artefatos que provoquem resultados singulares, que abram espaços de participação, que se baseiem no princípio da emancipação no ponto de partida, é uma dificuldade política. O modelo cientificista das respostas certas ou erradas é uma forma de operar que se torna reducionista e tendenciosa na arte. Mas, isso não significa que o 
esquema cientificista seja 'errado'. Ele pode ser útil em um dado momento e lugar porque o certo ou errado não são qualidades intrínsecas das coisas, mas das relações. O problema do modelo das ciências é que não é suficiente para a experiência estética como evento onde as relações são complexas e paradoxais. Esse modelo não deixa possibilidade para uma pedagogia cultural ou uma arte participante. No caso de 'Arte Popular Brasileira' há interatividade com o sistema, mas essa relação interativa se resume à resposta do sistema quando o participante relaciona uma imagem ao Estado correspondente (ou não) da região no mapa do Brasil. Mas o estudante não participa da construção desse conhecimento. No entanto, isso não impede que o artefato faça parte de um processo maior em que o estudante constrói o conhecimento com sua comunidade. Por esse motivo não se pode afirmar que um OA no modelo cientificista seja 'errado' para o ensino das artes visuais, ou de maneira mais ampla, na Educação em Visualidade. Ele pode ser ou não útil em um dado processo, depende, então, de outras variáveis.

A interface visual adotada entre as imagens e o mapa estabelece conexões em que se constrói um vocabulário visual em relação a uma espaço/tempo: uma imagem a um Estado ou a uma região em uma época dada (Fig. 106). A relação dos usuários com as áreas de interação são visíveis e a navegação é simples. Por outro lado os textos são claros e sintéticos. Tudo isso contribui para uma experiência estética no processo de aprender algo que de outra maneira poderia ser pura memorização de dados.

No entanto, não é possível dissertar sobre as questões poéticas do artefato. Pode-se, sim, valorizar sua potência para criar outras situações, que sendo poéticas ou não, contribuem na construção do conhecimento. Somente o fato de ser um jogo, de criar relações visuais e de interatuar com o estudante estabelece uma diferença fundamental com apresentações textuais. Assim como é um desvio da pedagogia tradicional e responde a um contexto específico (no caso EJA- EaD), é também um desvio em direção à virada da visualidade.

Mas é também um desvio na prática do participante ' $P$ '. Quando começou a elaborar o projeto sua preocupação era criar um material minimamente atrativo para os estudantes que apresentavam um alto índice de evasão (ver fig. 95, Quadro de Conversações, Fórum do capítulo III). Comentou nos encontros o quanto era difícil trabalhar a distância com estudantes do EJA. A ideia que apresentou no curso era difícil de implementar sem conhecimentos de HTML 5, sem uma experiência prévia em web-design. Mas isso não foi um impedimento para 
' $P$ '. Procurou profissionais e implementou a ideia. Os OA abriram um mundo novo para ' $P$ '. Nem tinha terminado o curso e já tinha projetos para criar OA para outras disciplinas da escola (ver fig. 96, Quadro de Conversações, Fórum do capítulo IV). Os desvios são, pois, caminhos férteis onde podem crescer ideias diversas.

Com este jogo novas possibilidades se abrem para ' $P$ ' (Quadro de Conversações, Fórum do capítulo IV) para elevar a qualidade da educação na EJA- EaD com artefatos que possam melhorar o aproveitamento de tempo e espaço para os estudantes e das necessidades que surgem do ensino a distância.

D) Relevante

\section{Título Museu Interativo. Autor: Participante ' $H$ ' - 1/2014. Dirigido a: Ensino Médio.}

Modalidade: Jogo interativo de investigação.
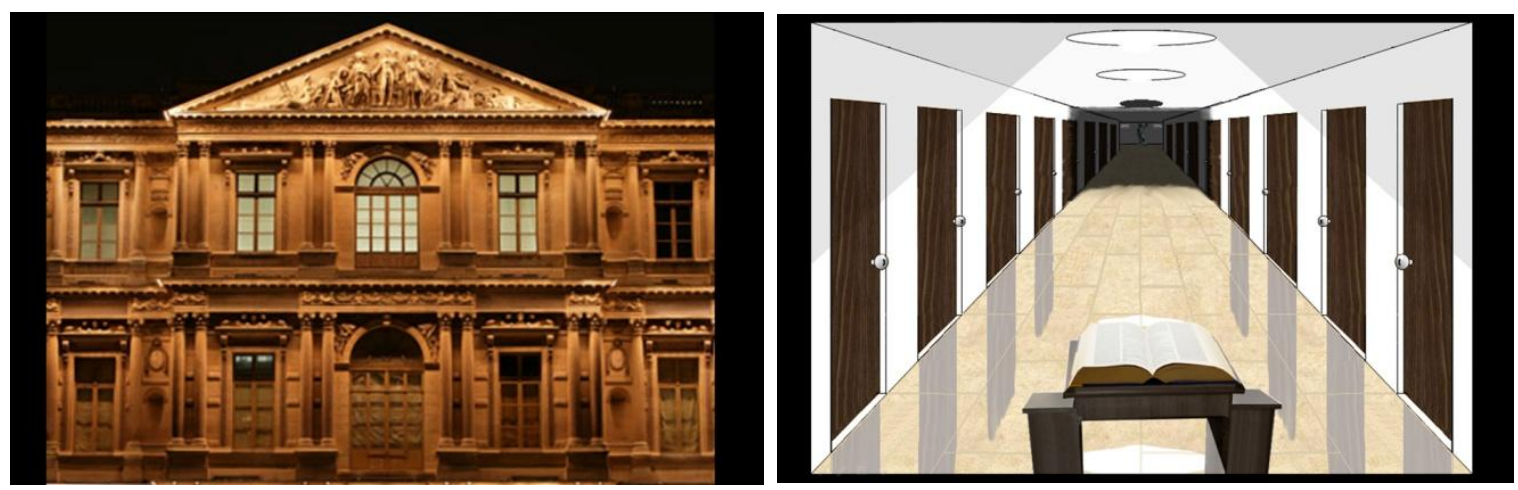

Fig. 107 Participante ' $H$ '. Museu Interativo. Entrada e corredor. Jogo Interativo Power Point para ensino médio, produzido no âmbito do curso de extensão 'Objetos de Aprendizagem Poéticos' no $1^{\circ}$ semestre de 2014, VIS/IdA/UnB.

O jogo de investigação 'Museu Interativo' criado em Power Point pelo participante ' $H$ ' foi inspirado na estética dos jogos interativos. Ele tem imagem, som e responde ao movimento espacial dentro de um espaço imaginário. No inicio do jogo o participante entra pela porta de uma fachada clássica (Fig. 107) e vai dar em um corredor com portas que levam a salas de exposição (Fig. 109). Nessas salas os estudantes encontram uma série de imagens da História da Arte e ao clicar nelas se abrem as fichas técnicas e outros dados sobre a obra. Na sala também se encontra uma placa que, ao clicar nela indica qual é a tarefa de investigação para os estudantes.

'H' descreve assim a ideia: "[...]onde está escuro o aluno não vai 


conseguir acessar enquanto ele não fizer essas primeiras portas, que
são justamente o primeiro bimestre... então ele vai clicar [...] aqui no
livro [...] e vai para a próxima página, e aqui vai explicar tudo que
precisa ser feito, inclusive [...] tem um e-mail [...] que é justamente
para os alunos me mandar o trabalho que eles produziram, para que
eu possa colocar [...], eles são obrigados a passar pelo livro [...] só
depois que sair do livro o corredor já está funcionando. [...] ele pode
ir em qualquer porta [...] ele vai decidir o percurso dele dentro do
Museu. [...]" (Participante 'H', transcrição de trecho do vídeo da
apresentação de resultados, encontro presencial, curso de extensão
Objetos de Aprendizagem Poéticos, 1/2014).

A ideia de ' $H$ ' é, a partir das salas que ele apresenta aos estudantes, montar outras salas de exposição com fotografias dos trabalhos práticos e com o produto da investigação e a curadoria feita pelos estudantes.

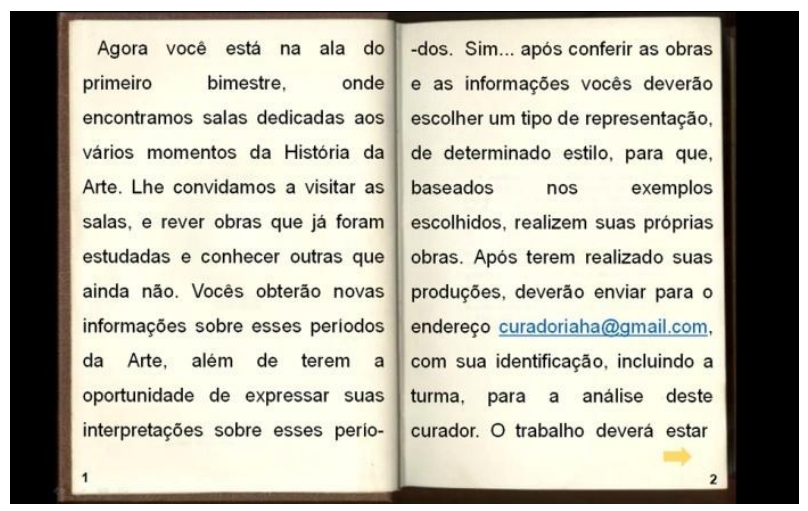

Fig. 108 Participante ' $H$ '. Museu Interativo. Jogo Interativo para ensino médio, produzido no âmbito do curso de extensão 'Objetos de Aprendizagem Poéticos' no $1^{\circ}$ semestre de 2014, VIS/IdA/UnB. Página de entrada à primeira tarefa.

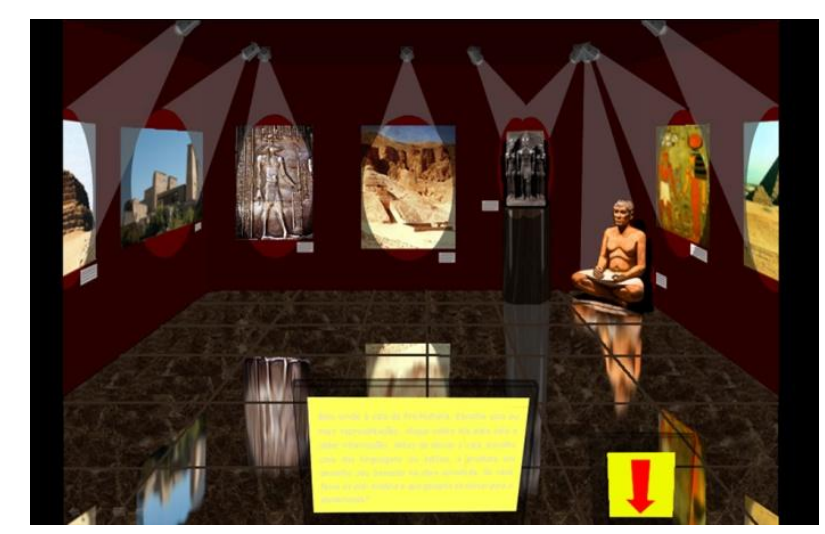


Fig. 109Participante ' $H$ '. Museu Interativo. Jogo Interativo para ensino médio, produzido no âmbito do curso de extensão 'Objetos de Aprendizagem Poéticos' no $1^{\circ}$ semestre de 2014, VIS/IdA/UnB. Páginas das galerias.

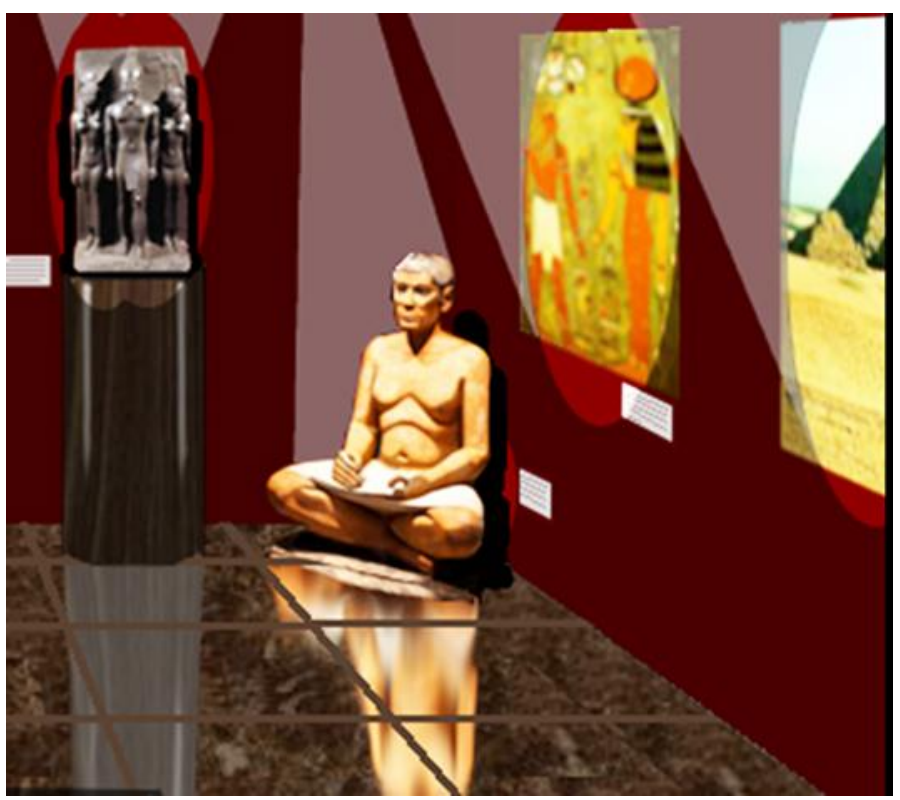

Fig. 110 Participante ' $H$ '. Museu Interativo. Jogo Interativo para ensino médio, produzido no âmbito do curso de extensão 'Objetos de Aprendizagem Poéticos' no $1^{\circ}$ semestre de 2014, VIS/IdA/UnB. Detalhe da galeria de arte egípcia.

O autor partiu da necessidade de otimizar o espaço e o tempo das aulas de arte e da observação das relações que seus estudantes tem com os jogos interativos e as novas tecnologias em geral. A sua preocupação é estabelecer uma conexão entre o mundo das jovens gerações e o mundo da história da arte por meio de um processo lúdico, imaginativo e produtivo. Para isso ele considerou necessário pensar como os estudantes:

No seu ensaio final ' $H$ ' comenta assim sobre as relações com os estudantes: "Fica óbvio que é muito mais fácil que nós os entendamos, que consigamos imaginar suas expectativas, seus interesses... é muito mais fácil 'nós entrarmos na cabeça deles'" (Participante 'H', Ensaio final, curso de extensão Objetos de Aprendizagem Poéticos, 1/2014).

Embora não seja tão fácil entrar na cabeça dos estudantes, ' $H$ ' procura na forma do jogo interativo uma ponte entre o professor, o estudante e o objeto de conhecimento de uma maneira lúdica e dinâmica com a clara intenção de trabalhar as competências delimitadas pela escola em uma grade curricular cientificista (linear e compartimentada, baseada em fatos verificáveis). 
$\mathrm{Na}$ sua avaliação o participante ' $H$ ' toma em conta os seguintes critérios para avaliar o artefato produzido: "Este objeto é de alta granularidade, pois além de já partir de grande quantidade de informações, a interação dos alunos torna sua capacidade de crescimento infinita. Quanto a qualidade do conteúdo, do ponto de vista conceitual ele segue o conteúdo previsto para o Ensino Médio. Do ponto de vista técnico, apresenta possibilidade de adaptação à uma plataforma mais robusta, que traga uma interação a nível mesmo dos jogos virtuais. Do ponto de vista estético, as imagens produzidas elou editadas com Word e GIMP, no caso de adaptação para outra plataforma, poderão ser mais elaboradas. Quanto as instruções, o jogo é auto explicativo. Orientações orais e escritas fazem parte do funcionamento da ferramenta. [...] A interatividade se dá pelos procedimentos dos alunos e a inserção de suas produções no objeto. $O$ envolvimento do educando na atividade se dará a nível de contato com conhecimentos já abordados, com a possibilidade de reflexão sobre esses conhecimentos e, a partir disso, a produção de seu próprio conhecimento, materializada em seus trabalhos e textos. O que ocorrerá também na possibilidade de apreciar a produção de outros alunos e poder interagir com elas. A operação do objeto é bem simples, até por usar uma metodologia que praticamente $100 \%$ dos alunos já dominam. Uma metodologia conhecida e a possibilidade de vir a fazer parte do objeto, são aspectos que trarão um grande incentivo a sua participação. A eficiência pedagógica reside no fato de que operando essa ferramenta o educando terá intenso contato com o conteúdo ("objetivo da escola") e produzirá e compartilhará seu próprio conhecimento (“objetivo do educador”). Este OAP produz resultados singulares, pois cada aluno é único; promove experiência estética, quando possibilita produções pessoais e o contato com trabalhos alheios, o que por si só exige da imaginação e da subjetividade; e estimula as posições diferentes, quando dá a oportunidade de se pensar sobre as produções dos colegas, e respeitálas." (Participante ' $H$ ', Ensaio final, curso de extensão Objetos de 
Aprendizagem Poéticos, 2/2014).

As vantagens que este artefato apresenta são os espaços criados que poderão ser reutilizados e crescer. Dessa maneira se torna um espaço virtual dentro do espaço da sala de aula. Com essa estratégia as aulas presenciais ganham mais folga para a prática, para a investigação e para o estudo. O trabalho que representa criar as primeiras salas é grande, é uma construção permanente que pode ser modulada ao longo dos anos, mas as vantagens em sala de aula são proporcionalmente grandes. Além de produzir espaços de aprendizagem sobre história da arte, se cria também um espaço de relações singulares com o objeto da aprendizagem. Nesse ambiente, os conhecimentos básicos de edição de imagem e web design fazem parte do processo. O jogo, além do mais, pode se inserir em plataformas web. .

No seu ensaio ' $H$ ' reflete sobre as potencialidades do artefato criado: " Uma excelente ferramenta, da qual podemos nos valer, principalmente na educação básica, são os Objetos de Aprendizagem (OA), ou no nosso caso, os Objetos de Aprendizagem Poéticos (OAPs). Essas ferramentas nos ajudarão a "entrar na cabeça do aluno", e nos valermos de seus interesses, suas expectativas, para estimulá-los a interagir com os conhecimentos que os auxiliarão na sua caminhada. Eu acredito que se faz necessário, sempre, descobrir o que desperta a curiosidade, o interesse do aluno. Normalmente esse interesse é algo compartilhado, principalmente hoje em dia quando as várias mídias disponíveis mantém as pessoas ligadas. $O$ que observamos hoje em dia, como grande interesse por parte dos jovens, e dos adultos também, é o mundo virtual. Em muitos casos esse interesse é tão intenso que pode ser prejudicial para a aprendizagem. Então sejamos inteligentes... em vez de tentarmos fazer o "barco" parar, vamos assumir, ou melhor, ajudar ao aluno a assumir o timão desse barco. Usemos o mundo virtual para possibilitar uma maior interação dos alunos com o conteúdo. Como o contato com o conteúdo não será imposto, mas sim partirá de um interesse deles, o processo será mais natural e mais prazeroso, e isso irá se refletir no mundo real. Eles descobrirão que aprender pode ser algo "legal" e divertido, mas 


"ligado" ao mundo deles. Assim eles passarão a olhar mais
atentamente para outros mundos, acabando por expandir os seus. O
aluno expandindo seu universo, interagindo com os dos demais,
resultando em um "mundo novo" ... isso é o que eu espero como
resultado do meu trabalho" (Participante 'H', Ensaio final, curso de
extensão Objetos de Aprendizagem Poéticos, 2/2014).

A relevancia do jogo, se tomamos em conta que ele se baseia exclusivamente na matriz curricular para ensino médio e favoreçe a abordagem histórica para preparar os estudantes para as avaliações externas que permitem o acesso às universidades como política da escola, é que ' $H$ ' negocia entre um currículo programado e um currículo (mais) vivo no mesmo espaço de aprendizagem. As salas de exposição que os estudantes/participantes preparam dentro do espaço como tarefa (ver Fig. 108), são os espaços de abertura ao diferente, os espaços em que se relacionam com o objeto de conhecimento. Os resultados dessas tarefas são imprevisíveis. Os participantes poderão se apropriar da aprendizagem para criar seus próprios territórios.

Essa abertura ao evento, como uma rachadura na estrutura linear estabelecida, lhe dá a potência poética que pode proporcionar novas configurações de exposição e reflexão no ensino das artes visuais. É importante destacar que a qualidade do artefato está em relação aos recursos básicos de edição de que dispõe (Fig 110). Pode-se pensar em estágios mais avançados, como aplicativos web, rede social e outras estratégias que vão se associando quando umas experiências levam a outras. É um OAP de alta granularidade porque se trata, sobretudo, de um espaço de aprendizagem onde outros OA são hospedados. Por outra parte, é um espaço de produção de conhecimento singular e plural. No caso dos participantes do 'Museu Interativo' de ' $H$ ', as relações sociais entre eles já está estabelecida porque são uma turma, mas o espaço promove relações entre os participantes e os que se encontram com eles: os artefatos da história da arte.

.O 'Museu Interativo' propõe uma estrutura para o ensino das artes visuais que, embora se baseia em uma perspectiva tradicional da arte e da sua educação, cresce junto com os participantes. Em outro contexto, a mesma estrutura, produzirá outras formas, outras experiências. Pode-se pensar em um aplicativo web que permita criar espaços de apresentação, investigação, criação, produção e exposição para o ensino das artes visuais em 
base a essa ideia. A relevância do artefato apresentado se encontra na potencialidade do espaço criado para o outro, o diferente, o dissidente, o singular, o participante, apesar de ainda reberverar objetivos que modulam as estruturas das relações de poder e dominação. Mas, esse espaço, como ideia, é relevante e pode tomar dimensões expressivas.

\section{Título: Estruturas. Autor: Participante ' $I$ ' - 1/2014. Dirigido a: Ensino Fundamental.}

\section{Modalidade. Jogo de peças escultóricas.}

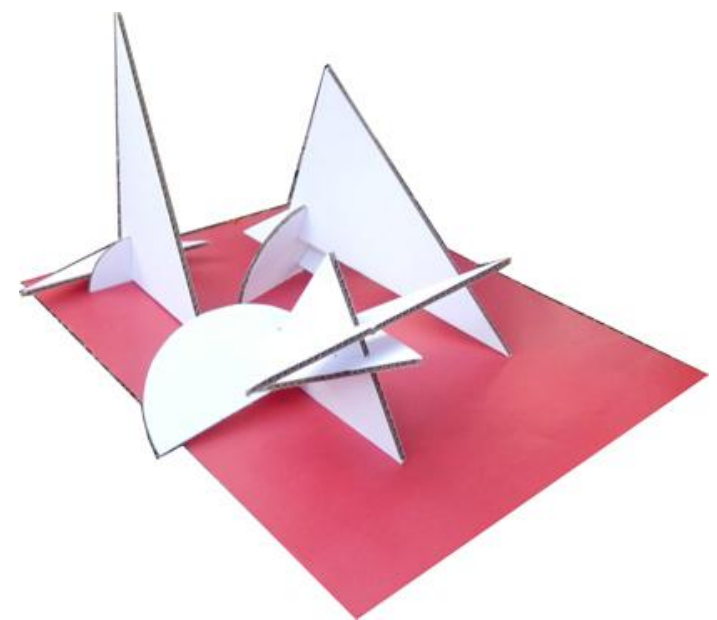

Fig. 111 Participante 'I'. Estruturas. Jogo de peças geométricas em papelão, produzido no âmbito do curso de extensão 'Objetos de Aprendizagem Poéticos' no $1^{\circ}$ semestre de 2014, VIS/IdA/UnB.

Trata-se de um conjunto de formas geométricas em cores primárias feitas em material firme e em tamanhos adequados para construção e observação de estruturas compositivas com diversos objetivos pedagógicos e com o potencial de se adequar a muitos outros, além dos objetivos formais e construtivos. As possibilidades, como aponta o participante, são diversas e podem ir do ensino fundamental ao ensino médio. As peças podem variar em tamanho, forma, cor e textura de maneira que pode se formar infinitas variantes (Figuras 111 a 113), inclusive de formas orgânicas.

O participante ' $T$ ' elaborou um conjunto de peças com "formas
geométricas básicas, recortadas em papelão ou papel paraná, com
corte de encaixe para formar estruturas tridimensionais". As
possibilidades pedagógicas que ' $T$ vê no artefato são amplas:
"elaborações de móbiles; esculturas em escalas maiores;
representação plana através de desenho; interpretar a estrutura




criada através do corpo; utilizar as estruturas em cenários de peças
teatrais, explorando luz e sombra." Se trata de um artefato em que "o
educador direciona as etapas de interpretação e intervenção,
organizando as informações que surgem, para que os alunos
construam significados nas relações que vão se estabelecendo e
assim consigam apropriar-se do saber construído. O percurso
constitui um caminho maleável, podendo ser modificado de acordo
com a realidade de cada professor e de cada turma." (Participante 'T,
Ensaio final, curso de extensão Objetos de Aprendizagem Poéticos,
1/2014).

É um artefato que pode ser usado em quase todos os níveis do ensino básico. São formas que guardam relação, como 'I' aponta na apresentação final dos trabalhos, com os bichos de Lygia Clark. E são como peças de LEGO planas que se encaixam umas em outras para formar diversas figuras tridimensionais. A escultura moderna também se relaciona com este artefato. Eu estabeleci relações com os presentes de Froebel a primeira vez que ' $I$ ' apresentou a proposta, ainda em projeto.

Na apresentação final dos trabalhos o participante 'I descreve assim
seu artefato: "Inicialmente eu tinha pensado na Lygia Clack e nos
bichos, mas eu tinha dificuldade de fazer a estrutura e como o aluno
manipular, ai eu cheguei nesse material [...] com cortes, adaptáveis
para o aluno [...] senti ai a dificuldade, como ele teria que dar uma
base para essa estrutura? como ele teria que pensar para elaborar?
também, quando a gente trabalha as cores, a influência das cores,
por que os fundos coloridos? a influência de um objeto colorido
sobre um fundo, as sombras que podem ser projetadas [...] nesse dos
quadriláteros eu posso fazer uma contextualização com De Stijl, com
Mondriam, Malevitch, [...] A questão da textura, que está diferente
nesse do centro. [...] A questão do branco, que se as vezes se
apresenta tão frio, mas pode contextualizar, mas de repente se você
jogar um fundo vermelho [...] a questão da figura geométrica que é
presente, trabalhar a questão da perpendicular, da diagonal, dos




ângulos, [...] do ritmo, [...] de luz e sombra. O aluno poderia
elaborar um trabalho em maior escala e o que poderia contextualizar
com essa imagem." (Participante ' $T$ ', transcrição de trecho do vídeo da
apresentação de resultados, encontro presencial, curso de extensão
Objetos de Aprendizagem Poéticos, 1/2014)

Nesse sentido 'Estruturas' é relevante para a investigação porque nos apresenta um questionamento que surgiu em todas as versões do curso. Um OA é um objeto especialmente desenhado para aprender, em quanto um caderno, ou o material para produzir uma escultura, por exemplo, não é. Eles não têm em si mesmos um projeto pedagógico. Já um OA é especificamente pensado para aprender, tem um projeto pedagógico. Nesse caso, se vemos as peças do artefato 'Estruturas' como figuras geométricas feitas de papelão, não se trata de um OA, mas de material para construção de um objeto. O que diferencia 'Estruturas' dessa função é que foi pensado na sua totalidade dentro do processo pedagógico. O participante ' $T$ ' criou um jogo de peças, escolhendo as formas, os tamanhos, as cores, as texturas, os fundos e os cortes de encaixe. Nesse sentido é o jogo de peças que consiste em um OAP (Fig. 112).
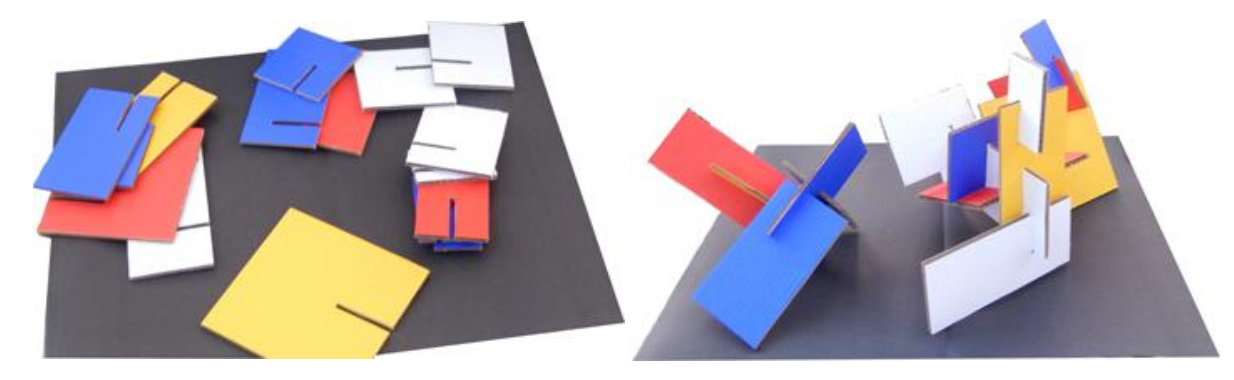

Fig. 112 Participante 'I'. Estruturas. Jogo de peças geométricas em papelão, produzido no âmbito do curso de extensão 'Objetos de Aprendizagem Poéticos' no $1^{\circ}$ semestre de 2014, VIS/IdA/UnB.

$\mathrm{O}$ artefato não requer de um manual de instruções, mas pode ser acompanhado de um catálogo de sugestões para trabalhar em sala de aula. Como 'I aponta na sua apresentação, a vantagem de 'Estruturas' é que pode ser usada para diversas experiências e aprendizagens sobre questões formais, teóricas e históricas nas artes visuais tanto no Ensino Fundamental como no Ensino Médio. O artefato também favorece uma aprendizagem corporificada que requer uma observação direta. Da mesma maneira, constitui material para criação poética no processo da aprendizagem sem perder a suas qualidades de OA ou de OAP. E ainda, assim 
como foram os presentes de Froebel e os brinquedos Montessori, podem ser usados para a aprendizagem das ciências exatas.

Na sua avaliação final 'I' destaca que "Podemos redimensionar nosso
papel como arte-educadores, desenvolvendo novas perspectivas de
aprendizagem, novos olhares perante o universo de nossos alunos. A
casa, a escola, a família, a mídia, ou qualquer outro espaço onde se
produza conhecimento. Essa reflexão aliada a um trabalho
interdisciplinar de incentivo constante contribui para o crescimento
do aluno enquanto indivíduo que busca uma melhor compreensão de
mundo" (Participante 'T', Ensaio final, curso de extensão Objetos de
Aprendizagem Poéticos, 1/2014).

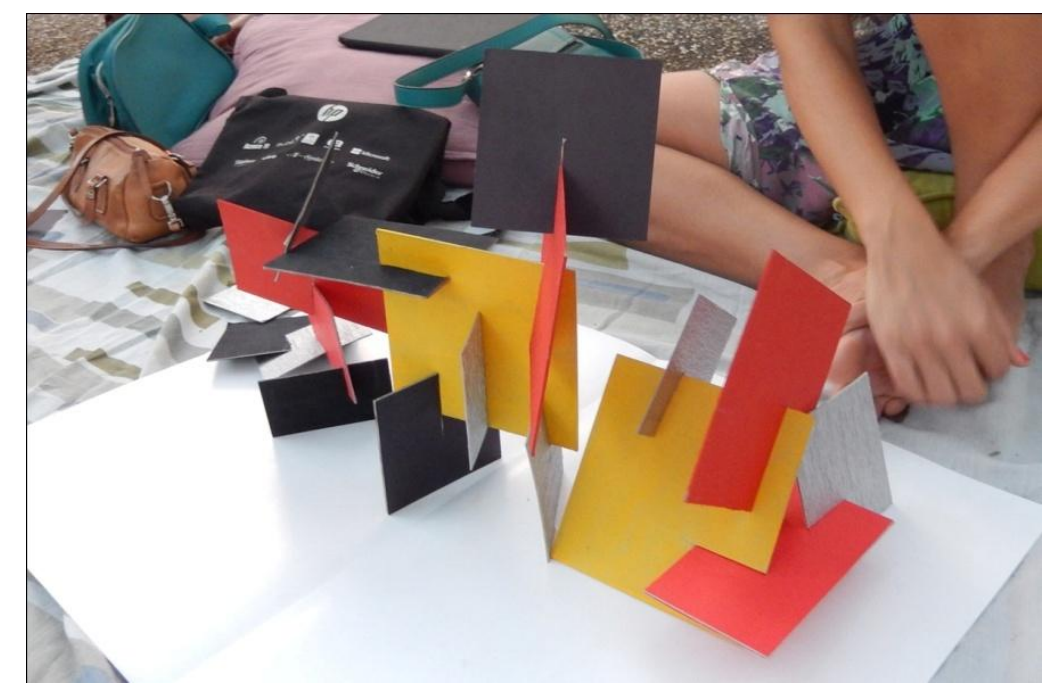

Fig. 113 Participante ' $I$ '. Estruturas. Jogo de peças geométricas em papelão, produzido no âmbito do curso de extensão 'Objetos de Aprendizagem Poéticos' no $1^{\circ}$ semestre de 2014, VIS/IdA/UnB.

O potencial poético é neste caso tão grande como o potencial pedagógico. Nesse aspecto acredito que o artefato pode ainda crescer no sentido da proposta. As formas podem ser infinitamente variáveis, da mesma forma que as outras qualidades, por esse motivo seu valor não pode se estacionar nas qualidades, mas nas propostas de ação. Froebel e Montessori, por exemplo, criaram os objetos e escreveram propostas para as diversas ações pedagógicas. Clarck deu à suas esculturas a forma de (tecno) "bichos" para realizar certas ações. Isso nos leva a outro assunto relevante na investigação: os OAP, como os artefatos da arte, são 
artefatos vivos que engendram outros no processo. O potencial poético é também aquilo que abre possibilidades outras numa construção e reconstrução do próprio ato criativo. As peças de 'Estruturas' não prometem artefatos permanentes, mas momentos de observação, eventos (Fig. 113). Essa capacidade reconstrutiva e mutante pode ser explorada como proposta poética e pedagógica.

Por esse motivo 'Estruturas' se apresentou como um OAP. Isto é, um artefato com espaços de potência. Mesmo nesse estágio, se mostra como uma ideia de grande valor para compreender, nas propostas de OAP, a necessidade de interfaces e estruturas flexíveis a diversas práticas e conhecimentos. Os artefatos que podem ser modelados oferecem uma grande capacidade de se desdobrar em outros a partir do contato com contextos ou necessidades diferentes. Da mesma maneira, quando se trata de um OA ou um OAP que oferece uma proposta flexível, as possibilidades de se gerarem outros são grandes. É também importante observar que, embora é comum na aprendizagem empírica se usar artefatos concretos, não é comum aprender sobre teoria da arte a partir da exploração de um artefato como 'Estruturas'. Mas ' $I$ ' cruza essa fronteira.

$$
\begin{aligned}
& \text { Para 'T, "A imagem não exige um ponto de partida nem um ponto de } \\
& \text { chegada para o curso da leitura, ela difere dos textos verbais, que impõem } \\
& \text { uma forma para serem lidos: lê-se da esquerda para a direita, sempre } \\
& \text { começando pela primeira palavra. Tal complexidade da linguagem visual } \\
& \text { requer verificar sua sintaxe para que possamos compreender melhor as } \\
& \text { mensagens visuais" (Participante I, Ensaio final, curso de extensão Objetos } \\
& \text { de Aprendizagem Poéticos, 1/2014) }
\end{aligned}
$$

É possível, pelo que podemos depreender das ideias de ' $I$ ', fazer leituras de imagens com esse artefato, e pela mesma razão, penso eu, escrever com imagens, onde podem se estudar os elementos visuais como textos em potência.

\section{Título: $O$ Crítico de Arte. Autor: Participante ' $G$ ' 1/2014. Dirigido a: Ensino Médio.} Modalidade: jogo de cartas 


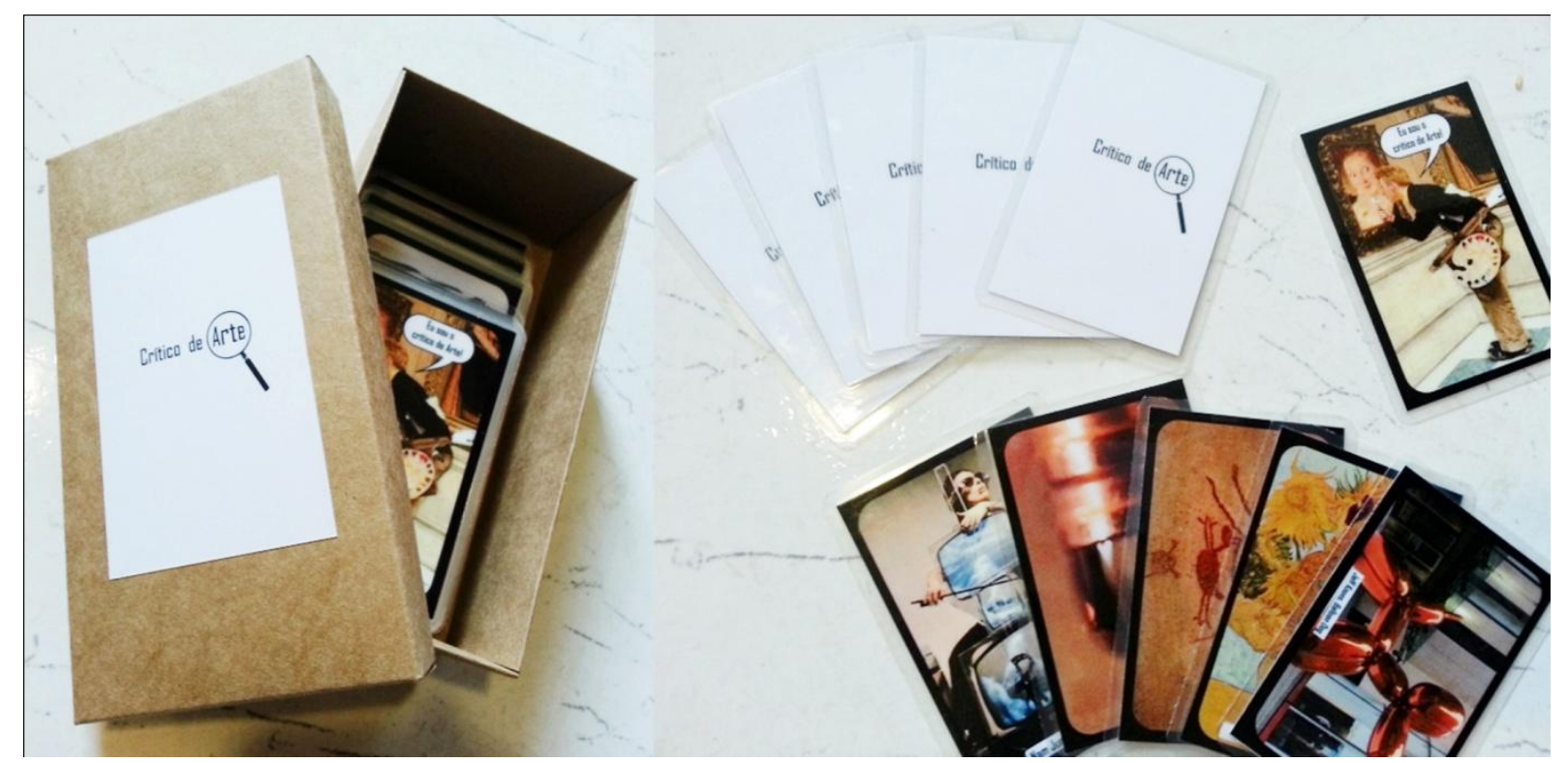

Fig. 114 Participante ' $G$ '. O Crítico de Arte. Jogo de cartas, produzido no âmbito do curso de extensão 'Objetos de Aprendizagem Poéticos' no $1^{\circ}$ semestre de 2014, VIS/IdA/UnB. Fotografia do participante autor.

Este é um jogo que 'G' preparou em base ao Jogo do Mico, como descreveu no fórum para os colegas (ver Quadro de Conversações, Fórum do capítulo III) (Fig. 114). Uma proposta que embora seja simples, como se apropriar de um jogo de cartas que já tem uma lógica conhecida (a de formar pares com uma carta sobrando), é complexa em termos de processos que vão ocorrer ali, por exemplo, que tipo de pares? O que pode ser considerado um par na imagem? A proposta de ' $G$ ' se centrava na ideia de que o jogador estabelecesse relações de semelhança entre imagens de obras de arte, seja por participar do mesmo movimento, ou por ser da mesma época, ou por ter o mesmo estilo, etc., mas, para surpresa de 'G', o critério de pares com imagens produziu resultados completamente diferentes para cada turma com quem jogou. (ver fig. 96, Quadro de Conversações, Fórum do capítulo IV). Isso se devia ao fato de que não havia associações únicas possíveis. Quando ' $G$ ' experimentou o jogo percebeu uma rachadura por onde o objeto de aprendizagem se tornou poético. As associações a cada jogo se renovam e possibilitam novas discussões.

Ontem reuni alguns estudantes e professores do ensino médio para
jogar. Foi muito, muito bacana mesmo. A receptividade do jogo foi
ótima e como a maioria deles já conhecia as regras, ficou mais fácil
estabelecer a dinâmica do processo. Primeiro dois professores
jogaram e depois os estudantes. Para os estudantes algumas
associações realmente foram difíceis, mas o retorno foi muito positivo.




Eles disseram que dificilmente se esquecerão daquelas imagens,
porque agora tiveram contato com elas de uma maneira divertida. Só
posso dizer que estou felicíssima. (Participante ' $G$ ', apresentação do
OAP, Fórum de apoio na produção, curso de extensão Objetos de
Aprendizagem Poéticos, 1/2014).

Além de ter sido experimentado com estudantes e professores (Fig. 115) também foi jogado em um dos encontros presencias do curso de extensão em que estávamos em processo de produção. Foi um momento muito fértil em termos de aprendizagem sobre OAP com vários dos participantes. Por exemplo, no meio do jogo um dos participantes perguntou se o autor das regras poderia dar um minuto de associação livre, porque já tinha encontrado muitas. A rica conversação que o jogo gerou paralelamente também alimentou o processo porque se conversou sobre objetos, experiências, ideias, se deram conselhos e se pensaram outras possibilidades.

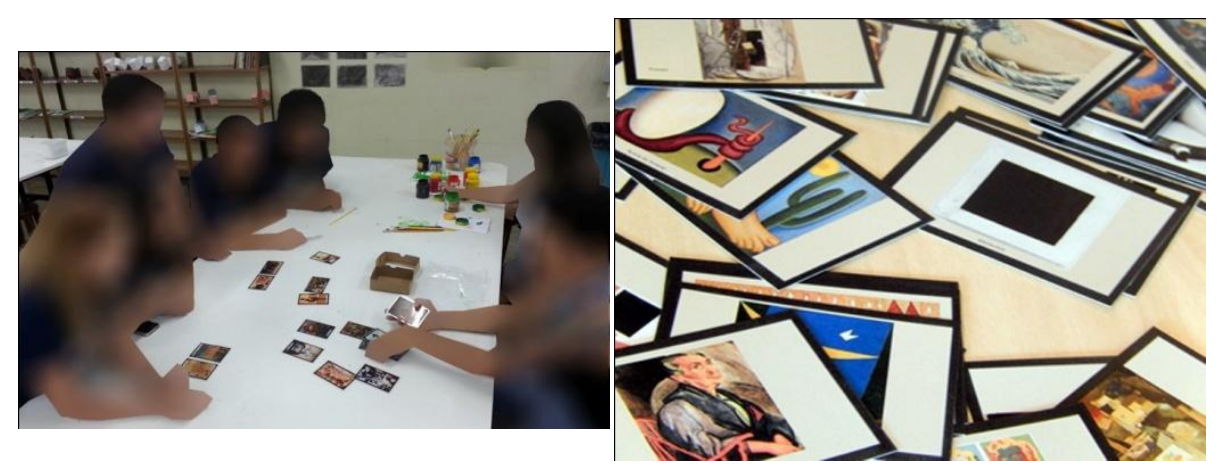

Fig. 115 Participante ' $G$ ' $O$ Crítico de Arte. Jogo de cartas, produzido no âmbito do curso de extensão 'Objetos de Aprendizagem Poéticos' no $1^{\circ}$ semestre de 2014, VIS/IdA/UnB. Fotografia do participante autor.

As cartas são um recurso muito antigo e com diversas possibilidades lúdicas para a educação. Para a criação de OAP são ideais porque trabalham por uma parte, com imagens e símbolos e por outra, com regras, consignas e/ou marcos de ação. Eles podem ser usados combinados com outros recursos de jogo, como tabuleiros, dados, etc. Eles são também parte visual importante nos RPG. No curso de extensão vários dos participantes usaram cartas como base para os OAP, mas em toda ocasião a forma de estabelecer as consignas e a lógica do jogo foi diferente. 
Na sua dimensão visual o jogo segue uma linha de imagens de obras de arte conhecidas na História da Arte, com versões saturadas que são características de esse tipo de baralho. O trabalho gráfico e o acabado são de qualidade e o jogo se apresenta em uma caixa. Na sua dimensão pedagógica o jogo trabalha sobre a habilidade de estabelecer relações de semelhança ou diferença para identificar, classificar, distinguir, etc. Sendo um jogo de cartas se abre à possibilidade de estabelecer outras regras e outros jogos. Cada conjunto de regras pode se adequar a diferentes níveis de complexidade. Poderia por exemplo, com um conjunto de regras, ser adequado para um jogo sobre arte com crianças e com outro conjunto de regras ser adequado para um jogo com adultos. Depende das consignas. O que é estético neste jogo é o espaço que se cria para estabelecer relações com as imagens dadas e com os outros participantes, onde todos participam. É nessa relação com o objeto e com o outro que se constroem os conhecimentos. O que é poético nele são as aberturas às possibilidades impensadas em que as pessoas se encontram para aprender.

\section{Título: Missão Egito. Autor: participante ' $F$ ' - 2/2014. Dirigido a: estudantes do $6^{\circ}$ ano} do Ensino Fundamental. Modalidade: jogo de investigação.

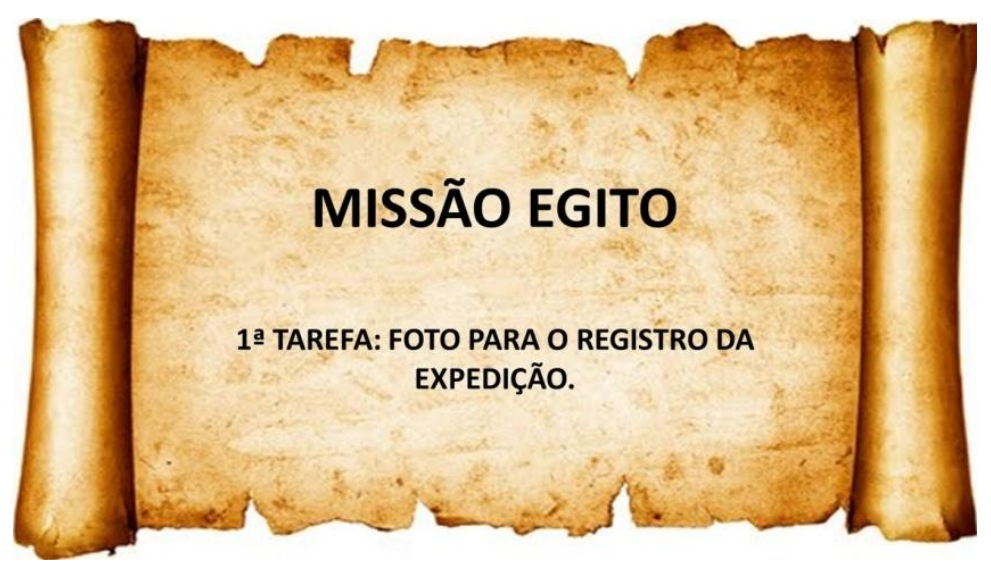

Fig. 116 Participante ' $F$ ' Missão Egito. Jogo de enigmas, produzido no âmbito do curso de extensão 'Objetos de Aprendizagem Poéticos' no $1^{\circ}$ semestre de 2014, VIS/IdA/UnB.

O jogo de investigação foi pensado por ' $F$ ' como uma expedição para resolver enigmas centrados em indagações que surgem entre os estudantes em aulas anteriores. A estrutura do jogo tem várias fases que incluem ver filmes, videoclipes e imagens, interpretar papéis (RPG), investigar dados e produzir eventos. Os enigmas são impressos em papel ou pano e entregues aos estudantes participantes (Fig. 116).

O participante ' $F$ ' descreve o jogo da seguinte maneira: 


"A minha ideia foi criar uma aula expositiva com o caráter de
representação de personagens a partir de trechos do filme "A múmia"
(1999) de Stephen Sommers. A proposta foi que durante a explicação os
alunos assumissem o personagem da Eve, bibliotecária que investiga a
história da cidade de Hamunaptra e encontra a múmia de Imhotep. A
partir dessa investigação, conversamos sobre o processo de mumificação,
as produções artísticas egípcias e o foco maior desse momento que era a
arquitetura. Após a explicação, cada aluno recebeu uma ficha como
representação de um papiro com dois enigmas que deveriam ser decifrados
em casa com o auxílio de um jogo identificado no próprio enigma. Em
outra aula, os alunos apresentaram as respostas encontradas para os seus
enigmas. Ainda com a ideia do personagem Eve, investigamos influências
da arte egípcia na atualidade com o clipe "Dark Horse" da cantora Katy
Perry. A investigação então seguiu para os hieróglifos, papiro, maquiagem
e lei da frontalidade. O jogo "Missão Egito", que será desenvolvido após o
recesso, será avaliativo. (Participante F, Ensaio final, curso de extensão
Objetos de Aprendizagem Poéticos, 1/2014)

O jogo é relevante para análise porque traz um modelo de jogo que integra diversos meios e mídias e apresenta um processo em várias fases. É uma proposta que se deve programar para longo prazo. Isso traz uma análise pertinente à investigação. A granularidade dos OA pode ser alta e inclusive, abranger muitas disciplinas, mas, para a maioria dos autores, os OA são unidades modulares pequenas, que fazem parte de um processo maior. Um objeto que se constrói ao longo do tempo (como o 'Museu Interativo' de ' $H$ ') pode ser de alta granularidade, mas conserva em si mesmo todo o processo, se auto-reproduz e pode ser reproduzido. Nessa perspectiva, 'Missão Egito' proporciona uma oportunidade para pensar qual é a diferença entre um OA (ou OAP, no caso), e um projeto de trabalho.

"A turma será dividida em grupos de 5 alunos. Inicialmente será apresentado a ideia de que cada grupo assume uma expedição investigativa e terá que descobrir 5 enigmas egípcios. Os grupos deverão compor uma cena da expedição que será fotografada. O tema dessa cena é 'Arte Egípcia'. Após essa etapa, cada grupo receberá 5 papiros com 
enigmas escritos em hieróglifos. Será projetado no quadro as letras correspondentes a cada símbolo. A proposta é decodificar a frase enigma e responde-la. Na aula seguinte será apresentado o resultado levando em consideração a expedição que respondeu o maior número de enigmas corretos e entregou em menor tempo. O grupo será premiado com um baú do tesouro (moedas de chocolate)." (Participante 'F', Ensaio final, curso de extensão Objetos de Aprendizagem Poéticos, 1/2014)

O que ' $F$ ' propõe é um percurso de investigação guiado pelos enigmas que os participantes devem resolver. $\mathrm{O}$ trajeto começa com um filme (que é um recurso exterior) de onde surgem conexões com o estudo da cultura egípcia com três séries de enigmas para resolver e diversas atividades para realizar como as fotografias ficticias, até o final do jogo. Em todo esse processo os participantes se relacionam com diversas mídias, formatos, informações, modalidades, etc. O que constitui então um OA ou OAP? O que ' $F$ ' apresenta é um projeto de trabalho em que se inserem os 'enigmas', que constituem OA ou OAP, dependendo da proposta. Os enigmas criados fazem parte de um projeto maior.

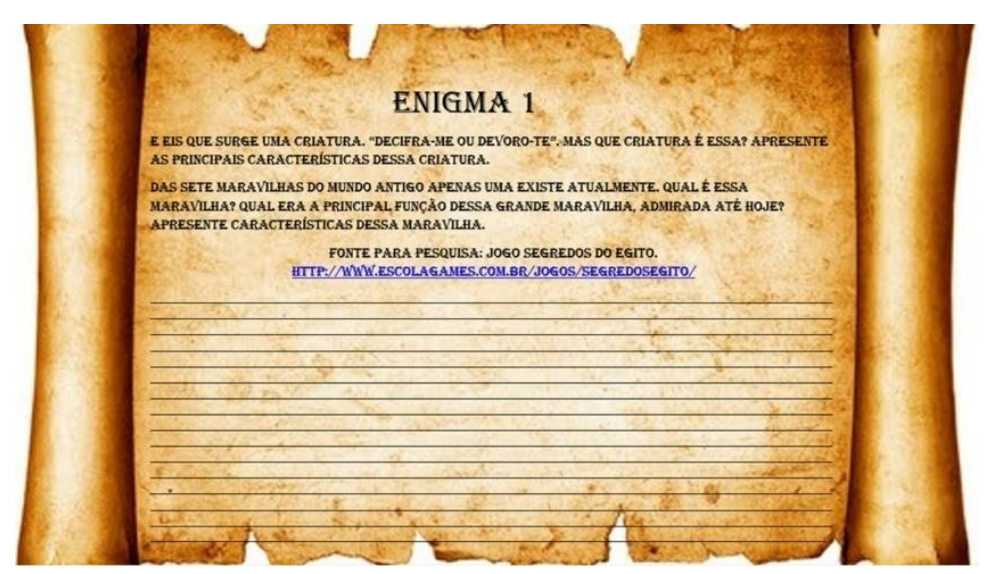




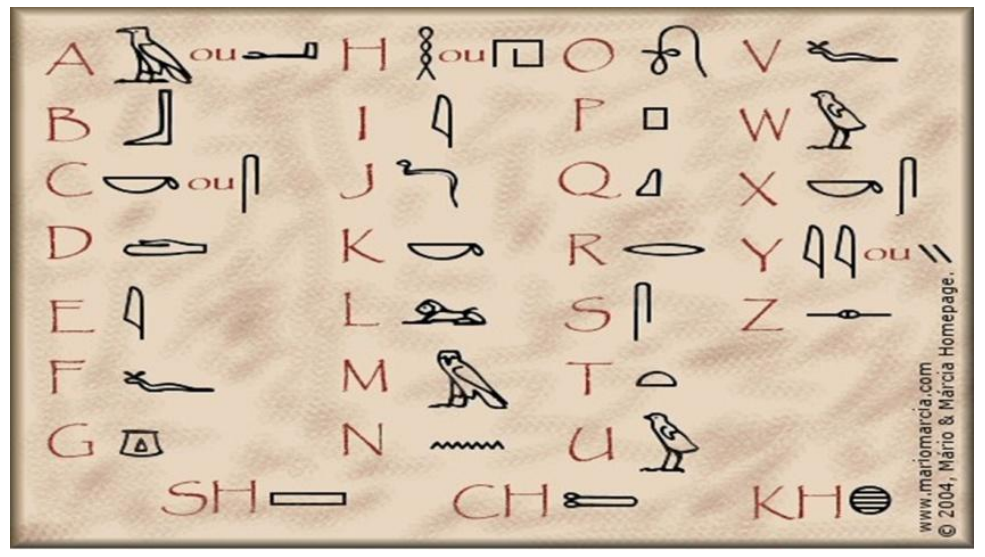

Fig. 117 Participante ' $F$ ' Relação estabelecida pelo autor entre o alfabeto e os hieróglifos para descifrar os enigmas, curso de extensão 'Objetos de Aprendizagem Poéticos' no $1^{\circ}$ semestre de 2014, VIS/IdA/UnB.

O enigma é um questionamento que pressupõe um paradoxo, uma situação aparentemente insolúvel, misteriosa, cifrada ou codificada e de difícil compreensão que requer de uma investigação ou de uma profunda reflexão para encontrar uma resposta convincente. Mas, no jogo os enigmas são consignas que devem ser decodificadas a partir de uma equivalência com o alfabeto (Fig. 117). Esse processo é simples para transcrever e as consignas são simples de realizar. A maioria delas desafia o estudante/participante a apresentar características e funções (no caso da arquitetura) dos artefatos estudados. Nesse caso, tanto o enigma como a consigna partem de um modelo de pedagogia tradicional.

O que então torna 'Missão Egito' um OAP e não um OA? Em termos de experiência estética, o processo apresentou diversas instâncias com fotografia, filmes, música, narrativa, performance e debate reflexivo e crítico, mas a maioria se situava fora do artefato (como OA), ainda que relacionadas a ele. É necessário, portanto, elaborar um artefato que articule todos os recursos e processos para ter um objeto de aprendizagem. E se vai ser poético deve ter uma abertura para os eventos. É possível no entanto elaborar um jogo de enigmas que incluam esses recursos no processo, como acontece com os RPG, que se projetam a longo prazo e que integram diversas variáveis no jogo.

A poética de 'Missão Egito' se encontra no espaço aberto nos enigmas para realizar fotografias de cenas que recriam as visualidades egipcias estudadas. Poderíamos incluir nesse aspecto poético os debates sobre o filme ou o videoclipe, porque proporcionam espaços de subjetivação importantes, mas eles se encontram fora do artefato. Para constituir um OAP com todas as partes integradas 'Missão Egito' poderia ser desenhado como um RPG com 
interface física ou virtual, que inclua um tabuleiro (espaço imaginário), cartas enigmas, tramas e avatares como a da bibliotecária Eve, e seja orquestrado por um 'Máster' com resultados diversos a cada jogo. Nesse contexto os enigmas são uma parte do artefato e os participantes ganham um espaço maior na formação do jogo. Mas o tempo de produção de um RPG é maior que aquele que o curso de extensão tem para a produção dos artefatos.

Contudo, o artefato criado por ' $F$ ' aponta questões relevantes para a investigação: assim como os artefatos artísticos, os OAP se constroem em processos longos de experimentação, de reconstrução de ideias e de projetos. Os OAP respondem a projetos maiores que o artefato em si. Para produzir OAP é necessário pensar no aspecto pedagógico e poético, mas também é necessário pensar com se insere dentro da estrutura planejada ou do sistema em que funciona. Pensar por exemplo se é mais importante fazer um pequeno OAP dentro de um projeto maior ou fazer um OAP que constitui em si um grande projeto, é crucial para uma maior potência pedagógica e poética. Da mesma forma pensar no design, na hermenêutica, na temporalidade, no espaço, nos recursos, no material disponível e no acesso a ferramentas. Ajustar todas as variáveis constitui uma tarefa artística.

Imaginar, planejar, construir, usar, reavaliar, imaginar novamente e continuar rodando em um processo de reconstrução é um processo poético e um processo pedagógico. Os artefatos que os paticipantes criaram nas três versões do curso, em especial os que aqui puderam ser analisados nas suas potencialidades e desafios, destacam o valor do evento no processo educativo e a centralidade das relações entre participante e artefato. Colocam também em evidência a possibilidade de manter uma tensão entre o se conhece e não se conhece ainda. Permitem observar que é possível construir um currere, porque apontam um horizonte em que existe um planejamento mas que dialoga com o mundo em movimento. Eles também resaltam a importância das ferramentas e recursos digitais na criação de artefatos híbridos para a Educação em Visualidade. Mas sobretudo mostram indícios das viradas e do atravessamento das fronteiras entre arte e educação. Revelam a dificuldade que há nesses espaços para sair das estruturas curriculares e metodológicas tradicionais, da linguagem que reforça as relações de dominação, dos modelos de arte e cultura coloniais, dos paradigmas cientificistas e das fragmentações identitárias.

\subsubsection{O que se produz com os OAP?}


O trabalho que artistas desenvolvem no estúdio, ou professores na sala de aula, na apertura de espaços de possibilidade, geralmente tem a potencia de transformar as pessoas que transformam o seu mundo. Como vimos, uma metodologia de IBA, ou de IEBA aponta ao que é possível, além do que é provável e plausível (SULLIVAN, 2010). Abrir espaços às possibilidades do que pode ser de outra maneira é trabalhar com a potência da transformação. Os OAP produzidos no curso de extensão evidenciam diferentes horizontes e caminhos e diversas formas de fazer as coisas. Uma das dificuldades que esta escolha metodológica representa é lidar com as diferenças e observar o que pode ter mudado e como em relação às práticas tradicionais no ensino da arte. Nessa tarefa os marcos de investigação de Sullivan (2010) proporcionam referências para analisar o espaço metodológico em que se encontram os eventos.

Ainda, é necessário esclarecer antes de proceder, que, como argumentam jagodzinski e Wallin (2013), os marcos de investigação de Sullivan se centram no interesse cognitivo dos modos de investigar dos artistas, que para ele, são críticos, criativos e transcognitivos. Já esta investigação se centra no encontro dos eventos artístico e pedagógico no contexto de um curso de extensão para estudantes e profissionais da educação e da arte. Uso os marcos de investigação de Sullivan porque permitem marcar os territórios metodológicos ocupados pelo encontro entre as viradas em que podem se identificar as formas de operar.

O curso de extensão se apresenta como um OA que contém vários OA e OAP e propõe aos seus participantes que produzam um (que poderia ser, por sua vez, uma proposta para criar outros na sala de aula). Dessa maneira, o curso contém, e é, sua própria metodologia. O curso foi realizado em uma estrutura tradicional, (horários, salas, cadeiras, quadro, projetor, etc.) em espaços não convencionais (ambientes virtuais de aprendizagem, participação assíncrona, participação por vídeoconferência, aulas pic-nic) (Figuras 83, 84 e 98). O que havia de poético eram as aberturas às possibilidades de singularizar por meio das experiências com os OAP para professores de arte e dos artefatos produzidos pelos participantes. No processo, eles, como participantes, indagaram e percorreram seus próprios caminhos e fizeram suas propostas.

Essa abertura a caminhos de investigação, metodologias de trabalho e resultados diversos é o que acontece no estúdio de arte. Quando as formas de operar no estúdio de arte (seja este um espaço físico ou virtual) são usadas no processo de aprendizagem, não podem se prever resultados quantificáveis, prováveis ou plausíveis, mas possíveis. A primeira tarefa é, como 
no estúdio de arte, abordar a ideia e lançar o desafio: provocar. Não podemos saber o que vamos ter ou ver no final, todos os resultados poderão nos surpreender. Seja por subestimar, superestimar ou imaginar certos resultados, a surpresa é algo que pode se esperar no estúdio de arte e em uma pedagogia cultural. Podemos inclusive esperar a surpresa dos participantes com os resultados e a aprendizagem da sua própria investigação. Aprende-se daquilo que estava planejado e daquilo que ninguém pensava que seria uma pauta para aprender.

Assim, em base aos marcos estruturados por Sullivan (2010) para compreender uma IBA ou uma IEBA, apresento um quadro de Marco de Investigação dos OAP produzidos pelos participantes do curso de extensão (Ver Anexo VII Fig. 118 Marco de Investigação dos OA e OAP) onde pode-se ter uma visão geral dos artefatos e compreender o que mudou nas camadas que se superpõem entre as viradas. A partir desse marco analiso onde se encontram as principais mudanças em direção às pedagogias culturais. Isto é, o que produzem estes artefatos? que ideias, formas ou situações culturais surgem de esses objétis?

No quadro do Marco de Investigação dos OAP é possível observar que, dos vinte artefatos produzidos pelos participantes (Ver Anexo VII Fig. 97), onze apontam questões relativas a práticas investigativas e criativas que favorecem as ideias, cinco apontam questões que favorecem 'situações' e três apontam questões que favorecem a criação de 'formas'. Aqui deve-se notar que os artefatos podem apontar a duas ou três questões ao mesmo tempo, mas aqui se alinham pelo que favorecem. É também importante ressaltar que nesta análise entram tanto as propostas que se colocam como OA ou como OAP. Os que se configuram como OAP, apontam a ideias, formas e situações que abrem territórios de subjetivação e procuram provocar novas performances epistemológicas. Para isso se valem de práticas transcognitivas que valorizam o conhecimento pós-disciplinar onde sentir é saber. Nessa perspectiva, os OAP podem ser considerados no coração da prática transcognitiva que ocorre em, ao redor, através e entre as formas de pensar, investigar e construir conhecimento. Em outras palavras, a criação de OAP é uma forma de pesquisa baseada nas artes, porque se baseia nas metodologias artísticas. Com essas ressalvas em mente os artefatos são alinhados para análise.

\subsubsection{Ideias}

Como vimos antes, Sullivan (2010) observa que as ideias que se formam no estúdio de arte apontam uma forma de investigação relacionada, na perspectiva da ciência, a práticas investigativas interpretativistas, que (por esse motivo) priorizam pensar nas linguagens. 
Geralmente estas formas de investigar se fazem em contextos de comunidade. Esse é o caso dos artefatos 'Museu Escolar', 'Idade Média', 'Varal do Saber', 'Jeopardy', 'Missão Egito', 'Arte Popular Brasileira', 'Trilha da Arte', 'Queres Quanto', 'Crítico de Arte', 'Museu Interativo' e 'Semana de 22' (Ver informações nas fichas da fig. 97). Independente de serem OA, ou OAP; ou da qualidade apresentada, a maior parte desses artefatos promoveram agenciamentos do que se propõem aprender, formas de apresentar os objetos de aprendizagem e, ou, formas de avaliar esses agenciamentos. Por esse motivo são práticas que proporcionam marcos de pensamento, ou dito de outra maneira, são práticas que emolduram com conceitos, sequencias, relações causais e/ou estruturas. O mais importante nesses artefatos são as idéias e suas interpretações. Nessa linha concorrem a maior parte dos artefatos para o ensino médio. No caso dos artefatos realizados para o curso de extensão, é importante observar que todos eles se relacionam à teoria e história da arte e da cultura e todos encontram soluções lúdicas. São, entre os três grupos, os que mais pesquisaram sobre novas tecnologias de edição, impressão, animação e interatividade. Nesse grupo, somente 'Jeopardy' favoreceu o uso exclusivo de texto, pois se tratava de um OA de avaliação que, devido ao formato de 'quiz show' não incluía imagens, embora isso fosse possível em contextos de respostas certas e erradas. Outros valorizaram o uso de imagens e textos sem predomínio de um sobre outro e outros se valeram de imagens na sua maior parte, como os jogos de cartas de 'Crítico de Arte', 'Museu Escolar' e 'Idade Média'.

Observei que nesse grupo há três artefatos configurados dentro do modelo do 'certo' ou 'errado': 'Jeopardy', 'Arte Popular Brasileira' e 'Varal do Saber' (ver fichas na Fig. 97). Esses artefatos propõem memorizar imagens ou ideias, características, funções ou procedimentos. $\mathrm{O}$ que se pede do participante é um raciocínio lógico e, "avaliar quanto consistentes são as ideias e conceitos para traduzir meios em fins, teoria em prática, e vice versa" (SULLIVAN, 2010, p. 67). Essa é, em parte, uma das maiores diferenças entre OA e OAP, embora isso não signifique que todo OA toma uma posição hegemônica e padronizadora ou que nenhum OA pode provocar eventos de aprendizagem. A diferença é que os artefatos poéticos devem trazer aberturas aos eventos e isso significa ir de uma pedagogia de resolução de problemas a uma pedagogia que problematiza. É importante observar, como apontado antes, que o evento não está na situação planificada para acontecer, mas nas aberturas deixadas por onde os eventos podem acontecer. Então, os eventos estão em outro lugar que não podemos prever. Produzemse fora dos artefatos, nas suas aberturas. Nos OA, que se regem pelos princípios dos resultados homogêneos, não há aberturas para eventos porque os limites da experiência se 
fecham dentro do artefato que registra respostas condicionadas a um prêmio, uma nota, uma emoção, ou um ganho outro. Um processo poético não é divertido ou prazeroso necessáriamente e os $\mathrm{OA}$ podem ser muito divertidos e prazerosos sem ser necessáriamente poéticos.

Para interpretar é preciso pensar na linguagem, por esse motivo as práticas interpretativas são muito valorizadas na educação em geral e na educação em artes visuais em particular. Esse grupo de artefatos que produzem ideias também se caracteriza pela proposta conceitual ligada às linguagens da arte. Entre os artefatos deste grupo, somente 'Semana de 22' se centra exclusivamente em fatos históricos. Para os outros, os fatos históricos ajudam a ordenar o trabalho teórico - conceitual. Por outra parte, dos onze artefatos, somente cinco propõem espaços onde os participantes podem experimentar estas linguagens. Quando esses artefatos abordam práticas criativas o fazem geralmente subordinando a prática e a poética à teoria, como acontece com 'Missão Egito', 'Trilha da Arte' ou 'Museu Interativo'. Desses cinco, somente 'Queres quanto ?' aborda a teoria e a prática como dobras da mesma experiência sem uma ser subordinada ou explicativa da outra (como as práticas para fixar conteúdo).

Ainda, podemos depreender da observação dos artefatos, que, embora são configurados para se fazer em comunidade, pois se trata de jogos, oito dos onze artefatos são pensados para serem resolvidos de maneira individual. Desses, 'Jeopardy', 'Varal do saber', 'Idade Média', 'Crítico de arte' e 'Trilha da arte' se jogam em grupo, mas centram os resultados na atuação individual dos participantes. De qualquer maneira, tendo em conta essa tendência à aprendizagem individualizada, podemos considerar o fato de serem jogados em grupo uma indicação de fronteira com os modelos tradicionais. 'Jeopardy' por exemplo, podia ter sido uma avaliação escrita individual comum, mas se tornou um show de perguntas e respostas (Quiz show) com a participação de dois grupos, em que se formaram torcidas. Os participantes respondem às perguntas e ganham pontos (representado pelo símbolo do dólar) para seu grupo. A vitória de um membro é festejada por todo o grupo por igual. No caso da experiência o sucesso daquele OA se estendeu a outras turmas. 'Jeopardy' foi um evento na escola, mas deve sua emoção à competição, não à aprendizagem de algo que envolvesse emocionalmente. As qualidades estão em outro lugar.

Posso inferir, nesse panorama, que há uma superposição entre práticas pedagógicas tradicionais e práticas inovadoras. Por outro lado, a quantidade de trabalhos que favorecem os 
modelos interpretativistas apontam a tendência à centralidade da teoria sobre a prática, onde, como apontam jagodzinski e Wallin (2013), o foco são as estruturas simbólicas, ou, o que a arte significa. No Brasil essa é a tendência da 'leitura de imagem' que se tornou a 'releitura' (BARBOSA, 2005). Isso evidencia que a virada da visualidade na educação ainda está ligada à 'virada linguistica' ou modelos linguísticos que vêm a linguagem como agente estruturador do conhecimento, pensamento esse relacionado às práticas interpretativas na pesquisa. Embora as mudanças nesse aspecto pareçam poucas, artefatos como 'Queres quanto?', 'Museu Interativo', 'Missão Egito', 'Trilha da arte', 'Museu escolar' e 'Crítico de arte' podem, ao mesmo tempo, promover práticas críticas que corporificam e práticas empiricistas que estruturam o conhecimento. Depende de como se conduzam na sala de aula. Posso deduzir pelos indícios que há uma rachadura por onde os eventos das viradas podem se precipitar. Os OAP podem então produzir ideias, como é caso do 'Quanto queres?' em que os participantes produzem novos passos para o samba, ou de 'Indentidades' em que reflete-ese sobre o selfie na construção de identidades. Produzir ideias no âmbito da educação é uma maneira de promover pedagogias culturais.

\subsubsection{Situações}

Nas observações de Sullivan (2010) o trabalho no estúdio de arte produz situações, de maneira análoga às práticas críticas na metodologia científica. Por este motivo é importante para esse tipo de práticas pensar nos contextos. Geralmente se tratam de ações que afetam, de modo geral, as culturas, que é o espaço de existência das comunidades. Os artefatos 'Regalo', Príncipes e Princesas da África', 'Vivências estéticas do Maracatu', 'Mapas de percursos' e 'Indentidades' operam dessa forma. Nesse aspecto, é interessante observar que todos os artefatos desse grupo constituem OAP, e todos se caracterizaram como casos extremos em direção à arte. 'Identidades' foi identificado para a análise porque foi, entre esses, o artefato que concluiu a ideia e apresentou mais dados. Todos os participantes do curso que produziram situações atúam no campo da arte e não da educação, a axceção de um que é também educador em visualidade, o participante ' $R$ '. Ele traz uma proposta de ação poética de mapeamento da existência singular no espaço público, que é o espaço plural com o OAP de participação 'Mapas de percursos', em relação à sua poética que é a do caminhar e mapear. O artefato consta de uma caixa de papelão que é ao mesmo tempo o suporte para a produção de um mapa do percurso que o participante realiza em um dado espaço urbano. No reverso da 
caixa, que o participante vê quando abre, se encontram perguntas para reflexão e consignas para as ações:

"Vocêe conhece bem sua cidade?, Quais locais visita
cotidianamente?, Que imagens te chamam a atenção?, [...]
Tem algo que gostaria que não existisse ou fosse diferente?
Como poderia ser?, Planeje uma obra de arte para a cidade"
(Participante 'R', Ensaio final, curso de extensão Objetos de
Aprendizagem Poéticos, 2/2014).

Dentro da caixa o participante encontra imagens de obras de arte que trabalham sobre mapas e mapeamentos e folhas brancas para desenhar respondendo à provocação para imaginar algo que poderia ser diferente.

As práticas que produzem situações abrem, como esses artefatos, a participação de dentro do artefato. Essa foi uma das grandes dificuldades para os participantes deste grupo: como diferenciar o OAP do resultado da aprendizagem se há momentos em que se tornam um?

$\mathrm{O}$ artefato 'Regalos' por exemplo, ofereceu de regalo tsurus da sorte em origami presos em uma gaiola (que caminha) aos que se encontram no caminho. Segue uma antiga crença japonesa na sorte que portam os tsurus dados como regalos. Se trata de um performance que regala sorte por onde passa. Os tsurus são os OAP? o performance é o OAP? É importante compreender a ação como um objétil. Todos esses artefatos que produzem situações são objétis. O OAP nesse caso deve ser entendido como um provocador. O que faz 'Regalos' ser um OAP não são os tsurus, nem a performance, mas o que provocam. No caso, provocam reflexões críticas sobre uma infinidade de aspectos. Por isso, esses artefatos podem nos ajudar a discernir entre o que é um OAP e o que são os elementos, os materiais, os autores, os participantes e os resultados. Um OAP não é nenhum destes. Um OAP é uma provocação para aprender que toma a forma mais adequada possível e que apresenta resultados diferentes. Os artefatos deste grupo atuam todos como ações poéticas provocadoras de aprendizagem, mas tiveram, no processo, dificuldade para dar forma pedagógica aos provocadores. 


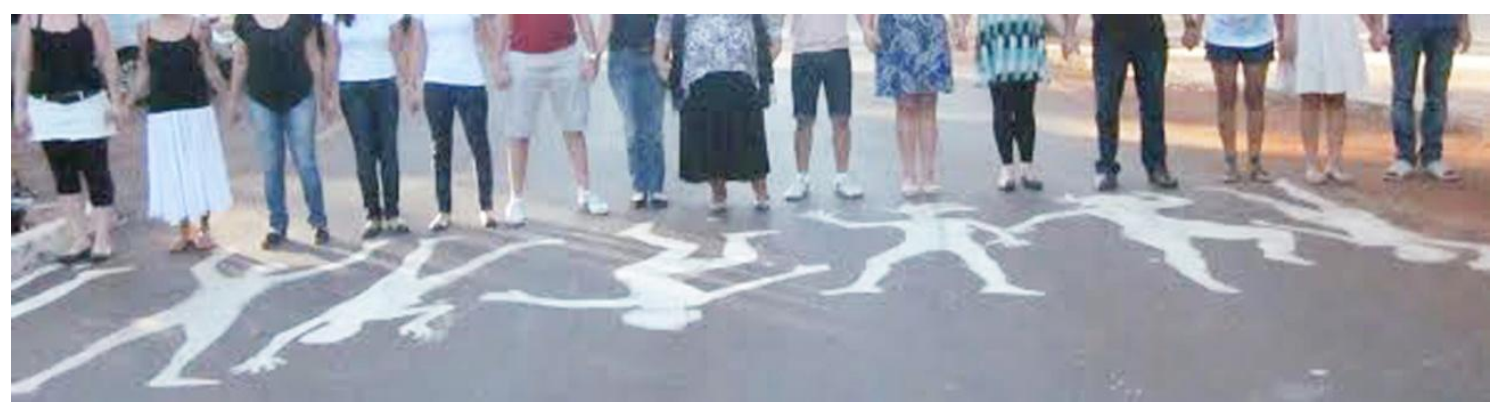

Fig. 119 Detalhe de Flash Mob Corpos que olham. Curso de extensão Objetos de Aprendizagem Poéticos, IdA/VIS/UnB 12014.

O participante ' $S$ ' teve dificuldade para pensar o provocador de maneira que se configurasse como um artefato que pudesse ser usado ou adaptado por outros. A proposta dirigida á educação infantil, se compõe de um conto gravado em CD para ouvir, sobre príncipes e princesas da África, três peças de tecido africano e um livreto com descrições de formas de amarração que se fazem com os tecidos, na África. O conto é uma produção própria, assim como o livreto. No processo as crianças participantes ouvem o conto e depois ensaiam vestimentas africanas aprendendo sobre amarrações e sobre a cultura africana com os livretos. A intenção é despertar um olhar crítico sobre as narrativas hegemônicas sobre príncipes e princesas que povoam o imaginário infantil (e adulto). Mas era necessário dar forma ao artefato como um provocador de situações. Poderia, nesse caso, se pensar em um jogo RPG adequado à idade. Uma história de príncipes e princesas na África, das quais eles participam na construção da situação onde os tecidos proporcionam os avatares. O tempo do curso de extensão limitou um desenvolvimento das ideias no caso deste artefato, mas é um exemplo da resistência que os OAP apresentam para estruturar uma interface que seja pedagógica, sem perder sua qualidade poética.

Por outra parte é interessante notar que em todos estes artefatos o papel dos estudantes/participantes é fundamental porque se constrói com eles, à diferença daquilo que acontece com os artefatos onde os participantes devem conhecer algo para participar, que é o caso de muitos dos artefatos realizados no curso. Nos artefatos que produzem situações, os participantes constroem o conhecimento no percurso. $\mathrm{O}$ papel do artista/investigador/professor nesse contexto é o do provocador de situações com máquinas para construir territórios de subjetivação. Em decorrência, os artefatos que produzem situações são os mais adequados para observar o princípio de emancipação no ponto de partida, crucial nas pedagogias culturais. É nesse modelo que 'Vivencias estéticas do 
Maracatú' se estruturou. Os participantes de um curso aprenderam através de uma dança em um cortejo do Maracatú para posteriormente produzir design de roupa. A vivência teve, pelo teor da narrativa do participante ' $E$ ', uma forma emancipadora:

"Agora, completando uma semana após o cortejo [...] ainda não estou
confortável para lidar com uma análise de forma objetiva. Talvez eu
não consiga enxergar a função da objetividade neste momento. o
subjetivo que por tantas amedronta os professores me fascinou, e
deixei ele inundar nossas vivências. Quanto mais elas pediam
respostas, mais eu perguntava. As inquietações se tornaram ações. O
empoderamento da experimentação as levou à dedicação pela
colaboratividade. O processo de ludo-terapia se tornou um trabalho
de reconstrução identitária. A construção simbólica transpassava os
objetos e percorria suas relações. Queria eu poder relatar à vocês com
precisão todas (as) potencialidades deste OAP, mas seus
desdobramentos ainda não me são palpáveis. Se multiplicam.[...] mas
desta vez eu estava sem chão, porque elas me proporcionaram o céu.
Extase enquanto artista, enquanto educador, enquanto arteducador."
(Participante 'E', Fórum de Apresentações de OAP, Fórum do capítulo
4, curso de extensão Objetos de Aprendizagem Poéticos, 2/2013).

Pelos seus depoimentos podemos depreender que os artefatos que proporcionam situações de aprendizagem envolvem também seus autores na aprendizagem e por este motivo manifestam essa forma de êxtase, que não é comum ocorrer em, ou com, artefatos que procuram separar conhecimentos certos de errados. É importante também notar que os artefatos deste grupo se constituem em práticas que corporificam. Esse tipo de propostas, ao incluir o participante, permitem que se sintam, existencialmente dentro, ou com o artefato. A aprendizagem ocorre em uma miríade de aspectos da existência.

Embora centrados em um modelo crítico, todos os artefatos apresentados conduzem também a práticas interpretativistas, mas o seu objetivo é a transformação (política, social, cultural), entender não basta. Da mesma maneira todos eles podem acentuar, ao mesmo tempo, sobre práticas empiricistas, que abordem as formas e estruturas de maneira crítica, de tal maneira que podem ser tornar práticas desconstrutivas. As mudanças de práticas pedagógicas 
tradicionais são mais perceptíveis nestes artefatos, se comparados com os do grupo anterior e tomando em conta que as propostas se mostram como extremos em direção à arte. Estes artefatos encontraram dificuldade para se estruturarem pedagogicamente, mas, é possível argumentar que foi a tensão com o extremo artístico que evitou cair nos modelos pedagógicos tradicionais.

\subsubsection{Formas}

Na perspectiva de Sullivan (2010) investigar e produzir formas no estúdio de arte é uma maneira de investigar análoga ao modelo empiricista de investigação nas ciências. Em decorrência disso prevalece uma tendência a pensar nos meios. Geralmente o campo de ação para estas práticas são os sistemas. Para criar uma forma é necessário encontrar o melhor meio segundo a intenção, mas isso requer conhecer o sistema que rege a matéria e a forma. Não pode-se fazer escultura em bronze sem conhecer a argila ou o material que será molde, nem gravura sem conhecer o contrário da imagem. Produzir nos sistemas, ao mesmo tempo, contribui ao crescimento ou mudança do sistema. E isso contribui a mudanças na existência. Esse é o caso das propostas do grupo de artefatos 'Texturas', 'Caixa', 'Mondriando' e 'Estruturas'.

Este grupo aponta a uma das dificuldades que surgiram durante o curso de extensão e que se evidencia nos seus artefatos: que a proposta se apresente como material de trabalho ou como recurso pedagógico. Os OA, 'Caixa' e 'Textura', apresentam uma série de objetos (a primeira) e uma série de texturas em material plano dentro de uma caixa (a segunda) para serem 'sentidos' e analisados pelos participantes de acordo ao seu nivel de dificuldade (ver fichas da Fig. 97). São artefatos que outros não poderiam, tal vez, entender como funcionam, mas que, no caso, teriam uma sequência e sentido de uso para uma atividade pedagógica. Mas não apresentam uma proposta pedagógica neles. O problema é que os OA e OAP devem apresentar uma proposta pedagógica e poética (a provocação) por meio de uma interface ou artefato que possa ser posteriormente usado ou adaptado por outro educador ou participantes, em outro contexto de ensino - aprendizagem. Assim como acontece com os presentes de Froebel, ou os brinquedos de Montessori, as formas que eles deram aos artefatos estavam relacionadas a uma série de propostas para cada atividade. Ambos realizaram, inclusive, longas investigações para produzir esses artefatos. 
O interessante das propostas deste grupo é que se baseiam no toque. Isso se pode explicar pelo fato de que uma proposta é para a educação especial e a segunda para o Ensino Fundamental I, mas se torna uma oportunidade de lembrar que o toque é um modo primordial de apreender o mundo.

Um aspecto observado é que as quatro propostas estão entre aquelas que não usaram as novas TIC em nenhuma das suas fases. A produção de formas no estúdio de arte geralmente está associado a formas concretas, mas também é possível que esta produção se refira a estruturas virtuais (ou estruturas em potência). O jogo 'Mondriando', embora seja feito de material concreto, entra no espaço das estruturas virtuais porque oferece uma série de pequenas formas para compor uma imagem semelhante às pinturas de Piet Mondrian. Os resultados, como ocorre no espaço virtual, não são permanentes, são infinitamente variáveis e podem ser registrados, mas ocorrem por um espaço de tempo determinado e desaparecem se não são salvas ou registradas. O alvo do jogo 'Mondriando' são as estruturas visuais (virtuais) que Mondrian inventa para a modernidade, não as formas geométricas. Estas estruturas estão hoje relacionadas com a estrutura das imagens virtuais que é modular. Esse artefato poderia ter a sua versão digital.

Os artefatos que se encontram nesse grupo favorecem práticas que estruturam o conhecimento. O artefato 'Estruturas', como vimos antes, se propõe estudar questões formais ligadas às relações entre as formas geométricas. Quando as peças podem se acoplar e formar outras novas criam uma estrutura. Mas nesse caso específico, acompanham uma mudança na estrutura do pensamento e, portanto, na forma como construímos o conhecimento. As práticas que estruturam também oferecem novas formas de pensar, não só novas formas de construir. As formas da escritura estruturam tanto a escritura como a forma de pensar, como acontece com os ideogramas ou os hieróglifos. No artefato 'Missão Egipto', por exemplo, a decodificação dos enigmas se dá em uma estrutura de pensamento ocidental onde a escritura é feita a partir um alfabeto que forma fonemas que se leem em uma certa direção, muito diferente da forma de pensar os hieróglifos egípcios. O jogo, no entanto, poderia ser uma oportunidade para uma abordagem empiricista que estude outras estruturas de pensamento e comunicação e invente outras novas possíveis.

Assim como acontece com os outros grupos, esses artefatos podem abordar de forma crítica (desconstrutiva) ou de forma interpretativista (discursiva) as formas e estruturas. De qualquer 
forma podemos observar que foram poucos os participantes que trabalharam na produção de formas ou estruturas. E desses, é importante notar que, somente 'Mondriando' e 'Estruturas' produziram um artefato; 'Caixa' e 'Texturas' não chegaram a se completar. Esses dados apontam a dificuldade que existe para abordar as questões de forma e estrutura na pedagogia tradicional. Por outra parte produzir formas e estruturas exige um conhecimento dos sistemas. Os dados parecem apontar que há poucas indagações nos sistemas e se produzem poucas formas e estruturas no processo pedagógico.

Os OA e OAP produzidos pelos participantes do curso de extensão podem ter muitos desdobramentos, não só aqueles que se completaram, que foram aplicados e avaliados. A maioria se propõem provocadores na busca de outras soluções, experiências, experimentos ou pensamentos. As mudanças que estes artefatos evidenciaram nos participantes, independente de terem produzido OA ou OAP se encontram no fato de abordar a pedagogia como produção, pensar nos participantes, cruzar fronteiras na educação e na arte, interpretar o contexto, experimentar e provocar outras experiências e finalmente, no fato de refletir sobre questões cruciais para a comunidade educativa.

Podemos também observar que muitos dos artefatos produzidos abriram espaços para a experiência estética, seja pela valorização da visualidade, das situações lúdicas, críticas, imaginativas ou criativas, seja pela ênfase na corporificação dos processos ou pelo esforço para configurar artefatos capazes de provocar eventos. No entanto, as brechas para a singularidade, a diferença ou a dissidência são mais evidentes nos projetos pensados como OAP.

Entre os participantes poucos sabiam o que eram objetos de aprendizagem. Muitos não sabiam identificar ou elaborar. Embora alguns declararam que em alguma oportunidade haveriam trabalhado com OA, não sabiam que se conceituava dessa maneira. A exploração das possibilidades virtuais que se apresentam em bancos de OA animou os participantes a experimentar. Muitos exploraram tutoriais e aprenderam sobre alguma questão tecnológica ou mediática. Mesmo assim, a maioria das propostas se inclinaram em direção a objetos concretos e evidenciaram um uso limitado de novas TIC. Minhas expectativas eram de que usariam celulares ou que fariam flash mobs através das redes sociais.

\subsubsection{Que afetos formam os OAP? Que afetos são formados pelos OAP?}


Entre as inteções iniciais desta investigação e as que foram se formando ao longo dos estudos e experiências com os participantes do curso de extensão há diferenças, embora a problemática da investigação fosse sempre a mesma, poderia ter tomado diferentes caminhos metodológicos. O que acontece nesses caminhos pode ser imprevisível. A paisagem sempre em movimento e hibridação requer programações flexíveis e fluídas. No princípio eu estava ineterssada em conhecer os afetos que surgiriam nos estudantes do ensino básico com os OAP, pois eles são os participantes em potência na minha paisagem. Mas, o que surgiu, com mais força, foram os afetos dos participantes do cuso de extensão. Pouco se falou dos estudantes - participantes nos espaços educativos onde os artefatos foram usados, mas houve muito que observar sobre os seus criadores.

O tempo do curso de extensão permitiu que os participantes chegassem a se conhecer estabelecendo uma forma de vínculo, incluíndo a participante ' $A$ ', que fez o curso totalmente a distância porque mora em outro Estado. A participação nos fóruns virtuais foi mais intensa na segunda versão que contou com muitos inscritos e menos intensa na terceira versão que contou somente com três participantes (quatro, na realidade, como veremos adiante). Isso afetou de maneira mais aguda as conversações nos fóruns virtuais, mas nos encontros presenciais a participação foi intensa em todas as versões.

Para a fase de avaliação do curso foi preparado um questionário interno com quatro perguntas e pedidos de sugestões sobre a qualidade do conteúdo, dos objetos de aprendizagem, a metodologia e os espaços com o objetivo de melhorar a cada nova versão. Nessa fase disponibilizei também um questionário de avaliação da UnB/DEX que avalia os projetos de extensão realizados. Em ambas avaliações os participantes se mostraram muito satisfeitos com o curso. Mas, o que chamou minha atenção nas contribuições dos participantes na avaliação é que nelas podemos encontrar vários indícios de como estes participantes se vêm no processo.

Para um dos participantes o processo representou voltar a acreditar em algo que era dele, como uma forma de voltar a ser quem era antes:

"Estamos carentes de novas ideias!. Foi um estímulo para a minha área (arte), é muito importante acreditar naquilo que você faz e o curso renovou algo que estava sendo perdido..." (Autor desconhecido, questionário de avaliação do curso de 
extensão Objetos de Aprendizagem Poéticos, 1/2014, Anexo II).

Em alguns casos os participantes mostraram que se sentiam parte de uma comunidade. Em outros casos apontaram uma mudança na forma de pensar:

Acerca da segunda pergunta do questionário interno "Os objetos
de aprendizagem utilizados foram efetivos (página web e outros)
na sua aprendizagem?" alguns participantes responderam: "sim,
foram e já há pessoas com interesse em usá-los em suas aulas".
(Autor desconhecido, questionário de avaliação do curso de
extensão Objetos de Aprendizagem Poéticos, 2/2013, Anexo II).
Outro participante argumentou assim: "Sim. Os objetos de
aprendizagem mudaram a minha forma de pensar a
aprendizagem. Os OAs utilizados foram adequados aos
conteúdos e ao perfil dos participantes." (Autor desconhecido,
questionário de avaliação do curso de extensão Objetos de
Aprendizagem Poéticos, $1 / 2014$, Anexo II).

A satisfação com o curso evidencia que havia uma expectativa anterior, uma potência que estava à procura de provocações para se transformar. No questionário da UnB/DEX, à pergunta número 6- comentários e sugestões finais em quanto à disciplina, alguns participantes responderam assim:

"Muitíssimo pertinente aos educadores" (Autor desconhecido, questionário de avaliação do curso de extensão Objetos de Aprendizagem Poéticos, UnB/DEX/Interfoco, 2/2013, Anexo II); O curso superou as expectativas, contribuindo amplamente para minha formação como arte-educadora. (Autor desconhecido, questionário de avaliação do curso de extensão Objetos de Aprendizagem Poéticos, UnB/DEX/Interfoco, 1/2014, Anexo II); "O conteúdo visto na disciplina se aplica diretamente com a nossa realidade como arte educadora. Os trabalhos apresentados, tanto nos fóruns quanto no encontro presencial, 


foram fantásticos para usarmos como OAPs dentro da nossa
sala de aula." (Autor desconhecido, questionário de avaliação do
curso de extensão Objetos de Aprendizagem Poéticos,
UnB/DEX/Interfoco, 1/2014, Anexo II).

É possível interpretar, dos comentários, que havia um espaço de espera, de algo que não sabemos o que é até o momento em que chega. Dessas avaliações podemos depreender que os OA e os OAP constituem inflexões na experiência dos participantes. Nesse ponto é importante analisar o alcance da experiência, pois ela se encontra tanto no artefato produzido (o curso de extensão e os OAP para educadores em visualidade) como no que aconteceu com os participantes. Os artefatos que eles produziram, na maior parte, não se completaram na sala de aula, e dos que se completaram, somente alguns tiveram tempo de analisar resultados. A maioria apenas introduziu a experiência, faltando fases a serem concluídas. Isso era esperado, pois a finalização dependia do que seria realizado no contexto. Mesmo nessas circunstâncias, vários deles obtiveram e apresentaram resultados motivadores. Alguns argumentos revelam o engajamento que estes artefatos alcançaram em algumas experiências:

"Desenvolver o jogo 'Crítico de arte' foi o ápice dessa viagem.
Observar os estudantes divertirem-se enquanto jogavam foi algo
indescritível. Ali eu realmente entendi a dimensão poética desses
objetos. Uma dimensão que está para além da expectativa. Que
só experienciamos no momento da prática. Que precisa do outro
para ter sentido" (Participante 'G', Ensaio final, curso de
extensão Objetos de Aprendizagem Poéticos, 1/2014).

Podemos observar que na situação do jogo o professor vê o estudante/participante como aquele que completa o sentido. São parte de um mesmo ato, de uma mesma identidade. Comentários similares surgiram nos últimos encontros presenciais em cada versão do curso entre os que concluíam ao menos uma fase do projeto. A maior parte deles manifestou a disposição que os estudantes/participantes mostravam com os artefatos. Do ensaio final podemos também recolher manifestações escritas sobre o impacto do curso nos participantes:

"Com o curso pude reafirmar que: Não só a imaginação dos 
alunos devem ser enfatizadas, mas também do professor; todo professor de arte é também um artista em sala de aula, não deve esquecer que o educador em artes visuais é também um artista atuante" (Participante 'O', Ensaio Final, curso de extensão Objetos de Aprendizagem Poéticos, 1/2014).

"Estou muito feliz por ter conseguido concluir o curso. [...] Essa foi uma experiência intensa e inesquecível para mim" (Participante ' $G$ ', apresentação do Ensaio final, curso de extensão Objetos de Aprendizagem Poéticos, 1/2014).

E ainda nos fóruns:

"Foi uma experiência incrível que, com certeza, levarei por toda minha vida como educadora" (Participante 'A', Fórum de despedida e dúvidas finais, Fórum do capítulo IV, curso de extensão Objetos de Aprendizagem Poéticos, 2/2013).

"Foi uma experiência fantástica! A princípio me pareceu muito difícil criar um OAP, mas assim que tive a primeira ideia e fui esboçando, as demais foram surgindo. No fim, fiquei muito contente e satisfeita com o jogo que elaborei. Inclusive com o fato dele não se constituir num objeto pronto e acabado, mas sim em um objeto de aprendizagem passível de modificações" (Participante 'A', Fórum de apresentação de OAP, Fórum do capítulo IV, curso de extensão Objetos de Aprendizagem Poéticos, 2/2013). 
É possível pensar, sobre esses apontamentos que, para muitos participantes houve uma grande mudança que ainda está em processo. O que eles produziram com as primeiras experiências é índice ou sintoma do que poderia se tornar. Os OAP levam tempo para se configurar porque devem se adaptar e crescer. Muitos deixaram claro que o trabalho apenas começou. Um sentimento de abertura a novas possibilidades é perceptível nas afirmações (Quadro de conversações, Fórum do capítulo IV).

Os encontros presenciais sempre foram muito intensos, especialmente no dia da apresentação dos artefatos quando o curso de extensão estava finalizando. Na segunda versão esse dia ficou conhecido como a aula pic-nic. Devido á greve de funcionários da UnB decidimos marcar o encontro nos jardins entre a Biblioteca e a Reitoria da UnB. Organizamos uma aula pic-nic para apresentar os trabalhos. O contexto da aula e os trabalhos apresentados contribuíram para um encontro memorável registrado em vídeo e fotografia (Figuras 83, 84, 98 e 99). Naquele momento, escutando uma a uma as apresentações sobre os artefatos produzidos, observei que o curso havia proporcionado em todos os casos, um novo território de existência: o do professor/artista/investigador. Nos depoimentos, todos manifestaram a dificuldade de pensar um artefato em termos de aberturas (ao poético). Essa dificuldade indica que houve uma tensão entre as ideias tradicionais na pedagogia e as ideias das pedagogias culturais. Poderíamos dizer que essa dificuldade indica um evento.

No entanto, a ideia da poética no objeto de aprendizagem não abandonou os participantes no processo de produção, a proposta era essa, embora pudessem fazer objetos de aprendizagem não poéticos se assim desejassem. Era necessário passar pela discussão do que era poético, o que era estético, o que era artístico e o que era pedagógico. O desafio era pensar em aberturas que são geralmente contrárias a uma ideia do que é pedagógico, como a abertura ao diferente e dissidente, ou à imaginação, ou ao singular/plural, ou inclusive á experiência estética. Para os participantes esses desafios significavam o risco de não ter controle sobre o resultado, mas também de não ter possibilidade prática de executar os artefatos com turmas grandes. Quase todos os que chegaram a aplicar o artefato em um espaço educativo o fizeram com turmas pequenas, dividindo grupos, ou aplicando em horários contra turno. Os artefatos poéticos também são exigentes na hora de avaliar os dados porque são complexos e relacionais. A avaliação é uma parte importante dos processos educativos e no ensino das artes visuais esse é um campo ainda pouco investigado. Isso me leva a pensar que os espaços de coincidência 
entre as viradas são espaços de risco porque exigem processos de investigação em espaços do desconhecido.

Mas, todos os participantes se ariscaram, mesmo cheios de dúvidas, na criação de algo que exigia atuar no espaço entre a arte e a educação. Essa é uma forma de pensamento que trabalha sobre paradoxos porque coloca em questionamento os mesmos esquemas mentais que lhes dão origem. Os participantes foram confrontados com formas de operar paradoxais, pois a provocação era fazer um artefato que fosse ao mesmo tempo poético e pedagógico. Na aula pic-nic observei que eles encontraram formas para tornar a contradição em potência, pois, mesmo quando os artefatos não se completaram, ou não alcançaram uma qualidade adequada às intenções, ou se estruturaram em artefatos não poéticos, houve um grande engajamento na investigação e a maioria expressou de diferentes maneiras que passou por uma transformação na forma de ver sua prática.

Os registros em vídeo guardam evidência da confluência que ocorreu na turma da segunda versão do curso no encontro da aula pic-nic. Alguns eram colegas da mesma escola, outros eram amigos dos tempos da graduação, outros eram colegas de estudo, outros foram meus estudantes na graduação e estavam já atuando em escolas. Havia já vínculos entre os participantes, mas o ambiente (cores, luz, clima temperado, canto dos pássaros) proporcionou um espaço propício em que se reconstruiu o sentimento de pertencimento a uma comunidade. Poderíamos dizer que o ambiente proporcionou a magia necessária para tornar aquela tarde uma experiência de intensa comunicação. E a comunicação surge, como sugere Dewey (1929) com a ideia de ação comunicativa, de construir juntos e nos reconstruir no processo.

Na perspectiva de uma investigação a/r/tográfica, a comunidade é o espaço da construção do conhecimento. De maneira semelhante as ideias, formas e situações em que esses artefatos forma produzidos foram construídos em comunidade, apesar de que $60 \%$ do curso foi a distância. Eu propus um nome e a comunidade de participantes lhe deram novas formas. Nesses casos não é o nome que inventa a prática e uma comunidade, mas a prática que inventa um nome para identificar uma comunidade. Os objetos de aprendizagem poéticos provavelmente sempre existiram, desde que existem objetos poéticos com intenção de educar. Mas no contexto atual estes artefatos ganham um nome próprio porque são parte das formas de aprender e de se relacionar dominantes. No curso de extensão os participantes se reconheceram e adotaram como suas as ideias comunitárias. Para minha surpresa, a 
comunidade que se interessa pelos OAP cresceu além das fronteiras do curso de extensão, dentro do Instituto de Artes na UnB. Esse interesse está de várias maneiras, relacionado às propostas da a/r/tografia que ganharam campo nos últimos anos: a ênfase nos espaços de subjetivação, nas formas de operar da arte (formas de construir conhecimento e territórios de existência) e nas formas de IBA e IEBA. A primeira transformação importante nos participantes, que esta investigação identifica no espaço do encontro entre as viradas, é a da se entender como a/r/tógrafos, criadores e investigadores de eventos pedagógico/poéticos (ver fig. 96, Quadro de Conversações, Fórum do capítulo IV, $3^{\circ}$ versão 2/2014, participante 'R').

Uma das questões centrais no curso é o direcionamento crítico que requer a identidade de a/r/tógrafo. Não se trata, então, de etiquetar processos que já existem. Trata-se de observar que rachaduras isso provoca:

"No desenvolvimento do OAP o curso abriu um leque de
possibilidades e reforçou o meu desejo de criação para sair um
pouco do formal e quebrar alguns paradigmas" (Participante 'Q',
Ensaio final, curso de extensão Objetos de Aprendizagem Poéticos,
1/2014).

"Eu aproveitei tanto, que já tenho vários projetos em andamento para realizar com os meus alunos, acredito que minhas aulas produzirão resultados inéditos para minha trajetória como arteeducadora" (Participante ' $N$ ', Ensaio Final, curso de extensão Objetos de Aprendizagem Poéticos, 1/2014).

Afirmações similares se ouviram nas três versões de maneira informal. Isso significa que há um desejo de transformar a prática. Poderíamos dizer que muitos dos participantes chegaram com a potência do desejo de transformar sua prática e a sua comunidade. Poderíamos dizer que muitos deles seguem um desejo de transformar seus territórios de existência, e seu êxtase procede de ver esse momento acontecer. Nesse sentido posso afirmar que a potência transformadora da maioria dos participantes recebeu energia poética e provocou uma 
rachadura por onde eles criaram, com respostas singulares, territórios onde podem ser, eles mesmos, transformadores. O ser a/r/tógrafo, se descobre em um espaço de poder.

A identidade de educador em visualidade, associada a um papel social muito inferior ao do artista, permeia as relações de poder herdadas do colonialismo. No primeiro encontro presencial de cada versão do curso essa questão foi abordada para estabelecer um espaço em que fosse possível ver o que acontece entre a identidade de professor e o de artista. $\mathrm{O}$ que podemos depreender das conversações nos fóruns, dos ensaios, dos depoimentos e das conversações informais nos corredores do $\mathrm{IdA} / \mathrm{UnB}$ é que, foi esse ponto de tensão que rachou os muros que cada um tem e permitiu ver do outro lado. Os professores de arte, de maneira particular, e os professores de maneira geral, podem se ver como produtores de cultura, e aqui a produção se entende como poética. Uma das consequencias de trabalhar com pedagogias culturais é reconsiderar a posição política que as pessoas têm na distribuição do sensível. Nesta investigação os indícios de uma transformação política nos participantes não foram registrados de forma explícita, mas posso interpretar, nas entrelinhas de vários dos registros escritos e verbais e, sobretudo nas expressões das miradas que minha memória registrou (e que reconheço nos registros videográficos e fotográficos, mas que seria impossível recortar), que os participantes reconheceram um senso crítico sobre sua prática e sobre si mesmos, como professores e como participantes de uma comunidade e pensaram nos estudantes como participantes do mesmo processo.

Isso também coloca em evidência um ponto crucial nas pedagogias culturais: o caráter comunitário da construção do conhecimento. O curso, na sua ebulição, provoca uma conversação que atravessa as fronteiras do que está no planejamento. Nos fóruns, os participantes postaram, além dos comentários e dúvidas sobre os temas tratados, vídeos, links, arquivos e imagens que proporcionam excelentes espaços para diversas reflexões. Na primeira versão houve pouca participação nos fóruns de maneira geral, a exceção dos últimos dois capítulos que se tornou mais frequente. Na segunda versão, que teve a maior quantidade de participantes, o diálogo foi intenso. Atribuo essa intensidade à quantidade elevada de participantes, mas também ao fato de ter diminuído a quantidade de fóruns na segunda versão, assim, as conversações ficaram mais concentradas. Na terceira versão que teve a menor quantidade de participantes, a conversação nos fóruns foi quase nula no primeiro capítulo. 
Preocupadas com a situação, a professora tutora e eu, em uma conversação sobre alter-ego na arte, decidimos trazer à cena a participante fictícia ' $U$ ', como um OAP, com o propósito de ativar conversações e provocar diálogos mais intensos. ' $U$ ' perguntava tudo de tal maneira que permitia uma maior orientação nos processos que os outros participantes conduziam de maneira silenciosa (ver Quadro de conversações do fórum do capítulo II). O personagem viveu até o último capítulo em que anunciou que não poderia completar o OAP por falta de tempo e que faria o próximo curso. ' $U$ ' estabeleceu uma relação colaborativa com seus colegas e ao mesmo tempo apresentou questionamentos importantes para todos. ' $U$ ' constitui, de uma maneira singular, o papel de objeto de aprendizagem porque perguntava tudo e contribuía no trabalho dos outros. É um artefato poético porque apresenta uma situação fabulada e absurda que provoca eventos dos quais não poderíamos ter controle (ver fig. 96, Quadro de conversações, Fórum do capítulo III e Quadro de conversações, Fórum do capítulo IV).

No encontro das viradas é possível observar que as identidades sofrem novas modulações políticas porque tornam-se agentes de transformação. Em muitos dos casos, os participantes já eram agentes culturais transformadores, mas não reconheciam-se nessa situação. No percurso das experiências, das conversações e das leituras os participantes expressaram de diversas maneiras seu interesse nas relações entre arte, educação e política. As ideias de artistas como Camnitzer e Helguera foram comentadas em diversas ocasiões e outras leituras que não estavam na bibliografia foram apresentadas (ver fig. 94, Quadro de conversações do Fórum do capítulo II, participante ' $N$ ', sábado 12/04/2014). Os participantes do curso evidenciaram, em muitos aspectos, o papel do professor e do estudante na distribuição do sensível e o valor do princípio de emancipação no ponto de partida. No ponto de chegada, que é apenas um ponto de inflexão no percurso, se abrem muitas outras possibilidades. Os dados escritos e verbais registrados de como os participantes se vêm nesse processo me pareceram poucos, deduzo que devido ao contraste com a experiência que guardo na memória corporal. No entanto, sobre estes indícios posso afirmar que, houve uma transformação importante na maneira como os participantes se vêm no processo de uma colisão, contaminação ou hibridação entre arte e educação e de como vêm seus estudantes/participantes e que esta seja, tal vez, a maior mudança que acontece no encontro das águas. O que eles encontraram é um mundo de possibilidades. Muitas coisas podem acontecer a partir dessas experiências.

As mudanças que os participantes manifestaram nas conversações e nos processo de singularização da produção maquínica apontam principalmente a uma reavaliação das suas 
posições frente às formas hegemônicas e colonialistas de abordar a história da arte, de separar teoria de prática e de poética e de invisibilizar o diferente e o dissidente. Nesse sentido houve uma reavaliação dos participantes das suas posições frente à pedagogia e à arte, embora os artefatos produzidos não chegarm a romper com a ordem estabelecida, mostraram o grau de complexidade que exigem estas viradas no campo da educação em visualidades.

Fig. 120 Illimani recortado. Tatiana Fernández. Imagem de Google Earth.

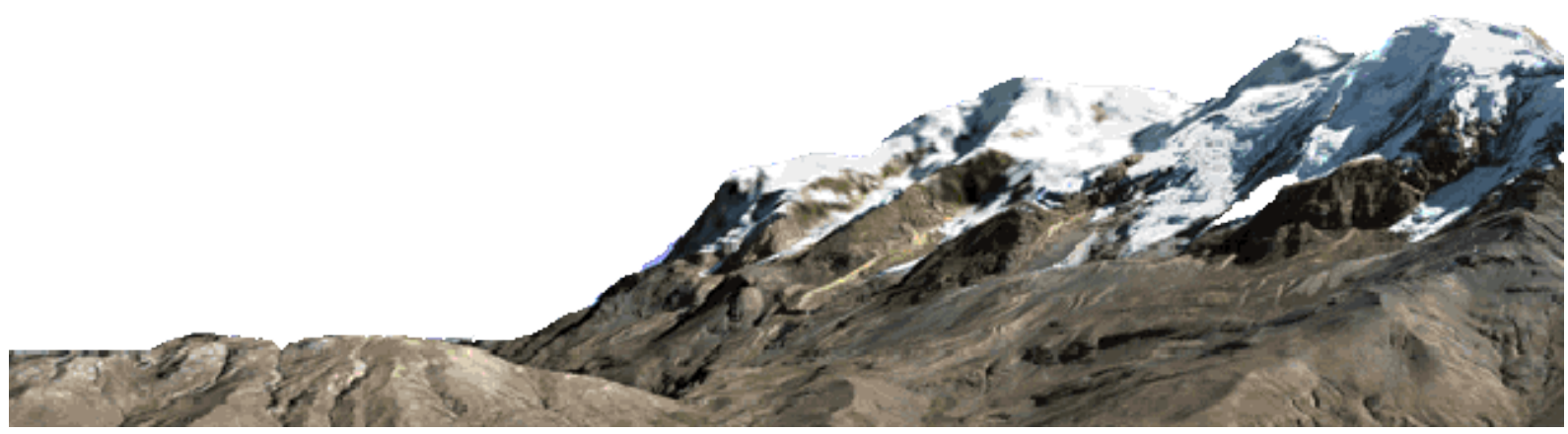




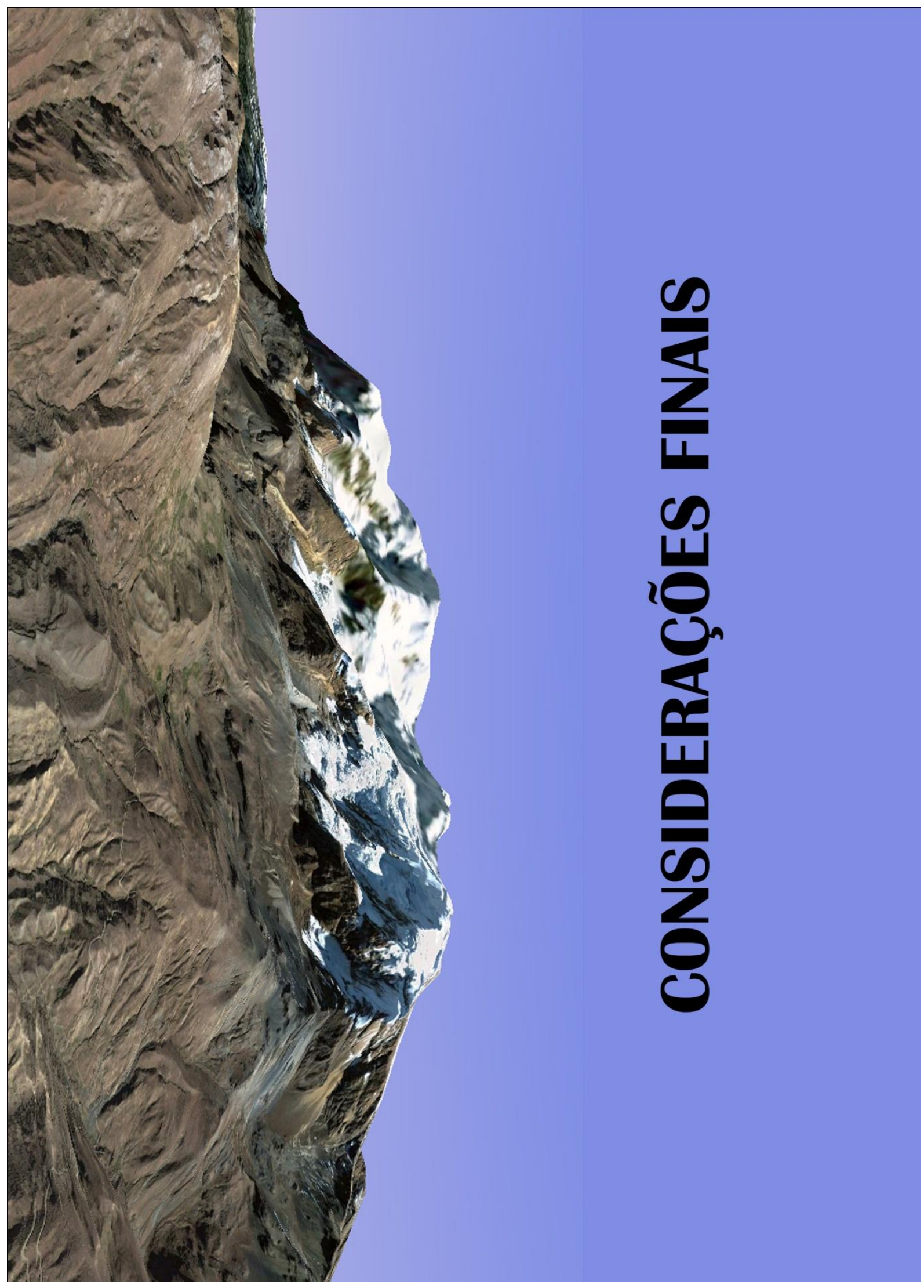

Fig. 121 Illimani de cabeça para abaixo. Tatiana Fernández. Imagem de Google Earth. 2015. 


\section{MAPAS DA POTÊNCIA}

Fundamentada no entendimento do evento como uma ruptura é possível depreender desta investigação, em primeiro lugar, que o evento artístico pode ser uma pedagogia no contexto das pedagogias culturais e a pedagogia pode ser um evento artístico no contexto de uma arte participante. Isso acontece na confluência da virada da visualidade na educação e a virada pedagógica na arte, em uma paisagem complexa que apresenta diversas camadas que se superpõem e se movimentam: a política, a estética e a pedagógica. Ambas viradas formam um encontro de águas que reviram as camadas e com elas trazem mudanças que contaminam, transmutam e pervertem ambas vertentes, mas também, que coincidem, se superpõem ou formam híbridos formando no processo novos territórios possíveis. Nessas bases estrutura-se a ideia do evento artístico como pedagogia e propõem-se os Objetos de Aprendizagem Poéticos, OAP, em contextos escolares, como provocadores destas confluências, para analisar as transformações que devem se tomar em conta na Educação em Visualidade.

Em segundo lugar, é possível depreender, na revisão de literatura, que ambas viradas encontram-se porque coincidem nos espaços filosóficos, políticos e metodológicos. Mas, também porque ambas vertentes (da arte e da educação) passam por mudanças próprias que o encontro vem realçar. A virada pedagógica na arte traz à luz as questões filosóficas e históricas sobre os artistas do século XX que se interessaram pela relação entre arte, educação e política. A investigação alcança um ponto alto com o estudo dos artistas contemporâneos que trabalham com interfaces pedagógicas com as quais assinalam um interesse cada vez maior em cruzar fronteiras disciplinares. O fato é que muitos artistas contemporâneos trabalham em colaboração com outras áreas, e, como pensa o grupo Pil e Galia Kollectiv, isso significa abrir "um novo cenário para o engajamento político" (FLUX CONVERSATIONS, $\mathrm{s} / \mathrm{p}, 2015)$. A esse respeito os estudos apontam as discussões sobre a autonomia e heteronímia da arte: alguns pensam que a arte perdeu a sua força crítica quando perdeu sua autonomia (respeito ao mercado, respeito à política e respeito à cultura), enquanto outros como Pil e Galia Kollectiv (FLUX CONVERSATIONS, 2015) pensam que a arte não é autônoma, e é justamente isso que assegura a sua força crítica, no sentido Benjaminiano ${ }^{84}$. A investigação realizada aponta, no entanto, a tensão entre autonomia e heteronímia da arte como o espaço de potência pedagógica, estética e política. As ideias de Rancière, as pesquisas de Bishop e as

\footnotetext{
${ }^{84}$ A ideia de Walter Benjamin de que a era da reprodutibilidade técnica torna a arte política.
} 
provocações de Camnitzer apontam as rupturas que essas tensões provocam na arte, na educação e na política. Ainda, Deleuze e Guattari proporcionam um campo de reflexões em que podemos situar essa tensão à luz do paradigma ético-estético. Nessa perspectiva a autonomia da arte se refere ao que jagodzinski e Wallin (2013) denominam monumentalidade da arte: a potência maquínica do evento sem o artista. A arte (como poiese, como evento) é autônoma da vontade do artista e é autônoma da práxis, mas como todo artefato faz parte dos territórios de subjetivação. A sua heteronímia está ligada a esses territórios. Essa tensão é análoga à tensão entre o ser singular/plural.

A virada da visualidade na educação, por outro lado, conduz aos Estudos da Cultura Visual e às propostas de educação em cultura visual. O que se debate nesse cenário são as questões da visualidade nas relações de poder, da qual a arte participa com outras dimensões da visualidade cultural. Em base a esses estudos, esta investigação se alinha com as pedagogias culturais (no plural), com propostas que consideram a educação como uma forma de produção cultural, e a cultura como uma forma de pedagogia. Entre essas, as leituras apontaram a pedagogia do evento (ou pedagogia contra o estado), a pedagogia de fronteira, a pedagogia espetacular e outras possíveis pedagogias que se formam nas fronteiras entre cultura e educação como a transpedagogia. Os questionamentos que embasam as pedagogias culturais sobre que conhecimentos são valiosos, de quem e para quem, conduziram ao conceito de currere de Pinar que propõe um cruzamento entre um currículo vivo e um currículo planejado na educação.

Ainda, esses questionamentos desbordam nas relações que se estabelecem entre sujeito e objeto nas estruturas sociais e culturais. A Educação em Visualidade conduz a reflexões sobre a imagem e o imaginário, e esse é, como sabemos, um espaço de grandes tensões culturais porque põe em evidência as formas de representação nas relações de poder, em determinados contextos. O agenciamento que proporciona a arte e a educação, e de maneira especial a Educação em Visualidade, para abordar estas tensões por meio das formas de operar da arte, é um dos argumentos centrais que permeiam muitas das propostas das pedagogias culturais. Isso signfica que uma Educação em Visualidade não trata somente das formas de construir conhecimento e significado, mas das formas de inventar mundos para uma vida possível.

Tanto as escolas que os artistas formam ou os projetos pedagógicos que produzem em espaços institucionalizados como as pedagogias que propõem os educadores cruzadores de fronteiras 
são formas de buscar transformações sociais em direção a uma distribuição do sensível. Os indícios, visíveis na arte e a sua educação, permitem pensar em formas de ocupar esses territórios de fronteira. Nesse marco, Rodríguez, Froebel, Montessori e Dewey anunciam as possibilidades dos espaços de cruzamento entre arte, educação e política no século XIX que moldaram as ideias no século XX. Hoje, começando o século XXI, Atkinson, Garoian e Gaudelius, Rogoff, Vidokle e Camnitzer, entre outros educadores, encarnam esse cruzamento em novas formas de pedagogias culturais.

Dessa forma, é possível reconhecer que a principal coincidência entre as viradas se dá no plano político. A ideia que atravessa o encontro é a emancipação, e essa é uma ideia política, mas também é, como vimos, uma ideia estética e pedagógica. Chegamos a ela, principalmente por meio de Rodríguez, Jacotot e Rancière. A emancipação do espectador é a emancipação do estudante, em direção à participação na distribuição do sensível. A possibilidade do evento artístico como pedagogia, é pensada e realizada para o contexto escolar em base ao princípio de emancipação no ponto de partida: o evento não se origina fora da escola, mas dentro dela. Por esse motivo se trata de um artefato produzido pelos professores/participantes com seus estudantes/participantes em um contexto educativo. O evento artístico (quando se torna uma pedagogia) se propõe como máquina para construir territórios de subjetivação. Trata-se de uma pedagogia que opera com a experiência estética abrindo espaços poéticos e precipitando a aprendizagem para criar territórios de existência singular/plural. Os OAP se declaram aberturas a esses espaços ou operadores de bifurcações da subjetividade.

A segunda coincidência se dá no plano metodológico. Ambas viradas apontam formas de investigação que focam sobre o papel da visualidade na construção do conhecimento e nas relações de poder, mas também seu papel no atravessamento multidisciplinar. Como bem apontam jagodzinski e Wallin, pensar a arte como forma de pesquisa, que é a tese central de Sullivan, "eleva o status da pesquisa baseada nas artes ao nível da ciência ou das ciências sociais sem se reverter ao método qualitativo, mas se focando na especificidade do processo artístico" (2013, p. 191). Dessa maneira as viradas aportam com formas de investigação criativas, críticas, reflexivas e transcognitivas que indagam no possível.

A ideia de emancipação no ponto de partida também tem consequências metodológicas porque considera o observador e o observado na construção dos conhecimentos e dos saberes 
visuais e porque mantém o conhecimento a constante escrutínio, como observa Sullivan (2010, p. 52). Um escrutínio constante do conhecimento implica uma constante visualização do conflito. Essas mudanças afetam a forma como pensamos o processo pedagógico, de uma relação de transmissão a uma de investigação, onde os professores e estudantes são pesquisadores e suas posições afetam a sua comunidade. Afeta também a forma como interpretamos os processos artísticos, de uma relação de significado contido na obra de arte a uma relação de construção e reconstrução coletiva do significado. Por outra parte afeta a forma como pensamos os processos políticos e culturais, de uma relação de colonialismo a uma relação de emancipação onde podem surgir "procedimentos da verdade" (ATKINSON, 2012).

Nessa perspectiva metodológica há também uma maior preocupação com práticas críticas que possam conduzir a processos criativos que respondam ao contexto e que tenham, como sugere Sullivan, "apelo transformador" (2010, p. 52). Esse é o acento da arte participante e das pedagogias culturais: não basta saber, o importante é o que fazemos com o que sabemos. Dessa maneira é também poético porque conduz o que é ao plano do que está em potência: do que pode ser.

A terceira coincidência se da no plano existencial, na forma como construímos territórios de subjetivação. Ambas viradas privilegiam o evento (ruptura) como o lugar da experiência estética, cujo valor é o de provocar outras experiências. Nessas condições, como vimos, as fronteiras fixas entre sujeito e objeto e entre imagem e realidade, entre arte e ciência, se desvanecem. As implicações sobre a arte se fazem evidentes no interesse cada vez maior sobre os agenciamentos maquínicos que abrem espaço ao pós-humanismo. Para a educação significa assumir uma relação de corporificação com os conhecimentos, onde o sujeito se cria na criação do conhecimento.

Por outra parte, ambas viradas se contaminam com os debates sobre o que pode e não pode ser ensinado na arte. Se é possível o evento artístico como pedagogia podemos nos questionar então se é possível uma escola de arte onde possa se aprender a ser artista? Há uma intensa discussão hoje no circuito internacional da arte sobre o papel das escolas de arte no contexto das políticas neoliberais globais que exigem profissionais qualificados para servir o sistema de mercado e como isso conduz o ensino da arte a uma forma de pesquisa acadêmica para produzir conhecimento mensurável e rentável, diminuindo o espaço de pro-dução poética 
(DUVE de, 2012, MADOF, 2009; ROGOFF, 2006; MOLLIN e REARDON, 2009; CAMNITZER, 2009c, entre outros). Tudo parece indicar que para que a arte se mantenha na Academia deve justificar-se como forma de construção de conhecimento com uma função social definida pelos parâmetros da economia. Da mesma maneira acontece na educação básica em que a arte não se justifica se não se adéqua os modelos cientificistas com objetivos econômicos. Agora, trata-se de pensar como é possível ensinar e aprender arte em estruturas metodológicas artísticas onde o diferente, o dissidente, o absurdo, o paradoxal, o irresolúvel, o impossível ou, o que ainda não tem um nome, pode ser visualizado Nessa perspectiva, o evento artístico como pedagogia, experimentado por artistas como Beuys, Cage, Bruguera, Helguera e outros, aponta uma ruptura com as formas tradicionais de ensino e aprendizagem da arte.

Os dados que aportam os artefatos criados nos curso de extensão são propícios para analisar as transformações que provocam: as formas de pensar (território político), as formas de fazer (território metodológico) e as formas de se ver e ver os estudantes nesse processo (território existencial). Pelos indícios deixados nas avaliações (Anexo II) e ensaios finais, para uma parte significativa dos participantes, a experiência de pensar um artefato para aprender e que fosse poético ao mesmo tempo propiciou uma transformação na forma de ver a si mesmos como provocadores de aprendizagem, produtores culturais, artistas, investigadores e estudantes ao mesmo tempo. Mas, por outro lado a análise mostrou que prevaleceram abordagens acríticas da situação do sujeito/estudante/comunidade frente ao que está se conhecendo. Mais da metade dos artefatos se configuraram em estruturas pedagógicas tradicionais que não questionam o que está se aprendendo, nem partem das experiências dos estudantes. Isso determinou em grande parte as formas de pensar e de fazer o artefato. Mesmo assim, é possível concluir que quase todos os participantes procuraram formas lúdicas ou interativas, envolvendo objetos concretos ou virtuais, para privilegiar a experiência estética, abrindo possibilidades de engajamento e corporificação no processo de aprendizagem.

No processo foi possível entrever que o sentido poético, que significa uma abertura ao desconhecido, ao outro, ao diferente e ao dissidente, pode parecer contraditório para quem trabalha com processos de planejamento pedagógicos. Do outro lado foi possível obervar que também pode parecer contraditório, para quem trabalha com a inexplicabilidade da arte, trazar estratégias pedagógicas para um artefato poético. Há um choque de objetivos na perspectiva de cada âmbito de ação. Os estudos mostraram que essas contradições são parte das 
inconsistências do sistema moderno/colonial que cria abismos entre sujeito e objeto, sensação e pensamento, ou teoria e práxis. Nesse sentido, a literatura me permitiu compreender que a situação radical marca o Momento Político Específico para ações que atravessem fronteiras dos modelos coloniais e antropocêntricos: América Latina e em especial o Brasil configuram espaços de investigação avantajados se comparados com outras partes do mundo nesse momento, sobre pedagogias culturais em contextos transculturais. Há, como mostra Camnitzer, uma tradição entre os artistas e professores latino-americanos, especialmente os das periferias, de se ver como agentes e produtores culturais. A mudança na forma como o educador em visualidade se vê a si mesmo é também uma forma de emancipação e de cruzamento de fronteiras sociais, culturais e políticas. Uma nova identidade se faz visível: a do educador em visualidade, a do provocador, a do produtor, a do criador, a do investigador, a do cruzador de fronteiras.

A investigação aponta a metodologia de IEBA, na qual a a/r/tografia se destaca, como uma plataforma adequada para uma tese que indaga no evento artístico como pedagogia, pois era necessário articular teoria, práxis e poiese. Nessas condições, a forma de estruturar as experiências deviam ser coerentes com a posição política, estética e pedagógica que embasa a filosofia da emancipação. Realizar a investigação na linha de Educação em Artes Visuais no PPG/Arte do IdA/UnB constitui um cenário adequado para indagar na convergência entre arte e educação em bases teóricas, práticas e poiéticas. Espaços disciplinares como o de Poéticas Contemporâneas no PPG/Arte, por exemplo, permitiu instituir os OAP como proposta poética, que de outra maneira não teriam cobrado vida, no sentido de evento artístico. A metodologia permitiu mergulhar em um processo complexo, extrair dados de um curso de extensão que fazem visíveis as diversas camadas que se superpõem entre as viradas e identificar as transformações e as potencialidades para a educação em visualidade na perspectiva das pedagogias culturais. Esta metodologia permite também deixar espaços de suspensão onde virtualmente se instala a potência da transformação. É importante notar aqui que a análise dos dados apontam rachaduras abertas nos sistemas e não padrões mensuráveis de mudança.

Dado que esta investigação se apresentou, por uma parte, como uma proposta de evento pedagógico e, como pensa Helguera, "quando um projeto de arte se apresenta como uma escola ou uma oficina, devemos nos perguntar o que, específicamente, está sendo ensinado e aprendido, e como" (2011, p. 78), foi necessário destacar os artefatos que os participantes 
realizaram e as conversações que conectaram a comunidade de pessoas que procuravam uma forma de reformular suas práticas. Mas, também, dado que a investigação se apresentou como uma proposta de evento artístico, e como pensa Helguera "é necessário se perguntar se um projeto dessa natureza oferece novas aproximações pedagógicas à arte" (Idem, p. 79) foi importante a apropriação da concepção de Objetos de Aprendizagem para torná-los Poéticos, como máquinas para criar terrítórios de subjetivação.

Assim, sendo, os achados desta investigação podem contribuir, no plano curricular, conceitual e metodológico, para uma maior troca de experiências entre educadores em visualidade, produtores culturais, artistas e academia. Nesse contexto observa-se que, a educação em visualidade, que é aonde as pedagogias culturais chegam com mais intensidade, oferece condições para agenciamentos maquínicos que podem contribuir na distribuição democrática do sensível. É possível, dadas essas condições, afirmar que o encontro entre as viradas é um evento que abre rachaduras nas formas como pensamos a arte, a sua educação, a sua teorização e a sua historicidade.

As experiências mostraram que o que mais valorizaram os participantes foi pensar a aula como um artefato estético. Enfrentaram os mesmo dilamas que enfrentam os artistas no estúdio, e os mesmos dilemas que enfrentam os professores em sala de aula. A proposta dos OAP os colocou frente a um encontro entre conceitos e formas de ver, de fazer e de se ver no mundo. Os participantes lidaram com aquilo que sabiam e com aquilo que queriam aprender. Os OAP os lançou a espaços desconhecidos que agora fazem parte da sua experiência. Nas paisagens em fluxo, o horizonte é a convicção de que podemos inventar uma sociedade completamente nova onde o novo e ver as coisas como se fossem pela primeira vez. Os mapas da potência nos conduzem além do horizonte, onde outras formas de pensar a arte e a educação são possíveis. 
Referências

AGUIAR, Adriana. Pesquisa Educacional Baseada nas Artes: experiências a/r/tográficas. Programa de Pós-Graduação em Arte, Instituto de Artes, Universidade de Brasília, 2011. 138 f. Dissertação de Mestrado.

AGUIRRE, Imanol. Cultura Visual, política da estética e educação emancipadora. In: MARTINS, Raimundo; TOURINHO, Irene (Orgs.). Educação da Cultura Visual: conceitos e contextos. Santa Maria: Editora UFSM, 2011.

ARGAN, Giulio Carlo. Arte Moderna: Do Iluminismo aos movimentos contemporâneos. São Paulo: Companhia das Letras, 1993.

ARNHEIM, Rudolph. Arte e Percepção Visual: Uma psicologia da Visão Criadora. São Paulo: Editora Pioneira, 2000.

APPLE, Michael. Is Social Transformation always Progressive? Rightist Reconstructions of Schooling Today. In JAMES, M.(Org.). Social Reconstruction trough Education: the Philosophy, History and Curriculum of a Radical Ideal. New Jersey: Ablex Publishing Corporation, 1995.

Educação, Mercado e culturas de controle. São Paulo: Revista E-Curriculum, vol. 2, n 3, dez. 2006.

Can Schooling contribute to a more just society?. Education, Citizenship and Social Justice. vol 3, $\mathrm{n}^{\circ}$. 3, p. 239- 261, Nov. 2008.

ATKINSON, Dennis. Art in Education: Identity and Practice. Netherlands: Kluwer Academic Publishers, 2002.

Art, Equality and Learning: Pedagogies against the State. Rotterdam: Sense Publishers, 2011.

ATKINSON, Dennis. Can Schooling contribute to a more just society?. Education, Citizenship and Social Justice. vol 3, nº. 3, p. 239- 261, November, 2008 a.

Pedagogy against the State. JADE. Vol. 27, No. 3, 2008 b.

.Contemporary Art and Art in Education: The New, Emancipation and Truth. iJADE, Vol. 31, n'. 1, p. 5 - 18, 2012.

AUDINO, Daniel; NASCIMENTO, Rosemy. Objetos de aprendizagem: diálogos entre conceitos e uma nova proposição aplicada à educação. Revista Contemporânea de Educação. Santa Catarina. Vol. 5, n. 10. Jul/dez, 2010.

BLANKINSHIP, Donna. Associated Press. Obama Administration Exempting Schools from Law's Testing Mandate. CNSnews.com. August 7th, 2011. Disponível em: $<$ http://cnsnews.com/news/article/obama-administration-exempting-schools-federal-law-stesting-mandate> Acesso em: 11 nov.2013.

BACHELARD, Gaston. La poética del espacio. Argentina: Fondo de Cultura Económica, 2000. 
BACON, David. Corporate Education Reform Hits San Francisco Community College. Truthout. Truth-Out Org. Tuesday, 19 March, 2013. Disponível em: <http://www.truthout.org/news/item/15213-corporate-education-reform-hits-san-francisco-community-college>, Acesso em: 19 mar. 2013.

BADIOU, Alain. Ética: um ensaio sobre a consciência do mal. Rio de Janeiro: Relume Dumará, 1995.

.Pequeno manual de inestética. São Paulo: Estação Liberdade, 2002.

Being and Event. New York: Continuum 2005.

BARBOSA, Ana Amália. Releitura, citação, apropriação ou o quê?. In BARBOSA, Ana Mae. Arte/Educação Contemporânea: Consonâncias Internacionais. São Paulo: Cortez, 2005.

BARONE, Tom; EISNER, Elliot. Arts Based Educational Research. In GREEN, J.; GREGO, C; BELMORE, P. Handbook of Complementary Methods in Education and Research. New Jersey: AERA, p. 95-109, 2006.

BARTHES, Roland. O rumor da língua. Lisboa: Edições 70, 1984.

BAUDRILLARD, Jean. La transparencia del mal: ensayo sobre los fenómenos extremos. Barcelona: Editorial Anagrama, 1991a.

Simulacros e simulação. Lisboa: Relógio d’Água, 1991 b.

BAUMAN, Zygmunt. Modernidad Líquida. México: Fondo de Cultura Económica, 2006.

BELTING, Hans. Por uma antropologia da imagem. Concinnitas. Ano 6, vol. 1, $\mathrm{n}^{\circ} 8$, julho, 2005.

BENJAMIN, Walter. Magia e técnica, arte e política: ensaios sobre literatura e história da cultura. São Paulo: Editora Brasiliense, 1987.

BETTIO, Raphael; MARTINS, Alejandro. Objetos de Aprendizagem - um novo modelo dirigido ao ensino a distância. Universia Brasil, 17 dez. 2004. Disponível em: $<$ http://noticias.universia.com.br/destaque/noticia/2004/12/17/493047/bjetos-aprendizado-umnovo-modelo-direcionado-ao-ensino-distncia.html> Acesso em 20, dez. 2014.

BHABHA, Homi. Cultural Diversity and Cultural Differences. In ASHCROFT, Bill; GRIFFITHS, Gareth; TIFFIN, Helen (Org.). The Post-Colonial Studies Reader. Londondon: Routledge, 1997.

BIESTA, Gert. What's the Point of Lifelong Learning if Lifelong Learning Has No Point? On the Democratic Deficit of Policies for Lifelong Learning. European Educational Research Journal. Volume 5, Numbers 3 \& 4, 2006.

Theorizing Learning Trough Complexity: an Educational Critique. Complicity: an International Journal of Complexity and Education. vol. $6 \mathrm{n}^{\circ}$ 1, p. 28-33, 2009a.

A New Logic of Emancipation: the methodology of Jacques Rancière. Educational Theory. vol. 60, $\mathrm{n}^{\circ} 1$, p. 39-59, 2010.

. Science or Democracy Knowledge: Evaluation and Judgment in the Knowledge
Society. $\quad$ UK: University of Stirling, 2012. Disponível em: 
$<$ http://static.sdu.dk/mediafiles//images/om_sdu/faellesadministrationen/sdue/gert\%20biesta.p df $>$. Acesso em: 15 jul. 2012.

BIESTA, Gert. Good Education: what it is and why we need it. Inaugural Lecture. UK: Stirling Institute of Education, 4th March, 2009b. Disponível em: $<$ http://www.ioe.stir.ac.uk/documents/GOODEDUCATION--

WHATITISANDWHYWENEEDITInauguralLectureProfGertBiesta.pdf $>$. Acesso em: 4 jul. 2012.

BISHOP, Claire (Org.). Participation. Cambridge: MIT Press, Whitechapel Ventures, 2006.

Verso, 2012.

Artificial Hells: participatory art and the politics of spectatorship. (ebook) London:

BOEHM, Gottfried; MITCHELL, J.W.T. Pictorical vs. Iconic Turn: Two letters. In CURTIS, Neal. 'As If': Situating the Pictorical Turn. In CURTIS, Neal. Culture, Theory and Critique. Routledge Tayor \& Francis Group. vol. 50 n² 2-3, p. 95-101, 2009.

BOLIVIA, Ministerio de Educación. Plan Educativo Avelino Siñani. La Paz: Viceministerio de Educación Regular, 2011.

BOURRIAUD, Nicolas. Pós-produção: como a arte programa o mundo contemporâneo. São Paulo: Martins Fontes, 2004.

Estética relacional. São Paulo: Martins, 2009.

BRASIL. MINISTÉRIO DE EDUCAÇÃO, SECRETARIA DE EDUCAÇÃO A DISTÂNCIA. Objetos de Aprendizagem: uma proposta de recurso pedagógico. Org. Carmem Lúcia Prata, Anna Christina Aun de Azevedo Nascimento. Brasília: MEC, SEED, 2007.

BREA, José Luis. Estudios Visuales: Notas del Editor. Madrid: Editorial Akal, 2003.

BROSTERMAN, Norman. Inventing Kindergarten. New York: Harry N. Abrams, 1997.

BRUGUERA, Tania. TANIA BRUGUERA. Cátedra Arte de Conducta. Glosario, s/d. Disponível em: 〈http://www.taniabruguera.com/cms/492-1-Ctedra+Arte+de+Conducta.htm>. Acesso em: 14 jun. 2013.

BUTLER, Judith. Undoing gender. New York: Routledge, 2004.

CAHAN, Susan, KOCUR, Zoya. Contemporary Art and Multicultural Education. New York: Routledge, 1996.

CAMNITZER, Luis. Didáctica de la Liberación: Arte Conceptualista Latinoamericano. Murcia: CENDEAC, 2009a. $2009 b$.

On art, artists, latin america, and other utopias. Texas: University of Texas Press,

CAMNITZER, Luis. Art and Literacy. e-flux Journal. $\mathrm{N}^{\circ}$ 3, february, 2009c. Disponível em, $<$ http://www.e-flux.com/journal/art-and-literacy/>. Acesso em 20 jan. 2015.

The Detweeting of Academia. e-flux Jounal, $\mathrm{N}^{\circ}$ 62, February, 2015. Disponível em: $<$ http://www.e-flux.com/journal/the-detweeting-of-academia/>. Acesso em 12 fev., 2015. 
CAPRA, Fritjof. O Ponto de Mutação. Pensamento Cultrix, 2001.

CAUQUELIN, Anne. Teorias da Arte. São Paulo: Martins Fontes, 2005.

Frequentar os Incorporais: contribuição a uma teoria da arte contemporânea. São Paulo: Martins Fontes, 2008.

CATALÀ DOMÈNECH, Josep. A forma do real: Introdução aos estudos visuais. São Paulo: Summus, 2011.

CERTEAU, Michel. A invenção do cotidiano: artes de fazer. Petrópolis: Editora Vozes, $3^{\circ}$ Ed., 1998.

CONFERÊNCIA GERARDO MOSQUERA. Centro Cultural España Córdoba, 2009. Disponível em: <http://hipermedula.org/2010/03/gerardo-mosquera-contra-el-artelatinoamericano/>. Acesso em: 14 maio 2013.

COMITÊ GESTOR DA INTERNET NO BRASIL. TIC Educação 2013: Pesquisa sobre o uso das tecnologias de Informação e comunicação nas escolas brasileiras. São Paulo: Núcleo de Informação e Coordenação do Ponto BR, 2014. Disponível em: <www.cetic.br〉. Acesso em 24 jan., 2015.

CRIMP, Douglas. On the Museum's Ruins. Cambridge Massachusetts: MIT Press, 1993.

DAMASIO, Antonio. O Erro de Descartes: emoção,razão e o cérebro humano. São Paulo, Companhia das Letras, 1996.

DANTO, Arthur. After the End of Art: Contemporary Art and the Pale of History. Princeton University Press, 1997.

DEBORD, Guy. A Sociedade do Espetáculo. Rio de janeiro: Contraponto Editora, 1997.

DELEUZE, Gilles. Lógica do Sentido. São Paulo: Perspectiva, Editora da Universidade de São Paulo, 1974.

Foucault. São Paulo: Brasiliense, 1988.

A dobra: Leibniz e o Barroco. Campinas, São Paulo: Papirus, $4^{\circ}$ edição, 2007.

DELEUZE, Gilles; GUATTARI, Felix. Mil Mesetas: Capitalismo y Esquizofrenia. Valencia: Pre-Textos, 2002.

O que é a filosofia?. $3^{\circ}$ edição São Paulo: Editora 34, 2010.

DERRIDA, Jacques. Gramatologia. São Paulo: Perspectiva Ed. Universidade de São Paulo, 1973.

On Touching: Jean Luc Nancy. California: Stanford University Press, 2005.

DEWEY, John. Reconstruction in Philosophy. New York: Henry Holt and Company, 1920.

Experience and Nature. London: George Allen \& Unwind, 1929.

Art as Experience. N.Y.: Penguin Group, 2005. 
DIAS, Belidson. O I/Mundo da Educação em Cultura Visual. Brasília: Editora da Pósgraduação em arte da Universidade de Brasília, 2011.

Pré-acoitamentos: os locais da arte/educação e da cultura visual. In MARTINS, Raimundo (Org.). Visualidades e educação. Coleção Desenrêdos Goiania FUNAPE, 2008.

Arrastão: o cotidiano espetacular e práticas pedagógicas críticas. In MARTINS, Raimundo; TOURINHO, Irene (Org.). Culturas das Imagens: desafios para a arte e para a educação. Santa Maria: Editora da UFSM, 2012.

Preliminares: A/r/tografia como Metodologia e Pedagogia em Artes. Anais da XVII CONFAEB, Congresso Nacional da Federação de Arte Educadores do Brasil. Universidade Federal de Santa Catarina, UFSC, 2007. Disponível em : <http://aaesc.udesc.br/confaeb/Anais/belidson.pdf >. Acesso em: 4 fev. 2012.

DIAS, Belidson; IRWIN, Rita (Org.). A/r/tografia. Santa Maria: Editora da UFSM, 2013.

DIKOVITSKAYA, Margaret. Visual Culture: the study of the visual after de Cultural Turn. USA: Massachusetts Institute of Technology, 2005.

DUNCUM, Paul. Por que a arte-educação precisa mudar e o que podemos fazer. In: MARTINS, Raimundo; TOURINHO, Irene (Orgs.). Educação da Cultura Visual: conceitos e contextos. Santa Maria: Editora UFSM, 2011.

DUVE, Thierry de. Fazendo escola (ou reafazendo-a?). Chapecó: Argos, 2012.

EDGAR, Ian. A Guide to Imagework: Imagination Based Research Methods. London: Routledge, 2004.

EFLAND, Arthur. A History of Art Education: Intellectual and Social Currents in Teaching the Visual Arts. New York: Teachers College Press, 1990.

EISNER, Elliot. The Arts and the Creation of Mind. London: Yale University Press, 2002.

FLICK, Uwe. Introdução à Pesquisa Qualitativa. 3 ed. Porto Alegre: Artmed, 2009.

FLUX CONVERSATIONS. Forum On Claims of Radicality in Contemporary Art. e-flux. February 3th, 2015. Disponível em: <http://conversations.e-flux.com/t/on-claims-ofradicality-in-contemporary-art/959>. Acesso em 19 fev. 2015.

FERNANDES, Anais. Artista formada na ECA expõe poética iminente. Jornal do Campus. Editoria Cultura. ECA-USP. Edição 401, out/2012. Disponível em: < http://www.jornaldocampus.usp.br/index.php/2012/10/artista-formada-na-eca-expoe-poeticaiminente/>. Acesso em 02 jan. 2014.

FERREIRA, Gloria; COTRIM, Cecília. Clement Greenberg e o debate crítico. Rio de Janeiro: Jorge Zahar Ed., 2001.

FOUCAULT, Michael. What is an author?. In SEARLE, John. Essay in the Philosophy of Language. Cambridge: Cambridge University Press, 1969.

Fearless Speech. Ed. Joseph Pearson. New York: Semiotext(e), 2001.

Vigiar e Punir: nascimento da prisão. Petrópolis: Vozes, 2008. 
FREIRE, Paulo. Pedagogia do Oprimido. Rio de Janeiro: Paz e Terra, 1987. 17 ed.

FREIRE, Paulo.; SHOR, Ira. A Pedagogy for Liberation: Dialogues in transforming Education. USA: Bergin \& Garvey Publishers, Inc, 1987.

FREEDMAN, Kerry. Teaching Visual Culture: Curriculum, Aesthetics and the Social Life of Art. N.Y: Teachers College Press, 2003.

GARCIA CANCLINI,. Néstor. Culturas Híbridas: Estrategias para entrar y salir de la modernidad. México D.F.: Grijalbo, 2001.

GARDNER, Howard. Frames of Mind: The theory of multiple intelligences. New York: Basic Books, 2011.

GAROIAN, Charles, GAUDELIUS, Yvonne. Spectacle Pedagogy: Art, Politics, and Visual Culture. New York: State University of New York Press, 2008.

GIBBSON, Andrew; NELSON, Jon; RICHARDS, Robert. The nature and origin of instructional objects. In WILEY David (Ed). The instructional use of Learning Objects. 2000. Versão online, encontrado em: <http://reusability.org/read/>, acesso em 20 dez. 2014.

GIROUX, Henry. Border Crossings: Cultural Workers and the Politics of Education. New York: Routledge, 2005.

GIROUX, Henry. Public Pedagogy as Cultural Politics. In ALLEN, Felicity (Org.). Education: Documents of Contemporary Art. London: Whitechapel Gallery, Cambridge: MIT Press, 2011.

Dangerous Pedagogy in the Age of Casino Capitalism and Religious Fundamentalist. Truthout. News Analysis. Wednesday, 29 February, 2012, 05:17. Disponível em: <http://truth-out.org/index.php?option=com_k2\&view=item\&id=6954:dangerous-pedagogyin-the-age-of-casino-capitalism-and-religious-fundamentalism>. Acesso em: 4 jul. 2012

GOMEZ, Pedro; MIGNOLO, Walter. Estéticas decoloniales. Bogotá: Universidad Distrital Francisco José de Caldas, 2012. Disponível em : <http://issuu.com/paulusgo/docs/est_ticasdecoloniales_gm>, Acesso em : 30 de julho de 2015.

GREENE, Maxine. Landscapes of Learning. Teachers College Press, 1978.

Releasing the Imagination: Essays on Education, the Arts, and Social Change. USA: Jossey Bass, 2000.

GREY, Paul; WILLIAMSON, John; KARP, David; DALPHIN, John. The Research Imagination: An introduction for Qualitative and Quantitative Methods. New York: Cambridge University Press, 2007.

GRIERSON, Elizabeth. Methodology and Interpretive Procedures in Educational Research: risk, imagination and reflexivity. NZARE/ AARE Conference, Educational Research: Risks and Dilemmas. New Zeland, Auckland University of Technology 29 nov - 3 dec, 2003.

GUATTARI, Felix. Chaosmosis: an ethico-aesthetic paradigm. Indianapolis: Indiana University Press, 1995. 
GUBA, Egon, LINCOLN, Yvonna. Fourth Generation Evaluation. Beverly Hills, CA: SAGE. 1989.

HABERMAS, Jurgen. Knowledge and Human Interests. Boston: Beacon Press. 1971.

O discurso filosófico da modernidade. São Paulo: Martins Fontes, 2002.

HALL, Stuart. Identidade Cultural na Pós-Modernidade. Rio de Janeiro: DP\&A Editora, 2006. 11 ed.

HELGUERA, Pablo. Education for Socially Engaged Art: a Materials and Tecniques Handbook.New York: Jorge Pinto Books, 2011a.

; HOFF, Mônica. Pedagogia no campo expandido. Porto Alegre: Fundação Bienal de Artes Visuais do Mercosul, 2011b.

HENRY, Michel. Seeing the invisible: on Kandinsky. New York: Continuum, 2009.

HERNÁNDEZ, Fernando. Transgressões e Mudança na Educação: Os Projetos de Trabalho. Porto Alegre: Artmed, 1998.

HERNÁNDEZ, Fernando. La Investigación Basada en las Artes: una propuesta para repensar la investigación en la educación. Educatio siglo XXI. n 26, p. 85-118, 2008.

HIGGINS, Hannah. Fluxus Experience. California: University of California Press, 2002.

HODGINS, Wayne. The Future of Learning Objects. In WILEY David (Ed). The instructional use of Learning Objects. 2000. Versão online, encontrado em: <http://reusability.org/read/>, acesso em $20 \mathrm{dez} .2014$.

HOLLY, Michael Ann; MOXEY, Keith (Eds.). Art History, Aesthetics, Visual Studies. Sterling and Francine Clark Art Institute. Massachusetts: Studley Press, 2002.

IEEE Learning Technology Standards Committee (LTSC). Draft Standard for Learning Object Metadata. Institute of Electrical and Electronics Engineers, Inc. LTSC., 2000. Learning technology standards committee website. Disponível em: <http://ltsc.ieee.org/> Acesso em: 20 de julho de 2007.

IRWIN, Rita; COSSON A. de. A/R/Tography: Rendering Self Trough Arts Based Living Inquiry. Vancouver, Canadá: Pacific Educational Press. 2004.

IRWIN, Rita ; BEER, R.; SPRINGGAY, S.; GRAUER, K.; XIONG, G.; BICKEL, B. The Rizomatic Relations of $\mathrm{A} / \mathrm{r} /$ tography. Studies in Art Education, A Journal of Issues and Research. 48(1), 70- 88, 2006. Disponível em <http://opensiuc.lib.siu.edu/ad_pubs/4> Acesso em 4 fev. 2012.

IRWIN, Rita. A/r/tography. Website, 2006. Encontrado em: <http://m1.cust.educ.ubc.ca/Artography/>. Acesso em: 21 abr. 2013.

JAGODZINSKI, Jan. Entre aisthetica e estética: o impacto de Deleuze - Guattari na educação estética. In MARTINS, Raimundo, TOURINHO, Irene. Educação da Cultura Visual: Narrativas de Ensino e de Pesquisa. Santa Maria: Editora UFSM, 2009.

Badiou`s Challenge to Art and its Education: or 'art cannot be taught - it can however educate!". Educational Philosophy and Theory. vol. 42, nº. 2, p. 177 - 195, 2010. 
JAGODZINSKI, Jan, WALLIN, Jason. Arts-Based Research: A critique and a Proposal. Rotterdam: Sense Publishers, 2013.

KEARNEY, Richard. Poetics of Imagining: Modern to Post- Modern. New York: Fordham University Press, 1998.

KINCHELOE. Joe. Critical Pedagogy. New York: Peter Lang Publishing, 2008.

KUONI, Carin (org.). Energy Plan for the Western man: Joseph Beuys in America. N. Y: Four Walls Eight Windows, 1993.

KRAUSS, Rosalind. Caminhos da Escultura Moderna. São Paulo: Martins Fontes, 1998.

LAKOFF, George, JOHNSON, Michael. Metaphors We Live By. IL: University of Chicago, Chicago, 1980.

LIPPARD, Lucy. Art Outdoors, In and Out of the Public Domain. Studio International. March- April, 1977.

LONGONI, Ana. El mito de Tucumán Arde. Horizons et dispositif des pays do Rio de la Plata (XXe Siècle). Artelogie. $\mathrm{N}^{\circ}$ 6, Juin. 2014. Disponível em: <http:cral.in2p3.fr/artelogie/spip.php?article 308>. Acesso em 10 abr. 2015.

LYOTARD, Jean François. A condição pós-moderna. Trad. Ricardo Corrêa Barbosa. Rio de Janeiro: José Olympio, 2011.

MACDONALD, Stuart. The History and Philosophy of Art Education. Cambridge: The Lutterworth Press, 2004.

MADOFF, Steven. Art School: Propositions for the 21st Century. London: The MIT Press, 2009.

MALOY, Thomas; HANLEY, Gerard. MERLOT: a faculty focused web site of educational resources. Behavior Research Methods, Instruments and Computers. 33 (2), p. 274-276, 2001.

MARTINS, Mirian Celeste. (Org.) Curadoria educativa: inventando conversas. Reflexão e Ação. Revista do Departamento de Educção/UNISC - Univerdsidade do Santa Cruz do Sul, vol $14 \mathrm{n}^{\circ} 1$, jan/jun 2006, p. 9-27.

MARTINS, Raimundo. Das belas artes à cultura visual: enfoques e deslocamentos. In: MARTINS, Raimundo (Org.). Visualidade e Educação. Goiânia: FUNAPE, 2008.

MATURANA, Humberto; VARELA, Fernando G. De Máquinas y Seres Vivos. Autopoiesis: la organización de lo vivo. Santiago. Chile: Editora Universitaria. 1995.

MATURANA, Humberto. Emoções e Linguagem na Educação e na Política. Belo Horizonte: Editora UFMG, 2005.

MAYHEW, Katherine. EDWARDS, Anna. The Dewey School: The Laboratory School of the University of Chicago. N.Y: D. Appleton-Century Company Inc., 1936. Disponível em:〈http://archive.org/details/deweyschoolthela008095mbp>. Acesso em: 16 dez. 2012. 
MERRIL, David. Knowledge objects and mental models. In WILEY David (Ed). The instructional use of Learning Objects. 2000. Versão online. Disponível em: <http://reusability.org/read/>, acesso em 20 dez. 2014.

McNIFF, S. Art as medicine: Creating a therapy of the imagination. Boston: Shanbhala Publications, 1992.

Art-based Research. London: Jessica Kingsley Publisher, 1998.

Creating with others: The practice of imagination in life, art and the workplace. Boston: Shanbhala Publications, 2003.

Arts Based Research. In KNOWLES, G. COLE, A. (Eds). Handbook of the Arts in Qualitative Inquiry: Perspectives, Methodologies, Examples and Issues. SAGE Publicatios, 2007.

MERLEAU-PONTY, Maurice. Fenomenologia da Percepção. São Paulo: Martins Fontes, 1996.

MIGNOLO, Walter. Local Histories/ Global Designs: Coloniaity, Subaltern Knowledges and Border Thinking. NJ: Princeton University Press, 2012.

MIRZOEFF, Nicolas. An Introduction to Visual Culture. New York: Routledge, 2009.

MITCHELL, W.J.T. Picture Theory. London: The University of Chicago Press, 1995.

What do pictures want? London: The University of Chicago Press, 2005.

MITCHELL, W.J.T. The future of the image: Rancière's road not taken. In CURTIS, Neal. Culture, Theory and Critique. Routledge Tayor \& Francis Group. vol. 50 n $^{\circ} 2-3$, p. 133 $144,2009$.

MISKOLCI, Richard. Teoria Queer: um aprendizado pelas diferenças. Belo Horizonte: Autêntica Editora, Universidade Federal de Ouro Preto, 2012.

MOLLIN, David; REARDON, John. Ch-Ch-Ch-Changes: artist talk about teaching. London: Ridinghouse, 2009.

NANCY, Jean Luc. Noli me tangere: on the rising of the body. New York: Fordham University Press, 2008.

. Being Singular Plural. Stanford: Stanford Unversity Press, 2013.

NOTES FOR AN ART SCHOOL. Manifesta 6. Nicosia, Cyprus. 2006. Disponível em: <http://manifesta.org/manifesta-6/>. Acesso em: 9 jun. 2013.

OLIVEIRA, Emerson de. História da Arte e apropriações contemporâneas: uma metodologia de ensino em construção. In: ROSÁRIO, Maria José (et. al.). IX Jornada do HISTEDBR. O nacional e o local na História da Educação, 2010, Belém-PA. Campinas-SP: HISTEDBR/EFUnicamp, vol. 1, n. 1, jul. 2010. Disponível am: < http://www.histedbr.fe.unicamp.br/acer_histedbr/jornada/jornada9/trabalhos.html>. Acesso em 10, jan. 2015.

ORTIZ, Fernando. Contrapunteo cubano del tabaco y el azúcar. La Habana: Editorial de las Ciencias Sociales, 1983. 
PALADINES, Carlos. Simón Rodríguez: el proyecto de una educación social. Educere. vol. $12 \mathrm{n}^{\circ} .40,2008$.

PINAR, William. The Passionate Mind of Maxine Greene: "I Am--Not Yet". Routledge, 1998.

What is curriculum theory?. London: Lawrence Erlbaum Associates, 2008.

PINAR, William. Multiculturalismo Malicioso. Currículo sem Fronteiras. vol. $9 \mathrm{n}^{\circ} .2$, p. 149 - 168, Jul/Dez, 2009.

PINAR, William; IRWIN, Rita. Curriculum in a New Key: The Collected Works of Ted. T. Aoki. London: Lawrence Erlbaum Associates, 2005.

PODESVA, L. K. A Pedagogical Turn: Brief Notes on Education as Art. Fillip, 6 Projectile Publishing Society, Vancouver, British Columbia Summer 2007. Disponível em: <http://fillip.ca/content/a-pedagogical-turn>. Acesso em: 12 mar. 20012.

RANCIÈRE, Jacques. O Mestre Ignorante. Belo Horizonte: Autêntica, 2002.

Sobre políticas estéticas. Barcelona: Museo de Arte Contemporáneo, Universidad Autónoma de Barcelona, 2005.

The future of the image. London: Verso, 2007.

Aesthetics and its discontents. UK: Polity Press, 2009a.

A Partilha do Sensível. São Paulo: Editora 34, 2009b. $2^{\text {a }}$ Ed.

On Ignorant Schoolmasters. In BINGHAM, Charles e BIESTA, Gert. Jacques Rancière: education, truth, emancipation. N.Y.: Continuum International Publishing Group, 2010a.

Dissensus: On Politics and Aesthetics. London: Continuum, $2010 \mathrm{~b}$.

The Emancipated Spectator. London: Verso, 2011.

RANCIÈRE, Jacques. Do pictures really want to live? In CURTIS, Neal. Culture, Theory and Critique. Routledge Tayor \& Francis Group. vol. 50 n² 2-3, p. 123-132, 2009c.

READ, Herbert. A educação pela Arte. São Paulo: Martins Fontes, 2001.

RICOEUR, Paul. Hermeneutics and the Human Sciences: Essays on language, action anda interpretation. UK: Cambridge University Press, 1981.

RODOWICK, David. Reading the Figural, Or, Philosophy after the New Media. U.S.A: Duke University Press, 2001.

RODRÍGUEZ, Simón. Sociedades Americanas. Caracas: Biblioteca Ayacucho. 1990. 2008 .

O inventamos o erramos. Caracas: Monte Ávila Editores Latinoamericana CA,

ROGOFF, Irit. Studying visual culture. In MIRZOEFF, Nicholas (Ed.) The visual culture reader. 2ed. London: Routledge, 1998. 
Turning. e-flux journal. \#0, November 2008. Disponível em: <http://www.eflux.com/journal/turning/>. Acesso em 11 abr. 2012.

ROGOFF, Irit. Academy as Potentiality. In NOLLEN, Angelika, et. al. (Eds.) A.C.A.D.E.M.Y. Frankfurt am Main: Revolver, p. 14-15, 2006.

ROOT, Deborah. Cannibal Culture: Art, Appropriation and the Commodification of Difference. Colorado: Westview Press, 1998.

ROSENBERG, Terrence. The Reservoir: Towards a poetic model of research in design. Working Paper in Art \& Design 1. 2000. Disponível em: http://sitem.herts.ac.uk/artdes_research/papers/wpades/vol1/rosenberg2.html> Acesso em: 4 fev. 2012.

SAID, Edward. Orientalismo: O Oriente como invenção do Ocidente. São Paulo: Companha das Letras, 2003.

SANTAELLA, Lúcia; NOTH, Winfried. Imagem: cognição, semiótica, mídia.São Paulo: Iluminuras, 2001.

SANTOS. Boaventura; MENESES, Maria P. Epistemologias do Sul. São Paulo: Editora Cortez, 2010.

SAWICKI, J. Disciplining Foucault: Feminism, Power and the Body. New York: Routledge, 1991.

SERVIGNY, Maurice; FAIRCHILD, Marguerite. Aprendizado Visual: uma análise sócio linguística sobre a crítica de arte no ensino de artistas. In BARBOSA, Ana Mae (org.) Arte/Educação Contemporânea: Consonâncias Internacionais. São Paulo: Cortez, 2005.

SHUSTERMAN, Richard. Vivendo a arte: o pensamento pragmatista e a estética popular. Trad. Gisela Domschke. São Paulo: Editora 34, 1998.

SILVA, Robson Santos da. Objetos de Aprendizagem para Educação a Distância. São Paulo: Novatec Editora, 2011.

SPIVAK, Gayatri. An Aesthetic Education in the Era of Globalization. Cambridge: Harvard University Press, 2012.

SPRINGGAY, S., IRWIN, R., KIND, S. A/r/tography as Living Inquiry through Art and Text. Qualitative Inquiry. vol. 11, nº 6, p. 897-912. 2005.

SPRINGGAY, S; IRWIN, R.; LEGGO, C.; GOUZOU, P. (orgs). ASIS Being with A/r/tography. Rotterdam: Sense Publishers, 2008.

SUASSUNA, Ariano. Iniciação à Estética. $9^{\circ}$ Ed. Rio de janeiro: José Olympio, 2008.

SULLIVAN, Graeme. Artistic thinking as transcognitive practice: A reconciliation of the process-product dichotomy. Visual Arts Research, vol. 22, n 1, p 2-17, 2002.

Art Practice as Research: Inquiry in Visual Arts. LA: SAGE Publications, 2010.

SZEWCZYK, Monika. Art of Conversation, Part I. e-flux journal. \#3, February 2009. Disponível em: <http://www.e-flux.com/journal/art-of-conversation-part-i/>. Acesso em 20 mai. 2015. 
TAROUCO, Liane; FABRE, Marie Christine; TAMUSIUNAS, Fabrício. Reusabilidade de Objetos Educacionais. Centro Interdisciplinar de Novas Tecnologias na Educação, Universidade Federal do Rio Grande do Sul, Porto Alegre, 11f. 2003.

TATARKIEWICZ, Wladyslaw. Historia de seis ideas: arte, belleza, forma, creatividad, mímesis, experiencia estética. Madrid: Editorial Tecnos, 1996.

TREND, David. Cultural Pedagogy: Art, Education, Politics. New York: Bergin \& Garvey, 1992.

VERWOERT, Jan. Apropos appropriation: why stealing images today feels different? Art \& Research. Summer, v 1 n 2, 2007. Disponível em: <www.artandresearch.org.uk/v1n2/verwoert.html>. Acesso em: 20, dez. 2014.

The Boss: On the Unresolved Question of Authority in Joseph Beuys Ouvre and Public Image. e-flux journal. December 2008. Disponível em: <http://www.eflux.com/journal/turning/>, Acesso em: 11 abr. 2012.

Animalisms. Art \& Research. Summer, v 4 n 1, 2011. Disponível em: <http://www.artandresearch.org.uk/v4n1/verwoert.php>. Acesso em: 20, dez. 2014.

VICTORIO FILHO, Aldo; BERINO, Aristóteles. Culturas Juvenis, cotidianos e currículos. Currículo sem Fronteiras. vol. 7, n 2, p. 7-20, Jul/Dez, 2007a.

. Pesquisar o cotidiano é criar metodologias. Educação e Sociedade. Campinas, vol. 28, n 98, p. 97- 110, jan./abr., 2007 b.

Ensino de arte hoje: desafios, sentidos e sintonias. In Anais da 31 ${ }^{\mathbf{a}}$ Reunião da Associação Nacional de Pós-graduação e Pesquisa em Educação, Caxambu, 2008.

VYGOTSKY, Lev. A Formação Social da Mente. São Paulo: Martins Fontes, 1984.

WEINER, Eric. Making the Pedagogical (Re) Turn: Henry Giroux's Insurgent Cultural Pedagogy. JAC. vol. $21 \mathrm{n}^{\circ}$. 2, p. 434- 451, Spring, 2001.

WILEY, David. The Instructional Use of Learning Objects. on-line version, 2000a. Disponível em: <http://www.reusability.org/read/>, encontrado em 27 agosto 2013.

Connecting learning objects to instructional design theory: A definition, a metaphor, and a taxonomy. Utah State University, Digital Learning Environments Research Group, 2000b. Disponível em: <http://reusability.org/read/> Acesso em: 28 abr., 2007.

WILLIAM PINAR SEMINAR Allegories of the Present: Curriculum development in a Culture of Narcissism and Presentism. Tallinna Ulikool. Haridus- ja kasvatusteaduste doktorikool. Tallinn Estonia. 22/08/2011. Vimeo, 1:56:54. Disponível em: <http://vimeo.com/28393833> Acesso em 12, dez. 2012.

WOLLHEIM, Richard. A arte e seus objetos. São Paulo: Martins Fontes, 1994.

ZANE SHAW, Devin. Inaesthetics and Truth: The debate between Alain Badiou and Jacques Rancière. Filozofski vestnik. vol. 28, n . 2, p. 183-199, 2007.

ZIBECHI, Raul. La educación en los movimientos sociales. Foro Latioamericano de Políticas Educativas. Programa de las Américas, Siver City NM: International Relations 
Center. 6 jul. 2005, FLAPE. Disponível em: <http://especiales.universia.net.co/dmdocuments/educacion_en_los_mov_sociales.pdf.> Acesso em: 07 jan. 2012. 